\title{
De heersende leer : honderd jaar verspreidingsjurisprudentie: 1892-1992
}

Citation for published version (APA):

de Winter, R. E. (1993). De heersende leer : honderd jaar verspreidingsjurisprudentie: 1892-1992.

[Doctoral Thesis, Maastricht University]. SDU, Juridische en Fiscale Uitgeverij.

https://doi.org/10.26481/dis.19930205rw

Document status and date:

Published: 01/01/1993

DOI:

10.26481/dis.19930205rw

Document Version:

Publisher's PDF, also known as Version of record

\section{Please check the document version of this publication:}

- A submitted manuscript is the version of the article upon submission and before peer-review. There can be important differences between the submitted version and the official published version of record.

People interested in the research are advised to contact the author for the final version of the publication, or visit the DOI to the publisher's website.

- The final author version and the galley proof are versions of the publication after peer review.

- The final published version features the final layout of the paper including the volume, issue and page numbers.

Link to publication

\footnotetext{
General rights rights.

- You may freely distribute the URL identifying the publication in the public portal. please follow below link for the End User Agreement:

www.umlib.nl/taverne-license

Take down policy

If you believe that this document breaches copyright please contact us at:

repository@maastrichtuniversity.nl

providing details and we will investigate your claim.
}

Copyright and moral rights for the publications made accessible in the public portal are retained by the authors and/or other copyright owners and it is a condition of accessing publications that users recognise and abide by the legal requirements associated with these

- Users may download and print one copy of any publication from the public portal for the purpose of private study or research.

- You may not further distribute the material or use it for any profit-making activity or commercial gain

If the publication is distributed under the terms of Article $25 \mathrm{fa}$ of the Dutch Copyright Act, indicated by the "Taverne" license above, 
De heersende leer 
Van dit proefschrift verschijnt ook een handelseditie onder ISBN 9054090499 


\title{
De heersende leer
}

Honderd jaar verspreidingsjurisprudentie: 1892 - 1992

\author{
PROEFSCHRIFT \\ ter verkrijging van de graad van doctor \\ aan de Rijksuniversiteit Limburg te Maastricht, \\ op gezag van de Rector Magnificus, prof. mr. M.J. Cohen, \\ volgens het besluit van het College van Dekanen, \\ in het openbaar te verdedigen \\ op vrijdag 5 februari 1993 \\ om 16.00 uur \\ door \\ Reiner Ernest de Winter
}

1993

$\begin{aligned} & \text { Sdu|Juridische } \\ & \text { \& Fiscale } \\ & \text { Uitgeverij }\end{aligned} \mid \mathrm{R}, \mathrm{B}$ 
Promotores:

Beoordelingscommissie: Mr. A.W. Heringa (voorzitter)

Prof.mr. J. de Boer

Prof.mr. J.E. Goldschmidt

Prof.mr. E.C.M. Jurgens

Prof.mr. F.A.M. Stroink 


\section{Voorwoord}

Dit boek is feitelijk het gevolg van "achterstallig onderhoud". We hebben in het staatsrecht maar zo weinig echte "leerstukken" en we gaan er zo slordig mee om. Waarom dan niet eens bekeken hoe het - op én zo'n gebiedje allemaal precies is verlopen? Het werd de hoogste tijd, vond ik. En omdat we in 1992 op de kop af honderd jaar na het "Haags ventverbod" leefden, leek dit mij het aangewezen jaar om het leerstuk van de "verspreidingsjurisprudentie" in kaart te brengen. Ik wilde daar althans een poging toe doen. De faculteit der rechtsgeleerdheid van de RL schonk mij drie maanden studieverlof en voor eigen rekening voegde ik daar een zelfde periode aan toe. Het resultaat ligt voor $\mathrm{u}$.

Maastricht, november 1992

Reiner de Winter 



\section{Inhoud}

Inleiding

Hoofdstuk 1 Vestiging van het leerstuk

1.1. Eerdere beslissingen 9

1.2. Het arrest van $1892 \quad 10$

1.3. De ontvangst van het arrest 13

1.4. Vooruitzichten 22

1.5. De eerste schreden 29

1.6. Bevestiging van "de leer" 37

1.7. Consolidering 44

Hoofdstuk 2 Voortzetting en uitbreiding 51

2.1. De Rotterdamse en Utrechtse plakverboden (1903 en 1909) 51

2.2. Avondklok voor venters (1909 en 1910) 54

2.3. Venten als aanleiding voor ongeregeldheden (1910) 58

2.4. Het bekendmaken van de inhoud (1910) 61

2.5. Beperkingen naar de tijd: Rosendaal (1916-1920) 65

2.6. Beperkingen naar de inhoud? Het Sanitas-arrest (1928) 70

Hoofdstuk 3 De jaren '30: kentering 75

3.1. Rekbare begrippen en onvoorziene nuanceringen (1932-1935) 75

$\begin{array}{ll}\text { 3.2. Verdere afkalving (1938) } & 82\end{array}$

3.3. Het klapstuk: de Heerenveense noodverordening (1939) 89

Hoofdstuk 4 Restauratie $\quad 99$

4.1. Een aarzelend begin (1948-1950) 100

4.2. Een nieuwe fundering: Tilburg en Sittard (1950) 106

4.3. Kleine renaissance: oude thema's keren terug (1951) 114

4.4. Nieuwe sjablonen houden stand (1952-1953) 119 
5.1. Voorafgaand verlof van rechthebbenden: Alkmaar (1960) 125

5.2. Vestigingsvergunningen (1960-1961) 130

5.3. Neonletters (1967) 141

5.4. Vietnam (1967) 146

5.5. Intermezzo (1968) 152

5.6. De manege Rehoboth (1969) 154

Hoofdstuk 6 De jaren zeventig: luwte 159

6.1. Gedachten of gevoelens: "Huifkax" (1972) 159

6.2. Invuloefening (1975) 160

6.3. De grondwetsherziening (1976-1979) 163

6.4. Plakverbod: Hengelo (1977) 165

6.5. Collecteverbod: Eindhoven (1978) 167

6.6. Pogingen tot navolging (1978-1979) 174

6.7. Het Dordtse plakverbod (1979) 180

Hoofdstuk 7 De jaren tachtig tot en met '92 185

7.1. De Utrechtse muurkrant (1980) 185

7.2. Een lange reeks plakverboden (1980-1982) 189

7.3. Klein intermezzo: Helden (1981) 201

7.4. Breda: verankering van een keerpunt (1983) 203

7.5. Nasleep: het "gebruik van enige betekenis" (1984-1989) 212

7.6. Vergunning- en ontheffingstelsels (1985-1991) 233

7.7. Absoluut verbod (1989-1990) 240

7.8. Verspreiding van drukwerk (1983-1990) 243

7.9. Gedachten of gevoelens (1986-1992) 250

$\begin{array}{ll}\text { Hoofdstuk } 8 \text { Slot } & 259\end{array}$ 
Inleiding

Hoofdstuk 1

Hoofdstuk 2

282

Hoofdstuk 3

288

Hoofdstuk 4

297

Hoofdstuk 5

305

Hoofdstuk 6

312

Hoofdstuk 7

319

Hoofdstuk 8

335

Chronologisch register van besproken Nederlandse uitspraken en beslissingen 



\section{Inleiding}

Arme Levie Cohen! Wie kent hem nog? Hij werd op 7 november 1892 ontslagen van alle rechtsvervolging. ${ }^{1}$ Alleen zijn "zaak" kunnen we nog terugvinden in het Weekblad van het Recht (dat trouwens drie keer per week verscheen). Samen met drie anderen - die zelfs niet tot dat Weekblad zijn doorgedrongen ${ }^{2}$ - had hij geprobeerd in Zwolle op straat wat krantjes te verkopen. En wat erger was: hij had geen ontheffing van B en W. Zonder zo'n ontheffing was het volgens de APV verboden "aan of op den openbaren weg eenig bedrijf uit te oefenen". Levie Cohen was, kortom, in overtreding. Acht keer op één dag zelfs! De Zwolse kantonrechter veroordeelde hem dan ook op 23 juni 1892 "tot acht geldboeten van $f$ 1,-, met vervangende hechtenis van 1 dag voor elk dezer boeten en in de kosten, invorderbaar bij lijfsdwang van ten hoogste 2 weken". De Hoge Raad, daarentegen, ontsloeg hem (zoals gezegd) van rechtsvervolging. De Zwolse APV-bepaling was namelijk "in hare algemeenheid ook op zoodanig bedrijf van toepassing (...), dat, zoals het bedrijf van venter, uit zijn aard niet wel anders dan aan den openbaren weg (kon) worden uitgeoefend". Daarom was dit verbod, volgens de Hoge Raad, "in zoover niet (...) overeen te brengen met art. 2 der wet op het recht van patent van 21 Mei 1819 (stbl. no. 34)". Wie op grond van deze wet eenmaal een "patent" had verworven, was immers bevoegd "om, gedurende den tijd, waar over hetzelve is uitgegeven, den daarin vermelden handel, bedrijf, beroep of nering allerwege, waar hij zulks zoude mogen verkiezen, uit te oefenen". Weliswaar was "een iegelijk (...) verpligt, zich, in de uitoefening van zijnen handel, beroep, bedrijf, handwerk of nering, te gedragen naar de verordeningen van de algemeene en plaatselijke politie", maar de Hoge Raad vond "dat deze regeling nooit zoo ver (kon) gaan dat daardoor iets zou worden verboden, waartoe de wet uitdrukkelijk de bevoegdheid (verleende)". De omstandigheid dat B en W volgens de Zwolse APV-bepaling een ontheffing konden verlenen, kon daar niet aan afdoen: "dat toch ook met deze uitzondering het verbod blijft in strijd met de wet, terwijl bovendien de uitzondering op zich zelve niet is overeen te brengen met de aangebrachte wetsbepaling, die de bevoegdheid tot de vrije uitoefening van het beroep verleent, onafhankelijk van eene vergunning van het plaatselijk bestuur".

Daarmee was de Hoge Raad geheel in lijn gebleven met eerdere uitspraken, waarin het onder meer ging om het venten met vis, respectievelijk met 
"blikwerk en galanteriën". ${ }^{3}$ Dat in dit geval sprake was van het venten met drukwerk, speelde geen enkele rol.

Anderhalf jaar later werd de wet op het recht van patent echter afgeschaft. ${ }^{4}$ Inmiddels weet nauwelijks iemand nog dat er ooit zo'n wet heeft bestaan. Geen wonder dat deze Zwolse zaak al lang en breed vergeten is.

Had Levie Cohen in Den Haag gewoond, dan was het hem vermoedelijk anders vergaan. Dáár was de verbodsbepaling namelijk met zoveel woorden toegesneden op drukwerk: "Het is verboden", aldus het toenmalige art. 11a van de Haagse APV, "zonder vergunning van den burgemeester, geschreven of gedrukte stukken op de openbare straat aan te kondigen, te venten, te verspreiden of te koop aan te bieden." Dergelijke bepalingen waren, "zooals een ieder weet, tegen de socialisten gericht. Dit is er wel niet bij gezegd, toen ze gemaakt werden, maar het is er niet minder waar om", aldus een promovendus uit die tijd. ${ }^{5}$ Een ander ${ }^{6}$ had zich kort daarvoor wat minder stellig uitgedrukt:

"De Haagsche verordening en dergelijke van andere plaatsen, hebben den schijn alleen tegen de socialistische bladen te zijn gekant. Of het werkelijk de bedoeling was, valt moeillijk uit te maken, maar het is een feit, dat alleen de socialistische venters aanleiding gegeven hebben tot het uitvaardigen van voormelde verordeningen. Daartoe bestond voorzeker eene bijzondere aanleiding. Het venten van andere couranten op straat behoort bij ons nog tot de uitzonderingen, geheel anders als in andere landen, en waar het geschiedt, met drukwerken van onschuldigen of onschadelijken aard (...), heeft het nog nimmer aanleiding gegeven tot ongerief voor anderen, en men zou zulks ongaarne verboden zien of belet. Ook het Leger des Heils geeft bij het venten zijner bladen en vlugschriften geen aanleiding tot overlast, die een verbod als in de Haagsche verordening uitgedrukt zou rechtvaandigen. Dit is eigenlijk alleen maar het geval met de socialistische bladen (...)."

Dat tegen die achtergrond al gauw art. 7 Grondwet in het vizier kwam, hoeft geen verbazing te wekken. ${ }^{7}$ Niemand heeft, volgens art. 7, "voorafgaand verlof noodig, om door de drukpers gedachten of gevoelens te openbaren, behoudens ieders verantwoordelijkheid volgens de wet" (vgl. het huidige art. 7 lid 1 Gr.w.). Toen de 26 -jarige letterzetter en boekbinder Arnold Langerak, zoals in het ambtsedig opgemaakte proces-verbaal van de veldwachter was te lezen, "op 8 Februari 1892, des namiddags ten omstreeks $11 \frac{1}{2}$ uur, op de openbare straat, de Groote Markt te 's-Gravenhage, zonder vergunning van den burgemeester dier gemeente gedrukte biljetten aan de voorbijgangers aanbood", ontsloeg de Kantonrechter hem - met een beroep op art. 7 Gr.w. - van alle rechtsvervolging. ${ }^{8}$ Het Haags ventverbod miste, 
volgens hem, "als in strijd met art. 7 der Grondwet bindende kracht". Dat grondwetsartikel bracht immers mee:

$" 1^{\circ}$. dat de Grondwet geene preventieve maatregelen, maar slechts repressieve maatregelen toelaat ten aanzien van de openbaarmaking van gedrukte stukken, en $2^{\circ}$. dat die repressieve maatregelen alleen vastgesteld kunnen worden bij de wet."

In hoger beroep, daarentegen, werd Langerak alsnog veroordeeld "tot betaling van eene geldboete van $f 1$,- en in de kosten van het geding, zoo in eersten aanleg als in hooger beroep gevallen, uitvoerbaar ook bij lijfsdwang, gedurende ten hoogste 2 dagen". Volgens de rechtbank was van strijd met art. 7 Gr.w. namelijk geen sprake: er werd geen censuur ingesteld en "de vrijheid om zonder voorafgaand verlof, gedachten of gevoelens door de drukpers te openbaren", werd al evenmin "aangerand". Een ieder bleef, met andere woorden, "vrij zijne denkbeelden door de drukpers te verkondigen, doch (...) alleen bij het venten en verspreiden van drukwerken op de openbare straat (moest hij zich) gedragen naar de maatregelen en voorschriften door de bevoegde macht, den gemeentewetgever, vastgesteld tot handhaving van het onbelemmerd verkeer en de openhare orde op de straat". Daar was, volgens de rechtbank, niets tegen.

De A-G Gregory schaarde zich in cassatie achter het standpunt van de rechtbank en concludeerde tot verwerping van het beroep. ${ }^{10}$ Hij wees erop dat "iemand die door middel van gedrukte biljetten zijn gedachten of gevoelens wenscht(e) te openbaren, dit doen (kon) zoveel en op welke wijze hij wil(de). Hij (kon) die zelfs huis aan huis bij de ingezetenen rondbrengen. De gemeente-verordening (stond) hem daarbij niet in de weg. Alleen (verbood) zij hem, zonder vergunning van den burgemeester, de openbare straat als plaats van openbaarmaking te kiezen. Alzoo niet een inbreuk op het recht dat bij art. 7 der Grondwet aan ieder is gewaarborgd, maar eene bepaling, die dat recht geheel onverlet laat".

Met het daaropvolgende arrest van de Hoge Raad is de cirkel rond: het vonnis van de rechtbank werd vernietigd en dat van de kantonrechter bevestigd (hoewel de Hoge Raad zich van een heel andere redenering bediende, waarover later méer). ${ }^{11}$ Het verbod om, "zonder vergunning van den burgemeester, geschreven of gedrukte stukken op de openbare straat aan te kondigen, te venten, te verspreiden of te koop aan te bieden", was dus toch onverbindend. De verdachte Langerak werd dan ook ten tweeden male ontslagen van alle rechtsvervolging: de grondslag aan de strafbaarheid van het door hem begane feit was immers komen te vervallen. 
Ogenblikkelijk werden er (voor zover ik weet) niet minder dan drie proefschriften aan dit arrest gewijd. Later gevolgd door een onstuitbare reeks andere publikaties en nog veel mér jurisprudentie. Een echt leerstuk - de zogeheten "verspreidingsjurisprudentie" - was geboren! Ook vandaag-de-dag beginnen beschouwingen over art. 7 lid $1 \mathrm{Gr}$.w. nog steeds met het Haags ventverbod. ${ }^{12}$ Geen wonder, want zoals Alkema eens in een noot schreef: "De grondslagen voor de tegenwoordig heersende leer over de drukpersvrijheid zijn al gelegd in een arrest van 1892 (HR 7 november 1892, W. 6259)". ${ }^{13}$ Achterom kijkend is alles klaarblijkelijk tot én punt terug te brengen.

Geldt het orngekeerde evenzeer? Was in 1892 al te voorzien waar de verspreidingsjurisprudentie ons naartoe zou voeren? Dat is nauwelijks voorstelbaar! "The continuation of something never has anything to do with how it began", aldus de hoofdpersoon in een roman van de verbannen Sovjetschrijver Zinoviev. ${ }^{14}$ "Do you remember what our revolution was concocted out of? And how do you think it's progressing now? And if you knew how it would end. you would discover another nhilosonhical trutb: the and is never the culmination of the process of continuation".

Wie terugblikt weet al waar hij uit is gekomen. Daardoor is alles "kloppend" te maken. Alleen de "relevante" stappen behoeven vermelding. Schijnbewegingen kunnen worden weggelaten. Maar wat is relevant? Dat is een kwestie van gezichtspunt. "There can be no history without a point of view", schreef Popper lang geleden ${ }^{15}$; "like the natural sciences, history must be selective unless it is to be choked by a flood of poor and unrelated material".

Het ene gezichtspunt is vruchtbaarder - laat minder onverklaard - dan het andere. Steeds gaat het echter om interpretaties. We interpreteren het verleden. Toekomstige gebeurtenissen moeten uitwijzen of onze zienswijze hout snijdt. Zij vormen het ijkpunt voor wat wij voor het geldend recht houden.

"Vast te stellen, wat feitelijk geldt", aldus F.G. Scheltema in zijn oratie uit 1927, "is een taak, waarvan, schoon de praktijk uiteraard geweldige moeilijkheden oplevert, in abstracto de volbrenging zonder meer denkbaar is". ${ }^{16}$ Mij gaat het hier vooral om die moeilijkheden. Dat de beteugeling daarvan in abstracto "zonder meer denkbaar is", neem ik graag aan. Maar hoe stelt men in concreto vast welke leer de "heersende" is? Donner suggereerde bijvoorbeeld in 1948 dat Van den Bergh's opvatting over het wetsbegrip in art. $7 \mathrm{Gr}$.w. meer gebaseerd was "op een constructie, die onder de jurisprudentie geschoven wordt, dan op de tekst der verschillende arresten zelf" ${ }^{17}$ Bij de eerstvolgende gelegendheid, evenwel, bleek de Hoge Raad 
toch juist de leer van Van den Bergh te huldigen en niet die van Donner! $!^{18}$ Wat moeten we hieruit afleiden? Ik denk: dat we het eenvoudig niet zonder "constructies" kunnen stellen! De tekst van een arrest is "op zichzelf" ontoereikend. Hij moet ergens in passen; we proberen er betekenis aan te geven. En dat geldt voor Donner niet minder dan voor Van den Bergh. Want ook Donner beriep zich niet louter op tekstuele argumenten. Hij verwees met name naar een juridische analyse van Van der Pot. ${ }^{19}$ Het tekstuele verwijt aan Van den Bergh was voornamelijk retorisch van belang. Op die manier werd de suggestie gewekt dat zijn opponent niet eens kon lezen. Even Jater repte hij zelfs van "een constructie, die subjectief aan wet en rechtspraak wordt ten grondslag gelegd, maar die noch hier noch daar in de bewoordingen is terug te vinden". Van den Bergh probeerde ons dus maar wat op te dringen. Zo iemand hoef je niet serieus te nemen... En zo werd de boodschap door de onvermoeibaar polemiserende ${ }^{20}$ Van den Bergh kennelijk ook opgevat. Hij had geen zin er verder nog op in te gaan, "te minder, waar (zijn) argumenten (en het is een opeenstapeling van tientallen argumenten) door collega Donner in zijn artikel niet besproken worden". ${ }^{21}$ Wanneer hij hem tenslotte rechtstreeks toespreekt, zegt hij (lichtelijk vermoeid geraakt): "Ach arme".22

Nou ja, de heren waren klaarblijkelijk niet verrukt van elkaar... De door Donner in diskrediet gebrachte "constructies, die subjectief aan wet en rechtspraak worden ten grondslag gelegd", verdienen het echter om in ere te worden hersteld. We kunnen niet zonder! Tenminste, zolang we erop uit zijn iets van het recht te snappen. De ene keer doen we een gelukkiger greep dan de andere. ${ }^{23}$ In dat opzicht kunnen we elkaar een handje helpen: lukt het $\mathrm{A}$ niet, dan kan ook B een poging wagen. Mér dan subjectieve inzichten kunnen we daarbij niet claimen. Maar dat wil niet zeggen dat we zo niet verder komen. Het hangt er maar vanaf of we bereid zijn onze eigen inzichten prijs te geven zodra daar aanleiding toe bestaat. Bijvoorbeeld als andere mér blijken te kunnen verklaren. Op die manier is er tòch nog iets te objectiveren: niet zozeer de inzichten zelf, als wel de toets waaraan ze worden onderworpen.

In dit boek wil ik - bij wijze van illustratie - nagaan hoe het de verspreidingsjurisprudentie in de eerste honderd jaar is vergaan: wat werd er, op welk moment zoal uit afgeleid en in hoeverre had zij zelf aanleiding gegeven tot die gevolgtrekkingen? Hoe luidde, kortom, de "heersende leer", en hoe ging de ene heersende leer over in de volgende? Het is - zoals met vrijwel alles - een geschiedenis van gissingen, illusies, "wishful thinking", leesfouten, drogredenen, vergeetachtigheid, gebrekkige verbeeldingskracht, te snelle redeneringen en koele calculaties. Zoals wel vaker in het recht, is niet 
altijd even duidelijk of het gaat om pogingen tot beschrijving, dan wel om pleidooien over wenselijkheden. Laat ik in elk geval proberen die twee enigszins uit elkaar te houden.

Veel meer dan een indruk van de gang van zaken zal ik wel niet kunnen geven. De heersende leer bestaat immers niet, en heeft ook nooit bestaan. De crux van het hele rechtsbedrijf is dat er telkens verschil van opvatting bestaat. Het is onmogelijk een ieder aan het woord te laten. Ik heb me - aan de hand van de courante literatuur - tot de meest in het oog lopende auteurs beperkt, en dat waren er al een heleboel. Daarnaast heb ik een cumulatieve lijst met rechterlijke uitspraken, conclusies, annotaties en schorsings- en vernietigingsbesluiten aangelegd. En dan nog: het is allemaal maar het topje van de ijsberg. De meeste opvattingen worden nu eenmaal nooit opgeschreven, en voor zover ze al worden opgeschreven gaat het vermoedelijk vooral om afwijkende opvattingen. Vanzelfsprekendheden - of in elk geval wat daarvoor doorging - zullen wel helemaal nooit aan het licht komen; anders spraken ze niet vanzelf!

Wel werpt het door mij verzamelde materiaal, naar mijn idee, een aardig licht op de totstandkoming van een leerstuk. Zoiets gaat stapje voor stapje. Er ligt geen "totaalvisie" aan ten grondslag. Steeds komen er nieuwe aspecten in beeld. Van geval tot geval worden oplossingen gezocht. Onderwijl getroost de doctrine zich de grootste moeite het nieuwe in te passen in datgene wat al bekend was. En ook de rechtspraak wekt soms de indruk dat alles min of meer logisch voortvloeit uit het voorgaande. ${ }^{24}$ Alsof ieder denkbaar probleem reeds in een eerder stadium onder ogen was gezien! Zelfs de "wil van de wetgever" komt er zo nu en dan aan te pas. ${ }^{25}$ Alweer is de gedachte klaarblijkelijk dat niets aan de aandacht van de wetgever - die gemakshalve als persoon wordt behandeld - is ontsnapt.

Maar hoe gaat dat realiter bij wetgeving? "De vrijheid van beroepskeuze", aldus J. d'Aulnis de Bourouill in een Themis-artikel uit $1895^{26}$, "de vrijheid van vestiging en verhuizing, de vrijheid van huwelijkskeuze, de vrijheid van handeldrijven, zij zijn nergens door de wet bepaald, omdat men bij het maken der wet zich niet kon voorstellen dat zij ooit zouden worden bedreigd." Of, zoals Buys het uitdrukte: "Onze kostbaarste en best gewaarborgde vrijheden zijn misschien die, welke de Grondwet stilzwijgend voorbijgaat". ${ }^{27}$ Geen wonder dat de Wet op het specifieke Welzijn van Elfen en Tovernimfen (WsWET) en de Aardmannetjes- en Koboldenwet (A en KW), waar Jurgens eens van repte ${ }^{28}$, in werkelijkheid nooit tot stand zijn gekomen. Eerst moet iemand op de gedachte komen zo'n wet te maken. En zolang er geen problemen in het vizier zijn, is die kans niet groot.

Rechtsvorming door de wetgever verschilt in dat opzicht nauwelijks van rechtsvorming door de rechter, vermoed ik. Beiden - zowel de wetgever als 
de rechter - komen pas in actie als hun iets is voorgelegd. Dat maakt het juist zo moeilijk hun uitspraken te interpreteren met het oog op kwesties die nog niet hun aandacht hebben getrokken. Toch komt het dáár op aan in de juristerij. Hoe dat - toegespitst op de rechtspraak - uitpakt, en hoe de verschillende stadia vervolgens aan elkaar worden "geplakt", is het onderwerp van dit boek. Dat mijn visie op wetgeving als reactief verschijnsel consequenties heeft voor mijn opvattingen over rechtsvinding (en de rol van rechters daarbij) ligt voor de hand. Maar daarover een volgende keer. ${ }^{20}$ 



\section{Hoofdstuk 1 Vestiging van het leerstuk}

\subsection{Eerdere beslissingen}

Sprak het vanzelf dat Arnold Langerak in november 1892 door de Hoge Raad werd ontslagen van alle rechtsvervolging? De rechtbank had hem op 30 mei nog veroordeeld. ${ }^{1}$ En ook de advocaat-generaal zag geen reden om niet tot een veroordeling te komen. ${ }^{2}$ In zijn conclusie ging hij onder meer in op een soortgelijke Belgische zaak die al op 18 januari van dat jaar was beslist - dus nog vórdat onze verdachte zijn fatale daad beging. Dankzij het Weekblad van het Recht van 8 juni (no. 6185) was die beslissing in Nederland tijdig onder de aandacht gebracht. ${ }^{3}$

Het ging daarbij om de gemeente Eecloo. Daar gold een verbod om "sans une permission préalable du bourgmestre" op de openbare weg "des écrits, journaux ou tous autres écrits, quelconques" te koop aan te bieden, rond te brengen of uit te delen; volgens het Belgische Hof van Cassatie was dat niet ongrondwettig. Daarmee werd de lijn die al in 1886 was ingezet gecontinueerd. Toen was een soortgelijk verbod van de gemeente Wetteren al evenmin strijdig bevonden met de grondwet, want: "Ia liberté illimitée de vendre des écrits imprimés sur la voie publique n'est nullement un corollaire de la liberté de la presse". En: "les ordonnances de police peuvent, en effet, prendre les dispositions nécessaires non seulement pour dissiper les rassemblements, mais aussi pour les prévenir et assurer la liberté de la circulation". ${ }^{4}$ Zolang het bij een dergelijk "règlement" maar om "le maintien de l'ordre" ging, was er - grondwettelijk beschouwd - niets op aan te merken, aldus het hof. ${ }^{5}$ Of er vooraf dan wel achteraf werd ingegrepen, was hooguit een kwestie van opportuniteit; het oordeel daarover was aan de Koning, niet aan de rechter. Immers, zo oordeelde het hof in 1892: aan de Koning kwam - met het oog op een eventueel besluit tot vernietiging - het exclusieve recht toe "de juger si les mesures préventives établies par un règlement communal sont nécessaires pour assurer l'ordre dans les rues et places publiques, ou si, malgré une apparence contraire, elles sont en réalité prises dans le but de restreindre l'usage de la liberté de la presse et d'exercer sur celle-ci une sorte de censure". 6

Dat de Belgische Koning daar inderdaad werk van maakte, was kort tevoren (op 8 augustus 1891) gebleken uit een brief van de minister van Binnenlandse Zaken en de gouverneur van Oost-Vlaanderen. Het Weekhlad van het Recht vond het "wellicht niet zonder belang" er ook in Nederland aandacht 
voor te vragen en drukte de "missive" af in het nummer van 16 oktober 1891 (no. 6084):

"La liberté de la presse", aldus de minister, "(...) a pour corollaire le droit de colporter, distribuer et vendre les livres, journaux et autres imprimés. Il faut donc considérer comme inconstitutionnels, les règlements communaux qui tendraient à subordonner à une autorisation du bourgmestre la vente sur la voie publique des livres et des journaux. L'autorité communale ne peut intervenir, à cet égard, que dans des cas spéciaux et exceptionnels, intéressant l'ordre, la tranquilité et la securité publics (...) ou encore pour empêcher les entraves à la libre circulation".

Wat opvalt, is dat in deze brief duidelijk afstand werd genomen van het standpunt dat eerder (in 1886) door het Hof van Cassatie was verkondigd. Toen heette het nog dat "la liberté illimitée de vendre des écrits imprimés sur la voie publique n'est nullement un corollaire de la liberté de la presse". Volgens de minister was er juist wel sprake van zo'n "corollaire". toch was zijn brief niet in tegenspraak met het arrest. Hij had het immers niet over "la liberté illimité de vendre". Waarom zou hij ook? Een dergelijke onbegrensde vrijheid werd door niemand geclaimd. Zelfs in 1886 al niet! Het hof had zich destijds duidelijk overschreeuwd. ${ }^{7}$ En de formule werd in 1892 dan ook niet herhaald. Zelf wilde het hof zijn neus echter nog steeds niet steken in dit soort zaken. In principe werd alles doorgeschoven naar de Kroon. lets dergelijk is ook wel voor Nederland bepleit. Van Riemsdijk Kreenen schreef bijvoorbeeld in 1895 :

"'Maar die verordeningen leiden tot censuur', roept men - zeker, daar kunnen zij toe leiden, indien men ze verkeerd gaat toepassen. Ik stem toe dat eene verkeerde toepassing zeer licht mogelijk is. Misschien zijn sommige verordeningen wel gecreëerd met het oogmerk om ze verkeerd toe te passen. Maar daarom zijn die verordeningen zelve nog niet ongrondwettig, en de rechter had ze daarom niet in strijd met de grondwet mogen verklaren. Het kan een reden zijn voor de administratie om te vernietigen."

\subsection{Het arrest van 1892}

De Hoge Raad koos voor een heel andere benadering. Laat ik de belangrijkste passages van het overbekende arrest - voor het gemak - nog even in de herinnering oproepen. Het is een lang verhaal, maar we zullen het nog bij herhaling nodig hebben. De Hoge Raad overwoog: 
"dat reeds in de inleiding der acte van staatsregeling voor het Bataafsche volk van 1798 de vrijheid van drukpers door een grondwettelijk voorschrift werd gewaarborgd;

dat immers art. 16 dezer inleiding luidde: "Ieder burger mag zijne' gevoelens uiten en verspreiden op zoodanige wijze als hij goedvindt, des niet strijdig met het oogmerk der Maatschappij. De vrijheid van drukpers is heilig, mits de geschriften met den naam van Uitgever, Drukker of Schrijver voorzien zijn. Dezen allen zijn, ten allen tijde, aansprakelijk voor alle zoodanige bedrijven door middel der drukpers, ten aanzien van afzonderlijke personen of der gansche maatschappij, begaan, die door de wet als misdadig erkend zijn";

dat een voorschrift van gelijke strekking niet voorkwam in de staatsregelingen der Bataafsche Republiek van 1801 en 1805 en in de constitutie van het Koninkrijk Holland van 1806;

dat na de inlijving van dit Koninkrijk in het Fransche Keizerrijk hier te lande werd executoir verklaard het Keizerlijk Decreet van 5 Febr. 1810, contenant réglement sur l'imprimerie et la librairie (Bulletin des lois, no. 264), dat, onder andere preventieve maatregelen ter beteugeling van de vrijheid van drukpers, ook in de artt. 10 tot 20,21, 23 en volgende erkende en regelde de staatscensuur;

dat reeds spoedig na het herstel van Nederlands onafhankelijkheid bij Besluit van den Souvereinen Vorst van 24 Jan. 1814 (Stbl. no. 17), in art. 4 erkennende ieders verantwoordelijkheid voor hetgeen hij schrijft, drukt of uitgeeft, gelijktijdig met voormeld decreet, in art. 1 werden afgeschaft alle andere Fransche wetten en reglementen, betrekkelijk de boekdrukkerij en den boekhandel, daaronder begrepen die welke de nieuwspapieren betreffen, uit overweging dat die wetten en reglementen "niet alleen in den boekhandel eene zeer nadeelige stremming veroorzaakten, maar eene strekking hadden om de vrijheid van drukpers volkomen te onderdrukken, den voortgang van de verlichting te beletten en alles te onderwerpen aan eene willekeurige censuur, ten eenemale strijdig met de liberale denkwijze, waarop elk regtgeaard Nederlander ten hoogsten prijs stelt, en die steeds het gouvernement dezer lande heeft gekenschetst";

dat echter deze vrijmaking der drukpers van alle preventieve maatregelen niet werd uitgedrukt in de Grondwet der Vereenigde Nederlanden van 29 Maart 1814, maar dat zij voor het eerst na 1798 weder door de hoogste staatswet uitdrukkelijk werd erkend in art. 227 der Grondwet voor het Koninkrijk der Nederlanden van 1815, in hoofdzauk bepalende, dat het aan een elk geoorloofd is zijne gedachten en gevoelens door de drukpers, als een doelmatig middel tot uitbreiding 
van kennis en voortgang van verlichting, te openbaren zonder eenig voorafgaand verlof daartoe noodig te hebben, behoudens elks verantwoordelijkheid voor hetgeen hij schrijft, drukt, uitgeeft of verspreidt; dat dit voorschrift bij de grondwetsherziening van 1848 uit het $10 e$ Hoofdstuk: "van het onderwijs en het armbestuur" als art. 8 is overgegaan in het lste Hoofdstuk: "van het rijk en zijne inwoners" in strekking geheel onveranderd, maar in gewijzigden en beknopter vorm, omdat de regeering meende, "dat wanneer het geldt de vestiging van een beginsel van vrijheid, behoudens verantwoordelijkheid, zooals dit het geval is met de vrijheid van drukpers, bij eene Grondwet het voorgestelde denkbeeld niet eenvoudig genoeg kan worden uitgedrukt, opdat bijvoegingen tot geene verkeerde gevolgtrekkingen leiden";

dat eindelijk art. 8 der herziene Grondwet van 1848 (nu art. 7) bij de herziening van 1887 geheel ongewijzigd bleef;

O. dat kan worden toegegeven, dat dit grondwettelijke voorschrift, beschouwd in het licht zijner geschiedenis, bepaaldelijk met het oog op de beweegredenen van het Besluit van 24 Jan. 1814 (Stbl. no. 17), de staatscensuur, zooals deze met het Fransche Decreet van 5 Febr. 1810 hier te lande was ingevoerd, in de eerste plaats wraakt, maar dat die geschiedenis - onmiskenbaar getuigende van des wetgevers bedoeling om, behoudens ieders verantwoordelijkheid voor hetgeen op zijn last of met zijn toedoen door middel van de drukpers is geopenbaard, die openbaring zelve niet door preventieve maatregelen te belemmeren - geen grond geeft om het voorschrift tot die uitsluiting te beperken, terwijl de woorden, waarin het is vervat, ongetwijfeld verder reiken:

dat toch art. 7 der geldende Grondwet bepaalt, dat niemand voorafgaand verlof noodig heefi om door de drukpers gedachten of gevoelens te openbaren, behoudens ieders verantwoordelijkheid voor de wet, zoodat ook nu nog geldt het in de staatsregeling van 1798 gehuldigde en in de oorspronkelijke Grondwet van 1815 eveneens erkende beginsel, dat-terwijl allen, die medewerken tot de openbaarmaking van gedrukte geschriften of deze bevorderen, daarvoor verantwoordelijk zijn volgens door de strafwet en de burgerlijke wet te stellen regels - die openbaarmaking zelve niet door preventieve maatregelen mag worden belet;

dat daardoor niet alleen wordt uitgesloten de censuur, noodig ter verkrijging van het verlof om een tot openbaarmaking bestemd geschrift te drukken of te doen drukken, maar evenzeer het "voorafgaand verlof" van het openbaar gezag om een gedrukt geschrift, en bijgevolg wat daarin is gedrukt, door het te verspreiden, openlijk ten 
toon te stellen of aan te slaan of wel door eenig ander middel, openbaar te maken; onverminderd de bevoegdheid van den gemeentelijken wetgever om de verspreiding van een gedrukt geschrift op de openbare straat, zonder haar in het algemeen te verbieden of van een voorafgaand verlof der overheid afhankelijk te stellen, te onderwerpen aan voorschriften in het belang der openbare orde, bepaaldelijk ter beveiliging van het openbaar verkeer;

dat derhalve met de Grondwet in strijd is art. 11a der Alg. Pol. Verord. voor 's Gravenhage, houdende volstrekt verbod om, zonder vergunning van den burgemeester, gedrukte stukken op de openbare straat aan te kondigen, te venten, te verspreiden of te koop aan te bieden; zoodat dit art. verbindende kracht mist;

$\mathrm{O}$. dat hiertegen te vergeefs zoude worden aangevoerd, dat, waar de Pol. Verord. de openbaarmaking van gedrukte stukken door bepaalde middelen op de openbare straat afhankelijk stelt van voorafgaand verlof van den burgemeester, de openbaarmaking zonder zoodanig verlof kan plaats hebben elders of wel door andere middelen, zoodat zij uit kracht der Pol. Verord. niet geheel kan worden belet;

dat toch, waar de Grondwet in zeer algemeene termen verbiedt de openbaarmaking van gedachten of gevoelens door de drukpers afhankelijk te stellen van een voorafgaand verlof, dat verbod geldt voor alle middelen van openbaarmaking zoowel op de openbare, voor iedere toegankelijke straat als op alle andere plaatsen; dat dan ook, nam men het tegendeel in strijd met de duidelijke en algemeene woorden der Grondwet aan, niets gemakkelijker zoude vallen dan het grondwettelijke voorschrift door verschillende bepalingen in rijkswetten en gemeenteverordeningen, ieder op zich zelve beperkt tot enkele daarbij aangewezen middelen van openbaarmaking, geheel te verijdelen."

\subsection{De ontvangst van het arrest}

De wetshistorische onderbouwing van dit resultaat valt niet uit de toon van hetgeen destijds - en feitelijke tot ver in de twintigste eeuw - gebruikelijk was. Krabbe beschreef de gang van zaken in 1899 als volgt: "Op het gehied van het privaatrecht is ten lange leste de wet, zoals $z i j$ spreekt als eenig richtsnoer erkend; maar in het administratieve recht kaatst men, bij de uitlegging der wet, elkaar nog altijd de boekdelen toe, waarin de geboorteweën der wet verzameld zijn". ${ }^{10}$ En Kamphuisen klaagde zelfs in 1933 nog over "de overschatting van het gewicht van de woorden der wet" en "de 
voorkeur van het staatsrecht voor grammaticale en wetshistorische interpretatie". ${ }^{11}$

Aardig is in dit verband vooral de ironische constatering van Vos - in 1897 , toen de Hoge Raad inmiddels twee andere verspreidingszaken in dezelfde zin had beslist ${ }^{12}$ - "dat de geschiedenis van art. 7 der Grondwet den Hoogen Raad steeds duidelijker wordt". ${ }^{13}$ In 1892 werd nog overwogen "dat kan worden toegegeven, dat dit grondwettelijke voorschrift, beschouwd in het licht zijner geschiedenis, (...), de staatscensuur, zooals deze met het Fransche Decreet van 5 Feb. 1810 hier te lande was ingevoerd, in de eerste plaats wraakt, maar dat die geschiedenis (...) geen grond geeft (curs. Vos) om het voorschrift tot die uitsluiting te beperken, terwijl de woorden, waarin het is vervat, ongetwijfeld verder reiken". Op 23 maart 1896 heette het "dat deze uitlegging der hier in aanmerking komende grondwetsbepaling, voortvloeiende uit de woorden waarin zij is vervat, steun vindt (curs. Vos) in hare geschiedenis". En op 1 november 1897 bleek opeens "dat door de woorden van dit artikel der Grondwet, geheel in overeenstemming met (curs. Vos) zijne geschiedenis, niet alleen wordt uitgesloten de censuur, (...) maar evenzeer het 'voorafgaand verlof' van het openbaar gezag om een gedrukt geschrift en bijgevolg wat daarin gedrukt is, op welke wijze dan ook, openbaar te maken".

Helemaal eerlijk was Vos helaas niet. Ook in 1892 al repte de Hoge Raad immers (zoals hierboven is na te lezen) van een wetsgeschiedenis "onmiskenbaar getuigende van den wetgevers bedoeling (curs. RdW) om, behoudens ieders verantwoordelijkheid voor hetgeen op zijn last of met zijn toedoen door middel van de drukpers is geopenbaard, die openbaring zelve niet door preventieve maatregelen te belemmeren". Alleen, die zinsnede werd door Vos niet aangehaald. Toeval? Misschien had hij er gewoon overheen gelezen, zoals dingen die niet met onze zienswijze stroken ons wel vaker ontgaan. Volgens Vos deugde dat historische verhaal namelijk van geen kant! ${ }^{14}$ En die gedachte werd natuurlijk alleen maar bevestigd door de waarneming dat de Hoge Raad er met het verstrijken van de tijd en het afnemen van de argumentatie steeds stelliger op werd. Daar kon geen serieuze wetenschap achter schuilgaan! De Hoge Raad probeerde ons eenvoudig wat wijs te maken, moet hij gedacht hebben. Vandaar dat hij er de draak mee stak en zich 'en passant' aardig in de kaart liet kijken. Of ben ik nu unfair tegen hem?

Hoe dan ook, volgens Vos moest men niet alleen om grammaticale redenen "tot de slotsom (...) komen dat de Hooge Raad in het art. meer leest dan er in te lezen staat", ook uit de wetsgeschiedenis van art. 7 (lid 1) Gr.w. bleek volgens hem "zoo ondubbelzinnig mogelijk dat bij de samenstelling van dit 
art. geen andere bedoeling heeft voorgezeten dan deze: in de Grondwet te handhaven het verbod, reeds uitgesproken bij Souv. Besl. v. 24 Jan. 1814, om voor het vervolg terug te keeren tot dat preventieve toezicht op de drukpers, dat bekend stond onder den naam van censuur en hier onder het Fransche bestuur gegolden had". ${ }^{15}$ Daarmee sloot hij aan bij de visie van Buys, die in 1883 het volgende had betoogd:

"levert onze Grondwet nu een voldoenden waarborg op, dat die vrijheid van drukpers (...) duurzaam aan het nederlandsche volk zal toebehooren, althans zoolang de Grondwet geldt? Zeker niet! Ons artikell verbiedt wat in den tegenwoordigen tijd bij beschaafde volken zich zelf verbiedt, namelijk wederinvoering van de censuur, en niets meer". ${ }^{16}$

Westra van Holthe ${ }^{17}$, Graevestein van Heyst ${ }^{18}$ en Van Riemsdijk Kreenen $^{19}$, die in de jaren 1893-1895 alle drie hun proefschrift aan dit arrest wijdden, huldigden dezelfde opvatting.

Vanwaar die zekerheid? Op Buys na beriepen ze zich allemaal op een korte passage (die telkens opnieuw integraal werd geciteerd) uit Van Maanens Aanteekeningen van het verhandelde over de Grondwet van $1815 . .^{\circ}$ Daaruit bleek, naar hun oordeel, in de eerste plaats dat het toenmalige art. 7 Gr.w. louter en alleen dankzij de Belgen is opgenomen. Van Hogendorp vond aanvankelijk dat opname van het beginsel van de vrijheid van drukpers "nodeloos is, als facto bestaande". "Ja, wel bij u", aldus het Belgische commissielid B.J. Holvoet, "maar niet bij ons, alwaar zij nooit bestaan heeft, en censure is geweest". Van Maanen wees in verband hiermee op het Soeverein Besluit van 24 januari 1814, waarin deze "materie" - met name in "de premissen" - werd behandeld, "en dat wel op eene zeer liberale wijze". De Soevereine Vorst overwoog destijds (zoals hierboven ook al uit het arrest van de Hoge Raad bleek):

"dat de Wetten en Reglementen aangaande de Boekdrukkerij en Boekhandel, door het Fransch Bestuur in deze Gewesten ingevoerd, niet alleen in den Boekhandel eene zeer nadeelige stremming veroorzaakten, maar ook eene strekking hadden, om de vrijheid der drukpers volkomen te onderdrukken, den voortgang van de verlichting te beletten, en alles te onderwerpen aan eene willekeurige censuur, ten eenenmale strijdig met de liberale denkwijze, waarop elk regtgeaard Nederlander den hoogsten prijs stelt, en die steeds het Gouvernement dezer Landen heeft gekenschetst". ${ }^{21}$

Van Hogendorp gaf vervolgens "in bedenking om de beginselen van 't besluit door van Maanen geciteerd, als artikel over te nemen". En dan luiden de aantekeningen van Van Maanen aldus: 
"Gendebien: men verwacht iets van dien aard.

de Mean, Dotrenge: ita, het is genoeg te bepalen, dat: er geene praeallabele censure zal plaats hebben.

Lijnden meent, dat vermits er wetten zijn over die materie, het nodeloos is dat er de Constitutie over spreke.

Van Maanen: juist omdat er die wetten zijn, vinde ik er minder zwarigheid in; - men heeft dus slechts te volgen het geen bestaat, en daar het in Belgie genoegen zal geven, stem ik voor.

En wordt dienvolgende geconcludeerd (...)"

Well blijken zeven leden van de commissie tegen te hebben gestemd - waaronder nota bene de eerdergenoemde De Méan, die in al die geschriften uit de jaren ' 90 van de vorige eeuw juist (samen met Dotrenge) als getuige werd opgevoerd voor de stelling dat het in art. $7 \mathrm{Gr}$.w. slechts om een censuurverbod ging! Daar werd echter destijds - in de jaren '90 - nooit melding van gemaakt.

Voert één en ander inderdaad "ondubbelzinnig" (zoals Vos het uitdrukte) tot de conclusie dat de Hoge Raad in 1892 gejokt heeft? Was de lezing van de Hoge Raad - om met. Westra van Holthe te spreken - "lijnrecht in strijd met de bij de behandeling van de Grondwet van 1815 uitgesproken woorden"? 22 Laat ik even voorbijgaan aan de vraag of datgene wat ooit binnenskamers door de ontwerpers van een wettekst is besproken - voor zover dat na ruim zeventig jaar is te reconstrueren aan de hand van toevallig gepubliceerde aantekeningen van slechts één van de gespreksgenoten - überhaupt kan dienen ter legitimatie van welke wetsinterpretatie dan ook. ${ }^{23}$ Ook afgezien daarvan lijkt de bewijsvoering niet echt dwingend. "Wij willen er alleen dit van zeggen", aldus een niet-ondertekende (redactionele?) bijdrage in het Weekblad van het Recht op 4 januari 1895, "dat de uit de "Aanteekeningen" aangehaalde plaatsen slechts aantoonen, dat - wat de H.R. reeds toegaf - art. 227 Gr.w. 1815 (vgl. het huidige art. 7 lid 1 Gr.w., RdW), beschouwd in het licht zijner geschiedenis, in de eerste plaats wraakt de Fransche censuur, maar volstrekt niet, dat het artikel volgens zijn onmiskenbare bedoeling aan alle andere censuur op de voortbrengselen der pers vrij spel zoude laten" ${ }^{24}$ En inderdaad, zo kan het verhaal $60 \mathrm{k}$ worden uitgelegd.

Feitelijk is het enige wat "vaststaat", dat de verspreidingsproblematiek in 1815 eenvoudig niet aan de orde is geweest. Moet daaruit worden afgeleid dat die kwestie dus niet onder de vrijheid van drukpers kan worden gevat? Dat hoeft niet. Het hangt er maar van af in welk perspectief je de geschiedenis wilt plaatsen. Er zijn.verschillende aanknopingspunten en waarom zou het ene beter zijn dan het andere? Beslissend is de geschiedenis in elk. geval niet. Vandaar misschien dat de Hoge Raad in het arrest over het Haags vent- 
verbod niet met die geschiedenis volstond. Enerzijds was er, volgens de Hoge Raad, historisch gesproken geen grond om art. $7 \mathrm{Gr}$.w. slechts als verbod op censuur te lezen, anderzijds reikten de woorden, "waarin het is vervat, ongetwijfeld verder".

Vos, daarentegen, vond

"dat uit een bloot taalkundig oogpunt de daad van het door de drukpers openbaren van gedachten is afgelopen met de daad van het drukken zelf en het ter kennis brengen van wien dan ook van dat gedrukte, zoodat als essentiëel bestanddeel van dat "openbaren door de drukpers" moet worden aangemerkt al wat noodzakelijk is om die gedrukte stukken ter kennis te brengen van wien dan ook, zooals het aan huis bezorgen bij de ingezetenen, het verkrijgbaar stellen aan de drukkerij en in winkels, maar dat daarbuiten valt al wat wellicht bevorderlijk, maar niet noodzakelijk is om die gedrukte stukken ter kennis van iedier te brengen. Dat nu onder dat 'essentiëele' van dat openbaren niet valt het op de openbare straat te koop loopen met gedrukte stukken, komt mij niet twijfelachtig voor. Men vergete niet dat de Grondwet niet uitsluit een voorafgaand verlof om gedachten te openbaren door welk middel dan ook, maar 'door de drukpers te openbaren' en van dit laatste middel van openbaren vormt het op de publieke straat te koop loopen met gedrukte stukken geen bestanddeel." 25

Het lijkt erop dat Vos zich heeft laten inspireren door het proefschrift van Simons uit $1883 .^{26}$ Daarin werd een onderscheid gemaakt tussen enerzijds de "eerste verspreider" (de uitgever), die er zorg voor draagt dat een stuk wordt gepubliceerd (dat wil zeggen dat "het publiek kennis kan nemen van den inhoud van 't gedrukte"), en anderzijds "de verspreiding als op zichzelf staande handeling" (vgl. art. $271 \mathrm{Sr}$ ). Dat lijkt nogal op het verschil tussen noodzakelijk en bevorderlijk: de activiteiten van de "eerste verspreider" vormen immers een noodzakelijke voorwaarde, wil het publiek kennis kunnen nemen van het drukwerk, terwijl de overige verspreidingshandelingen hoogstens ter vereenvoudiging van die kennisname dienen. ${ }^{27}$

Van Riemsdijk Kreenen wees - behalve op de wetsgeschiedenis - ook op de gebeurtenissen van 1830. Waarom, vroeg hij, zouden de Belgen destijds een decreet hebben uitgevaardigd "pour faire disparaitre les entraves, par lesquelles le pouvoir avait jusque là enchainé la presse dans son expression, sa marche, et ses développements"? Volgens hem omdat "ook de Belgen van oordeel waren, dat slechts de censuur door ons grondwetsartikel werd uitgesloten. Immers anders hadden zij willen 'faire disparaitre ces entraves' door een artikel op te stellen, dat hetzelfde behelsde als hetwelk zij afschaffen". 28 
Tja, dat is natuurlijk niet, onmogelijk. Maar echt dwingend is die verklaring toch niet. Er zijn nog wel andere "verklaringen" te verzinnen voor de gang van zaken na de Belgische afscheiding. Alle historische argumenten dienden dan ook - dat denk ik tenminste - vooral ter aankleding van een (destijds) veel dwingender idee, te weten: het primaat van de openbare orde. Alles werd daaraan ondergeschikt gemaakt. "Ordnung führ zu allen Tugenden! Aber was führt zur Ordnung?", had Lichtenberg een eeuw eerder al eens gevraagd; zijn boodschap was klaarblijkelijk nog niet aangekomen. "Het is de plicht van den gemeenteraad", schreef Westra van Holthe ${ }^{29}$, "te waken voor de openbare orde; hij ziet die orde bedreigd en zou niet in staat zijn in haar belang maatregelen te nemen? Eene dergelijke inconsequentie kan men bij den wetgever niet veronderstellen"'. Vandaar dat het Haags ventverbod, naar zijn mening, door de beugel kon.

Dat met de verspreiding van drukwerk wellicht iets omzichtiger moest worden omgesprongen dan met andere handelswaar en vermakelijkheden, sprak klaarblijkelijk nog niet vanzelf:

"Meent de Raad", aldus $\operatorname{Vos}^{30}$, dat de openbare orde en veiligheid langs den publieken weg gevaar loopt door het rondventen van gedrukte stukken, hij is bevoegd daarop regelen te stellen, gelijk hij morgen bevoegd is, zoo hij dit noodig acht, in het belang der openba re gezondheid omtrent het rondventen van vruchten of andere eetwaren voorschriften te geven. Eene belemmering der vrijheid van drukpers zijn deze regelen even zoo weinig als die andere voorschriften zijn eene belemmering van de vrijheid om op zijn land vruchten te teelen". Of, om met Graevestein van Heyst ${ }^{31}$ te spreken:

"Niemand heeft geloof ik ooit betwijfeld, dat de overheid het recht had, de ingezetenen tegen dien overlast te beschermen, waar het geldt draaiorgels of het venten van waren, en waarom zouden de verspreiders of venters van gedrukte stukken in dat opzicht geprivilegeerd zijn?"

Het conflict tussen de vrijheid van de én en die van de ander werd als het ware op Hobbesiaanse wijze opgelost:

"Geen onaantastbaarheid, maar eene gezonde vrijheid heeft (de drukpers) noodig orn hare hooge roeping naar eisch te vervullen", aldus Van Riemsdijk Kreenen ${ }^{32}$. "Maar die vrijheid; die hebben wij immers allen. We zijn immers allen vrije staatsburgers, en toch zal het. bij niernand onzer opkomen te beweren, dat hij zich, wanneer hij op straat verschijnt, niet behoeft te storen aan de maatregelen, in het belang der openbare orde, door het bevoegd gezag genomen. Waarom zou dan de vrije pers, wanneer zij op straat verschijnt, zich niet aan die maatregelen moeten onderwerpen? Omdat zij zich verschuilen kan 
achter artikel 7 der Grondwet? Daarvoor staat toch onze Grondwet, het bolwerk onzer vrijheid, te hoog, dat zij zich daartoe zou leenen! Onze meest onschatbare vrijheden zijn in haar nedergelegd, maar het is ook slechts de vrijheid, welke zij beschermt, en nooit late men haar dienen tot schild voor wanorde en bandeloosheid".

Met een dergelijk uitgangspunt waren alle problemen op voorhand uit de weg geruimd. De weg naar overdrijvingen stond echter wijd open. Dat de Hoge Raad met zijn arrest "wanorde en bandeloosheid" had gelegitimeerd, sprak bijvoorbeeld op z'n minst niet vanzelf. Straks mér daarover.

Een heel andere, feitelijk tegengestelde benadering werd bepleit door d'Aulnis de Bourouill. ${ }^{33}$ Velen redeneerden, stelde hij, "aldus: mits eene verordening maar gemaakt wordt in het belang der openbare orde, enz. mag de Raad alles bepalen wat hij wil. (...) In één woord: die zorg voor de openbare orde enz. is in veler oog le bon motif, dat alles dekt en met hetwelk alles goed gemaakt wordt. Met die redeneering ben ik het oneens. Het motief eener gemeenteraadsverordening is mijns inziens volkomen onverschillig. Het komt aan op den materieelen inhoud der bepalingen". En wat was nu het geval? Met dat Haagse verspreidingsverbod werd de vrijheid "verkort van openbaarmaking van gedachten of gevoelens door middel van de drukpers". In zoverre was hij het volkomen eens met de Hoge Raad. Maar vervolgens ging hij nog een stapje verder:

"(M)en erkenne het liever ronduit. De openbaarmaking van gedachten en gevoelens door middel van de drukpers is gevrijwaard tegen preventieve bepalingen en de aansprakelijkheid voor de openbaarmaking moet rusten op de wet. $\mathrm{Zij}$ is Rijksbelang geacht. Het treft nu voor de hierbedoelde gemeenteraden wel heel ongelukkig, dat zij met hun goede bedoelingen de Grondwet op hun weg vinden; maar ik zie, juist in deze materie der drukpers, geen grond voor belangrijken twijfel".

In feite deelde d'Aulnis de Bourrouill dus het standpunt van de kantonrechter in die Haagse zaak. De verspreiding van drukwerk was, volgens hem, voor gemeenten op zichzelf volstrekt onaantastbaar. Hoogstens konden zij zich tegen de kwalijke randverschijnselen richten, waarmee die verspreiding soms gepaard ging. Een - naar zijn idee geslaagde - poging daartoe had hij in de Utrechtse APV aangetroffen: "Hij, aan wien bij eene volksverzameling op den openbaren weg door de politie gelast wordt zich uit de volksverzameling te verwijderen, is verplicht aan dien last onmiddellijk te voldoen".

Niet alle reacties op het arrest waren overigens afwijzend. De al eerder genoemde - redactionele? - bijdrage in het Weekblad van het Recht van 4 
januari $1895^{34}$ was ronduit positief. Tegenover de visie van Buys en Vos - art. $7 \mathrm{Gr}$.w. behelst louter een censuurverbod - stelde het Weekblad: "indien aan art. $7 \mathrm{Gr}$.w. (...) deze enge en benepen uitlegging moet worden gegeven, dan schenkt het alleen de vrijheid on alles te drukken wat men goedvindt, doch dan laat het verder den censuur vrij spel in alles wat op het drukken volgt om het gedrukte openbaar te maken, op den weg van de drukkerij naar den colporteur, maar dan ook op den weg van de drukkerij naar den uitgever en van den uitgever naar den boekhandelaar of andere verspreiders". ${ }^{35}$

Inderdaad! Buys-zelf had zich vermoedelijk geheel kunnen vinden in deze kritiek (afgezien van de kwalificaties "eng" en "benepen"). "Levert onze Grondwet nu", vroeg hij, "een voldoende waarborg op, dat die vrijheid van drukpers, welke (...) in ons regeeringsstelsel eene zoo groote plaats inneemt, duurzaam aan het nederlandsche volk zal toebehooren, althans zoolang de Grondwet geldt? Zeker niet. " ${ }^{36}$ Hij betreurde de beperkte reikwijdte. Zijn navolgers, daarentegen, wekken - met hun primaat van de openbare orde bepaald niet de indruk de (eventuele) beperkingen van art. 7 Gr.w. te betreuren. Met name tegen hen - en in het bijzonder tegen Vos - richtte het stuk in het Weekblad van het Recht zich. Het hield hun voor dat de tekst van art. 7 - anders dan Buys betoogde - juist wees op een algeheel verbod van "preventief toezicht op alle middelen, dienstig om de voortbrengselen der pers tot gemeen goed te maken". Immers:

"Door middel der drukpers alleén kan men geen gedachten openbaren zoomin als men door middel van de drukpers alleen misdrijf kan plegen (...); maar verba valent usu, en gedachten openbaren door de drukpers beteekent dus niets anders dan gedachten openbaren in voortbrengselen der pers evenals misdrijven plegen door middel der drukpers niets anders beteekent en niets anders beteekenen kan dan misdrijven plegen in gedrukte, maar daarna ook openbaar gemaakte geschriften". ${ }^{37}$

Zoals de Hoge Raad repte van de geschiedenis, "onmiskenbaar getuigende van des wetgevers bedoeling", en van de bewoordingen die "ongetwijfeld verder reiken ${ }^{\text {"3i }}$, had Westra van Holthe dit standpunt - ik zei het al eerder - afgedaan als "lijnrecht" in strijd met de grondwetsgeschiedenis. ${ }^{39}$ En zoals Vos betoogde dat "zoo ondubbelzinnig mogelijk" bleek dat bij de totstandkoming van art. 7 "geen andere bedoeling heeft voorgezeten"40, verkondigde het Weekblad nu niet alleen dat art. 7 "niets anders beteekent", maar $6 \delta \mathrm{k}$ dat het "niets anders beteekenen kan". Wanneer je maar zegt dat een argument dwingend is, wordt het ook dwingend, was kennelijk de gedachte. ${ }^{41}$ In feite ging het telkens slechts om mogelijke interpretaties. 
Aanknopingspunten voor een ruime interpretatie waren - om die draad weer eens op te nemen - ook te vinden in de oorspronkelijke tekst van het grondwetsartikel, zoals die van 1815 tot 1848 heeft gegolden. Daarin werd immers het recht erkend "om zijne gedachten en gevoelens door de drukpers (...) te openbaren, zonder eenig voorafgaand verlof daartoe noodig te hebben, blijvende nogtans elk voor het geen hij schrijft, drukt, uitgeeft of verspreidt, verantwoordelijk (...)". Met het woord "nogtans" werd een tegenstelling aangegeven, die er wellicht op duidde dat in elk geval het schrijven, drukken, uitgeven en verspreiden als elementen van het "openbaren" moesten worden aangemerkt. ${ }^{42}$ Thorbecke, die als auctor intellectualis moet worden beschouwd van de stylering die het grondwetsartikel in 1848 heeft ondergaan ${ }^{43}$, schreef zelfs met zoveel woorden: "Zij, die openbaren, zijn de uitgever, die het stuk aan 't licht brengt, en de verspreider, dus ook elk handelaar, die verkoopt". ${ }^{4}$ Maar die passage is in de discussie van de jaren ' 90 nooit benut of bestreden. ${ }^{45}$ Voor De Bosch Kemper, daarentegen, was well een (bescheiden) rol weggelegd ${ }^{46}$ :

"Ieder, die op zijne verantwoordelijkheid, zijne meeningen door de drukpers wil openbaren", betoogde hij, "moet daartoe de ruimste gelegenheid vinden. Het beroep van uitgever, drukker en ombrenger moet aan geene belemmerende bepalingen onderworpen worden". ${ }^{47}$

Alleen, tegenover iemand die zich op de wetsgeschiedenis en de letter van de Grondwet beroept, maakt zo'n algemene frase natuurlijk weinig indruk. Zeker waar geen van beide zienswijzen dwingend zijn!

Al met al kan nauwelijks worden volgehouden dat de Hoge Raad met zijn arrest van 1892 ogenblikkelijk heeft "gescoord". De nieuwe "leer" werd bepaald niet door alle auteurs omhelsd. De meesten leken het arrest als een misstap te beschouwen..$^{48}$ Waarom dan toch die stap gezet? Diemer deed - 45 jaar nadat het arrest was gewezen - een (volgens mij) interessante suggestie ${ }^{49}$ :

Hij wees erop dat "reeds in het befaamde Koninklijk (lees: Soeverein, RdW) Besluit van 1814 de censuur "willekeurig" wordt genoemd. Uit deze aanduiding blijkt, dat men censuur hier opvatte in den beperkten, naar we meenen, eenig juisten zin, namelijk van voorafgaand onderzoek, dat tot verlof kan leiden", en niet het voorafgaand verlof zelf, dat immers zonder onderzoek kan worden verleend. Aangezien echter in de praktijk deze afscheiding van de beide beteekenissen niet voldoende gewaarborgd is en langs deze weg censuur in eigenlijken zin niet afdoende kan worden gekeerd, hetgeen de wetgever toch wil, is het in overeenstemming met de klaarblijkelijke bedoeling van de wet, als het begrip censuur in ruimeren zin genomen wordt". 
Op die manier wordt voorkomen dat onder het mom van iets anders (bijvoorbeeld handhaving van de openbare orde) feitelijk toch wordt gecensureerd. ${ }^{51}$

\subsection{Vooruitzichten}

Hoe zou de ontwikkeling nu verdergaan? Wat zouden de consequenties zijn als de Hoge Raad - ondanks alle kritiek - voet bij stuk hield?

Laat ik (om te beginnen) nog even de hoofdpunten van het arrest in herinnering brengen. Uitgegaan werd van het "beginsel, dat (...) de openbaarmaking zelve niet door preventieve maatregelen mag worden belet". Daaraan werden twee consequenties verbonden. In de eerste plaats werd "uitgesloten de censuur, noodig ter verkrijging van het verlof om een tot openbaarmaking bestemd geschrift te drukken of te doen drukken". In de tweede plaats werd "evenzeer het 'voorafgaand verlof' van het openbaar gezag om een gedrukt geschrift (...), door het te verspreiden, openlijk ten toon te stellen of aan te slaan of wel door eenig ander middel, openbaar te maken" uitgesloten. De gemeentelijke wetgever bleef echter bevoegd "de verspreiding van een gedrukt geschrift op de openbare straat, zonder haar in het algemeen te verbieden of van een voorafgaand verlof der overheid afhankelijk te stellen, te onderwerpen aan voorschriften in het belang der openbare orde, bepaaldelijk ter beveiliging van het openbaar verkeer".

Toegepast op de Haagse APV-bepaling, "houdende volstrekt verbod om, zonder vergunning van den burgemeester, gedrukte stukken op de openbare straat aan te kondigen, te venten, te verspreiden of te koop aan te bieden", leidde dit tot onverbindendverklaring van de betreffende bepaling. Dat "de openbaarmaking zonder zoodanig verlof (kon) plaats hebben elders of wel door andere middelen, zoodat zij uit kracht der Politieverordening niet geheel (kon) worden belet", was onvoldoende om de bepaling te redden. Immers, het verbod van voorafgaand verlof gold "voor alle middelen van openbaarmaking, zoowel op de openbare, voor ieder toegankelijke straat als op alle andere plaatsen". Nam men "het tegendeel" aan, dan zou "niets gemakkelijker (...) vallen dan het grondwettelijke voorschrift door verschillende bepalingen in rijkswetten en gemeenteverordeningen, ieder op zich zelve beperkt tot enkele daarbij aangewezen middelen van openbaarmaking, geheel te verijdelen".

Hedendaagse lezers zullen - voor zover zij enigszins zijn ingewijd in de latere jurisprudentie - in deze woorden al schimmen weten te ontwaren van toekomstige ontwikkelingen. Ik denk bijvoorbeeld aan de "zelfstandige middelen van verspreiding" die elk afzonderlijk bescherming genieten. ${ }^{52}$ 
Het is echter zaak ons voor ogen te houden dat dergelijke verfijningen destijds nog niet (met zoveel woorden) waren uitgesproken. In 1892 kon men zich bijvoorbeeld afvragen wat de Hoge Raad verstond onder het woordje "belet": wanneer werd de openbaarmaking door preventieve maatregelen bele?? Was daarvan alleen sprake in geval van een "volstrekt verbod", zoals in Den Haag? En gold die regel uitsluitend voor gedrukte geschriften? Mocht de gemeentelijke wetgever slechts "in het belang der openbare orde, bepaaldelijk ter beveiliging van het openbaar verkeer" beperkingen opleggen, en niet met het oog op andere huishoudelijke belangen van de gemeente? Hoe ver strekten de middelen tot openbaarmaking zich uit? Viel voorlezing er $66 \mathrm{k}$ onder?

De meeste geschriften over dit onderwerp waren er destijds vooral op gericht de eigen opvatting ingang te doen vinden. De Hoge Raad werd in het algemeen slechts gekscherend ten tonele gevoerd, als het zwakbegaafde broertje dat het allemaal niet zo goed kon volgen. Zo hield Westra van Holthe ${ }^{53}$ zijn lezers voor dat "de Hooge Raad consequent doorredeneerende (...) aan den gemeentewetgever ook de bevoegdheid (had) moeten ontzeggen de verspreiding van geschriften in het belang der openbare orde aan repressieve voorschriften te onderwerpen". Immers - en de kantonrechter had dat wel begrepen - "wanneer men uitgaat van de gedachte dat art. 7 van de Grondwet geene praeventieve maatregelen ten aanzien van de openhaarmaking van gedrukte stukken toelaat, dan volgt uit de laatste woorden van art. 7: 'behoudens ieders verantwoordelijkheid voor de wet', dat de repressieve maatregelen, die openbaarmaking betreffende, alleen hij de wet kunnen worden vastgesteld (...)". In plaats daarvan verklaarde de Hoge Raad "den Raad alleen onbevoegd om de verspreiding van gedrukte geschriften in 't algemeen te verbieden, of van voorafgaand verlof afhankelijk te stellen, dus b.v. wel bevoegd om voor te schrijven, dat de verkoop in sommige gevallen terstond op bevel van de politie (moest) worden gestaakt!".

Blijkens het uitroepteken was dat (volgens Westra van Holthe) vreselijk dom. Interessant is intussen dat het hier eerder een gissing betrof, dan een analyse. Of de gemeenteraad alleen onbevoegd was om de verspreiding van gedrukte geschriften in het algemeen te verbieden, of van voorafgaand verlof afhankelijk te stellen, was namelijk - strikt genomen - uit het arrest niet op te maken. Volgens de Hoge Raad was de gemeentelijke wetgever misschien niet zo zeer uitsluitend, als wel in elk geval onbevoegd dat soort verordeningen uit te vaardigen. Of Westra van Holthe's conclusie over de geoorloofdheid van politiebevelen juist was, viel dus nog te bezien. Alleen, wie niet waagt die niet wint - zonder gissingen zouden we, met andere woorden, nooit een stap verder zijn gekomen. 
Aardig (maar niet echt verrassend) is trouwens dat de volheid van het eigendomsrecht, volgens Westra van Holthe, met dit arrest niet was aangetast. "Zoo zal b.v. iedereen (dus ook de Hoge Raad, moeten we aannemen; RdW) het met mij eens zijn", schreef hij, ${ }^{34}$ "dat de vrijheid van drukpers geen inbreuk mag maken op het recht van eigendom". Ook een gissing, natuurlijk. In dit opzicht zag hij de Hoge Raad kennelijk nog wèl voor "vol" aan. Een aantal decennia later had hij zich vermoedelijk voorzichtiger moeten uitdrukken....! $!^{\text {ss }}$

Twijfel was er daarentegen bij Westra van Holthe omtrent de verenigbaarheid van dit arrest met een eerdere beslissing uit $1871 . .^{\circ}$ Daarbij ging het om een verordening van het Zeeuwse Hontenisse, die de lokale "tapperijen" verplichtte van 10 uur 's avonds ('s winters vanaf 9 uur) tot 4 uur 's ochtends gesloten te zijn. Op die tijdstippen kon er in die tapperijen dus $66 \mathrm{k}$ niet vergaderd worden. Toch was er volgens de Hoge Raad geen strijdigheid met het recht op vereniging en vergadering (art. $10 \mathrm{Gr} . w .1848$ ), "vermits de uitoefening van dat regt overal elders volkomen vrij wordt gelaten, en er geen de minste reden is om aan te nemen, dat de ingezetenen voor de uitoefening van hun regt van vergadering bij uitsluiting, of althans bij voorkeur, de nachtelijke uren in eene tapperij geschikt zullen oordeelen, zoodat zij ten gevolge van de afsluiting van die gelegenheid met der daad in hun regt verkort zouden zijn"..$^{57}$ Volgens Westra van Holthe was "ditzelfde" argument nu opeens door de Hoge Raad ondeugdelijk bevonden. De omstandigheid dat het Haagse verbod zich beperkte tot het aankondigen, venten, verspreiden of te koop aanbieden op de openbare straat - en men het drukwerk bijvoorbeeld zonder meer "huis aan huis bij de ingezetenen (kon) rondbrengen", zoals de advocaat-generaal het uitdrukte - was immers onvoldoende om de bepaling te redden. Want het verbod om het openbaren van gedachten of gevoelens afhankelijk te stellen van een voorafgaand verlof, gold volgens de Hoge Raad voor alle middelen van openbaarmaking. Waar het beroep op het recht van vereniging en vergadering afstuitte op de mogelijkheid van andere voorzieningen, werd het beroep op de vrijheid van drukpers - ondanks de aanwezigheid van andere voorzieningen - dus juist gehonoreerd! Vreemd...

Had Westra van Holthe gelijk met zijn kritiek? Alweer was hij te snel. In Den Haag mocht je namelijk nooit "zonder vergunning van den burgemeester" van een bepaald "middel van openbaarmaking" gebruikmaken. En in Hontenisse kon je slechts tijdens enkele uren niet over bepaalde gelegenheden beschikken. In het ene geval, kortom, een relatief verbod (met mogelijkheid van vergunning) op alle tijdstippen, in het andere een absoluut verbod (zonder mogelijkheid van vergunning) op enkele tijdstippen. "Tapperijen" konden buiten de genoemde uren gewoon voor vergaderingen worden benut; 
de openbare weg, daarentegen, mocht men - zonder tussenkomst van de overheid - op geen enkel ogenblik voor het verspreiden van drukwerk gebruiken. De relevantie van dat verschil was een eeuw geleden vermoedelijk veel minder evident dan vandaag-de-dag ${ }^{58}$; maar dat er sprake was van een verschil, kon ook toen al worden onderkend - zij het met wat meer geduld. Veel slordiger was de conclusie die hij verbond aan de overweging van de Hoge Raad

"dat toch, waai de Grondwet in zeer algemeene termen verbiedt de openbaarmaking van gedachten of gevoelens door de drukpers afhankelijk te stellen van een voorafgaand verlof, dat verbod geldt voor alle middelen van openbaarmaking zoowel op de openbare, voor ieder toegankelijke straat als op alle anders plaatsen".

"De toneelcensuur, in art. 188 lid 2 der Gem.wet opgedragen aan den burgemeester, zou dus volgens den Hogen Raad indruischen tegen art. 7 van de Grondwet", aldus Westra van Holthe..$^{50}$ "Niemand zal toch ontkennen, dat het toneel evenals het venten, eene plaats is om gedachten te verkondigen".

De Hoge Raad had het echter, zoals hierboven is na te lezen, over "de openbaarmaking van gedachten of gevoelens door de drukpers" (curs. RdW). En dat is iets anders dan het enkele verkondigen van gedachten, zelfs als het daarbij om de gedachten van een schrijver gaat. Het zou misschien heel mooi zijn geweest als de verspreiding van het gedachtengoed van auteurs zelfstandig onder art. $7 \mathrm{Gr}$.w. was gebracht, maar het arrest bood werkelijk geen enkel aanknopingspunt voor die opvatting. De Hoge Raad repte slechts van "een gedrukt geschrift, en bijgevolg wat daarin is gedrukt" (curs. RdW). De inhoud vormde weliswaar de ratio voor bescherming, maar het geschrift functioneerde (gezien de bewoordingen van art. $7 \mathrm{Gr}$.w.) als aanknopingspunt. De stap naar het toneel was, met andere woorden, niet veel meer dan een wilde speculatie. Niet echt onjuist, maar wèl zonder onderbouwing in het arrest.

Graevestein van Heyst, die een jaar later op hetzelfde onderwerp promoveerde, sloot zich "liever aan bij de beslissing der rechtbank, dan bij die van den Hoogen Raad". ${ }^{60}$ Toch verdiende "de vorm door den Haagschen gemeenteraad gekozen, het vorderen van een voorafgaand verlof van den burgemeester", volgens hem, "geene aanbeveling, daar hij mishruik bevordert". Tot op zekere hoogte kon hij zich dan ook vinden in de zienswijze - want veel mér zag men destijds klaarblijkelijk niet in arresten - van de Hoge $\mathrm{Raad}^{61}$ :

"In het algemeen is zeker het verspreiden een element van de openbaarmaking, die veronderstelt, dat het gedrukte ter kennisneming van het publiek wordt gesteld, onder het bereik van het publiek wordt 
gebracht. Een algemeen verbod hiervan is een verbod van openbaarmaking. De verspreiding van het gedrukte van een voorafgaand verlof afhankelijk te maken, is ongetwijfeld in strijd met art. 7 Grondwet." Maar daaruit volgde volgens hem niet:

"dat elke wijze van verspreiding geoorloofd is, elke beperking van het recht van verspreiding een beperking is van het recht van openbaarmaking, noch dat een bepaalde wijze van verspreiding niet zou mogen worden afhankelijk gesteld van een voorafgaande vergunning van de overheid, wanneer de noodzakelijkheid van een zoodanige vergunning op een meer algemeen beginsel rust".

Beslissend voor Graevestein van Heyst was klaarblijkelijk dat het gedrukte op enigerlei wijze ter kennis van het publiek gebracht kon worden. De Hoge Raad eiste, naar zijn indruk, mér. Hoeveel meer, is uit zijn beschouwing niet met zekerheid op te maken. Het bovenstaande zou erop kunnen wijzen - ik zeg het heel voorzichtig - dat de Hoge Raad, volgens hem, een drieledig standpunt innam:

1. elke wijze van verspreiding is geoorloofd;

2. elke beperking van het recht van verspreiding is een beperking van het recht van openbaarmaking;

3. een bepaalde wijze van verspreiding mag niet afhankelijk worden gesteld van een voorafgaande vergunning van de overheid. ad 1 .

Was elke wijze van verspreiding inderdaad blijkens het arrest geoorloofd? Het is moeilijk je aan die indruk te onttrekken. Alleen, onduidelijk is wat precies onder "verspreiding" moest worden verstaan. In de Haagse APV ging het om een verbod gedrukte stukken "aan te kondigen, te venten, te verspreiden of te koop aan te bieden". Wat was - in de eerste plaats - het verschil tussen "venten" en "te koop aanbieden", en waren dat - in de tweede plaats - niet allebei vormen van "verspreiden"? Zelf repte de Hoge Raad van het "openbaar maken" van "een gedrukt geschrift (...) door het te verspreiden, openlijk ten toon te stellen of aan te slaan of wel door eenig ander middel". Niet zo zeer alle wijzen van verspreiding waren dus, volgens het arrest, geoorloofd, als wel alle "middelen van openbaarmaking". Maar opnieuw rees dan de vraag: wanneer moest iets als "middel van openbaarmaking" worden aangemerkt? Was alles waarmee de openbaarmaking gepaard ging daaronder te brengen? Het arrest gaf op die vraag geen antwoord.

ad' 2.

Op de stelling dat elke beperking van het recht van verspreiding een beperking zou zijn van het recht van openbaarmaking, lijkt al evenmin veel af te dingen. De "verspreiding" was voor de Hoge Raad immers niets anders 
dan een "middel van openbaarmaking". Minder verspreiding betekende dus minder openbaarmaking. Het beginsel dat de openbaarmaking van gedrukte geschriften niet door preventieve maatregelen mocht worden belet, stond namelijk voorop. Daaruit werd "niet alleen" - voorafgaand aan het drukken een censuurverbod afgeleid, maar "evenzeer" het verbod van voorafgaand overheidsverlof voor het "openbaar maken" van een eenmaal gedrukt geschrift door enigerlei middel (bijvoorbeeld door verspreiding). Werd de term "openbaarmaking" dan in twee verschillende betekenissen gebruikt door de Hoge Raad? Aan de ene kant als overkoepelend begrip en aan de andere kant als bestanddeel (van zichzelf)?

Ik stel voor de Hoge Raad hier uitsluitend van inconsistenties te betichten als we echt niets fraaiers weten te verzinnen. In dit geval is het woord "openbaarmaking" ook op te vatten als aanduiding voor uitsluitend de laatste fase - dus voor het 'onder de mensen brengen'. Zo verstaan "klopt" het allemaal opeens. Ga maar na: "die openbaarmaking zelve" mocht niet door preventieve maatregelen worden belet, had de Hoge Raad overwogen. Dat wil zeggen dat de overheid zich er niet mee mocht bemoeien totdat het stuk "onder de mensen" was gebracht. Alles wat zich daarvór afspeelde, was voor de overheid taboe. Geen wonder dus dat niet alleen het openlijk tentoonstellen en verspreiden, maar ook het ongehinderd drukken gewaarborgd bleek te zijn. Anders kwam men aan de eigenlijke "openbaarmaking" niet eens toe! ${ }^{62}$

Hoe dan ook, om weer terug te komen op de tweede stelling van Graevestein van Heyst, elke beperking van het recht van verspreiding werd door de Hoge Raad inderdaad - per definitie! - aangemerkt als beperking van het recht op openbaarmaking. Maar dergelijke beperkingen hoefden niet ongeoorloofd te zijn. Want de gemeentelijke wetgever was bevoegd "de verspreiding van een gedrukt geschrift op de openbare straat, zonder haar in het algemeen te verbieden of van een voorafgaand verlof der overheid afhankelijk te stellen, te onderwerpen aan voorschriften in het belang der openbare orde, bepadidelijk ter beveiliging van het openbaar verkeer", aldus - zoals inmiddels bekend - de Hoge Raad. ${ }^{63}$ In de praktijk pakte dat echter wat strenger uit dan men op het eerste gezicht zou verwachten. Dat brengt mij bij de derde stelling.

ad 3.

Voor iedere wijze van verspreiding - of (algemener uitgedrukt) voor ieder middel van openbaarmaking - gold dat het vereiste van voorafgaand overheidsverlof - evenals trouwens een "algemeen verbod" - ongeoorloofd was. Alweer een correcte samenvatting, lijkt mij. Later is dit punt bij herhaling over het hoofd gezien. ${ }^{64}$ Misschien had de Hoge Raad daar zelf trouwens aanleiding toe gegeven. Gemeenten mochten de verspreiding immers reguleren, zonder haar in het algemeen te verbieden of van een voorafgaand 
verlof der overheid afhankelijk te stellen. Daaruit zou je afleiden dat de verspreiding (lees: "openbaarmaking") niet in haar geheel verboden of van een voorafgaand verlof afhankelijk gesteld mocht worden. Dus: dat het geschrift altijd op de én of andere manier openbaargemaakt moest kunnen worden. Dat bleek ook inderdaad de uitgangspositie te zijn. Alleen, ter waarborging daarvan besliste de Hoge Raad dat deze maatstaf moest worden aangelegd voor ieder "middel van openbaarmaking" - anders zou (zoals al eerder gezegd) "niets gemakkelijker (...) vallen dan het grondwettelijke voorschrift door verschillende bepalingen in rijkswetten en gemeenteverordeningen, ieder op zich zelve beperkt tot enkele daarbij aangewezen middelen van openbaarmaking, geheel te verijdelen". ${ }^{\text {s. }}$

Een heel andere kwestie, die door Graevestein van Heyst werd aangeroerd, is het "plakken". Vandaag-de-dag zou geen mens meer op de gedachte komen iets zo vanzelfsprekends op te schrijven. Maar wat nu vanzelf spreekt, sprak toen nog niet vanzelf. "Zoover mij bekend is", aldus Graevestein van Heyst, "is in het noorden het recht om het afficheeren te reglementeeren nog nooit betwist. Wanneer een verbod tot venten in strijd zou zijn met de grondwet, dan zou ook dit hiermede in strijd zijn". ${ }^{66}$ In beide gevallen ging het immers om een "middel van openbaarmaking". Daar was geen speld tussen te krijgen, lijkt mij. Een oude illusie moest worden prijsgegeven...

Ook Van Riemsdijk Kreenen was niet erg gecharmeerd van de Haagse verordening: "eene verordening die zoo ver gaat (...) is, dunkt mij, (...) af te keuren als noodeloos hinderend en al te zeer leidend tot partijdigheid". ${ }^{67}$ Maar hoewel "eene verkeerde toepassing zeer licht mogelijk" was, leidde dat, volgens hem, nog niet tot "ongrondwettigheid" van die "verordening zelve". ${ }^{68}$ "Zeer goed", daarentegen, vond hij de Nijmeegse en Amsterdamse oplossing. ${ }^{69}$ Daar gold respectievelijk (1) een ventverbod voor drukwerk "op marktdagen, Maandag en Donderdag, tusschen tien uur des voormiddags en tien uur des namiddags, en de overige dagen tusschen vier en tien uur des namiddags" (Nijmegen), en (2) een algemeen ventverbod "op openbare wegen en op uren, waarop dit (...) door den burgemeester, bij openbare kennisgeving, ongeoorloofd is verklaard" (Amsterdam). Dergelijke bepalingen zullen we in de loop van dit verhaal nog bij herhaling tegenkomen. En we zullen zien dat er soms - naar matstaven van de Hoge Raad gemeten ondanks het huldebetoon van Van Riemsdijk Kreenen toch wat op af te dingen viel. In hoeverre hij ze zelf in overeenstemming achitte met de "leer" van de Hoge Raad, valt uit zijn proefschrift niet op te maken. Beslissend voor het antwoord op die vraag had - lijkt mij - moeten zijn of er sprake was 
van een "algemeen verbod". Wat daar precies onder verstaan werd, kon - op grond van het arrest uit 1892 - hoogstens worden vermoed. ${ }^{\text {T }}$

In dat verband deed Van Riemsdijk Kreenen trouwens een interessante suggestie, waarmee hij zijn tijd meer dan een halve eeuw vooruit was. ${ }^{7}$ Naar aanleiding van een Utrechtse verordening, "waarbij den burgemeester", zoals hij het uitdrukte, "de bevoegdheid (werd) gegeven het venten (...) te verbieden in het belang van openbare orde en veiligheid, op sommige gedeelten van den openbaren weg en op sommige uren", trachtte hij te voorspellen welk oordeel de Hoge Raad over deze verordening zou vellen:

"Misschien zal hij haar goedkeuren omdat het verbod zich slechts tot sommige uren en plaatsen uitstrekt, maar, indien de Hoge Raad consequent doorredeneert, zal hij moeten zeggen dat men, door het aantal uren en plaatsen, waarop het venten verboden is, zeer ruim te nemen, de drukpersvrijheid weder illusoir kan maken". ${ }^{2}$

Was dit resultaat inderdaad inherent aan het arrest? Pas wanneer een middel van openbaarmaking in het algemeen verboden was (of van voorafgaand overheidsverlof afhankelijk gesteld), rees er een probleem voor de Hoge Raad. Wanneer was iets in het algemeen verboden? Ongetwijfeld wanneer - zoals in Den Haag - sprake was van een "volstrekt verbod", oftewel: wanneer een bepaald middel van openbaarmaking nooit of nergens (zonder voorafgaand verlof) mocht worden benut. Was dat de enige omstandigheid waaronder een middel geacht moest worden "in het algemeen" verboden te zijn? Nee, dat volgt daar niet uit. "In het algemeen" is een diffuus begrip. Het kan zowel "altijd" of "in alle opzichten", als "meestal" of "in de meeste opzichten" betekenen. Van Riemsdijk Kreenen koos klaarblijkelijk voor de laatste mogelijkheid. Vandaar dat hij al problemen ontwaarde als het verbod op zeer veel uren of ten aanzien van zeer veel plaatsen gold. Ook dan was de vrijheid van drukpers immers "illusoir" geworden. En dàt was wat de Hoge Raad had willen tegengaan. Die uitleg van het arrest was weliswaar niet noodzakelijk, zoals Van Riemsdijk Kreenen zijn lezers voorhield, maar wèl mogelijk! Op 17 maart 1953 bleek bovendien dat hij "gelijk" had. ${ }^{33}$

\subsection{De eerste schreden}

Waarop oriënteerde men zich nu in de praktijk? Op 5 december 1892 maakte de Gemeentestem melding van een vonnis van de kantonrechter in 's-Hertogenbosch. ${ }^{74}$ Bij die gelegenheid ging het om de volgende bepaling ${ }^{75}$ :

"Hij, die voortgaat op de openbare straten of wegen dag- of weekbladen of andere tijdschriften, liederen, strooibiljetten of in het algemeen geschriften, druk- of plaatwerk te verkoopen, te koop aan te bieden, 
gratis te verspreiden of uit te deelen, nadat hem zulks door den Burgemeester of van zijnentwege door een ambtenaar der gemeentepolitie is verboden, wordt gestraft met eene geldboete van hoogstens $f 25$ of ...".

Hier was het colporteren dus niet op voorhand al verboden. Toch kwam de rechter tot hetzelfde resultaat. De Gemeentestem berichtte het volgende:

"Evenals de H.R. ten aanzien van de Haagsche verordening beslist heeft (...), heeft de kantonrechter ook de verordening van 's Bosch, ofschoon deze de zaak op andere wijze regelde, strijdig met art. 7 der Grondwet verklaard en een colporteur aldaar - beklaagd van in de maand October j.l. te zijn voortgegaan met het socialistisch weekblad "Voorwaarts" te koop aan te bieden en te verkoopen, nadat dit een en ander hem van wege den burgemeester dier gemeente was verboden door een agent van politie en veldwachter aldaar - van alle rechtsvervolging ontslagen". ${ }^{76}$

En op 30 januari 1893 was in hetzelfde blad te lezen dat het vonnis van de kantonrechter in hoger beroep door de rechtbank was bevestigd "bij vonnis van 24 dezer". ${ }^{7}$ Op welke gronden de kantonrechter en de rechtbank tot hun oordeel kwamen, werd er niet bij gezegd. Het moet nog ergens in een archief zijn terug te vinden.

Is het vandaag-de-dag moeilijk voorstelbaar dat de rechter zich bij dat vonnis had laten inspireren door het arrest over het Haags ventverbod, destijds lag dat anders (hoewel de Bossche verordening "de zaak op andere wijze regelde"). De betekenis van het arrest was nog niet vast omlijnd. Tal van opties lagen open. Op voorhand was niet duidelijk welke reëel en welke irreëel waren.

Dat bleek bijvoorbeeld toen in Nijmegen een verbod tot stand kwam "om op de straten tusschen tien uur des voormiddags en twaalf uur des nachts, geschreven of gedrukte stukken aan te kondigen, te verspreiden, te venten of te koop aan te bieden". ${ }^{78}$ Volgens gedeputeerde staten van Gelderland was die bepaling in strijd met "de opvatting van art. 7 der Grondwet, gegeven door den Hoogen Raad bij het (...) arrest van 7 Nov. 1892", en wel:

"omdat die bepaling preventief zoude werken, terwijl de H.R. oordeelde dat artikel 7 der Grondwet het nemen van preventieve maatregelen in het belang der openbare orde, bepaaldelijk ter beveiliging van het openbaar verkeer toelaat, zoodat eene verbodsbepaling als in quaestie niet kan gelden voor een bepaald gedeelte van den dag, maar slechts voor de gevallen, dat het in het belang der openbare orde of veiligheid noodig is".

Die redenering was zeker niet in strijd met het arrest. De rechtbank en de kantonrechter hadden zich mogelijk van een soortgelijke motivering bediend 
ten aanzien van het Bossche verbod. Hun vonnissen zijn, zoals gezegd, nooit gepubliceerd, maar misschien vonden zij dat het verbod onvoldoende waarborgen behelsde tegen preventieve toepassingen die niet "in het belang der openbare orde, bepaaldelijk ter beveiliging van het openbaar verkeer" waren. Hoe dan ook, in Nijmegen besloot men, op grond van de bezwaren van gedeputeerde staten, tot aanpassing van de verordening. Er kwam een nieuwe bepaling. En die zijn we in de loop van dit verhaal al eerder tegengekomen. Voortaan zou het verboden zijn "op de straten, in het belang der openbare orde, bepaaldelijk ter beveiliging van het openbaar verkeer, en in het belang der huishouding van de gemeente, op de marktdagen, Maandag en Donderdag, tusschen tien uur des voormiddags en tien uur des namiddags, en de overige dagen tusschen vier en tien uur des namiddags, geschreven of gedrukte stukken aan te kondigen, te verspreiden, te venten of te koop aan te bieden". ${ }^{7}$ De eerste strafvervolging tegen overtreders van dit verbod werd, volgens de redactie van het Weekblad voor de Burgerlijke Administratie (oftewel: Mr. H. Vos), "met belangstelling tegemoet gezien door velen die de vrijheid, in artikel 7 der Grondwet gewaarborgd, ook nu nog tot groote verkorting der drukpersrechten, vrijwel aan ketenen gelegd (achtten)". ${ }^{80}$

Zover kwam het echter (bij mijn weten) niet. Op 23 augustus 1894 berichtte hetzelfde Weekblad voor de Burgerlijke Administratie dat het verbod ter vernietiging was voorgedragen aan de Kroon. ${ }^{81}$ Opnieuw beriepen GS zich daarbij op het arrest van de Hoge Raad. ${ }^{82}$ En ook de minister van Binnenlandse Zaken (Van Houten) achtte de verordening, zo bleek uit het nummer van 4 oktober ${ }^{k 3}$, "niet bestaanbaar, want de Raad is namens hem door Gedeputeerden uitgenoodigd de verordening in te trekken, ten einde eene vernietiging daarvan wegens strijd met de wet te voorkomen".

"Verklaarden", aldus dit weekblad, "Ged. Staten de verordening in strijd met de interpretatie door den Hoogen Raad van art. 7 der Grondwet gegeven, de Minister liet het arrest van dat rechtscollege in het midden, doch berichtte, dat zij z.i. strijdig was met art. 150 der gemeentewet (plaatselijke verordeningen treden niet in hetgeen van algemeen rijksbelang is), aangezien het hem voorkwam, dat alle bijzondere bepalingen, die binnen de perken van art. 7 der grondwet ten aanzien van het drukken en verspreiden van geschriften kunnen worden gemaakt, door den rijkswetgever moeten worden voorgesteld". De gemeente hield echter voet bij stuk. Op 21 december 1894 werd het verbod dan ook door de Kroon vernietigd. ${ }^{84}$ De motivering daarvan vertoonde een frappante gelijkenis met de eerdere brief van de minister. De Kroon overwoog:

"dat deze bepaling niet strekt om te waken tegen stoornis van orde 
door venters, in welk geval het onverschillig zou zijn, welke voorwerpen door hen werden gevent, maar bepaaldelijk betreft de wijze, waarop geschreven of gedrukte stukken ter algemeene kennis worden gebracht;

dat, aangezien het recht om door de drukpers gedachten of gevoelens te openbaren in art. 7 der Grondwet gewaarborgd wordt, behoudens ieders verantwoordelijkheid volgens de wet, het nemen van alle maatregelen, die binnen de perken van dat grondwetsartikel ten aanzien van het drukken en verspreiden van geschriften kunnen worden genomen, eene zaak is van algemeen Rijksbelang; dat art. 150 der Gemeentewet voorschrijft, dat de plaatselijke verordeningen niet mogen treden in hetgeen van algemeen Rijksbelang is; dat dus voormeld raadsbesluit van Nijmegen betreffende het aankondigen, verspreiden, venten of te koop aanbieden van geschreven en gedrukte stukken in strijd is met art. 150 der gemeentewet".

"Is de in dit KB gehuldigde leer juist", schreef het meergenoemde Weekblad voor de Burgerlijke Administratie op 3 januari $1895^{85 "}$, dan is het bekende arrest v.d. H.R. (...) onjuist. Immers dan had om art. 150 al. 2 de 's Grav. verordening moeten zijn toegepast, totdat zij vernietigd ware geworden". ${ }^{86}$ En het Weekblad van het Recht voegde daar op 7 januari aan toe "dat het $\mathrm{KB}$ an de slotwoorden van art. $7 \mathrm{Gw}$. eene onjuiste uitlegging (gaf)" ${ }^{87}$ Immers: "Die woorden betreffen kennelijk alléén 'ieders verantwoordelijkheid' voor den inhoud van het door de drukpers openbaar gemaakte geschrift 'volgens de wet'." Nu het Nijmeegse verbod met de inhoud niets uitstaande had, was die verwijzing in het KB naar dat zinsdeel dus volkomen uit de lucht gegrepen. Van Riemsdijk Kreenen vroeg zich bovendien af hoe het KB zo stellig kon beweren dat het verbod niet strekte "om te waken tegen stoornis van de openbare orde door venters", terwijl het tegendeel met zoveel woorden in de bepaling zelf was te lezen. ${ }^{89}$ Van het venten met drukwerk was, volgens hem (in navolging van de A-G Gregory vór HR 7 november 1892), eenvoudig het meest te vrezen - geen wonder dat men zich daarop richtte en niet tevens het venten met tal van onschuldige artikelen aan banden had gelegd! Trouwens, "zou geen enkel belang, dat door de Grondwet beschermd wordt" - met dit KB in het achterhoofd - "van gemeentewege geregeld mogen worden? (...) (W)aar moet het dan heen met de gemeentelijke autonomie?", vroeg hij retorisch.

Toen vervolgens een (Tilburgse) bepaling - die inhoudelijk overigens veel van het Haags ventverbod weg had - in letterlijk dezelfde bewoordingen (op de zinsnede over de strekking na) werd vernietigd ${ }^{\infty}$, schaarde Vos zich eveneens onder de critici. ${ }^{91} \mathrm{Hij}$ zag in die vernietigingsbesluiten "een nieuw 
bewijs (...) voor de wenschelijkheid om de beslissing van rechtsvragen in het publieke recht te onttrekken aan Ministers, dikwijls meer bedreven in de kunst der politiek dan in de kennis van het Staatsrecht". Niet alleen deelde hij de opvatting van het Weekblad van het Recht dat de "aansprakelijkheid volgens de wet", waar art. $7 \mathrm{Gr}$.w. van repte, slechts op de inhoud van geschriften zag. Maar het bedenkelijke van de KB's lag volgens hem vooral

"in de luchthartige wijze van interpretatie van Grondwet en Gemeentewet beide, waarvan deze besluiten blijk geven, en die een gevaar oplevert voor de zelfstandigheid der gemeenten ook ten aanzien van andere verordeningen. Wanneer het genoeg is dat in verband met eenig voorwerp ergens het woord "wet" geschreven staat - onverschillig in welk verband - om, gelijk hier, dat onderwerp te beschouwen als van "algemeen Rijksbelang", dan geloof ik dat er maar weinige gemeenteverordeningen zullen zijn die aan eene vernietiging door de Regeering behoeven te ontsnappen, ook al is van een werkelijken strijd met de wet schijn noch schaduw aanwezig".

Weliswaar kwam hem dat (op zijn beurt) een week later op kritiek te staan van G.M.W. Jellinghaus" - "Het is niet te verwonderen dat die zoo kundige kenner van ons gemeenterecht, waar hij gevaar voorziet, te velde trekt voor zijne geliefde autonomie der gemeenten" - maar enige bijval is deze Jellinghaus (voor zover ik weet) nooit ten deel gevallen. Zelf noemde hij zich een "warm voorstander eener behoorlijke autonomie der gemeente, maar niet minder eener royale uitlegging onzer grondwettelijke vrijheden, voorzoover het staatsbelang er zich niet tegen verzet". Dat bracht hem tot een heel andere benadering van artikel 7 Grondwet:

"Waar de wet de verantwoordelijkheid voor het aanwenden van alle middelen van openbaarmaking moet regelen gaat het niet aan het meest belangrijke geval: de verantwoordelijkheid voor de wijze van aanwending op iets anders dan de wet te laten steunen en door deze niet te laten regelen; bovendien is in de grondwet van deze fijne onderscheiding niets te vinden".

De Gemeentestem noemde deze "poging" ter verdediging van de vernietigingsbesluiten echter al gauw "mislukt"93 en daarbij bleef het voorlopig.

Wie had er nu gelijk? De Kroon, de critici of de criticus van de critici? En wat betekende én en ander met het oog op de "leer" van de Hoge Raad? Vooral die laatste vraag houdt mij hier bezig. Alleen, het valt niet mee die KB's te interpreteren; dat wil zeggen: zonder de Kroon van inconsistenties te betichten. Wat was bijvoorbeeld de status van de overweging in het KB over Nijmegen "dat deze bepaling niet strekt om te waken tegen stoornis van orde door venters, in welk geval het onverschillig zou zijn, welke voorwer- 
pen door hen werden gevent"? Zou de Kroon werkelijk hebben bedoeld dat het verbod niet tegen ordeverstoringen bij venten gericht was omdat alleen bepaalde vormen van venten konden worden aangepakt? Dat klinkt niet erg overtuigend. Zo dom zal de Kroon niet zijn. Ging het dan louter om een vaststelling? Te weten: dit verbod richtte zich niet tegen alle venters, maar slechts tegen een bepaalde groep onder hen. Een zinloze mededeling, want wie de bepaling gelezen had, wist dat allang. Ik denk dat het eenvoudig een beschuldiging was: de gemeente Nijmegen deed weliswaar of het hier om beteugeling van ordeverstoringen ging, maar daar geloven Wij - als Kroon niets van. Vreemd dat Van Riemsdijk Kreenen daar niet op kwam. Liet hij zich zozeer door verontwaardiging meeslepen dat hij over het hoofd zag wellicht op een toepassing te zijn gestuit van wat hijzelf had betoogd? Ik heb zijn woorden al eerder aangehaald: "Misschien zijn sommige verordeningen wel gecreëerd met het oogmerk om ze verkeerd toe te passen. (...) Het kan een reden zijn voor de administratie om te vernietigen". ${ }^{94}$

In dit geval leek het echter slechts een bijkomstige reden voor vernietiging te zijn. Uiteindelijk sneuvelde de bepaling op een heel andere grond. Of moeten we het KB zó begrijpen dat die andere grond pas in het vizier kwain toen "bleek" dat de bepaling feitelijk niet "tegen stoornis van orde" gericht was? Had zij, met andere woorden, wel door de beugel gekund als ze daar well op was gericht? Wie weet! Was de gemeente in dat geval volkomen vrij geweest? Hoezo, dat volgt daar niet uit! Misschien hanteerde de Kroon precies dezelfde maatstaven als de Hoge Raad en zou een volstrekt verbod bijvoorbeeld - ook al kwam het uit oprechte orde-motieven voort - ontoelaatbaar worden geacht. Een dergelijke interpretatie werd door het KB niet uitgesloten. Of het één, dan wel het ander bedoeld was... het bleef gissen. Maar zo zag men het destijds niet. Alsof er geen keus bestond, werd algemeen uitgegaan van de eerste optie. Het verhaal over de strekking werd hooguit opgevat als hint om vernietiging in de toekomst te voorkomen. In plaats van een ventverbod dat specifiek op drukwerk was gericht, zou een gemeente eenvoudig een algemeen ventverbod moeten afkondigen. Of ook de Hoge Raad daar genoegen mee zou nemen, was volgens Van Riemsdijk Kreenen echter de vraag, "omdat nu alle waren zullen moeten boeten voor wat de drukwerken misdrijven, zonder dat de vrijheid dezer laatsten er daarom grooter op wordt". ${ }^{95}$ Zaten Kroon en Hoge Raad dus niet "op én lijn"? Dat was, zoals hierboven al bleek, inderdaad de algemene opvatting onder de auteurs.

Centraal daarbij stond de overweging in het vernietigingsbesluit dat "het nemen van alle maatregelen, die binnen de perken van (art. 7 Grondwet) ten aanzien van het drukken en verspreiden van geschriften kunnen worden genomen, eene zaak is van algemeen Rijksbelang". Stond dat niet haaks op 
hetgeen de Hoge Raad ten aanzien van het Haags ventverbod had overwogen? Was dit niet nòg erger? Volgens de Hoge Raad mocht de gemeente tenminste nog iets; nu leek ze helemaal niets meer te mogen.

Vos had, zoals gezegd, in het Weekblad voor de Burgerlijke Administratie (WBA) geconcludeerd dat de Hoge Raad, uitgaande van de opvatting van de Kroon, het Haags ventverbod dus gewoon had moeten toepassen totdat het vernietigd was. Immers, wanneer de vraag rees of een gemeente met een verordening was getreden "in hetgeen van algemeen Rijks- of provinciaal belang" was, bleef zo"n verordening op grond van het toenmalige art. 150 gem.w. (vgl. het latere art. 193) verbindend totdat zij door de Kroon vernietigd (of geschorst) was.

Ik betwijfel of die redenering dwingend is. In de eerste plaats kon de Hoge Raad - anders dan de Kroon - niet beoordelen of het verbod feitelijk "om te waken tegen stoornis van orde" strekte. Daar moest hij - gezien het karakter van cassatierechtspraak - van uitgaan. Wie het arrest erop naleest zal dan ook opmerken dat de Hoge Raad zijn beslissing toespitste op "voorschriften in het belang der openbare orde, bepaaldelijk ter beveiliging van het openbaar verkeer". Dat waren dus precies de voorschriften waar het KB - blijkens de kwalificatie van de strekking van het Nijmeegse verbod wellicht geen betrekking op had. Misschien beoogde het KB slechts tot uitdrukking te brengen dat de gemeente, voor zover zij iets anders dan ordevraagstukken voor ogen had, op dit punt trad "in hetgeen van algemeen Rijksbelang" was. In dat geval was van tegenstrijdigheid geen sprake.

In de tweede plaats valt op dat de Hoge Raad tot onverbindendheid kwam wegens strijd met art. 7 Gr.w., terwijl de Kroon zich beriep op art. 150 gem.w. Art. 7 Gr.w. bracht volgens de Kroon mee dat het reguleren van drukken en verspreiden "eene zaak is van algemeen Rijksbelang". Het verbod was, kortom, in strijd met art. $7 \mathrm{Gr}$.w. van gemeentewege uitgevaardigd; daarnaast was het - gezien art. 7 Gr.w. - tevens in strijd met art. 150 gem.w., omdat een dergelijke bevoegdheid alleen bij de Rijksoverheid berustte. Zelfs al beriep de Kroon zich louter op art. 150 gem.w., dan nòg hoefde dat dus niet te betekenen dat een rechter niet op grond van art. 7 Gr.w. tot onverbindendheid kon besluiten. Het argument van Vos, dat met zoveel graagte - "dat is volkomen duidelijk" - door het Weekblad van het Recht was overgenomen ${ }^{* 6}$, was met andere woorden niet echt steekhoudend.

Ook de vrees voor ongebreidelde inperking van de gemeentelijke autonomie was - strikt genomen - niet mér dan speculatie (of wellicht een retorische overdrijving, bedoeld als "self-denying prophecy"). "Zou geen enkel belang, dat door de Grondwet beschermd wordt, van gemeentewege geregeld mogen worden?", had Van Riemsdijk Kreenen zich afgevraagd. Een tamelijk wilde 
suggestie, natuurlijk. Al was het maar omdat niet het grondwettelijke van die bescherming beslissend was voor het $\mathrm{KB}$, maar de inhoud ervan: de uitdrukkelijke verwijzing naar $d e$ wet. Zelfs de gematigde stelling van Vos - zodra in verband met enig voorwerp ergens het woord "wet" geschreven staat, is dat (onverschillig in welk verband) genoeg om dat voorwerp als van "algemeen Rijksbelang" te beschouwen - zelfs díe stelling berustte op overdrijving. Zeker, het was niet onmogelijk dat de vork op die manier in de steel zat. Alleen, het sprak bepaald niet vanzelf. Het ging bijvoorbeeld niet om "enig voorwerp", maar om een grondrecht; het woord "wet" was niet alleen ergens geschreven, maar had natuurlijk ook een betekenis; en onverschillig was het verband hoogstens in de ogen van Vos (doch vermoedelijk niet in die van de Kroon, voor zover die althans ogen had...).

Resteerde niettemin de vraag die ik al eerder stelde, namelijk of gemeenten het drukken en verspreiden volgens de Kroon in het geheel niet mochten reguleren. Als dat zo was, was de Kroon inderdaad een andere (strengere) koers ingeslagen dan de Hoge Raad. Met zekerheid viel daar, zoals we zagen, niets over te zeggen. Speculeren was dus onvermijdelijk (al kwam niemand daar voor uit).

Intussen lag er bovendien een vonnis van de Leidse kantonrechter. ${ }^{97}$ En daarmee was de verwarring compleet. Het ging in die zaak (waarin de "generaal agent van het sociaal-democratische volksblad De Baanbreker" werd vertegenwoordigd door Mr. P.J. Troelstra, advocaat en procureur te Utrecht) om een vordering van $f 54,84$ tegen de gemeente Leiden. In totaal waren daar namelijk 523 exemplaren van dit "volksblad" in beslag genomen, en wel na overtreding van het ongrondwettige ventverbod (dat immers sprekend leek op het Haagse), zo werd gesteld; ook die inbeslagneming kon dus niet door de beugel. Volgens de kantonrechter was op dat ventverbod echter niets aan te merken. "Wikkende en wegende" was hij "tot geen ander besluit (...) kunnen komen, dan dat in de bewoordingen (van art. 7 Gr.w.) niet ligt opgesloten de toekenning van het recht om de in druk geopenbaarde gedachten en gevoelens m.a.w. de door middel van de drukpers geopenbaarde gedachten en gevoelens door alle mogelijke middelen ter kennis van wien ook te brengen". Enerzijds erkende hij weliswaar, net als Vos korte tijd later in zijn Themis-artikel ${ }^{98}$, dat art. 7 Gr.w. de vrijheid impliceerde

"om de in druk geopenbaarde gedachten of gevoelens ter kennis te brengen van wien dan ook, op de voor dat ter kennis brengen volstrekt noodzakelijke wijze, daar anders immers de vrijheid, om zijne gedachten en gevoelens in druk te openbaren niets zou beteekenen". Anderzijds stelde hij echter dat de bewoordingen van dat grondwetsartikel "geene verdere strekking hebben en alzoo niet ten doel hebben te 
verleenen de absolute vrijheid om door alle mogelijke, zelfs de meest excentrieke middelen, al mochten die ook de vrees wettigen, dat zij aanleiding moeten geven tot het verstoren der openbare orde in eene gemeente, de eenmaal in druk geopenbaarde gedachten of gevoelens ter kennis van wien ook te brengen".

Dus mocht "het voor het ter kennis brengen van gedrukte stukken, niet volstrekt noodzakelijk middel, het in het openbaar verspreiden en venten of te koop aanbieden van gedrukte stukken, dag- of weekbladen enz." in het belang van de openbare orde "van de vergunning van den burgemeester afhankelijk (worden) gesteld". Kortom: een heel ander verhaal dan dat van de Hoge Raad.

Nog een variant - maar nu é́n waar de Hoge Raad zich wellicht nog niet over had uitgelaten - deed zich voor in Hilversum. Volgens het Weekblad voor de Burgerlijke Administratie van 25 juli $1895^{\circ}$ had de gemeenteraad daar "besloten in de algemeene politieverordening de bepaling op te nemen, dat het voortaan verboden is op den openbaren weg den inhoud van een gedrukt stuk of geschreven stuk verkort of in zijn geheel, in de bewoordingen van het stuk of in andere woorden bekend te maken. De wijze waarop in den laatsten tijd met Recht voor Allen en inzonderheid met De Baanbreker wordt gevent", aldus nog steeds dit weekblad, "maakt deze bepaling noodzakelijk". En op 16 maart 1896 meldde De Gemeentestem ${ }^{100}$ de bekrachtiging van "de bij verstek gewezen vonnissen dd. 5 Oct. en 23 Nov. 1895 tegen M. van Gelder en J. Wildschut, colporteurs van de bladen "Voorwaarts" en "De Baanbreker", wegens het in strijd met de politieverordening verkort bekend maken van den inhoud van een gedrukt stuk op den openbaren weg te Hilversum, waartegen beklaagden in verzet waren gekomen". Was ook het verkort of integraal "bekendmaken" van de inhoud van een gedrukt of geschreven stuk als "middel van openbaarmaking" aan te merken? Mocht je bij het venten bijvoorbeeld iets roepen, of een plakkaat ophouden? Daarover viel uit het arrest van 1892 niets met zekerheid af te leiden, denk ik. Alle ruimte dus voor gissingen! ${ }^{101}$

\subsection{Bevestiging van "de leer"}

Pas op 23 maart 1896 kon de Hoge Raad de draad weer opnemen. ${ }^{102}$ Het ging bij die gelegenheid om een bepaling van Krimpen aan den IJssel: "Het is verboden zonder schriftelijke vergunning van den Burgemeester langs of op de wegen liedjes te venten". De kantonrechter in Schoonhoven had een 51 -jarige overtreder van dit verbod op 20 december 1895 ontslagen van alle rechtsvervolging. Het ventverbod behelsde volgens hem namelijk een preven- 
tieve maatregel ten aanzien van de openbaarmaking van gedrukte stukken, en dat was in strijd met art. 7 Grondwet. Bij wet had wel repressief opgetreden kunnen worden. Bovendien overwoog hij:

"dat hoewel het motief van de verbodsbepaling, blijkens de plaatsing er van in het hoofdstuk van de openbare orde en veiligheid, is het bevorderen van de openbare orde en veiligheid, dit motief geen invloed kan uitoefenen op de bindende kracht der bepaling; dat het toch aankomt op den materiëlen inhoud der bepaling".

Daarmee had de kantonrechter klaarblijkelijk aansluiting gezocht bij de opmerking van d'Aulnis de Bourouill, die we al eerder tegenkwamen: wat deed het "motief voor eene bepaling" ertoe "zoolang het voor de geldigheid eener handeling des Raads aankomt op die handeling zelve, doch geenszins op de beweegreden, die er toe geleid heeft?"103 Later werd die opvatting door de Hoge Raad, die hier wellicht toch enkele problemen voorzag ${ }^{104}$, toegespitst op de toetsing aan art. $7 \mathrm{Gr}$.w. Alsof hij slechts weergaf wat de kantonrechter had overwogen, merkte de Hoge Raad op "dat het toch, gelijk bij het bestreden vonnis te recht is aangenomen, bij de toetsing van het verbod der plaatselijke verordening aan art. 7 der Grondwet aankomt op den inhoud, niet op het motief van dat verbod".

Ook overigens werd het vonnis van de kantonrechter door de Hoge Raad onderschreven, en wel in bewoordingen die een frappante gelijkenis vertoonden met het arrest uit 1892. De A-G Patijn, die tot vernietiging van het vonnis had geconcludeerd, werd dus niet gevolgd. "Ik vergeet natuurlijk niet", had hij gezegd, "het door den H.R. op den 7 Nov. 1892 gewezen arrest (W. 6259) en de K.B. van 21 Dec. 1894 (Stbl. no. 237) en van 30 Aug. 1895 (Stbl. no. 154) waarbij gemeenteverordeningen van Tilburg en Nijmegen werden vernietigd, maar ik kan niet gelooven dat door die rechterlijke uitspraak en door beide genoemde administratieve beslissingen het laatste woord over art. $7 \mathrm{G}$.W. in verband met art. 135 Gem. wet gezegd is". Vandaar dat hij nogmaals het hele repertoire aan bezwaren ten tonele voerde. Tevergeefs, zoals bleek, want de Hoge Raad hield voet bij stuk.

En passant werd de leer trouwens ook wat verduidelijkt. De passage waarin werd betoogd dat het bij toetsing aan art. $7 \mathrm{Gr}$.w. niet op het motief, maar op de inhoud van het verbod aankwam, wees er immers op dat beperkingen van gemeentewege niet per se "in het belang der openbare orde, bepaaldelijk ter beveiliging van het openbaar verkeer" hoefden te zijn (al kwamen die woorden ook nú weer in het arrest voor). Die boodschap is echter nooit overgewaaid naar de literatuur. Dresen schreef in 1949 bijvoorbeeld over "de weg, die in 1892 werd ingeslagen, toen t.a.v. een bepaald aspect van het openbaren en om bepaalde motieven, materiële wetgeving werd toegelaten" (curs. RdW). ${ }^{105}$ En zelfs in 1966 nog stelde Boukema: "Sinds 1892 acht 
de HR de inbreuk alleen toelaatbaar wanneer dit geschiedt 'in het belang der openbare orde, bepaaldelijk ter beveiliging van het openbaar verkeer". "106 Maar - eerlijk is eerlijk! - hij achtte het "niet onmogelijk, dat ook de behartiging van andere belangen voor de HR een rechtvaardigheidsgrond is voor wat betreft de inbreuk op de rechten van art. 7". Drie jaar later beschouwde hij die mogelijkheid pas als "meer aannemelijk". ${ }^{107}$ De reden daarvoor was al veel eerder door Donner ${ }^{108}$ genoemd:

"Men heeft zich wel is waar vastgebeten in de in jurisprudentie telkens weer terugkerende zinsnede, dat gemeentelijke beperkingen in het belang van de openbare orde geoorloofd waren en daaruit a contrario afgeleid, dat de gemeente dus deze beperkingen niet ter bescherming van andere belangen mag stellen (...). Daarbij is echter (...) over het hoofd gezien, dat de verwijzing naar de openbare orde niet bijzonderlijk moet worden betrokken op art. 7 Grondwet, maar eenvoudig voortvloeit uit art. 168 Gemeentewet, zoals dit door de rechter wordt opgevat".

Of, zoals Boukema het in 1969 uitdrukte:

"dat de Hoge Raad refereert aan de bevoegdheid die krachtens art. 168 gemeentewet aan de gemeenteraad toekomt en gezien het concrete geval alleen naar de openbare orde - in art. 168 speciaal genoemd - verwijst om duidelijk te laten uitkomen dat de gemeentelijke wetgever binnen de grenzen van zijn bevoegdheid is gebleven". ${ }^{109}$ Het arrest uit 1896 over Krimpen aan den IJssel bevatte zelf trouwens ook een hint in die richting. De Hoge Raad overwoog bij die gelegenheid namelijk "dat de strafwetgevende bevoegdheid der gemeenteraden uit kracht van art. 144, 2e lid, der Grondwet (vgl. art. 127 jo. 124 huidige Gr.w., $\mathrm{RdW}$ ) in het algemeen toegekend bij art. 135 in verband met art. 161 der Gemeentewet (vgl. respectievelijk art. 168 en 195 huidige, of art. 150 en 155 nieuwe Gem.w., RdW), eene noodwendige beperking vindt in de bijzondere voorschriften der Grondwet, die bij alle strafwetten en strafverordeningen in het belang der openbare orde, zedelijkheid en grezondheid vastgesteld, moeten worden in acht genomen". De aandacht van het "forum" was daar echter niet op gericht. In alle zaken ging het immers louter om handhaving van de openbare orde (zei men). Andere issues waren nog niet gerezen. Dus zag men eraan voorbij en werd het punt vergeten. ${ }^{110}$

Treuriger is misschien dat ook het inzicht dat het verbod van voorafgaand verlof voor alle "middelen van openbaarmaking" gold, later verloren zou gaan. ${ }^{111}$ Net als bij het Haags ventverbod speelde die kwestie namelijk in het arrest over Krimpen aan den IJssel. Het verbod had immers alleen betrekking op venten, doch liet "het verspreiden om niet onaangetast.", zo was in cassatie door het Openbaar Ministerie aangevoerd. Dus zou er geen 
strijd met art. 7 Gr.w. zijn... De Hoge Raad, echter, ging daar niet mee akkoord en herhaalde wat hij ook al naar aanleiding van het Haags ventverbod had overwogen:

"dat toch waar de Grondwet in algemeene termen verbiedt de openbaarmaking van gedachten of gevoelens door de drukpers afhankelijk te stelien van een voorafgaand verlof, dat verbod geldt voor alle middelen van openbaarmaking zoowel op den openbaren weg als op alle andere plaatsen".

Echt nieuw, daarentegen, was het geval dat zich in Olst (bij Deventer) had voorgedaan. ${ }^{112}$ Nou ja, wat heet nieuw? Het leek een beetje op die Hilversumse zaak waarin de kantonrechter twee mensen had veroordeeld omdat ze bij het colporteren de inhoud van hun krantjes hadden "bekend gemaakt". In Olst had iemand tot twee keer toe "des avonds omstreeks 7 uur op den openbaren weg (...), luid roepende of schreeuwende, te koop (...) aangeboden de courant genaamd de Volksvriend, door luidkeels te roepen en te schreeuwen 'lees de Volksvriend, ze kosten marar 3 cent'. " De kantonrechter had hem daarvoor veroordeeld "tot twee geldboeten, elke van $f 1$, en voor elke boete tot vervangende hechtenis van 1 dag". Het was in Olst namelijk "verboden op de openbare wegen, voetpaden of pleinen luid roepende of schreeuwende, te koop of om niet aan te bieden boeken, couranten, dag- of weekbladen en andere gedrukte of geschreven stukken, de lezing van zoodanige stukken aan te bevelen of den inhoud daarvan bekend te maken". ${ }^{113}$

Volgens de A-G Van Maanen was er "in de Olster verordening (...) geen sprake van eene vergunning van den Burgemeester of van een algemeen verbod; het verspreiden is vrijelijk toegestaan, mits het niet geschiedt door geroep of geschreeuw, hetgeen voor paarden en bespannen rijtuigen bedenkelijke gevolgen kan hebben, en vooral waar het opruiende schrifturen betreft, gevaarlijke oploopen doen ontstaan, alzoo eene bepaling in het belang der orde en veiligheid". Opvallend was overigens dat de conclusie deze keer geen spoor van twijfel meer verraadde omtrent de "leer" van de Hoge Raad. Zelf kwam de Hoge Raad aan herhaling van zijn "leer" niet eens toe. Hij volstond met een minimale afdoening, te weten:

"dat de Hooge Raad zich ten aanzien der bewering, dat de verordening in strijd is met art. 7 der Grondwet, vereenigt met hetgeen de kantonrechter daaromtrent heeft overwogen: dat art. 7 der Grondwet de bevoegdheid van den gemeentelijken wetgever om de verspreiding van gedrukte stukken enz. op den openbaren weg te onderwerpen aan voorschriften in het belang, der openbare orde, bepaaldeiijk ter beveiliging van het openbaar verkeer onaangetast laat" 
Hoe nu? Had de Hoge Raad zich dan tòch opeens door zijn opponenten laten overtuigen? Bleef de bevoegdheid om "in het belang der openbare orde, bepaaldelijk ter beveiliging van het openbaar verkeer" voorschriften uit te vaardigen werkelijk onaangetas? Hoe viel dat te rijmen met de eerdere arresten? Daarin was immers te lezen dat de gemeente bevoegd was "om de verspreiding van een gedrukt geschrift op de openbare straat, zonder haar in het algemeen te verbieden of van een voorafgaand verlof der overheid afhankelijk te stellen (curs. RdW), te onderwerpen aan voorschriften in het belang der openbare orde, bepaaldelijk ter beveiliging van het openbaar verkeer". Misschien was daarmee niet mér gezegd dan dat de gemeente weliswaar gewoon bevoegd bleef verordeningen uit te vaardigen, maar dat die bevoegdheid geen vrijbrief inhield om inbreuk te maken op art. $7 \mathrm{Gr}$.w. Een bevoegd gegeven regel kon, met andere woorden, onverbindend worden verklaard wegens strijd met een bepaling van hogere orde. In die zin liet art. $7 \mathrm{Gr}$.w. de verordeningsbevoegdheid inderdaad "onaangetast" en had de kantonrechter gelijk. Uit de omstandigheid dat in dit geval (volgens de Hoge Raad) met die simpele mededeling kon worden volstaan, moet dan worden afgeleid dat art. $7 \mathrm{Gr}$.w. hier zelfs niet in het vizier kwam. Waarom niet? Omdat "luid roepen" en "schreeuwen" kennelijk geheel los werden gezien van de "openbaar making" door het te koop of om niet aanbieden van boeken, kranten en meer van dat soort zaken.

Was de ene gedraging - zoals Vos eerder had gesuggereerd - noodzakelijker voor het openbaar maken dan de andere? De Hoge Raad liet zich daai niet over uit. Wel viel op dat hij - in ieder geval qua toonzetting - niet ongevoelig leek voor het standpunt van de critici. Zo overwoog hij:

"dat de Gemeenteraad ingevolge art. 135 der Gemeentewet bevoegd is, die handelingen te verbieden, welke de openbare orde bedreigen, en, bevindende dat wel het luid roepen of schreeuwen de openbare orde in gevaar brengt bij het venten van gedrukte stukken, doch niet bij het venten van andere koopwaren, ook bevoegd is, het luid roepen of schreeuwen alleen in het eerstgenoemde geval te verbieden en in zoover onderscheid kon maken, niet tusschen personen, maar tusschen handelingen, onverschillig door welke personen zij zijn gepleegd". ${ }^{114}$ Hebben we het mis wanneer we hierin de stemmen van Gregory (in zijn conclusie over het Haags ventverbod), Westra van Holthe ${ }^{115}$, Vos ${ }^{116}$, Graevestein van Heyst ${ }^{117}$ en Van Riemsdijk Kreenen ${ }^{118}$ herkennen? En passant werd op z'n minst de schijn gewekt dat bovendien afstand werd genomen tot het standpunt van de Kroon. ${ }^{119}$ "Het is een verschijnsel, hetwelk voor leeken wel altijd onverklaarbaar zal blijven", had d'Aulnis de Bourouill kort tevoren in dit verband geschreven, "hoe toch juristen zoo onder elkander van meening kunnen verschillen". ${ }^{120}$ 
Bleek het meningsverschil achteraf geen meningsverschil te zijn? Nam de Hoge Raad het alsnog op voor zijn critici? Was er sprake geweest van een misverstand, of hadden we te doen met een keerpunt? ${ }^{121}$

Opvallend was in elk geval "dat eene dergelijke bepaling in de Maastrichtse verordening in hetzelfde jaar wel aanleiding heeft gegeven tot schorsing (bij Kon. besl. v. 29 april 1897, Stbl. no. 114), maar deze niet door vernietiging gevolgd is", aldus een bericht in de Gemeentestem van 6 augustus 1902.122 Sloot de Kroon zich dus ten langen leste toch maar bij de Hoge Raad aan, nu zij opeens zoveel eensgezindheid tegenover zich ontwaarde? Wie weet? Ik weet het in elk geval niet. Mogelijk was de Kroon slechts - net als (wellicht!) de Hoge Raad - van oordeel dat het in die bepaling helemaal niet om openbaarmaking van drukwerk ging. Of, zoals burgemeester en wethouders van Amersfoort het in 1902 uitdrukten in een ambtsbericht aan de minister van Binnenlandse Zaken $^{123}$ :

"Het te koop of om niet aanbieden van boeken, couranten, dag- of weekbladen of andere gedrukte of geschreven stukken blijft geoorloofd. Alleen is in het belang der openbare orde verboden om daarbij luidkeels te roepen, te schreeuwen of op andere wijze geraas te maken".

Een dergelijke visie liet zich zowel met de jurisprudentie van de Hoge Raad verenigen als met die van de Kroon (voor zover die twee al verschilden). Pas op 10 april 1909 - maar nu lopen we wel erg ver vooruit op de ontwikkelingen - was in De Gemeentestem een aanwijzing te vinden dat de Kroon uiteindelijk toch echt op hetzelfde spoor was uitgekomen als de Hoge Raad. ${ }^{24}$ Gedeputeerde Staten van Zeeland hadden een ventverbod van Tholen ter vernietiging voorgedragen, omdat het - zoals in het jaarverslag van GS was te lezen - "ons voorkwam te strijden met de opvatting van art. 7 der Grondwet, welke bij het arrest van den Hoogen Raad van 7 Nov. 1892 (..) gehuldigd wordt. De Minister vereenigde zich met dat bezwaar, waarop de Raad, om vernietiging te voorkornen, in het artikel eene uitzondering voor drukwerken opnam". Dat de Kroon inderdaad niet langer op het standpunt stond - zoals eerder vrij algemeen werd verondersteld - dat regulering van deze materie überhaupt niet voor gemeenten was weggelegd (omdat het hier een "algemeen Rijksbelang" betrof), bleek korte tijd later. Op 3 juni 1909 gaf de minister van Binnenlandse Zaken namelijk te kennen dat "geen termen aanwezig" waren voor vernietiging van het Maastrichtse verbod om na zes uur 's avonds gedrukte stukken te venten. ${ }^{125}$ Dat wil natuurlijk niet zeggen dat de Kroon niet eerder op die "lijn" zat. Het was alleen nog niet gebleken. Er viel echter al ruimschoots over te speculeren. Sterker: bij gebrek aan beter kòn men voordien niet anders. En wie wilde weten waar hij aan toe was, moest dus wel. 
Iets anders was natuurlijk of zo'n ventverbod (na zes uur 's avonds) - dat niet met de (vermeende) oude opvatting van de Kroon strookte - wel in overeenstemming was met de leer van de Hoge Raad. Ook daarover viel slechts te speculeren. Wat zou immers de doorslag geven: dat je vór zessen vrijelijk kon venten, of dat na dat tijdstip een volstrekt verbod gold? De Hoge Raad gaf pas in 1910 uitsluitsel over de vraag: het verbod bleek door de beugel te kunnen. ${ }^{126}$ Maar voordien waren er duidelijke aanknopingspunten voor een andere uitkomst. Ik kom daar dadelijk op terug; laat ik niet te hard van stapel lopen.

Eerst bleek namelijk nog dat die uitspraak over "luid roepen en schreeuwen" inderdaad niet uit de pas liep van de jurisprudentie. Dat wil zeggen: de Hoge Raad herhaalde in de eerstvolgende zaak - over het ventverbod van Zuidbroek $^{127}$ - dat art. 7 Gr.w. de gemeentelijke verordeningsbevoegdheid onaangetast liet, maar deze keer voegde hij er uitdrukkelijk aan toe dat

"de Grondwet niet toelaat het verspreiden, waartoe behoort het venten van gedrukte geschriften in het openbaar, onvoorwaardelijk te verbieden of wel afhankelijk te stellen van een voorafgaand verlof der overheid".

De A-G Gregory - die wij nog kennen uit zijn conclusie over het Haags ventverbod - had die eerdere dubbelzinnigheid intussen echter al wel met beide handen aangegrepen. En - het wekt nauwelijks verbazing - hij had daarbij slechts én kant van de medaille belicht. Het ventverbod van Zuidbroek - op grond waarvan alleen ingezetenen zonder schriftelijke vergunning van $B$ en $W$ "voorwerpen of waren van welken aard ook" in het openbaar mochten "venten of te koop aanbieden" - was volgens hem dan ook geheel in de haak,

"omdat, gelijk de Hooge Raad nog zeer onlangs, nl. bij zijn arrest van 1 Febr. dezes jaars (W. no. 6928), besliste, (...) art. 7 der Grondwet de bevoegdheid van den gemeentelijken wetgever om de verspreiding van gedrukte stukken enz. op den openbaren weg te onderwerpen aan voorschriften in het belang der openbare orde, onaangetast laat". ${ }^{128}$ Bovendien ging het in deze bepaling niet om gedrukte stukken (zoals in het Haags ventverbod), maar om "voorwerpen of waren van welken aard ook", en had het verbod "zijn grond niet in de zucht om den verkoop van gedrukte stukken te belemmeren, maar in de zorg voor de openbare orde, die niet kon gedoogen dat de ingezetenen door allerlei vreemde lieden, in schijn koopllieden, maar inderdaad bedelaars, werden lastig gevallen". Mocht men er niettemin toch - "wat mij in redelijkheid niet wel mogelijk voorkomt", aldus Gregory - "een preventieve maatregel ten aanzien der openbaarmaking van gedrukte stukken (in) willen lezen, dan zou de gewilde belemmering slechts eene schijnbare zijn, omdat (...) de uitgever dier stukken zich slechts tot een 
of meer ingezetenen heeft te wenden om ze ongestraft verspreid te krijgen". Voor een deel ging het bij die laatste drie argumenten om een soort herhalingsoefening. Zo kon de verwijzing naar het motief (voorkoming van bedelarij) door de Hoge Raad eenvoudig worden afgedaan met een citaat uit eigen werk: "dat toch (...) het bij de toetsing van het verbod der plaatselijke verordening aan art. 7 der Grondwet, aankomt op den inhoud, niet op het motief van dat verbod". En die inhoud bracht mee dat het verbod "in zijn algemeenheid ook van toepassing is op het in het openbaar venten of te koop aanbieden van gedrukte stukken".

Daarmee stond het ventverbod volgens de Hoge Raad niet in zijn geheel op de tocht, maar slechts voor zover de toepassing ervan strijd met art. 7 Gr.w. opleverde. ${ }^{129}$ Welnu, die strijd was er. Dat buitenstaanders altijd de hulp van ingezetenen konden inroepen, mocht de gemeente niet baten. Waar het op aan kwam, was immers - en nu parafraseerde de Hoge Raad zichzelf dat,

"waar de Grondwet in algemeene termen verbiedt, de openbaarmaking van gedachten of gevoelens door de drukpers afhankelijk te stellen van een voorafgaand verlof, dat verbod geldt voor alle middelen van openbaarmaking, dus ook voor de openbaarmaking door middel van het in het openbaar venten of te koop aanbieden van gedrukte geschriften onverschillig of deze handeling geschiedt door een ingezetene dan wel door een niet ingezetene van de gemeente waar zij plaats heeft" (curs. RdW).

Een onderscheid tussen ingezetenen en niet-ingezetenen kon bij het openbaarmaken dus niet door de beugel. Was geen enkel onderscheid in dat opzicht geoorloofd? Eind jaren zeventig van deze eeuw bleek opeens - om alvast een blik vooruit te werpen - dat algehele gelijkheid toch niet in de bedoeling lag. ${ }^{130}$ In 1897 was dat nauwelijks voorstelbaar, lijkt mij. Tachtig jaar later trouwens evenmin...

\subsection{Consolidering}

Geleidelijk komen we, zoals ook al uit het voorgaande bleek, steeds meer bij een herhaling van zetten terecht. Het vonnis van de Groningse kantonrechter van 5 februari 1902 is in dat opzicht karakteristiek. ${ }^{131}$ Hele alinea's zijn vrijwel letterlijk overgenomen van de Hoge Raad. Er werd ook met zoveel woorden gewezen op "de beslissing van den hoogsten rechter (...) waarmede wij meenen ons te moeten vereenigen ${ }^{n}$. Het ging - voor zover ik weet - om de eerste "plakzaak" in onze geschiedenis. En zoals Graevestein van Heyst al in zijn proefschrift had voorspeld: "Wanneer een verbod tot venten in 
strijd zou zijn met de grondwet, dan zou ook dit hiermede in strijd zijn". ${ }^{132}$

Alleen, hij poneerde die stelling destijds om te laten zien hoe grotesk het standpunt van de Hoge Raad was. Immers: "het recht om het afficheeren te reglementeeren" was hier "nog nooit betwist"! Nu was het echter zover: het Groningse verbod om "zonder vergunning van B en W aan de straat eenige aanplakking te doen of te laten doen op eene plaats, die niet door hen daartoe is aangewezen" miste, volgens de kantonrechter, "verbindende kracht" en moest dan ook "buiten toepassing blijven". Interessant is de overweging:

"dat (...) bij de algemeenheid van het verbod van art. 7 Grondwet om de openbaarmaking van gedrukte geschriften aan eenig voorafgaand verlof te binden dat verbod geldt niet alleen voor alle middelen der openbaarmaking, maar ook voor alle plaatsen, zonder dat de straten daarvan zijn uitgezonderd".

Die passage doet ogenblikkelijk denken aan de overweging van de Hoge Raad waarin niet-ingezetenen van Zuidbroek werden gelijkgesteld met ingezetenen. In beide gevallen zien we hetzelfde redeneerpatroon. De eerste keer waren het alle middelen, onverschillig voor wie; de tweede keer: alle middelen, onverschillig waar. Zou het de derde keer om alle middelen gaan, onverschillig wanneer? Dan zou dat Maastrichtse verbod (om na zes uur te venten), waar ik het straks over had, onverbindend zijn. Op zich was dat weliswaar geen noodzakelijke ontwikkeling, maar iets dergelijks was destijds heel goed voorstelbaar.

Maar laat ik nog even bij die Groningse zaak blijven. In cassatie betoogde de Advocaat-Generaal Ort in zijn conclusie dat ten gevolge van die verbodsbepaling "juist de beoordeeling op welke plaatsen in de gemeente de door aanplakking beoogde openbaarmaking zal mogen plaats vinden, niet meer zal staan aan hem die zijne gevoelens of gedachten door de drukpers op die wijze wil openbaren en openbaart, maar aan de overheid wier verlof voor de openbaarmaking op de plaatsen, buiten de borden, vooraf zal moeten zijn verkregen. Het Grondwettelijk voorschrift mist daardoor zijn doel ", ${ }^{133} \mathrm{Hij}$ was het, kortom, met de kantonrechter eens. De Hoge Raad, echter, kwam via een andere route tot dezelfde uitkomst, te weten: verwerping van het beroep. De Hoge Raad meende, om te beginnen,

"dat de verordening (...) hier niet in het algemeen voorafgaand verlof tot eenige aanplakking aan de straat eischt, maar de aanplakking slechts onderwerpt aan een voorschrift, dat de wetgever in het belang der gemeentehuishouding wenschelijk achtte, en waarbij in dit geval de zorg zal hebben gewogen voor de openbare orde, zedelijkheid en vooral ook den welstand". ${ }^{134}$ 
Voor zover het plakken op een daartoe aangewezen plaats geschiedde, werd het immers vrijgelaten. De door de advocaat-generaal zo opgehemelde keuzevrijheid bij het bepalen van de plaats, was met andere woorden voor de Hoge Raad niet essentieel met het oog op de openbaarmaking. Vervolgens overwoog de Hoge Raad - geheel volgens het (eigen) boekje - dat naast het verbod van voorafgaand verlof van de overheid

"plaats is voor de bevoegdheid van den gemeentelijken wetgever om de verspreiding of andere middelen van openbaarmaking van gedrukte geschriften op den openbaren weg te onderwerpen aan voorschriften in het belang der openbare orde, bepaaldelijk ter beveiliging van het openbaar verkeer;

dat echter" - en nu komt het! - de "Groningsche politieverordening niet bevat zoodanig voorschrift waardoor de aanplakking in het openbaar aan eenige beperking in het belang der openbare orde wordt onderworpen, waar het alle aanplakking aan de straat zonder vergunning van Burgemeester en Wethouders verbiedt buiten de plaatsen die door hen daartoe zijn aangewezen, zoodat zelfs bij gebreke van die aanwijzing, onverminderd de administratieve verantwoordelijkheid van Burgemeester en Wethouders voor dat verzuim aan den Gemeenteraad (...), de aanplakking aan de straat nergens in de gemeente zonder "voorafgaand verlof' geoorloofd zoude zijn".

Diemer volstond jaren later met de mededeling dat de Hoge Raad hiermee "in gelijken zin" had geoordeeld als in zijn voorgaande arresten: "eenerzijds een ruime interpretatie van het grondwettelijk artikel, en anderzijds bevoegdheid voor den gemeentelijken wetgever, om verordeningen te maken in het belang van de openbare orde". ${ }^{135}$ Zeker, dat klopt. Toch is er wel mér over te zeggen, lijkt mij. Het door de Hoge Raad aangelegde criterium, dat Diemer hier bevestigd zag ${ }^{136}$, was in dit geval namelijk volstrekt geen punt van discussie. Alle partijen waren het erover eens. Het verbod sneuvelde echter om een heel andere reden. Het behelsde weliswaar een beperking van "de aanplakking", maar was eenvoudig niet "in het belang der openbare orde"! Niet art. 7 Gr.w. zorgde, met andere woorden, voor problemen, maar het toenmalige art. 135 gem.w. (vgl. het huidige art. 168 en het toekomstige art. $150 \mathrm{Gem} . w$.$) . Waar de Hoge Raad er in eerdere zaken$ steeds vanuit was gegaan dat het om bevoegd gegeven voorschriften ging, bleek dat uitgangspunt hier opeens onhoudbaar te zijn geworden. Een heel andere wijze van afdoening, kortom. Onbegrijpelijk dat er tot dusver louter oude kost in werd herkend. ${ }^{137}$

Veel meer aandacht trok een arrest dat nog geen maand later werd gewezen. ${ }^{138}$ We zitten dan in juni 1902 . Hoewel... de eerste sporen ervan waren 
pas te vinden in het Weekblad van het Recht van 18 augustus (W. 7780) - hetzelfde nummer, trouwens, als waarin dat eerdere arrest over Groningen stond. ${ }^{139} \mathrm{Nu}$ ging het echter nog niet om het arrest van de Hoge Raad, dat pas op 8 oktober (W. 7802) gepubliceerd zou worden, maar om het vonnis van de kantonrechter. Die had op 3 maart 1902 een 66-jarige arbeider uit Tilburg veroordeeld "in eene geldboete van $f 0,50$ " omdat hij "een biljet van openbare verkooping aan een telephoonpaal" had geplakt. Art. 26 van de Tilburgse APV verbood namelijk "aan anderen dan die daartoe door Burgemeester en Wethouders zijn aangesteld biljetten, drukwerken of geschriften op plaatsen aan of langs de openbare straat aan te plakken of vast te hechten".

Volgens de kantonrechter bleek uit de geschiedenis van die bepaling dat de bedoeling ervan was "alleen te besnoeien het recht om gewone handelsberichten, bekendmakingen van verkoopingen enz. aan te plakken langs de openbare straat". Daarbij ging het dus niet om "gedachten of gevoelens". Van strijd met art. $7 \mathrm{Gr}$.w. was daarom geen sprake, meende hij. De advocaat-generaal (Ort) vond daarentegen dat "de bewoordingen waarin art. 26 der verordening is vervat, eene dergelijke beperkte beteekenis niet toelaten, vermits daarin aan de niet uitgezonderde personen wordt verboden, welke drukwerken ook aan of langs de openbare straten aan te plakken of vast te hechten". ${ }^{140}$ De vraag "of art. 7 der Grondwet door zijn in algemeene termen gegeven voorschrift niet omvat de openbaarmaking van alles wat door de drukpers is voortgebracht", werd door hem dan ook "daargelaten". Hij kwam daar niet aan toe, omdat de APV-bepaling in zijn lezing zeker ó́k betrekking had op de gevallen die volgens de kantonrechter juist waren uitgezonderd.

De Hoge Raad kon die vraag - op zijn beurt - niet omzeilen. ${ }^{141}$ Los van de geschiedenis kwam hij - anders dan de advocaat-generaal - tot hetzelfde resultaat als de kantonrechter. Hij spitste de zaak geheel toe op het geval in kwestie en overwoog:

"dat aankondigingen van verkoopingen uit haar aard, waar, zooals hier, het tegendeel niet blijkt, niet behooren tot die voortbrengselen der drukpers, waardoor volgens de uitdrukking der Grondwet gedachten of gevoelens worden geopenbaard; dat alzoo art. 26a der Alg. Pol.

Verord. voor de gemeente Tilburg, in zoover het bij het bestreden vonnis is toegepast, niet in strijd is met art. 7 der Grondwet".

Tot dusver was een dergelijk onderscheid tussen enerzijds "voortbrengselen der drukpers, waardoor (...) gedachten of gevoelens worden geopenbaard" en anderzijds alle overige "voortbrengselen der drukpers" nog niet met zoveel woorden tot uitdrukking gebracht. Was het al wèl impliciet aanwezig geweest? Op 26 mei repte de Hoge Raad nog heel in het algemeen - en 
volgens het bijna klassieke sjablone - van "art. 7 der Grondwet (...) dat (...) zich verzet tegen den eisch van een 'voorafgaand verlof' der overheid om een gedrukt geschrift en bijgevolg wat daarin gedrukt is openbaar te maken". ${ }^{142}$ Waarom dan op 23 juni plotseling dat verschil? Misschien omdat het in die eerdere zaken steeds overduidelijk om "gedachten of gevoelens" ging. In Groningen, bijvoorbeeld, was de aanleiding een verkiezingsaffiche. Maar in dit geval ging het juist om iets volstrekt triviaals. Daardoor rees opeens de vraag of ook dat bescherming van art. 7 verdiende. Voór die vraag zich had aangediend, kon zij moeilijk al beantwoord zijn. Zeifs niet impliciet.

Iets anders is of dit "nieuwe" onderscheid (dat weliswaar niet uit de oudere rechtspraak te destilleren was) tevens uit de toon viel. Van den Bergh noemde de ontwikkeling enkele decennia later "volstrekt logisch en overtuigend". ${ }^{143}$ Dat lijkt mij, in elk geval wat de eerste kwalificatie betreft, overdreven. Hoogstens was de gang van zaken niet onlogisch: en was geen strijd met voorgaande uitspraken. Volgens Sybenga, echter, lag het arrest buiten "de lijn der eens door den H.R. aanvaarde jurisprudentie". ${ }^{144} \mathrm{Hij}$ vond het "geen sterk geargumenteerd arrest" en had liever gezien dat het Tilburgse verbod om een andere reden intact was gehouden, te weten omdat we hier eenvoudig niet te doen hadden "met een telkenmale, vóór elke aanplakking of vasthechting, te vragen verlof, dat dus van den inhoud afhankelijk zou kunnen zijn". ${ }^{14}$ De mogelijkheid van een inhoudelijke ingreep was volgens Sybenga klaarblijkelijk beslissend voor strijd met art. 7 . Klopt dat inderdaad? Zeker, de Hoge Raad repte vanouds (dat wil zeggen: sinds 1892) van "een gedrukt geschrift en bijgevolg wat daarin gedrukt is" (curs. RdW). De inhoud was dus bepaald niet over het hoofd gezien. Alleen, waarom zou daaruit moeten worden afgeleid dat er slechts een taboe rustte op inhoudelijke selectie? In Tilburg ging het - volgens de bewoordingen van het verbod - om "biljetten, drukwerken of geschriften" ongeacht de inhoud ervan, oftewel: met welke inhoud ook! Wie niet door B en W was aangesteld om "langs de openbare straat aan te plakken of vast te hechten" mocht zich daar niet aan bezondigen. Wat je ook wilde mededelen, op die manier mocht het niet - tenzij je zo'n aanstelling had. Was het nu echt aannemelijk dat de Hoge Raad een dergelijke ingreep toelaatbaar zou achten? Aannemelijk niet, lijkt mij, maar ik moet toegeven: het was ook niet uitgesloten. Want in zekere zin had Sybenga natuurlijk gelijk. Tot dat ogenblik had de Hoge Raad zich slechts gebogen over gevallen waarin je een individuele vergunning kon vragen. En dan bestond dus de mogelijkheid om van geval tot geval inhoudelijke maatstaven aan te leggen. Dat mocht niet. Iedereen was het daar inmiddels over eens. Maar het was niet het enige wat niet mocht, en daarover was men het kennelijk. nog niet eens. Logisch bezien kon dat ook. 
Beide standpunten waren, op basis van de jurisprudentie, verdedigbaar. Het arrest over het Tilburgse plakverbod bracht daar wellicht verandering in. Wellicht, want het was niet zeker. Het bleek hoogstens impliciet: waarom zou de Hoge Raad de zaak anders via dat nieuwe onderscheid - "gedachten of gevoelens" enerzijds, overige stukken anderzijds - hebben afgedaan? Zonder die maatregel kon het verbod kennelijk niet gesauveerd worden! $!^{140}$ Werd het eenmaal onder art. 7 gebracht, dan was het ten dode opgeschreven: er was immers voorafgaand verlof vereist. Hoewel... Misschien was de Hoge Raad daar echt niet aan toegekomen. Ik bedoel: als er al geen sprake was van "gedachten en gevoelens", hoefde men zich over de rest van art. 7 geen zorgen te maken. Dan was de "voorvraag" eenvoudig beslissend geweest.

Wie zal zeggen hoe de vork "werkelijk" in de steel zat? Merkwaardig was in ieder geval om - zoals Sybenga - de Hoge Raad aan te wrijven (wellicht) een andere weg te zijn ingeslagen dan je zelf op basis van eerdere arresten had verwacht, hoewel die eigen verwachting - zoals bleek - allerminst dwingend was. Het lijkt me dan eleganter om gewoon toe te geven dat je het mis had, of dat je het jammer vindt dat het anders is uitgepakt. Maar misschien had Sybenga zelf niet in de gaten dat er nog meer opties waren dan de zijne; ook dat is natuurlijk goed voorstelbaar (en - wat mij betreft niet zo vreselijk laakbaar).

Over het onderscheid tussen enerzijds "gedachten of gevoelens" en anderzijds de overige zaken die openbaar worden gemaakt, is vrijwel meteen al het nodige te doen geweest. D. Spanjaard poneerde dat

"hetgeen men door de drukpers doet openbaren, (...) per se nimmer iet anders (kan) zijn dan de uiting eener gedachte, welke ook; wat niet gedacht is, kan niet gedrukt worden. Al wat er in mij omgaat, al de voorstellingen die ik mij vorm, zijn mijne gedachten. Het woord in de beperkte beteekenis van 'oordeel over eene bepaalde zaak' op te vatten, strijdt zoowel met de algemeene uitdrukking in onze hoogste wet, als met de ratio der bepaling". ${ }^{147}$

Bovendien:

"Op welken wrakken grondslag overigens de onderscheiding berust, blijkt hieruit: plaats ik boven de eenvoudige aankondiging van den verkoop het woord 'aanbeveling' of iets dergelijks, dan ben ik volgens den Hoogen Raad niet meer strafbaar; want dan geef ik niet meer eene bloote aankondiging, maar openbaar ik tevens eene gedachte of een gevoelen. Heeft dat de Grondwetgever gewild?"

Een retorische vraag. Maar het ergst vond hij dat

"de gemaakte onderscheiding (...) nog veel verder reikende gevolgen (had), gevolgen bij de uitspraak zelve wellicht niet voorzien. Dat ze 
als onmiddellijk gevolg ook nog toelaat het wederinvoeren der censuur ten aanzien van dagbladen enz., althans wat de rubriek aankondigingen en advertenties betreft, en dus de inmenging van de overheid op een gebied, dat tot dusverre hier te lande geheel aan haar onttrokken was (...)".

Alleén "wat de rubriek aankondigingen en advertenties betreft"? Andere berichtgeving wellicht evenzeer, tenminste: zolang het slechts om feitelijke mededelingen ging. Of had de Hoge Raad zich daar niet over uitgesproken? Inderdaad, eigenlijk niet! Zelfs de opvatting dat aan "gedachten" in art. 7 Gr.w. slechts de betekenis van "oordeel over eene bepaalde zaak" werd toegekend, was niet rechtstreeks in het arrest te lezen. Het was niet meer dan één interpretatie waarmee het arrest "verklaard" kon worden. Ongetwijfeld heel handzaam, maar we moesten nog afwachten of we ermee uit de voeten konden. Best mogelijk dat er iets anders achter het arrest zou blijken schuil te gaan.

Ook Sybenga ${ }^{148}$ zag trouwens weinig in het door de Hoge Raad geaccentueerde onderscheid:

"Gedachten en gevoelens, diepgaand of oppervlakkig, kritisch of niet kritisch, voor kritiek al of niet vatbaar, buitengewoon of alledaagsch, hoe uiteenloopend en verschillend in rang, - het zijn toch alle gedachten en gevoelens. En ook het meest ordinaire gedachtenwerk, in eenige bekendmaking vervat, is en blijft niettemin gedachtenwerk". Diemer ${ }^{149}$ noemde het onderscheid later "vrij bedenkelijk" en Oud vond "met hem, dat de Grondwet het terrein van het gedrukte woord niet aldus heeft willen beperken". ${ }^{\text {s. }}$

In grote trekken lag het "leerstuk" intussen echter vast. Voor een deel begonnen zich herhalingen voor te doen ${ }^{151}$ en voor het overige ging het om verfijningen binnen het raamwerk van "de leer", zoals bijvoorbeeld in het bovenstaande geval over de gemeente Tilburg. Geen van de betrokkenen baseerde zich nog op iets anders; geen woord meer over de Belgische jurisprudentie. Het leerstuk was gevestigd (zij het dat de positie van de Kroon, zoals gezegd, nog enigszins onduidelijk was). 


\section{Hoofdstuk 2 Voortzetting en uitbreiding}

\subsection{De Rotterdamse en Utrechtse plakverboden (1903 en 1909)}

$\mathrm{Nu}$ het leerstuk eenmaal uit de steigers was, kwam het voorlopig aan op nuanceringen. Aan herbevestigingen van "de grote lijn" zal ik hier dan ook voorbij gaan. Vanaf nu zullen de stappen waarmee ik door de geschiedenis snel dus wat groter zijn. Soms, echter, is een zaak zo aardig, dat het jammer zou zijn er geen aandacht aan te schenken. Op 3 september 1904, bijvoorbeeld, werd iemand aangehouden omdat hij art. 12 van de Haagse APV zou hebben overtreden. Daarin was een verbod opgenomen om "op of aan de openbare straat bij het om niet of te koop aanbieden van gedrukte of geschreven stukken te roepen of te schreeuwen". ' Sinds 1897 weten we dat zo'n verbod volgens de Hoge Raad door de beugel kan. ${ }^{2}$ En ook deze keer bleek er niets op af te dingen. Maar de "verdachte" had een list verzonnen - een aanwijzing overigens, dat er vrij algemeen rekening mee werd gehouden dat de "leer" inmiddels vast lag en je hooguit met een truc kon proberen er "onderuit" te komen. Hij had geen gedrukse of geschreven stukken aangeboden, betoogde de colporteur, maar een blanco stuk papier; de brochure die daarin verpakt zat, gaf hij erbij cadeau. Zo ziet men dat iedere strafbepaling haar eigen verweer uitlokt. In dit geval mocht het overigens niet baten, want bij zijn aanbod had de colporteur $60 \mathrm{k}$. het cadeau al aangekondigd. Het aanbod betrof, met andere woorden, zowel de verkoop van het blanco omslag als de verstrekking om niet van de brochure. Juristerij is van alle tijden...

Maar de ontwikkeling ging verder. Een jaar na de Tilburgse zaak, waarmee het vorige hoofdstuk werd afgesioten, kwam er alweer een nieuw arrest over een soortgelijk verbod. Maar deze keer was de uitkornst anders. Het ging - in de woorden van de advocaat-generaal (Ort) - om een bepaling uit de Rotterdamse APV die "een iegelijk daartoe niet door Burgemeester en Wethouders gemachtigd" verbood "hetzij on een aanplakbord of zuil, hetzij elders op of aan de straat eenig aanplakbiljet of ander drukwerk of geschrift hoegenaamd, behoudens enkele hier niet ter zake dienende daarvan uitgezonderde geschriften en drukwerken, aan te plakken". ${ }^{3}$ De rechtbank had aan die bepaling, "wegens strijd met art. 7 der Grondwet, verbindende kracht ontzegd". En, zo ging de advocaat-generaal verder: "Dientengevolge werd de bij dat artikel behoorende strafbepaling niet toepasselijk geacht op de door den gerequireerde zonder machtiging van B. en W. aan de straat gedane aan- 
plakking van reclamebiljetten, bevattende, zooals het vonnis luidt: 'in beknopte reclamestijl de aankondiging aan het publiek van de meening en het gevoelen van den aanplakker of diens lastgevers dat de uit én stuk staal gebogen Ratner-brandkasten die verkrijgbaar zijn bij de firma Wijnmalen en Hausmann aan de Glashaven te Rotterdam van zoo deugdelijke constructie zijn dat wat daarin geborgen wordt tegen gevaar van brand afdoende beveiligd en verzekerd is!!'."

Zowel de advocaat-generaal als de Hoge Raad waren van oordeel dat die Rotterdamse eis van voorafgaand verlof inderdaad strijd met art. 7 Gr.w. opleverde. De advocaat-generaal haalde ook art. 135 Gem.w. (vgl. het huidige art. 168 en het toekomstige art. 150) erbij:

"De verordening gaat (...) m.i. verder dan art. 135 der Gemeentewet toelaat, omdat zij behelst eene bepaling in strijd met het voorschrift van art. 7 der Grondwet, zoodat daaraan geen verbindende kracht kan worden toegekend".

Was er dus zowel strijd met art. $7 \mathrm{Gr}$.w. als met art. 135 Gem.w.? Je krijgt de indruk dat de advocaat-generaal hier van twee walletjes probeerde te eten. Het zou mij niet verbazen als hij in verwarring was gebracht door het arrest van 26 mei 1902 over het Groningse plakverbod, waar hij trouwens naar verwees. In die zaak kwam de "openbare orde" van art. 135 ook opeens om de hoek kijken. Op het eerste gezicht werd daardoor de indruk gewekt dat het om een soort combinatie van art. 7 Gr.w. en art. 135 Gem.w. ging waaraan getoetst werd. Is het een wonder dat de advocaat-generdal vervolgens het zekere voor het onzekere koos en beide artikelen hand in hand ten tonele voerde?

De Hoge Raad wees deze keer op de onverenigbaarheid met art. 7 Gr.w., "onverminderd de bevoegdheid van den gemeentelijken wetgever om uit kracht van art. 135 der Gemeentewet de middelen van openbaarmaking van gedrukte geschriften op den openbaren weg te onderwerpen aan voorschriften in het belang der openbare orde, bepaaldelijk ter beveiliging van het openbaai verkeer". Een tamelijk ingewikkelde manier om tot uitdrukking te brengen dat een gemeente bij het bepalen van de inhoud van haar verordeningen niet alleen gebonden was aan art. $135 \mathrm{Gem} . w .$, maar tevens aan (0.a.) art. 7 Gr.w. De frase "onverminderd ... etc." stond klaarblijkelijk voor iets in de trant van: "hoewel de gemeente in beginsel bevoegd is om...". In zoverre was er nauwelijks nieuws onder de zon.

Belangrijker lijkt me dat de inhoud van het aanplakbiljet nu - stilzwijgend als "gedachte of gevoelen" werd aangernerkt. De rechtbank had het daar - blijkens de weergave van de advocaat-generaal - zelfs met zoveel woorden over. Daarmee was de advertentierubriek, waar Spanjaard naar aanleiding van het arrest over 'Tilburg voor vreesde, voor een groot deel veilig gesteld 
- het ging in deze zaak immers om zuivere handelsreclame. ${ }^{5}$ Ook dàn konden er, met andere woorden, "gedachten of gevoelens" in het spel zijn. Ik zeg met nadruk konden, want mér was - strikt genomen - niet uit dit arrest af te leiden; wellicht was het niet altijd zo - denk bijvoorbeeld aan de volgende advertentie (zonder een spoor van aanprijzing o.i.d.), te vinden in hetzelfde nummer van het Weekblad van het Recht als het hier besproken arrest:

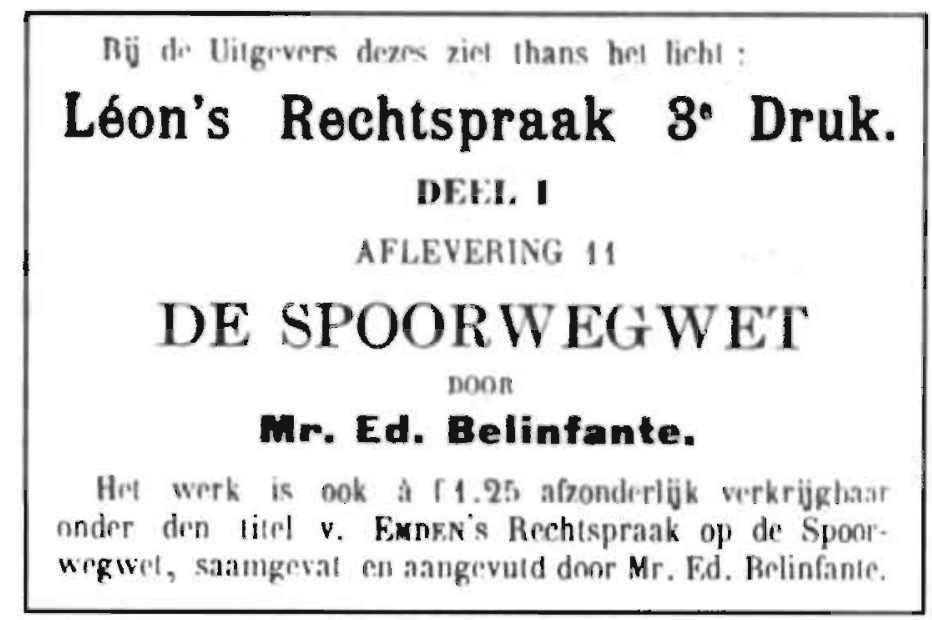

Louter een feitelijke mededeling. Louter? Waarom zou die uitgever dit werk van Mr. Ed. Belinfante dan onder onze aandacht willen brengen?

Nieuw, maar op een heel ander front, was de kwestie die in een beslissing van GS van Utrecht aan de orde kwam. In het Weekblad voor de Burgerlijke Administratie van 5 juni 1909 viel daarover het volgende te lezen':

"In eene verordening in de provincie Utrecht was verboden: "biljetten of bekendmakingen, van welken aard ook, anders te doen aanplakken dan op de door de gemeente daartoe bestemde aanplakborden, terwijl alle biljetten, zonder onderscheid, door den gemeenteboden zullen moeten worden aangeplakt'.

Gedep. Staten schreven naar aanleiding hiervan aan het gerneentebestuur: 'Het komt ons voor, dat volgens deze bepaling, in strijd met art. 7 der grondwet, niet de volledige vrijheid, om gedachten en gevoelens door middel van de drukpers te openbaren, wordt gewaarborgd.

Het zal toch volgens dit artikel verboden zijn mededeelingen te doen door aanplakking aan eigen voorwerpen.

Naar het ons voorkomt zal de Raad wel kunnen verbieden aan te plak- 
ken op de door de gemeente daartoe bestemde aanplakborden, tenzij zulks geschiedt door den gemeentebode, ook het aanplakken op aan anderen in eigendom behoorende voorwerpen zonder hunne toestemming, desnoods ook het aanplakken van verkoop- of reclamebiljetten elders dan op de door de gemeente daartoe besternde aanplakborden, doch mag hij niet verder gaan, door het aanplakken van alle mededelingen te verbieden op de wijze, als zulks in deze bepaling is geschied'."

Was de stand van de jurisprudentie daarmee correct weergegeven? Over de verhouding tot het eigendomsrecht - andere rechten bleven buiten het vizier van GS! - was feitelijk nog nooit een zaak geweest. ${ }^{7}$

Het Rotterdamse plakverbod van zoëven gold voor "een iegelijk": zonder machtiging van $\mathrm{B}$ en $\mathrm{W}$ mocht niemand daar plakken. Dat in het bijzonder eigenaren daar onder leden, kwam toen niet aan de orde - maar dat wil natuuriijk niet zeggen dat dit ook onder geen enkele omstandigheid relevant zou kunnen zijn.

In Groningen ${ }^{8}$ was het zonder vergunning van B en W verboden aan te plakken "op eene plaats die niet door hen daartoe (was) aangewezen". Volgens de Hoge Raad ging dat - zoals gezegd - te ver. Wekt het dan nog verbazing dat een nog verdergaande bepaling in een Utrechtse gemeente - waar niet alleen slechts op de daartoe aangevezen plaatsen mocht worden geplakt, maar bovendien slechts "door den gemeentebode" - evenmin door de beugel kon? Een retorische vraag, zou ik denken. Het resultaat waartoe GS kwam, was dan ook niet verrassend. De redenering echter wèl. Daarnaast spraken de andere voorbeelden die GS gaf - zacht gezegd - niet allemaal vanzelf. Waarom, bijvoorbeeld, zou een gemeente wèl "het aanplakken van verkoop- of reclamebiljetten elders dan op de door de gemeente daartoe bestemde aanplakborden" mogen verbieden? Was dat na het arrest over het Rotterdamse plakverbod van $1903^{\circ}$ nog te verdedigen? Opnieuw een retorische vraag, lijkt mij. In zoverre viel veel meer begrip op te brengen voor het door GS toelaatbaar geachte verbod om aan te plakken "op aan anderen in eigendom behoorende voorwerpen zonder hunne toestemming". Daar bestond in elk geval geen rechtspraak over, waaruit het tegendeel kon worden afgeleid. Nee, het was eenvoudig een speculatie, en - zeker in die tijd! - een zeer plausibele.

\subsection{Avondklok voor venters (1909 en 1910)}

Ging het bij de plakverboden tot dusverre om beperkingen naar de plaats waarop geplakt mocht worden (en gedeeltelijk om de vraag wie mocht plak- 
ken), bij het Maastrichtse ventverbod kwam vervolgens een beperking naar de tijd aan de orde. Volgens art. 30 bis van de APV-Maastricht was het "des avonds na zes uur" verboden om "boeken, couranten, losse bladen, prenten, tijdschriften of andere gedrukte of geschreven stukken" te "venten op den openbaren weg of aan de huizen der ingezetenen". Een raadslid van Maastricht, dat de Kroon om vernietiging van dit verbod had gevraagd, kreeg nul op het rekest. ${ }^{10}$ Daarmee volgde de Kroon het oordeel van GS. Volgens GS kon de bepaling door de beugel omdat zij - in de eerste plaats - geen "voorafgaande vergunning" eiste.

"Evenmin stelt zij een absoluut verbod van venten vast, want vór 6 uren des avonds blijft het venten geoorloofd, terwijl ná dat uur nog steeds drukwerken enz. gratis kunnen worden verspreid"."

Daarbij werd door GS naar de jurisprudentie van de Hoge Raad verwezen. ${ }^{12}$ Alleen, de Hoge Raad had juist uitdrukkelijk overwogen dat het bij een verbod niet terzake deed dat je het geschrift nog wèl op een andere wijze openbaar kon maken. Alle "middelen van openbaarmaking" moesten openstaan. Waarom was GS daaraan voorbijgegaan? Vergeetachtigheid? Nu al? Op 4 april 1910 sprak de Hoge Raad zich over hetzelfde verbod uit. ${ }^{13}$ En opnieuw was de afloop gunstig voor Maastricht:

"Naar mijn bescheiden mening", aldus de A-G Ledeboer voorafgaand aan het arrest, "zou er vooral nadruk op moeten worden gelegd, dat in het grondwetsartikel niet meer ligt, dan een verbod van elk preventief toezicht op den inhoud van door de drukpers openbaar te maken geschriften, ten einde te voorkomen, dat de subjectieve meening van wien dan ook, belemmerend of verhinderend zou kunnen werken, op het vrijelijk openbaren van gedachten of gevoelens door middell van de pers".

Was de advocaat-generaal al te "bescheiden", of verkondigde hij gewoon de opvatting van de Hoge Raad? Je krijgt de indruk dat hij vooral door Sybenga geïnspireerd was. ${ }^{14}$ Ik ben daar al eerder op ingegaan. ${ }^{15}$ Laat ik mezelf dan ook niet herhalen en er slechts aan herinneren dat zijn zienswijze - wat de jurisprudentie van de Hoge Raad betreft - allerminst vanzelf sprak. Geheel in de lijn van Sybenga veroordeeide Ledeboer

"eene bepaling in eene gemeentelijke verordening, die het verspreiden van gedrukte stukken afhankelijk stelt van een voorafgaand verlof van de plaatselijke overheid. Immers aan de autoriteit wier verlof daartoe vereischt wordt, is daarmede overgelaten, naar welgevallen en dus ook op grond van dezer subjectieve meening met betrekking tot den inhoud van het geschrift, eene vergunning te weigeren of te verienen".

Wanneer de mogelijkheid van inhoudelijke toetsing er niet was, was dus ook de ratio voor zijn "veroordeling" komen te vervallen. Toch kwam hij 
- anders dan Sybenga - niet tot de conclusie dat een verbod (of vergunningvereiste) waarbij die mogelijkheid zich niet voordeed, zonder meer geoorloofd was. Nee, hij drukte zich subtieler ${ }^{16}$ uit:

"Een onvoorwaardelijk verbod om geschriften van welken aard ook te verspreiden enz., mits beperkt naar plaats, tijd en wijze of middel, komt mij (...) volkomen geoorloofd voor (curs. RdW). (...) De inhoud der geschriften blijft daarbij geheel buiten beschouwing".

Waar die tussenzin - "mits beperkt naar plaats, tijd en wijze of middel" - op stoelde, werd in zijn conclusie helaas niet duidelijk gemaakt. Wat bedoelde hij bovendien? Moest een verbodsbepaling echt zowel naar plaats als naar tijd beperkt zijn? Ging het, met andere woorden, om een cumulatieve of om een alternatieve opsomming? En wat behelsde die beperking naar "wijze of middel" van verspreiding? Was de advocaat-generaal misschien net zo vergeetachtig als GS? Laten we het er maar op houden dat hij zich op het standpunt van de Hoge Raad stelde - dat is immers (gezien de bewoordingen) niet uitgesloten. Dan zou dus per "wijze of middel" van verspreiding (of liever: openbaarmaking) moeten gelden dat er gebruik van kon worden gemaakt (oftewel - zoals het Hoge Raad het in 1892 uitdrukte - dan gold dat de "openbaarmaking zelve niet door preventieve maatregelen (mocht) worden belet").

Blijft echter de vraag of zo'n onvoorwaardelijk verbod, mits beperkt naar tijd en/of plaats, inderdaad geoorloofd was. Kon je daar, aan de hand van eerdere jurisprudentie, iets over zeggen? Het enige onvoorwaardelijke verbod dat we tot nu toe tegenkwamen, stond in de APV van Tilburg. Zowel naar tijd als naar plaats ging het daarbij tevens om een onbeperkt verbod. Maar of dat volgens de Hoge Raad enige weerslag had op de al dan niet verbindendheid ervan, weten we niet. Het enige wat we er feitelijke over weten, is dat het wel verbindend was ten aanzien van een geschrift dat niet onder art. $7 \mathrm{Gr} . \mathrm{w}$. viel. ${ }^{17}$ Was het dus niet verbindend ten aanzien van geschriften die wel onder art. 7 vielen? Laten we hopen dat de advocaatgeneraal een beter argument had voor zijn bewering. Maar welk?

De Hoge Raad hield zijn motivering uiterst beknopt. Na de traditionele alinea waaruit blijkt dat art. 7 weliswaar heel ver reikt, maar dat gemeenten toch ook regels mogen stellen (zij het niet onbegrensd), volgden drie korte overwegingen. De laatste hield in dat "de vraag of en in welke mate de openbare orde te Maastricht" de gewraakte beperking vorderde, "de doelmatigheid der verbodsbepaling (betrof), welke niet (...) ter beantwoording van de rechterlijke macht (stond)". Nam de Hoge Raad daarmee niet een ander standpunt in dan op 26 mei $1902 ?^{18}$ Toen overwoog hij nog rechttoe rechtaan dat het Groningse plakverbod "niet bevat zoodanig voorschrift, waardoor de aanplakking in het openbaar aan eenige beperking in het belang 
der openbare orde wordt onderworpen". Wel een beperking dus, maar niet "in het belang der openbare orde".

Kon de Hoge Raad in het ene geval well een oordeel uitspreken over hetgeen door de openbare orde werd gevorderd, en in het andere plotseling niet meer? Zo kùn je het ongetwijfeld lezen. Maar het hoeft niet. Laten we het er dus op houden dat de Hoge Raad consistent was. Dat wil zeggen dat in Groningen iets anders aan de hand was dan in Maastricht. De bepaling kon respectievelijk niet in het belang van de openbare orde zijn (Groningen), en zij kon dat wel zijn, maar was het in werkelijkheid wellicht niet (Maastricht). Het eerste lees je als het ware uit de bepaling-zelf, het tweede vergt een grondig onderzoek en een afweging ter plekke.

In de twee andere overwegingen werd allereerst geconstateerd dat de gemeenteraad bij de vaststelling van het ventverbod, "slechts gebruik makende van de hem door art. 135 der Gemeentewet verleende en door art. 7 der Grondwet onaangetaste bevoegdheid, de grenzen van die bevoegdheid niet (had) overschreden". Daarmee was natuurlijk niets nieuws gezegd. We herkennen die zin uit vorige arresten. Maar opvallend is dat de daaropvolgende overweging begint met "dat toch". Duidt dit op een toelichting van de voorgaande? De Hoge Raad overwoog:

"dat toch in de gewraakte bepaling de openbaarmaking van gedrukte stukken niet in het algemeen wordt verboden of van een voorafgaand verlof ${ }^{19}$ afhankelijk gesteld, doch slechts de vrijheid om zoodanige. stukken op de openbare straat door een bepaalde wijze van verspreiding, namelijk het venten, openbaar te maken, wordt beperkt door een voorschrift omtrent den tijd, waarop zulks met het oog op het publiek verkeer is verboden".

Inderdaad, een toelichting op het voorgaande, zou ik denken: de verordening was bevoegd gegeven, want zij had "het oog op het publiek verkeer". Art. 7 Gr.w. kwam niet eens aan de orde, nu het venten "niet in het algemeen (werd) verboden of van een voorafgaand verlof afhankelijk gesteld". Vandaar dat vervolgens - in de derde overweging - kon worden volstaan met de mededeling dat de vraag of het verbod eigenlijk wel nodig was "niet staat ter beantwoording van de rechterlijke macht". Kortom: de bepaling kon door de beugei.

Wat begon als een kwestie over de vrijheid van drukpers, werd afgedaan via het loket van de bevoegdheid. Meér zat er, volgens de Hoge Raad, niet in. De gang van zaken leek op die ten aanzien van het "schreeuwen en roepen". Ook dár werd telkens herhaald dat art. 7 Gr.w. de verordeningsbevoegdheid van gemeenten onverlet liet. En aangezien al dat geschreeuw en geroep, volgens de Hoge Raad, niets met de openbaarmaking te maken had, werd vervolgens uitsluitend nog stilgestaan bij de vraag of de gemeente bevoegd 
was. ${ }^{20}$ In dit geval was er weliswaar - anders dan bij "schreeuwen en roepen" - een rechtstreeks verband met het openbaar maken, maar zolang het venten niet in het algemeen werd verboden of van een voorafgaand verlof afhankelijk gesteld, was er klaarblijkelijk geen vuiltje aan de lucht. Simpel, elegant en geheel consistent met voorgaande uitspraken - alleen: moeilijk om te voorspellen!

\subsection{Venten als aanleiding voor ongeregeldheden (1910)}

Twee weken later sprak de Hoge Raad zich alweer uit over de Maastrichtse "verordening op de straatpolitie". ${ }^{21}$ Deze keer ging het om art. 32:

"Wanneer het venten op den openbaren weg of aan de huizen aanleiding geeft tot volksoploopen, ongeregeldheden of overlast voor de ingezetenen, zijn de venters verplicht op de eerste aanmaning van wege de politie het venten te staken".

Daarmee zijn we feitelijk weer terug bij het begin van de discussie. D'Aulnis de Bourouill schreef (zoals gezegd) in $1895 \mathrm{al}$ :

"De verstoringen der openbare orde vloeiden niet voort uit het pak couranten, dat de colporteur droeg, doch uit de eigenaardige gedragingen, welke de colporteur zich veroorloofde. Welnu, men stelle dat eigenaardige gedrag strafbaar, en dan is men op den goeden weg". ${ }^{22}$ Diezelfde opvatting was men wellicht in Maastricht toegedaan (voor zover het venten zich althans vór zes uur 's avonds afspeelde, want daarna was het - hebben we net geleerd - verboden). In elk geval had men (overdag) niet het venten-zelf aangepakt (en al helemaal niet louter het venten met drukwerk). Slechts wanneer het "aanleiding" gaf tot "volksoploopen" kon ertegen worden opgetreden.

Vandaar ook dat de aangehouden colporteur van "De Voorvechter" zich erop beriep dat de bepaling alleen beoogde:

"de tusschenkomst der politie in te roepen en de venters op de eerste aanmaning van wege de politie met venten te doen staken, indien de venter zelf door eenige daad de oorzaak is van - of aanleiding geeft tot volksoploopen, ongeregeldheden of overlast voor de ingezetenen, en niet wanneer anderen, die den venter achtervolgen, daarvan de oorzaak zijn of daartoe aanleiding, zooals ten deze".

De venter moest, met andere woorden, niet het slachtoffer worden van een "hostile audience".

Volgens de Hoge Raad, echter, vond die opvatting "geen steun in de bewoordingen" van de bepaling. Bovendien wees het voorschrift zelf er niet op dat een dergelijk "beperkte strekking" de gemeentelijke wetgever voor ogen 
had gestaan. Dat betekende dus dat "daarbij niet bepaaldelijk de eisch (werd) gesteld, dat de venter, door zijne handelingen bij het venten, zelf tot de bedoelde orde- of rustverstoring aanleiding (had) gegeven"'. Art. 7 Gr.w. leverde daar, meende de Hoge Raad, geen beletsel voor op, nu het Maastrichtse voorschrift immers

"alleen in het geval dat het venten op den openbaren weg of aan de huizen tot orde- of rustverstoring aanleiding geeft, de verplichting oplegt om op last der politie gegeven met het oog op de eischen van de oogenblikkelijk verstoorde openbare orde tijdelijk aldaar het venten te staken, maar overigens onaangetast laat de vrijheid om gedrukte geschriften op elke andere plaats en op elke andere wijze, en zonder voorafgaand verlof te verspreiden" (curs. RdW).

In de toelichting op het cassatiemiddel was eerder betoogd dat de Maastrichtse bepaling "de mogelijkheid (opende) om het venten van geschriften op den openbaren weg geheel te beletten, waardoor het daarin vervatte voorschrift een bedekten en ongeoorloofden aanslag" zou inhouden op (onder meer) art. 7 Gr.w. Gezien de motivering van het arrest over het Haags ventverbod, had een zekere gevoeligheid van de Hoge Raad op dit punt voor de hand gelegen. Juist de dreiging van een verkapt algeheel verbod - niets zou namelijk "gemakkelijker (...) vallen dan het grondwettelijk voorschrift door verschillende bepalingen in rijkswetten en gemeenteverordeningen, ieder op zich zelve beperkt tot enkele daarbij aangewezen middelen van openbaarmaking, geheel te verijdelen" - juist die dreiging gaf toen de doorslag het verbod van voorafgaand verlof op alle "middelen van openbaarmaking" van toepassing te verklaren.

In deze Maastrichtse zaak bleek de Hoge Raad echter ongevoelig voor dit argument. Hij ging er althans niet op in. De zaak werd eenvoudig - zoals inmiddels gebruikelijk was geworden - via een zeer algemeen gestelde overweging afgedaan. Zoals we in eerdere zaken in het duister moesten tasten waarom schreeuwen en roepen los van het venten stond, waarom sommige drukwerken geen "gedachten of gevoelens" behelsden, en waarom een absoluut verbod slechts absoluut was als het de gehele dag besloeg, zo konden we nu alleen maar gissen waarom het gevaar van uitdijing niet relevant meer was.

Gold in het arrest van veertien dagen tevoren nog de regel dat er geen vuiltje aan de lucht was, zolang het venten niet in het algemeen werd verboden of van een voorafgaand verlof afhankelijk gesteld, in deze zaak lijkt alles in orde te zijn, zolang in elk geval de vrijheid onaangetast blijft om gedrukte geschriften op elke andere plaats en op elke andere wijze, en zonder voorafgaand verlof te verspreiden. Stemmen die criteria met elkaar overeen? Vreemd, dat die vraag - voor zover ik weet - nooit door iemand werd opge- 
worpen. Diemer vond het arrest weliswaar "nadere vermelding waard", maar dat betekende slechts dat hij de belangrijkste overwegingen ervan overschreef. ${ }^{23}$

Laat ik die criteria maar eens naast elkaar zetten:

\section{4 april 1910}

- geen algemeen verbod

- geen voorafgaand verlof nodig

\section{8 april 1910}

- geen voorafgaand verlof nodig

- andere plaats beschikbaar

- andere verspreidingswijzen beschikbaar

Wat in de eerste plaats opvalt, is dat op 18 april niets over een algemeen verbod werd gezegd. Erg zwaar hoeven we daar niet aan te tillen, denk ik. Het enkele bestaan van andere ventmogelijkheden impliceerde immers dat van een dergelijk verbod geen sprake was.

Interessanter was de verwijzing op 18 april naar andere plaatsen, waar nog well gevent mocht worden. Daarmee correspondeerde de impliciete verwijzing naar de beschikbaarheid van andere tijdstippen in het arrest van 4 april. In die zin reikte het eerste arrest feitelijk verder dan het tweede. Toen ging het immers om een verbod voor de hele stad gedurende een bepaalde tijd. De tweede keer gold het verbod evenmin permanent, maar betrof het tevens slechts een bepaalde plaats. In geen van beide situaties hadden we, volgens de Hoge Raad, met een "algemeen verbod" te doen. Wat kunnen we daaruit afleiden? Als je een bepaald "middel van openbaarmaking" nooit op enigerlei (openbare) plaats kunt benutten, lijkt er weinig ruimte voor twijfel: als dàt geen algemeen verbod is, wat dan well? Maar stel nu eens dat je zo'n "middel van openbaarmaking" slechts op een bepaalde plaats (of op bepaalde plaatsen) nooit mag benutten. Wat dan? Daar leerde deze rechtspraak ons - strikt genomen - niets over, al was het feit dat in het arrest van 18 april (als mogelijk alternatief) losjes naar "elke andere plaats" werd verwezen, wellicht veelzeggend en was het verstandig er vanuit te gaan dat een absoluut verbod ten aanzien van een bepaalde plaats (of bepaalde plaatsen) toelaatbaar zou worden geacht.

Opmerkelijk was tenslotte dat in het laatste arrest gewag werd gemaakt van de mogelijkheid andere verspreidingsmiddelen te benutten, in plaats van te venten. Stond dat niet haaks op hetgeen sinds 1892 tot ontwikkeling was gebracht? De bescherming van art. $7 \mathrm{Gr} . \mathrm{w}$. gold toch voor alle "middelen van openbaarmaking" gelijkelijk? Was de Hoge Raad dat even vergeten? Wie weet! Maar wacht even: niet te snel! We hoeven de Hoge Raad hier niet van inconsistentie te betichten. Laat ik uitleggen wat ik bedoel. 
Wat hield die klassieke opvatting van de Hoge Raad ook al weer in? Dat een algemeen verbod van een bepaald "middel van openbaarmaking" niet kan worden gecompenseerd door de beschikbaarheid van een ander "middel van openbaarmaking". We moeten, kortom, bezien wat er van het arrest overblijft, wanneer we ervan uitgaan dat die opvatting werd gehandhaafd. Dan telt de verwijzing naar die andere mogelijkheden (denk bijvoorbeeld aan thuisbezorging) dus niet mee als argument. Dat wil zeggen dat de zaak uitsluitend werd afgedaan op grond van de beschikbaarheid van andere plaatsen waar zonder voorafgaand verlof kon worden gevent. Het vrije venten was om die reden, volgens de Hoge Raad, niet uitgebannen. Dus vond de verwijzing naar andere "middelen van openbaarmaking" hier niet ter compensatie van het weggevallen venten plaats; dat wàs immers in de ogen van de Hoge Raad juist niet weggevallen als "middel van openbaarmaking"! Die verwijzing naar andere middelen was, met andere woorden, niet redengevend, maar aanvullend - een hint, als het ware. Is het niet veelzeggend dat we dergelijke vriendelijkheden niet verwachten van "ons hoogste rechtscollege"?

\subsection{Het bekendmaken van de inhoud (1910)}

Van Maastricht belanden we vervolgens in Hilversum. Daar gold een verbod om "op of aan den openbaren weg den inhoud van eenig gedrukt of geschreven stuk volledig of verkort, 't zij met de bewoordingen van dat stuk of in andere bewoordingen bekend te maken". We zijn die bepaling al eerder tegengekomen. ${ }^{24}$ Toen ging het nog om een vonnis van de kantonrechter. Deze keer (15 jaar later) kwam de Hoge Raad eraan te pas. ${ }^{25}$

In april 1909 had iemand - ongetwijfeld met het oog op de aanstaande geboorte van een nazaat van koningin Wilhelmina - de brochure "Een gouden wieg en het volk in ellende" op straat te koop aangeboden. En bij die gelegenheid had hij ook de inhoud ervan verkort "bekend gemaakt, door voorzegd opschrift van dat stuk ten aanhoore van het publiek luide uit te roepen onder bijvoeging van de woorden 'kost maar één cent'." Dat leidde tot een veroordeling door de rechtbank en volgens de advocaat-generaal (Ledeboer) was daar - in cassatie - niets op af te dingen. Immers, art. 7 Gr.w. liet

"de bevoegdheid van den plaatselijken wetgever (onaangetast) om de verspreiding, het venten van gedrukte stukken in het openbaar, te onderwerpen aan voorschriften in het belang der openbare orde, bepaaldelijk ter beveiliging van het openbaar verkeer en een verbod om te doen, wat in casu als bewezen is aangenomen, kan zeker zijn 
van die strekking". ${ }^{26}$

Hij meende zich daarbij gesteund te weten door zowel de rechtspraak als de literatuur. En inderdaad, zelfs pal daarvór nog (op 13 juni 1910) bleek de veroordeling van een colporteur, die luid roepende "De Vrije Socialist" had gevent, in cassatie onaantastbaar te zijn. ${ }^{27}$

De Hoge Raad echter, kwam nu tot een andere uitkomst. Naar aanleiding van de Hilversumse bepaling overwoog hij:

"dat dit artikel niet inhoudt zoodanige voorschriften omtrent de verspreiding van gedrukte of geschreven stukken op of aan den openbaren weg, als de gemeentewetgever krachtens art. 135 Gemeentewet (vgl. art. 168 huidige en art. 150 toekomstige Gem.w., RdW) bevoegd is, in het belang der openbare orde vast te stellen, maar onvoorwaardelijk verbiedt den inhoud van dergelijke stukken op welke wijze ook te Hilversum op of aan den openbaren weg bekend te maken;

dat het artikel daardoor rechtstreeks in strijd komt art. 7 Grondwet, vermits met de daarin gewaarborgde vrijheid om door de drukpers gedachten of gevoelens te openbaren, zoodanig onvoorwaardelijk verbod niet is overeen te brengen;

dat de toegepaste verbodsbepaling derhalve mist bindende kracht en de Rechtbank door desondanks op grond van die bepaling den requirant te veroordeelen, art. 7 Grondwet heeft geschonden".

Het verschil tussen de bekende "roep-en-schreeuw-verboden" enerzijds, en bepalingen zoals deze Hilversumse anderzijds, was eerder al gesignaleerd door de minister van Binnenlandse Zaken, en wel naar aanleiding van het voorstel van GS van Zeeland om over te gaan tot vernietiging van een bepaling uit Terneuzen. Daar had men niet alleen het roepen, schreeuwen en luidkeels aanbevelen verboden (art. 24 lid 1 en 2), maar daar gold tevens een verbod (art. 24 lid 3) om:

"door middel van een reclamebord of met luide stemme den inhoud (van gedrukte of geschreven stukken) geheel of gedeeltelijk bekend te maken, hetzij door middel van een reclamebord, hetzij door zichtbare teekenen, hetzij door geraas makende middelen op de bedoelde stukken of den inhoud daarvan de aandacht te vestigen".

Op 17 november 1903 ontvingen GS het volgende commentaar van de minister ${ }^{28}$ :

"Tegen 1 en 2 van art. 24 bestaat bij mij geene bedenking, wijl door roepen, schreeuwen en luidkeels aanbevelen de openbare orde kan worden verstoord. Met betrekking tot art. 24. sub 3 zij opgemerkt, dat ook door bekendmaking met luider stemme en door geraas-makende middelen de openbare orde kan worden verstoord; niet echter door 
reclameborden en door zichtbare teekenen. De vermelding van laatstbedoelde middelen behoort alzoo uit het artikel te worden gelicht".

En dat laatste geschiedde vervolgens, "ten einde eene voordracht tot vernietiging te voorkomen".

De Hoge Raad leek hetzelfde standpunt in te nemen als de minister. De term "bekendmaken" werd klaarblijkelijk te ruim geacht. Daarmee werd immers niet alleen geschreeuw en geroep verboden - wat op zich mogelijk was geweest - maar werd tevens iedere andere wijze van "bekendmaking" (= openbaarmaking?) onmogelijk gemaakt. Net als de minister wees de Hoge Raad erop dat het verband met de openbare orde dan ver te zoeken was. Alleen, waarom overwoog de Hoge Raad "dat dit artikel niet inhoudt zoodanige voorschriften (...) als de gemeentewetgever (...) bevoegd is in het belang der openbare orde vast te stellen"? Was dat niet lichtelijk overdreven? Gedeeltelijk kon de bepaling tenslotte heel goed de openbare orde betreffen; het enige was dat zij $60 \mathrm{k}$ dingen betrof die daar niks mee te maken hadden. En daar mocht de gemeente op grond van de toenmalige artikelen 135 Gem.w. en $144 \mathrm{Gr}$.w. niet aankomen. Een bepaling die daar toch aankwam, hield (met andere woorden) niet een zodanig voorschrift in als de gemeentewetgever bevoegd was vast te stellen. Want met zo'n bepaling overschreed die wetgever zijn bevoegdheid. Dat was, in de ogen van de Hoge Raad, klaarblijkelijk fataal. De bepaling werd in haar geheel onverbindend geacht, en niet alleen voor zover zij de openbare orde niet kon betreffen (zoals men wellicht op grond van het arrest over het ventverbod in Zuidbroek (1897) zou verwacht). ${ }^{29}$ De colporteur van "De gouden wieg en het volk in ellende", die luid roepend had gevent, werd daarom van elke rechtsvervolging ontslagen, hoewel de gemeente dat "luid roepen" op zich well had kunnen verbieden.

Speelde art. $7 \mathrm{Gr} . w$. dan in het geheel geen rol bij de onverbindendverklaring? Toch wel, en daardoor hangt het voorgaande eigenlijk een beetje in de lucht. Hoe de vork precies in de steel zat, is mij (eeriijk gezegd) niet duidelijk. Kort samengevat kwam de redenering van de Hoge Raad hierop neer:

1. de gemeente was niet bevoegd de betreffende bepaling in het belang van de openbare orde uit te vaardigen;

2. de bepaling behelsde een onvoorwaardelijk verbod de inhoud op welke wijze ook bekend te maken;

3. zo'n onvoorwaardelijk verbod was in strijd met art. 7 Gr.w.;

4. dus was de bepaling onverbindend en leverde toepassing ervan strijd met art. 7 Gr.w. op.

Was de gemeentelijke bevoegdheid overschreden omdat er strijd met art. 7 Gr.w. was? Vreemd, want wat had het ene (art. 135 Gem.w.) te maken met 
het andere (art. 7 Gr.w.)? Nou ja, misschien deden die twee overschrijdingen zich alleen maar - toevallig - tegelijkertijd voor. Waarom dan de onverbindendverklaring uitsluitend op grond van art. 7 Gr.w.? Nee, ik denk eerder dat het een wat ongelukkige poging was om - opnieuw tot uitdrukking te brengen dat gemeenten weliswaar op grond van art. $135 \mathrm{Gem} . w$. en art. $144 \mathrm{Gr} . w$. bevoegd waren in het belang van (onder meer) de openbare orde voorschriften vast te stellen, maar dat daarmee geen vrijbrief was gegeven om in strijd met art. $7 \mathrm{Gr} . w$. te handelen. Dan wordt ook die nadruk op het onvoonwaardelijke karakter van het verbod opeens zinvol. Want een onvoorwaardelijk verbod "den inhoud van (gedrukte of geschreven) stukken op welke wijze ook (...) op of aan den openbaren weg bekend te maken", kon - gezien de eerdere jurisprudentie - natuurlijk niet door de beugel. Veelal zal zo'n wijze van bekendmaking immers tevens als "middel van openbaarmaking" in de zin van art. 7 zijn aan te merken. Zo opgevat bracht het arrest, kortom, niets nieuws. De uitkomst was niet alleen consistent met vorige uitspraken, maar - bij wijze van uitzondering - $66 \mathrm{k}$ voorspelbaar (zij het dat moeilijk te voorzien was dat de Hoge Raad de bepaling geheel onverbindend zou verklaren en niet slechts gedeeltelijk).

Sybenga ${ }^{30}$ noemde het arrest niettemin "moeilijk te verdedigen". Volgens hem werd in het Hilversumse artikel niet alleen geen "voorafgaand verlof" geëist, bovendien werd "geen volstrekt verbod van publicatie (...) gesteld, maar enkel een zonder uitzondering geldende beperking van plaats en wijze of middel". En daarom zou onverbindend verklaring misplaatst zijn geweest. "Enkel een beperking"... Dat was natuurlijk een gotspe! Maar belangrijker was dat Sybenga eenvoudig een ander criterium hanteerde dan de Hoge Raad. Enerzijds ging het er, volgens de Hoge Raad, inderdaad om of er een "voorafgaand verlof" werd geëist; in zoverre had Sybenga gelijk, alleen daarvan was in casu geen sprake. Dat werd door niemand betwist. Anderzijds echter mocht geen enkel middel van openbaarmaking in het algemeen worden verboden, en dat ging veel verder dan dat er geen "volstrekt verbod van publicatie" mocht worden gesteld. Is het dan een wonder dat de Hoge Raad op problemen stuitte waar Sybenga geen enkele ongerechtigheid kon ontwaren?

Nog bonter maakte Diemer het later in zijn proefschrift. ${ }^{31}$ Hij was van mening "dat de Hoge Raad in dit arrest te ver (ging)".

"Het karakter van drukwerk brengt nu eenmaal met zich", aldus

Diemer, "dat het wordt verspreid, niet dat het wordt gedeclameerd.

Tusschen spreken en schreeuwen, waarvan het verbod meermalen is goedgekeurd, ligt niet een nauwkeurig te ornschrijven grens, en zoo deze grens bestaat, is zij niet van principieëlen aard".

"Bekendmaken" stelde hij kennelijk gelijk met "declameren". En als 
"schreeuwen" verboden mocht worden, waarom "declameren" dian niet? Tja, dat ligt ongetwijfeld tamelijk subtiel. Te subtiel, wellicht (al heeft de Hoge Raad zich vele jaren later toch aan iets dergelijks gewaagd toen hij het "hoorbaar aanbevelen" van De Wachttoren door een Jehova's getuige onder art. 7 bracht). ${ }^{32}$ Maar in dit geval lag het allemaal veel minder subtiel. Want onder "bekendmaken" viel niet alleen "declameren", ook het gebruik van bijvoorbeeld reclameborden, affiches en sandwich-mannen viel eronder.

\subsection{Beperkingen naar de tijd: Rosendaal (1916-1920)}

Het thema dat in het arrest van 4 april 1910 (Maastricht) aan de orde was gekomen, kwam een paar jaar later terug in twee arresten over het Gelderse Rosendaal. Ging het in Maastricht om een verbod na zes uur 's avonds "boeken, couranten, losse bladen, prenten, tijdschriften of andere gedrukte of geschreven stukken" te venten ${ }^{33}$, in Rosendaal was het "verboden zonder schriftelijke vergunning van B en W tusschen des morgens 8 uur en des avonds 8 uur prentbriefkaarten, andere voorwerpen of waren van welken aard ook, hetzij op of aan den openbaren weg, hetzij aan de huizen te verkoopen, aan te bieden of ten verkoop in voorraad te hebben". ${ }^{34}$

Het Maastrichtse verbod kon, zoals gezegd, door de beugel. Er was, volgens de Hoge Raad, slechts sprake van een geaorloofde beperking "met het oog op het publieke verkeer", zonder dat de "openbaarmaking" in het algemeen werd verboden of afhankelijk gesteld van een voorafgaand verlof. Ten aanzien van het Rosendaalse verbod overwoog de Hoge Raad echter:

"dat deze bepaling in hare algemeenheid mede betreft prentbriefkaarten, indien die zijn gedrukte stukken en geschriften, waarin gedachten of gevoelens worden geopenbaard en waarop mitsdien van toepassing is het voorschrift van art. 7 der Grondwet, dat niemand voorafgaand verlof noodig heeft om door de drukpers gedachten of gevoelens te openbaren ${ }^{35}$;

dat die bepaling dientengevolge in zooverre, als behelzende niet een regeling en beperking in het belang der openbare orde van de uitoefening der vrijheid om gedachten en gevoelens door zoodanige prentbriefkaarten te openbaren, maar als bevattende een algemeen verbod daarvan, zij het op bepaalde uren, tenzij men daartoe schriftelijke vergunning van $B$ en $W$ mocht hebben verkregen, in strijd is met gemeld grondwetsartikel en alzoo verbindende kracht mist". ${ }^{36}$

Zodra er sprake was van een algemeen verbod, hield de bepaling kennelijk op "een regeling en beperking in het belang der openbare orde te zijn". Een dergelijke mengvorm van enerzijds de bevoegdheidsproblematiek en ander- 
zijds de begrenzing van hetgeen een gemeente in verband met art. $7 \mathrm{Gr}$.w. vermag, zijn we nu al bij herhaling tegengekomen. Dat maakt het helaas niet gemakkelijker er een coherente "verklaring" voor te verzinnen. Laat ik toch weer een poging wagen. Misschien moeten we de Hoge Raad aldus verstaan dat de bepaling niet louter een regeling en beperking in het belang der openbare orde behelsde, maar tevens in strijd kwam met artikel 7. Die lezing biedt het voordeel dat zij consistent is met - eveneens moeilijk te vatten eerdere uitspraken op dit punt. Of moeten we de knoop nu maar doorhakken en het er eenvoudig op houden dat de verordenende bevoegdheid ex art. 135 Gem.w. (oud) volgens de Hoge Raad werd beperkt door (onder meer) het bepaalde in art. $7 \mathrm{Gr} . w$. ? Voor het resultaat maakt het geen verschil of je voor de ene oplossing kiest, of voor de andere.

Nog minder duidelijk is het verschil in uitkomst vergeleken met die eerdere zaak over Maastricht. De advocaat-generaal (Tak) had in zijn conclusie, voorafgaand aan het Rosendaalse arrest, betoogd "dat eigenlijk in iedere prentbriefkaart het denken en voelen van haren auteur kan worden gevonden".

"Dan echter genieten zij de bescherming van art. 7 der Grondwet", zo ging hij verder, "en dient de censuur geweerd, die gelegen zijn kan in het vereischt voorafgaand schriftelijk verlof van Burgemeester en Wethouders voor hunne verspreiding.

Weliswaar tracht de Rosendaalsche wetgever dit bezwaar te ondervangen door die verspreiding niet geheel te verbieden en haar gedurende den nacht vrij te laten, doch tevergeefs wil hij aldus aan Uw greep ontkomen, daar hij zich van iedere verlofverleening had moeten onthouden, indien hij werkelijk eene eventueel terecht gemaakte verdenking van preventief toezicht wilde ontgaan".

Het verschil tussen de Maastrichtse en de Rosendaalse zaak zat, volgens hem, dus in het feit dat Rosendaal - anders dan Maastricht - een verlofstelsel kende. Waar het Maastrichtse verbod voor alle drukwerk en geschriften gold, ongeacht de inhoud ervan, liet het Rosendaalse ruimte voor selectie - en dus voor misbruik. We zijn die gedachtengang al eerder tegengekomen - opmerkelijk genoeg steeds in conclusies - en zagen toen al dat de rechtspraak er geen duidelijke aanknopingspunten voor bood. ${ }^{37}$ Maar uitgesloten was het niet. Het Rosendaalse arrest bracht ons in dat opzicht niet veel verder. Beslissend was immers dat het ging om "een algemeen verbod" prentbriefkaarten te verkopen en daardoor gedachten of gevoelens te openbaren, "zij het op bepaalde uren, tenzij men daartoe schriftelijke vergunning van $B$. en $W$. mocht hebben verkregen". Wanneer beoogd was daarbij de nadruk op het vergunningstelsel te leggen, had men wel een erg ongelukkige formulering gekozen. 
Opvallend was overigens dat niemand op de gedachte kwam de ene vorm van drukwerk (prentbriefkaarten) uitwisselbaar te achten met de andere (bijvoorbeeld brochures), zoals men soms ook had betoogd dat het ene "middel van openbaarmaking" (bijvoorbeeld venten) uitwisselbaar zou zijn met het andere (bijvoorbeeld in de bus doen, of aanplakken). De verkoop van die andere soorten drukwerk was namelijk (naar ik aanneem ${ }^{38}$ ) van het verbod uitgezonderd. Kortom, zo had men kunnen redeneren, waarom dan geen ander medium benut om dezelfde gevoelens of gedachten te openbaren? Echter: geen spoor daarvan! Ook niet in het arrest van de Hoge Raad. Moeten we daaruit afleiden dat voor de verschillende media hetzelfde gold als voor de verschillende "middelen van openbaarmaking", te weten: dat zij geen van alle "belet" mochten worden? We kunnen het hoogstens vermoeden, en wellicht ook hopen.

Bleef echter de vraag of de onverbindendheid van het Rosendaalse verbod inderdaad haaks stond op de toelaatbaarheid van het Maastrichtse. Of stak er tòch één en dezelfde theorie achter? Een eerste mogelijkheid was, zoals gezegd, dat het Rosendaalse verbod gepaard ging met een vergunningstelsel (waardoor inhoudelijk geselecteerd kon worden). Een ander punt was dat beide bepalingen als het ware elkaars spiegelbeeld vormden: in Maastricht was het verbod beperkt tot de avond en nacht, terwijl het in Roosendaal juist uitsluitend overdag gold; pas als er nauwelijks meer iemand op straat liep, mocht je er prentbriefkaarten verkopen. Zou dat misschien van belang zijn geweest? In het arrest was ook daar geen aanwijzing voor te vinden. Er werd slechts gerept van "een algemeen verbod (...), zij het op bepaalde uren" - ongeacht welke uren.

Die laatste formulering riep trouwens weer een andere vraag op: als "een algemeen verbod, zij het voor bepaalde uren" niet door de beugel kon, hoe zat het dan met "een algemeen verbod, zij het voor bepaalde plaatsen"? Vragen, vragen en nog eens vragen! Er moest nog heel wat worden opgehelderd. In de literatuur is er, vreemd genoeg, niets over terug te vinden. ${ }^{39}$

Een paar jaar later bleek de gemeente Rosendaal haar verordening te hebben aangepast, en omdat de verkoop van prentbriefkaarten daar kennelijk een grote vlucht had genomen, gaf dat aanleiding tot een nieuwe zaak. ${ }^{40}$ De nieuwe bepaling luidde als volgt:

"Het is verboden in de maanden Mei, Juni, Juli, Augustus en September op of aan den openbaren weg of aan de huizen der ingezetenen tusschen elf uur des voormiddags en vijf uur des namiddags prentbriefkaarten te verkoopen of ten verkoop aan te bieden".

Volgens de advocaat-generaal (Ledeboer ${ }^{4 \mathrm{I}}$ ) was er deze keer niets op aan te merken. Alle bekende frasen werden ter toelichting van dat standpunt in 
herinnering gebracht:

"Aangenomen mag worden, dat, volgens den Hoogen Raad, de openbaarmaking van gedrukte stukken niet in het algemeen mag worden verboden of van een voorafgaand verlof afhankelijk gesteld, daarentegen de vrijheid om zoodanige stukken op de openbare straat op eene bepaalde wijze te verspreiden $\mathrm{nl}$. door venten of te koop aanbieden ${ }^{42}$, mag worden beperkt door een voorschrift omtrent den tijd, waarop zulks met het oog op het publiek verkeer is verboden. Naar mijn oordeel is de Gemeenteraad van Rosendaal met het verbod (...) geheel gebleven binnen de perken van zijne bevoegdheid. Slechts in bepaalde maanden en dan nog slechts op bepaalde uren, wordt het venten aan den openbaren weg of aan de huizen der ingezetenen verboden, overigens blijft het geheel vrij. Van schending der Grondwettelijke bepaling in het middel genoemd (art. 7 Gr.w., RdW) kan onder deze omstandigheden naar mijn oordeel geene sprake zijn". ${ }^{43}$

Was een soortgelijke redenering niet ók mogelijk geweest naar aanleiding van het vorige ventverbod van Rosendaal, dat niet door de beugel bleek te kunnen? Ook dat verbod gold immers "slechts op bepaalde uren". Of gaf de omstandigheid dat het nu "slechts" vijf maanden van kracht was - vermoedelijk juist de maanden waarin de grootste afzet was te verwachten! - de doorslag? Wat had je, met andere woorden, aan al die frasen, als je er nú eens het ene resultaat mee kon bewerkstelligen en dàn weer het andere? Zou de advocaat-generaal tot dezelfde uitkomst zijn gekomen, als het niet om prentbriefkaarten ging, maar om kranten? Was het ontbreken van een vergunningsmogelijkheid - waar de A-G Tak de vorige keer zo verrukt van was - wellicht beslissend voor hem? We weten het niet; hij liet zich er niet over uit.

Wat we wel weten, is dat de Hoge Raad hem gelijk gaf. Na de geijkte overweging dat de gemeente de verspreiding, "zonder haar in het algemeen te verbieden of van een voorafgaand verlof afhankelijk te stellen", aan "voorschriften in het belang der openbare orde" mocht "onderwerpen", concludeerde hij dat Rosendaal zijn - overigens door art. $7 \mathrm{Gr}$.w. "onaangetaste $^{\text {n4t }}$ - verordeningsbevoegdheid niet had overschreden:

"dat toch in de gewraakte bepaling de openbaarmaking van gedrukte stukken niet in het algemeen wordt verboden of van een voorafgaand verlof afhankelijk gesteld, doch slechts de vrijheid om zoodanige stukken door een bepaalde wijze van verspreiding door deze namelijk op of aan den openbaren weg of aan de huizen der ingezetenen te verkoopen of ten verkoop aan te bieden, ten aanzien van eene bepaalde soort, prentbrietkaarten, wordt beperkt door een voorschrift omtrent de maanden en de uren, waarop zulks met het oog op de openbare 
orde is verboden;

dat die beperking niet zoo ver gaat, dat de vrijheid om prentbriefkaarten in de gemeente Rosendaal te verspreiden kan gezegd worden metterdaad te zijn opgeheven, terwijl de vraag, of de openbare orde in de genoemde gemeente de voorgeschreven beperking vordert, betreft de doelnnatigheid der verbodsbepaling, welke niet staat ter beoordeeling van de rechterlijke macht". "s

Dat laatste - over hetgeen de openbare orde "vordert" - zijn we al eerder tegengekomen, en bracht dus geen nieuws. Maar ook de rest klinkt bekend. Alleen de uitkomst verraste misschien.

Lag het in 1916 allemaal zo anders dan in 1920 ? Wat waren de verschillen? Dat het verbod beperkt was tot "eene bepaalde soort" gedrukte stukken, t.w. prentbriefkaarten, werd de vorige keer weliswaar niet met zoveel woorden door de Hoge Raad opgemerkt, maar gold ook toen al. Daarin school dus geen verschil. Daarnaast wees opnieuw niets erop dat het nu ontbrekende ontheffingsstelsel (o.i.d.) de lucht opeens had doen opklaren. Zeker, volgens de nieuwe bepaling was het gemeentebestuur niet meer in de gelegenheid om (op inhoudelijke gronden) te selecteren; het verbod gold eenvoudig - zonder uitzondering - voor een ieder. Maar er was geen enkele aanwijzing dat de Hoge Raad juist om die reden tot een ander resultaat was gekomen. Nee, beslissend was kennelijk dat de "beperking niet zoo ver gaat, dat de vrijheid om prentbriefkaarten in de gemeente Rosendaal te verspreiden kan gezegd worden metterdaad te zijn opgeheven".

Twee opmerkingen daarover. In de eerste plaats ging de beperking in 1916 dus klaarblijkelijk wel "zoo ver (...), dat de vrijheid om prentbriefkaarten in de gemeente Rosendaal te verspreiden (kon) gezegd worden metterdaad te zijn opgeheven" (aangenomen, tenminste, dat de onverbindendverklaring toen inderdaad niet gebaseerd was op de mogelijkheid vergunning te verlenen). Dan zat het verschil, met andere woorden, in de tijd die beschikbaar was om de bedoelde verspreidingswijze te benutten. Die tijd wàs er wel, maar te kort. Z $Z$ kort dat de vrijheid om prentbriefkaarten te verspreiden kon "gezegd worden metterdaad te zijn opgeheven". Oftewel: hoewel officieel geen sprake was van een algemeen verbod, werd het - gezien de te geringe mogelijkheden die resteerden - wèl als zodanig aangemerkt. Een vergeten voorloper van het Nuth-arrest, kortom, waarin deze draad - begin jaren vijftig - weer werd opgenomen. ${ }^{* 6}$

In de tweede plaats repte de Hoge Raad van de "vrijheid om prentbriefkaarten (...) te verspreiden". Algemener gezegd gold voor een bepaald type geschrift of drukwerk (en waarom dus niet voor ieder type?) dat het verspreid moest kunnen worden. Of alle wijzen van verspreiding voor ieder type geschrift of drukwerk beschikbaar moesten zijn, leek - gezien de 
formulering van het arrest - twijfelachtig. Het kwam er immers op aan dat de vrijheid om te verspreiden gehandhaafd bleef. Was de ene verspreidingswijze dus uitwisselbaar tegen de andere, zolang er maar een verspreidingswijze overbleef? Ik denk het niet. Verspreiding was immers een "species" van het "genus" openbaarmaking - en wel: een voor prentbriefkaarten essentieel "species". Welnu, als voor geschriften en drukwerken in het algemeen gold dat alle middelen van openbaarmaking beschikbaar moesten zijn, dan gold - logisch gesproken - $66 \mathrm{k}$ voor eén bepaald type geschrift of drukwerk dat alle in aanmerking komende middelen van openbaarmaking (waaronder middelen van verspreiding) benut moesten kunnen worden. Opnieuw geldt - alles bij elkaar - dat de stap die de Hoge Raad zette well consistent (te maken) was met voorgaande uitspraken; wie terugschrok voor gissingen had de ontwikkeling echter onmogelijk kunnen voorspellen.

\subsection{Beperkingen naar de inhoud? Het Sanitas-arrest (1928)}

Veel aandacht trok vervolgens een zaak die ons alwér in Maastricht brengt. Behalve het socialisme dreigden er klaarblijkelijk nog meér gevaren. Artikel 34 van de plaatselijke verordening werd in 1927 uitgebreid met de volgende leden:

"Lid 2. Eveneens is het verboden op den openbaren weg te vertoonen borden, doeken of zeilen of soortgelijke voorwerpen, die op eenige wijze zijn voorzien van eenige reclame, schilder- of drukwerk of geschrift hoegenaamd ook, welke tot bestemming hebben of geschikt zijn om onder bedekte termen bekend te maken adressen, aan welke op aanvrage verkrijgbaar zijn middelen, welke om hunne algemeene bestermming dienen of dienen kunnen tot voorkoming of verstoring van zwangerschap, ook al kunnen deze middelen tot eenig ander gebruik aangewend worden.

Lid 3. Onder bedekte termen als in het vorige lid bedoeld worden 0. a. verstaan aanduidingen als 'Sanitas', 'sanitaire artikelen', 'gummiewaren', 'gummieartikelen' en soortgelijke". ${ }^{7}$

Zou het destijds werkelijk verboden zijn geweest om "onder bedekte termen" reclame te maken voor breipennen? Of voor zeepsop en slecht verende fietszadels? Zover ging het waarschijnlijk net niet. Wel, echter, werd iemand veroordeeld omdat

"hij, den 12en sept. 1927, des n.m. circa $81 \frac{1}{2}$ uur, te Maastricht, op den openbaren weg de Markt heeft vertoond een aan beide zijden van een drukwerk voorzien bord, waarop aan een zijde vermeld was: 'Haarverfkam van Dr. Montreux geeft direct blond, bruin of zwart Hoofd- 
of Baardhaar. Prijs compleet $f 3,25$. Alleen de origineele bij Sanitas Novum, Heerlen, Stationstraat 18, Roermond, Stationstraat 15a', en aan de andere zijde: 'Oh! Oh! Oh! Wat heb ik een jeuk. Het jeukmiddel De Walvisch geneest jeuk, huiduitslag, infectie, baardschurft. Prijs $f 2,75$, proefflacon $f 1$. Alleen de origineele bij Sanitas Novum, Heerlen, Stationstraat 18, Roermond, Stationsplein 15a. Let op ons adres! ${ }^{48}$ welke drukwerken geschikt waren om door de aanduiding Sanitas - zij het ook met de bijvoeging Novum - onder bedekte termen bekend te maken adressen aan welke op aanvraag verkrijgbaar waren middelen, welke naar hunne algemeene bestemming dienden tot voorkoming van zwangerschap".

Volgens de advocaat-generaal (Van Lier) kon die veroordeling niet door de beugel. Immers, zo schreef hij in zijn conclusie ${ }^{49}$ :

"Een voorschrift, dat het openlijk gebruiken van bepaalde woorden verbiedt, ook wanneer daarmede niets wordt uitgedrukt, dat op de zedelijkheid betrekking heeft, en de zedelijkheid daarbij niet is betrokken, kan niet gezegd worden vereischt te zijn in het belang der zedelijkheid, en evenmin in het belang der openbare orde of de gezondheid, of wel de huishouding der gemeente te betreffen".

Dus had de gemeente haar bevoegdheid met die bepaling overschreden. ${ }^{50}$ Bovendien zou er - en dat is in het kader van dit boek interessanter - strijd zijn met art. 7 Gr.w.:

"Bij openbaring van gedachten of gevoelens op de in de verordening bedoelde wijze door middel van drukwerk zou men alzoo strafbaar zijn, indien men de woorden in lid 3 van art. 34 aangeduid daarbij bezigt. Art. 7 der Grondwet laat een zoodanige censuur niet toe".

De term "censuur" was in dit verband niet bijster gelukkig gekozen. Dresen $^{51}$ meende daarom (ruim twintig jaar later)

"dat we bij deze opvatting niet lang behoeven stil te staan, daar het voor iedereen duidelijk is, dat hier van een repressieve maatregel sprake is, al bevat deze maatregel vanzelfsprekend een preventief element. Maar dit is eigen aan, of nog beter, dit is de bedoeling van elke repressie. Volgens Van Lier zouden dus alle repressieve wetsbepalingen in strijd met art. 7 Grondwet zijn".

Ook díe formulering was niet echt gelukkig - hij bedoelde natuurlijk: alle repressieve wetsbepalingen ten aanzien van drukwerk en geschriften - maar afgezien daarvan had hij well gelijk, denk ik. De Hoge Raad ${ }^{52}$ koos dan ook voor een andere oplossing:

"Overwegende dat het eerstbedoeld voorschrift (art. 34 lid 2, RdW) op het bewezen verklaarde niet had mogen worden toegepast;

dat toch daarbij geheel algemeen wordt verboden het op den openba- 
ren weg vertoonen van borden, voorzien van eenig drukwerk van een zekeren inhoud, hetgeen in strijd is met de bepaling van art. 7 der Grondwet".

En omdat het bewezen verklaarde feit ook nergens anders onder viel - in het bijzonder niet onder het toenmalige art. 451 ter $\mathrm{Sr}$, op grond waarvan (onder meer) het openlijk als verkrijgbaar aanwijzen van enig middel tot voorkoming van zwangerschap strafbaar was - werd de "verdachte" van alle rechtsvervolging ontslagen.

Wat moest hier nu uit worden afgeleid? Het "op den openbaren weg vertoonen van borden, voorzien van enig drukwerk van een zekeren inhoud" werd "geheel algemeen (...) verboden". En dat was in strijd met art. 7. Volgens J.H.P.M. van der Grinten was "het standpunt, neergelegd in het arrest van den Hoogen Raad, niet juist". ${ }^{53}$ Op grond van de eerder behandelde jurisprudentie betoogde hij dat "een onvoorwaardelijk verbod tot bekendmaking van gedrukte stukken, ongeacht hun inhoud, (...) naar art. 7 der Grondwet niet toelaatbaar was.

"Evenmin", zo ging hij verder, "een verbod waarvan de Burgemeester ontheffing kan verleenen (...). Wel is toelaatbaar de verspreiding van gedrukte stukken, wederom ongeacht hun inhoud, te onderwerpen aan voorschriften in het belang der openbare orde, bepaaldelijk ter beveiliging van het openbaar verkeer.

Doch de onderhavige Maastrichtse verordening betreft niet de verspreiding van gedrukte stukken, ongeacht hun inhoud, doch verbiedt de vertooning o.m. van drukwerk van een bepaalden inhoud (...).

Zulk een verbod nu, dat betreft den inhoud van drukwerk, komt met art. 7 der Grondwet geenszins in conflict. De algemeene en de plaatselijke wetgever (deze laatste uiteraard binnen de grenzen zijner wetgevende competentie) zijn volkomen bevoegd drukpersdelicten te creëren door de verspreiding of vertooning van drukwerk van zekeren, in het wettelijk voorschrift omschreven, inhoud te verbieden, onder deze voorwaarde alleen, dat invoering van censuur, d.w.z. een voorafgaande beoordeling door de overheid van den inhoud van het gedrukte stuk, niet mag worden voorgeschreven. (...) 'Behoudens ieders verantwoordelijkheid volgens de wet' zegt de Grondwet ten overvloede, waardoor dus vaststaat de volkomen vrijheid voor den wetgever om aan drukpersopenbaringen, die naar zijn meening ongeoorloofd zijn, strafrechtelijke en burgerrechtelijke gevolgen te verbinden.

Met art. 7 der Grondwet is dus art. 34, lid 2 en 3, der Maastrichtse verordening niet in strijd".

Had hij gelijk, en had de Hoge Raad zich dus vergist? Was die oude jurisprudentie inderdaad zo eenduidig als Van der Grinten haar afschilderde? 
En was het nieuwe arrest eveneens slechts voor zrjn uitleg vatbaar? Twee - retorische - vragen, kortom. Ze verdienen allebei onze aandacht.

Eerst de stand van de jurisprudentie tot dat moment. Kort gezegd kwam het erop neer dat een "middel van openbaarmaking" niet algemeen verboden of van een voorafgaand verlof van de overheid afhankeiijk gesteld mocht worden. Volgens Van der Grinten volgde daaruit dat het verboden was om, ongeacht de inhoud (dus geheel in abstracto), een algemeen verbod uit te vaardigen of voorafgaand verlof te eisen. Met het oog op stukken die een bepaalde inhoud hadden, was zo'n beperking dus wel toegestaan, meende hij; dan gold het voorschrift namelijk niet in abstracto voor alle, maar slechts in concreto ten aanzien van bepaalde uitingen. Dat is frappant! Ik had die clausule tot nu toe heel anders begrepen. ${ }^{54}$ Volgens mij was een algemeen verbod of een eis van voorafgaand verlof niet toegestaan, ongeacht de inhoud van de stukken (zolang er althans "gevoelens of gedachten" in werden geopenbaard). Voor alle stukken - wat ook de inhoud ervan was gold dan hetzelfde regime: ze moesten (zonder voorafgaand verlof) openbaar gemaakt kunnen worden.

Beide zienswijzen waren, op basis van de jurisprudentie vór 1928 , te verdedigen, lijkt mij - vooral omdat de Hoge Raad zich er nooit uitdrukkelijk over uitsprak. Sinds dit arrest over het Maastrichtse Sanitas-verbod ligt dat echter anders. De visie van Van der Grinten is daar eenvoudig niet mee te verenigen; hij zag dat zelf ook in, alleen was volgens hem de Hoge Raad het spoor bijster geraakt. Je kunt dat evengoed omkeren en constateren dat hij het klaarblijkelijk bij het verkeerde eind had - vooral nu er een andere "verkliring" voorhanden is, die zowel met de oude arresten strookt, als met het nieuwe.

Dat brengt mij op de tweede kwestie van zoëven: het arrest-zelf. Betrof het Sanitas-verbod louter de inhoud van het drukwerk, zoals Van der Grinten betoogde? Nee, niet het indirect - "onder bedekte termen" - bekendmaken van de gewraakte adressen was verboden, maar uitsluitend het gebruik daartoe van bepaalde middelen. Andere middelen van openbaarmaking (zoals advertenties in kranten of huis-aan-huis verspreide foldertjesi) waren niet verboden. Aangezien het ene middel van openbaarmaking echter niet uitwisselbaar was tegen het andere - en de Hoge Raad er, zoals gezegd, kennelijk van uitging dat ieder drukwerk of geschrift ongeacht de inhoud ervan openbaar gemaakt moest kunnen worden - was de afdoening, van deze zaak geheel volgens het boekje: de bepaling was onverbindend omdat "daarbij geheel algemeen (werd) verboden het op den openbaren weg vertoonen van borden, voorzien van eenig drukwerk van een zekeren inhoud, hetgeen in strijd (was) met de bepaling van art. 7 der Grondwet". 55

Dat die afloop op voorhand niet duidelijk was, is een andere kwestie. 
Achteraf is de puzzel niettemin keurig "kloppend" te maken. ${ }^{56}$ Merkwaardig alleen, dat daar eigenlijk nooit een poging toe is gedaan. Het beste wat ik over dit arrest ben tegengekomen, is het stuk van Van der Grinten. Anderen zetten zich (meestal pas tegen het eind van de jaren dertig) tegen zijn zienswijze af, of poneerden hun eigen leer nást die van de Hoge Raad. De enige die - ook vele jaren na dato trouwens, en min of meer "en passant" - met een eigen analyse kwam, was (voor zover ik weet) P.J.M. Kalien. ${ }^{57}$

"Alleen wanneer de Hooge Raad in zijn praemissen had kunnen stellen", aldus Kallen, "dat hier sprake was van een algerneen verbod van vertoonen enz. van drukwerk, waardoor gedachten en gevoelens worden geopenbaard, had hij de conclusie van de ongrondwettigheid mogen trekken!

Aangezien de praemissen als onjuist moeten worden beschouwd, omdat den Hooge Raad in casu drukwerk of geschriften, bestemd of geschikt om bepaalde adressen bekend te maken ten onrechte volkomen heeft gelijk gesteld met drukwerk en geschriften, waardoor gedachten en gevoelens worden geopenbaard, is met de onverbiddelijke noodzakelijkheid van de logica te concludeeren, dat de door den Hoogen Raad uit deze praemisse getrokken conclusie eveneens onjuist is".

Dat was, voor de afwisseling, tenminste eens een helder betoog. Het sloot bovendien keurig aan bij eerdere (zij het niet onomstreden) jurisprudentie. ${ }^{58}$ Maar de weerlegging ervan, door Van den $B^{2}$ rgh $^{59}$, was volgens mij niet minder adequaat. Het ging in Maastricht, schreef Van den Bergh, om geschriften,

"die tot bestemming hebben of geschikt zijn om onder bedekte termen bekend te maken adressen, waar op aanvrage verkrijgbaar zijn...enzv. Welnu: geschriften, die aan deze omschrijving voldoen, kunnen wel degelijk gedachten en gevoelens openbaren; de verordening heeft geenszins uitsluitend betrekking op geschriften, die dat niet doen.

Dat moet bij nadere overweging toch ook den heer Kallen duidelijk zijn. Het kost toch waarlijk geen moeite een kort stuk op te stellen, bevattende slechts enkele volzinnen, maar waarin tal van gedachten en gevoelens omtrent geboortebeperking liggen opgesloten. Indien dan daarop volgt: "Inlichtingen zijn verkrijgbaar aan het volgende adres", dan valt dit geschrift stellig onder de omschrijving van de verordening. En deze verordening is onverbindend, omdat zulk een geschrift nu eenmaal de bescherming van art. 7 geniet". ${ }^{\infty}$ 


\section{Hoofdstuk 3 De jaren '30: kentering}

Het is natuurlijk altijd gewaagd om de geschiedenis in perioden te verdelen. Maar omwille van de hanteerbaarheid, is het soms wel handig. Laat het alleen geen aanleiding zijn de verschillen met voorafgaande en opvolgende perioden te overdrijven. Wat de verspreidingsjurisprudentie betreft, zagen we bijvoorbeeld tot nu toe niet uitsluitend voortgang. In sommige opzichten leverde de jurisprudentie niet op wat we ervan mochten (of hoopten te) verwachten. Ik denk aan de toelaatbaarheid van een ventverbod gedurende grote delen van de dag, en het ontbreken van bescherming tegen een "hostile audience". Maar er zat in elk geval een duidelijke lijn in de rechtspraak (al was de richting vooraf nauwelijks te voorspellen). In de jaren dertig kwam daar verandering in. De bewoordingen van de arresten suggereerden weliswaar continuîteit, maar de uitkomsten waren - in het licht van de eerdere jurisprudentie - minst genomen opvallend. ${ }^{1}$

Wie uit is op historische trends zal zich hier niet over verbazen. Dan is er immers nooit reden tot verbazing. De trend is de gebeurtenissen als het ware vooruitgesneld. Iets anders hing eenvoudig niet in de lucht. Kortom: wat wil je, de jaren dertig! Zo kort na de Wall Street Crash, in het voorportaal van de Tweede Wereldoorlog...

Gelukkig gaat het in dit boek niet om historische, maar om gewone wetten!

\subsection{Rekbare begrippen en onvoorziene nuanceringen (1932-1935)}

Op 28 januari 1932 had iemand in Rotterdam "omstreeks te $151 / 4$ ure, op den openbaren weg de Hoogstraat, ter aanbeveling van gedrukte stukken (...) geroepen: 'roomsch recht of Nederlandsch recht. Het schandaal van den Bosch, vijftien cents. Koopt en leest het schandaal van den Bosch', althans woorden van die strekking".

De kantonrechter veroordeelde de verdachte, zoals de procureur-generaal (Tak) het later in cassatie zou uitdrukken, "in eene geringe geldboete, daarbij aannemende, dat het hier om eene principieele uitspraak zou te doen zijn en van ernstige overtreding der openbare orde niet is gebleken". Het vonnis werd precies vijf maanden nadat het feit gepleegd was al bevestigd in hoger beroep - de "redelijke termijnen" werden destijds (wat er ook zij van de historische trends) keurig in acht genomen!

Waarop stoelden die veroordelingen? Op art. 138 van de Rotterdamse 


\section{"Verordening op de Straatpolitie":}

"Het is verboden op of aan den weg, ter verspreiding, aanbeveling, aankondiging of bekendmaking van gedrukte of geschreven stukken of afbeeldingen, te roepen of met reclamemiddelen te rijden, te gaan of te staan".

Wie vergunning van $B$ en $W$ had, of "slechts de naam en/of de prijs van eene courant of van een tijdschrift" noemde, was vrijgesteld van het verbod. Dat het roepen verboden mocht worden, wisten we allang; sinds het arrest uit 1897 over de gemeente $\mathrm{Olst}^{2}$ was dat vaste jurisprudentie. Maar de toevoeging dat je ób niet met "reclamemiddelen" mocht rijden, gaan of staan, was nieuw. Kon dàt verbod door de beugel? De procureur-generaal (Tak, zoals gezegd) merkte in zijn conclusie ${ }^{3}$ op dat art. 7 Gr.w. niet meebracht,

"dat ieder de wijze van publiciteit mag kiezen, welke hem lust. Dan toch zou de openbare orde in de knel kunnen komen en waar de gemeenteraden daarvoor hebben te waken, is het vanzelfsprekend, dat zij de openbaarmaking van gedrukte en geschreven stukken en afbeeldingen in zooverre kunnen begrenzen als die orde dat vordert, mits het resteerend deel slechts vrijheid tot openbaring laat en deze ongedeerd blijft".

Geen wonder dat ook het extraatje over de "reclamemiddelen" volgens hem geoorloofd was. Maar in het voorbijgaan had hij stilletjes - wat overigens niet wil zeggen dat hij te kwader trouw was! - iets afgeknaagd van het criterium dat door de Hoge Raad placht te worden aangelegd. Het ging er immers niet alleen om dat er "vrijheid tot openbaring" werd gelaten, als wel dat een dergelijke vrijheid aan ieder "middel van openbaarmaking" toekwam. In de visie van de procureur-generaal zou het ene middel kunnen worden gecompenseerd door het andere, en dat was nu net niet de bedoeling! Hij had zich, met andere woorden, moeten afvragen of het rijden, gaan of staan met "reclamemiddelen" zelf als "middel(en) van openbaarmaking" moest worden aangemerkt; zo ja, dan kon de bepaling - gezien het algemene karakter ervan - niet door de beugel. ${ }^{4}$

De Hoge Raad liet zich evenmin over deze kwestie uit, althans niet met zoveel woorden. Hij varieerde eenvoudig - alsof hij zich van een tekstverwerker bediende - op de standaardfrase die ook altijd ten aanzien van het roepen en schreeuwen werd gebruikt, voegde "het rijden, gaan of staan met reclameborden" eraan toe en overwoog:

"dat een zoodanig verbod niet in strijd is met art. 7 der Grondwet, dat wel niet toelaat om het verspreiden enz. van gedrukte stukken onvoorwaardelijk te verbieden of afhankelijk te stellen van een voorafgaand verlof der overheid, maar onaangetast laat de bevoegdheid aan den 
gemeentewetgever bij art. 168 (oud 135) der Gemeentewet, in verband met art. 144 der Grondwet, toegekend, om de verspreiding enz. van gedrukte stukken op of aan den weg te onderwerpen aan voorschriften in het belang der openbare orde en ter beveiliging van het openbaar verkeer".

Oude koek, kortom. Zo leek het althans. Maar wat viel er niet allemaal onder "het rijden, gaan of staan met reclamemiddelen"! Dat bleek nu opeens integraal verboden te mogen worden "in het belang der openbare orde en ter beveiliging van het openbaar verkeer". Het klassieke verbod van geschreeuw en geroep was vergeleken daarmee een kleinigheid.

Maar, toegegeven, het kon, dat wil zeggen: het was op basis van de oude jurisprudentie niet uitgesloten. Want wat precies als "middel van openbaarmaking" moest worden aangemerkt, was nooit uit de doeken gedaan. Daardoor kon die categorie naar willekeur worden ingekrompen (zolang er althans in eerdere zaken nog niet over was beslist). ${ }^{6}$ Alleen, zou er op die manier nog wel iets overblijven? Wat was, met andere woorden, de volgende stap die gezet zou worden?

Eerst kwamen nog wat andere kwesties aan de orde. Op 18 november 1935 wees de Hoge Raad een arrest over het Zaanse ventverbod. ${ }^{7}$ Een verwant verbod kwannen we eerder tegen in Groningen en Rosendaal. ${ }^{8}$ Art. 44 van de APV van Zaandam luidde als volgt:

"Het is verboden gedrukte of geschreven stukken of afbeeldingen om niet of te koop aan te bieden, het koopen of de kennisneming daarvan aan te bevelen of de inhoud daarvan geheel of gedeeltelijk bekend te maken op de door burgemeester en wethouders in een door hen af te kondigen besluit aan te wijzen openbare wegen of gedeelten van openbare wegen op de in dit besluit te bepalen dagen en uren".

Op grond van deze bepaling verklaarden $B$ en W het verbod van toepassing op "alle openbare wegen in de gemeente", en wel op "alle dagen tusschen 0 en 5 uur en tusschen 16 uur en 24 uur, bovendien de Zaterdagen tusschen 12 en 16 uur en de Zondagen tusschen 9 uur en 16 uur". Oftewel: vain maandag tot en met vrijdag mocht van 5-16 uur gevent worden, op zaterdag (destijds een werkdag) van 5-12 uur en op zondag van 5-9 uur.

Welnu, op vrijdag 5 januari 1935, om half vijf 's middags, liep iemand - de tijden waren veranderd! - met "Volk en Vaderland" te venten. Mocht hij wegens schending van het ventverbod veroordeeld worden? Was het verbod, kortom, in strijd met art. 7 Gr.w.?

Leefde hij in 1902, dan was hij vermoedelijk ontslagen van alle rechtsvervolging. Toen lette de Hoge Raad namelijk allén op de APV-bepaling, zonder het uitvoeringsvoorschrift van B en W erbij te betrekken. En het verbod van 
de gemeente Groningen, waar het destijds over ging, kon volgens de Hoge Raad niet door de beugel, omdat "het alle aanplakking aan de straat zonder vergunning van Burgemeester en Wethouders verbiedt buiten de plaatsen die door hen daartoe zijn aangewezen, zoodat zelfs bij gebreke van die aanwijzing (...) de aanplakking aan de straat nergens in de gemeente zonder 'voorafgaand verlof' geoorloofd zoude zijn".' Dat er op grond van het uitvoeringsbesluit van $B$ en W nog wèl plakmogelijkheden bestonden op "de van gemeentewege geplaatste en door de gemeente verhuurde aanplakborden", was klaarblijkelijk niet relevant.

Deze keer, echter, bleek het verbod opeens well geoorloofd te zijn. De Hoge Raad verklaarde de nationaal-socialistische venter namelijk "strafbaar aangezien van geen reden is gebleken waarom hij dit niet zoude zijn". Was van zo'n reden well gebleken - bijvoorbeeld omdat het verbod niet in de haak was - dan was de venter ook nu ontslagen van alle rechtsvervolging. ${ }^{10}$ "Eene andere vraag is echter", aldus Taverne in zijn noot onder deze uitspraak, "of uit het arrest (...) valt op te maken, of de jurisprudentie op art. 7 gehandhaafd is. Daarbij kan de vraagstelling alleen déze zijn, of uit het thans gewezen arrest blijkt, dat de vroegere jurisprudentie is losgelaten". Taverne, die hier niet alleen als annotator optrad maar tevens deel had uitgemaakt van de kamer die de zaak had beslist, beantwoordde die laatste vraag "ontkennend". Dat wil zeggen: "ook indien de HR over art. 7 Grondwet nog denkt als vroeger (...) zou de beslissing niet anders geweest zijn".

Waarom zou dat volgens hem zo zijn? Omdat hij alleen het arrest over het Rosendaalse ventverbod uit 1920 erbij betrok. ${ }^{.}$Daarbij ging het, zoals we al eerder zagen, om het verbod

"in de maanden Mei, Juni, Juli, Augustus en September op of aan den openbaren weg of aan de huizen der ingezetenen tusschen 11 uur des voormiddags en 5 uur des namiddags prentbriefkaarten te verkoopen of ten verkoop aan te bieden".

Die bepaling werd door de Hoge Raad geaccepteerd, aangezien zij "niet zoo ver (ging), dat de vrijheid om prentbriefkaarten (...) te verspreiden (kon) gezegd worden metterdaad te zijn opgeheven". En ook nu, in Zaandam, kon dat volgens Taverne niet gezegd worden ten aanzien van het venten met "gedrukte of geschreven stukken of afbeeldingen". De mogelijkheid daartoe was eenvoudig niet "metterdaad opgeheven". Er waren immers nog - klaarblijkelijk voldoende - tijdstippen beschikbaar.

Bleef echter - aangenomen dat Taverne met zijn inschatting gelijk had - de vraag waarom het uitvoeringsbesluit er deze keer bijgetrokken mocht worden. Hij wees op het in 1931 van kracht geworden art. 169 gem.w. (157 nieuw) op grond waarvan delegatie aan B en W expliciet was toegestaan; daardoor trad het college op als een soort verlengstuk van de raad. Ook de 
Hoge Raad maakte daar gewag van. Weliswaar werd er vór 1931 evenzeer al vaak gedelegeerd, maar toen was men er nooit zeker van of het door de Hoge Raad geaccepteerd zou worden. Volgens Oppenheim was de Hoge Raad "tegenover de gemeenteraden een alles behalve gemakkelijke tuchtmeester, als men voor hem eene raadsverordening (kwam) aanvallen met de grief, dat daarin delegatie voorkwam". ${ }^{12}$ Dat verklaart dus misschien waarom de zaak in 1902 al "kapot" ging op de bepaling uit de verordening. In elk geval wordt op die manier begrijpelijk dat de Hoge Raad in 1935 eerder op de gedachte kwam het uitvoeringsbesluit bij de verordening te trekken dan in 1902. Maar of de Hoge Raad echt op die gedachte kwam, is feitelijk niet uit het arrest af te leiden.

Strikt genomen waren er vier mogelijkheden:

1. de Hoge Raad week af van het arrest uit 1902, trok het uitvoeringsbesluit bij de verordening en sauveerde het verbod via de "Rosendaal-constructie" uit 1920;

2. de Hoge Raad trok niet alleen het uitvoeringsbesluit bij de verordening, maar week bovendien af van de "Rosendaal-constructie", bijvoorbeeld door voortaan alleen tot onverbindendheid te besluiten wanneer het venten geheel onmogelijk zou zijn en niet reeds wanneer "gezegd kon worden" dat dit het geval was ${ }^{13}$;

3. de Hoge Raad hield vast aan zijn standpunt dat de verordening los van het uitvoeringsbesluit moest worden beoordeeld, maar achtte het in de verordening neergelegde verbod niet in strijd met art. $7 \mathrm{Gr}$.w.;

4. de Hoge Raad achtte een algeheel ventverbod voor drukwerken e.d. - hoe dit ook tot stand was gebracht (via delegatie of rechtstreeks) - niet langer in strijd met art. 7 Gr.w.

Het arrest past op zich bij al deze vier varianten. Maar de eerste gaat duidelijk het minst ver. Bovendien is het in zekere zin plausibel dat het $\mathbf{z o}$ is gegaan. Daar moeten we het - met Ockham in het achterhoofd - dan ook maar op houden, lijkt me. Taverne had dus gelijk (denk ik). Uit "het thans gewezen arrest" bleek niet dat de vroegere jurisprudentie op art. 7 was "losgelaten". De prijs voor die conclusie was echter dat het arrest uit 1902 als achterhaald moest worden beschouwd - niet vanwege een andere opvatting over art. $7 \mathrm{Gr}$. $\mathrm{w}_{\text {s, }}$ maar op grond van gewijzigde ideeën over delegatie. ${ }^{14}$

Intussen werd het well steeds moeilijker om vol te houden dat er niets aan het verschuiven was. Formeel was alles tot nu toe misschien bij het oude gebleven, maar materieel waren de beperkingsmogelijkheden stapje voor stapje uitgebreid. Op 12 mei 1937 veroordeelde de kantonrechter in Utrecht een NSB-er die drie weken tevoren "des voormiddags omstreeks te 9 uur, te Buurmalsen een aldaar gelegen onroerend goed, namelijk een woning, 
gedeeltelijk tot reclame (had) gebezigd, door op de omheining van een bordes van die woning aanwezig te hebben vier platen, op elk waarvan een manspersoon was afgebeeld (hoofd, schouder(s) en borst), met op den achtergrond een fabriek of een wei- of bouwland met ploeg, en op elk waaryan stond te lezen: 'Ik stem Mussert', welke afbeeldingen van manspersonen en welke woorden respectievelijk duidelijk zichtbaar en leesbaar waren vanaf een openbaren weg". is

Het lijkt wel een parodie! Maar ik verzin hier niets. En het ergste was nog dat we niet alleen met een slecht medemens te maken hadden, maar dat juist zijn nobeler eigenschap - die slechtheid niet te verbloemen - strafbaar was gesteld. Dat lag aan de artikelen 1 en 2 van de "Verordening tot het weren van ontsierende reclame in de landelijke gedeelten der gemeenten in Gelderland". Op grond daarvan was het

"verboden een onroerend goed of eenige zaak, daarop aanwezig, op welke wijze ook, hetzij geheel of gedeeltelijk, tot reclame te bezigen of daartoe te bestemmen, indien dat onroerend goed is gelegen in een gemeente, welke, of in het gedeelte van een gemeente, hetwelk (...) als 'landelijk' is aangewezen".

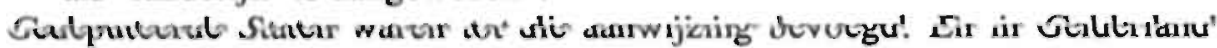
hadden ze ó́k Buurmalsen aangewezen, waar die ene NSB-er woonde. Sommige reclames werden echter ongemoeid gelaten. Het verbod betrof volgens de verordening namelijk niet

"de reclame voor zaken, die worden vervaardigd op of in het betrok-

ken onroerend goed, noch de reclame in het deel van een onroerend goed hetwelk als winkel wordt gebruikt, noch de reclame in een gebouw, welke niet van den openbaren weg zichtbaar is".

Voor het overige was reclame vanaf onroerende goederen (of "zaken", zoals ze tegenwoordig heten) verboden. Ging dat niet wat ver? Werden sommige "middelen van openbaarmaking" door zo"n absoluut verbod niet volstrekt onmogelijk gemaakt?

De kantonrechter ging aan die vraag voorbij. Hij keek in de eerste plaats of provinciale staten bevoegd waren een dergelijke bepaling uit te vaardigen. ${ }^{16}$ Hier zag hij geen enkel probleem; zij hadden immers "in het belang der provincie slechts het zichtbaar stellen voor het publiek van reclamemiddelen, waaronder ook gedrukte stukken kunnen vallen, voor een klein deel (...) beperkt". Dat was inderdaad een weinig gewaagde bewering; het tegengaan van "ontsiering van de landelijke schoonheid", is nu eenmaal al gauw "in het belang van de provincie". Daarnaast, echter, was er volgens de kantonrechter evenmin sprake van strijd met art. 7 Gr.w. Integendeel, de zinsnede "behoudens ieders verantwoordelijkheid volgens de wet" gaf volgens hem juist de mogelijkheid van zo'n beperking. 
Aan alle eerdere rechtspraak over art. 7 had deze kantonrechter duidelijk geen boodschap. De vraag of de door hem geopperde beperkingsmogelijkheid zelf ongelimiteerd was (zolang de grenzen van de verordeningsbevoegdheid maar niet werden overschreden), kwam daardoor niet aan de orde. Laat staan dat hij zich afvroeg of de limiet in dit geval wellicht was overschreden, en zo nee: waarom niet?

De A-G Van Lier, die in zijn conclusie vo6r het Sanitas-arrest ${ }^{17}$ nog zo streng was en zelfs van "censuur" repte, was inmiddels kennelijk tot inkeer gekomen. Deze keer zag ook hij althans geen enkel bezwaar:

"De verordening", schreef hij, "laat in het algemeen de bevoegdheid tot verspreiding onverkort, en verbiedt alleen én wijze van bekendmaking, welke het landschap ontsiert. Het provinciaal bestuur is hiertoe bevoegd en ik acht het beginsel der drukpersvrijheid door de verordening niet aangetast".

Waarom dat beginsel hierdoor niet werd aangetast, liet hij in het midden. In die zin had zijn conclusie ons nog minder te bieden dan het vonnis van de kantonrechter. "Ik vereenig mij (voor zover hier van belang, RdW) met de opvatting van den Kantonrechter", had hij eenvoudig geschreven, en dus - naar we moeten aannemen - ook met diens overweging dat de verkiezıngspropaganda door het Gelderse verbod

"wel van een propagandamiddel verstoken is, doch dit voor ons als eene niet ter zake dienende omstandigheid is aan te merken, en de ondervinding heeft geleerd, dat nog tallooze andere middelen voor propaganda overblijven"'.

Een "niet ter zake dienende omstandigheid"... Hoe was dat te verenigen met het taboe op uitwisselbaarheid van "middelen van openbaarmaking"? Mocht het ene middel nu opeens tòch onmogelijk worden gemaakt, omdat er nog wel een ander middel beschikbaar was? Misschien had deze advocaatgeneraal zich hier wat veel laten inspireren door de conclusie van zijn (in 1934 overleden) collega Tak vór het arrest over het Rotterdamse ventverbod van $1932 .{ }^{18}$ Zolang er maar vrijheid tot openbaarmaking resteerde, miste men één, twee middelen niet - zo kunnen we de visie van Tak kort samenvatten.

De Hoge Raad liet zich bij de afdoening van het beroep vervolgens alleen leiden door de toelichting op het cassatiemiddel. ${ }^{19}$ De klacht was weliswaar heel in het algemeen dat art. I van de provinciale verordening in strijd was met art. $7 \mathrm{Gr}$.w., maar volgens de toelichting ging het erom

"dat deze verordening het vertoonen van drukwerken verbiedt op het geheele grondgebied eener als landelijk aangewezen gemeente, ook indien men er mede loopt of de drukwerken op een wagen rondrijdt, daar ook hierdoor de onroerende grond, waarop men loopt of rijdt, tot 
reclame wordt gebezigd".

De Hoge Raad kon zich daarom beperken tot de kale mededeling dat het hier bedoelde lopen en rondrijden "niet onder alle omstandigheden als het bezigen van dien grond tot reclame is te beschouwen en reeds hierom het middel geen doel kan treffen".

Daar worden we dus niet wijzer van. Eigenlijk valt nog het meest af te leiden uit het resultaat van de beslissing: het beroep werd verworpen en het kantonrechtervonnis bleef dus in stand. Daar volgt natuurlijk niet uit dat de Hoge Raad zich in alle opzichten met dat vonnis verenigde. Maar, uitgaande van de eenmaal vastgesteide feiten, kon de uitkomst zeker wèl door de beugel. Dat betekent dat de gewraakte bepaling van de provinciale verordening (inclusief de aanwijzing van Buurmalsen) niet in strijd was met art. 7 Gr.w. Anders had immers geen veroordeling kunnen volgen - zelfs niet tot een luttel bedrag van drie gulden, zoals in deze zaak!

Waarom liet die verordening zich rijmen met art. $7 \mathrm{Gr}$.w.? We kunnen er alleen maar naar gissen. Deelde de Hoge Raad de opvatting van de advocaatgeneraal? Was een verbod, dat zich tot. "én wijze van bekendmaking" beperkte, kortom toch geoorloofd (zolang er tenminste andere mogelijkheden waren)? Of werd ontsierende reclame - net als hinderlijk geschreeuw en "het rijden, gaan of staan met reclameborden" in Rotterdam - eenvoudig niet als "middel van openbaarmaking" aangemerkt? ${ }^{20}$ Wie zal het zeggen? Misschien legde de Hoge Raad voor provincies wel een soortgelijke maatstaf aan als voor gemeenten, maar dan in het groot. Ik bedoel: misschien was zo'n provinciale verordening alleen onverbindend als "niet gezegd kon worden" dat het betreffende "middel van openbaarmaking" binnen de provincie nog benut kon worden - dan was het wegvallen van dat middel in één enkele gemeente inderdaad "niet ter zake dienende" (zolang het tenminste niet in alle gemeenten was weggevallen).

$\mathrm{Ja}$, misschien dit, of wellicht dat... Het werd langzamerhand wat ingewikkeld om alles nog onder de noemer van de "verspreidingsjurisprudentie" te brengen. Was er eigenlijk wel sprake van een "leer"? Zo ja, ging het dan niet om een heel andere leer? Maar welke? Vanaf welk arrest moesten we de zaken opnieuw gaan rangschikken? Op dit moment leek vrijwel niets meer uitgesloten. Het woord van de Hoge Raad was tot een machtswoord geworden.

\subsection{Verdere afkalving (1938)}

1938 brak aan. Er zouden dat jaar niet minder dan vier arresten door de Hoge Raad worden gewezen, die voor ons van belang zijn. ${ }^{21}$ Drie daarvan 
betroffen opnieuw het opkomende nationaal-socialisme en én ging gewoon over oude jenever (het andere volksgevaar).

De eerste zaak lag - sinds het arrest over het Zaanse ventverbod ${ }^{2}$ - tamelijk simpel. Volgens de Algemeene Strafverordening van Oss was het "verboden, de bestrating, verharding of bedekking, van openbare wegen, zoomede de vanaf den openbaren weg zichtbare plaatsen, muren, schuttingen, ramen, deuren, zuilen, palen, boomen, borden en dergelijke te voorzien van geschriften, aanplakbiljetten, teekens, letters, cijfers en afbeeldingen, die uiting geven aan eenig politiek streven, tenzij op bepaalde door Burgemeester en Wethouders daartoe aangewezen plaatsen".

Uitgaande van het arrest over het Groningse plakverbod van $1902^{23}$ had men ongetwijfeld verwacht dat ook deze bepaling niet geaccepteerd zou worden. ${ }^{24}$ Maar dankzij het Zaanse ventverbod weten we dat de zaak intussen anders lag. En inderdaad, nadat de kantonrechter aanvankelijk nog het spoor van 1902 had gevolgd, kwam de rechtbank in hoger beroep tot veroordeling van de verdachte, die op een plaats die "door Burgemeester en Wethouders (...) daartoe niet was aangewezen" - te weten: een raam van een huis - Mussert of Moskou had geplakt. De klacht dat dit plakverbod in strijd zou zijn met art. $7 \mathrm{Gr}$.w. werd vervolgens door de Hoge Raad verworpen, "daar (het plakverbod) enkel verbiedt het openbaar maken met de daarin vermelde middelen op andere plaatsen dan de door B. en W. aangewezene". ${ }^{25}$

Of door B en W daadwerkelijk plaatsen waren aangewezen, en of dat voldoende was, kwam in de hele zaak niet aan de orde. Ook de vraag of "gezegd kon worden" dat het betreffende "middel van openbaarmaking" niet meer benut kon worden, bleef dus onbeantwoord. Maar de Hoge Raad viel daar niet over (en bracht de kwestie zelf evenmin ter sprake).

Moeten we daaruit afleiden dat de Hoge Raad hier dus geen belang meer aan hechtte? Nee, dat kunnen we er hoogstens uit afleiden. Maar ook het tegendeel is eruit af te leiden. Er was immers niets gebleken omtrent de (on)mogelijkheid om "metterdaad" te plakken e.d. Dus was evenmin gebleken dat daar iets op aan te merken viel! Misschien had de rechtbank zich wel uitvoerig met die kwestie beziggehouden en was zij na rijp beraad tot de conclusie gekomen dat het daarmee - naar Rosendaalse maatstaven geme$\operatorname{ten}^{26}$ - well goed zat. Alleen had zij in haar vonnis niets van haar inspanningen op dit terrein "doen blijken". Had dat niet eigenlijk wèl gemoeten? Nee, oordeelde de Hoge Raad klaarblijkelijk - en in zoverre is er dan toch iets met zekerheid uit dit arrest af te leiden - de rechtbank hoefde er (in dit geval) geen blijk van te geven dat zij had nagegaan of "gezegd kon worden" dat er "metterdaad" niet meer geplakt kon worden. ${ }^{27}$ 
Alles bij elkaar: toch weer meer van hetzelfde. Formeel was het bouwsel - met enige moeite - nog wel staande te houden. Of er méer van over was dan een façade, bleef echter de vraag.

De daaropvolgende zaak was in dat opzicht niet bepaald hoopgevend. In het Brabantse Zundert was - buiten de bebouwde kom - op een "landbouwschuur" met zwarte letters, tegen een gele achtergrond, "Wijers, O.J." geschilderd. Oftewel: reclame voor Wijers oude jenever. En dat was verboden. Art. 1 van de provinciale verordening tot regeling van reclame op of aan onroerende goederen luidde namelijk als volgt:

"Het is aan den eigenaar of gebruiker van eenig onroerend goed verboden:

le. daarop of daaraan te hebben getimmerten, borden of andere voorwerpen, bestemd of gebezigd tot reclame;

2e. het onroerend goed op eenige andere wijze te bezigen tot reclame of toe te laten, dat dit tot reclame gebezigd wordt".

Alleen voor zover gedeputeerde staten ontheffing hadden verleend, of als het feit zich "binnen de kom eener gemeente" voordeed, gold het verbod top grond van art. 2) niet.

Die reclame voor Wijers oude jenever was dus ten enen male ongeoorloofd. Maar was het verbod-zèif eigenlijk wel in de haak? Stond het niet op gespannen voet met art. 7 Gr.w.? De kantonrechter vond van niet. In de eerste plaats zag het verbod volgens hem slechts op commerciele reclame, en $d u s$ ging het niet om "het openbaren van gedachten en gevoelens, als waarop art. 7 der Grondwet blijkens zijn geschiedenis doelt". ${ }^{28}$ Denkend aan het eerdere arrest over de Gelderse reclameverordening ("Ik stem Mussert") ${ }^{29}$, wees de advocaat-generaal (Rombach) er in cassatie echter op, "dat de verordening zeer ruim is gesteld. Ruimer dan de Kantonrechter meent, want het verbod heeft m.i. zeker niet alleen betrekking op commercieele reclame". ${ }^{30}$

Daar viel weinig op af te dingen, lijkt mij. Het tweede argument van de kantonrechter was dan ook in feite interessanter. Het sloot aan bij de jurisprudentie op dit punt. Van strijd met art. $7 \mathrm{Gr}$.w. was naar zijn mening namelijk bovendien geen sprake,

"waar luidens art. 2 der verordening reclame welke voorkomt binnen

de kom eener gemeente zonder meer toegelaten blijft, zoodlat de beperking niet zooverre gaat, dat de vrijheid om gedachten of gevoe-

lens te openbaren kan gezegd worden, metterdaad te zijn opgeheven". Weliswaar ging het in de "officiële" leer - zoals gezegd - niet zozeer om "de vrijheid om gedachten of gevoelens te openbaren" in het algemeen, als wel om de mogelijkheid ieder "middel van openbaarmaking" metterdaad te 
benutten, maar die nuance leek al eerder verloren te zijn gegaan.

De advocaat-generaal, echter, was opnieuw niet onder de indruk:

"Ook dit argument van den kantonrechter acht ik onjuist. Dat de provinciale Wetgever de kommen der gemeenten uitzonderde van zijn verbod is m.i. niet een bedoelde of niet-bedoelde omstandigheid die art. 7 der Grondwet op een afstand houdt. De reden daarvan is m.i. geen andere dan dat de provincie de vraag, of in een bepaalde gemeente zoodanig verbod ook binnen de kom moet gelden, heeft willen overlaten aan het plaatselijk bestuur, dat van zijn bevoegdheid in dit opzicht ook in tal van gemeenten gebruik heeft gemaakt". ${ }^{3 !}$

En dat laatste mocht volgens hem kennelijk ook. Speelde de vraag of "gezegd kon worden" dat het middel "metterdaad" niet meer benut kon worden, voor dergelijke gemeenten opeens geen rol meer? Of had de advocaat-generaal daar even niet aan gedacht? Wie weet? Maar hij hoefde er vanuit zijn gezichtspunt niet eens aan te denken, want je kwam er volgens hem gewoon niet aan toe:

"M.i.", aldus de advocaat-generaal, "is het geheele verband van de reclameverordening met art. 7 der Grondwet te gezocht. De drukpers heeft de mogelijkheid doen ontstaan om stukken in groote hoeveelheid te vervaardigen die onder het publiek worden verspreid. Dit gebruik van de drukpers wordt door de verordening in geen enkel opzicht belet. Alleen een zeer bepaald gebruik van het gedrukte stuk, de aanhechting daarvan aan onroerend goed om zoodoende reclame te maken is verboden. ${ }^{32}$

Hiertegen is geen bezwaar. Evenmin als er bezwaar is tegen een verbod om de verspreiding van gedrukte stukken op een bepaalde wijze langs de straat tegen te gaan, hetwelk Uw Raad bij zijn arrest van 24 October 1932 W. 12580 (Rotterdams roep- en reclameverbod, RdW) heeft gesanctioneerd".

Het standpunt van de Hoge Raad bleef, zoals destijds gebruikelijk, duister. ${ }^{33}$ Maar deze keer drukte hij zich wel bijzonder cryptisch uit. Het cassatiemiddel steunde volgens de Hoge Raad op de opvatting dat het provinciale reclameverbod "ook treft het trekken van de opmerkzaamheid van het publiek door middel van gedrukte stukken", hetgeen in strijd zou zijn met art. 7 Gr.w. Naar aanleiding daarvan overwoog hij:

"dat het middel reeds hierop afstuit, dat het bedoeld verbod is beperkt tot het geval, dat op de wijze als in het voorschrift aangegeven, een onroerend goed wordt gebezigd".

Wat was daar nu uit af te leiden? Was er in dit geval überhaupt geen sprake van "gedrukte stukken" die de bescherming van art. 7 genoten, zoals de advocaat-generaal had gesuggereerd? Of hadden we "slechts" met een her- 
haling van het arrest over het Gelderse reclameverbod ${ }^{34}$ te maken? Ook toen ging het om een verbod onroerende "goederen" (lees: zaken) "tot reclame te bezigen of daartoe te bestemmen". En waarom dat verbod door de beugel kon, was destijds al evenmin te achterhalen.

Feitelijk weten we alleen dat reclameverboden die beperkt bleven tot onroerende zaken in principe geoorloofd waren. In principe, want in beide gevallen gold het verbod behoudens uitzonderingen. Zou het ook zonder die vitzonderingen geaccepteerd zijn? Wie weet? En hoe stond het met een reclameverbod dat niet tot onroerende zaken beperkt bleef, maar tot roerende? Zat ' $\mathrm{m}$ de crux in de beperktheid van het verbod? $?^{35} \mathrm{~W}$ as de bescherming van ieder middel van openbaarmaking, met andere woorden, ècht komen te vervallen en ging het er louter om dat de boodschap nog op enigerlei wijze aan de man gebracht kon worden?

November '38, de maand van de Reichskristallnacht, leverde twee arresten op. Het ene ging over "Zwart Front", het andere over "De Nationaal Socialist". Een wrange samenloop van omstandigheden.

In 's-Hertogenbosch was het (op grond van art. 48 van de APV)

"verboden (...) op straten of wegen luid roepende of schreeuwende aan te bieden couranten, dag- of weekbladen en andere gedrukte of geschreven stukken, en lezing van zoodanige stukken aan te bevelen of den inhoud daarvan geheel of gedeeltelijk bekend te maken".

Die bepaling moest volgens de Hoge Raad ${ }^{36}$ "aldus (...) worden gelezen (...) dat de woorden 'luid roepende of schreeuwende' slechts betrekking hebben op het 'aanbieden' van de in het artikel genoemde stukken". Het luide roepen of schreeuwen had, met andere woorden, geen betrekking op het aanbevelen van het lezen en het geheel of gedeeltelijk bekendmaken van de inhoud. Dat was ook zonder geroep of geschreeuw al verboden. De bakker uit Den Bosch, die "op of omstreeks 2 April 1938 des namiddags circa $7 \frac{1}{2}$ uur (...) op den openbaren weg" de inhoud van "Zwart Front" gedeeltelijk "bekend" had gemaakt, was dus in overtreding. Hij had dat blad niet "met geheel opengevouwen voorpagina voor het lichaam" mogen houden.

Tenminste... volgens die Bossche verordening! Maar was dat niet in strijd met art. $7 \mathrm{Gr}$.w.? In 1910 had de Hoge Raad, zoals bekend, een Hilversumse bepaling onverbindend verklaard, waarin werd

"verboden op of aan den openbaren weg den inhoud van eenig gedrukt

of geschreven stuk volledig of verkort, 't zij met de bewoordingen van

dat stuk of in andere bewoordingen bekend te maken". ${ }^{37}$

Nu dat artikel "onvoorwaardelijk" verbood "den inhoud van dergelijke stukken op welke wijze ook te Hilversum op of aan den openbaren weg 
bekend te maken", kwam het - zo is in het arrest te lezen - "rechtstreeks in strijd (...) met art. 7 Grondwet, vermits met de daarin gewaarborgde vrijheid om door de drukpers gedachten of gevoelens te openbaren, zoodanig onvoorwaardelijk verbod niet (was) overeen te brengen".

Ruim achtentwintig jaar laten, op 7 november 1938, kwam de Hoge Raad tot een heel ander resultaat. Hij overwoog:

"dat requirant $(\ldots)$ betoogt, dat $(\ldots)$ het voorschrift in strijd is met artikel 7 der Grondwet, immers (...) zou inhouden een onvoorwaardelijk en onbeperkt verbod om de lezing van gedrukte stukken aan te bevelen of den inhoud daarvan geheel of gedeeltelijk bekend te maken; dat evenwel daarbij uit het oog wordt verloren, dat bovenaangehaalde bepalingen van art. 48 der verordening, - zoals uit het onderling verband blijkt -, het op straten of wegen aanbieden van gedrukte stukken, mits dat niet luid roepende of schreeuwende geschiedt, vrijlaten, en art. 7 der Grondwet zich er niet tegen verzet, dat in het belang der openbare orde worden gegeven voorschriften als de onderhavige, die bij de verspreiding van drukwerken moeten worden inachtgenomen".

Vanwaar dat verschil? De advocaat-generaal (Holsteyn), die tot dezelfde uitkomst was gekomen, meende zelfs - voorafgaand aan dit arrest $\mathrm{al}^{38}$ - dat "deze beperking volgens art. 7 der Grondwet, blijkens de jurisprudentie van den H.R. daaromtrent, geoorloofd" was (curs. RdW). Het enige precedent op dit punt - het arrest uit 1910 - verzuimde hij helaas te vermelden.

Was de Hoge Raad "om" gegaan? Of was het Hilversumse "bekendmaken" in een beslissend opzicht toch niet identiek aan dat van 's-Hertogenbosch? Wellicht! In Hilversum ging het om een "alomvattend" begrip. De Hoge Raad repte daarom van een verbod "den inhoud (...) op welke wijze ook (...) bekend te maken" (curs. RdW). In 's-Hertogenbosch, daarentegen, had "bekendmaken" een engere betekenis: het aanbieden (mits niet luid roepend of schreeuwend) was ervan losgemaakt - dat was, met andere woorden, niet verboden. Zo bleek er dus - ondanks het precedent uit 1910 - toch nog manoeuvreerruimte gevonden te kunnen worden. We zullen aan dat oude arrest dan ook met terugwerkende kracht een andere betekenis moeten toekennen. Het enige probleem daarbij is dat we dan tevens de gedachte moeten prijsgeven dat ieder "middel van bekendmaking" apart bescherming verdient. Als het immers alleen nog maar aankomt op de mogelijkheid iets "bekend" te maken, worden tal van afzonderlijke middelen op één hoop geveegd. Er hoeft nog maar één middel overeind te staan (zoals in dit geval het "aanbieden"), wil men de andere kunnen verbieden... Wie had dat in 1892 kunnen voorspellen? 
Het andere november-arrest, echter, was - na lange tijd - eindelijk weer eens "recht in de (oude) leer". In Arnhem was het

"verboden op openbare wegen en op dagen of gedeelten van dagen, in het belang van de openbare orde of veiligheid door B. en W. aan te wijzen, (...) gedrukte of geschreven stukken of afbeeldingen te koop aan te bieden, te verspreiden, aan te bevelen, aan te kondigen of hierop de aandacht te vestigen".

Je mocht op die plaatsen op de aangewezen tijdstippen dus zelfs niet wijzen naar een boek... Hoe dan ook, B en W hadden een aantal straten aangewezen, waarop dat verbod "tusschen 12 uur 's middags en 12 uur 's nachts" van toepassing was. Toen jemand op én zo'n straat om half acht 's avonds "de aandacht (had) gevestigd op een courant genaamd de Nationaal Socialist, door deze courant voor een ieder zichtbaar voor de borst te houden", was er dus sprake van een overtreding. Hij had weliswaar niet eens de inhoud "gedeeltelijk bekend gemaakt", zoals zijn collega van Zwart Front in 's-Hertogenbosch, maar hij had eenvoudig het verkeerde ogenblik (en de verkeerde plaats) voor zijn actie gekozen.

De kantonrechter ontsloeg hem niettemin van alle rechtsvervolging, omdat het bewezenverklaarde geen strafbaar feit zou opleveren. De Hoge Raad zag dat echter anders. De verordening had, in samenhang met het uitvoeringsbesluit, gewoon toepassing "behooren te vinden, hetgeen, nu in de aanteekening van het mondeling vonnis geenerlei grond wordt genoemd waarom zulks niet het geval zoude zijn, nader betoog niet behoeft", aldus de Hoge Raad heel zuinigjes. ${ }^{39}$

De advocaat-generaal (Rombach) was wat minder krenterig. Hij constateerde in zijn conclusie voor het arrest dat B en $\mathrm{W}$ in hun uitvoeringsbesluit "niet een algemeen verbod (hadden) uitgevaardigd, maar slechts in het belang der openbare orde en veiligheid (van het verkeer blijkbaar) een aantal Arnhemse straten (hadden) aangewezen, waarop het tusschen 12 uur 's middags en 12 uur 's nachts verboden (was) te colporteeren met gedrukte of geschreven stukken of afbeeldingen". Onder verwijzing naar de "Rosendaal-doctrine"40 concludeerde hij dat dus van strijd met art. $7 \mathrm{Gr}$.w. geen sprake was. En inderdaad, vergeleken met die zaak lag het niet voor de hand in dit geval aan te nemen dat "gezegd kon worden" dat het openbaringsrecht "metterdaad" was "opgeheven". ${ }^{41}$ Het Arnhemse regime was weliswaar geen toonbeeld van ruindenkendheid, maar het was niet ongrondwettig. 


\subsection{Het klapstuk: de Heerenveense noodverordening (1939)}

Het arrest over de Heerenveense noodverordening ${ }^{12}$ zette verreweg de meeste pennen in beweging. "Het arrest werpt", aldus Van den Bergh destijds ${ }^{43}$, "de gehele, in de loop der jaren zorgvuldig opgebouwde, bewonderenswaardige jurisprudentie van de $\mathrm{HR}$, die ik met vreugde op college heb uiteengezet, met én enkele stoot ondersteboven".

Wat was er gebeurd? Bevreesd "dat de van omstreeks 28 September 1938 tot 5 October 1938 voorgenomen tournee van een propagandawagen van den zoogenaamden oorlogs-waarschuwingsdienst bij de bevolking ernstige verontwaardiging (kon) wekken en alsdan stoornis der openbare orde te duchten (was)", had de burgemeester van Heerenveen een noodverordening uitgevaardigd. Op grond daarvan was het

"verboden in het openbaar, in welken vorm ook, eenige propaganda

te voeren, die zich richt tegen de verdediging of de weermacht van het

Koninkrijk, of eenige afbeelding of geschrift, hierop betrekking hebbende, te verspreiden".

En prompt op 28 september werden de eerste pacifistische activisten opgepakt, omdat ze propaganda hadden gevoerd "die zich richtte tegen de verdediging en/of de weermacht van het Koninkrijk". De kantonrechter ontsloeg ze echter van alle rechtsvervolging, omdat hij het verbod in strijd met art. 7 Gr.w. achtte. De rechtbank, daarentegen, veroordeelde ze "ieder tot een geldboete van vijf en twintig gulden en een vervangende hechtenis van vijf en twintig dagen" - een straf die vele keren hoger was dan in welke van de voorafgaande zaken ook. De noodverordening was volgens de rechtbank niet in strijd met art. 7. Het "voorschrift van den Burgemeester" had immers "niet de strekking (...) voor jemand voorafgaand verlof noodig te maken om door drukpers gedachten of gevoelens te openbaren". Het stelde "slechts verantwoordelijkheid" vast voor degenen die een bepaalde soort propaganda maakten. En die mogelijkheid werd in art. $7 \mathrm{Gr}$.w. juist "uitdrukkelijk opengelaten". De rechtbank overwoog in dat verband

"dat toch onder 'verantwoordelijkheid volgens de wet' in die bepaling niet slechts moet worden verstaan: verantwoordelijkheid vastgesteld

bij een wet in den zin van art. 124 Grondwet (vgl. het huidige art. 87, RdW), doch daaronder naar de mening van de Rechtbank is begrepen 'verantwoordelijkheid vastgesteld bij voorschriften en uitgevaardigd en afgekondigd door autoriteiten, welke daartoe krachtens de wet in den zin van art. 124 Grondwet bevoegd zijn'."

Die opvatting was klaarblijkelijk geen gemeengoed. De advocaat-generaal (Holsteyn) verkondigde in zijn conclusie vóor het arrest van de Hoge Raad althans iets heel anders: 
"Gelet nu op de jurisprudentie van den Hoogen Raad ten aanzien van art. 7 der Grondwet in verband met gemeente-verordeningen, acht ik voormelde motiveering en voormeld op deze motiveering gebaseerd oordeel der Rechtbank, als met die jurisprudentie in strijd, niet aanvaardbaar en meen ik dat volgens die jurisprudentie moet worden aangenomen, dat (...) de Burgemeester het in dat grondwetsartikel gegarandeerde recht om zonder voorafgaand verlof door de drukpers gedachten en gevoelens te openbaren wel nader kan regelen en beperken in het belang van de openbare orde, doch dit recht niet onvoorwaardelijk en algemeen kan verbieden, wat in casu is geschied voorzooveel betreft propaganda die zich richt tegen de verdediging of de weermacht van het Koninkrijk. Immers het 'op deze wijze verantwoordelijkheid vaststellen' zou volgens het door de Rechtbank, blijkens haar voormelde motiveering, ten aanzien van art. 7 der Grondwet ingenomen standpunt ook bij gewone, op art. 168 der Gemeentewet gebaseerde, gemeenteverordening mogen geschieden, hetgeen toch zeker in strijd zou zijn met voorbedoelde jurisprudentie".

Toch kreeg de rechtbank uiteindelijk gelijk. De Hoge Raad overwoog namelijk:

"dat een verbod tot het in het openbaar voeren van propaganda, als in bovenaangehaald algemeen voorschrift van politie omschreven, in den bij art. 220 der Gemeentewet bedoelden toestand noodig kan zijn ter bescherming van de openbare orde, en dus naar zijn aard valt binnen de aan den Burgemeester in deze gegeven bevoegdheid;

dat de Rechtbank voorts met juistheid heeft beslist, dat aan de geldigheid van het voorschrift niet afdoet, dat onder het verbod ook valt het voeren der verboden propaganda door middel van gedrukte stukken en het verspreiden van afbeeldingen of geschriften van de gewraakte strekking;

dat ten betooge van het tegendeel ten onrechte een beroep is gedaan op art. 7 der Grondwet, welks voorschrift, dat niemand voorafgaand verlof noodig heeft om door de drukpers gedachten of gevoelens te openbaren, niet in den weg staat, - zooals door het in de tweede zinsnede gemaakte voorbehoud nog uitdrukkelijk wordt bevestigd -, aan wettelijke bepalingen, waarbij tegen het openbaar maken of verspreiden van gedrukte stukken of afbeeldingen van bepaalde strekking straf wordt bedreigd, (...) terwijl de Rechtbank terecht onder 'wet' hier ook heeft begrepen geoordeeld een verordening, door den Burgemeester op grond van art. 220 der Gemeentewet uitgevaardigd".

De reacties logen er niet om. Van den Bergh kwamen we aan het begin van deze paragraaf al tegen. "Een revolutie in ons staatsrecht", schreef een 
ander. ${ }^{45}$ "Het arrest van 1910 (Hilversums ventverbod, RdW) is hiermede geheel achterhaald", meende Duynstee. ${ }^{46}$ "... lijkt mij met dat van 1928 (Sanitas, RdW) in strijd", aldus Pompe. ${ }^{47}$ En: "een ander geluid" (Van der Pot). ${ }^{48}$ Maar zij hadden ook hun tegenhangers: "oud nieuws" ${ }^{\text {"49 }}$, "niets bijzonders" $"$ en "noodeloos alarm"s1 , waarop Van den Bergh dan weer repliceerde met "S.O.S.". .52

"De nieuwe leer is dus deze:"wet" in artikel 7 moet worden opgevat in materiëlen zin", aldus Van den Bergh in 1939. ${ }^{53}$ Klopte dat? Ook Van der Pot $^{54}$ en Dresen ${ }^{55}$ - om slechts twee anderen te noemen - huldigden die opvatting; de én met zin, de ander met tegenzin. Hadden ze gelijk? "Naar de meening van de rechtbank" was onder "verantwoordelijkheid volgens de wet" inderdaad begrepen "verantwoordelijkheid vastgesteld bij voorschriften en uitgevaardigd en afgekondigd door autoriteiten, welke daartoe krachtens de wet in den zin van art. 124 Grondwet (vgl. het huidige art. 87, RdW) bevoegd zijn" (curs. RdW). De Hoge Raad oordeelde vervolgens dat "de Rechtbank terecht onder 'wet' hier ook heeft begrepen geoordeeld een verordening, door den Burgemeester op grond van art. 220 der Gemeentewet uitgevaardigd".

Let wel: dat laatste is niet hetzelfde als de rechtbank had beslist. Van de brede categorie voorschriften die de rechtbank onder het begrip "wet" had gebracht, nam de Hoge Raad slechts één soort over. Dat wilde natuurlijk niet zeggen dat voor die andere soorten dus iets anders gold, maar het wilde evenmin zeggen - zoals Van den Bergh c.s. voetstoots aannamen - dat dus voor alle andere soorten hetzelfde gold. Het enige wat we zeker weten, is dat het oordeel van de rechtbank, voor zover het voorschrifien op grond van art. 220 gem.w. betrof, in de ogen van de Hoge Raad "terecht" tot stand was gekomen (waarmee de Hoge Raad zich overigens niet uitsprak over de redenen waarom de rechtbank tot haar oordeel was gekomen).

Voor een apart regime ten opzichte van voorschriften ex art. 220 Gem.w. sprak misschien het bijzondere rechtskarakter ervan: het waren - in elk geval vo6r bekrachtiging door de gemeenteraad - geen gewone verordeningen; aan de andere kant waren het - ondanks de strafbepaling in art. $443 \mathrm{Sr}$ - ook geen echte wetten. ${ }^{56}$ En het ging natuurlijk steeds om noodmaarregelen; dan staan eisen van doelmatigheid nu eenmaal voorop. Zaaijer $^{57}$ wees er - in het verlengde daarvan - op

"dat zij, uitsluitend bedoeld zijn te gelden voor de zeer buitengewone omstandigheden, waarvoor zij zijn uitgevaardigd. Kan men nu wellicht uit dien hoofde zeggen, dat de verordening reeds krachtens haar karakter een beperkte strekking heeft, en dat daarom ook in zulk een. noodverordening een algemeen verbod, om door middel van de drukpers gedachten of gevoelens te openbaren, toelaatbaar zou zijn, 
immers slechts als een beperking van de drukpersvrijheid zou moeten worden beschouwd?"

Volgens Van Haren ${ }^{58}$ was "de kwestie of 'wet' in art. 7 der Grondwet in materieelen of in formeelen zin moet worden verstaan" zelfs "niet aan de orde". De Hoge Raad had, naar zijn idee, "niets anders gedaan dan uitgesproken dat de verordening, door den Burgemeester op grond van art. 220 der Gemeentewet uitgevaardigd, eenzelfde 'wets'-karakter heeft als de verordening van den gemeenteraad, wanneer dit college een beperkt colportageverbod uitvaardigt". En daarbij dacht hij - in navolging van Zaaijer vooral aan "de talrijke provinciale of gemeentelijke reclameverordeningen". Heel begrijpelijk, lijkt mij, want op dat vlak had zich inderdaad heel wat afgespeeld. In Rotterdam stuitten we al op een verbod om - zonder schriftelijke vergunning van $B$ en $W$ - met reclamemiddelen te rijden, te gaan of te staan. ${ }^{59}$ In Gelderland gold in landelijke gemeenten (of gedeelten daarvan) een verbod om onroerende zaken voor reclame te benutten. ${ }^{0}$ In NoordBrabant iets soortgelijks ${ }^{61}$, terwijl Arnhem de kroon spande door te verbieden op bepaalde plaatsen en tijdstippen ergens "de aandacht (op) te vestigen" ${ }^{62}$ Waarin school eigenlijk het verschil tussen deze oude bekenden en het Heerenveense propaganda-verbod? Was propaganda niet $60 \mathbf{k}$ een vorm van reclame?

Akkoord, maar hier richtte het verbod zich niet tegen propaganda in het algemeen, maar tegen propaganda van bepaalde strekking, aldus de tegenwerping van Van den Bergh. ${ }^{63}$ Later $^{64}$ verwoordde hij zijn standpunt als volgt:

"Impliceert de drukpersvrijheid het recht van vrije verspreiding ook in de drukste straten en op de drukste uren met in-gevaar-brengen van de veiligheid van het verkeer? Immers neen! Impliceert de drukpersvrijheid het recht van vrije aanplakking op alle bomen en op alle muren van openbare gebouwen met aantasting van de eisen der aesthetica? Immers neen! Impliceert de drukpersvrijheid gelijke behandeling door de gemeenteverordening van alle gedachten-of-gevoelens-openbarende drukwerken, onafhankelijk van hun inhoud? Immers ja, duizendmaal ja!"

Maar..., werd daar dan weer tegenin gebracht, "niet om de bepaalde strekking allén sauveerde de H.R. de noodverordening, inaar omdat die strekking leiden zou tot stoornis van de openbare orde". ${ }^{65}$ En daarmee zijn we feitelijk weer terug waar dit verhaal begon: in 1892 . Ook toen werd door sommigen al betoogd dat de inhoud van een geschrift soms wel als aanknopingspunt mocht dienen, zolang hij maar niet de aanleiding tot de ingreep vormde. "Neen", schreef zelfs Westra van Holthe ${ }^{66}$, "welk geschrift het ook moge zijn, dat zijne verspreiding op de straat wanorde kan veroorzaken, 
moet de eenige maatstaf zijn bij het weigeren van het verlof". En, betoogde Van Riemsdijk Kreenen twee jaar later" meening is, dat met het oog op den geest der bevolking, het venten van een geschrift wanorde zou verwekken, zelfs al is de inhoud naar zijne meening nog zoo goed, en al verdienen de daarin verkondigde stellingen nog zozeer onder het volk verspreid te worden, dan moet hij het venten verbieden". Van den Bergh ${ }^{68}$ vreesde echter dat alle remmen nu los waren:

"De gevolgen van de nieuwe jurisprudentie zijn onafzienbaar. Bijvoorbeeld: gemeentelijke verordeningen, houdende een verspreid- of ventverbod van drukte stukken van bepaalde strekking (met een bepaalde inhoud) zijn in beginsel rechtsgeldig. Plattelandsgemeenten, in het gelid! Gij vindt het wellicht onaangenaam, dat op gezette tijden propagandisten van elders zich in uw gemeente vertonen en daar pamfletten verspreiden, misschien keurig gesteld in parlementaire taal, maar van een strekking, die u onaangenaam is, omdat zij is communistisch, socialistisch, anti- of juist pro-katholiek, pro- of anti- dit-ofdat; gij meent dat daardoor de rust of de openbare wordt aangetast?... Welnu: de oplossing is voortaan gegeven; gij verbiedt deze verspreiding, d.w.z. juist die verspreiding, die u onaangenaam is. Art. 7 Grondwet zal geen beletsel meer vormen. Verspreidverboden vindt gij niet afdoende?... Met een gerust hart kunt gij tot publicatieverboden, in welke vorm ook, overgaan. In uw gemeente is een werkstaking, die gij ongerechtvaardigd acht en die tot grote moeilijkheden aanleiding geeft?... Gij verbiedt geschriften, die de strekking hebben de stakers tot volhouden aan te sporen". Enz. enz.

Of dat er allemaal echt uit volgde, viel intussen nog te bezien. In de eerste plaats bracht het arrest, zoals gezegd, niet noodzakelijkerwijs mee dat "wet" in art. 7 inderdaad op alle wetten in materiele zin zag. Volgens Van Haren $^{6 \oplus}$ had de Hoge Raad zich bovendien uitsluitend over het propagandaverbod uitgesproken (want alleen dat was overtreden). De rest van het noodvoorschrift - over het gewone verspreiden - zou dus niet aan de orde zijn gekomen. Zo bezien waren de conclusies die Van den Bergh aan het arrest verbond nergens op gebaseerd. Heel subtiel...

Maar die stelling van Van Haren klopt naar mijn idee niet. Laten we - ook met het oog op de verdere bespreking van dit arrest - nog eens goed kijken naar de overwegingen van de Hoge Raad. Het waren er - voor zover hier van belang - drie:

1. het verbod kan nodig zijn ter bescherming van de openbare orde, dus was de burgemeester bevoegd;

2. aan de geldigheid van het voorschrift doet niet af dat ook propaganda 
door middel van gedrukte stukken en het verspreiden van "afbeeldingen of geschriften van de gewraakte strekking" verboden was;

3. art. 7 Gr.w. staat niet in de weg aan wettelijke bepalingen die het openbaar maken of verspreiden van gedrukte stukken of afbeeldingen van bepaalde strekking strafbaar stellen, terwijl ook voorschriften op grond van art. 220 gem.w. hier als 'wet' moeten worden aangemerkt.

De eerste overweging behelsde slechts een uiterst marginale toetsing of voldaan was aan de in art. 220 bedoelde omstandigheden (veel mér was, gezien het laatste lid van die bepaling, niet mogelijk). Wie (zoals Van den Bergh) op basis van de derde overweging tot de conclusie kwam dat "wet" in art. 7 zag op wetten in materiële zin, hoefde in deze eerste overweging dus geen algemene beperking te lezen: de eerste overweging had slechts betrekking op wetten in materiële zin die tevens als voorschrift ex art. 220 waren aan te merken.

De tweede overweging is moeilijker te vatten. Maar zoveel is duidelijk: ook de verspreiding was meegewogen. Van Haren's analyse was, met andere woorden, subtieler dan die van de Hoge Raad. ${ }^{70}$ Toch was hier wellicht een openingetje. De overweging was namelijk - net als de verbodsbepaling-zelf dubbelzinnig. Wat was precies de strekking van het verbod? Ging het, zoals Van Haren suggereerde, om twee soorten gedragingen (resp. het voeren van propaganda en het verspreiden), of werd ook het verspreiden gezien als vorm van propaganda? Betrof het verbod, met andere woorden, propaganda door middel van o.a. (1) gedrukte stukken en (2) het verspreiden, dan wel (1) propaganda door middel van o.a. gedrukte stukken en (2) het verspreiden? Het voorschrift-zelf lijkt een onderscheid te maken tussen enerzijds propaganda voeren en anderzijds verspreiden. Maar in de bewezenverklaring liepen die twee al aardig door elkaar: het ging over een rijdende, met reclamebiljetten beplakte, personenauto, "gevolgd door een reclameaanhangwagen" waarop allerlei affiches en foto's waren aangebracht, "terwijl voorts in de auto een groote hoeveelheid propagandamateriaal als boekjes en pamfletten werd medegevoerd". Kortom: propaganda door middel van verspreiding? Of was het rondrijden met al die leuzen nog geen vorm van verspreiding?

Daar viel natuurlijk eindeloos over te twisten (wat destijds overigens niet is gedaan). Ik wil het hier laten bij de constatering dat de Hoge Raad er geen uitspraak over heeft gedaan. Wellicht werd alles dus onder de noemer van "propaganda" gebracht. In dat geval was de stap, ten opzichte van eerdere uitspraken, het kleinst. Want, zoals gezegd, op het vlak van de reclame vertoonde de jurisprudentie al de nodige deuken. ${ }^{71}$ Weliswaar was een verbod van specifieke reclames nooit eerder door de Hoge Raad geaccepteerd (en trouwens evenmin afgewezen!), maar hoe principieel lag dat. 
eigenlijk? Had men in Heerenveen well een verbod voor politieke propaganda van welke aard ook mogen uitvaardigen ${ }^{72}$ Was dat dan niet een pluim op de hoed van de hypocrisie? Er was op dat moment immers maar één soort propaganda die de grondslag voor zo"n verbod kon vormen. Nee, problematischer was misschien dat het om een algemeen verbod ging voor alle propaganda "tegen de verdediging of de weermacht". Tot nu toe waren er steeds - naast zo'n verbod - allerlei andere reclamemogelijkheden geweest. Maar goed, of dat een vereiste was, wisten we eigenlijk niet. Het leek er in feite op dat reclame, net als roepen en schreeuwen, buiten de sfeer van art. 7 was gebracht - en wat deed het er dan nog toe of het geheel en al werd verboden? Bovendien bood de opmerking van Zaaijer hier uitkomst: het verbod gold slechts zolang er "zeer buitengewone omstandigheden" waren. ${ }^{3}$ Daarna werd het weer opgeheven. Welnu, waarom zou zo'n in de tijd beperkt verbod dan niet door de beugel kunnen? Zelfs tegen de achtergrond van de oude jurisprudentie waren er, kortom, nog legio constructies te verzinnen om de zaak alsnog "recht" te praten.

Maar nu de derde overweging. Daarover was destijds de meeste commotie ontstaan. De Hoge Raad had twee dingen betoogd. In de eerste plaats dat art. $7 \mathrm{Gr}$.w. "niet in de weg staat (...) aan wettelijke bepalingen, waarbij tegen het openbaar maken of verspreiden van gedrukte stukken of afbeeldingen van bepaalde strekking straf wordt bedreigd". En in de tweede plaats dat beroemde verhaal over het begrip 'wet'.

Laat ik met het eerste beginnen. Zo op het oog staat er niets nieuws. Toch spreekt het niet allemaal vanzelf. Waarom, bijvoorbeeld, repte de Hoge Raad opeens van "openbaar maken of verspreiden van gedrukte stukken" etc.? Was de verspreiding tot dan toe niet louter van belang met het oog op de openbaarmaking? Nou ja, misschien had de Hoge Raad zich laten leiden door het taalgebruik in het Heerenveense voorschrift; dan hoeven we er tenminste geen consequenties aan te verbinderi... Waar het op aankwam was dat uitingen "van bepaalde strekking" door "wettelijke bepalingen" met straf mochten worden bedreigd. Het Wetboek van Strafrecht bood (en biedt) inderdaad ettelijke voorbeelden. In haar algemeenheid was op die stelling dan ook weinig af te dingen. Jansen ${ }^{74}$ wees echter - in verband met de Heerenveense bepaling - op "het nauwe verband" tussen de aard van de propaganda en "de te duchten verstoring van de openbare orde". Het arrest van de Hoge Raad impliceert volgens hem dan ook niet dat iedere "strekking" bij dergelijke voorschriften door de beugel kon. Zeker, daar had hij gelijk in! In ruimere zin moest in dit soort gevallen steeds recht worden gedaan aan het in art. 220 neergelegde criterium. Anders was de burgemeester eenvoudig niet bevoegd. Maar wat nu, als het om andere voorschriften ging, bijvoorbeeld gewone gemeentelijke verordeningen? Ook dan rees natuurlijk aller- 
eerst de vraag of zo'n gemeente wel bevoegd was. En hoe zat het vervolgens met art. 7?

Dat brengt me, met andere woorden, bij het tweede onderdeel van de derde overweging. Wie mochten eigenlijk inhoudelijke beperkingen opleggen? In de eerste plaats de wetgever in formele zin; dat werd door niemand bestreden. Nieuw was, dat ook de burgemeester dit mocht op grond van art. 220 gem.w. Wat zat daar voor redenering achter? Ik ben daar straks al op ingegaan en zal mezelf niet nu al herhalen. Van belang is wel, dat op tamelijk. grote schaal werd aangenomen dat "wet" in art. 7 Gr.w. door de Hoge Raad voortaan als "wet in materiële zin" werd uitgelegd. Dan had Van der Grinten uiteindelijk dus tòch gescoord met zijn artikel uit 1929 over het Sanitasarrest! $!^{75}$ Een "onvoorwaardelijk verbod tot bekendmaking van gedrukte stukken, ongeacht hun inhoud", was weliswaar - zoals eerder weergegeven in zijn visie op de rechtspraak van de Hoge Raad ongeoorloofd, maar dat impliceerde volgens zijn geheel eigen logica dat "drukwerk van een bepaalden inhoud" wèl verboden mocht worden.

Van den Bergh $^{76}$ kwam in 1939 met een reeks argumenten aanzetten waarom het woordje "wet" in art. $7 \mathrm{Gr}$.w. niets anders dan wet in formele zin kon betekenen. Niet alleen had dat woord bijna alle 192 keer dat het in de Grondwet voorkwam die betekenis (en zelfs steeds wanneer van "regeling bij de wet" o.i.d. sprake was), bovendien stond of viel de waarde van art. 7 als grondrecht hiermee. "De geschiedenis van artikel 7 bewijst het zonneklaar", aldus Van den Bergh. Boukema was daar later heel wat minder stellig over:

"ook al heeft de wetgever bij de zinsnede 'volgens de wet' waarschijn-

lijk vooral gedacht aan de wetgever in formele zin, uit niets blijkt dat het de bedoeling van de wetgever is geweest om de lagere wetgever de bevoegdheid tot vaststellen van verordeningen, waaruit een beperking van de drukpersviijheid zou kunnen voortvloeien, te ontnemen". ${ }^{n}$

Het lijkt mij, eerlijk gezegd, geen zinvol onderwerp voor een vruchtbare discussie. Wat is immers de bedoeling van de wetgever, en dan ook nog eens gemeten over een periode van mér dan honderd jaar? De wetgever is geen persoon, maar een procedure. ${ }^{78}$ Talloze "bedoelingen" spelen dus een rol; sommige worden uitgesproken, andere niet. Waarom zouden we er - aangenomen dat der sprake was van én bepaalde "bedoeling" - ten eeuwigen dage aan gebonden zijn? Gaat daar iets verheffenders dan voorouderverering achter schuil (voor zover onze voorouders al in Nederland woonden)?

Nou ja, het gaat er op dit moment voornamelijk om dat het woordje "wet" volgens sommigen - op welke gronden ook - uitsluitend op wetten in formele zin zag. Anderen - Van der Grinten en Van der Pot voorop ${ }^{79}$ lazen er wetten in materiele zin in. Maar het zou niet 'fair' zijn die laatste twee over 
én kam te scheren. Waar Van der Grinten duidelijk ruimte zag voor inhoudelijke beperkingen van gemeentewege, schrok Van der Pot daarvan terug. Hij achtte het

"in het algemeen wel bedenkelijk, als aan den lageren wetgever wordt toegestaan om zijn verbodsbepalingen te richten naar den inhoud der gedachtenopenbaringen en, vond dit voorbeeld navolging op de wijze, als Van den Bergh in levendige kleuren schetst, dan zou ik een optreden van de Kroon daartegen met het vernietigingsrecht van harte toejuichen".

Maar het was Van der Pot niet duidelijk hoe men, ervan uitgaande dat "wet" in art. $7 \mathrm{Gr}$.w. enkel ziet op wetten in formele zin,

"de talrijke andere bepalingen en gemeentelijke verordeningen, die op - ook volgens Van den Bergh - geoorloofde wijze iets met betrekking tot het verspreiden van drukwerken, dus ook van gedachten of gevoelens openbarende drukwerken, verbieden, kan rechtvaardigen. Als alleen de wet in formeelen zin verbodsbepalingen op het door art. 7 Gr.w. bestreken terrein mag geven, is elke gemeentelijke verordening betreffende verspreiding van zulke drukwerken onverbindend. De noodzakelijke consequentie van het halen van de verspreiding binnen de sfeer van art. 7 is, of dat men den gemeentelijken wetgever alle vrijheid tot regeling ook op dit gebied ontzegt, of dat men voor art. 7 het materieele wetsbegrip aanvalardt. Het laatste is niet volstrekt ongeoorloofd en de Hooge Raad heeft kennelijk deze oplossing verkozen". ${ }^{80}$

$\mathrm{Ja}$, kennelijk! Want het ging hier - zoals gezegd - om een gissing: de Hoge Raad had zich er niet met zoveel woorden over uitgesproken.

Van den Bergh kreeg het betoog van Van der Pot pas in Buchenwald onder ogen. Pas na de oorlog kwam hij ertoe te reageren. Hij was het er - vanzelfsprekend - niet mee eens. Ook hij meende weiliswaar dat de Hoge Raad "wet" als "wet in materiële zin" las, maar hij zag de noodzaak daar - anders dan Van der Pot - absoluut niet van in. Volgens Van der Pot gold, zo vatte Van den Bergh ${ }^{81}$ diens standpunt samen,

"van tweeën één: of gij ontzegt de gemeentelijke wetgever alle vrijheid tot regeling op dit gebied, of gij aanvaardt het materiële wetsbegrip voor de bepaling van artikel 7. En dit laatste is 'niet volstrekt ongeoorloofd'.

Welnu, dit dilemma kan ik niet aanvaarden, althans niet in de zin, die collega Van der Pot eraan geeft. Ja, inderdaad: ik ontken de vrijheid van de gemeentelijke wetgever tot regeling op dit gebied. $1 \mathrm{k}$ ontken de bevoegdheid van de gemeentelijke wetgever om enige bepaling te ontwerpen, die ook maar een spoor van inbreuk maakt op het grondrecht 
der drukpersvrijheid. Dit is ook steeds het standpunt geweest van de Hoge Raad, tot aan het noodlottige arrest. Maar ik ontken tevens, dat de talrijke gemeenteverordeningen, die - ofschoon zij betrekking hadden op het verspreiden van gedrukte stukken - de toets van de Hoge Raad glansrijk doorstonden, ook maar een spoor van inbreuk op dat grondrecht hebben gemaakt. Juist omdat zij dat niet deden(ook niet volgens de Hoge Raad) konden zij die toets doorstaan. Daarom regelden zij ook niets 'op dit gebied'."

Je vraagt je bij zoveel stelligheid af waarom het dan in de praktijk zo moeilijk was te voorspellen of een bepaling al dan niet door de beugel kon. Toch lijkt ook mij de stelling dat het in die oudere zaken om iets heel anders ging dan in het arrest over Heerenveen goed verdedigbaar. Tot dusver stond de mogelijkheid om iets openbaar te maken immers steeds voorop. Ieder stuk moest - zo was de gedachte - openbaar gemaakt kunnen worden. Dat hoefde weliswaar niet permanent en overal, op welke wijze ook, te kunnen, maar de beperkingen mochten niet zover gaan dat gezegd kon worden dat de mogelijkheid tot openbaarmaking metterdaad was opgeheven. ${ }^{82}$ Zodra echter het openbaar maken van bepaalde stukken om inhoudelijke redenen werd verboden, kon - met het oog op die stukken - toch moeilijk worden volgehouden dat de mogelijkheid tot openbaarmaking niet was opgeheven! Er was dan - zou je kunnen zeggen - sprake van een absoluut verbod, zij het ten aanzien van bepaalde stukken. En dat strookte niet met het eerste deel van art. 7 Gr.w. Ergo: zo'n verbod was ongeoorloofd. De traditionele beperkingen op het openbaar maken van drukwerk werden dus niet zo zeer gerechtvaardigd door het tweede deel van art. 7 ("behoudens ieders verantwoordelijkheid volgens de wet"), maar vormden eenvoudig - omdat zij het openbaarmaken "onverlet" lieten - (nog net) geen inbreuk op het eerste deel. Dárom waren zij toelaatbaar, en wel: uitsluitend dárom. Uit de eerdere jurisprudentie viel, met andere woorden, niets af te leiden over de opvatting van de Hoge Raad omtrent het tweede deel van art. 7, en dus evenmin omtrent het woordje "wet". Het kon - in die zienswijze - zowel voor "wet in formele zin" staan, als voor "wet in materiële zin".

De constructie-Van der Pot was, kortom, niet dwingend. Het was slechts eén van de mogelijkheden, zoals ook de constructie-Van den Bergh niet mér dan een mogelijkheid behelsde. Na zóveel rechtspraak was er blijkbaar nog steeds geen "leer" te ontwaren. Zowel A als niet-A was onder verwijzing naar de rechtspraak verdedigbaar. Wat had je dan aan zulke verwijzingen? Misschien was de voornaamste vrucht dat tal van "oningewijden" werden weerhouden van deelname aan het debat. Zij konden er immers niet over meepraten. Wie wel? 


\section{Hoofdstuk 4 Restauratie}

Na 1939 volgden er jaren van stilte. Stilte tijdens de storm. Want dat het verspreidingsrecht toen weinig belangstelling genoot, is moeilijk vol te houden. Het probleem zat 'm eerder in de rechtsgang - die was er niet! Vrij Nederland - tusssen ' 40 en ' 45 "ondergronds" verspreid - blikte in zijn bevrijdingsnummer ${ }^{1}$ nog even terug:

"Met weemoed en diepe dankbaarheid denken wij hier aan degenen die ons door den dood ontvielen. (...) Ook denken wij aan onze gevangenen en gedeporteerden. Aan allen, die voor ons gemeenschappelijk werk huis en goed verloren, die onderduiken moesten. In het bijzonder denken wij ook aan de drukkers, deze prachtige dappere kerels, die mede van het zwaarste en gevaarlijkste werk hadden en ons nooit in den steek lieten.

Wij denken aan allen, die op belangrijke en onbelangrijke posten (maar in het verzetswerk waren geen onbelangrijke posten!) dag in dag uit en vaak nacht in nacht uit hun werk hebben verricht. Speciaal ook aan onze koeriersters, die, vaak door opleiding en kennis tot ander werk in staat, dit eenvoudige werk hebben verricht met een ijver en toewijding, die ons vaak verbaasd deed staan!"

Geleidelijk nam het "gewone" leven een aanvang. De draad werd opgenomen waar hij "reeds voór de oorlog, o.a. in Bussum"2, was blijven liggen. Alles werd weer tot hanteerbare proporties teruggebracht. Wel kneuterig, maar niet typisch Nederlands trouwens. Tom Lanoye ${ }^{3}$ beschreef hetzelfde voor België aan de hand van de negenjarige Achille van den Branden die zijn beklag deed in de bibliotheek:

"Mijnheer Conings, hier staan 31 boeken die ik mag lezen. De meeste daarvan heb ik al drie keer gelezen. Sommige vijf keer. Waarom moet ik wachten tot ik mijn Communie doe? Mag ik niet nu al boeken lezen van Categorie B? Maar als dat niet mag, mijnheer Conings, koopt u dan tenminste níeuwe boeken voor mij. Een veertigtal volstaat'.

Mijnheer Conings, aan een grote schrijftafel gezeten, draaide geamuseerd zijn snorpunten. Zijn opvattingen waren ruim, zijn budget klein. Hij gaf de jongen zijn toestemming, niet alleen voor de boeken van Categorie B, maar voor alle boeken. Want, zo overlegde mijnheer Conings met zichzelf, dit was de ideale gelegenheid om de kleine Achille de billijkheid te doen inzien van het systeem der Categorieën. 
Stel dat de jongen boeken koos uit de Categorieën C, D of E - Rijpere Jeugd, Jongvolwassenen, Volwassenen - dan zou hij daarvan zo weinig begrijpen dat hij, verveeld, ze uit zichzelf terzijde zou leggen".

Maar ze vielen juist reuze in de smaak! Achille wilde er mér en mér van lezen. Er ging geen dag voorbij of hij kwam langs.

"Ook gebeurde het dat de jongen gewoon van tussen de rekken riep: 'zeg Conings, Het bordeel van Ika Loch, van Paul van Ostaijen, is dat wat?' Mijnheer Conings kromp ineen als een slak in een zoutvat. Hij wachtte tot Achille de deur uit was en haastte zich dan om, bij twee nog aanwezige leden der Gemeentelijke Bibliotheek, met luide stem de luiheid aan te klagen van volwassenen die, in plaats van zelf om hun boeken te komen, een jong familielid erop uitstuurden, zonder acht te slaan op de nadelige gevolgen die, dat was wetenschappelijk bewezen, de jeugd ondervond wanneer zij op welke manier ook in contact kwam met literatuur van Categorie E".

\subsection{Een aarzelend begin (1948-1950)}

"Ieder die voor ander werk niet meer ten volle geschikt is", aldus Donner ${ }^{4}$ in 1948, "kan zich een paar duizend tweedehandsboeken kopen en een bibliotheekje beginnen". Vooral de verspreiding van pornografie op die manier baarde sommigen zorgen. Donner niet overigens.

"Het eigenlijke en veel grotere gevaar zit niet in die hoek", meende hij". "Dat gevaar ligt veel meer in het ontstellend lage peil van de lectuur, die door alle bibliotheken wordt verspreid. De kleffe zoetelijkheid en romantiek, die via dit kanaal week in week uit haar weg vindt onder brede lagen der bevolking kan noch aanstotelijk voor de eerbaarheid noch direct gevaarlijk worden genoemd, maar het is wel een sluipend bederf van smaak en maatstaven".

Maatregelen daartegen waren volgens hem echter onmogelijk. Toch waren bibliotheekverordeningen geen uitzondering. "Het is geen geheim", aldus nog eenmaal Donnero," "dat de bibliotheekverordeningen vooral in het zuiden des lands beogen niet alleen de onzedelijke, maar ook de meeste anti-RoomsKatholieke geschriften te weren". F.M.J. Jansen", daarentegen, hield vol "dat de bibliotheekverordeningen in het Zuiden des lands zich slechts bewegen - ook in de feitelijke toepassing - op het gebied van de morele toelaatbaarheid. Laten wij de wetenschappelijke discussie niet vertroebelen door het te doen voorkomen alsof de achtergrond een politiek of religieuze zou zijn; dit is positief niet waar. Genoemde verordeningen willen de gemeenschap (sic! RdW) slechts beschermen 
tegen het giftige vuil, dat uit de riolen van over de grens, maar ook van boven de rivieren toestroomt".

Echt geruststellend klonk dat vermoedelijk niet... In 's-Hertogenbosch was het, hoe dan ook "verboden een openbare bibliotheek of leeszaal te hebben, te beheren of te exploiteren, zonder voorafgaande schrifelijke vergunning van Burgemeester en Wethouders". Bovendien konden B en W aan zo'n vergunning voorwaarden verbinden. Zo bleek er een commissie te zijn ingesteld die toezag op de van gemeentewege verplichte indeling van boeken "als jeugdlectuur, lectuur voor allen, voor personen boven 18 jaar, voor geestelijk volwassenen", of als "streng verboden lectuur". Daarnaast gold als voorwaarde dat de vergunning zou worden ingetrokken:

"a. indien boeken en periodieken worden uitgeleend aan personen die niet vallen onder de categorie waarvoor lectuur geschikt is verklaard.

b. indien zonder toestemming van B. en W. bepaalde boeken en periodieken worden uitgeleend, waarvan B. en W. hebben verklaard, dat de uitlening niet zonder hun toestemming mag geschieden.

c. wanneer boeken en periodieken in de bibliotheek of leeszaal aanwezig zijn, waarvan $B$. en W. hebben verklaard dat zij niet in de bibliotheek of leeszaal voorradig of en depot mogen zijn."

"Daarin is niet alleen gevaar voor censuur gelegen, maar de instelling van censuur is kennelijk bedoeld", schreef Donner. ${ }^{9}$ En ook Van den Bergh ${ }^{10}$ vond een dergelijk regime "ongrondwettig". De "vrijheid van verspreiding" mocht, volgens hem, slechts worden beperkt

"door bepalingen, welke een redelijke behartiging beogen van openbare belangen die los staan van het beginsel der drukpersvrijheid"." Donner, daarentegen, zag weinig in dat criteritum:

"Men kan slechts gissen wat met 'het belang van de vrijheid' van drukpers is bedoeld en afgezien daarvan heeft een bepaling in de Grondwet welke die vrijheid erkent, juist de bedoeling dat recht veilig te stellen, niet alleen om directe maar ook om indirecte, ter bescherming van 'andere' belangen aangebrachte beperkingen". ${ }^{12}$

Van den Bergh, op zijn beurt, was vanzelfsprekend niet erg onder de indruk van die tegenwerping. Kon "collega Donner" werkelijk "slechts gissen, wat met het belang van de vrijheid van drukpers is bedoeld"? ${ }^{13}$ En wat de bescherming tegen indirecte gevaren betreft: "Ach arme, indien het zo ware, dan was het met de juridische wetenschap toch wel droevig gesteld. Dan zouden wij krijgen een uitbreiding van de "détournement de pouvoir", tot de 'possibilité de détournement de pouvoir'. Dan moeten we uitdrukkelijk gaan vastleggen, of misschien reeds als geldend ongeschreven recht aanvaarden, 
dat mede als in strijd met de wet beschouwd wordt "het scheppen van een bevoegdheid, die ook ter behartiging van niet door de wet beoogde belangen zou kunnen worden gehanteerd'. "14

Hier stuiten we op een oud refrein. We kwamen diezelfde benadering ook aan het begin van dit verhaal al tegen in de Belgische rechtspraak. En in eigen land gingen Graevestein van Heyst en Van Riemsdijk Kreenen Van den Bergh in dit opzicht vóor. "De mogelijkheid van misbruik eener bevoegdheid, maakt de toekenning dier bevoegdheid niet onwettig", schreef de eerste ${ }^{15}$, terwijl de tweede (zoals al eerder bleek) zelfs nog verder ging:

"Misschien zijn sommige verordeningen wel gecreëerd met het oogmerk om ze verkeerd toe te passen. Maar daarom zijn die verordeningen zelve nog niet ongrondwettig (...). Het kan een reden zijn voor de administratie om te vernietigen". ${ }^{16}$

De Hoge Raad zou hun later gelijk geven ${ }^{17}$, maar die uitspraak is niet onbestreden gebleven. ${ }^{18}$ Uiteindelijk werd, zoals we nog zullen zien, een elegantere oplossing gevonden. ${ }^{19}$

Terug naar de leesbibliotheken! Het ministerie van Binnenlandse Zaken kwam op 8 januari 1948 met een circulaire over dat onderwerp. Daarin stond in verband met art. $7 \mathrm{Gr}$.w. onder meer het volgende ${ }^{20}$ :

"De jurisprudentie ter zake leidt tot de conclusie, dat gemeentelijke voorschriften, welke het uitoefenen van een voorafgaande censuur op de inhoud van de uit te lenen boekwerken inhouden of mogelijk maken, niet toelaatbaar moeten worden geacht.

In dit licht bezien moet een verbod tot het exploiteren van een openbare bibliotheek zonder voorafgaande vergunning van burgemeester en wethouders alleen dan aanvaardbaar worden geacht, indien in de desbetreffende bepaling duidelijk tot uitdrukking wordt gebracht, dat de vergunning niet zal worden geweigerd om redenen, of aan de vergunning geen voorwaarden zullen worden verbonden, welke verband houden met de inhoud van de uit te lenen geschriften".

Wie niet beter wist, zou op grond van dit stuk vermoeden dat er een uitgebreide jurisprudentie bestond over censuur. Feitelijk was er niets. Maar dat wil niet zeggen dat de circulaire om die reden niet klopte. Het standpunt over censuur was onomstreden en werd sinds het arrest over het Haags ventverbod als het ware voorondersteld" ("dat daardoor niet alleen wordt uitgesloten censuur (...), maar evenzeer ..."). Het was een vanzelfsprekendheid. Sprak de volgende alinea van de circulaire eveneens vanzelf? $\mathrm{Zij}$ volgde er in elk geval niet logisch uit.

"Blijkbaar heeft de opstellers de hierboven vermelde, vooral door Van den Bergh gelanceerde constructie door het hoofd gespeeld", aldus Donner des- 
tijds. ${ }^{21}$ En inderdaad, volgens Van den Bergh konden beperkingen door de beugel zolang ze maar "een redelijke behartiging (beoogden) van openbare belangen die los staan van het beginsel der drukpersvrijheid". Van enige begrenzing in dat opzicht werd door hem nooit gerept; ook een absoluut verbod zou dan dus geoorloofd zijn.

In een ander opzicht had Donner echter zijn zin gekregen. Niet alleen voorschriften die de uitoefening van censuur inhielden, werden ontoelaatbaar verklaard, maar $606 \mathrm{k}$ voorschriften die dit mogelijk maakten. De "possibilité de détournement de pouvoir" was, met andere woorden, als vernietigingsgrond geaccepteerd.

Het wekte dan ook weinig verbazing dat korte tijd later de Brunssumse bibliotheekbepaling, die in grote trekken overeenkwam met de eerdergenoemde Bossche bepaling, vernietigd werd. ${ }^{22}$ Of er - gezien de gehanteerde "voorwaarden" - daadwerkelijk sprake was van censuur, kwam daarbij in het geheel niet aan de orde. Dat hoefde ook niet, want de enkele mogelijkheid daartoe was al voldoende. De Kroon overwoog

"dat, daar dit besluit geen enkele aanwijzing geeft omtrent de gronden, welke tot weigering van een gevraagde vergunning mogen leiden, het de mogelijkheid open laat, dat zulk een vergunning wordt geweigerd op grond van het oordeel van burgemeester en wethouders omtrent inhoud of strekking van boekwerken en andere gedrukte stukken, welke zullen worden uitgeleend of ter lezing gegeven; dat artikel 7 van de Grondwet, voorschrijvende, dat behoudens ieders verantwoordelijkheid voor de wet, niemand voorafgaand verlof nodig heeft om door de drukpers gedachten of gevoelens te openbaren, zich derhalve tegen een algemeen verbod, als in het besluit vervat, verzet". Om het in de geijkte terminologie uit te drukken: het gebruik van een bepaald middel van openbaarmaking (de leesbibliotheek) werd hier in het algemeen afhankelijk gesteld van voorafgaand verlof van de overheid, terwijl de mogelijkheid was opengelaten dat de beslissing omtrent dat verlof werd bepaald door overwegingen van inhoudelijke aard. Was die laatste mogelijkheid niet opengelaten - waren en bijvoorbeeld duidelijke criteria geformuleerd die niets uitstaande hadden met de inhoud van de boeken - dan was de beperking kennelijk geoorloofd geweest. Dat betekende toch op z'n minst een verdere aankleding van de rechtspraak van de Hoge Raad, lijkt mij. Volgens die rechtspraak was er immers al sprake van onverbindendheid zodra er voorafgaand verlof in het spel was. Die hele toevoeging over mogelijke inhoudelijke bemoeienis hoorde er tot nu toe niet bij. Maar misschien was het een onuitgesproken overweging geweest. ${ }^{23}$ 
Zo moest er telkens iets worden bijgeschaafd om de zaken nog te kunnen inpassen. Het volgende obstakel bevond zich in Breda. $\mathrm{Na}$ al die jaren weer eens een ventverbod! Deze keer ging het om een evangeliste die op 2 april 1949, 's middags om tien over drie, "met meer gedrukte stukken (had) gevent op den voor het publiek toegankelijken weg, de Eindstraat". En het vervelende voor haar was dat het in Breda op grond van de APV verboden was

"met gedrukte of schreven stukken te venten op of aan door B. en W.

bij openbare kennisgeving aangewezen wegen en aan de langs die wegen gelegen huizen".

Welnu, de Eindstraat hoorde tot het door B. en W. aangewezen gebied waarbinnen "op alle dagen tussen 6 en 23 uur" een verbod gold om met drukwerk te venten. Dus beging onze evangeliste een overtreding. De kantonrechter veroordeelde haar tot vijf gulden boete.

Volgens de advocaat-generaal (Hooykaas), echter, was het ventverbod in strijd met art. 7 Gr.w. ${ }^{24}$ Hij was - ongetwijfeld geïnspireerd door de toelichting op het cassatiemiddel - tot de conclusie gekomen dat het verbod "de gehele binnenstad van Breda" betrof. Afgezien van "enkele nachtelijke uren" (en een mogelijkheid van ontheffing van het verbod, te geven door $\mathrm{B}$ en W) was daarmee "de vrijheid gedrukte of geschreven stukken of afbeeldingen te verspreiden", volgens hem, "voor de gemeente Breda (...) metterdaad opgeheven".

In dat laatste herkennen we het door de Hoge Raad aangelegde criterium ten aanzien van het ventverbod in Rosendaal. ${ }^{25}$ Het ventverbod ging toen "niet zoover $(.$.$) , dat de vrijheid om prentbriefkaarten (...) te verspreiden" - want$ daar ging het toen over, RdW - "(kon) gezegd worden metterdaad te zijn opgeheven".

De Hoge Raad, evenwel, was het met de zienswijze van zijn advocaatgeneraal niet eens. Voor Breda gold, volgens dit rechtscollege, hetzelfde als destijds voor Rosendaal,

"aangezien, al mogen dan B. en W. een groot aantal wegen der gemeente Breda, te zamen blijkbaar uitmakende de gehele binnenstad, hebben aangewezen als wegen waarop en waaraan het bovenbedoelde venten verboden is, toch niet gezegd kan worden, dat zij een te ver gaand gebruik hebben gemaakt van hun bevoegdheid;

Overwegende immers dat, hoezeer ook tengevolge van art. 7 Grondwet de gemeentewetgever niet bevoegd zou zijn het venten van gedrukte stukken in zijn gemeente geheel te verbieden, hij niettemin..." etc. etc. (volgt de bekende frase over "het belang der openbare orde" en "het openbaar verkeer"). ${ }^{26}$

De grens van het toelaatbare was dus niet overschreden. Hoe moeten we het 
woordje "blijkbaar" opvatten? Het verbod gold voor "een groot aantal wegen (...), te zamen blijkbaar uitmakende de gehele binnenstad". Betekent het zoiets als "naar men zegt"? In dat geval gaat het niet om een feitelijke constellatie waar de Hoge Raad vanuit is gegaan. Dat wil zeggen dat uit het arrest niet kan worden afgeleid dat het inderdaad geoorloofd was in de gehele binnenstad van Breda het venten met drukwerk te verbieden. Maar je kunt het ook anders lezen. "Blijkbaar" staat dan voor de bereidheid van de Hoge Raad er bij de beoordeling van deze zaak vanuit te gaan dat het venten in de gehele binnenstad verboden was. ${ }^{27}$ Zelfs dáárvan uitgaande kon dan niet gezegd worden dat het verbod te ver ging; kortom: in die lezing was er well iets uit het arrest af te leiden omtrent de toelaatbare omvang van het ventverbod in Breda. Beide interpretaties laten zich overigens wonderwel verenigen met de eerste jurisprudentie. Moeilijk te voorspellen, kortom, maar makkelijk te "verklaren"...

Well nieuw, maar naar mijn idee evenmin strijdig met eerdere arresten, was de overweging van de Hoge Raad naar aanleiding van de mogelijkheid om ontheffing van het verbod te krijgen. B en W waren tot het verlenen van zo'n ontheffing bevoegd. En de vraag rees of zij daardoor niet al te zeer in de verleiding konden komen zich bij hun besluitvorming door de inhoud van het drukwerk te laten leiden. De Hoge Raad overwoog evenwel

"dat niet valt in te zien, dat een dispensatiebevoegdheid een geldige regeling onverbindend zou maken alleen op grond van de mogelijkheid dat van die bevoegdheid misbruik zou worden gemaakt".

Aldus kon Van den Bergh (zoals al aangekondigd) alsnog zijn "gelijk" oogsten; hier althans was de "possibilité de détournement de pouvoir" - anders dan in het KB over de Brunssumse leesbibliotheken - niet fataal gebleken. Maar waarin school nu het nieuwe van deze overweging? Welnu, om te beginnen had de Hoge Raad geconstateerd dat het ventverbod op zich - afgezien van de ontheffingsmogelijkheid ${ }^{8}$ - door de beugel kon. Het venten met gedrukte stukken was immers niet geheel verboden (terwijl kennelijk evenmin gezegd kon worden dat het metterdaad onmogelijk was). Waarom zou een verzachting van dat regime, door middel van een ontheffingsbevoegdheid, dan wèl bezwaar opleveren? Dat viel niet in te zien! Maar, en nu komt het: het was $66 \mathrm{k}$ geen vrijbrief om de é́n op inhoudelijke gronden makkelijker aan een ontheffing te helpen dan de ander. Want dan was er sprake van misbruik.

Tot dusver had de Hoge Raad zich nog niet over die situatie uitgelaten. In het woordje "misbruik" zat dus de vernieuwing. Daarmee werd voor het eerst een uitspraak gedaan over de toepassing van een bepaling die - op zichzelf genomen - aanvaardbaar was. Sommige toepassingen bleken opeens niet aanvaardbaar te zijn. Op die manier werd het recht op openbaarmaking, 
vergeleken met eerdere arresten, toch weer een tikkeltje versterkt. Alleen, het is, voor zover ik weet, nooit door iemand opgemerkt. De omvang van het Bredase ventverbod, waardoor realiter nauwelijks meer iets overbleef, heeft alles overschaduwd, lijkt het wel.

"Men ontkomt niet aan de indruk", schreef Röling in zijn noot onder het arrest, "dat practisch een algemeen ventverbod gold, dat met een formele beperking genoegen werd genomen, en dat, waar de doelmatigheidsvraag naar constante jurisprudentie niet ter toetse kan komen, het er slechts om gaat, dat de gemeentewetgever stelt, dat hij het venten verbiedt om redenen van openbare orde en dan is de verordening onaantastbaar". ${ }^{29}$

Boukema noemde het arrest later zelfs "niet in overeenstemming met het arrest van de HR van 7 nov. 1892, W. 6259, waarin een verbod om, zonder vergunning van de burgemeester, gedrukte stukken te verspreiden, onverbindend werd verklaard". ${ }^{30}$ Alsof daarmee een duidelijke norm was gesteld...

\subsection{Een nieuwe fundering: Tilburg en Sittard (1950)}

Van den Bergh had het leerstuk van 1892 weliswaar bij herhaling de hemel in geprezen, maar al twee decennia lang had de Hoge Raad slechts de ene beperking na de andere gesauveerd. Sinds het Sanitas-arrest van 1928 was geen enkel vent- of plakverbod meer onverbindend verklaard. De twijfel van Röling, waar de vorige paragraaf mee afsloot, was dus wel te begrijpen. Hadden we louter te maken met een sjablone om zaken mee af te doen? Of was er toch ook nog een zekere waarborg in het spel?

1950 werd in dat opzicht het "jaar van de waarheid", om het maar eens pathetisch uit te drukken. Aanleiding was opnieuw de strijd tegen vieze blaadjes en boeken. Ondanks "Brunssum"31 was die klus nog lang niet geklaard. Deze keer speelde het zich in Tilburg en Sittard af - we blijven voorlopig nog in het Zuiden! Eigenlijk ging het om drie zaken. ${ }^{32}$ Maar alle drie gingen over dezelfde kwestie, en ze werden in cassatie ook op dezelfde dag besiist. In grote trekken drie keer dezelfde beslissing. ${ }^{33}$

Zowel in Tilburg als Sittard was het verboden

"op of aan de(n) (openbaren) weg of in voor het publiek toegankelijke lokaliteiten, winkels (en leesbibliotheken) daaronder begrepen, geschriften, afbeeldingen of voorwerpen, geschikt (of klaaiblijkelijk bestemd) om de zinnelijkheid te prikkelen, hetzij te verkopen (,uit te lenen) of te verspreiden, hetzij ten verkoop (,ter uitlening) of ter verspreiding voorhanden te hebben, hetzij ten toon te stellen, aan te bieden, aan te slaan of als verkrijgbaar aan te kondigen". ${ }^{34}$ 
Drie boekhandelaren, die respectievelijk "Adam", "Badzout" en zowel "Adam" als "Actie" no. 19 "ten verkoop voorhanden" hadden (of zelfs "openlijk tentoongesteld"!), waren dus in overtreding. Niet alleen stond op de kaft van twee van die geschriften namelijk "een in bad- respectievelijk strandcostuum geklede vrouwspersoon" afgebeeld - "geschikt om de zinnelijkheid van de jeugd te prikkelen" - bovendien stonden in die geschriften telkens (niet nader omschreven!) afbeeldingen die (ook?) ten aanzien van niet-jeugdigen "geschikt" waren "onn de zinnelijkheid te prikkelen".

"Niemand zal willen ontkennen", schreef Langemeijer in zijn conclusie, "dat het uit zedelijk oogpunt negatief moet worden gewaardeerd wanneer iemand zinnenprikkeling zoekt door lectuur en afbeeldingen als waarom het hier gaat". ${ }^{35}$ Niemand? Nou ja, het was vermoedelijk well de "heersende" opvatting. ${ }^{36}$ Ludwig Marcuse - die behalve zijn achternaam niets gemeen heeft met Herbert! - wees er eens op dat onze zintuigen slechts de rol van dienaar is toebedeeld,

"zodat ze zich nauwelijks ontwikkeld hebben; tenzij voor specifieke diensten - en voor het Hogere, God of Cultuur. De ogen worden getraind wanneer iemand instrumentmaker wil worden of voor klassikaal bezoek aan het museum. Goede oren zijn van belang, voor het horen van bijgeluiden aan een motor en voor het bezoeken van de sociaal belangrijke abonnementsconcerten. (...)

Wie oefende ooit zijn ogen terwille van de ogenlust? Dat alle zintuigen kunnen jubelen is onbekend gebleven naast het gejubel van de raadselachtige ziel tot de raadselachtige God". ${ }^{37}$

Welnu, "op wie Sexus terug te brengen is wordt", aldus (nog steeds) Marcuse, "door de theologen en hun erfgenamen, de filosofen, betwist. Tot de goddelijkste rechtvaardigingen van het satanische monstertje horen: ten eerste de platonische liefde die het niet zelden in zuivere ether oplost, en ten tweede de interesse van de schepper aan het voortbestaan van het mensenras. Sexus mag passeren: als midldel tot én van twee doelen".

Maar, om weer terug te keren tot Tilburg en Sittard, dit weerhield Langemeijer - evenmin als zijn ambtgenoot Van Asch van Wijk en (later) de Hoge Raad - er niet van het gemeentelijk porno-verbod onverbindend te achten. Het was, meenden zij, in strijd met art. 7 Gr.w.

Dresen $^{38}$ had kort tevoren in zijn proefschrift betoogd dat uit het arrest van 1892 (Haags ventverbod) volgde "dat t.a.v. de modus quo (d.w.z.: de wijze waarop geopenbaard wordt; RdW) het woord 'wet' in art. 7 ook materieel (mocht) worden opgevat". Hij was daar, zoals we al eerder zagen, tegen. Van Asch van Wijk zou het, blijkens zijn conclusie ${ }^{39}$,

"liever zo zien, dat art. 7 zich alleen bezig houdt met het id quod, doch de modus quo niet betreft, behalve dan in die indirecte zin dat 
de regeling van de modus quo nimmer de vrije meningsuiting (het id quod) illusoir mag maken. In art. 7 kan m.i. slechts van én begrip wet sprake zijn".

En daarbij ging het dan om een formeel wetsbegrip. Hij nam, met andere woorden, afstand tot het arrest over de Heerenveense noodverordening en de opvatting van Van der Pot daarover. De toegestane beperkingen op het verspreidingsrecht waren volgens hem immers niet op het tweede deel van art. 7 gebaseerd ("verantwoordelijkheid volgens de wet"), maar stonden in principe $l o s$ van het grondwetsartikel. Hoogstens vonden ze hun begrenzing in het openbaringsrecht (d.w.z.: het eerste deel van art. 7), want de Hoge Raad verstond - naar zijn oordeel - "onder gevoelens of gedachten openbaren, mede het verspreiden enz. van geschriften". Dus was ook het verspreiden beschermd op grond van art. $7 \mathrm{Gr}$.w. en mocht dit niet van overheidswege $^{40}$ worden belet. Anders zou het onmogelijk zijn de inhoud bekend te maken; de ingreep op de "modus quo" raakte dan aan het "id quod". En dat was fataal. Alleen bij wet in formele zin kon men vanwege de inhoud van een geschrift aansprakelijk worden gesteld. Er was, volgens Van Asch van Wijk, geen enkele aanwijzing dat dit ook op andere wijze kon. Integendeel: de geschiedenis, het grondwettelijk taalgebruik, het belang van de vrijheid van drukpers en de absurde consequentie dat anders uitsluitend vernietiging door de Kroon mogelijk zou zijn, kortom feitelijk alles wees hierop.

Langemeijer, die de beide Sittardse zaken voor zijn rekening nam, sloot zich "geheel" aan bij het betoog van zijn "ambtgenoot". ${ }^{41}$ Alleen, daar hoefde volgens hem niet uit te worden afgeleid dat "Heerenveen" verlaten moest worden. Dat kwam door art. $443 \mathrm{Sr}$, op grond waarvan overtreding van de noodverordening destijds strafbaar was. Immers, die bepaling

"berust kennelijk op de gedachte dat de Rijkswetgever het van zodanig belang acht de naleving te verzekeren van de voorschriften, die de Burgemeester met toepassing van art. 220 der Gemeentewet geeft, dat hij daartoe zelfs bereid is zijn strafsanctie te verlenen aan voorschriften vañ een inhoud die hij niet voorzien kan, een toch zeker niet alledaagse stap. Deze opvatting van de wetgever doet de gesanctioneerde voorschriften delen in de rechtswaarde van de formele wet die ze sanctioneert". ${ }^{42}$

Die laatste constructie, waar in 1939 door niemand van gerept werd (en die ook allerminst in de tekst van het arrest over Heerenveen besloten leek te liggen), werd terstond door de Hoge Raad overgenomen. De Hoge Raad overwoog, dat waar een noodvoorschrift ex art. 220 Gemeentewet

"zich als bestanddeel invoegt in de omschrijving der in de rijksstrafrechtsregeling opgenomen overtreding tegen het openbaar gezag van art. $443 \mathrm{Sr}$, het de laatstgenoemde bepaling en dus de wet is, die in 
dien noodtoestand van oproerige beweging, samenscholing of dergelijke de zeer tijdelijke onderbreking van de uitoefening van het grondrecht gedoogt, zodat van strijd met art. 7 der Grondwet geen sprake is". ${ }^{3}$

Pompe was in zijn noot onder de arresten duidelijk verbaasd. En Van den Bergh schreef in het NJB:

"Welk een geluk, dat art. 195 Gemeentewet (vgl. art. 155 nieuw; $\mathrm{RdW}$ ) niet voor de gewone gemeenteverordeningen dezelfde vorm heeft gekozen. Ware het anders - het arrest hadde volgens de H.R. in tegenovergestelde zin gewezen moeten worden". ${ }^{4}$

Maar voor het overige was er alom tevredenheid. Pompe sprak van "magistrale arresten" en volgens Van den Bergh was "ernstig dreigend gevaar (...) afgewend". Het porno-verbod was namelijk onverbindend verklaard. De gemeentelijke wetgever mocht - art. $220 \mathrm{Gem} . \mathbf{w}$. uitgezonderd - niet "treden in het regelen hoedanigen inhoud een door den druk geopenbaarde gedachteuiting (mocht) hebben". De bevoegdheid daartoe was "door de Grondwet aan de samenwerking van Koning en Staten-Generaall in de wet (...) toegewezen". 45

Was de Hoge Raad dan tòch weer op het rechte spoor van voór '39 teruggekeerd? Dat volgt daar niet uit. Van den Bergh ${ }^{46}$ noemde de overwegingen in het arrest "zeer ingewikkeld" en "niet zeer helder". Maar (zozeer was hij kennelijk met het resultaat in zijn nopjes!): "wij zullen - geloof ik - goed doen door hier niet te diep op in te gaan". Laat ik niettemin pogen er een beetje op in te gaan.

Om te beginnen wees de geschiedenis er volgens de Hoge Raad niet op dat onder 'wet' in art. 7 Gr.w. "de oudtijds als politie-reglementen bekend staande bepalingen zouden (moeten) worden begrepen", of dat lagere wetgevers was toegestaan drukpersdelicten te scheppen ("Tilburg"). Sterker: in de versie van "Sittard I" wees "de totstandkomingsgeschiedenis der bepaing" er zelfs op dat het woord 'wet' hier - net als elders in de Grondwet - zag op wet in formele zin.

Vervolgens gaf de Hoge Raad een recapitulatie van zijn eigen leer ${ }^{47}$ :

"Overwegende dat overigens in art. 7 steeds is neergelegd geacht het grondrecht van een ieder om, zonder voorafgaand verlof der Overheid, gedachten en gevoelens door middel van de drukpers te uiten zo dat zij voor anderen kenbaar zijn, terwijl de burgerlijke wet en de strafwet de uiting van gedachten en gevoelens van een ongeoorloofd geachten inhoud kunnen verbieden;

dat later naast dit de geesteswereld betreffende recht tevens, als tot het met dat recht beoogde doel onmisbaar doch aan dat recht ondergeschikt, door den rechter is aangenomen het recht van een ieder om een 
gedrukt geschrift en het daarin gedrukte, door het te verspreiden, openlijk ten toon te stellen of door enig ander middel, in het openbaar aan het publiek bekend te maken, welk het verkeer op den openbaren weg rakend en dus een ruimtelijke sfeer bestrijkend recht evenwel wegens dien anderen aard zijn eigen beperking medebracht...".

Stop! Hier val ik de Hoge Raad in de rede. Laten we namelijk meteen even verifiëren of het allemaal klopt. Die laatste overweging refereert ongetwijfeld aan het arrest van 1892. Het is hetzelfde "deuntje". Laat ik het nog eens in herinnering brengen. De Hoge Raad ${ }^{48}$ overwoog toen dat in art. 7 het beginsel was neergelegd dat de openbaarmaking zelve niet door preventieve maatregelen mocht worden belet, en

"dat daardoor niet alleen wordt uitgesloten de censuur, noodig ter verkrijging van het verlof om een tot openbaarmaking bestemd geschrift te drukken of te doen drukken, maar evenzeer het 'voorafgaand verlof' van het openbaar gezag om een gedrukt geschrift en bijgevolg wat daarin is gedrukt, door het te verspreiden, openlijk ten toon te stellen of aan te slaan of wel door eenig ander middel, openbaar te maken; onverminderd de bevoegdheid van den gemeentelijken wetgever om de verspreiding van een gedrukt geschrift op de openbare straat, zonder haar in het algemeen te verbieden, of van een voorafgaand verlof der overheid afhankelijk te stellen, te onderwerpen aan voorschriften in het belang der openbare orde, bepaaldelijk ter beveiliging van het openbaar verkeer".

En waarachtig, bijna letterlijk dezelfde zinsnede, beginnend met "onverminderd" en eindigend met "het openbaar verkeer" volgde ook in 1950 op de eerder aangehaalde passage over het "verspreiden" en "tentoonstellen". Maar ging het in 1892 nog over "openbaar maken" door middel van verspreiding e.d., in 1950 was die - an art. 7 ontleende! - term opeens vervangen door "in het openbaar aan het publiek bekend te maken". En dat bekendmaken blijkt dan weliswaar met het oog op het doel van het uiten door middel van de drukpers "onmisbaar" te zijn, maar tevens "ondergeschikt" eraan. ${ }^{49}$

In "Tilburg" werd die ondergeschiktheid eenvoudig gepostuleerd en vervolgens plausibel gemaakt met de "andere aard", die "zijn eigen beperkingen medebracht". In de overweging daarna werd gesteld dat de "rechterlijke erkenning van dit recht tot verspreiden dan ook plaatsvond onverminderd de bevoegdheid van de gemeenteraden" tot beperking, zolang er maar geen sprake was van een algemeen verbod etc. Enfin, de bekende frase. Maar met de woorden "dan ook" werd - anders dan in 1892 - aangegeven dat die beperkingsmogelijkheid te maken had met ondergeschiktheid. "Sittard I"so gaf daarentegen ook een argument voor het verschil in status tussen "uiten" en "bekendmaken". De Hoge Raad overwoog in dat arrest namelijk: 
"dat toch naast de delicten waarin de wet het doen van uitingen van bepaalden inhoud verbood, langen tijd delicten waarin zij het verspreiden van geschriften van dien inhoud verbood hebben ontbroken en, als later behalve de auteur ook de colporteur strafbaar gesteld werd, tegen de verspreidingsdelicten lagere straffen bedreigd werden dan tegen de uitingsdelicten". 51

Kennelijk had een recht een hogere status naarmate misbruik zwaarder gestraft kon worden. Een interessante, maar toch niet echt vanzelfsprekende gedachte, lijkt mij. Ten aanzien van drukpersdelicten rees bovendien de vraag of het bezwaarlijke van sommige uitingen niet vooral in de verspreiding ervan zat.

Hoe dan ook, tot 1950 werd de verspreiding van geschriften algemeen als element van het openbaarmaken gezien.

"Ware het anders", aldus Van den Bergh in 1946, "zou art. 7 alleen een vrijheid van drukken erkennen, dan zou de drukpersvrijheid geen redelijke zin hebben. Dan zouden wij pakhuizen vol gedrukte stukken kunnen krijgen, met de politie voor de deur! De verspreiding is dus niet 'binnen de sfeer van artikel 7 gehaald'. De jurisprudentie van de Hoge Raad heeft slechts erkend, wat. rechtens niet anders kòn zijn: ook het verspreiden van gedrukte stukken wordt door artikel 7 beheerst. ${ }^{52}$

Maar, zo bleek in 1950, in mindere mate dan het ter perse brengen van de uiting. ${ }^{53}$ Of daarmee ook materieel iets teweeg was gebracht, viel nog te bezien.

In het verleden was - in het voetspoor van d'Aulnis de Bourouill ${ }^{54}$ - door de Hoge Raad overwogen dat het "bij de toetsing van het verbod der plaatselijke verordening aan art. 7 der Grondwet aankomt op den inhoud, niet op het motief van dat verbod".55 Gold dat ook nú nog, onder het nieuwe regime? De beperkingsmogelijkheden werden in 1950 immers - met zoveel woorden - gerechtvaardigd door de "ruimtelijke sfeer". En daarna kwam ogenblikkelijk de overweging dat de gemeenteraad de verspreiding dan ook kon "onderwerpen aan voorschriften in het belang der openbare orde, bepaaldelijk ter beveiliging van het openbaar verkeer". Was de betekenis van die klassieke frase nu opeens veranderd en moest er niet langer een verwijzing naar de algemene bevoegdheidsbepaling van art. 168 gem.w. (150 nieuw) in worden gelezen? Werd er alsnog een doelcriterium ingevoerd? ${ }^{56}$ Vragen... Wel duidelijk, daarentegen, was de Hoge Raad in zijn opvatting dat de vrijheid om bepaalde gedachten "in druk te uiten" (afgezien van art. 220 gem.w.) uitsluitend bij wet in formele zin aan banden mocht worden gelegd. Hoewel... Zou een (gedeeltelijk) verbod van politieke 
propaganda voortaan - anders dan in '38! - ongeoorloofd zijn? Of - in meer algemene zin - reclame? Mocht daar nu - gezien het inhoudelijke taboe - niet meer tegen worden opgetreden? We kunnen er slechts naar gissen (wat overigens - bij mijn weten - destijds (en ook later) door niemand is gedaan). Ik gok erop dat alles in dit opzicht bij het oude bleef. Dat leid ik uit de motivering af. Die werd namelijk ook hier weer gegoten in de vorm van een beschrijving van de eigen jurisprudentie. Er was klaarblijkelijk niets nieuws onder de zon. Hoewel... in werkelijkheid schrok de Hoge Raad er opnieuw niet voor terug aan sommige uitspraken - achteraf! - de nodige "meerwaarde" toe te kennen. Alleen uiterst speculatieve lezers hadden er hetzelfde uit kunnen halen. Zo overwoog de Hoge Raad naar aanleiding van de gemeentelijke beperkingsbevoegdheid:

"dat echter, waar dergelijke bevoegdheid van den gemeenteraad ter sprake kwam, zij steeds uitdrukkelijk bepaald werd tot genoemd recht tot het verspreiden ener gedrukte uiting in kennelijke tegenstelling tot het recht tot het openbaren, het doen drukken der uiting zelf, en geregeld ervan is uitgegaan dat een gemeenteraad bij het regelen, op welken tijd, plaats of wijze de verspreiding niet kan plaats hebben zonder het belang der openbare orde binnen zijn gemeente in gevaar te brengen, niet mag treden in het regelen, hoedanigen inhoud een door den druk geopenbaarde gedachteuiting niet mag hebben. ${ }^{57}$

Wie had dat - geheel op eigen kracht - uit de eerdere in dit boek besproken arresten kunnen afleiden? Toch kwam het resultaat, gezien de rechtspraak van vór ' 39 , niet echt onverwacht. Dat lag vooral aan het bekende Sanitasarrest van 1928 , lijkt mij. ${ }^{58}$ Daarin werd immers beslist dat een "middel van openbaarmaking" (zoals het toen nog heette) niet mocht worden afgesloten voor mededelingen die een bepaald soort inhoud hadden. En als zoiets voor één "middel van openbaarmaking" geldt, wekt het weinig verbazing dat het ten aanzien van alle middelen al helemaal vaststaat! Alleen wanneer de Hoge Raad de (later geformuleerde) opvatting van Van der Grinten $^{59}$ had overgenomen, zou het anders zijn gelopen. maar daar werd deze keer juist uitdrukkelijk afstand van genomen. In "Tilburg" overwoog de Hoge Raad naar aanleiding van de opvatting dat de gemeentelijke wetgever geen inhoudelijke beperkingen mocht stellen,

"dat van dezen omvang der gemeentelijke bevoegdheid ook uitgaat voormelde begrenzing, dat de beperkingen der verspreiding nooit zover mogen gaan een verspreiding van een gedrukt geschrift op de openbare straat in het algemeen te verbieden, welke begrenzing toch den gemeenteraad niet alleen het geven van een verbod tot verspreiding van alle gedrukte stukken ontzegt - waarnaast voor zijn bevoegdheid om verspreiding van gedrukte stukken van bepaalden inhoud te 
verbieden nog plaats zou zijn ${ }^{60}$-, maar de ontzegging van het geven van een verbod van laatstbedoelden aard mee omvat" ${ }^{61}$

Daarmee was het pleit beslecht.

De vrucht van deze arresten was voornamelijk terminologisch van aard. Voortaan moesten we een onderscheid maken tussen enerzijds het uiten van gedachten en gevoelens door middel van de drukpers zo dat zij voor anderen kenbaar zijn, en anderzijds het in het openbaar aan het publiek bekendmaken van die uiting. Alleen het tweede mocht van gemeentewege beperkt worden, zij het niet volledig en (behalve in het kader van art. $220 \mathrm{Gem}$.w.) ook niet op inhoudelijke gronden. Voor het overige riepen de uitspraken - zoals gebruikelijk - vooral vragen op; sommige daarvan konden we voordien nog als "reeds beantwoord" beschouwen, maar nu hadden ze zich opnieuw aangediend. Daarnaast kwam - en dat was misschien belangrijker - de hele onderbouwing van het taboe op een algemeen verspreidingsverbod in de lucht te hangen. Op grond van het arrest uit 1892 was dat taboe te "verklaren" uit het gegeven dat het "openbaarmaken" zonder verspreiding eenvoudig niet voltooid was. Welnu, de vrijheid om te openbaren (inclusief versprejiden.) was in. ast. 7. verankerd; dus mocht die niet. van gemeentewege worden kapotgemaakt. Nu het verspreiden voortaan echter los van het openbaarmaken moest worden gezien, rees de (overigens nooit gestelde) vraag waar een begrenzing van de beperkingsmogelijkheden dan nog op berustte. Kon de "ruimtelijke sfeer", die kennelijk (los van de Grondwet!) haar eigen normen schiep, soms niet zodanige beperkingen "meebrengen" dat zij (bepaalde vormen van) verspreiding integraal verbood? Met die "ruimtelijke sfeer" was een "mer à boire" opengesteld. Wie kende de omvang ervan? Of hing alles op - zoals de Hoge Raad het uitdrukte - de onmisbaarheid van het verspreidingsrecht wanneer men iets (in de nieuwe zin van het woord) "openbaar" maakte (d.w.z.: het drukken)? Wat onmisbaar was, kon immers niet gemist worden! Had de "ruimtelijke sfeer" daar dan geen vat meer op? Hoezo niet? lk heb geen flauw idee! Het valt nu eenmaal niet mee om normen uit feiten af te leiden...

Blijft natuurlijk de vraag waarom de Hoge Raad zoveel overhoop had gehaald. Op de vooroorlogse wijze kwam hij er blijkbaar niet meer uit. Was dit de tol voor "Heerenveen"? Was al het voorgaande daardoor in het perspectief van "ieders verantwoordelijkheid volgens de wet" getrokken? En moest er eenvoudig iets verzonnen worden, opdat de ene wet de andere niet zou zijn? Anders kon inderdaad iedere uiting van gemeentewege worden verboden! in die zin was het onderscheid tussen "uiten" en "verspreiden" ongetwijfeld ingenieus, om een term van De Meij te gebruiken. ${ }^{62}$ Maar dan ook uitsluitend in die zin! Want die "verantwoordelijkheid volgens de wet" 
was - zoals gezegd - niet het enige perspectief dat voorhanden was. En de complicaties die erdoor werden veroorzaakt, waren niet gering. Misschien moeten we, als beoefenaren van de wetenschap, de hand in eigen boezem steken en kwam het allemaal door de tamelijk slappe wijze waarop de jurisprudentie destijds in kaart was gebracht. Het "leerstuk" was na al die jaren nog steeds niet uiteen "gerafeld". Van enig analytisch "vóórwerk" was dan ook geen sprake. Iedere stap was een sprong in het duister.

\subsection{Kleine renaissance: oude thema's keren terug (1951)}

Van Tilburg naar Eindhoven is niet ver. In de NJ van 1951 was het maar 335 nummers. Op 27 februari 1951 had de Hoge Raad zich namelijk over twee bepalingen uit de Eindhovense APV uitgesproken. Op grond van de eerste bepaling was het verboden "strooibiljetten op den weg uit te geven". Volgens de kantonrechter mocht dat inderdaad verboden worden en was er geen strijdigheid met art. 7 Gr.w. De bepaling was

"Kennelijk bedoeld om verontreiniging van de wegen te voorkomen;

het is een bekend feit dat er onder de personen die een strooibiljet ontvangen een aantal plegen te zijn, die dit biljet na gehele of gedeeltelijke lezing achteloos weg werpen; op grond van art. 168 der Gemeentewet is de gemeenteraad derhalve in het belang der gemeentelijke huishouding bevoegd verbodsbepalingen op dit stuk bij verordening uit te vaardigen; het staat propagandisten, die strooibiljetten willen verspreiden onder het publiek vrij deze biljetten op andere wijze te verspreiden bijvoorbeeld door toezending per post". ${ }^{63}$

Ook de A-G (Van Asch van Wijk) vond dat dit verbod door de beugel kon. Volgens annotator Röling "blijkbaar" omdat hij - net als de kantonrechter de beschikbaarheid van andere verspreidingswijzen voldoende achtte. ${ }^{64}$ Zelf betoogde de advocaat-generaal slechts dat de bepaling zijns inziens "geheel binnen de bevoegdheden van de gemeentelijke wetgever (viel), als betreffende de "modus quo" ". Dat lijkt mij, eerlijk gezegd, iets anders. Na de arresten over Tilburg en Sittard is die zienswijze bovendien goed voorstelbaar. Zolang de uiting zèlf maai niet werd aangepakt en de ingreep beperkt bleef tot de "ruimtelijke sfeer" van de verspreiding, was de zaak immers (grosso modo) in orde. Dáár lag destijds het accent van de rechtsontwikkeling, en dan is het begrijpelijk dat andere punten aan de aandacht ontsnapten.

Want dat de verspreiding niet ongelimiteerd aan banden mocht worden gelegd, was - zoals gezegd - bepaald niet vanzelfsprekend; de "ruimtelijke sfeer" kon nu eenmaal veeleisend zijn... Weliswaar had de Hoge Raad in de porno-arresten van 1950 6ók de beroemde frase - "zonder haar in het 
algemeen te verbieden of van een voorafgaand verlof der overheid afhankelijke te stellen" - weer obligaat opgenomen, maar wannér zou iets dergelijks zich ooit voordoen? Denk bijvoorbeeld aan de verstrekkende reclame-, schreeuw- en propagandaverboden uit de jaren ' 30 ; die bleken allemaal door de beugel te kunnen. Waarom dít verbod, dat zich eveneens tegen hinder richtte, dan nief?

Toch bleek dat laatste juist het geval te zijn: de Hoge Raad vond het Eindhovense verbod in strijd met art. $7 \mathrm{Gr}$.w. Hij overwoog:

"dat dit voorschrift een volstrekt verbod inhoudt tot het op den weg (...) uitgeven van strooibiljetten;

dat dit verbod in zijn algemeenheid ook betreft gedrukte stukken waarin gedachten of gevoelens worden geopenbaard en raakt een middel tot verspreiding van deze laatste hetwelk, naast andere, zelfstandige betekenis heeft en met het oog op die verspreiding in een bepaalde behoefte kan voorzien;

dat dan ook een dergelijk voorschrift, waarbij niet het bezigen van een bepaald middel wordt beperkt doch algeheel verboden, in strijd is met het in art. $7 \mathrm{Gr}$.w. bepaalde en verbindende kracht mist". ${ }^{\text {.5. }}$

Daarmee was opeens in ferme bewoordingen gestalte gegeven aan een oud beginsel dat inmiddels - en helaas niet zonder reden, zoals bleek - al aardig in de vergetelheid was geraakt. Röling, althans, schreef in zijn noot onder het arrest:

"Met de formule van de HR in 1892 gebruikt ware verdedigbaar een algeheel verbod van verspreiding door strooibiljetten, indien verspreiding door venten of door middel van reclameborden toegelaten bleef". In werkelijkheid, echter, had de Hoge Raad destijds - het wordt eentonig het aldoor te herhalen - de ongeoorloofdheid van een algemeen verbod ten aanzien van ieder middel van openbaarmaking uitgesproken, en uitdrukkelijk niet ten aanzien van de openbaarmaking (lees intussen: verspreiding) in het algemeen. "Foutje!", zouden we tegenwoordig zeggen.

Maar wat werd precies bedoeld met "een middel tot verspreiding van gedachten of gevoelens hetwelk, naast andere, zelfstandige betekenis heeft en met het oog op die verspreiding in een bepaalde behoefte kan voorzien"? Het "uitgeven van strooibiljetten" was klaarblijkelijk als zo'n middel tot verspreiding aan te merken. Daarom mocht het immers niet aan een algeheel verbod worden onderworpen. Volgens Röling ging het bij een dergelijk middel "blijkbaar"' om

"een wijze van verspreiden die personen kan bereiken, die door andere wijzen (sic! RdW) niet of minder gemakkelijk kunnen worden benaderd". 
Zou het, behalve met de personen die benaderd worden, niet $66 \mathrm{k}$ iets met de aard van de mededeling te maken kunnen hebben? Met het ene medium (bijvoorbeeld krant) kun je nu eenmaal een ander soort boodschap overbrengen dan met het andere (bijvoorbeeld spandoek), en dan kan het éen het ander dus ook moeilijk substitueren.

Hoe dan ook, de stand van zaken werd, volgens mij, treffend samengevat in het vervolg van Rölings noot:

"De bepaalde, maatschappelijk gebruikelijke methoden om de inhoud van geschriften onder de aandacht van het publiek te brengen, en zodoende de daarin gelegen gedachten te openbaren - zoals venten, verspreiding door strooibiljetten, winkelverkoop, vertoning op reclameborden e.d. - dienen dus onderzocht op de mogelijkheid, dat daardoor in een bepaalde behoefte kan worden voorzien".

Daarmee werd tevens aangegeven dat er eindelijk een (vaag) soort kader was geformuleerd waarbinnen de bescherming van een verspreidingsvorm bespreekbaar was. Tot dusverre moesten we altijd maar gissen waarom bijvoorbeeld die roep- en schreeuwverboden telkens geaccepteerd werden. Nu wisten we eindelijk dat de "vóorvraag" in die gevallen blijkbaar negatief beantwoord was: er was gewoon geen middel van verspreiding in het spel, dat naast andere zelfstandige betekenis had. Omgekeerd wisten we dat "venten" (vgl. "Tilburg") en het "uitgeven van strooibiljetten" wèl "zelfstandige betekenis" hadden. Een bescheiden vorm van discussie - waarom is dit wel, en dat niet zelfstandig? - was daardoor mogelijk geworden. Verdere verfijning lag op die manier wellicht in het verschiet; zolang het om een orakel ging was de kans daarop nihil.

Dat er nog een lange weg te gaan was, viel diezelfde dag al te constateren aan de hand van het tweede arrest over de Eindhovense APV. Daarin ging het om het verbod om "met reclamewagens, reclameborden, reclamedoeken, reclamezuilen of dergelijke reclamemiddelen zich te bevinden op, aan of langs den weg". De Hoge Raad was deze keer van oordeel dat er geen algeheel verbod in het geding was "van het middel van verspreiding van gedachten of gevoelens, hetwelk bestaat in het op of aan den openbaren weg bekendmaken van gedrukte of geschreven stukken of afbeeldingen". ${ }^{66}$ Nou ja, met een dergelijke ruime omschrijving van het in aanmerking komende "middel van verspreiding", was zoiets ook nauwelijks voorstelbaar. Maar de vraag was natuurlijk waarom dat middel zó ruim omschreven moest worden dat er welhaast van een compleet verspreidingsverbod - in welke vorm ook! sprake moest zijn, wilde het niet door de beugel kunnen. Eén "middel van verspreiding" kon zelfs op verschillende wijzen worden uitgeoefend. Dat bleek toen de Hoge Raad vervolgens uit de doeken deed dat het Eindhovense 
reclameverbod slechts "deel (uitmaakte) van een regeling, welke het recht tot het bezigen van dat middel (te weten: het op of aan de openbare weg bekendmaken van gedrukte of geschreven stukken of afbeeldingen, RdW) beperkt, door zijn uitoefening op bepaalde wijze, namelijk met behulp van reclameborden en dergelijke voorwerpen te ontzeggen, terwijl het zich bevinden met reclameborden en dergelijke is verwezen naar plaatsen waar die voorwerpen, wat den weg betreft, slechts vanaf dezen zichtbaar zijn". Want dat laatste - "het zich met reclamewagens, reclameborden, reclamedoeken of reclamezuilen op zodanige plaatsen bevinden, dat die voorwerpen vanaf den weg zichtbaar zijn" - was in principe wèl geoorloofd. Zolang men zich daarbij maar niet "op of aan den weg" bevond, was er dus niets op aan te merken.

Röling vond dat "wel een heel subtiel, en in de practijk weinig belangrijk verschil". ${ }^{67}$ Dat lijkt mij ook. Alleen, of dit - zoals hij stelde - inderdaad beslissend was voor de al dan niet "toelaatbaarheid der de openbaringsmogelijkheid beperkende verordening", viel (volgens mij) te betwijfelen. Ik denk juist dat het zo weinig subtiel omschreven "middel van verspreiding" daar de oorzaak van was. Dat kon immers nog op tal van andere "wijzen" worden "uitgeoefend", zodat een algemeen verbod in de verste verte niet in het vizier was. ${ }^{68} \mathrm{Na}$ verloop van tijd zou die benadering - zoals we nog zullen zien - onhoudbaar blijken. ${ }^{\oplus}$ Dat danken we misschien aan de minieme vorm van bespreekbaarheid die de materie intussen had gekregen. Want wie iets - hoe weinig ook! - te berde brengt, stelt het ter discussie (om maar weer een keer op Guépin te variëren). ${ }^{7}$

Maar de gang van zaken bleef moeilijk voorspelbaar. Dat bleek opnieuw toen - na de Eindhovense bepalingen - de Arnhemse verordening op de straatpolitie aan bod kwam. In Amhen was het namelijk verboden om - zonder vergunning van B en $W$ - "aankondigingen op den openbaren weg om te roepen of bekend te maken". Een aanhangster van de Watch Tower Bible and Tract Society, die op straat een kartonnen plaat voor haar borst droeg waarop een lezing was aangekondigd, werd daarom door de kantonrechter tot één gulden boete veroordeeld - met verbeurdverklaring van de plaat, overigens. Langemeijer ${ }^{71}$ concludeerde tot verwerping van het cassatieberoep. Volgens hem gold hier hetzelfde als ten aanzien van het Eindhovense reclameverbod. In de eerste plaats ging het namelijk slechts, zo stelde hij, om het roepen en bekendmaken $o p$ de openbare weg, en niet $o p$ of aan de weg. Naamborden van artsen en advocaten zouden daardoor buiten het verbod vallen. In de tweede plaats moest men zijns inziens "bedenken dat het artikel spreekt van 'aankondigingen bekend maken', niet van 'aankondigingen hebben', 'aankondigingen vertonen', 'aankondigingen tentoongesteld 
hebben" of iets dergelijks". Wanneer men niet speciaal iets had ondernomen dat bij uitstek gericht was op het bekendmaken, maar bijvoorbeeld slechts een bestelauto met de naam van de ondernenning erop liet rijden, viel men dus buiten het verbod, meende hij. Vandaar dat hier - evenmin als in Eindhoven - sprake was van een algemeen verbod "van het middel van verspreiding van gedachten of gevoelens, hetwelk bestaat in het op of aan de openbare weg bekend maken van gedrukte of geschreven stukken of afbeeldingen".

De Hoge Raad, evenwel, kwam in soortgelijke bewoordingen tot een ... tegengesteld resultaat! Hij overwoog dat het verbod raakte aan het recht van een ieder om door de drukpers geopenbaarde gedachten of gevoelens in het openbaai aan het publiek bekend te maken;

"dat de uitoefening van dit recht wel allereerst omvat het middel van

verspreiding hetwelk bestaat in het op den openbaren weg - zulks ook

wel afgerond tot het op of aan den openbaren weg - bekend maken

van gedrukte of geschreven stukken of afbeeldingen". ${ }^{2}$

Hetzelfde "middel", kortom, als in Eindhoven. In zoverre kreeg Langemeijer dus gelijk. Maar daar bleef het dan ook bij. Want het onderscheid tussen op en op of aan de openbare weg werd kennelijk te subtiel bevonden - het is ook nooit goed, zou je bijna denken: de ene keer kan het niet subtiel genoeg, en de keer daarna komt het er opeens niet meer op aan!

Hoe dan ook, het gebruik van dat "middel" mocht, zoals inmiddels bekend was, door de gemeente aan voorschriften worden onderworpen, zolang die maar niet "neerkomen op een in het algemeen verbieden".

Waarom zo'n ingewikkelde formulering? In de Eindhovense beslissing werd nog volstaan met de constatering dat de bepaling "niet een algeheel verbod vormt". ${ }^{73}$ Was de Rosendaalse draad uit $1920 \mathrm{nu}$ eindelijk toch weer opgenomen? ${ }^{74}$ Ging het er, met andere woorden, om of de beperking zo ver ging dat de vrijheid om het verspreidingsmiddel te benutten "gezegd (kon) worden metterdaad te zijn opgeheven"? Het leek erop. ${ }^{75}$ Want naar aanleiding van de vraag of de Arnhemse bepaling neerkwam op "een in het algemeen verbieden", overwoog de Hoge Raad:

"dat dit laatste (...) het geval is met voormelde verbodsbepaling, 'aankondigingen op den openbaren weg bekend te maken', welke, door in haar ontzegging onbepaald alle wijzen van bekendmaken te onvatten, van bedoeld middel geen bezigen van enige betekenis overlaat".

Wellicht waren de bestelauto's van Langemeijer dus inderdaad van het verbod uitgesloten, maar vond de Hoge Raad dat niet voldoende. ${ }^{76}$ Of werd de bepaling eenvoudig ruimer opgevat, waardoor zelfs die auto's verboden waren? Dan was de constatering dat "van bedoeld middel geen bezigen van 
enige betekenis" werd overgelaten, mogelijk niet meer dan een chiquer klinkende variant op de vaststelling dat we met een algeheel verbod te doen hadden.

\subsection{Nieuwe sjablonen houden stand (1952-1953)}

De volgende evangelist - we zijn het evangelie, het socialisme, de NSB en (zoals later zal blijken) de Vietnamese oorlog in dit opzicht veel dank verschuldigd - slaagde erin de vastgelopen jurisprudentie ook op een ander punt in beweging te brengen. Hij had namelijk in Deventer op straat bij het "venten van gedrukte stukken, althans bij het verspreiden daarvan alstoen aldaar, deze hoorbaar met woorden (...) aanbevolen, zonder daartoe vergunning van B. en W. (...) te bezitten". Een "brigadier van politie te Deventer, tevens onbezoldigd rijksveldwachter" had in zijn proces-verbaal opgetekend

"dat een mij onbekende man, op de openbare straat, de K-straat te Deventer, bij het verspreiden van gedrukte stukken (de Wachttoren van de Jehova getuigen) deze hoorbaar bij het passerend publiek aanbeval. Ik zag n.n. dat hij het blad: "De Wachttoren" in zijn rechter hand hield en dit ter hoogte van het gelaat van het publiek hield en hoorde dat hij daarbij telkens zeide: 'Heeft $U$ nog interesse voor onze Wachttoren' of ook wel: 'Lees de Wachttoren", of wel 'Moet U nog een Wachttoren'."

De kantonrechter veroordeelde de man voor dit delict - want dat was het! tot een geldboete van twee gulden. En wel op grond van art. 67 van de lokale Verordening Straatpolitie:

"Het is verboden, tenzij met schriftelijke vergunning van B. en W.,

bij of ter gelegenheid van het op straat venten of verspreiden van gedrukte of geschreven stukken of vliegende blaadjes, deze hoorbaar aan te bevelen, te roepen, te zingen, te schreeuwen, gebruik te maken van een reclamebord of eenig instrument te bezigen om de aandacht te trekken".

Volgens de kantonrechter was hierbij geen sprake van "een onvoorwaardelijk verbod of het onvoorwaardelijk afhankelijk stellen van een voorafgaande schriftelijke vergunning van $\mathbf{B}$. en W. voor het verspreiden van gedrukte stukken, nu het stilzwijgend verspreiden en aanbevelen is vrijgelaten en art. $7 \mathrm{Gr}$.w. onverlet laat de bevoegdheid aan de gemeentewetgever bij art. 168 Gemeentewet toegekend, om de verspreiding van gedrukte stukken op straat te onderwerpen aan voorschriften in het belang der openbare orde" $" 7$ 
Had de Hoge Raad het zelf mooier kunnen uitdrukken? Dezelfde termen en dezelfde toonsoort... En bovendien heel plausibel, gezien de eerdere rechtspraak. In 1938, bijvoorbeeld, had de Hoge Raad het Bossche roep- en schreeuwverbod gesauveerd door erop te wijzen dat de betreffende bepalingen "het op straten of wegen aanbieden van gedrukte stukken, mits dat niet luid roepende of schreeuwende geschiedt, vrijlaten en art. 7 der Grondwet zich er niet tegen verzet, dat in het belang der openbare orde worden gegeven voorschriften ails de onderhavige, die bij de verspreiding van drukwerken moeten worden inachtgenomen". ${ }^{78}$

Ook de advocaat-generaal (Van Asch van Wijk) zag geen enkel bezwaar tegen het Deventer verbod. Anders dan de kantonrechter liet hij zich echter niet door de jaren '30 inspireren, maar door Dresen, toegepast op het Arnhemse arrest van zoëven. Het "hoorbaar aanbevelen" betrof, volgens hem $^{79}$, "de 'modus quo', brengt een beperking aan die allerminst zover gaat dat zij neerkomt op een in het algemeen verbieden en kan dus bevoegdelijk worden verboden".

De Hoge Raad volgde evenwel een andere koers. Geheel volgens het (eigen) boekje ging hij eerst na welk "middel van verspreiding" hier in het geding was. En, anders dan op grond van het eerder aangehaalde arrest uit '38 verwacht kon worden ${ }^{80}$, bleek het deze keer te gaan om "dat middel van verspreiding, waarbij men het op den openbaren weg te koop of om niet aanbieden van gedrukte of geschreven stukken doet vergezeld gaan van een mondeling bekendmaken". ${ }^{81}$ Daarmee waren de kaarten in feite geschud. De ontsnappingsroute van ' 38 was op die manier immers afgesloten. ${ }^{82} \mathrm{De}$ vraag of het verbod "neerkomt op een in het algemeen verbieden", die nog wel door de Hoge Raad werd opgeworpen, was dan ook op voorhand al beantwoord. De bepaling, "welke in haar algemeenheid mede omvat elke niet luidruchtige mondelinge uitlating, ten doel hebbende de aandacht van het publiek op de te venten of te verspreiden geschriften te vestigen" liet vanzelfsprekend "van bedoeld middel van verspreiding - nu hoorbaar aanbevelen in de praktijk veelal moeilijk van hoorbaar mondeling bekendmaken te onderscheiden zal zijn - geen gebruik van enige betekenis (over)". Dus was het verbod in strijd met art. 7 Gr.w. ${ }^{83}$

Toch maakte die uitspraak ons wel iets wijzer. Niet alleen bleek hoezeer alles afhing van de (toevallige?) omschrijving van het verspreidingsmiddel, maar bovendien werd deze keer een vraag beantwoord waar we bij het vorige arrest mee bleven zitten. Ik bedoel de term "gebruik van enige betekenis". Daarmee werd - zo bleek nu - iets in de trant van "voldoende betekenis" bedoeld. De enkele omstandigheid dat "aanbevelen" veelal (dus niet altijd!) moeilijk te onderscheiden viel van "bekendmaken" leidde namelijk tot de conclusie dat dus geen gebruik van enige betekenis van het 
middel werd overgelaten. De Hoge Raad was, met andere woorden, wat vriendelijker geworden. Vriendelijker voor degenen die zich op art. $7 \mathrm{Gr}$.w. beriepen, wel te verstaan! Het grondrecht leverde hun voortaan niet pas iets op als zij geheel in de kou kwamen te staan, maar $66 \mathrm{k}$ wanneer zij daar bijna geheel verkeerden.

Dat voor colporteurs van "De Wachttoren" in Zuid-limburg nog heel wat te doen was, behoeft geen betoog. Maar colportage was - zoals intussen wel duidelijk is - nogal eens aan banden gelegd. In Nuth was het

"verboden gedrukte of geschreven stukken of afbeeldingen om niet of te koop aan te bieden, het kopen of de kennisgeving daarvan aan te bevelen of de inhoud daarvan geheel of gedeeltelijk bekend te maken op de door B. en W. in een door hen af te kondigen besluit aan te wijzen straten of wegen of gedeelten van straten en wegen op de in dat besluit te bepalen dagen en uren".

$\mathrm{B}$ en $\mathrm{W}$ hadden, op grond van die bepaling, een verbod afgekondigd dat betrekking had "op alle straten en wegen in deze gemeente, behalve op Dinsdag en Woensdag voormiddag van 9 tot 11 uur". De evangelist die "te Nuth, op vrijdag, 5 October 1951, omstreeks 18 uur, exemplaren van het gedrukte blad 'De Wachttoren' op de openbare weg de Raadhuisstraat om niet (had) aangeboden", overtrad dus op die manier de voorschriften. Volgens Langemeijer, echter, moest hij desondanks worden ontslagen van alle rechtsvervolging. ${ }^{84} \mathrm{Hij}$ was van oordeel

"dat enerzijds niet denkbaar is dat de openbare orde een zo ver gaande beperking als de door $\mathrm{B}$. en W. toegepaste eiste en dat anderzijds door het gegeven voorschrift de mogelijkheid van openbaar maken van gedrukte stukken practisch geheel is weggenomen".

Het eerste bezwaar stoelde blijkbaar op art. 168 gem.w. ${ }^{85}$, en het tweede op art. 7 Gr.w. Er was, met andere woorden, een "beperking in de wijze van bekend maken van gedrukte stukken" in het geding, "welke neerkomt op een in het algemeen verbieden, doordat zij geen vorm van bekendmaken van enige betekenis overlaat". en dat was, concludeerde hij op grond van HR 29 mei 1951 (NJ 1952, 367), "ontoelaatbaar".

Was de bepaling dus onverbindend? Alleén het besluit van B. en W., meende Langemeijer. De verordening kon door de beugel. Men hoefde, volgens hem, "niet reeds de bepaling van de verordening onverbindend te achten omdat deze naast tal van uitwerkingen die met de Grondwet in overeenstemming kunnen zijn een uitwerking niet uitsluit welke zich wellicht met de Grondwet niet verdraagt".

De Hoge Raad was het, voor de afwisseling, in alle opzichten met zijn advocaat-generaal eens. ${ }^{86}$ Het enige was dat in het arrest wat strikter de 
hand werd gehouden aan de (door de Hoge Raad zelf verzonnen) systematiek. Dus werd eerst nog even vastgesteld dat het in dit geval om het "verspreidingsmiddel" ging "dat in het om niet aanbieden van drukwerk is gelegen". En daarna volgde, volgens een enigszins aangepast sjablone:

"dat het recht tot gebruik van dit middel wel door den gemeenteraad of, bij delegatie, door B. en W. kan worden onderworpen aan voorschriften in het belang der openbare orde, door het gebruik op bepaalde plaatsen of op bepaalde tijden te ontzeggen, doch die beperkingen van dat middel nooit zover mogen gaan dat zij neerkomen op een in het algemeen verbieden;

dat dit gevolg echter in het leven wordt geroepen door het aangevallen Besluit van B. en W., hetwelk door als plaats en tijd voor de werking van het in het verordeningsvoorschrift vervat verbod aan te wijzen alle straten en wegen in de gemeente en alle tijden, met uitzondering slechts van een tweetal ochtenduren op twee dagen in de eerste helft der week, van bedoeld verspreidingsmiddel geen gebruik van enige betekenis overlaat;

dat dat Besluit dus verbindende kracht mist".

De Rosendaalse jurisprudentie ${ }^{87}$ van 1920 was, kortom, echt in ere hersteld (hoewel niemand daarop wees). Je kon het - zoals gezegd - al een tijdje zien aankomen, maar nu stond het toch wel vast. Destijds bleek een ventverbod "tusschen des morgens 8 uur en des avonds 8 uur" ongeoorloofd te zijn; pas toen het was ingekrompen tot "de maanden Mei, Juni, Juli, Augustus en September (...) tusschen elf uur des voormiddags en vijf uur des namiddags" ging het volgens de Hoge Raad "niet zoo ver" dat het verspreidingsrecht "gezegd (kon) worden metterdaad te zijn opgeheven". Een criterium dat - ik herhaal het nog maar een keer - feitelijk al in 1895 door Van Riemsdijk Kreenen ${ }^{88}$ was aangereikt, toen hij erop wees "dat men, door het aantal uren en plaatsen, waarop het venten verboden is, zeer ruim te nemen, de drukpersvrijheid weder illusoir kan maken".

Volgens Oud ${ }^{89}$, evenwel, maakten de uitspraken van de Hoge Raad intussen,

"als het gaat om de vraag, wanneer sprake is van een algemeen verbod on drukwerken op de openbare weg te verspreiden, de indruk niet vrij te zijn van een zekere willekeur. Als de gemeente Nuth het aanbieden van drukwerken op al haar straten en wegen verbiedt, behalve op dinsdag en woensdag van 9 tot 11 uur voormiddag, concludeert de Hoge Raad, dat dit neerkomt op een algeheel verbieden, omdat de enkele uren, waarop zij is toegestaan, aan het verspreidingsmiddel geen gebruik van enige betekenis overlaten. (...) Toen echter de gemeente Breda enkele jaren eerder de gehele binnenstad 
had verklaard tot verboden terrein voor het venten met gedrukte stukken, kon zij naar het oordeel van de Hoge Raad niet gezegd. worden van haar bevoegdheid een te vèr gaand gebruik te hebben gemaakt. (...) Daarentegen krijgt Eindhoven de pen op de neus, als het gemeentebestuur het uitgeven van strooibiljetten op de openbare weg heeft verboden. $\mathrm{Nu}$ is er strijd met het in art. $7 \mathrm{Gr} . w$. bepaalde, omdat een bepaald middel niet wordt beperkt doch algeheel verboden (...)."

Een zekere willekeur... Je zou ook kunnen zeggen dat de auteur er niet in geslaagd was die uitspraken onder én noemer te brengen. Stel je voor dat iets dergelijks zich in de scheikunde voordeed: een stukje ijzer blijkt de ene keer well te roesten en de andere keer niet; is er dan reden om zo'n stukje te gaan uitfoeteren? Vreemde wetenschapsopvatting...

Goed dan, is er niet iets op te verzinnen? Over "Breda" schreef ik eerder al dat het eigenlijk niet duidelijk is of de Hoge Raad zich heeft uitgesproken over de omstandigheid dat het verbod voor de hele binnenstad gold. En wanneer hij zich er well over zou hebben uitgesproken, viel het eenvoudig. buiten zijn competentie om een oordeel te vellen over de relevantie van dat gegeven. Immers, het antwoord op de vraag of in dat geval "een gebruik van enige betekenis" aan het verspreidingsmiddel was gelaten, hing geheel en al af van de feitelijke situatie ter plekke. In Nuth, echter, ging het niet om de plaatsruimte die beschikbaar was, maar om de tijd. Welnu, daarvoor hoef je niet af te reizen naar Limburg; het verloop van de tijd is nu eenmaal niet "situationeel bepaald", zoals bepaalde sociologen het plegen uit te drukken. Dat twee keer twee uur per week (en dan 6́k nog eens op twee opeenvolgende dagen aan het begin van de week) nergens reële ventmogelijkheden opleverde, was een feir van algemene bekendheid en kon dus - $66 \mathrm{k}$ in cassatie - worden vastgesteld. ${ }^{90}$ Van willekeur hoeft het verschil in uitkomst tussen "Nuth" en "Breda", met andere woorden, echt niet te getuigen. Ziezo, en nu "Eindhoven" nog. Waarom kon het verbod om "strooibiljetten op den weg uit te geven" daar niet door de beugel, terwijl het Bredase verbod om in een bepaald gebied "tussen 6 en 23 uur" te venten wèl genade kon vinden? Omdat de Hoge Raad - zoals gezegd - dat Bredase verbod onmogelijk kon interpreteren als "een in het algemeen verbieden", terwijl zo'n interpretatie voor het Eindhovense verbod niet eens nodig was: het uitdelen van "strooibiljetten" wàs eenvoudig (voor de hele gemeente) met zoveel woorden in het algemeen verboden. Die zaak lag feitelijk dus nog eenvoudiger dan "Nuth"! 



\section{Hoofdstuk 5 De jaren zestig}

De terminologie die in de jaren vijftig ingang had gevonden, had weliswaar niet geleid tot eensgezindheid omtrent de uitkomsten, maar wèl was er in procedureel opzicht meer duidelijkheid gekomen. We wisten nu tenminste welke elementen van belang waren en welke stappen in welke volgorde gezet moesten worden, alvorens tot een oplossing te komen. In zoverre was het orakel teruggetreden. De materie was bespreekbaar geworden, al bleken verrassingen nog steeds in de lucht te hangen.

\subsection{Voorafgaand verlof van rechthebbenden: Alkmaar (1960)}

De jaren zestig begonnen met een zaak die ruim vijftien jaar later pas in het centrum van de belangstelling kwam. Op het moment zèlf stond zij als het ware in de schaduw van een ander arrest (over de verkoop van pocketbooks), dat in dezelfde aflevering van de NJ was gepubliceerd en waar uit sociaal-economisch oogpunt veel meer plezier aan kon worden beleefd. Intussen is dat tweede arrest - ik kom er dadelijk op terug - alweer vrijwel vergeten. ${ }^{1}$

Goed dan, eerst die uitspraak die aanvankelijk min of meer onopgemerkt bleef. ${ }^{2}$ Twee mensen waren in Alkmaar 's nachts om half twee ("in elk geval op een tijdstip gelegen tussen 10.00 uur namiddags en 6 uur voormiddags") op een brug betrapt met een busje plakspullen (stijfsel e.d.). Daarmee waren zij in overtreding. Niet alleen gold er namelijk een plakverbod in Alkmaar, daarnaast was het tussen 10 uur 's avonds en 6 uur 's ochtends verboden met plakartikelen op straat te lopen - tenzij je kon aantonen het plakverbod niet te willen overtreden. Twee artikelen waren, met andere woorden, van belang:

Art. 191 APV Alkmaar:

"Het is verboden, hetzij op een aanplakbord of zuil, hetzij elders op of aan de openbare weg of op enige plaats, van de openbare weg af zichtbaar, enig aanplakbiljet, papier, doek of enig opschrift of drukwerk, hoe ook genaamd, aan te plakken of te bevestigen.

Dit verbod is niet van toepassing:

a. voor zover wordt gehandeld in overheidsdienst, dan wel krachtens door $b$. en w. schriftelijk verleende vergunning;

b. voor zover het aanplakken of bevestigen op of aan enig goed ge- 
schiedt door of met schriftelijke toestemming van de rechthebbende".

\section{Art. 191 b APV Alkmaar:}

"Het is verboden tussen 10 uur namiddags en 6 uur voormiddags op de openbare weg te vervoeren of bij zich te hebben enig plak- of bevestigingsmiddel, plakgereedschap, teer, krijt, kalk, of enig andere kleur of verfstof, enig schabloon of ander voorwerp, bestemd tot het aanbrengen van afbeeldingen, letters, cijfers of tekens.

Dit verbod is niet van toepassing, wanneer kan worden aangetoond, dat deze voorwerpen of stoffen niet zijn gebezigd bij, noch bestemd zijn voor handelingen, welke ingevolge het bepaalde bij de artikelen 191 en 191a zijn verboden".

Via het tweede lid van art. $19 \mathrm{lb}$ stonden deze bepalingen dus in verbinding met elkaar. Wie uit was op ontslag van alle rechtsvervolging had aan de onverbindendheid van één van beide dan ook voldoende. ${ }^{3}$ Dan was de voor strafbaarheid vereiste keten immers verbroken. Geen wonder dat beide bepalingen in cassatie onder vuur werden genomen. Tevergeefs, echter. Wat het eerste artikel betreft (het plakverbod) overwoog de Hoge Raad:

"dat weliswaar het in art. 7 Grondwet verankerde recht om gedachten en gevoelens neer te leggen in drukwerk mede omvat het recht om dezelve in het openbaar aan het publiek bekend te maken, hetgeen onder meer kan geschieden door openlijk aanplakken of bevestigen als bedoeld in genoemd artikel, doch deze bepaling op dit grondrecht geen inbreuk makkt, nu zij blijkens het tweede lid uitsluitend beoogt zodanig aanplakken en bevestigen tegen te gaan, indien daardoor eens anders recht zou worden geschonden".

Opmerkelijk! Hier blijkt de uitingsvrijheid het recht op bekendmaking opeens weer mede te omvatten. Hoe nu? Sinds "Tilburg"4 werd ons steeds voorgehouden dat die twee naast elkaar stonden: de uitingsvrijheid van art. 7 Gr.w. enerzijds, en het daartoe onmisbare, maar tegelijk ondergeschikte bekendmakingsrecht anderzijds. Werden ze nu toch weer onder ến noemer gebracht? Of moesten we dat niet zo letterlijk nemen? Nou ja, praktisch gesproken leken er geen duidelijke consequenties aan verbonden te zijn. Misschien was het dus de moeite niet waard eraan te tillen.s

Belangrijker was de vraag of "het openlijk aanplakken of bevestigen" van "enig aanplakbiljet, papier, doek of enig geschrift of drukwerk, hoe ook genaamd" op basis van dit arrest moest worden aangemerkt als verspreidingsmiddel "hetwelk, naast andere, zelfstandige betekenis heeft en met het oog op die verspreiding in een bepaalde behoefte kan voorzien". ${ }^{6}$ De Hoge Raad liet zich daar - strikt genomen - niet over uit. ${ }^{7} \mathrm{Er}$ staat slechts dat het bekend maken onder meer op die wijze kan geschieden. Nu zijn er op z'n 
minst twee redeneringen mogelijk. Ofwel de Hoge Raad volgde zijn geijkte procedure en vroeg zich allereerst af met welk "verspreidingsmiddel " hij van doen had; in dat geval is er weinig ruimte voor twijfel en staat die frase eenvoudig voor het oordeel dat "het openlijk aanplakken of bevestigen etc." inderdaad is aan te merken als zo'n verspreidingsmiddel. Maar je kunt die overweging ook anders lezen, en dan zijn we bij de tweede redenering: aangezien de uitkomst er niet van afhangt, kan de kwestie blijven rusten; ook al zou je ervan uitgaan dat er sprake was van een verspreidingsmiddel met zelfstandige betekenis, dan nòg zou de bepaling niet onverbindend zijn.

Voor beide interpretaties is wel iets te zeggen. Zelf vind ik de eerste, geloof ik, het mooist. Maar daar staat tegenover dat de Hoge Raad zich in het algemeen niet gauw laat verleiden tot het doen van overbodige mededelingen. En dat brengt mij dan tot de eigenlijke uitkomst van die hele overweging; waarom maakt de APV-bepaling geen inbreuk op het grondrecht als zij uitsluitend beoogde tegen te gaan dat "eens anders recht zou worden geschonden"?

"Deze overweging kan", volgens Boukema", "tot veel misverstand aanleiding geven. Welke rechten vallen onder 'eens anders recht'? Moet het tegengaan van de schending van andermans rechten toelaatbaar worden geacht, omdat dit geschiedt in het belang der openbare orde? Opheldering is hier gewenst".

Helaas ondernam hij zelf geen enkele poging daartoe. Maar goed, welke rechten precies onder "eens anders recht" vallen, lijkt mij, eerlijk gezegd, niet zo vreselijk belangrijk in dit verband. Het ging feitelijk alleen maaĩ om het beginsel dat je andermans zaken sowieso al niet mocht beplakken als die ander daar bezwaar tegen had. Wie precies tegen wie bezwaar kon maken, dus wie welke zaak als de zijne mocht beschouwen, kwam pas aan de orde wanneer dat beginsel eenmaal vastlag. Zowel eigenaren als huurders - en wellicht ook onderhuurders - konden bezwaar maken als een derde hun woning wilde beplakken. Maar kon de huurder $66 \mathrm{k}$ bezwaar maken tegen plaksels van de eigenaar? En de eigenaar tegen aanplakbiljetten van de huurder? Interessante vragen, maar daar ging deze zaak niet over. Nee, de gemeente had, volgens de Hoge Raad, eenvoudig iets verboden wat - op andere gronden - tòch ai verboden was. ${ }^{9}$ De precieze reikwijdte van dat al bestaande verbod was op dit moment niet aan de orde.

En daarmee komt ook die tweede vraag van Boukema, volgens mij, in de lucht te hangen. Tenminste, voor zover hij daarbij het oog had op het al dan niet vereist zijn van een bepaald motief bij beperkingen op het verspreidingsrecht. In dit geval was immers van een extra beperking - in de visie van de Hoge Raad althans - geen sprake. Ook het motief kon dus - als het überhaupt al van belang was! - onbesproken blijven. Voor het overige moest natuurlijk 
wèl voldaan zijn aan de normale eisen van art. $168 \mathrm{gem} . \mathrm{w}$. In die zin was het - ruime - begrip "openbare orde" inderdaad van belang, maar dat staat verder los van art. 7 Gr.w. ${ }^{10}$

Iets anders is of dat Alkmaarse plakverbod inderdaad louter zag op het tegengaan van "schending" van "eens anders recht". Het eiste ofwel een schriftelijke vergunning van $\mathrm{B}$ en $\mathrm{W}$, ofwel schriftelijke toestemming van de rechthebbende. ${ }^{11}$ Het vergunningvereiste van B en W gold, volgens de Hoge Raad, kennelijk alleen voor zover de gemeente rechthebbende was. Anderen - inclusief andere overheden (denk bijvoorbeeld aan rijksgebouwen) - moesten schriftelijk toestemming verlenen. Mondelinge toestemming, laat staan onverschilligheid of de afwezigheid van bezwaren voldeden niet. Toch was er dan evenmin "schending" van "eens anders recht". ${ }^{12}$ Het verbod strekte zich, met andere woorden, tevens uit over gevallen waarin van "schending" geen sprake was. Kortom: toch een extra beperking, hoewel de bepaling op het eerste gezicht slechts verbood wat allang verboden was. Maar, zo is daartegen in te brengen: dat neemt niet weg dat op die manier het "schenden" van "eens anders recht" wel kon worden tegengegaan. Wanneer nlakkers een schrifteljike tnestemming mnesten vertonen, wist, ie tenminste zeker dat de rechthebbenden hun activiteiten goedkeurden. "Voortijdig" plakken kon zo inderdaad worden aangepakt. Zelfs zonder voorafgaand verlof van de overheid te eisen! $!^{13}$ Alleen, dat was slechts én effect van de regeling. Het andere was, zoals gezegd, een beperking van het bekendmakingsrecht. Waarom werd dat laatste niet meegewogen (en desnoods - na weging! - te licht bevonden)? Volgens de Hoge Raad beoogde de gemeente uitsluitend "schending" tegen te gaan. Gaf het motief dus de doorslag? Was alle aandacht voor wat feitelijk teweeg werd gebracht opeens verdwenen? Dat klinkt - na de opkomst van het begrip "gebruik van enige betekenis" - niet plausibel. Moeten we dat "beogen" dan wellicht anders opvatten? De bepaling beoogde "blijkens het tweede lid" uitsluitend "schending" tegen te gaan, aldus de Hoge Raad. Het motief werd, met andere woorden, uit de bepaling-zelf afgeleid. Het werd de gemeente als het ware door de Hoge Raad in de mond gelegd. En wel (naar ik aanneem) op grond van hetgeen door die bepaling - naar de inschatting van de Hoge Raad! zou worden teweeggebracht. Welnu, in dit geval wees alles, volgens de Hoge Raad, klaarblijkelijk in ến richting. Betekende dat niet vooral dat hij het andere effect over het hoofd had gezien? Zo niet, dan rees immers de vraag waarom het niet was meegewogen. Want hoe mooi ook het motief, volgens de eerdere jurisprudentie vormde het nooit een vrijbrief ter beknotting van het recht op bekendmaking.

Nou ja, genoeg hierover! Feitelijk was het in Alkmaar niet eens tot plakken gekomen. De veroordeling vond plaats "terzake van overtreding van 
art. 191b", oftewel het bezit van plakspullen. Alleen "wanneer (kon) worden aangetoond, dat deze voorwerpen of stoffen niet (waren) gebezigd bij, noch bestemd (waren) voor" - kort gezegd - plakken, was dit verbod "niet van toepassing", aldus het tweede lid van die bepaling. Was dat niet in strijd met de "praesumptio innocentiae"? Onzin, aldus advocaat-generaal (Van Oosten), "omdat de Hoge Raad een voorschrift van de gemeentelijke wetgever als dat van art. 191b niet toetst aan ongeschreven rechtsbeginselen, daargelaten nog, dat de praesumptio innocentiae niet aanvaard, noch aanvaardbaar is als uitgangspunt van "het systeem van ons strafstelsel'".

Die eerste stelling - over toetsing aan ongeschreven rechtsbeginselen - was destijds inderdaad goed verdedigbaar ${ }^{14}$, maar voor het overige sneed dit standpunt, gezien art. 6 lid 2 EVRM, toch weinig hout. Pompe wees daar dan ook fijntjes op in zijn noot onder het arrest.

Volgens de Hoge Raad moest het tweede lid van art. 191b

"aldus (...) worden verstaan, dat de omstandigheid, dat die voorwerpen of stoffen niet gebezigd zijn bij, noch bestemd waren voor handelingen, welke ingevolge het bepaalde bij de artikelen 191 en 19la zijn verboden een rechtvaardigingsgrond oplevert" (curs. RdW).

Er viel dan ook niets op deze bepaling af te dingen, vond de Hoge Raad. Niets? Was die kwalificatie als "rechtvaardigingsgrond" dan werkelijk afdoende? Was het mér dan een benaming? Hoefde men zijn onschuld dus niet te bewijzen, om aan veroordeling te ontkomen? ${ }^{15}$ Tot op zekere hoogte: een rechtvaardigingsgrond hoeft slechts aannemelijk te worden gemaakt. Toch is het of we in de wereld van Kurt Schwitters terecht zijn gekomen:

Das Kind spielte. Und sah einen Mann stehen. "Mama", sagte das Kind; die Mutter: "Ja". - "Mama" - "Ja" - "Mama" - "Ja" - "Mama, da steht ein Mann!" - "Ja" - "Marna", dat steht ein Mann!" - "Ja" "Mama, da steht ein Mann." - "Wo?" - "Marna, da steht ein Mann." - "Wo?" - "Mama, da steht ein Mann." - "Wo steht ein Mann?" "Mama, da steht ein Mann!" - "Wo steht ein Mann?" - "Mama, da steht ein Mann!" - "Ach was!" - "Mama, da steht ein Mann!" - "Laß doch den Mann stehen." - "Mama, da steht ein Mann!" Die Mutter kommt. Tatsẩchlich steht da ein Mann. Merkwürdig, was mag der da wohl zu stehen haben? Man sollte doch lieber den Vater mal rufen. Die Mutter: "Vater!" Der Vater: "Jawohl." - "Vater, da steht ein Mann." - "Jawohl." - "Vater, da steht ein Mann." - "Laß ihn stehen". - "Vater, da steht ein Mann!" - "Was will denn der Mann?" - "Das weiß ich nicht, frag ihn doch mal!" - "Laß doch den Mann stehen!" "Vater, nun komm aber endlich, da steht jemand und steht." - Der Vater kommt. Tatsächlich, da steht jemand und steht. "Mein Herr, 
warum stehen Sie da?" - Der Mann steht. "Mein Herr, aus welchem Grunde stehen Sie da?" - Der Mann steht. Das ist doch ganz außerordentlich, da steht ein Mann und antwortet nicht. "Mein Herr, ich frage

Sie zum dritten Male, weshalb stehen Sie da?" - Der Mann steht. ${ }^{16}$ Enzovoort, enzovoort, enzovoort. Een grote mensenmenigte kwam tenslotte op de been om de man te bekijken. Had hij een potje lijm bij zich gehad, dan was hij in Alkmaar allang ingerekend - tenzij hij kon aantonen... etc. Want dan had hij een rechtvaardigingsgrond. Ik moet toegeven: bij mij wekt dat toch wel enige verbazing.

\subsection{Vestigingsvergunningen (1960-1961)}

Meer aandacht, echter, ging destijds naar het tweede arrest uit, dat diezelfde dag in de NJ stond. ${ }^{17}$ Niet het venten of plakken stond daarbij centraal, maar "de uitoefening van het boekverkopersbedrijf". Volgens art. 2 van de Vestigingsbeschikking boekverkopersbedrijf 1958 was het "verboden het boekverkopersbedrijf uit te oefenen zonder vergunning van de SociaalEconomische Raad". Doel van die maatregel was het bevorderen van kredietwaardigheid en vakbekwaamheid. Nobele doelstellingen; er werd niettemin van begin af aan kritiek op uitgeoefend. ${ }^{18}$ De maatregel zou in strijd zijn met art. 7 Gr.w. Een Haagse sigarenwinkelier die pockethooks verkocht, werd dan ook door de politierechter ontslagen van alle rechtsvervolging. En het Hof overwoog in hoger beroep eveneens

"dat gemelde beschikking het bedrijfsmatig verkopen van boeken

- een, zelfs in het bijzonder, geëigend middel van verspreiding van door de drukpers in boekvorm geopenbaarde gedachten en gevoelens dus in wezen ook het openbaren van die gedachten en gevoelens, afhankelijk stelt van voorafgaand verlof der overheid, hetgeen strijdt met art. 7 Grondwet".

Beperking van de verspreiding was dus, volgens het Hof, in wezen tevens beperking van het openbaren. Dat was op zichzelf een nogal vrije vertaling van het arrest over het Tilburgse porno-verbod, maar op het taboe van "voorafgaand verlof der overheid" viel natuurlijk weinig af te dingen. Ook de advocaat-generaal (Van Oosten) concludeerde daarom tot onverbindendheid van de Vestigingsbeschikking. In zijn breed opgezette betoog herinnerde hij eraan dat de Hoge Raad vanouds geen boodschap had aan het motief van een regeling, als het op toetsing aan art. $7 \mathrm{Gr}$.w. aankwam. De inhoud was beslissend. ${ }^{19}$

"Uw College acht derhalve", concludeerde hij ietwat snel, "waar het gaat om de verbindendheid van een voorschrift van de lagere wetge- 
ver, waarbij een verspreidingsmiddel van een voorafgaand verlof der overheid afhankelijk wordt gesteld, een mogelijk verband met prealabele censuur op de inhoud van het voortbrengsel van de drukpers, irrelevant". ${ }^{20}$

En die uitkomst was, volgens hem,

"kwalijk te verenigen met de opvatting van degenen (hij dacht met name aan Dresen, $R d W)^{21}$, die leren, dat de jurisprudentie van Uw Raad over de vraag, in hoeverre de voorschriften van de lagere wetgever ten aanzien van een verspreidingsmiddel (de boekverkoop, het bedrijfsmatige uitlenen van boeken) zich verdragen met art. 7 Grondwet, tot de conclusie leidt, dat voorschriften van de lagere wetgever, welke het uitoefenen van een voorafgaande censuur op de inhoud van de te verspreiden geschriften niet inhouden, niet beogen of niet mogelijk maken, toelaatbaar moeten worden geacht".

Of de positie van de Hoge Raad in dit opzicht werkelijk zo ondubbelzinnig was als Van Oosten haar afschilderde, lijkt mij de vraag. Uit het gegeven dat de Hoge Raad niet bereid was een APV-bepaling te sauveren wanneer de gemeente geen inhoudelijke bemoeienis beoogde, leidde hij immers af dat zo'n bepaling evenmin gesauveerd zou worden wanneer inhoudelijke bemoeienis onmogelijk was. Eerst zien, dan geloven, zou ik denken.

De Hoge $\mathrm{Raad}^{22}$ ging er ook deze keer niet op in. Zonder zich over de mogelijkheid van inhoudelijke bemoeienis uit te laten, overwoog hij heel in het algemeen:

"dat deze wijze van verspreiden (te weten: "het bedrijfsmatig aan anderen dan wederverkopers verkopen van boeken", RdW) bij uitstek geschikt is om de in art. 7 Grondwet gewaarborgde vrijheid, door de drukpers gedachten en gevoelens te openbaren, te dienen;

dat dienvolgens het boekverkopersbedrijf van overheidswege aan geen andere regeling mag worden onderworpen dan de zodanige, welke de vervulling van die dienende taak onverlet laat;

dat dit laatste bij de onderhavige regeling niet het geval is, nu voor de vestiging van het bedrijf een voorafgaand verlof wordt vooigeschreven.".

In het handboek van Van der Pot, Donner en Prakke ${ }^{23}$ is vandaag-de-dag naar aanleiding van deze passage te lezen dat "de uitoefening van het boekverkopersbedrijf (...) door de hoge raad niet een middel van verspreiding (is) genoemd, maar wel is beslist dat deze wijze van verspreiden bij uitstek geschikt is om de in art. $7 \mathrm{Gw}$ gewaarborgde vrijheid te dienen". Die tegenstelling ontgaat mij, eerlijk. gezegd. Volgens Boukema ${ }^{24}$ en De $\mathrm{Meij}^{25}$, daarentegen, was er niet alleen sprake van een verspreidingsmiddel, maar was het zelfs "bij uitstek geschikt". Niet zomaar een verspreidingsmid- 
del dus ("hetwelk, naast andere, zelfstandige betekenis heeft en met het oog op die verspreiding in een bepaalde behoefte kan voorzien"26), maar een heel belangrijk! Dat lijkt mij inderdaad plausibeler (maar - toegegeven zeker is hier niets). De verkoop van boeken was immers, volgens de Hoge Raad, "bij uitstek geschikt om de in art. 7 Grondwet gewaarborgde vrijheid (...) te dienen". En diezelfde dienstbaarheid van het verspreidingsrecht - "ondergeschikt", maar ook "onmisbaar" - stond in het Tilburgse pornoarrest voorop.

Des te opmerkelijker, trouwens, dat zowel Stellinga als Van Wijnbergen daar destijds overheen lazen. "Ons hoogste rechtscollege", aldus Stellinga ${ }^{27}$, "heeft vastgehouden aan zijn eerdere jurisprudentie door de verspreiding ook nu onder art. 7 Grondwet te doen vallen". Of, zoals Van Wijnbergen het uitdrukte ${ }^{28}$ : "wij weten nu, dat volgens de Hoge Raad, althans het boekverkopersbedrijf rechtstreeks door het Grondwetsartikel wordt bestreken". Nee, wij weten nu juist dat dit niet zo is. Maar goed, voor de praktijk maakt dat allemaal weinig (misschien zelfs geen) verschil.

Interessant is intussen hoe de verschillende auteurs het arrest uitlegden. Ieder hleef in zjin eigen straatie. Ofwel hji zag er een hevestiging in wan wat hji altijd al verkeerd had gevonden - "ik heb reeds", schreef Stellinga op zijn bekende verongelijkte wijze $e^{29}$ - ofwel hij herkende er zijn eigen gelijk in. Hoezeer de Hoge Raad het bij het verkeerde eind had, werd door Stellinga geaccentueerd door er zelf een schepje bovenop te doen ${ }^{30}$. Zo bracht de eis dat de "dienende taak" van het boekverkopersbedrijf onverlet werd gelaten hem tot de volgende conclusie: "Hier wordt dus een regeling voor het boekverkopersbedrijf op zichzelf niet afgewezen, doch deze zou nooit aan de verspreiding iets in de weg mogen leggen". "Nooit... iets in de weg mogen leggen...". Was dat - gezien de jurisprudentie sinds 1892 , waarin we de term "onverlet" wel vaker zijn tegengekomen - niet ietwat overdreven? Nou ja, hij vond het in elk geval een vreemd resultaat,

"als men zich herinnert, hoe de Hoge Raad van de zijde van de gemeentebesturen wel bepaalde beperkingen van de verspreiding aanvaardt, als deze maar niet de inhoud van het gedrukte stuk raakt, hetgeen ook i.c. zeker niet het geval is".

Tja, als dat zo was, zou het inderdaad heel vreemd zijn. Maar het was, zoals bekend, bij lange na niet zo. Wie zijn eerdere beschouwingen had gemist, zou denken dat de hele verspreidingsjurisprudentie aan Stellinga voorbij was gegaan! Hij hield nog steeds aan zijn eigen stelsel vast, en daarin was voor "verspreiding" e.d. volstrekt geen plaats weggelegd. "Inderdaad verbiedt art. 7 een voorafgaand verlof", schreef hij dan ook, "doch dit betreft het doen drukken van een geschrift, en niet het uitoefenen van een bepaald bedrijf". Dat zo'n bedrijf misschien aan de "verspreiding" bij kon dragen, 
was in zijn stelsel niet relevant. Twee alinea's verder verviel hij zelfs in regelrechte demagogie: "Is alleen dan de drukpersvrijheid in Nederland gewaarborgd, als boeken behalve door de boekhandelaren, ook door kruideniers kunnen worden verkocht?" Nee, natuurlijk was dat niet de enige waarborg, net zo min trouwens als alleen kruideniers door het Vestigingsbesluit werden benadeeld.

Maar ook van de andere kant werd het arrest als het ware ingelijfd. Niet als schrikbeeld, maar als voorbeeld. Zo juichte Van Wijk ${ }^{31}$ het arrest toe omdat het de mogelijkheid uitsloot dat de vergunningsbevoegdheid zou worden gebruikt om de verkoop van bepaalde boeken te dwarsbomen:

"waaròm heeft de Hoge Raad al sinds jaar en dag die vrijheid van verspreiding mede door artikel 7 beschermd geacht? Uiteraard omdat de vrijheid om gedachten en gevoelens te openbaren, onder de mensen te brengen, mogelijkerwijs in het gedrang zou kunnen komen indien die vrijheid van verspreiding onbeschermd was. Om de mogelijkheid uit te sluiten dat bepaalde gedachten en gevoelens geweerd worden uit de geestelijke communicatie der mensen, daarom bij uitstek moet ook de verspreiding in beginsel vrij zijn".

Vandaar ook zijn afkeer van het slot van het arrest over de Bredase ventverordening, waarin de Hoge Raad overwoog dat de mogelijkheid van misbruik de betreffende bepaling niet onverbindend maakte. ${ }^{32}$

"Wat er zij van een dergelijke overweging in andere situaties", aldus Van Wijk, "hier, in het kader van een vrijheidsrecht is zij onaanvaardbaar".

Met het arrest over het Boekverkopersbedrijf had de Hoge Raad zich klaarblijkelijk echter weer van zijn goede kant laten zien. Van Wijk meende daarom "dat de jurisprudentie, als men zich voor het verstaan daarvan de moeite getroost die reeds uit respect voor de Hoge Raad gevergd mag worden, duidelijk en consequent is, ... behoudens op eén punt (...): het (staartje van het) arrest-Breda (...)" .

Was die inlijving terecht? Kon Van Wijk dit arrest inderdaad voor zijn karretje spannen? ${ }^{33}$ De Vestigingsbeschikking bood ongetwijfeld de mogelijkheid inhoudelijke maatstaven aan te leggen bij de beslissing om al dan niet vergunning te verlenen. ${ }^{34}$ Dat was eén kant van de medaille. Aan de andere kant, echter, bood het arrest-zelf geen enkele aanwijzing dat die omstandigheid voor de Hoge Raad een rol had gespeeld. En de advocaatgeneraal had zelfs beweerd - zoals we hierboven zagen - dat een mogelijke inhoudelijke bemoeienis voor de Hoge Raad irrelevant was. Beide standpunten waren ná het arrest even goed (of slecht) verdedigbaar als voordien. We werden er, met andere woorden, weinig wijzer van. De Hoge Raad bediende zich van zijn bekende sjablones. Sommigen konden daar maar niet aan 
wennen. Anderen slaakten een zucht van verlichting. Geen wonder dat het arrest vergeten werd.

Nauw verwant aan het vorige arrest was een uitspraak van enkele maanden later over het Vestigingsbesluit leesbibliotheekbedrijf $1958 .{ }^{35}$ Het "bedrijfsmatig verhuren van boeken voor zover daarmede het maken van winst wordt beoogd" was op grond van dit besluit "verboden zonder vergunning van de Kamer van Koophandel en Fabrieken". Net als bij het boekverkopersbedrijf kon ook hier zo'n vergunningstelsel volgens de Hoge Raad niet door de beugel. En wel: vrijwel op identieke gronden. ${ }^{36}$ Het enige verschil was dat de uitoefening van het leesbibliotheekbedrijf nu eenvoudig als geschikt werd aangemerkt "om de in art. 7 Grondwet gewaarborgde vrijheid (...) te dienen", terwijl de uitoefening van het boekverkopersbedrijf daartoe bij uitstek geschikt was. Of we hier mér uit moeten afleiden dan dat de raadsheren boeken - terecht overigens! - liever zelf in eigendom hadden dan dat ze ervoor naar de bibliotheek moesten, lijkt me de vraag.

Intussen bood de gang van zaken rond dit arrest trouwens wel een aardig inzicht in de verworvenheden van de nieuwe terminologie die we aan de arresten uit 1950 hadden overgehouden. De economische politierechter ${ }^{37}$ had de zaak aanvankelijk namelijk via een ouderwetse - en dus volstrekt ondoorzichtige - afweging afgedaan:

"De verspreiding van het boek", aldus deze politierechter, "geschiedt op velerlei manier, waarvan het uitlenen én is. Ook dit uitlenen vindt plaats op verschillende wijzen: door particulier aan particulier, door niet-commerciële bibliotheken en door leesbibliotheken, die boeken verhuren terwille van de verdienste. Het vestigingsbesluit verbiedt slechts dit laatste bedrijf uit te oefenen zonder vergunning van de Kamer van Koophandel en geeft de eisen aan, waaraan men moet voldoen om de vergunning te krijgen. Deze eisen, die in het besluit omschreven zijn, betrefien kredietwaardigheid, handelskennis en vakbekwaamheid. Het Vestigingsbesluit leeshibliotheekbedrijf 1958 beperkt het grondrecht niet op zodanige wijze, dat het in strijd komt met art. 7 Grondwet".

Dit ongestructureerde verhaal kon in de ogen van de advocaat-generaal (Van Oosten) geen genade vinden. In de eerste plaats ging het hier niet om het uitlenen, maar om het verhuren van boeken. Maar belangrijker nog was de wijze waarop de vraag naar eventuele strijdigheid met art. 7 was benaderd. Alle procedureregels die in het afgelopen decennium met het oog daarop door de Hoge Raad waren ontwikkeld, had de politierechter immers in de wind geslagen. Vandaar dat de advocaat-generaal het allemaal nog eens uit de doeken deed: 
"De beantwoording der zojuist opgeworpen vraag", aldus Van Oosten, "dient men te benaderen, door zich er op te bezinnen, of het voorschrift van art. 2 van het Besluit ('Het is verboden het leesbibliotheekbedrijf uit te oefenen zonder vergunning van de Kamer van Koophandel en Fabrieken') het daarbij aangegeven middel van openbaarmaking, te weten het bedrijfsmatig verhuren van boeken, de verspreiding van boeken in het algenneen beperkt of van een verlof van de overheid afhankelijk stelt. Op de vraag, of het onderhavige besluit het bedrijfsmatig verhuren van boeken als zelfstandig verspreidingsmiddel beperkt en - zo ja - of deze beperking zo ver gaat, dat zij neerkomt op een algemeen verbieden blijt het bestreden vonnis m.i. het antwoord schuldig.

Echter, zelfs al ware het antwoord op de laatstelijk gestelde vraag wel in dit vonnis gegeven of te lezen, ook dan nog zou daardoor niet ten definitieve zijn uitgemaakt, of het voorschrift van art. 2 al dan niet verbindend is, vermits die verbindendheid mede hierdoor bepaald wordt, of de verspreiding van het boek bij wege van het bedrijfsmatig verhuren daarvan al dan niet afhankelijk is gesteld van een voorafgaand verlof der Overheid".

Op dit manier werd als het ware een skelet aangereikt waaraan de feitenrechter zijn bevindingen - ongeacht de uitkomst - kon ophangen. Of het in alle opzichten een adequate weergave vormde van de stand van de jurisprudentie, is een andere vraag. Maar waar het nú om gaat is, dat het überhaupt mogelijk was geworden over dit onderwerp te spreken. Daardoor was het ook mogelijk om tegen te spreken. Op de weg van intimidatie naar argumentatie geen onbelangrijke stap, lijkt mij. ${ }^{38}$

"De moderne economische ordening moet het afleggen, als zij op het gebied van de nog steeds actuele drukpersvrijheid komt", schreef Pompe kort daarop in een noot onder alweer een aniest over een vestigingsbesluit. ${ }^{39}$ Deze keer was het de beurt van het Vestigingsbesluit Grafische Bedrijven I 1952. En ook nu was de afloop fataal. Dat was met een opkomende interventiestaat inderdaad tameijk frustrerend. Maar, gezien de rechtspraak op art. 7 Gr.w. was het anderzijds niet echt verrassend te noemen. Of had die rechtspraak zich bijtijds moeten aanpassen aan de gewijzigde omstandigheden waarin een actievere rol voor de overheid was weggelegd? Stellinga, bijvoorbeeld, vroeg zich in verband met het vergunningvereiste voor boekverkopers af

"hoe ooit door het stellen van eisen van credietwaardigheid en vakbekwaamheid aan boekverkopers de drukpersvrijheid in gevaar kan komen. De verspreiding wordt immers in geen enkel opzicht beperkt, 
wanneer men zorgt voor een behoorlijke boekverkopersstand! Eerder het tegendeel"..$^{40}$

Heel anders, echter, oordeelde Van den Bergh ${ }^{41}$ :

"Heeft iemand gedachten en gevoelens op papier gesteld, en deze in gedrukte of andere vorm vermenigvuldigd of doen vermenigvuldigen, dan eist de vrijheid van drukpers, dat hij ook in staat moet zijn deze voortbrengselen van zijn geest op de gebruikelijke wijze onder het oog van het publiek te brengen. En wanneer hij dan geen uitoefenaar van het boekverkopersbedrijf bereid mocht vinden de door hemzelf geschreven boeken op de door hemzelf gewenste voorwaarden te verkopen, of wanneer hij overigens om hem moverende redenen tot eigen verkoop wenst over te gaan, dan volgt rechtstreeks uit artikel 7, dat hij daartoe zonder enig voorafgaand verlof van wie ook vrijelijk in staat moet zijn". En:

"niet anders ligt de zaak, wanneer iernand een vurige bewonderaar is van boeken van een bepaalde schrijver, of met een bepaalde strekking, en hij er zelf rechtstreeks aan wil meewerken, dat deze boeken met de darin vervattegedacbten en gevoelens onder het ogg, van bet nubliek worden gebracht. Hij meent - en misschien niet eens ten onrechte - dat zijn enthousiasme meer dan iets anders in staat zal zijn deze gedachten en gevoelens tot het hart der mensen te doen doordringen. Daarnaast kan hij ook nog een uitnemend kruidenier zijn!"

Frappant, niet zozeer dat Van den Bergh en Stellinga van opvatting verschilden, maar vooral dat beiden hun eigen opvatting ook in het staatsrecht zagen neergelegd!

Maar hoe zat het nu met dat Vestigingsbesluit Grafische Bedrijven I 1952? Zonder vergunning van de Kamer van Koophandel en Fabrieken was de vestiging van bepaalde grafische kleinbedrijven, die "ten behoeve van het publiek" drukten, verboden. Op die manier wilde men de kredietwaardigheid, handelskennis en vakbekwaamheid op dit terrein bevorderen. "Enige voorwaarde met betrekking tot de inhoud van de te vervaardigen drukwerken of de wijze of de omvang van de verspreiding daarvan", kon volgens de advocaat-generaal (s'Jacob) niet worden gesteld. ${ }^{42}$ Dat wil zeggen: misbruik van de bevoegdheid om vergunning te weigeren was natuurlijk niet uitgesloten, maar daartegen waakte het "aan de afgewezene toegekende beroep op de - aan de volksvertegenwoordiging verantwoording verschuldigde - minister, alsook, en wellicht nog in sterkere mate, de hier te lande (...) bestaande vrijheid van meningsuiting, welke een dergelijk détournement de pouvoir wel spoedig via de pers (sic! RdW) ter kennis van de volksvertegenwoordiging zou doen komen". 
"Bovendien", aldus nog steeds de advocaat-generaal, die Van Wijk hiermee geen plezier zal hebben gedaan, "kan bij de beantwoording van de vraag, in hoeverre een wettelijke regeling met art. 7 Grondwet in strijd komt, toch bezwaarlijk rekening worden gehouden met de mogelijkheid, dat die regeling door de overheidsinstanties onjuist, in fraudem legis, zou worden toegepast".

Slechts heel weinig mensen zouden, al met al, niet voor een vergunning in aanmerking komen, meende hij. De vraag leek hem "bovendien gerechtvaardigd of de uitsluiting van deze kleine groep voor de vrijheid van meningsuiting hier te lande inderdaad een verliespost en niet eerder winst betekent". Welnu, dan was het besluit niet alleen nooit bedoeld "om ook maar in enig opzicht te treden op het terrein van de beperking van de vrijheid van meningsuiting", ook "de facto" was "van een belemmering of beperking van de door art. 7 Grondwet gewaarborgde vrijheid, om door middel van de drukpers gedachten en gevoelens te openbaren (...) niet of nauwelijks, sprake". Volgens hem was "dan ook niet in te zien waarom dit besluit, als met art. 7 Grondwet in strijd, onverbindend zou zijn te achten".

De advocaat-generaal tapte hier duidelijk uit een heel ander vaatje dan inmiddels gebruikelijk was geworden. Van de bekende stapsgewijze benadering, die de vorige keer nog zo nadrukkelijk door zijn ambtgenoot Van Oosten onder de aandacht was gebracht, viel in deze conclusie althans geen spoor te bekennen. Maar misschien kon dat ook niet anders. In het arrest over het Tilburgse porno-verbod ${ }^{43}$ had de Hoge Raad immers een onderscheid gemaakt tussen "het recht (...) om een gedrukt geschrift en het daarin gedirukte $(\ldots)$ in het openbaar aan het publiek bekend te maken", en "het grondrecht $(\ldots)$ om (...) gedachten en gevoelens door middel van de drukpers te uiten zo dat zij voor anderen kenbaar zijn". Oftewel: enerzijds "het recht tot het verspreiden ener gedrukte uiting" (waarover de vorige zaken gingen) en anderzijds "het recht tot het openbaren, het doen drukken der uiting zelf". Hier hadden we wellicht met dat laatste te maken. Dan ging dat pas ontwikkelde sjablone dus niet op. Hoewel... Zelf beriep s'Jacob zich niet op het arrest uit 1950. Hij makte er zeifs geen melding van! Integendeel, hij hield nog steeds vast aan de "leer" van 1892: "Uw Raad achtte reeds in zijn arrest van 7 nov. 1892 (W. 6259) onder het in art. 7 Grondwet genoemde openbaren door middel van de drukpers van gedachten of gevoelens begrepen het verspreiden en openlijk ten toon stellen of aanslaan van door de drukpers vermenigvuldigde geschriften". Alsof zich inmiddels geen ontwikkelingen hadden voorgedaan...

Het was moeilijk je aan de indruk te onttrekken dat iedere auteur louter zijn eigen opvattingen in het recht herkende. En er scheen, volgens die auteurs, ook steeds maar énn opvatting mogelijk te zijn. Alles wat daar niet in paste, 
werd ofwel genegeerd (zoals hier door s'Jacob) ofwel bestreden (zoals door Stellinga en Van Wijk). In het geval van s'Jacob leidde dat overigens tot een hoogst originele visie op het begrip "drukpers":

"De drukpers is in het grondwetsartikel slechts te zien als een hulpmiddel om gedachten en gevoelens een zodanige kenbaarheid te geven, dat verspreiding, en daarmede 'openbaring' mogelijk wordt. Dat die drukpers in verschillende van de grondwettelijke voorschriften, waarin het beginsel van de vrijheid van meningsuiting werd neergelegd, telkens weer wordt genoemd, vindt dunkt mij zijn oorzaak in de eerste plaats in het feit, dat ten tijde van het ontstaan dier voorschriften de drukpers, gezien de toenmalige stand der techniek, het enige middel was om gedachten en gevoelens in verspreidbare vorm te vermenigvuldigen, en in de tweede plaats omdat het hier (...) juist gaat om openbaring van gedachten en gevoelens in een vorm, die niet aan tijd of plaats is gebonden".

Hier werd de drukpers dus in hetzelfde "dienende" perspectief geplaatst als het boekverkopers- en leesbibliotheekbedrijf eerder. ${ }^{44}$ Alleen, bij die laatste twoe ging the om verspreidirgsmiddalor. De drukpers, daarenteger, kiwam al aan bod vó́rdat er van verspreiding sprake kon zijn. Kortom: hoe konden al die zaken over én kam geschoren worden? Dat was slechts mogelijk toen alles nog onder dat ene - ruime - begrip "openbaren" viel (zoals in 1892). $\mathrm{Nu}$ dat sinds 1950 niet meer het geval was, leken beperkingen alleen geoorloofd met het oog op de verspreiding, en dus niet met het oog op het daaraan voorafgaande.

Toch liet de Hoge Raad zich uitgerekend door dít onderdeel van de conclusie inspireren. Na een korte historische uiteenzetting, waarin erop werd gewezen dat de vrijheid van drukpers in de qua strekking gelijkluidende bepaling van 1815 werd gezien als "een doelmatig middel tot uitbreiding van kennis en voortgang van verlichting", overwoog de Hoge Raad:

"dat, nu blijkens de geschiedenis van het artikel de grondwetgever de drukpers heeft gezien als het hulpmiddel dat - blijkbaar dank zij de door de ontwikkeling van de druktechniek mogelijk geworden vermenigvuldiging van geschriften - bij uitstek dienstig is aan voorschreven met de bepaling beoogde doel, de in het artikel gewaarborgde vrijheid om door de drukpers gedachten of gevoelens te openbaren zich mede uitstrekt tot de vrijheid om zich van de drukpers - of, naar den zin van het voorschrift, enige andere sedertdien ontwikkelde, met de drukpers in eigenlijken zin op eśn lijn te stellen vermenigvuldigingstechniek als hulpmiddel bij de openbaring in geschrifte van gedachten of gevoelens te bedienen;

dat dit medebrengt dat de uitoefening van het boekdrukbedrijf in den 
zin van het Vestigingsbesluit Grafische Bedrijven I 1952 (..) van overheidswege aan geen andere regeling mag worden onderworpen dan de zodanige welke de vervulling van die dienende taak onverlet laat".

$\mathrm{Nu}$ vestiging echter "zonder voorafgaande vergunning van de Kamer van Koophandel en Fabrieken" verboden was, kwam dit verbod in strijd met art. $7 \mathrm{Gr} . w$. Geen verschil, kortom, met de wijze waarop die andere vestigingsvergunningen "onderuit" werden gehaald. De "dienende taak" moest "onverlet" worden gelaten, en het vereiste van een voorafgaande vergunning was daarmee niet te verenigen.

Sommige auteurs leidden hieruit af dat het bedrijfsmatig drukken dus kennelijk als verspreidingsmiddel met zelfstandige betekenis moest worden aangemerkt (net als de bedrijfsmatige boekverkoop en het bedrijfsmatig verhuren van boeken). ${ }^{45}$ Boukema ${ }^{46}$, echter, wees op de formulering van de Hoge Raad waarin gesteld werd dat de vrijheid van art. 7 "zich mede uitstrekte tot de vrijheid orn zich van de drukpers te bedienen".

"De Hoge Raad zoekt voor deze interpretatie", aldus Boukema, "geen steun in de term 'openbaren', maar in de overweging, dat het hier gaat om een gebruik van de drukpers die door de grondwetgever gezien is als "het hulpmiddel dat ... bij uitstek dienstig is aan voorschreven met de bepaling beoogde doel'.

Ons inziens kan de opvatting van de HR nu als volgt worden samengevat. Onder openbaren moet worden verstaan "het uiten van gedachten en gevoelens, zodat zij voor anderen kenbaar zijn" (HR 22 maart 1960, NJ 274). De vrijheid daartoe wordt door art. 7 beschermd. Openbaren omvat in deze gedachtengang niet het verspreiden en het zich bedienen van de drukpers. Aangezien echter zowel het én als het ander een dienende functie vervult t.o.v. de openbaringsvrijheid (...) heeft de rechter aangenomen dat ook het verspreidingsrecht en het recht zich van de drukpers te bedienen onder de bescherming van art. 7 valt als aan het grondrecht van art. 7 ondergeschikte rechten. Bij de beperking van deze rechten mag niet zover gegaan worden, dat de dienende taak wordt aangetast. Tot het beschermen van het verspreidingsrecht komt de HR dan door een teleologische interpretatie van art. 7, terwijl voor de bescherming van het recht zich van de drukpers te bedienen in het woord 'drukpers' een aanknopingspunt is gevonden".

Ik betwijfel of het echt plausibel is, ervan uit te gaan dat de Hoge Raad zich niet op het begrip "openbaren" heeft gebaseerd. De advocaat-generaal, die het allemaal had verzonnen, ging daar immers well vanuit. Maar goed, het is niet onmogelijk. Alleen, hoe passen we Boukema's verklaring nu in de 
arresten van 1950? Uit het pocketbooks-arrest destilleerde hij de regel dat "openbaren" wil zeggen: "het uiten van gedachten en gevoelens, zodat zij voor anderen kenbaar zijn". Vermoedelijk bedoelde hij het arrest over het Tilburgse porno-verbod van tien jaar eerder ${ }^{47}$, want op 22 maart 1960 werd hier met geen woord van gerept. En het vervelende is dat het in die Tilburgse zaak ook net een tikkeltje anders was geformuleerd dan Boukema ons voorhield. De Hoge Raad had het toen over "het grondrecht van een ieder om, zonder voorafgaand verlof der Overheid, gedachten en gevoelens door middel van de drukpers te uiten zo dat zij voor anderen kenbaar zijn" (curs. $\mathrm{RdW}$ ).

Hoe nu? Staat het grondrecht om gedachten en gevoelens door middel van de drukpers te uiten los van "het zich bedienen van de drukpers"? Dat klinkt natuurlijk tamelijk absurd. Toch valt er wel iets op te verzinnen. In datzelfde arrest uit 1950 werd namelijk nog een tweede keer - en passant - een omschrijving van "openbaren" gegeven: "het doen drukken der uiting zelf". Welnu, het doen drukken is inderdaad duidelijk iets anders dan het drukken. Bovendien omschreef de Hoge Raad het openbaringsrecht als een "de

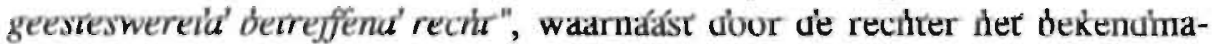
kingsrecht was aangenomen (dat zich in de "echte" wereld afspeelde). Misschien is het openbaren dus volbracht zodra het scheppingsproces ten einde is. De geuite gedachten en gevoelens zijn op dat moment immers kenbaar voor anderen, te weten: voor de drukkers. ${ }^{48}$ Het grondrecht gedachten en gevoelens door middel van de drukpers te uiten, ziet in die opvatting slechts op het vrijhouden van de weg naar de drukker toe. De overheid mag daar niet tussenkomen. Het persklaar maken van kopij is taboe voor haar.

Op die manier kan het drukken-zelf inderdaad worden losgeweekt van de vrijheid van drukpers. Het arrest over de grafische bedrijven kan daardoor toch nog - zij het op 't nippertje - op én lijn worden gebracht met de eerdere "trendsetter" uit 1950. Eenmaal "los" van art. 7 geniet de drukpers immers ook niet meer de status van dat artikel. Er is dan ruimte voor beperkingen - tenminste: zolang de "dienende taak" onverlet wordt gelaten. Want net als bij verspreidingsmiddelen is er weliswaar sprake van ondergeschiktheid, doch evenzeer van onmisbaarheid.

Net als bij verspreidingsmiddelen? Ja, volgens Boukema wel. Want het gebruik van de drukpers is geen verspreidingsmiddel, meende hij.

Waarom zo ingewikkeld? Waarom drie categorieën - het grondrecht, het verspreidingsiecht en het recht zich van de drukpers te bedienen - waar ook twee al voldoen? Ik bedoel: wat is er eigenlijk tegen om het gebruik van de drukpers onder "verspreiding" te brengen? Het arrest van 1950 wekt de indruk dat er slechts twee varianten in het spel waren: enerzijds het openba- 
ren, en anderzijds de verspreiding. Misschien komt dat omdat het gebruik van de drukpers toen eenvoudig niet aan de orde was. Want inderdaad, zo'n derde categorie wordt evenmin uitgesioten.

Wie het gebruik van de drukpers als verspreidingsvorm ziet, kan zich vervolgens de vraag stellen of de onvermijdelijkheid van beperkingen ook hier uit de "ruimtelijke sfeer" verklaard moet worden, en of daarmee tevens is aangegeven dat beperkingen alleen dáruit mogen voortvloeien - een vraag die overigens ten aanzien van alle verspreidingsmiddelen gesteld kan worden.

lets anders is natuurlijk of dit nu allemaal te voorzien was. Onmogelijk, lijkt mij. Wie had ooit kunnen voorspellen dat de Hoge Raad zich op sleeptouw zou laten nemen door een constructie van de advocaat-generaal die uitging van achterhaalde jurisprudentie? Had het niet veel mér voor de hand gelegen, als de Hoge Raad - zoals Stellinga later suggereerde $e^{49}$ - eenvoudig had overwogen

"dat ook de boekdrukker, die geschriften van een ander drukt, de openbaringshandeling van art. 7 verricht, en dus aanspraak heeft op de bescherming van dit artikel"?

Ik betwijfel het. In dat geval was het namelijk veel moeilijker om in de toekomst ooit (nu wellicht nog onvoorziene) beperkingen in dit vlak te accepteren. Ik denk dat daarin juist de verklaring schuilt van de ingewikkelde manoeuvre die de Hoge Raad hier heeft ondernornen. Het ging er niet zozeer om dit specifieke vergunningvereiste "onderuit" te halen, alswel om de deur voor overheidsinterventie op een behoorlijke kier te houden. Want ook al vinden we het gebruik van de drukpers tegenwoordig in rijtjes met "zelfstandige verspreidingsmiddelen" opgenomen, in feite is dat gebruik met dit arrest eerder aantastbaar geworden, dan beschermd. Het staat nu immers "los" van art. 7.

\subsection{Neonletters (1967)}

"Ter ondersteuning van de mening van een 32-tal hoogleraren, die (betoogden) dat de mensheid bezig (was) zich zelve uit te roeien", was in het midden van de jaren ' 60 op de toren van de Chemische fabriek Naarden "en well op de bovenrand van deze toren en daar direct onder tegen de toren, een opschrift (...) aangebracht in kapitale drukletters ter hoogte van naar schatting $1.20 \mathrm{~m}$, luidende: 'Nederland ontwapent' in blauwe kleur, welke letters bij nacht neon licht (uitstraalden) in blauwe kleur, welk opschrift zowel bij dag als bij nacht duidelijk zichtbaar (was) vanaf een voor het publiek toegankelijke plaats". ${ }^{50}$ Dat was in strijd met de Verordening 
Landschapsschoon Noord-Holland. Volgens art. 1 van die verordening was het verboden

"in het landelijke gedeelte ener gemeente (...) op, aan of in hetzij een onroerend goed, hetzij enig daarop aanwezig roerend goed, reclame, welke van een voor het publiek toegankelijke plaats af zichtbaar is, aan te brengen dan wel als eigenaar of gebruiker van dat onroerend goed of van het daarop aanwezige roerende goed die reclame in stand te houden of de aanwezigheid te gedogen".

In art. 3 werd vervolgens bepaald dat het gebied "buiten de ingevolge art. 27 Wegenwet vastgestelde grenzen der bebouwde korn of kommen" als "landelijk" werd aangemerkt; ten aanzien van gemeenten waarvoor geen "kom of kommen ingevolge art. 27 Wegenwet" waren afgeperkt, betrof het verbod van art. 1 "het gehele grondgebied". En op grond van art. 5 konden GS ontheffing, verlenen "indien daardoor naar hun oordeel het landschapsschoon niet op ontoelaatbare wijze wordt geschaad".

Waren we zoiets niet al eens eerder tegengekomen? Zeker, twee keer zelfs! In 1937 en 1938. Beide keren achtte de Hoge Raad het verbod - met een uiterst cryptische motivering - acceptabel. ${ }^{51}$ De zaak uit 1937 ging over de "Geldersche reclameverordening". Laat ik de gewraakte bepaling nog even in herinnering brengen; het was - op enkele kleine uitzonderingen voor winkels en fabrieken na - verboden

"een onroerend goed of eenige zaak, daarop aanwezig, op welke wijze ook, hetzij geheel of gedeeltelijk, tot reclame te bezigen of daartoe te bestemmen, indien dat onroerend goed is gelegen in een gemeente, welke, of in het gedeelte van een gemeente, hetwelk, overeenkomstig het tweede lid van dit artikel als 'landelijk' is aangewezen".

Volgens het tweede lid wezen GS,

"na overleg met het gemeentebestuur, aan, of een gemeente in haar geheel of gedeeltelijk als 'landelijk' wordt aangemerkt en stellen in het laatste geval de omschrijving van het 'landelijk' gedeelte vast".

In 1938 was de beurt aan de Brabantse reclameverordening die het "den eigenaar of gebruiker van eenig onroerend goed" verbood:

"1e. daarop of daaraan te hebben getimmerten, borden of andere voor werpen, bestemd of gebezigd tot reclame;

2e. het onroerend goed op eenige andere wijze te bezigen tot reclame of toe te laten, dat dit tot reclame gebezigd wordt".

Dat verbod gold echter niet:

"1e. voor reclame waarvoor door Gedeputeerde Staten ontheffing is verleend;

2e. voor reclame welke voorkomt binnen de kom eener gemeente". Beide verordeningen konden, zoals gezegd, de toets der kritiek doorstaan. 
Dan zou het dus $66 \mathrm{k}$ wel loslopen met die Noordhollandse verordening op het landschapsschoon! Hoewel... Volgens Prins ${ }^{52}$ maakte deze laatste verordening "geen onderscheid (...) naar gelang reclame is aangebracht op roerend(e) dan wel op onroerend(e) (zaken)", terwijl die vooroorlogse bepalingen "alleen het gebruik van onroerende (zaken) voor reclamedoeleinden aan banden legden". Waar hij dat verschil zo opeens vandaan toverde, is mij niet duidelijk. Wie, zoals (vermoedelijk) de Hoge Raad ${ }^{53}$, zowel het Gelderse als het Brabantse reclameverbod uitsluitend op onroerende zaken-zèlf betrekt, zal ten aanzien van het Noordhollandse verbod tot dezelfde conclusie moeten komen, lijkt mij.

Welnu, de advocaat-generaal (Berger) vond inderdaad - net als de kantonrechter en de rechtbank, overigens - dat er niets op het verbod viel af te dingen. ${ }^{54}$ Alleen, die uitspraken uit de jaren ' 30 noemde hij niet eens! De zaak stuitte volgens hem al af op een voorvraag:

"Men zal toch moeilijk kunnen volhouden", aldus de advocaat-generaal, "dat het aanbrengen van neon-letters op een fabriekstoren is aan te merken als het openbaren van gedachten of gevoelens door de drukpers. Inmers welke ruime technische interpretatie men aan het woord "drukpers" in art. $7 \mathrm{Gw}$. ook zal willen geven, de in deze bepaling gegarandeerde vrijheid zal steeds tot het gedrukte geschrift en tot de gedrukte afbeelding beperkt blijven. Het zou in strijd zijn met de historische achtergrond van deze bepaling, indien men ieder verband met de drukpers zou verbreken en haar aldus zou doen evolueren tot een regeling van het recht op vrije meningsuiting in het algemeen als hoedanig zij immers bepaaldelijk niet bedoeld is".

Alsof het werkelijk nodig was ieder verband met de drukpers te verbreken, indien ook neonletters de bescherming van art. 7 zouden genieten! En alsof dat onherroepelijk zou uitmonden in "een regeling van het recht op vrije meningsuiting in het algemeen". Trouwens, waarom gaf de historische achtergrond hier de doorslag? En wat behelsde die achtergrond eigenlijk? Om met annotator Prins ${ }^{55}$ te spreken:

"De ratio van het systeem brengt mede, dat het evengoed voor gedrukten moet gelden als voor geschreven of in neon-letters gestelde teksten. Dat de grondwetgever aan geschreven stukken geen aandacht heeft gewijd is te verklaren uit het feit, dat dit middel van verkondiging van meningen destijds slechts een zeer beperkt effect kon sorteren en dan ook geen aanleiding had gegeven tot maatregelen van preventieve censuur, waarmede men na het einde van de Franse tijd wilde breken".

Maar, veel belangrijker, de advocaat-generaal had kennelijk ook het zoëven besproken arrest uit 1961 gemist. ${ }^{\$ 6}$ Daarin werd het begrip "drukpers" 
immers danig gerelativeerd. Het bleek slechts een "hulpmiddel" te betreffen en werd in én adem genoemd met "enige andere sedertdien ontwikkelde, met de drukpers in eigenlijken zin op éen lijn te stellen vermenigvuldigingstechniek.

De Hoge Raad ${ }^{57}$ bleek dan ook niet overtuigd door de advocaat-generaal. Sterker: zelfs van een vermenigvuldigingstechniek werd nu niet meer gerept. Maar laat ik niett ter hard van stapel lopen.

Eerst werd het "klassieke" repertoire afgedraaid:

1. In aansluiting op art. $7 \mathrm{Gr}$.w. is door de rechter aangenomen dat niemand voorafgaand verlof nodig heeft om "de inhoud van gedrukte of geschreven stukken of afbeeldingen, waarin gedachten of gevoelens, zijn geopenbaard, aan het publiek in het openbaar bekend te maken" ${ }^{58}$;

2. Op grond van art. 90 Provinciewet (vg!. 146 nieuw) kan het bekendmaken in het belang der provincie aan beperkingen worden onderworpen, zij het "dat deze beperkingen nooit zover mogen gaan dat het gebruik van een bepaald middel van bekendmaking, dat naast andere middelen zelfstandige betekenis heeft en met het oog op die bekendmaking in een bepaaide behoefte kan voorzien, in het algemeen wordt verboden of van een voorafgaand verlof der overheid afhankelijk wordt gesteld" .

Allemaal "ouwe koek", hoewel en passant toch ook nog een kleine controverse beslecht leek. Nu de algemene bevoegdheidsomschrijving van art. 90 Prov.w. - "het belang der provincie" - immers als beperkingsgrond door de beugel bleek te kunnen, was er geen duidelijke aanwijzing meer dat beperkingen slechts geoorloofd waren voor zover zij een bepaald motief hadden (zoals "het helang der openbare orde, bepaaldelijk ter beveiliging van het openbaar verkeer", dat we al zo dikwijls zijn tegengekomen). ${ }^{59}$

Maar goed, hoe werd dit standaard-skelet in dit geval aangekleed?

Om te beginnen werd geconstateerd

"dat de artt. 1 en 5 van voormelde verordening medebrengen dat het aanbrengen aan of in hetzij een onroerend goed hetzij enig daarop aanwezig roerend goed van gedrukte of geschreven stukken of afbeeldingen, waarin gedachten of gevoelens zijn geopenbaard" - kortweg: stukken in de zin van art. $7 \mathrm{Gr}$.w.; RdW - "welke stukken van een voor het publiek toegankelijke plaats af zichtbaar zijn, in het landelijk gedeelte ener gemeente in het algemeen is verboden zonder voorafgaand verlof van gedeputeerde staten".

En omdat "zodanig aanbrengen" vervolgens als zelfstandig middel van verspreiding werd aangemerkt ${ }^{60}$, rees dus de vraag of het gebruik ervan in het algemeen was verboden, dan wel afhankelijk gesteld van "een voorafgaand verlof der overheid". In dat verband moest het aanbrengen van een opschrift op een toren, "weliswaar in kapitale drukletters, maar kennelijk niet zijnde 
een gedrukt of geschreven stuk"', volgens de Hoge Raad "op én lijn worden gesteld "met het aanbrengen van gedrukte of geschreven stukken",

"nu dit als middel van bekendmaking in het maatschappelijk verkeer dezelfde functie heeft als het aanbrengen van geschriften in eigenlijke zin".

Daarmee was de hindernis die door de advocaat-generaal was opgeworpen, met andere woorden, genomen. De functie in het maatschappelijk verkeer bleek beslissend te zijn. Bekendmaking door middel van neonletters was, vanuit dat perspectief, niet minder dan bekendmaking door middel van "echte" drukletters. Ze werden nu eenmaal op dezelfde manier gebruikt. Alweer zo'n bruggetje van feiten naar normen...

Hoe dan ook, de afweging kon nu beginnen. Was de provincie te ver gegaan met haar verbod? De Hoge Raad overwoog:

"dat weliswaar het in art. 1 van genoemde verordening vervatte verbod beperkt is tot het landelijk gedeelte ener gemeente, doch deze beperking, mede gelet op het bepaalde in art. 3 der verordening, en tevens in aanmerking nemende, dat die beperking de gemeentelijke wetgever er niet van zou behoeven te weerhouden, voor de bebouwde kom der gemeente een soortgelijk verbod uit te vaardigen als de provinciale verordening van de provincie Noord-Holland bevat ten aanzien van de landelijke gedeelten der gemeenten binnen die provincie, niet van zodanige betekenis is, dat zij aan het gestelde verbod een algemeen karakter zou vermogen te ontnemen".

De precieze betekenis hiervan is moeilijk te achterhalen. Het verbod was weliswaar "beperkt", maar die beperking was, "mede gelet op" dit, "en tevens in aanmerking nemende" dat, niet van zodanige betekenis "dat zij aan het gestelde verbod een algemeen karakter zou vermogen te ontnemen", Dus miste het verbod "verbindende kracht".

Zou het verbod $60 \mathrm{k}$ zonder dit en dat onverbindend zijn geweest? Of wellicht als alleén dit (of dat) zich zou hebben voorgedaan? Zo niet, dan moeten we uit dit arrest afleiden dat de enkele mogelijkheid dat het gebruik van dit "middel van bekendmaking" in sommige gemeenten in het algemeen was verboden, fataal bleek te zijn. ${ }^{61}$ Maar zekerheid daarover werd ons door de Hoge Raad niet verschaft. Misschien werd het "landelijk gedeelte" eenvoudig zo ruim geacht dat dárdoor al geen gebruik van enige betekenis meer werd overgelaten.

Hoe dit allemaal te rijmen viel met die eerdere arresten uit de jaren dertig, bleef intussen een raadsel. Prins wees er, zoals gezegd, op dat deze Noordhollandse bepaling zich, in tegenstelling tot haar Gelderse en Brabantse voorgangsters, niet tot onroerende zaken beperkte. Maar dat klonk, zoals ik $\sigma 6 \mathrm{k}$ al eerder zei, niet bijster overtuigend. Boukema ${ }^{62}$ loste de tegenstrijdig- 
heid met retorische middelen op. Hij sprak van "een duidelijke lijn":

"Toch zit er een duidelijke lijn in de rechtspraak van de Hoge Raad nl. deze dat naarmate men met latere arresten te doen heeft eerder aan middelen van verspreiding een zelfstandige betekenis wordt toegekend. Illustratief zijn in dit verband de arresten over enkele provinciale reclameverordeningen. In het arrest van 31 oktober 1938, NJ 1939, 206, wordt het aanbrengen van reclame op buiten de bebouwde kom gelegen onroerend goed kennelijk niet beschouwd als een verspreidingsmiddel met zelfstandige betekenis, terwijl zulks wel het geval is in HR 24 jan. 1967, NJ 1967, 270."

Had hij gelijk? Nee, hij had aantoonbaar ongelijk. Het middel in kwestie was immers niet omschreven als het aanbrengen op buiten de bebouwde kom gelegen onroerend goed, maar enkel als het aanbrengen op onroerend goed (etc.). Daarom zei de Hoge Raad ook dat het verbod beperks was; het gold immers (in principe) uitsluitend buiten de bebouwde kom. Alleen, dat was niet voldoende.

Niettemin, wie er "een lijn" - in de zin van ontwikkeling - in wilde ontwaren, kon natuurlijk zijn gang gaan. Er zijn weinig dingen waar geen lijn in zit. Maar wat is daarmee gezegd?

\subsection{Vietnam (1967)}

De eerstvolgende stappen danken we aan de oorlog in Vietnam. In het eerste nummer van de NJ in het revolutiejaar 1968 stonden twee arresten van de Hoge Raad die allebei op 30 mei 1967 waren gewezen. Ze staan intussen bekend als "Vietnam I" en "Vietnam II". In het ene geval bleek art. 7 nog net well van toepassing te zijn, in het andere net niet meer.

Eerst "Vietnam I". ${ }^{63}$ Daarbij ging het om het Rotterdamse verbod om zonder vergunning van $B$ en $W$ "op of aan de weg met reclame- of propagandamiddelen te rijden" (art. 18 APV). Een "sandwichman" die aan de voorkant het opschrift "Refuse to serve in Vietnam" droeg, en aan de achterkant "Stop misdadige bombardementen op Hanoi", werd wegens overtreding van dat verbod tot tien gulden boete veroordeeld. De rechtbank had zich kennelijk laten inspireren door een arrest van de Hoge Raad uit $1951 .{ }^{64} \mathrm{Zij}$ overwoog namelijk dat

"art. 18 APV Rotterdam niet zonder meer in strijd met het bepaalde in art. 7 Grondwet (was). Immers, de vergunning in genoemd art. 18 APV bedoeld, wordt niet vereist voor het openbaren van gedachten en gevoelens door middel van de drukpers als zodanig, doch voor het, voor zover thans van belang, met propaganda-middelen op of aan de 
openbare weg rijden, gaan of staan. Enerzijds vallen niet alle geschriften onder het begrip propagandamiddel, anderzijds vallen propagandamiddelen in de vorm van raamaffiches, teksten op muren, lichtreclames, aanplakbiljetten, alsmede propagandistische drukwerken in winkels en kiosken, ook voor zover deze vanaf de openbare weg zichtbaar zijn, naar de mening van de $\mathbf{R b}$. niet onder de werking van art. 18 voormeld, welk artikel zich immers uitdrukkelijk beperkt tot het zich met genoemde middelen op of aan de openbare weg bevinden". 65

In 1951 had de Hoge Raad, naar aanleiding van het Eindhovense verbod om "met reclamewagens, reclameborden, reclamedoeken, reclamezuilen of dergelijke reclamemiddelen zich te bevinden op, aan of langs den weg", overwogen dat dit

"niet een algemeen verbod vormt van het middel van verspreiding van gedachten of gevoelens, hetwelk bestaat in het op of aan den openbaren weg bekendmaken van gedrukte of geschreven stukken of afbeeldingen, doch deel uitmaakt van een regeling welke het recht tot het bezigen van dat middel beperkt, door zijn uitoefening op bepaalde wijze, namelijk met behulp van reclameborden en dergelijke voorwerpen te ontzeggen, terwijl het zich bevinden met reclameborden en dergelijke is verwezen naar plaatsen waar die voorwerpen, wat den weg betreft, slechts vanaf dezen zichtbaar zijn". ${ }^{6}$

Dat was toen klaarblijkelijk voldoende; het betreffende "middel van verspreiding" werd immers slechts gedeeltelijk aan banden gelegd, terwijl in principe voor alle uitingen ruimte bleef. Mocht de rechtbank er dan niet op vertrouwen dat het deze keer in Rotterdam net zo zou liggen? Helaas, dat sprak toch niet helernaal vanzelf, lijkt me. Het "middel van verspreiding" was in die Eindhovense zaak namelijk opvallend ruim omschreven: "het op of aan den openbaren weg bekendmaken van gedrukte of geschreven stukken of afbeeldingen". Intussen was de Hoge Raad in andere zaken wat meer gaan specificeren. Het arrest over de gemeente Nuth ${ }^{67}$ betrof bijvoorbeeld "het verspreidingsmiddel dat in het om niet aanbieden van drukwerk is gelegen". Zo had er bijna ongemerkt een ontwikkeling plaatsgevonden, die moeilijk kon worden teruggedraaid. Want waarom zou het eerdere precedent in stand moeten blijven ten koste van het latere?

Geen wonder dat die zaak uit 1951 in de conclusie van de advocaat-generaal (s'Jacob) alleen nog nnaar figureerde in een lange opsomming van arresten waarin hij de stand van de jurisprudentie weergaf. Prins noemde de zaak zelfs niet eens in zijn noot onder het arrest. ${ }^{68}$ Volgens de advocaat-generaal $^{69}$ lag het sinds "Nederland ontwapent" allemaal tamelijk simpel:

"Zou vo6r dit arrest wellicht nog twijfel hebben kunnen rijzen omtrent 
de vraag of de ten laste van rekwirant bewezenverklaarde handeling wel viel onder het begrip 'door de drukpers gedachten of gevoelens openbaren", naar de thans door Uw Raad gehuldigde opvatting is dit zonder twijfel wel het geval. (...) De inhoud van het geopenbaarde mag nooit aanleiding zijn tot een verbod tot het openbaren van gedachten en gevoelens door middel van de drukpers. Slechts de gevolgen, welke een dergelijke openbaring van gedachten en gevoelens, wanneer deze in het openbaar plaats heeft, kan hebben, met name verstoring van de openbare orde, mag aanleiding tot zodanige beperking zijn, mits bovendien die beperking niet de vorm heeft van een aan die openbaring voorafgaande goedkeuring door de gemeentelijke overheid".

Even afgezien van het feit dat de advocaat-generaal het begrip "openbaren" hier klaarblijkeiijk - anders dan de Hoge Raad! - als een soort equivalent van publiceren gebruikte, kwam hij vervolgens tot het oordeel dat het Rotterdamse verbod de "mogelijkheid" openliet "van een verdergaande beperking van het in art. 7 Grondwet neergelegde grondrecht", dan volgens de jurisprudentie toelaatbaar was. Daarmee bedoelde hij kennelijk dat de vergunning mogelijkerwijs om inhoudelijke redenen geweigerd zou worden. Dat leid ik tenminste af uit zijn toevoeging dat het opschrift van de afdeling van de APV, waaronder het verbod was geplaatst ("Openbare orde en veiligheid"), aan zijn oordeel niet afdeed:

"Dit opschrift brengt niet mee, dat $b$. en $w$. een vergunning als bedoeld in art. 18 (..) slechts zouden kunnen weigeren op gronden, ontleend aan de bescherming van de openbare orde en/of veiligheid". Had de bepaling, volgens hem, door de beugel gekund als dat wel zo was? Opmerkelijk... Hoe dan ook, daarnaast leek het hem

"niet twijfelachtig, dat de door rekw. en zijn medeverdachten gebezigde methode om hun gevoelens en gedachten te openbaren, te weten door het langs de straat gaan met propagandaborden, wel degelijk is een zelfstandige vorm van openbaring van gedachten en gevoelens, welke, ongeacht of er nog andere middelen zouden zijn aan te wijzen om diezelfde gedachten en gevoelens te openbaren, niet zover mag worden beperkt als art. 18 APV Rotterdam mogelijk maakt".

Het leek er, met andere woorden, op dat de advocaat-generaal van alle walletjes tegelijk wilde eten. Hij had het duidelijk moeilijk om grip te krijgen op de "leer" van de Hoge Raad. Toch kreeg hij uiteindelijk gelijk. Ook de Hoge Raad ${ }^{x}$ vond het verbod in strijd met art. 7. Zoals inmiddels gebruikelijk, werd allereerst overwogen "dat in aansluiting aan het in art. 7 Grondwet erkende recht" om te openbaren, door de rechtspraak een recht is "aangenomen" om stukken "aan het publiek in het openbaar bekend te 
maken" - zij het dat beperkingen hier op grond van art. 168 Gem.w. geoorloofd zijn, zolang de bekendmaking althans niet "in het algemeen wordt verboden of van een voorafgaand verlof der overheid afhankelijk wordt gesteld". Vervolgens overwoog de Hoge Raad (geheel en al volgens het bekende stramien):

"dat art. 18 van genoemde verordening, sprekende van 'reclame- of propagandamiddelen', in zijn algemeenheid mede oinvat gedrukte of geschreven stukken of afbeeldingen, waarin gedachten of gevoelens zijn geopenbaard;

dat het artikel dus mede brengt dat het bezigen van zodanige stukken of afbeeldingen als reclame- of propagandamiddel waarmede op of aan de weg - in de zin der verordening - wordt gereden, gegaan of gestaan, in het algemeen is verboden zonder voorafgaand verlof van b. en w.;

dat zodanig rijden, gaan of staan echter moet worden aangemerkt als een middel van bekendmaking, dat naast andere middelen zelfstandige betekenis heeft en met het oog op die bekendmaking in een bepaalde behoefte kan voorzien, zodat het gebruik van dit middel niet in het algemeen mag worden verboden of van een voorafgaand verlof der overheid afhankelijk mag worden gesteld".

Kortom: het Rotterdamse verbod, dat dit wel deed, was in strijd met art. 7 Grondwet en miste dus "verbindende kracht". De verenging van het "middel van bekendmaking" was, met andere woorden, beslissend. Weliswaar is onduidelijk of het betreffende middel ziet op het op of aan de weg rijden, gaan of staan met gedrukte of geschreven stukken of afbeeldingen (waarin gedachten of gevoelens zijn geopenbaard) in het algemeen, dan wel specifiek op reclame en propaganda ${ }^{71}$, maar zoveel is zeker: naast geschriften die op onroerende zaken (vgl. "Nederland ontwapent") zijn aangebracht, genieten ook verplaatsbare geschriften dankzij dit arrest bescherming. Vooraf was dat niet duidelijk; er viel nog over te twisten. Wekt de uitkomst verbazing? Niet ècht, lijkt mij; de trend naar verdere specificatie was nu eenmaal al ingezet. Bovendien, zoals annotator Prins ${ }^{72}$ opmerkte:

"Wat voor verschil maakt het, of men een tekst of afbeelding aanbrengt op enig (onroerend of roerend) goed, dan wel daarmede op de openbare weg rijdt, gaat of staat? Men zou kunnen stellen, dat bij dit laatste de kans op wanordeiijkheden groter is, maar het initiatief zal dan meestal niet uitgaan van de propagandist (in dit geval een sandwichman), doch van diens tegenstanders, zodat het eer op de weg van de overheid ligt om op te treden tegen het agressief gedrag van deze laatsten dan om de propagandist te belemmeren in het verkondigen van zijn mening"'. 
Of ook dit laatste destijds "de heersende leer" was, kan overigens worden betwijfeld.

In "Vietnam II"73 ging het om een optocht. De "Aktiegroep Vietnam" had op 15 mei 1966 een stille tocht in Amsterdam gehouden; daarbij werden aan voorbijgangers pamfletten uitgedeeld. Alleen, er was geen vergunning voor aangevraagd. Dus was die optocht, op grond van art. 101 APV (dat een vergunning van de burgemeester eiste), verboden. En ook het deelnemen eraan was verboden.

Kon dat wel door de beugel van art. $7 \mathrm{Gr}$.w.?

"Een optocht als waarover het in deze zaak gaat", aldus de advocaatgeneraal (opnieuw s'Jacob), "zal dunkt mij wel kunnen worden aangemerkt als een massale meningsuiting. Zij kan echter, zelfs bij een zo extensieve interpretatie als door Uw Raad van art. 7 Grondwet gegeven in zijn arrest van 24 jan. 1967 (NJ 1967, 270), in dat grondwetsartikel geen steun vinden. Ik kan althans in genoemd arrest niet lezen, dat Uw Raad het standpunt heeft ingenomen, dat art. 7 op elke meningsuiting, in welke vorm dan ook, van toepassing zou zijn. Het artikel blijft - althans zo wil het mij voorkomen - ook na het arrest van 24 jan. 1967 alleen op leesbare meningsuitingen van toepassing". Waar de Hoge Kaad bij herhaling ook afbeeldingen binnen de steer van art. 7 had gebracht, was die laatste formulering ongetwijfeld wat te beperkt uitgevallen. ${ }^{74}$ Maar had hij voor het overige well gelijk? Wat had die "extensieve interpretatie" in "Nederland ontwapent" hier eigenlijk mee te maken? In dat arrest ging het om de vraag of een toren met neonletters was aan te merken als een toren waarop een geschrift "in eigenlijke zin" was aangebracht. Zo ja, dan was er - zoals de Hoge Raad (anders dan in de jaren 30) zonder enige omhaal van woorden aannam - een middel van bekendmaking met zelfstandige betekenis in het spel, hetgeen impliceerde dat het vereiste van voorafgaand verlof taboe was. Deze keer ging het om een optocht (waarbij pamfletten werden uitgedeeld, en wellicht borden meegedragen). Opnieuw was de vraag of we met een middel van bekendmaking met zelfstandige betekenis te doen hadden.

In die zin was er inderdaad enige gelijkenis. Toch lagen beide zaken niet hetzelfde, lijkt mij. "Nederland ontwapent" betrof in zekere zin slechts een kwalificatie-probleem: is een neon-tekst aan te merken als een geschrift? In "Vietnam II", daarentegen, moest niet het eén met het ander gelijk worden gesteld, maar ging het om de erkenning van het middel-zelf - de optocht als middel van bekendmaking met zelfstandige betekenis. Waar in het ene geval die status van het middel intussen niet echt omstreden meer leek, draaide het daar in het andere juist om. De interpretatie van de Hoge Raad 
in "Nederland ontwapent" was dan ook niet zo zeer extensief ten aanzien van het middel, als wel ten aanzien van hetgeen eronder werdl gebracht. Hier - bij de optocht - waren we nog niet zover. Pas wanneer de optocht als middel van bekendmaking was erkend, rees de vraag of de ene optocht (waarin bijvoorbeeld borden werden meegedragen) gelijkgesteld kon worden met de andere (waarin - ik zeg maar wat -pamfletten werden uitgereikt). Dan pas rezen er, met andere woorden, problemen zoals die zich in "Nederland ontwapent" hadden voorgedaan.

Ik geloof dus dat de advocaat-generaal niet alleen geen argumenten pro bescherming van de optocht uit "Nederland ontwapent" kon destilleren, maar evenmin argumenten die daartegen pleitten; het arrest ging eenvoudig over iets anders. Hoe dacht de Hoge Raad er zèlf over? De zaak lag kennelijk tamelijk simpel. Hij overwoog dat

"ten deze tevergeefs beroep wordt gedaan op art. 7 Grondwet, omdlat een optocht wel het karakter kan hebben van een demonstratie, doch in zodanig geval de wijze van openbaren van gedachten of gevoelens te zeer verschilt van die, bedoeld in voormeld artikel van de Grondwet, om daarmede op een lijn te kunnen worden gesteld;

dat strijd met art. 7 Grondwet ook niet volgt uit de (...) omstandigheid, dat een demonstratie gepaard kan gaan met het openbaar maken van geschriften door het tonen van borden met teksten (...), reeds omdat (...) art. 101 APV niet medebrengt dat het openbaar maken van geschriften door het tonen van borden met teksten in het algemeen zou zijin verboden of van een voorafgaand verlof der overheid afhankelijk zou zijn gesteld". ${ }^{75}$

Kortom: in de eerste plaats werd een demonstratieve optocht-zèlf niet gelijkgesteld met het openbaren van gedachten of gevoelens door de drukpers, en in de tweede plaats werd zo'n optocht - voor zover het ging om het bekendmaken van op borden getoonde teksten - blijkbaar niet aangemerkt als middel van bekendmaking met zeifstandige betekenis. Zolang "het tonen van borden met teksten" - hetgeen op zichzelf schijnbaar wèl als zelfstandig middel moest worden aangemerkt! - niet in het algemeen was verboden of van een voorafgaand verlof der overheid afhankelijk gesteld, was er (in het licht van art. 7 Gr.w.) geen vuiltje aan de lucht. Gezien de eerdere schreeuw- en roepverboden die, zoals bekend, telkens door de Hoge Raad waren gesauveerd, hoefde die uitkomst geen verbazing te wekken, lijkt mij. ${ }^{76}$ Bleef echter de vraag waarom in het geval van zo"n demonstratie waarin leuzen werden meegevoerd geen sprake was van "een middel van bekendmaking, dat naast andere middelen zelfstandige betekenis heeft en met het oog op die bekendmaking in een bepaalde behoefte kan voorzien". De Hoge Raad bracht die kwestie niet eens ter sprake! En ook in de literatuur 
werd er niet op ingegaan. De meeste aandacht ging uit naar de bescherming van demonstratieve optochten op zich. Geen wonder, want de Grondwet bood destijds in dat opzicht geen enkel ander aanknopingspunt. ${ }^{m}$

"Wellicht kan uit de betrokken arresten ("Nederland ontwapent" en "Vietnam II", RdW) worden afgeleid", aldus Boukema in 196978, "dat volgens de Hoge Raad slechts die wijzen van openbaren van gedachten en gevoelens onder de bescherming van art. 7 vallen, waarbij letters, tekens of symbolen worden getoond die ook op schrift kunnen worden gesteld". Daar lijkt het inderdaad op. Hoewel... Hoe staat het dan met demonstraties waarbij als het ware met mensen (of met de kleur van hun kleding) wordt "geschreven" door ze op een bepaalde wijze te rangschikken? Behalve bij majorettenkorpsen zie je zoiets soms bij massale gebeurtenissen zoals een openingsceremonie van de Olympische spelen. Ieder individu vormt dan een onderdeel van een tekst (bijvoorbeeld: WELCOME). Is art. $7 \mathrm{Gr}$.w. dan opeens weer wèl van toepassing, ook al gaat het om een "optocht"?

\subsection{Intermezzo (1968)}

Onderwijl ging de ontwikkeling langs de al mér gebaande wegen natuurlijk gewoon verder. De jurisprudentie van de Hoge Raad deed de vonnissen van "lagere" rechters zo nu en dan als het ware "resoneren". Zo was in een uitspraak van de Maastrichtse kantonrechter ${ }^{79}$ te lezen dat het lokale reclameen propagandaverbod "in zijn algemeenheid mede omvat gedrukte of geschreven stukken of afbeeldingen, waarin gedachten of gevoelens zijn geopenbaard, zodat, nu volgens constante jurisprudentie art. 7 G.W. ten deze van toepassing is, niemand voorafgaand verlof nodig heeft om door het verspreiden, openlijk tentoonstellen of door enig ander middel, de inhoud van voormelde stukken of afbeeldingen in het openbaar aan het publiek bekend te maken, een en ander behoudens ieders verantwoordelijkheid volgens de Wet".

Waar hadden we die frase ook alweer eerder gelezen? Inderdaad! Vervolgens overwoog de kantonrechter dan ook

"dat echter dit in het openbaar aan het publiek bekend maken, krachtens art. $168 \mathrm{Gem} . w$. aan beperkingen in het belang der openbare orde en wel bepaaldelijk ter beveiliging van het openbaar verkeer kan worden onderworpen, mits die beperkingen niet zover gaan, dat het gebruik van een middel van bekendmaking, dat naast andere middelen zelistandige betekenis heeft en met het oog op die bekendmaking in een bepaalde behoefte kan voorzien, van een voorafgaand verlof der overheid athankelijk wordt gesteld, dan wel wat tijd en plaats betreft 
zodanig wordt beperkt, dat redelijkerwijze aan het middel geen gebruik van enige betekenis wordt gelaten".

Ik denk dat de Hoge Raad wel tevreden was met die formulering. Interessant was echter dat de kantonrechter daar niet mee volstond. Vervolgens boog hij zich namelijk over de vraag of er feitelijk inderdaad "geen gebruik van enige betekenis" werd gelaten. "Weliswaar" maakten de straten en pleinen, waar het verboden was na 12 uur 's middags reclame of propaganda te maken, volgens de kantonrechter "het grootste deel (...) van het eigenlijk centrum der stad (uit), doch dit (is) ook juist het gedeelte (...) waardoor het grote verkeer zich beweegt, terwijl bovendien in de tijd na 12 uur (...) het verkeer - mede door de daarin vallende spitsuren - het grootst is, zodat de onderhavige algemene beperking, die kennelijk de beveiliging van dit verkeer ten doel heeft, zeker als redelijk kan worden beschouwd (...)". Van strijd met art. 7 was, met andere woorden, geen sprake; een beperking die "als redelijk kan worden beschouwd", liet volgens de kantonrechter klaarblijkelijk per definitie tevens ruimte voor "een gebruik van enige betekenis".

Nou ja, dat laatste sprak natuurlijk niet helemaal vanzelf, maar de moeite die deze rechter zich getroostte om behadve het juridische regime tevens de feitelijke stand van zaken erbij te betrekken, was toch tamelijk opmerkelijk. En, gezien de jurisprudentie van de Hoge Raad, consequent, lijkt mij.

Een andere kantonrechter ${ }^{80}$ kwam enkele jaren later tot de conclusie dat de uitzonderingen ten aanzien van het Tilburgse plakverbod niet "van zodanige betekenis (waren) dat zij aan het verbod het algemene karakter zouden kunnen ontnemen". Ook in dàt vonnis was het door de Hoge Raad ingezette deuntje - over "een middel van bekendmaking dat naast andere middelen zelfstandige betekenis heeft" - duidelijk te herkennen. Het betreffende plakverbod kende slechts twee uitzonderingen, namelijk voor:

"a. stukken, waarvan het bevestigen krachtens wettelijk voorschrift of ingevolge opdracht van het daartoe bevoegd openbaar gezag geschiedt;

b. raambiljetten, welke zich binnenshuis bevinden, mits daardoor noch de openbare orde verstoord of bedreigd wordt, noch de goede zeden aanstoot gegeven wordt".

De kantonrechter oordeelde dat die eerste bepaling "voor zich spreekt en als uitzondering op het algemene verbod slechts van zeer geringe betekenis is, terwijl de (tweede) uitzonderingsbepaling geen feitelijke betekenis heeft daar het uiteraard is toegestaan - ook zonder dat zulks uitdrukkelijk zou zijn vermeld - om binnenshuis raambiljetten te bevestigen c.q. bevestigd te hebben voor zover dan de openbare orde daardoor niet wordt verstoord of bedreigd danwel de goede zeden daardoor geen aanstoot wordt gegeven". Vandaar die conclusie dat er geen gebruik van enige betekenis werd gelaten. 
Wie zich het arrest over het Alkmaarse plakverbod ${ }^{81}$ uit het begin van de jaren zestig nog herinnert, zal mogelijk op de gedachte komen dat het allemaal wellicht wat minder evident lag dan de kantonrechter het hier afschilderde. In elk geval was de bewering dat het een ieder in principe vrij stond om binnenshuis raambiljetten op te hangen - en dat de gemeente daar dus nooit aan kon komen - (helaas!) apert onjuist. In 1938 had de Hoge Raad immers een bepaling gesauveerd, waarin onder meer verboden werd "de vanaf den openbaren weg zichtbare (...) ramen (...) te voorzien van geschriften, aanplakbiljetten, tekens, letters, cijfers en afbeeldingen, die uiting geven aan eenig politiek streven". 2 De Ossenaar die een raam van zijn woning had "voorzien van een aanplakbiljet" met de woorden "Mussert of Moskou", kon dan ook zonder bezwaar worden veroordeeld. ${ }^{83}$ Maar afgezien daarvan leek de Tilburgse kantonrechter in zijn eerdergenoemde vonnis - gezien zijn woordkeus en benadering - toch duidelijk uit te zijn op navolging van de Hoge Raad, en dár ging het mij op dit moment om.

\subsection{De manege Rehoboth (1969)}

Het eind van de jaren zestig werd gemarkeerd door een reprise van "Nederland ontwapent". Alleen, deze keer ging het niet over Noord-, maar ZuidHolland. Het $O M$ was in cassatie gegaan omdat de verdachte was ontslagen van alle rechtsvervolging, hoewel hij "te Schipluiden op 8 november 1966 als eigenaar van een in het landelijk deel van die gemeente gelegen erf van het aan de openbare weg (...) gelegen perceel (...) dat erf ten dele (had) aangewend voor het opschrift 'Manege Rehoboth' en de afbeeldingen van een zadel en een paardehoofd, welk opschrift en welke afheeldingen van die openbare weg af zichtbaar waren". ${ }^{84}$ Op grond van de artikelen 1 en 2 van de Verordening bescherming landschap Zuid-Holland was dat verhoden. In grote trekken gold hier namelijk hetzelfde als destijds in Noord-Holland, en eerder (in de jaren '30) in Gelderland en Noord-Brabant. ${ }^{85}$

Waarom ging het $\mathrm{OM}$ dan in cassatie? Was deze materie met "Nederland ontwapent" niet voldoende tot klaarheid gebracht? Prins ${ }^{86}$ gaf in zijn noot onder het arrest een plausibele verklaring:

"Het was na HR 24 jan. 1967, NJ 1967, 270 ("Nederland ontwapent") te verwachten dat een poging zou worden ondernomen ter afwending van de dreigende consequenties van dit arrest voor de bescherming van het landschapsschoon tegen ontsierende reclame. Een kans daartoe leek besloten in HR 30 mei 1967, NJ 1968, 4, een uitspraak die het bestaan veronderstelt van stukken en afbeeldingen, die niet strekken tot openbaring van gedachten of gevoelens, waaronder naar de mening 
van sommigen begrepen zouden zijn stukken enz. op het gebied van de commerciële reclame. Het onderhavige opschrift was in ieder geval goed gekozen, want het behelsde niet anders dan de naam van een op het betrokken erf uitgeoefend bedrijf, geflankeerd door enkele daarmede verband houdende voorstellingen, en kon dus gevoeglijk beschouwd worden als een simpel naambord".

De waarnemend advocaat-generaal (Kist) vroeg zich in zijn conclusie inderdaad af of "Nederland ontwapent"

"niet de mogelijkheid openlaat dat een verbod als waarvan toen, en ook nu, sprake is, door Uw Raad verbindend wordt geacht, indien het gaat om een opschrift dat geen gedachten of gevoelens openbaart. De rechter past immers het recht, i.c. het verordeningsartikel, toe op het concrete geval en is niet verplicht te doen blijken dat zijn oordeel in een ander concreet geval (bijv. zoals i.c. t.a.v. de verbindendheid van een verordeningsartikel) om een bepaalde reden anders zou zijn".

Het bleek een retorische vraag, want de uitkomst van zijn betoog was dat het verbod zou moeten worden gesplitst "in een wel en een niet verbindend gedeelte, naar gelang van de aard van de betrokken opschriften, aankondigingen of afbeeldingen". Voor zover er gedachten of gevoelens in het geding waren, zou de bepaling met andere woorden onverbindend zijn, maar voor het overige moest zij, naar zijn oordeel, gewoon verbindend worden geacht. Dat was ook in andere zaken wel gebeurd, zo betoogde hij. Wat art. $7 \mathrm{Gr}$.w. betreft had hij daarbij nog op een oud arrest uit 1897 kunnen wijzen. ${ }^{87}$ Sinds het arrest van 9 januari 1968, NJ 1968, 105 (Maastrichts schakelkastje) was die opvatting echter nauwelijks meer te handhaven, zoals Prins volgens mij terecht opmerkte in zijn noot.

De Hoge Raad kwam dan ook tot een ander resultaat. Laat ik echter, met het oog daarop, eerst even de betreffende bepalingen weergeven (voor zover ze hier althans van belang waren):

"Art. 1. 1. Het is de eigenaar of gebruiker van enig onroerend goed in het landelijk deel van een gemeente verboden:

$a$. dit goed geheel of ten dele aan te wenden of de aanwending daarvan te gedogen voor opschriften, aankondigingen of afbeeldingen, die van een openbare weg, een openbaar vaarwater of een andere voor het publiek toegankelijke plaats af zichtbaar zijn; (...)

Art. 2. 1. Het verbod, gesteld in art. 1 is niet van toepassing: (...)

f. op opschriften, aankondigingen of afbeeldingen binnenshuis, voor zover het pand als winkel, toonzaal, café, restaurant, werkplaats en/of garage wordt gebruikt; 


\section{g. $(\ldots)$;}

h. op aankondigingen en opschriften op zuilen, borden en muren, welke daarvoor door de overheid zijn aangewezen".

Welnu, om te beginnen constateerde de Hoge Raad

"dat art. 1, eerste lid, aanhef en onder a, van de Verordening mede bestrijkt het aanwenden van enig onroerend goed als in die bepaling bedoeld voor opschriften, aankondigingen of afbeeldingen als in die bepaling omschreven waarin gedachten of gevoelens zijn geopenbaard".

Dat betekende, zo ging hij verder, dat "het bezigen van een onroerend goed voor het aanwezig hebben van opschriften, aankondigingen of afbeeldingen welke - kort gezegd - vanaf een voor het publiek toegankelijke plaats zichtbaar zijn" verboden was. En aangezien het daarbij ging om een middel van bekendmaking met zelfstandige betekenis ${ }^{88}$, was er aanleiding nog eens alle geijkte frasen op te lepelen, uitmondend in de inmiddels welbekende conclusie. Vervolgens overwoog de Hoge Raad, én en ander op de voorliggende casus toepassend:

"dat mitsdien de omstandigheid dat de werking van genoemde bepaling, naar in het middel wordt gesteld, is 'beperkt' tot onroerend goed, niet belet dat aan die bepaling verbindende kracht moet worden ontzegd indien bedoeld aanwenden in het algemeen wordt verboden of van een voorafgaand verlof der overheid athankelijk wordt gesteld; dat de in art. 2 Verordening vermelde gevallen, waarin het verbod, gesteld in art. 1, niet van toepassing is, niet van zodanige betekenis zijn dat zij aan laatstbedoeld verbod een algemeen karakter zouden vermogen te ontnemen;

dat art. 2, eerste lid, sub $f,(\ldots)$ slechts betrekking heeft op opschriften, aankondigingen of afbeeldingen 'binnenshuis' en dan nog slechts 'voor zover het pand als winkel, toonzaal, cafe, restaurant, werkplaats en/of garage wordt gebruikt';

dat art. 2, eerste lid, sub $h(. .$.$) slechts betrekking heeft op aankondi-$ gingen en opschriften op zuilen, borden en muren, "welke daarvoor door de overheid zijn aangewezen';

dat in het bijzonder de hierboven tussen aanhalingstekens gezette omstandigheden medebrengen dat aan gemelde bepalingen een slechts zo geringe betekenis kan worden toegekend dat zij niet geacht kunnen worden het in art. 1, eerste lid, aanhef en sub a, vermelde verbod op zodanige wijze in te perken dat aan dat verbod het karakter van algemeenheid zou worden ontnomen".

Bovendien was het verbod "in zodanige algemeen luidende bewoordingen (...) vervat, dat daarin onvoldoende aanknopingspunt (was) te vinden voor 
een splitsing" als gesuggereerd door de advocaat-generaal.

Dat laatste wees er volgens De Meijs op dat de Hoge Raad het betreffende opschrift inderdaad niet als openbaring van "gedachten of gevoelens" aanmerkte - anders kon zo'n splitsing immers "reeds" op die grond geen hout snijden. Daar zit wat in, lijkt mij. Maar op een ander punt moet ik De Meij helaas afvallen. En dan doel ik niet op zijn bewering dat het arrest van 14 januari 1969 ("Rehoboth") én jaar later werd gewezen dan het arrest van 24 januari 1967 ("Nederland ontwapent"). ${ }^{90}$ Immers, zoals Popper ${ }^{91}$ ooit schreef:

"I (...) believe that clarity is an intellectual value since, without it, critical discussion is impossible. But I do not believe that exactness or precision are intellectual values in themselves; on the contrary, we should never try to be more exact or precise than the problem before us requires".

Geen kwaad woord dus over die rekensom, want die is wat mij betreft irrelevant. Nee, het gaat mij om de volgende passage:

"Dat de Hoge Raad (...) ook wel eens zelf het spoor bijster raakt, blijkt uit de overweging in het laatstgenoemde arrest ("Rehoboth", $\mathrm{RdW}$ ) dat de beperking van het verbod tot onroerend goed niet van zodanige betekenis is, dat hierdoor aan het verbod het algemene karakter wordt ontnomen. Zo worden echter het zelfstandige verspreidingsmiddel en de daarop toegestane beperkingen door elkaar gehaald". ${ }^{2}$

Vreemd... Een dergelijke overweging is in dat hele arrest nergens te vinden! Zeker, het $O M$ had in zijn cassatiemiddel onder meer angevoerd dat "de werking van genoemde Verordening beperkt is tot onroerend goed". Maar de Hoge Raad zag daar juist in het geheel geen beperking in. Het betreffende "middel van bekendmaking" werd immers, zoals in het arrest is na te lezen, zelf als iets onroerends omschreven: het ging om "het bezigen van een onroerend goed"! Vandaar dat het woordje "beperkt" door de Hoge Raad tussen aarhalingstekens werd geplaatst. Niet de "beperking" tot onroerende zaken (zoals we tegenwoordig zouden zeggen) werd als onvoldoende aangemerkt om het algemene karakter aan het verbod te ontnemen, maar hetgeen op grond van art. 2 van het verbod werd uitgezonderd. Hier past wellicht een woord uit het Weekblad van het Recht ${ }^{\text {93: }}$

"Wij verheugen er ons over, dat de beslissingen van ons hoogste rechterlijk college voortdurend aan kritiek worden onderworpen; maar het is niet te veel gevergd, dat zij, die deze kritiek ondernemen, zich vooraf goed op de hoogte stellen van 's Hoogen Raads rechtspraak". Ik denk, eerlijk gezegd, dat het arrest om een heel andere reden opmerkelijk is. En wel, precies om datgene wat er met zoveel woorden in te lezen is, te 
weten: "dat de in art. 2 Verordening vermelde gevalten, waarin het verbod, gesteld in art. 1, niet van toepassing is, niet van zodanige betekenis zijn dat zij aan laatstbedoeld verbod een algemeen karakter zouden vernogen te ontnemen". Raar dat daar - voor zover ik weet - nooit op gewezen is. Eén van die uitzonderingen betrof immers "aankondigingen en opschriften op zuilen, borden en muren, welke daarvoor door de overheid zijn aangewezen". Iets soortgelijks gold in die "Mussert of Moskou"-zaak uit de gemeente Oss ${ }^{94}$, waar ik onder 5.5 aan herinnerde. Alleen, dàt plakverbod werd juist door die van overheidswege aangewezen plaatsen gered. De Hoge Raad overwoog destijds kortweg dat de APV-bepaling "enkel (verbood) het openbaar maken met de daarin vermelde middelen op andere plaatsen dan de door B. en W. aangewezen, hetgeen niet in strijd is met art. 7 der Grondwet". Eénendertig jaar later haalde hij, kortom, bakzeil - maar niet voor lang, zoals we nog zullen zien. ${ }^{95}$ 


\section{Hoofdstuk 6 De jaren zeventig: luwte}

Er brak een luwte aan: weinig zaken, en (voor zover ze er al waren) nauwelijks iets nieuws. Alweer "een teken des tijds", net als in de jaren dertig? Waren alle controverses - vanuit de praktijk beschouwd - inmiddels voldoende beslecht? Of ging het om een stilte voor de storm?

\subsection{Gedachten of gevoelens: "Huifkar" (1972)}

Een vervolg op "Rehoboth" kwam pas op 18 januari $1972 .{ }^{1}$ Na Noord- en Zuid-Holland waren we nu in Zeeland beland. De bepaling in kwestie was vrijwel letterlijk gelijk aan de vorige. In én opzicht was er niettemin een belangrijk verschil. Alleen, daarmee is tevens aangegeven waarom de zaak hier slechts zijdelings van belang is. Onder de uitzonderingen op het verbod werden deze keer namelijk "opschriften, aankondigingen en afbeeldingen" genoemd, "welke dienen tot het openbaren van gedachten of gevoelens, als bedoeld in art. 7 Grondwet". Op die manier was strijd met het grondwetsartikel heel listig op voorhand al uitgesloten. De enige vraag die in dat verband nog overbleef, was of in een concreet geval inderdaad sprake was van "het openbaren van gedachten of gevoelens". Dan gold het verbod immers niet. Zo had in Hulst "de eigenaar en gebruiker van een onroerend goed, te weten een perceel weiland, gelegen langs de Absdaalseweg aldaar, op dat weiland een opschrift (...) gehad, namelijk een bord - welk bord door middel van twee palen op dat weiland was geplaatst - voorzien van de in duidelijk leesbare letters aangebrachte tekst: 'Café-Restaurant de Huifkar - Rombouts Koffie - Na 100 meter linksaf', terwijl dat bord met die tekst vanaf de Absdaalseweg (...) zichtbaar was". Ging het daarbij om "het openbaren van gedachten of gevoelens"? Het antwoord van de kantonrechter was ontkennend, "blijkende ook niet uit de opgave van verdachte aan verbalisanten dat deze daarop een beroep heeft gedaan". En de Hoge Raad overwoog dat de kantonrechter, "wat er zij van de hiervoor door hem aangevoerde (...) gronden, het bewezenverklaarde terecht strafbaar heeft verklaard". Kortom: het bord behelsde geen uiting van "gedachten of gevoelens" in de zin van art. 7 Gr.w., anders was van strafbaarheid geen sprake geweest. ${ }^{2}$ Waarom dat zo was, werd echter niet uit de doeken gedaan. Er moest - na zoveel duidelijkheid - kennelijk iets te gissen overblijven... Ging het om commercjele reclanne? Kwamen daar geen "gedachten en gevoelens" in de zin van 
art. $7 \mathrm{Gr}$.w. aan te pas? Prins twijfelde:

"Commerciële reclame", schreef hij in zijn noot onder het arrest, "kan naar mij dunkt zonder veel moeite gestoken worden in het beschermend gewaad van de meningsuiting. Recente ervaring ${ }^{3}$ leert, dat zelfs de simpelste aankondiging van een bepaald merk koffie (zoals toevallig in het onderhavige opschrift voorkwam) onder omstandigheden als provocatief kan worden opgevat".

Was dàt inderdaad waar het op aankwam? Waren uitingen van gedachten of gevoelens per se "provocatief"? Of ging het hier slechts om een voorbeeld? Laten we het dáár maar op houden. Ik denk tenminste dat er weinig twijfel over bestond dat $66 \mathrm{k}$ allerlei niet provocerende handelsreclame - zoals affiches van Toulouse Lautrec, Mucha, Steinler en "onze eigen" Piet Zwart en Paul Schuitema - zonder meer als uitingen van "gedachten of gevoelens" moesten worden aangemerkt.

In die zin waren de bezwaren van Prins dus nog danig uit te breiden. De Meij ${ }^{4}$ meende niettemin dat handelsreclame op grond van de jurisprudentie "in vele gevallen" buiten de bescherming van art. $7 \mathrm{Gr} . w$. viel. Maar, zo voegde hij eraan toe, "de grens zal niet altijd gemakkelijk te trekken zijn". En waar het precies van afhing of iets aan de ene kant van die grens terechtkwam, dan wel aan de andere, maakte ook hij niet duidelijk.

Opvallend was in eik gevai dat de artistieke vormgeving van het bord voor de Hoge Raad blijkbaar niet relevant was. Of hoefde daar slechts naar gekeken te worden als de verdachte er een beroep op had gedaan? Moeilijke vraag! Nú werd in elk geval de indruk gewekt dat louter de aard van de mededeling beslissend was. Boon leidde daaruit af dat er dus "kennelijk feitelijke mededelingen (curs. RdW) (waren) die buiten het begrip 'gedachten of gevoelens' (vielen)". Alle "feitelijke mededelingen"? Dat lag niet voor de hand, want dan zou een groot deel van de krant eveneens buiten het bestek van art. 7 vallen. ${ }^{6}$ Maar welke mededelingen dan wel? En vooral: op welke gronden? Waaraan kan de rechter aflezen of er gedachten of gevoelens in de zin van art. $7 \mathrm{Gr}$.w. in het spel waren? Was dat bovendien een taak voor de feitenrechter, of kon de Hoge Raad er ook zelf over oordelen? We konden er slechts naar raden.

\subsection{Invuloefening (1975)}

Inmiddels was er in zoverre sprake van een "leer" dat duidelijk was geworden dat telkens dezelfde vragen werden opgeworpen. Hoe ze beantwoord zouden worden, was minder duidelijk. Maar er waren vaste sjablones ontstaan. Eerst kwam de ene kwestie aan de orde, dan pas de andere. Ik heb 
daar al eerder op gewezen. Toen kwalificeerde ik het als een verrijking van het debat: het bood immers aanknopingspunten voor tegenspraak. Tegelijkertijd was er natuurlijk een vorm van verschraling in te herkennen: alles werd over én kann geschoren. Wel makkelijk, maar niet altijd even subtiel. Dat maakt het soms wat ingewikkeld om aan oningewijden uit te leggen hoe de vork precies in de steel zit. Het Veenendaalse sinaasappel-kraampje biedt daar een aardig voorbeeld van. In het kader van de "Boycot Outspan Aktie" kon men daar, tegen betaling van een kwartje, met een rotte sinaasappel op de kaart van Zuid-Afrika mikken. Wie raak gooide, ontving een goede sinaasappel. In Veenendaal was het echter

"zonder vergunning van $B$. en $W$. verboden:

a. op wegen (niet zijnde rijks- of provinciale wegen) of van deze wegen toegankelijk en vanaf de openbare weg zichtbaar (...) een wagen, kraam, keet, loods of ander dergelijk voorwerp te plaatsen, op te richten of te hebben, teneinde daaraan, daaruit of daarin voorwerpen of waren, van welke aard ook, aan het publiek aan te bieden, te verkopen of te verstrekken;

b. op of boven de onder a bedoelde wegen koopwaar te plaatsen of uit te stallen".

Dus werd de actievoerder, die geen vergunning had aangevraagd, veroordeeld tot $f 25$,- boete, omdat hij

"op de voor het publiek toegankelijke weg (...) (niet zijnde een rijksof provinciale weg) koopwaar, t.w. een of meer kisten met sinaasappelen, heeft geplaatst en/of heeft uitgestald, zulks zonder vergunning van B. en W. dier gemeente".

Het verweer dat hier in het geheel geen sprake was van "koopwaar", mocht niet baten:

"Door betaling van $f 0,25$ kon het publiek een rotte sinasappel verkrijgen", aldus de rechtbank. "Met welk doel het publiek bereid was een dergelijke transactie an te gaan kan in het midden blijven, omdat in ieder geval door het openstellen van de mogelijkheid om een dergelijke transactie aan te gaan rotte sinaasappelen aldus koopwaar werden in de gangbare betekenis van dat woord".

Of dat op de markt werkelijk de "gangbare betekenis" was, lijkt mij twijfelachtig. In ieder geval zullen er, naar ik aanneem, weinig mensen op het kraampje zijn toegesneld met het oogmerk eens flink wat lekkere rotte sinaasappelen in te slaan. Nietternin was er volgens de advocaat-generaal (Remmelink) niets af te dingen op het oordeel van de rechtbank, en de Hoge Raad sloot zich daarbij aan. ${ }^{8}$ Daarna kon de zalak met een eenvoudige herhaling van "Vietnam II"9 worden afgedaan (voor zover het althans art. 7 Gr.w. betrof); de Hoge Raad overwoog: 
"dat in geval het plaatsen of uitstallen van koopwaar (...) op of boven wegen (...) het karakter heeft van een demonstratie, de wijze van openbaren van gedachten of gevoelens te zeer verschilt van die bedoeld in art. $7 \mathrm{Gr} . w$. om daarmede op een lijn te kunnen worden gesteld".

Voor zover het "plaatsen of uitstallen" geen demonstratief karakter had, lag het dus misschien onder omstandigheden - denk bijvoorbeeld aan een boekenkraam - anders. In dit geval, echter, ging het - net als een optocht - te ver voor art. 7. Het leek te weinig op openbaren "door de drukpers". Had het anders gelegen wanneer de gehavende en besmeurde kaart van ZuidAfrika naderhand als "protest-kunstwerk" zou zijn tentoongesteld? ${ }^{10}$ Dan hadden we immers te maken met een vorm van "action-painting" en was het verband met de drukpers opeens overduidelijk geweest. Of niet? ${ }^{11}$

Hoe dan ook, deze keer gaf het demonstratieve karakter de doorslag. Alleen, waarom richtte alle aandacht zich eigenlijk op de gewraakte gedraging? Weliswaar ging het cassatiemiddel daarover, maar dat ontsloeg de Hoge Raad niet van de verplichting - ambtshalve - $60 \mathbf{k}$ op de APV-bepaling te letten. Vooral nu daar - eveneens in verband met art. $7 \mathrm{Gr}$.w. - volgens de toenmalige opvattingen het nodige op leek af te dingen. Het vergunningvereiste betrof immers alle koopwaar - dus bók gedrukte stukken of afbeeldingen waarin gedacnten or gevoelens weroen geopenoaard: Ging dăt niet wat ver? Ongetwijfeld, tenminste wanneer het op of boven de weg "plaatsen of uitstallen" van te koop aangeboden gedrukte stukken of afbeeldingen als middel van bekendmaking met zelfstandige betekenis moet worden aangemerkt. Maar het gevolg daarvan zou zijn dat de bepaling in haar geheel onverbindend was. Want zij was evident "in zodanige algemeen luidende bewoordingen vervat, dat daarin onvoldoende aanknopingspunt was te vinden voor een splitsing" in een onverbindend gedeelte (betreffende drukwerk) en een verbindend gedeelte (betreffende andere zaken).

Nu de verdachte evenwel niet van rechtsvervolging werd ontslagen, moeten we het er op houden dat de verbodsbepaling wel degelijk verbindend werd geacht. Strikt genomen betekent dat, dat de Hoge Raad ofwel "het op of boven de weg plaatsen of uitstallen van te koop aangeboden gedrukte stukken of afbeeldingen" niet als middel van bekendmaking met zelfstandige betekenis wenste aan te merken, ofwel dat hij de leer van de onsplitsbare wilsverklaring op een andere wijze toepaste dan de literatuur ons voorhield. ${ }^{12}$ Zelfs een simpele uitspraak als deze leverde op die manier meer vragen dan antwoorden op. ${ }^{13} \mathrm{Zij}$ werden echter niet gesteld. 


\subsection{De grondwetsherziening (1976-1979)}

Op 2 april 1976 diende de regering een voorstel tot wijziging van de Grondwet in. Het toenmalige art. 7 zou worden uitgebreid met drie leden, die uiteindelijk ook woordelijk zo in het Staatsblad terecht zijn gekomen. ${ }^{14}$ Het voorstel om art. 7 in het nieuwe grondwetsartikel een plaatsje als eerste lid te gunnen, werd door de regering als volgt toegelicht:

"Wij staan op het standpunt de noodzakelijke voorwaarden voor het behoud van de zogenaamde verspreidingsjurisprudentie onaangetast te moeten laten. Hieraan menen wij het beste te kunnen voldoen door de huidige formulering van artikel 7 voor de drukpers ongewijzigd te handhaven" ${ }^{\text {". }}{ }^{5}$

Maar een tekst ontleent zijn betekenis natuurlijk niet alleen aan hetgeen er staat; ook wat er niet staat, is van belang. En het oude artikel 7 werd nu eenmaal niet geflankeerd door de leden $2 \mathrm{t} / \mathrm{m} 4$. Daardoor rezen er afbakeningsproblemen. Het nieuwe lid 4, waardoor handelsreclame buiten de boot valt, is bijvoorbeeld veel stelliger geformuleerd dan tot dusver uit de jurisprudentie ten aanzien van drukwerk e.d. viel af te leiden. Zelfs De Meij, die (zoals we al zagen) in dit opzicht het verst ging, was terughoudender ${ }^{16}$ :

"Valt op grond van de besproken jurisprudentie alle handelsreclame buiten de bescherming van art. 7 Grondwet? In vele gevallen wel lijkt mij, maar de grens zal niet altijd gemakkelijk te trekken zijn" (curs. RdW).

Zijn conclusie ten aanzien van het nieuwe grondwetsartikel sloot daarop aan $^{17}$ :

"Voor de handelsreclame verandert daarmee de juridische positie niet noemenswaard. Voor de rechter zijn de afbakeningsproblemen echter duidelijk eenvoudiger geworden. Moest hij op grond van art. 7 onderzoeken of een reclamebord wellicht (mede) een gedachte of gevoelen inhoudt, nu zal hij slechts moeten beslissen of er sprake is van handelsreclame".

Ik ben het daarmee eens, zij het dat de formulering wat ongelukkig is uitgevallen. De vraag of er "gedachten of gevoelens" in het spel zijn, blijft immers $66 \mathrm{k}$ ten aanzien van het nieuwe eerste lid ( $=$ art. 7 oud) van beiang - anders is die bepaling eenvoudig niet van toepassing! Maar inderdaad, zodra het om handelsreclame gaat, komt art. 7 niet meer aan de orde - de vraag of er tevens "gedachten of gevoelens" geopenbaard worden, hoeft in dat geval (in principe) niet eens meer gesteld te worden.

Ook ten aanzien van het tweede en derde lid doet zich zo'n afbakeningskwestie voor. "In de jurisprudentie op artikel 7 Grondwet worden", zo is in 
de memorie van antwoord aan de Eerste Kamer te lezen ${ }^{18}$, "bandopnamen, grammofoonplaten, video-tapes en filmrollen niet onder 'drukpers' begrepen". Helaas ben ik geen enkel geval op het spoor gekomen, waarin die kwestie was beslecht. De jurisprudentie had, voor zover ik weet, realiter in alle talen gezwegen over deze materie. Wel had Van den Bergh er in 1940 ooit een tijdschriftartikel aan gewijd. ${ }^{19}$ Alleen, hij kwam toen juist tot het tegenovergestelde resultaat! Immers:

"Wat is het principiële verschil, of ik de gedachten en gevoelens vastleg met grote aantallen inktmoleculen op papier of door microscopische gaatjes en bolletjes in een wasrol of (de allermodernste vorm) met zilvermoleculen op celluloid?"20

Tammes en Duynstee ${ }^{21}$, daarentegen, spraken zich in 1949 inderdaad voor een beperktere uitleg uit - Duynstee overigens iets minder absoluut dan Tammes. Boukema ${ }^{22}$, tenslotte, gaf weliswaar toe "dat art. 7 een uitwerking is van een meer algemeen beginsel, maar de tekst van art. 7 verzet zich er tegen aan te nemen, dat dit algemeen principe in het artikel reeds volledig is neergelegd". Hij beriep zich daarbij met name op het arrest over het Vestigingsbesluit Grafische bedrijven uit $1961^{23}$, waarin de Hoge Raad het had over een "met de drukpers in eigenlijken zin op éen lijn te stellen vermenigsvuldigingstechniek". Daaruit leidde hij af "dat de gedachten en gevoeilns, op weike wijże aán ook', op scrirıft (moesten) zijn gesteld". Waarom het één noodzakelijkerwijs uit het ander volgde, is mij echter niet duidelijk. Ook onder handhaving van de later inderdaad bij herhaling terugkerende eis dat het betreffende middel "op een lijn" gesteld kan worden met openbaringen door de drukpers, was volgens mij op zich verdedigbaar dat bandopnames, grammofoonplaten, video-tapes en filmrollen - in elk geval onder omstandigheden - bescherming op grond van het oude art. 7 genoten. Waarom zouden zij immers nooit op één lijn met produkten van de drukpers te brengen zijn? De memorie van antwoord was op dit punt, met andere woorden, wat al te stellig, zou ik zeggen. Ongemerkt werd er op die manier van het oude art. 7 iets afgeknabbeld.

En passant werd er overigens ook iets aan toegevoegd. Had Van den Bergh in 1939 nog betoogd dat "zuiver feitelijke mededelingen" buiten de sfeer van art. 7 vielen ${ }^{24}$, en bood ook de latere jurisprudentie wel aanknopingspunten voor die opvatting ${ }^{25}$, de regering bleek daar aanzienlijk genuanceerder over te denken:

"Een wezenlijk doel van artikel 7 Grondwet", aldus de regering ${ }^{26}$, "was en is het bieden van garanties voor de persvrijheid. Elementair voor het functioneren van de persvrijheid is de vrijheid (feitelijke) informatie te verschaffen. bovendien zijn vaak feitelijke informatie en nieuwsanalyse, opinie en commentaar niet te scheiden. De selectie van 
feiten en het kader waarin ze worden gepubliceerd geven aan de informatie veeleer het karakter van een meningsuiting. Wij menen daarom, dat ook het openbaren van feitelijke mededelingen of inlichtingen in het algemeen onder het begrip 'openbaren van gedachten of gevoelens' valt. Er zijn echter gevallen denkbaar waarin het geven van inlichtingen zozeer buiten de sfeer van het artikel is gelegen, dat toepassing van het artikel oneigenlijk zou aandoen. Te wijzen valt bijvoorbeeld op de vermelding van de samenstelling van een produkt op een verpakking".

Hoewel het oude art. 7 in de nieuwe gedaante geheel en al behouden bleef, was er in zekere zin dus toch sprake van een wijziging. De "overname" geschiedde niettemin onder het motto dat alles bij het oude bleef. Wie inzicht wilde verwerven in de stand van de jurisprudentie, leek dus te rade te kunnen gaan bij de kamerstukken. Vertekening lag daardoor op de loer. We zullen zien of zij heeft toegeslagen.

\subsection{Plakverbod: Hengelo (1977)}

Met het Hengelose plakverbod werd vervolgens de toon gezet voor het komende decennium. In feite was het een reprise van de Alkmaarse zaak ${ }^{27}$ waarmee de reeks van de jaren zestig werd geopend. Waar in Alkmaar echter schriftelijke toestemming van de rechthebbende nodig was om te plakken e.d., was het in Hengelo

"verboden de weg of eens anders eigendom voor zover dit eigendom van de weg af zichtbaar is, wederrechtelijke te beschrijven, te bekrassen of te bekladden, dan wel de weg of dat eigendom op andere wijze te verontreinigen".

Feitelijk een mildere variant, kortom. In Hengelo werden lichtere eisen aan plakkers en kladderaars gesteld dan in Alkmaar; zij hadden geen schriftelijke toestemming nodig. Bovendien moesten degenen die in Alkmaar 's avonds laat met plakspullen over straat liepen, aantonen dat ze niet net illegaal hadden geplakt of van plan waren dat te doen. In Hengelo ging je al vrijuit "indien deze voorwerpen of stoffen" daartoe "niet zijn gebezigd, of niet zijn bestemd". Dat maakte het voor de vervolgende instanties heel wat lastiger. Geen wonder dat het Hengelose verbod door de beugel bleek te kunnen ${ }^{28}$; de Alkmaarder variant was immers ó́k geoorloofd.

De kantonrechter had die Alkmaarder zaak klaarblijkelijk goed bestudeerd. Het Hengelose verbod leverde volgens hem - geheel in het spoor van de Hoge Raad - geen strijd met art. 7 Gr.w. op,

"nu de betreffende bepalingen slechts een zodanige verspreiding 
treffen waarbij andermans eigendom op de weg beschadigd of veronitreinigd wordt".

Daarnaast overwoog hij ${ }^{29}$ echter (deze keer zijn eigen inzicht volgend), "dat aldus niet alleen andere voortbrengselen van de drukpers dan aanplakbiljetten vrijelijk kunnen worden verspreid, doch er ook t.a.v. aanplakbiljetten verspreidingswijzen overblijven, zoals het meedragen daarvan, bijv. als 'sandwichman', alsmede het aanbrengen op eigendommen van verdachte en diens medestanders;

dat door de bewuste APV artikelen, welke slechts een bescherming van (andermans) eigendom beogen, er gebruik van middelen van enige betekenis overblijft".

Naar de precieze betekenis hiervan kunnen we slechts raden. Wellicht zag hij het plakken e.d. niet als middel van bekendmaking met zelfstandige betekenis. Wellicht! Ik ben bang dat het ene middel van bekendmaking in zijn visie eenvoudig gecompenseerd kon worden door het andere. Vandaar ook die rare siotzin, denk ik, waarin hij overweegt dat er "gebruik van middelen (curs. RdW) van enige betekenis overblijft". "Tja, het wordt een beetje een eentonig verhaal: telkens weer diezelfde vergissing...

En het wordt zelfs nòg eentoniger. Want ook Remmelink betoogde in zijn conclusie dat de verdachte "in dit geval gebruik (had) moeten maken van een andere - verwante - propagandamethode, bijv. door middel van sandwichman". ${ }^{30}$ Voor het overige verwees hij echter gewoon naar de afdoening van die Alkmaarder zaak, waarin het plakverbod toelaatbaar werd verklaard, nu het "uitsluitend beoogt zodanig aanplakken en bevestigen tegen te gaan, indien daardoor eens anders recht zou worden geschonden"."

"Het komt mij voor", aldus Remmelink, "dat deze uitspraak van Uw Raad aldus moet worden verstaan, dat Uw Raad aanvaardt dat deze methode van propaganda maken derhalve langs deze weg wel eens geheel onmogelijk gemaakt zou kunnen worden, wanneer de betrokken propagandisten geen 'wanden' hebben, waar ze hun materiaal kunnen plakken, noch van de kant van de gemeente of andere rechthebbenden toestemming krijgen om elders te plakken. Het is echter duidelijk, dat een dergelijke situatie gevoeglijk als een casus non dabilis beschouwd kan worden".

Dit thema zou de komende jaren nog bij herhaling worden aangeroerd. De Hoge Raad verschafte voorlopig echter weinig duidelijkheid. Zelfs de vraag welk middel (of: welke middelen) van bekendmaking met zelfstandige betekenis hier precies in het geding was (waren), werd in het midden gelaten. ${ }^{32}$ Volstaan werd met de standaardoverweging dat beperkingen niet zover mogen gaan "dat het gebruik van een (curs. RdW) bepaald middel van bekendmaking. dat naast andere middelen zelfstandige betekenis heeft en met het 
oog op die bekendmaking in een bepaalde behoefte kan voorzien, in het algemeen zou worden verboden of van voorafgaand verlof der overheid afhankelijk wordt gesteld". En pal daarop volgde de mededeling dat in dit geval "deze grens niet is overschreden". Daarom werd het betoog afgerond met de overweging:

"dat toch dit samenstel van bepalingen slechts medebrengt een beperking van het gebruik van bepaalde middelen van bekendmaking voor zover door het gebruik daarvan eens anders recht zou worden geschonden en voor het overige elk gebruik van middelen van bekendmaking onverlet laat".

Merkwaardig! Duidt die laatste zinsnede, waarbij de Hoge Raad zich kennelijk door de kantonrechter heeft laten inspireren, erop dat het ene middel nu opeens well tegen het andere mocht worden ingeruild? ${ }^{33}$ Misschien, maar zo hoef je die zinsnede niet te begrijpen. De omstandigheid dat de betreffende beperking voor het overige elk gebruik van middelen van bekendmaking onverlet laat", kan immers $6 \sigma \mathrm{k}$ in verband worden gebracht met hetgeen er direct aan voorafgaat. Dat wil zeggen dat - afgezien van dit specifieke gebruik van bepaalde middelen van bekendmaking (zoals "plakken") - elk gebruik van middelen van bekendmaking (dus $66 \mathrm{k}$ van deze middelen!) "onverlet" wordt gelaten. En dan hebben we in principe dezelfde uitkomst bereikt als in "Alkmaar". Waarom in het ene geval de ene formulering is gevolgd, en in het andere geval de andere, blijft op die manier weliswaar onopgehelderd, maar misschien gaat het daarbij slechts om een kwestie van stijl - geen van de raadsheren (waaronder éen dame), die het arrest over Hengelo wezen, maakte in 1960 (toen "Alkmaar" aan de orde was) deel uit van de Hoge Raad.

\subsection{Collecteverbod: Eindhoven (1978)}

Dat we niet alleen maar met een herhaling van zetten te doen hadden - of liever: dat sommige zetten tot verrassende consequenties yoerden - bleek in. 1978. Volgens art. 44 van de Eindhovense APV was het "slechts met vergunning van B. en W. (...) toegestaan op of aan de weg of aan de huizen een inzameling van geld of goederen te houden". En:

"Onder inzameling van geld of goederen wordt mede verstaan het daartoe aanbieden van bonnen, speldjes, prentbriefkaarten, kalenders, briefpapier of dergelijke voorwerpen, alsmede van snuisterijen en versnaperingen".

Een collectant die - zonder vergunning - huis aan huis "een inzameling van geld (had) gehouden door het toen aldaar aan de bewoners van genoemde 
huizen aanbieden van krantjes waarbij gelijktijdig een geldelijke bijdrage werd gevraagd", liep op grond van die bepaling een boete van $f 25,-$ op (met verbeurdverklaring van de in beslag genomen voorwerpen). Remmelink stelde zich in zijn conclusie de vraag of er eigenlijk wel een "inzameling" in het spel was ${ }^{34}$ : "Men zou zich nl. kunnen afvragen of hier wellicht niet sprake was van 'venten' met gedrukte stukken, waarop de APV (videte art. 45, lid 2) niet van toepassing (was)". Maar er was, naar zijn oordeel, geen twijfel mogelijk. Dat bleek uit de verklaringen van enkele bewoners in het voor het bewijs gebezigde proces-verbaal, meende hij:

"Zo verklaart Henrica W. van Iersel, dat req. haar een vrijwillige bijdrage vroeg voor een krantje, waarna zij een krantje kocht en de man een gulden gaf. Het is duidelijk, dunkt mij, dat de gegeven gulden onder deze omstandigheden niet als contraprestatie hoeft te worden aangemerkt. voor het krantje, zulks ondanks de term 'kocht'. En de bewoner Alfred Broekman verklaart: Hij, req. zei hem, Broekman, dat hij, als hij een krantje wilde hebben, dat krantje tegen een vrijwillige bijdrage kon krijgen. Ook dit is een terminologie die niet duidt op een normale kooptransactie".

Daar lijkt inderdaad weinig op af te dingen. Vond hij het in de Veenendaalse Boycot Outspan-zaak nog aannemelijk dat er mensen waren die rotte sinaasappels wilden kopen ${ }^{35}$, intussen was op dit punt kennelijk toch een vorm van realisme bij hem doorgebroken...

Goed dan, een collecte. Daarmee was de zaak, wat Remmelink betreft, voor elkaar. En er was ook weinig reden er langer bij stil te staan. Een middel van cassatie was door (of namens) de verdachte immers niet voorgesteld. De Hoge Raad, echter, zag aanleiding om ambtshalve in te grijpen. Dat gebeurt slechts bij hoge uitzondering, als er tenminste niet tevens een middel is voorgesteld ${ }^{36} \mathrm{Er}$ was dus kennelijk iets heel belangrijks aan de hand. Welnu, gelet op de nadere omschrijving van het begrip "inzameling", overwoog de Hoge Raad:

"dat (...) het (...) voorschrift dat zulk een inzameling op of aan de weg of aan de huizen slechts is toegestaan met vergunning van B. en W. ook betreft het aanbieden van gedrukte stukken waarin gedachten of gevoelens worden geopenbaard;

dat gemeld voorschrift aldus raakt een middel tot verspreiding van die gedrukte stukken, namelijk het aanbieden - zij het dan bij gelegenheid van een inzameling van geld of goederen - van die stukken, hetwelk, naast andere, zelfstandige betekenis heeft en met het oog op die verspreiding in een bepaalde behoefte kan voorzien;

dat dan ook een dergelijk voorschrift waarbij de toelaatbaarheid van het bezigen van een bepaalde middel afhankelijk wordt gemaakt van 
een voorafgaande vergunning van B. en W., in strijd is met het

bepaalde in art. $7 \mathrm{Gr} . w$. en derhalve verbindende kracht mist" ${ }^{37}$

"Bovenstaande uitspraak bevestigt de heersende leer over art. 7 Gr.w.", aldus Alkema in het toen nog obscure NJCM-Bulletin" ; "zij voegt zelfs een nieuwe krul toe aan de toch al barokke rechtspraak over de drukpersvrijheid". De Meij ${ }^{39}$ noemde het arrest

"in het kader van de jurisprudentie over artikel 7 (...) op zichzelf niet opzienbarend. Er wordt aangesloten bij het reeds bekende begrip van het verspreidingsmiddel met zelfstandige betekenis. Het blijft wel steeds weer een verrassing of in een bepaalde zaak een dergelijk zelfstandig middel door de Hoge Raad wordt onderkend of geconstrueerd. In dit geval was de rechter wel zeer liberaal op dit punt. Het verspreiden van gedrukte stukken in het kader van een inzameling wordt als een zelfstandig verspreidingsmiddel aangemerkt, naast het reeds eerder aanvaarde middel van het langs de deuren verkopen van gedrukte stukken".

Of - zoals Alkema ${ }^{40}$ het uitdrukte - "er zijn twee zelfstandige verspreidingsmiddelen: op commerciële basis en voor charitatieve doeleinden".

Hadden zij gelijk? Volgens de Hoge Raad raakte het voorschrift een middel tot verspreiding van gedrukte stukken waarin gedachten of gevoelens worden geopenbaard "namelijk het aanbieden - zij het dan bij gelegenheid van een inzameling van geld of goederen - van die stukken".

Wat betekende die tussenzin ("zij het dan..." etc.)? Alkema en De Meij lazen er allebei een nadere specificatie van het betreffende zelfstandige verspreidingsmiddel in. Hoe wisten zij dat zo zeker? Laat ik maar bekennen dat $\mathrm{k}$ er aanvankelijk iets heel anders uithaalde. Ik verkeerde in de veronderstelling dat het middel van verspreiding bestond uit "het aanbieden van die stukken" (waarin gedachten of gevoelens worden geopenbaard), zij het dat dit aanbieden zich hier (toevalligerwijs) in een zeer specifieke context afspeelde (te weten: "bij gelegenheid van een inzameling van geld of geederen"). Voor mfj hoorde die inzameling dus niet bij het middel. En ik had daar zelfs een argument voor: het Eindhovense voorschrift raakse dat middel immers slechts. Geen wonder, er waren nog allerlei andere manieren om dergelijke stukken aan te bieden!

Toch geloof ook ik intussen dat het inzamelen er well bij hoorde. Een probleern met mijn interpretatie was namelijk dat zij mij ertoe dwong aan te nemen dat de Hoge Raad met dit arrest alle voorgaande arresten over art. 7 had prijsgegeven. Want tot nu toe mocht een gemeente een zelfstandig middel van verspreiding aan beperkingen onderwerpen, zolang het maar niet in het algemeen werd verboden of van voorafgaand verlof van de overheid afhankelijk gesteld. En daarvan was in dit geval - nu het betreffende middel 
(d.w.z. "het aanbieden") grotendeels ongemoeid werd gelaten - absoluut geen sprake.

Ook Alkema ${ }^{4 i}$, die de inzameling (zoals gezegd) well bij het middel trok, was - opvallend genoeg - op hetzelfde probleem gestuit. Maar hij maakte er korte metten mee. Had hij eerst betoogd dat het arrest toonde "dat de oude doctrine (nog?) niet is verlaten", vervolgens stelde hij eenvoudig:

"Het arrest gaat zelfs nog een stap verder. Het voorschrift van de APV wordt niet gewraakt, omdat het 'een zelfstandig middel van verspreiding in het algemeen verbood' (of van voorafgaande verlof van de overheid afhankelijk stelde, RdW) - zoals het meestal heet maar omdat het voorschrift een dergelijk middel 'raakt'. Omzichtiger kan het haast niet. Vreesde de HR misschien dat de gemeente Eindhoven op grond van deze bepaling de inhoud van stukken zou gaan beoordelen?"

Dat laatste leek - gezien de eerdere jurisprudentie - niet erg plausibel, zou ik denken. Nee, er viel, volgens mij, wel iets anders te verzinnen, dat bovendien ook beter "paste". En daarmee is en passant tevens aangegeven dat het woordje "raakt" bepaald niet tot mijn interpretatie $d w o n g$ (zoals ik eerst veronderstelde). Laat ik het door de Hoge Raad gebruikte beeld (want dat is het!) even volgen. Wat gebeurt er wanneer een APV-bepaling een zelfstandig middel van verspreiding raakt? Dan wordt dat middel getroffen. Wat is de schade in zo'n geval? Dat hangt ervan af! Waarvan? Van het raakvlak! Dat wil zeggen: van de "afdruk" die de APV-bepaling als het ware op het middel maakt. Maar in dit geval werd het eng geformuleerde middel - juist door die enge formulering - in zijn geheel door de APV-bepaling getroffen. Er resteerde geen enkele mogelijkheid om zonder vergunning van B en W "bij gelegenheid van een inzameling van geld of goederen" gedrukte stukken "waarin gedachten of gevoelens worden geopenbaard" aan te bieden. Het betreffende middel werd dus - zoals het heet - "van voorafgaand verlof der overheid afhankelijk gesteld". Vandaar dat de bepaling (in zoverre) onverbindend werd verklaard. Er was, met andere woorden, niets nieuws onder de zon.

Kortom: ook de enge opvatting - waarin de "inzameling" als specificatie van "het aanbieden" zelf tot zelfstandig verspreidingsmiddel was verheven - bleek verdedigbaar. Beter zelfs dan de ruime opvatting - waarin "het aanbieden" als zelfstandig verspreidingsmiddel werd aangemerkt - want zo werden we tenminste niet gedwongen al het voorgaande in eén klap prijs te geven. In eerdere zaken waren andere specifieke vormen van "aanbieden" immers al evenzeer als zelfstandig middel aangemerkt. Denk bijvoorbeeld aan het arrest over het Deventer ventverbod uit $1952 .^{42}$ Daarin ging het om het "middel van verspreiding, waarbij men het op den openbaren weg te koop of om niet 
aanbieden van gedrukte of geschreven stukken doet vergezeld gaan van een mondeling bekendmaken". En in "Nuth"43 repte de Hoge Raad van "het verspreidingsmiddel dat in het om niet aanbieden van drukwerk is gelegen". Waarom zou "het aanbieden" hier dan opeens in zijn algemeenheid als zelfstandig middel moeten worden opgevat?

Toch zou men, volgens De Meij ${ }^{44}$, "nog kunnen opmerken dat het Eindhovense arrest buiten het normale stramien van de artikel 7 jurisprudentie valt orn een geheel andere reden. In dit arrest werd namelijk", ging hij verder, "een (zelfstandige) verspreidingswijze van gedrukte stukken onderkend, terwijl het hier in wezen ging om een verspreidingsvorm die gekoppeld was aan een andere gedraging die op zich niet onder art. 7 valt, zoals het althans tot op heden geïnterpreteerd is, namelijk collecteren". Daarin ontwaarde hij een heel andere benadering dan in "Vietnam II"45, toen een demonstratieve optocht met borden en opschriften buiten de sfeer van art. 7 bleek te vallen. Een dergelijke uitkomst was ook nu denkbaar geweest, schreef hij:

"Wellicht heeft men hiervan afgezien, omdat het in Eindhoven ging on individuele collectanten, terwijl een demonstratie in optochtvorm een massaal karakter draagt (...) en ook de individuele sandwichman onder de bescherming van art. 7 Grondwet is gebracht".

Dan ging het "in wezen" dus toch om iets anders...

Hoe dit verder ook zij, over de consequenties van een en ander, waren de auteurs het zo te zien redelijk eens:

"Een verbod tot het houden van een inzameling zonder vergunning zal niet mogen gelden voor het geval daarbij gedrukte stukken worden aangeboden" (Scheltema) ${ }^{46}$;

- "Het is duidelijk dat inzamelingen gekoppeld aan de verkoop van drukwerk niet in een kollekteplan kunnen worden ingepast" (Alkema) ${ }^{47}$.

Dat laatste ging wellicht wat verder dan het eerste, malar over de strekking van hun betoog kon geen misverstand bestaan: zodra aan een collecte gedrukte stukken te pas kwamen, was terughoudendheid van de gemeente geboden. De Meij ${ }^{48}$ wees er bovendien op dat de "leer" op dit punt nog wel eens kon uitdijen:

"(W)aarom zou (...) een collectant met bijv. een flinke badge op de borst waarop de woorden 'Bestrijd de Apartheid' zijn vermeld, niet reeds aan de voorwaarden voldoen om een collecte van het Comité Zuidelijk Afrika buiten de vergunningsregeling te brengen? Ook zal men bij het verspreiden van gedrukte stukken in het kader van collectes niet uitsluitend aan folders en pamfletten hoeven te denken. Bij bepaalde collectes worden well speldjes e.d. uitgereikt, die waarschijnlijk primair gedacht zijn om de milde gevers te beschermen tegen nieuwe verzoeken om een bijdrage. Door de aard van de afbeel- 
ding en of woorden op een dergelijk vlaggetje of speldje kan hierin echter ook een 'gedrukt stuk' in de zin van artikel 7 worden gezien. Bepaalde actiecomité's hebben immers duidelijk herkenbare symbolen en of slogans. Door de gevers een dergelijk speldje aan te bieden vraagt men hen mee te doen bepaalde 'gedachten of gevoelens' verder uit te dragen. Ook hier is de collectant met een verspreidingshandeling in de zin van artikel 7 bezig".

De verbazing van het NJCM (verwoord door A.W. Heringa) ${ }^{49}$, toen de VNG te kennen gaf haar modelverordening over dit onderwerp niet te willen wijzigen, was dan ook voorspelbaar. Het model luidde (voor zover hier van. belang) als volgt:

"1. Het is verboden zonder vergunning van burgemeester en wethouders op de weg of aan de huizen een openbare inzameling van geld of goederen te houden, al dan niet met gebruikmaking van speldjes, snuisterijen, versnaperingen of andere dergelijke voorwerpen.

2. Onder een inzameling van geld of goederen wordt mede verstaan het bij het aanbieden van geschreven of gedrukte stukken aanvaarden van geld of goederen, indien daarbij een beroep wordt gedaan op de gehele of gedeeltelijke bestemming van dat geld of die goederen voor een kerkelijk, liefdadig of ander niet-commercieel doel".

De vraag was natuurlijk hoe dit alles viel te rijmen met het arrest over het Eindhovense collecteverbod. Welnu,

"De model-bepaling", aldus de $\mathrm{VNG}^{50}$, "laat het aanbieden of verspreiden van geschreven of gedrukte stukken onverlet. Zij verbiedt dat alleen als er geld of goederen voor worden gevraagd ten bate van een 'goed doel'; in dat geval is een vergunning van burgemeester en wethouders vereist".

Mocht dàt dan wel? Het zelfstandige verspreidingsmiddel was door de Hoge Raad omschreven als het aanbieden - zij het bij gelegenheid van een inzameling van geld of goederen - van gedrukte stukken waarin gedachten of gevoelens worden geopenhaard. Daarin was over de door de VNG bedoelde uitzondering niets terug te vinden. Wel was de formulering in de modelbepaling, vergeleken met het arrest, net andersom: niet de inzameling stond voorop, maar het aanbieden. Met andere woorden: kon het bij het aanbieden van geschreven of gedrukte stukken aanvaarden van geld of goederen ten behoeve van een niet commercieel doel (VNG-model) gelijk worden gesteld met het aanbieden - zij het bij gelegenheid van een inzameling van geld of goederen - van gedrukte stukken etc. (HR)? In het ene geval stond het aanbieden van gedrukte stukken misschien wat meer op de voorgrond dan 
in het andere. Ik bedoel: in het arrest van de Hoge Raad ging het om het aanbieden bij gelegenheid van een inzameling. Het aanbod kwam er toen als het ware als extraatje bij; de inzameling stond voorop. In het VNG-model, daarentegen, stond het aanbod juist voorop en kwam de inzameling pas op de tweede plaats. Dan lag het toch voor de hand, zou ik zeggen, die primair op het aanbod gerichte handeling met nog minder aarzeling binnen de sfeer van art. 7 te brengen dan de inzameling waar de Hoge Raad over had geoordeeld - voor zover de verschillen in de praktijk al waarneembaar waren!

Maar wat bleek bovendien? O6k de VNG had met haar modelbepaling primair het oog op inzamelingen (en dus niet op het aanbod, zoals zij suggereerde). Wat schreef zij namelijk in antwoord op de bezwaren van het NJCM? Onder meer het volgende:

"Bij het opstellen van dit model is als uitgangspunt gehanteerd, dat het er in wezen niet om gaat een regeling te geven voor het venters- of colportagevraagstuk, maar om een (laakbaar) verkapte vorm van openbare inzamelingen te bestrijden". ${ }^{51}$

Daarmee kwarn die hele constructie van zojuist dus in de lucht te hangen. Voor zover de in de modelbepaling omschreven gedraging afweek van hetgeen door de Hoge Raad als zelfstandig middel van verspreiding was aangemerkt, was dat slechts schijn. De vasthoudendheid van de VNG viel - na het arrest over het Eindhovense collecteverbod - dan ook moeilijk te vatten, lijkt mij. ${ }^{52}$

Of de boodschap al wel was overgewaaid naar de Afdeling rechtspraak van de Raad van State (ARRS) bleef intussen nog even de vraag. Kort na die Eindhovense zaak - maar lang vórdat het arrest in de vakpers terecht was gekomen en besproken - deed de Afdeling uitspraak over de Amsterdamse weigering het Medisch Komitee Palestina een collectevergunning te verlenen. ${ }^{53} \mathrm{~B}$ en W vreesden - gezien "het controversiële en selektieve karakter van de doelstelling van het Palestina Komitee Nederland", waarmee het Medisch Komitee "nauw gelieerd" was - dat "de handhaving van de rust en de vrede op de openbare weg" met zo'n collecte "in het gedrang" zou komen. Het Medisch Komitee bracht daar tegenin louter "humanitaire doelstellingen" te hebben: "Dit is nog wat anders dan het wekken van sympathie voor de 'Palestijnse zaak'." Door een "pamflet met informatie betreffende het doel waarvoor gecollecteerd wordt" te verstrekken, zou een en ander worden duidelijk gemaakt. Dat op die manier - indirect - de vrijheid van drukpers in het geding was (om van art. 10 EVRM nog maar te zwijgen!), werd klaarblijkelijk door niemand opgemerkt. Ook de Afdeling rechtspraak ging er in haar uitspraak aan voorbij. B en W konden volgens haar in redelijkheid concluderen dat de doelstelling van het Medisch Komitee 
"binnen de Amsterdamse samenleving als selectief en controversieel moe(s)t worden aangemerkt". De vergunning mocht dus geweigerd worden. Over art. $7 \mathrm{Gr}$.w. en de aan het vergunningvereiste ten grondslag liggen APVbepaling: geen woord!

Was art. 7 hier, volgens de Afdeling, dus niet van toepassing? Verwierp zij de "leer" van de Hoge Raad? Of maakte zij wellicht een onderscheid tussen het aanbieden van stukken bij huis-aan-huis collectes (zoals in Eindhoven), en bij straatcollectes (zoals hier)? Wie weet! Het zou mij, eerlijk gezegd, niet verbazen als zij er per ongeluk aan voorbij was gegaan. Eenvoudig, omdat geen van de betrokkenen erop had gewezen - zoals ook het urinoir nooit als kunstwerk was aangemerkt, totdat Marcel Duchamp er in 1917 éen tentoonstelde. $^{54}$

\subsection{Pogingen tot navolging (1978-1979)}

Volgzaam was de Afdeling rechtspraak zeker in een uitspraak over de Leidse Verordening op het stadsschoon. ${ }^{55}$

"Ingevolge art. 1, eerste lid, Verordening op het stadsschoon-1965 der gemeente Leiden", aldus de Afdeling, "is het de eigenaar of gebruiker van een onroerend goed verboden dit goed geheel of ten dele te gebruiken of het gebruik ervan te gedogen voor het daarop of daaraan aanbrengen van opschriften, aankondigingen of afbeeldingen, in welke vorm dan ook.

Het tweede lid van dit artikel bepaalt, dat onder opschriften, aankondigingen en afbeeldingen alleen worden begrepen die opschriften, aankondigingen en afbeeldingen, welke zichtbaar zijn vanaf de openbare weg, het openbaar water, enige andere voor het publiek toegankelijke plaats of vanaf de spoorbaan.

Ingevolge art. 2 Verordening is het bepaalde in art. 1 niet van toepassing t.a.v. - onder andere - opschriften, aankondigingen en afheeldingen m.b.t. welke B. en W. vergunning hebben verleend. Zulk een vergunning kan ingevolge art. 4 worden geweigerd wegens gevaar voor ontsiering van het onroerend goed of de omgeving daarvan, dan wel wegens het schaden van het stadsschoon in het algemeen".

Een "drietal (...) rechthoekige borden in bruine kleur, waarop in wit (waren) aangebracht de woorden 'textiel-discount' en 'fabrieksprijzen'", kwam - onder verwijzing naar deze bepalingen - volgens B en W niet in aanmerking voor een vergunning. De borden waren namelijk "lang achtereenvolgens $3 \mathrm{~m}, 2 \mathrm{~m}$ en $1.55 \mathrm{~m}$, breed $1 \mathrm{~m}$ en dik $0,02 \mathrm{~m}^{n}$, en "aangebracht aan de 
gevel van het pand Morsweg 57b/hoek Rijnzichtstraat". Volgens het college waren ze "zodanig aangebracht dat de raamindeling van het betreffende pand grotendeels onzichtbaar (was) geworden, waardoor de harmonie in de bouw (werd) verstoord". Bovendien waren "de borden en de daarop aangebrachte opschriften onevenredig groot".

Erg lelijk, kortom. Maar de Afdeling liet zich daardoor niet van haar stuk brengen. Geheel volgens het boekje van de Hoge Raad - en wel volgens de nieuwste uitgave daarvan! $!^{56}$ - werden alle standaardoverwegingen "afgedraaid", uitmondend in de conclusie dat een algeheel verbod en afhankelijkheid van voorafgaand verlof van de overheid taboe zijn. Vervolgens werd - gezien "Nederland ontwapent" ${ }^{57}$ en "Rehoboth"58 niet echt verrassend vastgesteld dat hier een middel van bekendmaking met zelfstandige betekenis in het spel was. En omdat, zo ging het aan de Hoge Raad ontleende deuntje verder, het verbod "in zodanige algemeen luidende bewoordingen (was) vervat, dat daarin geen voldoende aanknopingspunten (waren) te vinden voor een splitsing van de wilsverklaring van de gemeenteraad in het gebruiken van onroerend goed voor opschriften, aankondigingen of afbeeldingen, waarin gedachten of gevoelens (waren) geopenbaard en het aanwenden van onroerend goed voor andere opschriften, aankondigingen of afbeeldingen", restte er volgens de Afdeling slechts én slotsom: het verbod miste "verbindende kracht" wegens strijd met art. $7 \mathrm{Gr}$.w.

Een keurige uitspraak... Sprak het dus allemaal vanzelf? Retorische vraag! In de eerste plaats valt op dat de Afdeling niet is ingegaan op suggesties die we hiervбor wel zijn tegengekomen, te weten dat een bepaling door de beugel zou kunnen wanneer inhoudelijke tussenkomst van de overheid was uitgesloten. In dit geval mocht de vergunning alleen geweigerd worden "wegens gevaar voor ontsiering van het onroerend goed of de omgeving daarvan, dan wel wegens het schaden van het stadsschoon in het algemeen". Dat stond op zichzelf (tamelijk) los van de inhoud, lijkt mij; toch werd het verbod zonder meer onverbindend verklaard. In de tweede plaats wijst de uitdrukkelijke verwerping van splitsing erop dat in dit geval, volgens de Afdeling althans, geen sprake was van "gedachten of gevoelens" in de zin van art. 7 Gr.w. - anders was er geen reden geweest dit onderwerp uitdrukkelijk aan te roeren! Erg verrassend mag dat inzicht overigens niet heten - we waren in dat opzicht al het nodige gewend (ik herinner bijvoorbeeld aan "Rehoboth"). Maar het sprak toch niet helemaal vanzelf. Welke criteria er gehanteerd werden, is bij.jvoorbeeld ook na deze uitspraak nog onduidelijk.

De kantonrechter in Tiel trok zich, daarentegen, heel wat minder aan van de Hoge Raad. Hij liet zich vooral door zijn collega in Tilburg inspireren, die (zoals we zagen) $)^{59}$ het lokale plakverbod in 1971 onverbindend had ver- 
klaard. Maar waar in Tilburg - gezien de woordkeus van het vonnis - nog sprake leek van navolging van de Hoge Raad, is dat in Tiel ${ }^{60}$ niet langer vol te houden. Het is misschien aardig die zaken naast elkaar te leggen. Zowel in het ene als in het andere geval gold in principe een algemeen plakverbod, zij het met de volgende uitzonderingen (lid 2):

Tilburg: "m.b.t.

a. stukken, waarvan het bevestigen krachtens wettelijk voorschrift of ingevolge opdracht van het daartoe bevoegd openbaar gezag geschiedt;

b. raambiljetten, welke zich binnenshuis bevinden, mits daardoor noch de openbare orde verstoord of bedreigd wordt, noch de goede zeden aanstoot gegeven wordt".
Tiel: "indien gehandeld wordt in overheidsdienst dan wel door of met toestemming van de rechthebbende op het goed, dat zich op of aan de weg bevindt".

In geen van beide gevallen lieten de uitzonderingen, volgens de kantonrechters, aan het betreffende middel van bekendmaking met zelfstandige betekenis onvoldoende ruimte:

Tilburg:

Omdat "de in lid 2 sub a (...) omschreven uitzonderingsbepaling voor zich spreekt en als uitzondering op het algemene verbod slechts van zeer geringe betekenis is, terwijl de in lid 2 sub b (...) omschreven uitzonderingsbepaling geen feitelijke betekenis heeft daar het uiteraard is toegestaan - ook zonder dat zulks uitdrukkelijk zou zijn vermeld om binnenshuis aanplakbiljetten te bevestigen c.q. bevestigd te hebben voor zover dan de openbare orde daardoor niet wordt verstoord of bedreigd dan wel de goede zeden daardoor geen aanstoot wordt gegeven."
Tiel:

"immers de eerste uitzondering spreekt voor zich en is als uitzondering op het algemene verbod slechts van zeer gering belang, terwijl de tweede uitzondering geen feitelijke betekenis heeft, daar het uiteraard is toegestaan - ook wanneer zulks niet uitdrukkelijk zou zijn vermeld - om met toestemming van de rechthebbende op een goed dat zich op/ aan de weg bevindt biljetten en affiches te bevestigen, voor zover althans de openbare orde of de goede zeden daarbij niet zijn betrokken."

De gelijkenis is tamelijk pijnlijk. ${ }^{61}$ Zelfs die laatste zinsnede over "de openbare orde of de goede zeden" - die in Tilburg ongetwijfeld op de ge- 
wraakte bepaling zag, maar in Tiel nergens op sloeg - was overgenomen. En passant had de Tielse kantonrechter niettemin twee dingen over het hoofd gezien. In de eerste plaats was het Tilburgse regime veel extremer dan het Tielse: zelfs met toestemming van de rechthebbende mocht je er niet plakken! En in de tweede plaats had de Hoge Raad intussen al tot tweemaal toe anders beslist. ${ }^{62}$ Dat laatste wil natuurlijk niet zeggen dat de kaarten dus voortaan geschud waren. Wat is er tegen vindingrijke kantonrechters die eens iets nieuws proberen? Het treurige is dan ook, wat mij betreft, niet zozeer dat die Tielse kantonirechter verzuimd heeft het arrest van de Hoge Raad over te schrijven, maar dat hij heeft overgeschreven - en dan бók nog het verkeerde!

De kantonrechter in Hilversum had zijn huiswerk in elk geval beter gedaan. Misschien wel een beetje te goed. Hij dichtte de Hoge Raad - net als de meeste auteurs, trouwens - wat mér toe dan strikt genomen viel waar te maken. ${ }^{63}$ En vervolgens schreef hij: "De Kantonrechter is geneigd de Hoge Raad in zijn opvatting te volgen, zolang niet blijkt dat de Hoge Raad anders oordeelt".

Waar ging het over? Het was een ouderwets ventverbod en de zaak leek een beetje op het bekende Bredase geval uit 1950, toen het verbod voor de hele binnenstad bleek te gelden. Dat mocht destijds. En aan die Bredase uitspraak $^{64}$ wilde de kantonrechter zich ook deze keer houden. In Hilversum was het namelijk

"verboden op of aan de door B. en W. aan te wijzen gedeelten van de openbare weg op door hen te bepalen dagen en uren, voor wat betreft gedrukte (...) stukken: a. deze (...) te koop aan te bieden".

B en W hadden vervolgens bepaald dat het verbod de gehele binnenstad bestreek, en wel dagelijks na 6 uur 's middags, behalve 's zaterdags, want dan goid het al na 11 uur 's ochtends.

Een vrouw die op zaterdag 6 mei 1978 op de openbare weg "om ongeveer 15.30 uur één of meer gedrukte exemplaren van het dagblad 'De Waarheid' te koop (had) aangeboden" - had ze maar handgeschreven exemplaren bij zich gehad! - werd op grond van die bepaling door de kantonrechter tot. $f 25$,- boete veroordeeld. Haar advocaat had, onder verwijzing naar de Hoge Raad en geheel in de traditie van auteurs als Van den Bergh en Van Wijk ${ }^{65}$, ter zitting aangevoerd dat de vrijheid van drukpers "illusoir" is zonder verspreidingsmogelijkheid:

"Voor een periodiek als 'De Waarheid' is colportage een noodzakelijk middel om gedachten en gevoelens te verspreiden. De colportage is door de HR erkend als middel van bekendmaking met zelfstandige betekenis in het maatschappelijk verkeer. Hier kan de colportage 
slechts verwezenlijkt worden onder bepaalde voorwaarden. Het onderhavige verbod treft alleen de economisch zwakkeren, die geen dure reclame-campagnes kunnen voeren. Een middel om toch het grote publiek te bereiken is het recht op colportage. Omdat 'De Waarheid' zich richt tot de werkende bevolking, wordt het colporteren daarmee in dat opzicht in tijd beknot. De werkende bevolking is slechts bereikbaar 's-avonds en in het weekeinde. Ook heeft het colporteren alleen zin op plaatsen waar de meeste mensen zich ophouden en dat is in de binnenstad. De gehele binnenstad wordt echter door het verbod bestreken en daardoor wordt colportage in feite onmogelijk gemaakt".

De kantonrechter hield evenwel (zoals gezegd) vast aan hetgeen hij voor de opvatting van de Hoge Raad aanzag - en die liet geen ruimte voor souplesse in dit geval:

"Toegeven kan worden dat de economisch zwakkeren wel in hun mogelijkheid gedrukte stukken onder de aandacht van het publiek te brengen worden beperkt. Er wordt niet aannemelijk geacht dat als gevolg van genoemde bepalingen in de gemeente Hilversum het colporteren praktisch onmogelijk is geworden, immers er blijven ook hinnen ste habuwole kgm vea' gldasenr over wad net verbod" niet geldt. Voorts geldt het verbod niet op alle uren".

En dan volgt dus die verwijzing naar het arrest uit 1950, dat de kantonrechter - naar eigen zeggen - "geneigd" was te volgen. Het verweer werd, met andere woorden, verworpen: er was geen strijd met art. $7 \mathrm{Gr}$.w.

Bood dat oude arrest inderdaad geen manoeuvreerruimte? Dat zou wel zéér uitzonderlijk zijn! Het lag dan ook wat ingewikkelder. In de eerste plaats was het - zoals ook al bij de bespreking van het arrest aan de orde kwam niet zeker of de ontoegankelijkheid van de binnenstad destijds door de Hoge Raad als vaststaand was annvaard. In de tweede plaats was het (ik herhaal mijzelf ook hier weer) voor de Hoge Raad onmogelijk om na te gaan of - ondanks het verbod - feitelijk nog een gebruik van enige betekenis mogelijk was; als cassatierechter kon de Hoge Raad zich daar niet in verdiepen. Voor de kantonrechter, daarentegen, lag dat anders. En de vraag in deze Hilversumse zaak was of hij bereid zou zijn rekening te houden met de specifieke colportageproblemen van een bepaald dagblad, dan wel of hij in abstracto zou nagaan of de colportagemogelijkheden in het algemeen voldoende waren. Hoe die keus bij de kantonrechter precies is uitgevallen, is moeilijk te zeggen. Enerzijds gaf hij toe dat "economisch zwakkeren" in hun verspreidingsmogelijkheden beperkt werden, anderzijds werd het colporteren toch niet "praktisch onmogelijk" gemaakt. Misschien moeten we het erop houden dat er, volgens de kantonrechter, бok voor "economisch zwakkeren" nog 
voldoende colportagemogelijkheden overbleven. Daarbij hanteerde hij twee maatstaven: 1) op een heleboel plaatsen "binnen de bebouwde kom" gold eenvoudig geen verbod, en 2) daarnaast gold het verbod $60 \mathrm{k}$ "niet op alle uren". Dat laatste was inderdaad opvallend, zeker vergeleken met Breda (waar het verbod destijds van 's avonds 6 tot 's morgens 11 gold). Maar waar kwam die "bebouwde kom" opeens vandaan? Waarom werden de beperkingen in de binnenstad gecompenseerd door hetgeen elders in de bebouwde kom nog mogelijk was? Was dat altijd zo - eenvoudig omdat er nog andere plaatsen beschikbaar waren? Wie weet? De Hoge Raad had zich daar nog niet over uitgelaten. Of had de kantonrechter het oog op de feitelijke omstandigheden ter plekke? Waren er, volgens hem, ook buiten de binnenstad voldoende relevante plekken voor colporteurs? Het vonnis was in dat opzicht niet duidelijk.

Wel duidelijk was intussen dat de Hoge Raad zo'n uitspraak onmogelijk kon vernietigen. Ofwel hij vond de beschikbaarheid van "vele plaatsen" binnen de bebouwde kom op zich al voldoende, ofwel hij eiste een feirelijke beoordeling van de colportagemogelijkheden in Hilversum. En aangezien het vonnis (zoals gezegd) zowel in de ene als in de andere zin kon worden verstaan, was het onaantastbaar geworden - aangenomen tenminste dat het überhaupt op dit punt zou hangen, want wellicht was het tijdsbestek waarbinnen wel gecolporteerd mocht worden volgens de Hoge Raad al toereikend (zodat de overige beperkingen, die zich buiten dat tijdsbestek afspeelden, niet meer aan de orde hoefden te komen). Het zou - hoe dan ook - goed aflopen met dit vonnis. En zo ging het dan ook.

Om te beginnen stelde de Hoge Raad vast dat het Hilversumse ventverbod een "middel tot verspreiding" ${ }^{66}$ met zelfstandige betekenis "raakt" - te weten: "het op of aan de openbare weg te koop aanbieden van gedrukte stukken waarin gedachten of gevoelens worden geopenbaard" ${ }^{67}$ Vervolgens werd op de mogelijkheid van beperkingen "op de voet van art. $168 \mathrm{Gem}$.w. (...) in het belang van de openbare orde, waaronder begrepen het openbaar verkeer ${ }^{168}$ gewezen.

"(M)aar", zo ging de Hoge Raad verder, "die beperkingen van het middel mogen i.v.m. het grondrecht neergelegd in art. $7 \mathrm{Gr}$.w. nooit zover gaan dat zij zouden neerkomen op een in het algemeen verbieden. Met name zou dit laatste het geval zijn indien een verbod door de plaats en de tijd van de werking ervan geen gebruik van enige betekenis van bedoeld verspreidingsmiddel zou overlaten."

In dit geval, evenwel, had de kantonrechter

"geredelijk kunnen oordelen dat het onderhavige verbod - hetwelk kennelijk in het belang van het openbaar verkeer is gesteld - zodanig gevolg niet in het leven roept, nu het zich weliswaar, gelijk de 
Kantonrechter heeft vastgesteld, over de gehele binnenstad - doch niet over de gehele bebouwde kom - van Hilversum uitstrekt, echter in de binnenstad niet geldt op de zaterdagen vóor 11 uur en op de overige dagen van de week vó́r 18 uur".

"Weliswaar... doch niet... echter...". Kunnen we hier - ondanks de voorspelbare uitkomst - iets uit afleiden omtrent het standpunt van de Hoge Raad? Toch wel, denk ik; de openingszet - weliswaar geldt het verbod voor de hele binnenstad - suggereert dat zo"n verbod in beginsel niet door de beugel kan. In dit geval waren er twee factoren waaronder het uiteindelijk tòch weer goed kwam. Gaf én daarvan de doorslag? Moeilijke vraag. Wat is bijvoorbeeld de status van dat tussenzinnetje waaruit blijkt dat het verbod niet "de gehele bebouwde kon"' betrof? Lag het anders wanneer het zich daar wèl over had uitgestrekt? Of had het beperkte tijdsbestek, dan uitkomst geboden? Nee, zoveel weten we zeker: het tijdsbestek was op zich onvoldoende. Volgens de Hoge Raad had de kantonrechter immers "geredelijk kunnen oordelen" dat een gebruik van enige betekenis mogelijk bleef. Als het tijdsbestek op zich al toereikend zou zijn geweest, was een andere uitkomst rechtens zelfs ondenkbaar. Dan had de kantonrechter, met andere woorden, terecht (zij het niet op juiste gronden, want hij betrok de gehele bebouwde kom erbij) geoordeeld dat gebruik van enige betekenis niet was uitgesloten. Nu hij volgens de Hoge Raad slechts "geredelijk (had) kunnen oordelen" dat dit het geval was, was er kennelijk een "margin of appreciation" in het spel (om die term maar even te lenen van het Hof in Straatsburg). Dus was het tijdsbestek-alleén blijkbaar ontoereikend. Daarnaast moesten $60 \mathrm{k}$ de plaatselijke omstandigheden bekeken worden. In Hilversum waren die - naar het oordeel van de kantonrechter - niet echt dramatisch. De Hoge Raad moest zich bij die "feitelijke" vaststelling neerleggen."

\subsection{Het Dordtse plakverbod (1979)}

Of er nog net wel, of net niet meer "gebruik van enige betekenis" overbleef, speelde ook ten aanzien van het Dordtse plakverbod. ${ }^{00}$ Iemand die "tezamen en in vereniging met een ander, een aanplakbiljet (had) opgeplakt op een met planken dichtgemaakt raam van een pand aan de voor publiek toegankelijke weg, de Wijnstraat", was ondanks dat verbod' zowel door de kantonrechter als door de rechtbank ontslagen van alle rechtsvervolging. Toch hoefde die Dordtse bepaling - na "Alkmaar" (1960) en "Hengelo" (1977) - op zich weinig opzien te baren; zij luidde (voor zover hier van belang) als volgt: 
"1. Het is verboden enig aanplakbiljet of ander geschrift, afbeelding of aanduiding aan te brengen of te projecteren:

a. op de weg, of

b. op of aan enig goed hetwelk zich op of aan de weg bevindt of van de weg af zichtbaar is.

2. Van het in het eerste lid gestelde verbod kan ontheffing worden verleend door $\mathbf{B}$. en $\mathbf{W}$.

3. (...)

4. Het in het eerste lid sub b gesteld verbod geldt niet, indien gehandeld wordt door of met toestemming van de rechthebbende".

Volgens de rechtbank was dat in strijd met art. $7 \mathrm{Gr}$.w. De bepaling behelsde immers "een algemeen verbod van aanplakking op de weg of op of aan enig goed hetwelk zich op of aan de weg bevindt of van de weg zichtbaar is zonder voorafgaande ontheffing c.q. toestemming van B. en W. van de gemeente Dordrecht c.q. de rechthebbende". Op grond van dit APVartikel was "aanplakking in het openbaar" - dat als een zelfstandig middel aangemerkt moest worden - "slechts mogelijk (...) indien degene die gedachten en gevoelens aan het publiek bekend wenst te maken daartoe eigendornmen van hernzelf of zijn medestanders kan benutten, hetwelk niet altijd het geval behoeft te zijn". De rechtbank concludeerde dan ook:

"dat mitsdien niet door een ieder - zonder voorafgaand verlof van de gemeentelijke overheid - van het middel van aanplakking gebruik van enige betekenis kan worden gemaakt".

En dat kon niet door de beugel. De rechtbank meende:

"dat indien de gemeenteraad haar en/of andermans eigendommen tegen beschadigingen en verontreinigende aanplakking wenst te beschermen, zij deze bescherming dusdanig in een verordening dient vast te leggen, dat onverlet wordt gelaten de mogelijkheid, dat een ieder door aanplakking zonder voorafgaand verlof van de gemeentelijke overheid gedachten of gevoelens openbaar kan maken, zoals door het daartoe uitzonderen en aanwijzen van aanplakplaatsen".

De advocaat-generaal (Mok) kon zich hierin vinden. Hij beperkte zich in feite tot een nadere uitwerking van, en toelichting op hetgeen ook door de rechtbank al was gesteld. De Hoge Raad, daarentegen, zag geen aanleiding om terug te komen van de in "Alkmaar" en "Hengelo" ingeslagen weg. Niet verrassend, natuurlijk, want "Dordrecht" lag - juridisch gesproken - tussen "Alkmaar" en "Hengelo"' in. Ging het in "Alkmaar" immers om plakken zonder vergunning of schriftelijke toestemming, in "Hengelo" was het verboden andermans eigendom wederrechtelijk te verontreinigen. Het Dordtse vereiste van (niet per se op schrift gestelde) toestemming was dus enerzijds lichter dan het Alkmaarder regime, en anderzijds zwaarder dan het Hengelose (nu 
plakken zonder toestemming niet noodzakelijkerwijs wederrechtelijk was - denk bijvoorbeeld aan dichtgetimmerde slooppanden, zoals in dit geval). Maar al is de uitkomst - gezien die precedenten - niet opvallend, de motivering ervan verdient de aandacht. Nog niet eerder, namelijk, was de in "Alkmaar" en "Hengelo" beproefde afdoening - te weten dat het slechts om een beperking ging voor zover "eens anders recht" zou worden geschonden, en dat het plakken voor het overige "onverlet" werd gelaten - geconfronteerd met die andere eis dat er een "gebruik van enige betekenis" moest worden overgelaten. ${ }^{11}$ Hoe loste de Hoge Raad dit op?

Om te beginnen werden de geijkte frasen over art. $7 \mathrm{Gr}$.w. weer ten tonele gevoerd, onveranderlijk leidend tot de conclusie dat beperkingen waren toegestaan, zolang een zelfstandig middel maar niet "in het algemeen zou worden verboden of van voorafgaand verlof der overheid afhankelijk zou worden gesteld". Vervolgens herhaalde de Hoge Raad hetgeen al eerder in "Alkmaar" en "Hengelo" was gezegd. Daarna, echter, kwam iets nieuws. De Hoge Raad overwoog dat de rechtbank ervan was uitgegaan

"dat een verbod als het onderhavige van het betrokken middel van

bekendmaking slechts dan gebruik van enige betekenis zou toestaan indien een ieder in de gelegenheid zou zijn om zonder het verbod te overtreden van dat middel gebruik te maken.

Door deze zienswijze aan haar beslissing ten grondslag te leggen, heeft de Rechtbank de betekenis van het in art. $7 \mathrm{Gr}$.w. neergelegde recht miskend".

Volgens Scheltema ${ }^{72}$ kon

"men in het licht van de belangrijke versterking van de vrijheid van meningsuiting in de HR jurisprudentie van de laatste twintig jaar enige vraagtekens zetten bij dit arrest. Vooral omdat bij de verwerping van de visie van de $\mathrm{Rb}$. zo hard wordt gezegd dat ook dan nog van gebruik van enige betekenis van een bekendmakingsmiddel sprake is, wanneer niet een ieder daartoe in de gelegenheid is. (...) Grondrechten worden aan een ieder toegekend, en hun bescherming behoort zich, ook in onderdelen, niet tot bepaalde rechthebbenden uit te strekken. Zij die geen rechthebbende zijn, hebben immers niet minder behoefte aan de vrijheid van meningsuiting".

Dat klonk inderdaad heel sympathiek. Maar was het ook geldend recht? Zeker! Dat wil zeggen: de Hoge Raad had er zelf ooit al eens op gewezen. En niet eens en passant, maar juist in het arrest waarin de "leer" zo omstandig werd onderbouwd. Ik bedoel het arrest over het Tilburgse pornoverbod van 28 november $1950 .{ }^{73}$ Daarin werd, zoals bekend, voor het eerst gesteld dat naast het de geesteswereld betreffende uitingsrecht "tevens, als tot het met dat recht beoogde doel onmisbaar doch aan dat recht onderge- 
schikt, door den rechter is aangenomen het recht van een ieder (curs. RdW) om een gedrukt geschrift en het daarin gedrukte, door het te verspreiden, openlijk ten toon te stellen of door enig ander middel, in het openbaar aan het publiek bekend te maken".

In combinatie met de - inniddels bij herhaling uitgesproken - notie dat het vereiste van een "gebruik van enige betekenis" voor ieder zelfstandig middel van bekendmaking gold, was de conclusie volgens mij onontkoombaar: zo'n middel moest ook voor een ieder openstaan. Of liever: het gebruik ervan mocht ten opzichte van niemand van "voorafgaand verlof der overheid" afhankelijk worden gesteld of "neerkomen op een in het algemeen verbieden". Alleen, stond dat niet haaks op hetgeen de Hoge Raad in het arrest over de gemeente Dordrecht had overwogen? Waren er stilaan zoveel verschillende criteria aanvaard dat consistentie niet langer verzekerd was?

Nee, het leek klaarblijkelijk maar zo. Feitelijk stond er slechts dat art. 7 Gr.w. niet meebrengt dat een ieder in de gelegenheid moet zijn van een zelfstandig middel gebruik te maken zonder daartoe een verspreidingsverbod te overtreden. Art. 7 verzekerde dus niet de toegang tot zo'n middel. En inderdaad, het verbood slechts dat bepaalde belemmeringen werden opgeworpen: het gebruik van een middel mocht in de eerste plaats, zoals gezegd, niet afhankelijk worden gesteld van "voorafgaand verlof der overheid", en in de tweede plaats niet zozeer worden beknot dat het neerkwam op een algemeen verbod. Dus was er, volgens de Hoge Raad, geen vuiltje aan de lucht! $!^{74}$ Dus? Gingen de beperkingen in dit geval niet te ver? Ik vond destijds van wel. ${ }^{75}$ Samen met A.W. Heringa betoogde ik dat de uitkomst van de Hoge Raad weliswaar niet in strijd was met de eerdere jurisprudentie, maar dat zij er evenmin uit voortvloeide. De vraag was immers wanneer er nog sprake was van "gebruik van enige betekenis". Van der Burg ${ }^{76}$ schreef weliswaar dat "enig gebruik (in de zin van het Nuth-arrest)" daarvoor voldoende was, maar dat leek ons weinig verhelderend; die nadruk op enig deed bovendien (aangenomen dat het niet grappig bedoeld was) het ergste vermoeden. Wij meenden dat de gewraakte APV-bepaling te weinig waarborgen behelsde om te bewerkstelligen dat er ook voor niet-rechthebbenden voldoende gebruiksmogelijkheden resteerden. Aan de feitelijke omstandigheden ter plekke kwamen wij - evenmin als de rechtbank, trouwens - niet toe. De enkele - weliswaar reëel bestaande - kans dat het mis was, gaf voor ons de doorslag.

Vandaag-de-dag zou op dat laatste, zoals we nog zullen zien, heel wat af te dingen zijn. Maar dat lag toen anders. Ook de rechtbank had immers niet vastgesteld dat er soms geen medestanders te vinden waren wier eigendommen door niet-rechthebbenden beplakt mochten worden. Zij had slechts geopperd dat dergelijke medestanders er niet altijd behoefden te zijn. En de 
Hoge Raad had vervolgens beslist dat zoiets geen reden voor onverbindendheid was; niet omdat het om een speculatie ging (en er feitelijk niets was vastgesteld), maar omdat er zelfs onder die omstandigheid nog gebruik van enige betekenis overbleef, of althans over kon blijven! $!^{77}$ De redenering van de rechtbank was, met andere woorden, niet dwingend en kon dus niet tot onverbindendheid leiden.

Waarom bleef er, volgens de Hoge Raad, gebruik van enige betekenis mogelijk, ook al kwamen (sommige) niet-rechthebbenden niet aan hun trekken? Gold het bekendmakingsrecht opeens niet meer voor een ieder? Ik denk, bij nader inzien, dat eenvoudig het aloude criterium hier de doorslag gaf: Was het gebruik van het middel afhankelijk gesteld van "voorafgaand verlof der overheid"? Geen sprake van! De rechtbank had de zaken op hun kop gezet: omdat er te weinig particulieren waren die wilden meewerken, waren niet-rechthebbenden als het ware gedwongen zich tot de overheid te wenden. Eenmaal dár aangekomen wilden zij in eén keer alles op die overheid verhalen en waren zij vergeten wie hun eerder géén veĩlof hadden verleend.

Maar was er feitelijke dan geen situatie ontstaan die neerkwam op een algemeen verbod? Wellicht, maar geen algemeen verbod dat van overheidswege was opgelegd. ${ }^{7 /}$ Rechthebbenden konden hun toestemming immers altijd al weigeren.

Toegegeven, het staat allemaal wat los van de wereld en is voor "leken" nauwelijks nog te snappen. Doctrinair gesproken, sluit het niettemin als een bus. Voor de Hoge Raad gaf dat laatste kennelijk de doorslag. Alleen, het had natuurlijk ook anders gekund. De uitkomst sprak niet vanzelf. Daarvoor liet het "gebruik van enige betekenis" nog te veel speelruimte. Het standpunt van de rechtbank was dan ook niet absurd, lijkt mij, al was het misschien eleganter geweest wanneer zij zich niet door speculaties had laten leiden. Waarom zou zo'n bepaling nú immers moeten sneuvelen, terwijl zij in "Alkmaar" en "Hengelo" - waar op soortgelijke wijze viel te speculeren - in stand werd gehouden? 


\section{Hoofdstuk 7 De jaren tachtig tot en met '92}

De relatief rustige jaren zeventig werden gevolgd door zeer woelige jaren tachtig. Geen enkel decennium leverde tot nu toe zóveel (gepubliceerde) rechtspraak op. Vooral "plakzaken" bleken in trek te zijn. De sporen van de jaren zeventig bleven echter duidelijk zichtbaar. Zo besliste de kantonrechter in Leeuwarden bijvoorbeeld dat een voor hem gevoerd verweer moest "worden verworpen gelet op het arrest van de Hoge Raad van 2 oktober 1979, NJ 1980, nr. 105, waarbij werd beslist, dat art. 7 APV gem. Dordrecht (...) verbindend is". ${ }^{1}$ Andere zaken kwamen pas in de jaren tachtig bij de Hoge Raad, hoewel zij al in de jaren zeventig waren begonnen. En voorts werd ook de "leer" natuurlijk gewoon van het ene decennium "meegenomen" naar het volgende. Laat ik er, met andere woorden, opnieuw op wijzen dat we vooral voorzichtig moeten zijn met het etiketteren van perioden. ${ }^{2}$ Het gevaar dreigt anders dat we onze waarnemingen laten beïnvloeden door het etiket, in plaats van andersom. Mijn startpunt is, zoals steeds in dit boek, de stand van de jurisprudentie tot dusver.

\subsection{De Utrechtse muurkrant (1980)}

Muurkranten hoorden bij China. Opgewekte arbeiders vernamen op die manier eind jaren ' 60 , begin jaren ' 70 hoe het stond met de vorderingen van de "Culturele Revolutie". Op tal van andere plaatsen leidde dat tot navolging. Zelfs in Nederland. En vooral in Utrecht. "De toon is scherp", schreef De Meij destijds ${ }^{3}$, "vaak op het beledigende af, en de vele onthullingen, waar of onwaar, zullen door de betrokken 'bazen en bovenbazen' in de regel wel als zeer onplezierig ervaren worden". In 1973 besloot de gemeente op te treden tegen dit telkens opnieuw verschijnende anonieme geschrift. De volgende bepaling werd opgenomen in de APV:

"1. Het is verboden zonder vergunning van B. en W. op of tegen een onroerend goed gelegen in het niet-landelijk gedeelte van de gemeente, afbeeldingen, letters, cijfers of andere tekens dan wel illuminatie aan te brengen of te hebben, welke van de openbare weg af zichtbaar zijn.

2. Het bepaalde in het eerste lid is niet van toepassing ... etc.

3. Het bepaalde in het eerste lid is evenmin van toepassing op het aanbrengen van meningsuitingen of bekendmakingen, geen 
betrekking hebbende op commerciële reclame, indien dit geschiedt:

a. op door B. en W. bij openbare kennisgeving daartoe aangewezen plaatsen en

b. overeenkomstig de bij die kennisgeving gestelde voorschriften, welke geen betrekking mogen hebben op de inhoud van de meningsuitingen of bekendmakingen."

In aansluiting daarop werd door B en W een aantal "op de openbare weg geplaatste borden" aangewezen, waarop geplakt mocht worden, zij het dat die plaksels dan well moesten "worden voorzien van de naam en het adres van de voor de publicatie verantwoordelijke persoon of instantie".

Twee beperkingen, kortom. In de eerste plaats mocht er - kort gezegd zonder vergunning van $\mathrm{B}$ en $\mathrm{W}$ uitsluitend op daartoe aangewezen borden worden geplakt, en in de tweede plaats waren anonieme plaksels verboden. Was dat niet in strijd met art. 7 Gr.w.? Die eerste maatregel - beperking tot plakborden - waren we eerder al eens tegengekomen. Maar dat was in een zaak die om een heel andere reden bekend was geworden. Vandaar misschien dat niemand er in dit verband op gewezen heeft. ${ }^{4} \mathrm{Ik}$ bedoel het arrest over de manege Rehoboth. ${ }^{5}$ Daarin ging het om een provinciaal verbod voor "de eigenaar of gebruiker van enig onroerend" goed in het landelijk deel van een gemeente" om zonder vergunning van GS "dit goed geheel of ten dele aan te wenden of de aanwending daarvan te gedogen voor opschriften (etc., $\mathrm{RdW}$ ) die van een (...) voor het publiek toegankelijke plaats af zichtbaar zijn". Uitgezonderd waren ook toen (onder meer) "aankondigingen en opschriften op zuilen, borden en muren, welke daarvoor door de overheid zijn aangewezen". De Hoge Raad nam daar echter geen genoegen mee. De uitzondering was slechts van "zo geringe betekenis" dat zij niet "geacht (kon) worden het (...) verbod op zodanige wijze in te perken dat aan dat verbod het karakter van algemeenheid zou worden ontnomen".

Zou dat nu opeens anders liggen? Zo nee, dan hoefde die tweede kwestie - over het verbod van anonieme geschriften - niet meer aan de orde te komen: de bepaling was immers toch al onverbindend! Alleen, zoals gezegd, niemand dacht meer aan die manege en dus spitste het debat zich - wat art. 7 Gr.w. betreft - toch op de anonimiteit toe. De Meij wijdde er een uitgebreid tijdschriftartikel aan, waarin hij overigens allereerst betoogde dat dit punt dooĩ de strafwetgever uitputtend was geregeld, zodat hier voor gemeentelijke regelgeving geen plaats meer was. ${ }^{6}$ Wat art. 7 betreft, herinnerde hij aan het beroemde arrest uit 1950 over het Tilburgse pornoverbod. ${ }^{7}$ Daarin had de Hoge Raad, zoals bekend, naast het "de geesteswereld betreffende" openbaringsrecht tevens van een bekendmakingsrecht gerept, "hetwelk het verkeer op den openbaren weg rakend en dus een ruimtelijke sfeer bestrijkend recht 
evenwel wegens dien anderen aard zijn eigen beperking medebracht". Welnu, had déze beperking inderdaad iets te maken met "die andere aard"?

"In het Tilburgse arrest", aldus De Meij, "wordt de toegestane mogelijkheid om de verspreidingsvrijheid te beperken in het belang van de openbare orde nader geëxpliciteerd als de regeling 'op welke tijd, plaats of wijze de verspreiding niet kan plaats hebben. Mijns inziens is het Utrechtse vereiste van vermelding van naam en adres van de verantwoordelijke persoon of instantie echter van geheel andere orde. (...) Het gaat er kennelijk om de justitie behulpzaarn te zijn bij het achterhalen van de voor een bepaald drukpersdelict verantwoordelijke persoon. Dit betekent echter dat het hier om een verspreidingsregeling gaat die aanknoopt bij de inhoud van de verspreide publicatie, want op grond van de inhoud alleen kan er van een drukpersdelict worden gesproken. Maar bemoeienis met de inhoud van gedrukte stukken is nu juist aan de formele wetgever voorbehouden! ${ }^{n}$

Dat laatste klopt niet helemaal en klinkt ook een beetje gezocht, lijkt mij. De Hoge Raad overwoog in die Tilburgse zaak namelijk slechts dat de gemeenteraad "niet mag treden in het regelen, hoedanigen inhoud een door den druk geopenbaarde gedachteuiting niet mag hebben". Nu de ondertekening-zelf (of het weglaten ervan) vermoedelijk slechts zelden als uiting van gedachten of gevoelens kan worden aangemerkt, kan een verbod van anonimiteit vanuit dàt gezichtspunt nog wel door de beugel, zou ik denken. Het eerste bezwaar daarentegen - dat aanknoopt bij het verband tussen de "ruimtelijke sfeer" en beperkingen - lijkt mij sterker. Maar het elegantst was misschien de suggestie van Peters. ${ }^{8}$ Hij zag in anonieme geschriften een vorm van alternatieve verspreidingsmiddelen:

"Groepen kunnen er belang bij hebben dat hun naam niet bekend wordt. Zo kunnen krakers er belang bij hebben dat hun opvattingen naar buiten komen zonder dat zij zich daarmee blootstellen aan intimidatie van knokploegen of dat hun naam bekend wordt bij de huiseigenaar. Ook aktiegroepen die bijvoorbeeld ageren tegen bordelen in hun wijk of tegen café's kunnen zich geïntimideerd voelen en belang hebben bij anonimiteit".

Of, zoals Opzoomer in het midden van de vorige eeuw al schreef:

"Zeer dikwijls zijn er omstandigheden, waarin heilige pligten het verzwijgen van den naam des schrijvers vorderen, en niet zelden zijn zij, die hun naam moeten verbergen, de eenigen, die in staat zijn de nuttige waarheid aan het licht te brengen".

Zo'n vaart zou het allemaal trouwens wel niet lopen, immers:

"namelooze geschriften zijn van zelf minder geacht en hebben minder invloed, dan werken, die een beroemden naam dragen: waarom zal 
men dan voor nameloos geschrijf zoo bijzonder bevreesd zijn? (...) Het is dus raadzaam, ook hierin aan de vrijheid haar ongehinderden loop te laten; de nameloosheid van den aanval zal den eerlijken man dikwijls noopen, van alle verdediging af te zien, zal anderen dikwijls aansporen, er weinig of geen geloof aan te schenken".

Dat laatste spreekt vandaag-de-dag wat minder vanzelf dan anderhalve eeuw geleden. Daarvoor hebben we intussen te veel ervaring opgedaan met hetzes. Maar afgezien daarvan leek er toch veel voor te zeggen om naast het "gewone" plakken $66 \mathrm{k}$ het anoniem plakken als een "middel van bekendmaking" aan te merken, "dat naast andere middelen zelfstandige betekenis heeft en met het oog op die bekendmaking in een bepaalde behoefte kan voorzien". Eenmaal in dit licht geplaatst, kon het Utrechtse verbod - dat immers geen enkel gebruik van dat middel toeliet - onmogelijk door de beugel.

Maar zo is het niet gegaan. Toen het uiteindelijk tot een "zaak" kwam, bleek de advocaat-generaal (mevrouw Biegman-Hartogh) nog wel de mening van De Meij te onderschrijven "dat het vereiste van vermelding van naam en adres van geheel andere orde is dan een beperking van de verspreidingsvrijheid zoals in de vorige arresten weergegeven"; zij meende "dat naar huidige opvattingen het litigieuze artikel een niet meer toelaatbare inbreuk op art. 7 Gr.w. maakt(e) $)^{*} .{ }^{\prime}$ De Hoge Raad, echter, oordeelde anders. ${ }^{\text {II }}$ Weliswaar was hier een zelfstandig middel van verspreiding in het geding - "namelijk het op of tegen een onroerend goed gelegen in het niet-landelijk gedeelte van de gemeente aanbrengen of hebben van meningsuitingen of bekendmakingen welke van de openbare weg af zichtbaar zijn"12 - maar de beperking ging niet zover "dat het gebruik van voormeld verspreidingsmiddel in het algemeen (werd) verboden of van voorafgaand verlof der overheid afhankelijk werd gesteld". Immers: het verbod gold niet voor "mededelingen of bekendmakingen op de bij (het) besluit aangewezen, aan de openbare weg geplaatste, borden".

Met de beschikbaarheid van borden was alles klaarblijkelijk (anders dan in "Rehoboth") opgelost. Over het verbod van anonimiteit: geen woord. Alleen, daar was in het cassatiemiddel in dit verband ook niet op gewezen! Het hele middel was erop toegesneden dat de uitzondering op het verbod "niet van zodanige betekenis" was dat zij het algemene karakter eraan ontnam. Over de werkelijke issue heeft de Hoge Raad zich dan ook - bij gebrek aan goede schriftuur - uitsluitend indirect uitgelaten. In de eerste plaats door er ambtshalve geen aandacht aan te schenken, en in de tweede plaats door anoniem plakken niet als zelfstandig middel aan te merken. Vooral dat laatste en de breuk met "Rehoboth" (als ik het tenminste goed zie) ${ }^{\text {i3 }}$ lijkt mij van belang. Het waren - opnieuw - stappen die niet "logisch" voortvloeiden uit het voorgaande. Daarnaast rees de vraag wat we in het vervolg nog aan 
moesten met die principiële onderbouwing van de verspreidingsjurisprudentie in "Tilburg": kwamen de toegestane beperkingen inderdaad louter voort uit de "ruimtelijke sfeer"? Volgens de Hoge Raad liet ook dit geval zich daar - naar ik aanneem - wel onder brengen: het verbod kon immers, zo overwoog hij, het belang van de openbare orde dienen, want het beoogde "te voorkomen dat de van gemeentewege aangewezen aanplakborden (werden) gebruikt tot het anoniem beledigen van anderen zonder daarvoor achteraf ter verantwoording te kunnen worden geroepen". Of was hier - waar een weggelaten ondertekening (vermoedelijk) geen "gedachte of gevoelen" uitdrukt eenvoudig geen sprake van een "beperking" in de zin van "Tilburg"?

\subsection{Een lange reeks plakverboden (1980-1982)}

De stroom "plakzaken" hield intussen gewoon aan. Het eind was nog lang niet in zicht. En veel ervan was louter herhaling. Enige consideratie met de lezer is hier vereist. Een aantal zaken zal ik daarom in sneltreinvaart (dus toch nog op enigszins verantwoorde wijze) de revue laten passeren.

- In de gemeente Doorn gold een algemeen verbod om wederrechrelijk te plakken (art. $43 \mathrm{APV}$ ), kortom: naar het model van Hengelo. ${ }^{14}$ Daarnaast was het (zoais gebruikelijk) verboden om 's avonds plakmiddelen e.d. te vervoeren, behalve als ze niet "gebezigd of bestemd" waren ter overtreding van het plakverbod (art. 44 APV). De rechtbank ${ }^{15}$ oordeelde, geheel conform "Hengelo", dat "dit samenstel van bepalingen slechts medebrengt een beperking van het gebruik van bepaalde middelen van bekendmaking voor zover door het gebruik daarvan eens anders recht zou worden geschonden en voor het overige elk gebruik van middelen van bekendmaking onverlet laat". Geen wonder dat de rechtbank, volgens de Hoge Raad, "op goede gronden terecht (had) geoordeeld dat art. 44 APV Doorn, gezien in samenhang met art. 43 dier verordening, niet in strijd (was) met art. 7 Gr.w.". Een saillant detail was alleen dat opnieuw door een advocaat-generaal (deze keer was het Haak zij het in het voetspoor van Remmelink) de stelling werd betrokken dat de beperking op het ene verspreidingsmiddel (i.c. plakken) door een ander verspreidingsmiddel (hij dacht aan de sandwichman) kon worden gecompenseerd.

- Interessanter was hetgeen zich in Arnhem had voorgedaan. ${ }^{16}$ Ook daar gold een plakverbod naar het model-Hengelo. En de rechtbank kon het verweer dat er strijd zou zijn met art. 7 Gr.w. dus op de geijkte wijze afdoen. Dat deed zij dan ook, maar zij voegde er nog iets aan toe: 
"Dat hiermee slechts een irreële mogelijkheid om het middel te benutten overblijft, gaat er bij de Rechtbank niet in. Met enige inventiviteit toch zullen verdachte en zijn medestanders (in de binnenstad) best een aantal plekken kunnen vinden waarvoor desgevraagd van de rechthebbenden toestemming is te verkrijgen om er gratis te plakken.

Bovendien vallen er (in de binnenstad) wel gebouwen en dergelijke aan te wijzen welke door de rechthebbenden in zulk een deplorabele staat worden gelaten dat ervan mag worden uitgegaan dat zij zich om de uiterlijke staat niet bekommeren en dan ook tegen het beplakken ervan geen bezwaar zullen hebben, zodat het vooraf vragen van hun toestemming niet nodig lijkt (blijkt dat achteraf anders te liggen, dan zal de plakker het geplakte alsnog hebben te verwijderen).

Al met al kan dus niet gezegd worden dat in de praktijk te Arnhem geen gebruik van enige betekenis voor het middel van plakken resteert. Zouden de genoemde plaatsen naar de mening van verdachte en de zijnen nog te weinig in getal en/of te weinig in het oog vallend zijn om het nagestreefde effect te sorteren, dan zijn dat veeleer bezwaren welke eigen zijn aan het middel van plakken zèlf".

Dat er onvoldoende plakmogelijkheden overbleven werd door de rechtbank, met andere woorden, kennelijk als een "casus non dabilis" beschouwd, zoals Remmelink het bij een eerdere gelegenheid uitdrukte. ${ }^{17}$ Daarmee ging zij minder ver dan de rechtbank in Dordrecht ${ }^{18}$, die destijds - zoals gezegd had overwogen dat de gemeente desnoods "aanplakplaatsen" moest "aanwijzen" of van het verbod moest "uitzonderen". Ook de Arnhemse rechter had niettemin duidelijk oog voor de feitelijke context van de APV-bepaling. En de Hoge Raad oordeelde dat de rechtbank

"het beroep van de verdachte op de onverbindendheid van de onderhavige verbodsbepaling zonder miskenning van het recht (had) verworpen op gronden welke die beslissing geredelijk kunnen dragen.

Hieraan kan niet afdoen dat ten tijde als in de bewezenverklaring vermeld door voornoemde gemeente geen plakplaatsen in de binnenstad waren aangewezen".

Let wel: het verzuim om plakplaatsen aan te wijzen kan aan het voorgaande niet afdoen; het is hier dus als argument irrelevant. De motivering van de rechtbank kon de verwerping van het beroep op onverbindendheid al geredelijk dragen; van miskenning van het recht was daarbij niet gebleken. De Hoge Raad nam die motivering dus niet over - dat kon ook moeilijk, want voor de juistheid van alle feitelijke vaststellingen kon hij moeilijk instaan. Maar zoveel was zeker: de rechtbank kon - "zonder miskenning van het recht" - tot dit resultaat komen; zij kon dat zelfs "geredelijk" (oftewel: 
zonder aarzelen, zoals Van Dale leert).

Had de rechtbank het dan mogelijkerwijs toch mis, hoewel dat niet gebleken was? Inderdaad, die mogelijkheid mocht volgens de Hoge Raad klaarblijkelijk niet worden uitgesloten. ${ }^{19}$ Anders had hij wel overwogen dat het beroep op onverbindendheid terecht was verworpen (waarmee alleen iets over het resultaat was gezegd, en niets over de gronden). Gezien het eerdere arrest over de gemeente Doorn - toen de rechtbank had volstaan met oplepeling van de ( $6 \sigma \mathrm{k}$ door de Arnhemse rechtbank gehanteerde) Hengelo-formule zou een dergelijke afdoening ook voor de hand hebben gelegen. In "Doorn" bleek het beroep immers "op goede gronden terecht" verworpen te zijn. Nu er aan die gronden nog iets (feitelijks) was toegevoegd, had de verwerping met andere woorden zeker nog terecht moeten zijn. Maar de Hoge Raad vond die toevoeging intussen blijkbaar zó essentieel dat de juistheid ervan beslissend was voor de vraag of het beroep terecht was verworpen. "Henge10 " was, kortom, op subtiele wijze aan het wankelen gebracht. ${ }^{20}$

- Veel eenvoudiger lag het allemaal in een zaak die de Afdeling Rechtspraak van de Raad van State ruim een week later te beslissen kreeg. ${ }^{21}$ De Haagse Verordening op het reclamewezen verbood, behoudens vergunning van burgemeester en wethouders, "in het niet-landelijk gedeelte der gemeente" reclame aan te brengen. Dat kon vanzelfsprekend - net als indertijd het Leidse reclameverbod ${ }^{22}$. niet door de beugel. Het gebruik van het betreffende verspreidingsmiddel, zonder voorafgaand verlof van burgemeester en wethouders, was immers "geheel in het algemeen verboden". De Afdeling Rechtspraak bleek opnieuw in het voetspoor van de Hoge Raad te treden.

- Of ze allebei gelijke tred hielden, was echter een andere vraag. Op 28 april 1981 sprak de Afdeling Rechtspraak zich uit over het Nijmeegse plakverbod. ${ }^{23}$ Het was in die gemeente, als je tenminste geen vrijstelling van B en W had,

"verboden de bestrating, verharding of bedekking van wegen of zich daarop bevindende palen, zuilen en andere vaste voorwerpen, met uitzondering van de door B. en W. aangewezen openbare aanplakgelegenheden, te voorzien van enig aanplakbiljet, aanplakdoek, spandoek, bord, drukwerk, geschrift of afbeelding".

Volgens de Afdeling Rechtspraak waren de grenzen van het toelaatbare daarmee overschreden. Het ging hier immers om een zelfstandig middel van bekendmaking, waarvan het gebruik "geheel is verboden zonder voorafgaand verlof van B. en W.". En:

"De op vorenomschreven verbod gemaakte uitzondering betreffende door B. en W. aangewezen openbare aanplakaangelegenheden, acht de 
Afdeling van onvoldoende betekenis om met vrucht te kunnen stellen dat $(. .$.$) het verbod daardoor op zodanige wijze wordt ingeperkt dat$ daaraan het algemene karakter wordt ontnomen".

Was die uitkomst voorspelbaar? Laat ik eerlijk zijn: niet voor mij. In de eerste plaats was, volgens mij, niet te voorzien dat deze vorm van plakken als zeifstandig middel zou worden aangemerkt. In andere "plakzaken" ging het steeds om een verbod om op een van de weg af zichtbare plaats te plakken of iets dergelijks. Deze bepaling betrof slechts een klein onderdeel daarvan (al was de term "weg" in de APV heel ruim omschreven). Je had je dus kunnen voorstellen dat de Afdeling zou hebben geoordeeld dat het - ruimer geformuleerde - middel van bekendmaking niet geheel verboden was zonder voorafgaand verlof van B en W. Je kon immers nog op tal van andere wijzen zichtbaar plakken! ${ }^{24}$ In de tweede plaats had de Hoge Raad in het arrest over de Utrechtse muurkrant ${ }^{25}$ juist met zoveel woorden overwogen dat het Utrechtse - eveneens algemene - plakverbod de grens van het toelaatbare niet had overschreden, "aangezien het verbod niet geldt voor mededelingen of bekendmakingen op de (door B en W, RdW) aangewezen, aan de openbare weg geplaatste borden". De Afdeling Rechtspraak, daarentegen, leek opeens weer aansluiting te zoeken bij "Rehoboth" ${ }^{26}$, dat door de Hoge Raad in die Utrechtse zaak net was prijsgegeven. Waar voor de Hoge Raad voldoende feitelijke gebruiksmogelijkheden overbleven, constateerde de Afdeling Rechtspraak een tekort. Uit rechtspolitiek oogpunt was dat wellicht aantrekkelijk: zo kon men de Afdeling uitspelen tegen de Hugu Raad. ${ }^{27}$ Wie uit was op een inzichtelijke "leer", kon alleen maar in verwarring raken.

- Laat ik even bij de Afdeling Rechtspraak blijven en eerst nog twee andere uitspraken bespreken, vớr ik weer terugga naar de Hoge Raad. De eerste uitspraak ging over het belangwekkende vraagstuk of de Overijsselse gemeente Wierden (onder meer) aan de provinciale Vriezenveenseweg "richtingborden" naar het plaatselijke sportpark mocht aanbrengen. Volgens het Provinciaal Wegenreglement Overijssel was daar toestemming van het "gezaghebbend orgaan" voor nodig, in dit geval: GS. Die toestemming werd echter geweigerd, omdat volgens GS "onvoldoende aangetoond" was dat plaatsing van deze borden "noodzakelijk (was) vanuit een oogpunt van bevordering van de verkeersveiligheid". Vandaar dat de zaak vervolgens bij de Afdeling Rechtspraak terechtkwam. En bij die gelegenheid kwam art. 7 Gr.w. opeens in het vizier. Het provinciale verbod om - zonder ontheffing van "het gezaghebbend orgaan" - "van een weg gebruik te maken tot het plaatsen en laten staan van borden en zuilen, met uitzondering van de wettelijk voorgeschreven verkeersaanduidingen", ging volgens de Afdeling 
namelijk te ver ${ }^{28}$ Waarom? Omdat een dergelijk gebruik van wegen (waaronder ook bermen vallen) moest worden "aangemerkt als een middel van bekendmaking dat naast andere middelen zelfstandige betekenis heeft en met het oog op die bekendmaking in een bepaalde behoefte kan voorzien", zoals de Afdeling uit Het Grote Spreukenboek had overgeschreven. Daarmee was het pleit natuurlijk beslecht. Zo'n middel mocht immers "niet in het algemeen worden verboden of afhankelijk worden gesteld van een voorafgaand verlof van de overheid". Bovendien was de bepaling niet zodanig te splitsen dat zij - voor zover zij geen betrekking had op gedachten of gevoelens in de zin van art. $7 \mathrm{Gr} . w$. - nog gered kon worden. Het verbod bleek, met andere woorden, tot ieders verbazing onverbindend te zijn. Maar, zo vroeg De Meij zich in een "aantekening" onder de uitspraak af":

"Is het reëel om het plaatsen van borden e.d. met opschriften die onder artikel 7 vallen op zulke wegen plus bermen als een zelfstandig verspreidingsmiddel te zien? Criterium hiervoor is volgens de literatuur met name of via zo'n middel van bekendmaking een ander publiek bereikt kan worden dan met de overige verspreidingsmiddelen. Het publiek op de provinciale wegen kan toch evengoed bereikt worden via het plaatsen van borden in weilanden langs die wegen of op huizen daarlangs? Op de wegen en in de bermen horen alleen verkeerstekens thuis."

Afgezien van dat laatste, dat meer weg heeft van een persoonlijke ontboezeming, sprak het - in het licht van de eerdere jurisprudentie - inderdaad niet vanzelf dat hier een zelfstandig middel in het spel was, net zomin als het in die Nijmeegse zaak vanzelf sprak dat we met een zelfstandig middel te maken hadden. Maar opnieuw bleek de omschrijving verder verengd te kunnen worden. Wie zich nog herinnert dat de Hoge Raad het middel aanvankelijk $\mathrm{k}^{30}$ nog heel aigemeen omschreef als "het op of aan den openbaren weg bekendmaken van gedrukte of geschreven stukken of afbeeldingen", zal zich realiseren dat geleidelijk steeds meer verspreidingsvormen bescherming van art. $7 \mathrm{Gr}$.w. zijn gaan genieten. Wat tegenwoordig immers zèlf als "middel" werd aangemerkt, was vroeger slechts een onderdeel van een veel ruimer omschreven "mididel" en kon toen dus in principe zonder meer verboden worden zonder dat het (ruim omschreven) middel daardoor onderuit werd gehaald.

Vreemd is alleen dat De Meij het door hem in "de literatuur" gevonden criterium, dat ooit door Röling werd bedacht ter verklaring van de rechtspraak $^{31}$, nu zelfs boven de rechtspraak plaatst. Ligt het niet méer voor de hand dat criterium zonodig bij te stellen, als gebleken is dat het geen adequate voorspellingen oplevert? Welnu, waarom zou een verspreidingsmiddel, zoals De Meij het in het voetspoor van Röling voorstelt, alleén zelfstan- 
dige betekenis hebben voor zover het voor de ontvanger in een behoefte voorziet? Voor menige verspreider blijkt het in de praktijk heel wat eenvoudiger om bomen en lantaarnpalen te beplakken of van borden te voorzien, dan vanuit weilanden of huizen te "opereren" (nog afgezien van de bezwaren die daaraan verbonden zijn uit oogpunt van landschaps- en stadsschoon). Bovendien is het bewerken van bomen en lantaarnpalen meestal veel goedkoper dan het bouwen van een grote stellage in het landschap of op een dak. En je kunt er ook een ander soort boodschap mee uitdragen (bij iedere boom een andere leus, bijvoorbeeld, of - omgekeerd - juist benutting van de mogelijkheid tot herhaling, eventueel gecombineerd met een plotselinge afwijking om de aandacht te trekken.

Er zijn, met andere woorden, allerlei redenen te verzinnen om - net als de Afdeling Rechtspraak - aan te nemen dat in dit geval sprake was van een ongeoorloofde beperking van een zelfstandig middel. Te voorzien was dat echter nauwelijks.

- Interessant was ook een beslissing van de enkelvoudige kamer van de Afdeling Rechtspraak (oftewel: mevrouw Barendsen-Cleveringa) over het reclameverbod in Pijnacker. ${ }^{32}$ In die gemeente was het

"de eigenaar of gebruiker van enig onroerend goed verboden daarop of daaraan een verlichting of reclame te hebben, indien burgemeester en wethouders hem schriftelijk hebben medegedeeld dat die verlichting of reclame de verkeersveiligheid in gevaar brengt, of een voor de omgeving hinderlijk effect sorteert".

Deze keer was er, voor de afwisseling, geen strijd met art. 7 Gr.w. Weliswaar zag deze bepaling, in de woorden van de Afdeling, "zowel op zogenaamde commerciële reclame, als op reclame waarin gedachten of gevoelens zijn geopenbaard als bedoeld in artikel 7 van de Grondwet", maar zij behelsde (in krom Nederlands) "noch een algemeen verbod, noch (werd) het hebben van een reclame van een voorafgaand verlof van de overheid afhankelijk gesteld". Dus was er geen vuiltje aan de lucht.

Verstedeni ${ }^{33}$ vroeg zich naar aanleiding van deze uitspraak echter af of het verschil met verbodsbepalingen waarbij wel voorafgaand verlof wordt vereist inmiddels nog reëel is - vooral wanneer de weigeringsgronden in zo'n vergunningstelsel uitdrukkelijk beperkt zijn tot verkeersveiligheid en hinder voor de omgeving:

"Een verschil is dat men in de gemeente Pijnacker zijn gang kan gaan totdat burgemeester en wethouders ingrijpen en dat men dat bij de andere constructie niet kan. Maar per saldo is het verschil slechts procedureel.

Materieel zijn beide constructies gelijk want in beide gevallen zal de 
bekendmaking slechts kunnen worden tegengehouden op grond van gevaar voor de verkeersveiligheid of hinder voor de omgeving.

Of, anders gezegd, bij beide constructies hebben burgemeester en wethouders per saldo evenveel mogelijkheden tot beperking. Het verschil in benadering is dan ook niet goed te begrijpen.

Overigens rijst, nu de Afdeling rechtspraak de Pijnackerse weg is ingeslagen, de vraag of het nog wel zinvol is zo krampachtig vast te houden aan de veroordeling van het voorafgaand verlof voor openbare bekendmaking. De bezwaren hiertegen stammen uit de tijd dat het verbod van détournement de pouvoir, dat voor bestuursorganen bij het uitoefenen van de beschikkingsbevoegdheid geldt, nog geen of nauwelijks erkenning had gevonden en op de naleving van de daarmee corresponderende plicht zuiverheid van oogmerk aan de dag te leggen nog geen goede controle bestond".

Daar zat natuurlijk wel iets in; zeker vanuit bestuurlijk oogpunt. Maar de crux van art. 7 wàs nu juist procedureel van aard. Het ging erom dat je niet eerst bij de overheid hoefde aan te kloppen, ook al mocht diezelfde overheid slechts op welomschreven - niet inhoudelijke! - gronden weigeren toestemming te verlenen. Dat was al bij herhaling beslist. En in dat licht bezien, wekt de suggestie van Versteden dan ook verbazing. Hij deed of procedurele waarborgen er eigenlijk niet toe doen, zolang de zaken "materieel" maar in orde zijn. Je zou zijn stelling evengoed kunnen omdraaien: nu B en W repressief konden optreden, bestond het gevaar dat de procedurele waarborg van art. 7 in het gedrang zou komen. Wie zou het immers wagen een fors bedrag in een - niet per se commerciële - lichtreclame te investeren, zonder vooraf te informeren of B en W wellicht een gevaar voor de verkeersveiligheid, dan wel "een voor de omgeving hinderlijk effect" voorzagen? Tja, dat de dreiging van repressief optreden de vrijheid van meningsuiting soms mér beknot dan openiijke censuur was ook in de $19 \mathrm{e}$ eeuw al bekend. "Veel liever dan zulke vrijheid hadden wij DE CENSUUR", schreef het Weekblad van het Regt bijvoorbeeld in $1845^{34}$, "dan weet men ten minste, waaraan men zich houden moet". Die - ironisch bedoelde - raad is echter nooit opgevolgd. Voorafgaand verlof - met welk oogmerk ook - bleef dus verboden. Moeten we, gezien de preventieve werking ervan, ó k het repressieve optreden dan maar verbieden? Een dergelijke conclusie is niet minder dwingend dan die waartoe Versteden kwam, lijkt mij.

- Terug naar de Hoge Raad. Na "Arnhem" had hij zich op 9 juni 1981 over het Deventer plakverbod uitgelaten. ${ }^{35}$ Daarin ging het niet om een verbod "wederrechtelijk" te plakken (zoals in Hengelo en Arnhem), maar om een variant op "Dordrecht" ${ }^{36}$ : het verbod "op of aan de weg of openbare 
grond een aanplakbiljet of dergelijk voorwerp aan te brengen" was "niet van toepassing ten aanzien van aanplakbiljetten of dergelijke voorwerpen, welke door of met goedvinden van de rechthebbende (werden) aangebracht".

In plaats van toestemming (zoals in Dordrecht) was hier dus goedvinden vereist. Maakte dat verschil? Volgens de raadsman in cassatie kon men eerder van "goedvinden" spreken dan van "toestemming" - het ene kon impliciet gebeuren, het andere alleen uitdrukkelijk. ${ }^{37}$ Zelfs die raadsman zal dus wel niet verbaasd zijn geweest dat de (volgens hem) minder verstrekkende Deventer bepaling - net als het verderstrekkende Dordtse en Alkmaarder regime - door de beugel bleek te kunnen! De Hoge Raad - die nu het op of aan de weg plakken als zelfstandig middel aanmerkte - volstond eenvoudig met een standaardafdoening: de stelling dat de Deventer APV-bepaling "vrijwel neerkomt op een algeheel verbod van het aldaar bedoelde middel van bekendmaking (kon) niet als juist worden anvaard". Zij bracht "immers slechts mee een beperking van het gebruik van dit middel van bekendmaking voor zover door dat gebruik eens anders recht zou worden geschonden". En:

"Zulks is niet anders indien in genoemde Verordening niet is voorzien

in de oprichting van openbare aanplakborden".

Ook dat laatste hoefde - na "Arnhem" (waar evenmin aanplakborden waren) - geen verbazing te wekken. Maar "Arnhem" - met zijn opening naar de feitelijke omstandigheden te plekke - was destijds misschien nog niet naar waarde geschat; het arrest was in de NJ ook niet van een noot voorzien. De kritiek van Alkema in zijn noot onder dit arrest, lijkt mij daarom niet helemaal terecht.

"Welbewust", aldus Alkema, "heeft de grondwetgever de door de rechter opgebouwde doctrine ook in de nieuwe Grondwet willen handhaven en de tekst van art. $7 \mathrm{Gw}$. daartoe woordelijk overgenomen. Dat impliceert, dat het aan de rechter is om de drukpersvrijheid "au courant" te houden. Daarom stelt het teleur, dat dit arrest geen enkele opening biedt voor verdere verfijning".

Zo'n "verfijning", echter, had al bij een eerdere gelegenheid plaatsgevonden. Deze uitspraak was geheel en al in overeenstemming daarmee, hoewel zij op zichzelf genomen ook in een minder verfijnde context zou hebben gepast.

- Een half jaar nadat de Afdeling Rechtspraak zich over het Nijmeegse plakverbod had uitgesproken ${ }^{38}$ volgde een arrest van de Hoge Raad ${ }^{39}$ over hetzelfde verbod. De verdachte, die "tezamen en in vereniging met een ander een op het trottoir van de voor het publiek toegankelijke weg, de Grote Markt, staande lantaarnpaal van enig aanplakbiljet (had) voorzien", was - alwér door de Arnhemse rechtbank - ontslagen van alle rechtsvervolging. Het Nijmeegse plakverbod was volgens de rechtbank namelijk in strijd met 
art. 7 Gr.w. Anders dan de Afdeling Rechtspraak, echter, spitste de rechtbank haar beslissing niet toe op én k.ein onderdeeltje van dat verbod. $\mathrm{Zij}$ betrok het plakregime in zijn totaliteit erbij. Daardoor hoefde zij ook niet een bepaalde micro-verspreidingsvorm tot "zelfstandig" middel te verheffen, zoals de Afdeling Rechtspraak had gedaan (zie hiervór). Nee, in het vonnis van de rechtbank ging het heel algemeen om "het aanbrengen van geschreven of gedrukte teksten of van afbeeldingen op onroerende goederen (en/of toebehoren) en op de bestrating e.d. van wegen (en daarop staande palen e.d.)".

Erg eenvoudig was het plakregime in Nijmegen overigens niet. Het was in twee APV-bepalingen neergelegd: art. 198 en 199. De Afdeling Rechtspraak had zich alleen over art. 199 uitgesproken. Daarin was het verbod neergelegd om "de bestrating, verharding of bedekking van wegen of de zich daarop bevindende palen, zuilen en andere vaste voorwerpen, met uitzondering van de door $\mathbf{B}$. en $\mathbf{W}$. aangewezen openbare aanplakgelegenheden" te beplakken e.d. Bovendien was het - net als elders - verboden om "enig ander onroerend goed" zonder toesternming van de eigenaar of gebruiker voor "opschriften, aankondigingen of afbeeldingen in welke vorm ook" te gebruiken (voor zover ze tenminste zichtbaar waren vanaf de openbare weg).

Art. 198, echter, bevatte tevens voor eigenaren en gebruikers een beperking. Zij mochten, op hùn beurt, slechts met vergunning van $B$ en $W$ hun onroerende zaken, "of enig daarop aanwezige zaak, geheel of ten dele (..) gebruiken of het gebruik daarvan (...) gedogen voor opschriften, aankondigingen of afbeeldingen, in welke vorm dan ook, welke vanaf de openbare weg (...) zichtbaar (waren)". Op grond van het tweede lid waren bepaalde aankondigingen van het verbod uitgezonderd (mits ze niet te groot waren uitgevoerd) en gold het verbod niet voor "aankondigingen en opschriften op zuilen, borden en muren, welke daarvoor door $\mathbf{B}$. en W. (waren) aangewezen".

Het ging dus om een soort tweetraps raket. Afgezien van straten, palen en dergelijke, waarop al helemaal niet geplakt mocht worden zonder vergunning, had je in principe steeds toestemming van de eigenaar of gebruiker nodig. Maar ook zij waren weer gebonden: zonder vergunning van B. en W. mochten hun zaken in beginsel niet beplakt worden. Praktisch gesproken gold er, met andere woorden, een algemeen plakverbod - zij het met enige kleine uitzonderingen (ten aanzien van specifieke feitelijke aankondigingen), plus de mogelijkheid "aankondigingen en opschriften" aan te brengen "op zuilen, borden en muren, welke daarvoor door B. en W. waren aangewezen."

De rechtbank vond dat, zoals gezegd, te weinig. De enige ongeclausuleerde plakmogelijkheid was immers op de door B. en W. aangewezen plaatsen. En 
het belang daarvan moest, volgens de rechtbank, "worden beoordeeld aan de hand van de vraag of dergelijke aanplakmogelijkheden inderdaad (waren) aangewezen en - zo ja - of dit in een zo ruime mate (was) gebeurd dat gezegd (kon) worden dat dientengevolge het karakter van algemeenheid aan de betreffende verbodsbepalingen (was) komen te ontvallen". Dat bleek echter niet het geval, want:

"Uit een bij de processtukken aanwezige brief van de Hoofdcommissaris van Politie te Nijmegen aan de Burgemeester van Nijmegen van 21 sept. 1979 (viel) af te leiden, dat op het tijdstip waarop het ten laste gelegde feit door verdachte (was) gepleegd nog in het geheel geen besluit van $\mathrm{B}$. en $\mathrm{W}$. tot aanwijzing van openbare aanplakgelegenheden was tot stand gekomen".

Dus waren de verbodsbepalingen "op genoemd tijdstip onverbindend", aldus de rechtbank.

Maar de Hoge Raad dacht daar anders over,

"aangezien de verbindendheid van een gemeentelijke verordening ${ }^{40}$ niet afhangt van de wijze waarop daaraan uitvoering wordt gegeven. (...) Op grond van het volgende leidt dit evenwel niet tot vernietiging van het bestreden vonnis.

De artt. 198 en 199 gaan er voor de gelding van de daarin vervatte verboden kennelijk van uit dat door B. en W. aanwijzing als evenbedoeld is gedaan. Nu zulks niet het geval is had de Rechtbank daarin reden moeten vinden die verboden buiten toepassing te laten, hetgeen eveneens tot ontslag van rechtsvervolging zou hebben geleid".

Kortom: geen onverbindendverklaring, maar buiten toepassing laten. De technische merites daarvan zal ik in dit verband laten rusten. ${ }^{41}$ Maar kunnen we er iets uit afleiden omtrent het standpunt van de Hoge Raad over art. $7 \mathrm{Gr}$.w.? Een aantal auteurs, waaronder ikzelf, meende van wel.: Zij veronderstelden dat de bepaling buiten toepassing moest worden gelaten omdat er geen gebruik van enige betekenis overbleef. Bij nader inzien lijkt me dat eerder een vorm van "wishful thinking". In de eerste plaats omdat er - zoals de rechtbank feitelijk had vastgesteld - uberhaupt geen gebruik overbleef zonder voorafgaand verlof van de overheid. ${ }^{43}$ En in de tweede plaats omdat de Hoge Raad geen enkele inhoudelijke eis leek te stellen aan de door $\mathrm{B}$ en $\mathrm{W}$ uit te vaardigen aanwijzing. De omstandigheid dat die aanwijzing er niet was, was fataal; niet de omstandigheid dat er op die manier geen gebruik van enige betekenis resteerde. Of was dat laatste wellicht de reden waarom de artikelen 198 en 199 er volgens de Hoge Raad kennelijk vanuit gingen dat zo'n aanwijzing had plaatsgevonden? Waar bleven we immers als we ervan uitgingen dat een gemeente welbewust de wet overtrad?! En de wet bracht mee, zoals de Hoge Raad ons al bij 
herhaling had voorgehouden, dat er op z'n minst een mogelijkheid tot gebruik van enige betekenis moest resteren.

Wat de Hoge Raad met dit arrest precies voor ogen stond, is met andere woorden moeilijk uit te maken. Dat het Nijmeegse regime, dat neerkwam op een algemeen verbod zonder dat ook maar enige anplakgelegentheid was angewezen, in strijd werd bevonden met art. $7 \mathrm{Gr}$.w. was intussen echter niet verrassend.

- In Maastricht, tenslotte, was het "aan anderen dan degene, die daartoe gemachtigd is" verboden om - kort gezegd - te plakken en kladden (art. 8 APV). Daarnaast gold het bekende verbod om 's avonds met plakmiddelen, aanplakbiljetten en soortgeiijke artikelen op straat te zijn, tenzij je aannemelijk kon maken dat die zaken voor iets anders waren "bestemd of gebezigd" dan voor overtreding van het plak- en kladverbod (art. 9 APV). Maria Philomène Emilie Hyacintha G., die tegen half drie in de nacht op straat was aangetroffen met een stapel aanplakbiljetten, werd op grond van die laatste bepaling door de rechtbank veroordeeld tot vijftig gulden boete. ${ }^{44}$

In cassatie had haar raadsman zich op Stellinga beroepen en betoogd dat "wet" in art. $7 \mathrm{Gr}$.w. "dient te worden beschouwd als Wet in formele zin, zodat uitsluitend de formele wetgever beperkingen kan opleggen ten aanzien van al die verspreidingsmiddelen die onder art. 7 Gr.w. vallen". Dat bracht de Hoge Raad ertoe nogmaals - zij het verkort - het oude verhaal uit 1950 op te dienen over het "de geesteswereld betreffende recht" enerzijds en het weliswaar onmisbare maar toch ondergeschikte verspreidingsrecht anderzijds. ${ }^{45}$ Vervolgens werd de frase "anderen dan degene, die daartoe gemachtigd is" verstaan als "anderen dan degene, die door de verboden gedragingen geen inbreuk maakt op eens anders recht". En daarmee waren we weer terug op het bekende terrein van eerdere uitspraken, zoals "Hengelo", "Dordrecht"

en "Doorn". Maar de Hoge Raad overwoog $66 \mathrm{k}$ nog het volgende:

"Indien overigens met een beroep op plaatselijke omstandigheden - bij voorbeeld het ontbreken van openbare, door het bevoegd gezag aangewezen aanpiakgelegenheden - wordt betoogd, dat toepassing van bepalingen als (hiervóor, RdW) weergegeven dezelfde uitwerking heeft als een algemeen verbod, dan is een zodanig verweer - gelet op de eigen aard van het onderhavige middel tot bekendmaking - van feitelijke aard, zodat het niet met vrucht voor het eerst in cassatie kan worden voorgedragen, terwijl vaststellingen ${ }^{46}$ dienaangaande door de feitenrechter in cassatie slechts in beperkte mate kunnen worden getoetst".

Op die manier werd opnieuw de indruk gewekt dat dergelijke feitelijke vaststellingen "op zichzelf" wel relevant (konden) zijn voor het oordeel over de grondwettigheid van een plakverbod ${ }^{47}$ Hoewel.... Ook als ze niet rele- 
vant waren, kon de Hoge Raad er natuurlijk - gezien het feitelijke karakter ervan - weinig over zeggen. Maar dan had hij vermoedelijk overwogen dat zo'n beroep op de feiten aan het voorgaande niet kon afdoen, of dat het reeds afstuitte op de omstandigheid dat geen rechtsregel ertoe dwong daar acht op te slaan, dan wel iets anders in dat genre. Ik hou het er dan ook op dat de deur naar de feiten hier met opzet is opengehouden; die uitleg biedt bovendien het voordeel van consistentie met "Arnhem", waar immers hetzelfde was gebeurd. ${ }^{48}$

Maar het blijft, vanzelfsprekend, slechts een gissing.

Kistenkas ${ }^{49}$ maakte zich echter zorgen over die zinsnede waaruit bleek dat de lokale plakbevindingen van de feitenrechter "in cassatie slechts in beperkte mate kunnen worden getoetst". In dit geval had de feitenrechter namelijk vastgesteld "dat uit het onderzoek der zaak niet is gebleken, dat de bepaling van art. 8 in feite geen gebruik van enige betekenis van voormeld middel zou toelaten". Welnu, die vaststelling moest volgens de Hoge Raad - onder verwijzing naar de hierboven aangehaalde passage - in cassatie worden "geëerbiedigd". Was dat niet wat al te marginaal? Voer de Hoge Raad nu "toch weer klakkeloos op het kompas van de lagere rechter", zoals Kistenkas het uitdrukte? Tia. alleen: zo werkt cassatierechtsnraak nu eenmaal. De Hoge Raad gaat in principe uit van de feiten, zoals die door de lagere rechter zijn vastgesteld - tenzij er reden is om aan de juistheid daarvan te twijfelen. Maar dan moet er wèl eerst zo'n reden zijn. Het oordeel kan bijvoorbeeld onbegrijpelijk zijn, of het is onvoldoende gemotiveerd. Was daar in dit geval sprake van? Onbegrijpelijk was het zeker niet. Dat wil zeggen: je kunt je "op zichzelf" heel goed voorstellen dat een gebruik van enige betekenis in Maastricht nog mogelijk was. Maar was die constatering ook voldoende gemotiveerd?

Op grond van art. 358 lid $3 \mathrm{~Sv}$ moet de rechtbank "bepaaldelijk eene beslissing geven" indien zij "in strijd met het te dien aanzien door den verdachte uitdrukkelijk voorgedragen verweer" aanneemt "dat het bewezen verklaarde een bepaald strafbaar feit oplevert". En volgens art. 359 lid 2 Sv moet 20 'n beslissing in het vonnis "met redenen omkleed" worden. Dat geldt dus $606 \mathrm{k}$ voor een beroep op onverbindendheid (dat immers gericht is op ontslag van alle rechtsvervolging). Maar de vraag is natuurlijk hoever zo'n motivering moet gaan. Hier ligt ongetwijfeld een taak voor de Hoge Raad. Alleen, in dit Maastrichtse geval is uit het arrest niet eens op te maken of überhaupt - en zo ja: welk - verweer op dit punt is gevoerd. Bezwaren tegen de volgzaamheid van de Hoge Raad zijn dan wel wat voorbarig, lijkt mij. Afgezien daarvan moeten we ons ook niet te veel illusies maken omtrent de mogelijkheden om aan de hand van motiveringen na te gaan of een zaak feitelijk in orde is. In die zin lijkt cassatie vaak een woordenspel. Zolang de 
feitenrechter zich maar van de juiste termen bedient, is zijn oordeel voor de Hoge Raad veelal onaantastbaar. ${ }^{.0} \mathrm{Hij}$ kan de Hoge Raad inderdaad met een kluitje in het riet sturen. Als hij dat wil, althans. Soms is er niettemin iets aan te doen. Hoe gedocumenteerder het verweer op de zitting is, des te moeilijker het voor de feitenrechter wordt om met holle frasen te volstaan. De enkele omstandigheid dat de Hoge Raad in dit geval met betrekkelijk weinig genoegen nam, zegt "op zichzelf" dus niks omtrent de relevantie van de feitelijke omstandigheden ter plekke. Die relevantie wàs er - tenminste, daar mochten we sinds "Arnhem" vanuit gaan (al had niemand dat destijds in de gaten...).

De arme Maastrichtse verdachte kreeg kortom - niet echt onverwacht - nul op haar rekest. Ook het namens haar gevoerde betoog dat art. 9 APV in strijd was met de "presumptio innocentiae", omdat het aan hár was aannemelijk te maken dat de aanplakbiljetten niet "bestemd of gebezigd" waren voor overtreding van het plakverbod (en haar schuld dus eigenlijk werd voorondersteld), werd niet gehonoreerd. Geen wonder, het ging hier slechts om een rechtvaardigingsgrond, zoals de Hoge Raad al eerder in "Alkmaar ${ }^{n 1}$ had uitgemaakt. Onbevredigend, wellicht, maar niets nieuws. ${ }^{52}$

\subsection{Klein intermezzo: Helden (1981)}

Voor een kleine afwisseling in de onafzienbare reeks plakzaken zorgde "een twaalftal personen, mannen en vrouwen", zoals een verbalisant ze omschreef, Zij stonden op het Raadhuisplein voor het gemeenschapshuis te Panningen, gemeente Helden. "Genoernde personen hielden zich op nabij de ingang van de in clat gebouw gevestigde dienst "Sociale Zaken" van de gemeente Helden". Een aantal van hen deelde pamfletten uit. Sommigen "droegen over hun kleding een soort cape of poncho, kennelijk vervaardigd van een wit laken". Daarop stonden in grote letters leuzen geschreven, zoals: "Gem. Helden ronselt werklozen voor uitzendbureaus met dwang". En twee "personen" hielden samen "een geel geverfd triplex bord omhoog, waarop met zwarte letters geschilderd was: 'Door uitzenden meer ellende'. De afmetingen van dit bord waren plus minus 1.80 bij 0.60 meter".

Dirk de Vroome, alias "De Rooie Reus", was ook van de partij. ${ }^{53} \mathrm{Hij}$ werd door de rechtbank tot vijftig gulden boete veroordeeld wegens overtreding van art. 40 APV-Helden:

"Het is verboden zonder vergunning van de Burgemeester op een weg" een optocht, een demonstratie of een spreekkoor te houden of daaraan deel te nemen."

Werd het gedrag van De Rooie Reus en de zijnen dan niet beschermd door 
art. $7 \mathrm{Gr}$.w.? De rechtbank meende van niet en overwoog:

"dat uit de omstandigheid, dat de onderhavige demonstratie gepaard is gegaan met het openbaar maken van geschriften door het tonen van een bord met tekst en het dragen van capes met teksten, (...) niet volgt, dat er sprake is van strijd met art. 7 Gr.w., nu art. 40 lid 1 APV niet medebrengt, dat het openbaar maken van geschriften door het tonen van een bord met tekst en het dragen van een cape met tekst in het algemeen zou zijn verboden of van voorafgaande toestemming van de overheid afhankelijk zou zijn gesteld"..$^{54}$

Niet de individuele verspreiding was, met andere woorden, van voorafgaand verlof van de overheid afhankelijk gesteld, maar uitsluitend de verspreiding in het kader van "een optocht, een demonstratie of een spreekkoor". Dus was het verbod geoorloofd. Sinds "Vietnam II" ${ }^{\text {"35 }}$, waar de rechtbank zich duidelijk door had laten leiden, leek daar inderdaad weinig op af te dingen. Hoewel... Volgens Remmelink ${ }^{56}$ was hier feitelijk geen sprake van een demonstratie. Bij een demonstratie stelde men zich zijns inziens toch voor, "dat er een onderlinge band (geestdrift) is tussen (bij) de mensen, of liever de menigte (hier waren maar 12 personen) met een agerende spreker en spreekkoren. Wat hier blijkt is eigenlijk niet veel meer dan een verzameling van sandwich-men, met andere woorden van een gebeuren, waarbij duidelijk domineert het verspreiden en ten toon stellen van gedrukte of geschreven stukken, en ik moet aannemen, dat de gemeentelijke wetgever zijn bepaling hierop niet mede heeft willen afstemmen".

Dat zag de Hoge Raad ${ }^{57}$ evenwel anders: met de gewraakte APV-bepaling waren "een aantal gedragingen aan een vergunning van de Burgemeester onderworpen, welke hierdoor gekenmerkt (werden) dat zij openlijk en in groepsverband (geschiedden)". En in dit geval kon uit de gebezigde bewijsmiddelen inderdaad worden afgeleid dat "de wijze waarop gedachten en gevoelens werden geopenbaard gekenmerkt werd doordat zulks openlijk en in groepsverband geschiedde". Vooral dat "groepsverband" zal wel fataal geweest zijn, want dat het openbaren openlijk geschiedde, hoefde weinig opzien te baren, lijkt mij. Hoe dan ook, er was sprake van een demonstratie. En dan "verschilt de wijze van openbaren van gedachten en gevoelens", zoals ook al in Vietnam II was uitgemaakt, "te zeer van die bedoeld in art. 7 Gr.w. om daarmede op een lijn te kunnen worden gesteld".

Was die uitkomst te voorzien? Zodra je tot de vaststelling was gekomen dat het om een demonstratie ging wel. Maar hoe kon je dat vaststellen? Wanneer was er sprake van een "groepsverband"? Gold hier het befaamde "two is company, three is a crowd"? 


\subsection{Breda: verankering van een keerpunt (1983)}

Ook. Breda kende vanzelfsprekend een plakverbod. Net als in Alkmaar had je daar zelfs schriftelijke toestemming van de rechthebbende(n) nodig (art. 136 lid ! APV). En verder gold er het overbekende verbod om 's nachts met plakspullen in de weer te zijn, tenzij... etc. Petrus Wilhelmus Leonardus Hendricus $\mathbf{M}$. werd op grond van dat laatste verbod op 22 april 1982 door de rechtbank veroordeeld omdat hij 's nachts "te omstreeks 01.50 uur" 20 aanplakbiljetten bij zich had. ${ }^{58} \mathrm{Zijn}$ verweer,

"dat (...) de gemeente Breda nog steeds geen openbare aanplakborden heeft aangewezen, noch andere mogelijkheden heeft geboden om te kunnen plakken, bijvoorbeeld door aanwijzing van een aantal voor de sloop bestemde panden", zodat het verbod "geen, althans onvoldoende mogelijkheden open (laat) gebruik te maken van het onderhavige middel van verspreiding en bekendmaking hetwelk zelfstandige betekenis heeft",

mocht niet baten. De rechtbank repliceerde eenvoudig volgens het bekende sjablone:

"dat de Rechtbank van oordeel is, dat het verbod (...) slechts een beperking van het gebruik van het in dat artikel bedoelde middel van bekendmaking brengt voor zover door dat gebruik eens anders recht zou worden geschonden;

dat het verbod voor het overige elk gebruik van dat middel onverlet laat".

En zij voegde daaraan toe:

"dat zo"n beperking c.q. voorschrift in het onderhavige geval mogelijk een remmende werking heeft op de verspreiding van de aanplakbilijetten, doch dat ter terechtzitting van heden niet aannemelijk is geworden dat zulks die verspreiding onmogelijk zou maken c.q. in ontoelaatbare mate zou belemmeren;

dat het merendeel van de voor aanplakking gebruikte panden in Breda particulieren als rechthebbende kent en niet de gemeente c.q. de overheid, zodat in het onderhavige geval, gelet op art. 136 APV 1978, die beperking geen algemeen verbod inhoudt."

In cassatie werd hier echter tegen ingebracht dat met name het vereiste dat de toestemming schriftelijk moest zijn gegeven, te ver ging. Daarmee werd van plakkers mér gevergd "dan noodzakelijk is ter voorkoming van schending van rechten van anderen" en bleven er onvoldoende gebruiksmogelijkheden over.

Opnieuw was de poging tevergeefs. Remmelink" noemde een "dergelijke formalisering" in zijn conclusie "alleszins redelijk": 
"Het genoegen nemen met een mondelinge toesternming zou de rechthebbenden in een uiterst zwakke positie brengen tegenover plakkers die, zij het volmaakt ten onrechte, beweren, dat zij zo'n toestemming hebben ontvangen. Daarbij kan men ook nog denken aan de situatie, dat zij beweren, dat zij stilzwijgend toestemming hebben gekregen, zoals men die nu reeds in globo als gegeven wil veronderstellen door hen, die rechthebbende zijn van een in slechte toestand verkerend pand".

Daarnaast merkte hij, in aansluiting op "Maastricht" ${ }^{\text {"60 }}$, op:

"dat de vaststelling van de Rechtbank dat niet aannemelijk is geworden, dat de onderhavige bepalingen de verspreiding van pamfletten onmogelijk zouden maken of deze in ontoelaatbare wijze zouden belemmeren in cassatie niet wel toetsbaar is. Uw Raad zal zich bij zo'n vaststelling, tenzij deze apert onredelijk is, moeten neerleggen".

En dat deed de Hoge Raad ${ }^{61}$ dan ook:

"Door te overwegen zoals hiervoren (...) is weergegeven heeft de rechtbank het (...) verweer van verdachtes raadsman verworpen op gronden welke die verwerping kunnen dragen.

In de overweging dat niet aannemelijk is geworden dat de remmende werking van het vereiste van schriftelijke toestemming van de rechthebbende(n) de verspreiding van de aanplakbiljetten 'onmogelijk zou maken c.q. in ontoelaatbare mate zou belemmeren', ligt het oordeel van de Rechtbank besloten dat niet aannemelijk is geworden dat ten gevolge van die remmende werking geen gebruiksmogelijkheden van enige betekenis van het onderhavige middel van verspreiding en bekendmaking zouden overblijven. Aangezien dit oordeel van de Rechtbank steunt op een waardering van de feitelijke omstandigheden welke zich in de gemeente Breda voordoen, moet het in cassatie worden geëerbiedigd."

Bovendien werd die schriftelijke toestemming, volgens de Hoge Raad, wel degelijk ter voorkoming van schending van de rechten van anderen geëist. Sterker, dat vereiste

"strekt kennelijk ter voorkoming van onzekerheid over de vraag of bedoelde toestemming al dan niet is gegeven of geacht kan worden te zijn gegeven in gevallen waarin degenen die biljetten hebben aangeplakt beweren, doch de rechthebbenden ontkennen, dat tot dit aanplakken toestemming is gegeven. Voorkoming van onzekerheid hierover is in het belang van beide partijen".

$\mathrm{Na}$ "Alkmaar" 62 , toen een soortgelijk regime door de beugel bleek te kunnen, wekt die uitkomst "op zichzelf" nauwelijks verbazing. Hoogstens valt op dat niemand op dat eerdere arrest heeft gewezen. Niet alleen de raadsman 
maakte er - om begrijpelijke redenen - geen melding van, ook Remmelink zweeg er in zijn conclusie over. En Borman schreef in zijn noot in de NJ zelfs dat het arrest

"een nieuw element aan de jurisprudentie (toevoegt), maar niet in voor de plakkers gunstige zin. Afgewezen wordt $\mathrm{nl}$. hun argument (...) dat de gemeentelijke verordening, door te eisen dat de toestemming van de rechthebbende op schrift is gesteld, de grens overschrijdt die de HR in zijn jurisprudentie omtrent de verenigbaarheid van de Alkmaarconstructie met art. 7 eerste lid Gr.w. zelf getrokken heeft".

Ik vrees dat het Alkmaarder arrest hern bij het opschrijven van die passage niet meer precies voor de geest stond. Had hij het even geverifieerd, dan had hij gezien dat het arrest juist in dat opzicht geen enkel "nieuw element" bevatte.

Wel nieuw - maar vrijwel onopgemerkt ${ }^{63}$ - was daarentegen dat we in dit arrest als het ware met een combinatie van "Arnhem"64 en "Maastricht" 65 te maken hadden. En daarmee was in éen klap duidelijk dat de vraag of er al dan niet strijd met (inmiddels) art. 7 lid $1 \mathrm{Gr}$.w. was, niet uitsluitend door het juridische regime van een APV-bepaling werd beslecht. Van twee kanten werd ons nu aangereikt dat ook de feltelljke verhoudingen ter plekke van belang waren. In de eerste plaats bleek de rechtbank het verweer - dat er geen gebruik van enige betekenis meer mogelijk was - te hebben "verworpen op gronden welke die verwerping kunnen dragen". Dat wil zeggen dat het de Hoge Raad niet uitsluitend om juridische factoren ging. De omstandigheid dat de gewraakte bepaling er slechts toe strekte te voorkomen dat "eens anders recht" werd geschonden, was dus - anders dan bijvoorbeeld in "Dordrecht" 66 - niet het enige waarop gelet werd. Was dat wèl zo geweest, dan had de Hoge Raad - zoals ik al eerder (naar aanleiding van "Arnhem") betoogde - geoordeeld dat het verweer terecht was verworpen. Immers, de rechtbank had keurig op die strekking gewezen. Maar de rechtbank had - zij het summier - nog op mér gewezen, te weten: op de omstandigheden ter plekke. Alleen, die konden door de Hoge Raad natuurlijk niet worden nagetrokken. Maar hij vond ze kennelijk wèl van belang. Vandaar die overweging dat het verweer verworpen was "op gronden welke die verwerping kunnen dragen". Inderdaaj: kunnen, want of het allemaal klopte, kon de Hoge Raad niet nagaan; absurd was het echter zeker niet.

In de tweede plaats werd het betoog van de raadsman, die erover had geklaagd dat het gemeentelijke plakverbod onvoldoende plakmogelijkheden overliet, door de Hoge Raad beantwoord met een verwijzing naar hetgeen de rechtbank had overwogen. Daaruit viel namelijk - net als in "Maastricht" - af te leiden dat feitelijk wel degelijk een gebruik van enige betekenis mogelijk was (althans dat het tegendeel niet aannemelijk was geworden). 
Zo'n oordeel moest in cassatie weliswaar "geëerbiedigd" worden, maar dat hier wèi een taak voor de feitenrechter lag, was duidelijk - anders had volstaan kunnen worden met een analyse van de APV-bepaling (zoals destijds in "Dordrecht").

Twee aanknopingspunten, met andere woorden, voor dezelfde conclusie. Ging het in "Dordrecht" nog om een "gebruik van enige betekenis" dat door de overheid ongemoeid moest worden gelaten (opdat er niet heimelijk toch iets werd ingevoerd dat feitelijk neerkwam op een algemeen - door de overheid ingesteld - verbod of verlofstelsel), inmiddels leek dat begrip een veel ruimere strekking te hebben gekregen. Een middel van bekendmaking moest nu werkelijk op enige schaal benut kunnen worden. Was dat niet het geval, dan ging het er niet langer om of dit louter en alleen aan een verbodsbepaling was te wijten, maar of daar verandering in viel te brengen door die verbodsbepaling ongeldig te verklaren. De feitelijke omstandigheden ter plekke stonden dus voorop.

Of vergis ik mij nu toch? Pal na die overweging van de rechtbank, waarin volgens de Hoge Raad besloten lag dat feitelijk nog gebruik van enige betekenis mogelijk bleef, wees de rechtbank er immers - bij wijze van motivering? - op "dat het merendeel van de voor aanplakking geschikte panden in Breda particulieren als rechthebbende kent en niet de gemeente c.q. de overheid". Was dat de feitelijke omstandigheid waar de Hoge Raad indirect op doelde? Dan zou er - materieel - sinds "Dordrecht" niets veranderd zijn! Toen werd iets dergelijks gewoon aangenomen, onder het motto: je bent helemaal niet afhankelijk van de overheid, vraag toch toestemming aan een particulier! Maar dan moeten er well voldoende particulieren zijn om een gebruik van enige betekenis mogelijk te maken. En daar is - goed beschouwd - inderdaad een feitelijk onderzoek voor nodig, hoewel de uitkornst daarvan in Nederland tamelijk voorspelbaar is. Ja, zó voorspelbaar zelfs dat we wel mogen spreken van een feit van algemene bekendheid. Alleen, zo'n feit kan ook op eigen houtje door de Hoge Raad worden vastgesteld. Daar valt, met andere woorden, niets aan te "eerbiedigen" in cassatie. Dus zag de Hoge Raad blijkbaar op iets anders, iets wat niet door hemzelf kon worden vastgesteld: de feitelijke verhoudingen ter plekke die bepalen in hoeverre er daadwerkelijk geplakt kan worden.

Het arrest bevestigde, kortom, wat we al konden zien aankomen (als we goed hadden gekeken): "Dordrecht" was verlaten; de feitenrechter zou het druk krijgen - de Hoge Raad wat minder. Zo leek het tenminste.

Nog geen drie maanden later deed de Hoge Raad al uitspraak in een volgende plakzaak. ${ }^{67}$ Of liever, eigenlijk in twee volgende zaken, maar over die tweede kom ik zo dadelijk te spreken. 
In de gemeente Zevenaar was het verboden om wederrechtelijk te plakken (art. 9 APV). Er gold, kortom, een bepaling in de traditie van "Hengelo" en "Arnhem". Volgens de Arnhemse rechtbank was het plakken daarmee niet in het algemeen verboden of van "voorafgaand verlof der overheid" afhankelijk gesteld; "alleen wederrechtelijk plakken" was immers verboden, "terwijl voorts B. en W. op grond van art. 3 APV nog ontheffing van het plakverbod (konden) verlenen". Leijten, die in cassatie als advocaat-generaal optrad, had "wat moeite" zich iets voor te stellen bij die ontheffingsmogelijkheid:

"Het gaat natuurlijk om ontheffing van wederrechtelijk plakken, immers anders is er geen strafbaar feit. Indien nu de gemeente ontheffing zou verlenen van het verbod om op gemeente-eigendommen te plakken, is dat - praktisch - op te vatten als een toestemming om te plakken op eigendommen van de publiekrechtelijke eigenaar. En ligt het erg voor de hand dat de gemeente ontheffing zal verlenen van het verbod om te plakken op particuliere eigendommen? In ieder geval zal het plakken daardoor niet nièt-wederrechtelijk worden, dunkt mij, maar mogelijk wel niet-strafbaar".

Maar los daarvan kon het oordeel van de rechtbank, volgens hem, toch nog net door de beugel. Hij vergeleek de Zevenaarse bepaling met de Arnhemse, die de Hoge Raad, zoals bekend, $2 \frac{1}{2}$ jaar eerder had laten passeren. Zij kwamen in grote lijnen overeen.

"Het valt op", aldus Leijten, "dat de Rechtbank toén haar beslissing uitvoerig en duidelijk gemotiveerd heeft en nu slechts een beroep doet op het feit dat alleen wederiechtelijk plakken verboden is (en dat bovendien ontheffing van het verbod kan worden verleend). Een minimale motivering, die echter m.i. wel nèt voldoende is, want, gelet ook op de betekenis, die wederrechtelijk volgens de toelichting van de gemeente Zevenaar hier heeft, valt elk gebruik dat niet in strijd is met het recht van een ander buiten de verbodsbepaling en dan blijft er, als men dat gaat uitleggen, genoeg ruimte over on geen ongeoorloofde beperking van deze wijze van uiting van meningen te moeten aannemen. In de summiere motivering kan m.a.w. m.i. 'ingelezen' worden en dient in redelijkheid ook ingelezen te worden dat naar het oordeel van de rechtbank 'nog een gebruik van enige betekenis' overblijft".

Dat laatste vond de Hoge Raad ook. Maar de weg er naar toe verliep wat anders. Om te beginnen bracht het Zevenaarse plakverbod, volgens de Hoge Raad

"slechts mee een beperking van het gebruik van het onderhavige middel tot verspreiding voor zover door dat gebruik eens anders recht zou worden geschonden. Derhalve kan - behoudens het geval dat bijzondere plaatselijke omstandigheden zouden medebrengen dat het 
verbod in feite geen mogelijkheid tot gebruik van enige betekenis van het onderhavige middel van bekendmaking openlaat (curs. RdW) - niet worden gezegd, dat art. 9 in strijd is met het toenmalige art. 7, art. 7 lid 1 Gr.w."

Op die manier was de oogst van "Breda", met andere woorden, op overzichtelijke wijze veiliggesteld: de specifieke feiten van het geval gaven de doorslag. Hoe stond het daar nu mee in Zevenaar?

"De Rechtbank", zo meende de Hoge Raad, "heeft het beroep van de verdachte op de onverbindendheid van de onderhavige verbodsbepaling (...) zonder miskenning van het recht verworpen op gronden welke haar beslissing kunnen dragen" (curs. RdW).

De enkele, juridische betekenis van de term "wederrechtelijk" was dus (anders dan Leijten had betoogd) niet voldoende; er kwam ook een feitelijk oordeel aan te pas. Maar daar was, volgens de Hoge Raad, eveneens aan voldaan. In het oordeel van de rechtbank lag namelijk de opvatting besloten, "dat het verbod slechts meebrengt een beperking van het gebruik van het onderhavige middel van bekendmaking voor zover door dat gebruik eens anders recht zou worden geschonden, en dat de verbodsbepaling nog gebruik van enige betekenis van het onderhavige middel van bekendmaking onverlet laat" (curs. RdW).

Dat was ongetwijfeld een buitengewoon vriendelijke - maar inderdaad niet onmogelijke - interpretatie. Volgens Kistenkas ${ }^{68}$ had de Hoge Raad hier "toch weer klakkeloos op het kompas van de lagere rechter" gevaren. Nu de rechtbank eenmaal vond dat er nog "gebruik van enige betekenis" mogelijk was, zou dat "dus (...) in feite ook wel zo zijn", had de Hoge Raad - volgens Kistenkas - gemeend. ${ }^{69}$

Zou de Hoge Raad inderdaad altijd zo welwillend oordelen over hetgeen door de feitenrechter heette te zijn vastgesteld? Wellicht! Dan hoefde die feitenrechter dus nooit te motiveren waarom hij van oordeel was dat er nog ruimte voor een gebruik van enige betekenis overbleef - zelfs niet als op dat punt (zoals hier) uitdrukkelijk verweer was gevoerd. Maar helemaal zeker ben ik daar niet van. Of zou het werkelijk toeval zijn dat de Hoge Raad de lezers van het arrest een beetje liet meegluren door de "papieren muur"? Zo onthulde hij de inhoud van twee brieven van B. en W. die door de "verdachte" ter terechtzitting aan de rechtbank waren overgelegd (en volgens de Hoge Raad deel uitmaakten van het proces-verbaal van de terechtzitting). Daaruit viel in de eerste plaats af te leiden - wat trouwens ook al door de "verdachte" was opgemerkt - dat ten tijde van het delict in het centrum van de gemeente op drie plaatsen (bij wijze van proef) aanplakborden stonden. In de tweede plaats was B en W "gebleken dat van de borden regelmatig gebruik is gemaakt (...). (...) Volgens onze waarneming", aldus B en W, "is er 
echter niet direct sprake van een overbezetting van de borden. ${ }^{\text {" Welnu, in }}$ dat licht beschouwd was de gedachte dat een gebruik van enige betekenis verzekerd was, natuurlijk niet volstrekt ridicuul. De rechtbank kon duidelijk tot dat oordeel komen. En daarorn moest het er misschien voor gehouden worden dat zij kennelijk ook tot dat oordeel wàs gekomen.

Diezelfde dag besliste de Hoge Raad tevens over het Tilburgse plakverbod. ${ }^{70}$ Ook in dat geval was, zoals gebruikelijk, aangevoerd dat er geen gebruik van enige betekenis meer mogelijk was, nu het "aan anderen dan de rechthebbenden of degene die toestemming (had) van de rechthebbenden" verboden was om te plakken. Dat verweer was echter - ook alweer volgens het gebruikelijike patroon - door de rechtbank verworpen, zij het deze keer wat subtieler dan in het geval van "Zevenaar". Behalve dat de bepaling "slechts een beperking (meebracht) (...) voorzover (...) rechten van anderen werden geschonden en voor het overige elk gebruik van het middel mogelijk (bleef)", overwoog zij namelijjk:

"dat geenszins aannemelijk is geworden dat vrijwel alle eigenaren of huurders in de gemeente Tilburg hun toestemming zouden weigeren indien hen zou worden gevraagd om die te verlenen tot aanplakking op een hen goeddunkende wijze;

dat al evenmin aannemelijk is geworden dat eventuele toestemming van huurders zou kunnen worden ontkracht door optreden van verhuurders; dit met name niet voor de situatie waarin de toegestane wijze van aanplakking verhuurders niet in hun belangen raakt; dat de omstandigheid dat de gemeente weigert openbare aanplakborden te plaatsen en om toestemming te geven tot aanplakken van haar panden geen verandering brengt in deze waardering, aangezien, zoals vermeld, voldoende andere mogelijkheden openblijven".

Van te weinig gebruiksmogelijkheden was, met andere woorden, geen sprake.

Dat het verweer op die manier, volgens de Hoge Raad, was "verworpen op gronden welke die verwerping (konden) dragen", hoefde vervolgens - na al het voorgaande - niemand meer te verbazen. Het oordeel van de rechtbank steunde bovendien "op een waardering van de feitelijke omstandigheden welke zich in de gemeente Tilburg (voordeden)" en moest "in cassatie worden geëerbiedigd".

Niettemin:

"Aan de laatste zin", aldus Melai destijds in Delikt en Delinkwent ${ }^{71}$,

"valt gemakkelijk enige reserve te verbinden, omdat de onvermijdelijke beperking van grondrechten - zowel ten opzichte van elkaar als in confrontatie met andere belangen - nu juist onvermijdelijk de 
kernvraag meebrengt: hoever dergelijke beperkingen kunnen gaan wil het betrokken recht zich nog als grondrecht kunnen doen gelden. Vanuit dat gezichtspunt is er onmiskenbaar sprake van een fundamentele rechtsvraag, voor zover de beantwoording daarvan bepalend is voor de draagwijdte of de operationele ruimte van de grondrechten in de Nederlandse samenleving. Daarbij zijn vanzelfsprekend voor alles onze rechtsopvattingen in het geding".

De verbanning van dit onderwerp naar de feitenrechter viel bij Melai dus niet in goede aarde. Over de oplossing die hem voor ogen stond, verschafte hij evenwel geen duidelijkheid. Hij volstond met het signaleren van het tekort. Kistenkas ${ }^{72}$ kwam ogenblikkelijk met een suggestie:

"Werd in het klassieke Nuth-arrest zelve niet door de HR gekeken naar wat er uiteindelijk nog overbleef voor het gebruik van enige betekenis? De gemeentelijke regeling werd niet alleen beschouwd 'on its juridical face' maar ook 'as practically applied', zou men kunnen zeggen. Een tweetal ochtenduren op twee dagen in de eerste helft van de week laat geen gebruik van enige betekenis over, aldus de HR". Iets dergelijks moest hier, volgens hem, kennelijk ook gebeuren. Maar ja, het beoordelen van tijdstippen waarop gevent mag worden, is - zoals ik ook al bij de bespreking van het Nuth-arrest zei - iets anders dan het beantwoorden van de vraag of ergens voldoende plakgelegenheden zijn. Voor dat laatste moet je alle "ins" en "outs" ter plaatse kunnen overzien. De tijd, daarentegen, heeft de eigenschap in de raadkamer van de Hoge Raad even snel te verstrijken als elders. Nee, ik denk eerlijk gezegd dat er weinig anders te verlangen valt dan dat de feitenrechter zijn bevindingen behoorlijk motiveert. En in dat opzicht moeten onze verwachtingen - ik herhaal mijzelf opnieuw - vooral niet te hoog gespannen zijn: het zal altijd mogelijk blijven de Hoge Raad iets op de mouw te spelden. Alleen, hij zou het de feitenrechter (ook naar mijn smaak) wel wat moeilijker kunnen maken. Een verwerping om de enkele reden dat het verweer "niet aannemelijk" is geworden, stelt een verdachte immers voor een haast onmogelijke opgave: hoe zal hij er ooit in kunnen slagen zijn verweer aannemelijk te maken? Of, zoals het in de cassatieschriftuur werd uitgedrukt:

"Een enquête onder 150.000 inwoners had men toch moeilijk van rekwirant kunnen vergen".

En bovendien: bij welke uitkomst van zo'n enquête zou er nog net well, en bij welke net niet meer "gebruik van enige betekenis" mogelijk zijn? De Hoge Raad had tot nu toe nooit enig criterium daarvoor ontwikkeld. Hij gaf, zo leek het althans, volstrekt geen leiding aan de rechtsontwikkeling op dit punt; alles was - zolang het maar niet onbegrijpelijk werd (want dan zou cassatie volgen) - overgelaten aan de feitenrechter. 
Maar goed, in zoverre bracht dit arrest over het Tilburgse plakverbod eigenlijk niets nieuws. In zekere zin had de rechtbank de zaak zelfs eleganter afgewikkeld dan haar Arnhemse collega's in het vorige geval. Wel nieuw, daarentegen, was de reactie van de Hoge Raad op het verweer dat de gemeente zich aan censuur schuldig had gemaakt door soms toestemming te geven om te plakken, en andere keren toestemming te weigeren.

"Publiekrechtelijk gezien", zo hadden de raadslieden ter terechtzitting van de rechtbank betoogd, "mag de gemeente Tilburg niet censureren. Het kan toch niet de bedoeling zijn dat zij dit privaatrechtelijk gezien wel zou mogen?"

Dat sloot inderdaad naadloos aan op hetgeen in de Memorie van Toelichting op de Grondwetsherziening ${ }^{73}$ te lezen was:

"Wij zijn van mening dat de overheid in elke relatie waarin zij tot de burger kan staan - derhalve ook in privaatrechtelijke rechtsbetrekkingen - de grondrechten in acht dient te nemen. Publiekrechtelijke en privaatrechtelijke rechtsfiguren komen zozeer verweven voor, dat een daarop berustend criterium voor de gelding van grondrechten in tal van gevallen niet hanteerbaar is. Bovendien biedt een zodanig criterium ruime mogelijkheden voor willekeur en rechtsongelijkheid, aangezien in vele gevallen wel een privaatrechtelijke oplossing te construeren valt wanneer de publiekrechtelijke niet het beoogde gevolg heeft".

Niet echt een dwingende argumentatie, natuurlijk. In de eerste plaats is niet duidelijk waarom het onderscheid dat ongetwijfeld "in tal van gevallen niet hanteerbaar" zal zijn (en voor die gevallen dus niet verboden hoeft te worden), ook niet gehanteerd mag worden als het wèl hanteerbaar is. In de tweede plaats rijst de vraag waarom ook de gevallen waarin geen sprake van "willekeur en rechtsongelijkheid" is, niet door de beugel kunnen. Misschien verklaart dat de afhoudende reactie van Remmelink in zijn conclusie vór het arrest van de Hoge Raad. Volgens hem sneed het censuur-argument hier geen hout,

"aangezien een (eventueel onjuist) optreden van de gemeente slechts voor de verbindendheid van de bepaling een rol kan spelen, wanneer als gevolg daarvan de actieradius voor het zelfstandige verspreidingsmiddel te gering zou zijn geworden. Nu dat (volgens de Rechtbank) niet het geval is, kan een dergelijk optreden de verbindendheid m.i. niet raken, terwijl onjuiste uitvoering op zichzelf daarop geen invloed heeft".

De Hoge Raad, echter, beantwoordde de ene "sweeping statement" eenvoudig met een andere: de klacht ging niet op "mede gelet op de omstandigheid dat (zij) betrekking heeft op het beleid van de gemeente Tilburg als rechtheb- 
bende op gemeente-eigendommen en niet rechtstreeks (het plakverbod) of de toepassing (daarvan) betreft". ${ }^{74}$ Kennelijk was de gemeente "als rechthebbende op gemeente-eigendommen" in het geheel niet aan het censuurverbod onderworpen! Nou ja, dat gaat nu weer wat al te ver, zou ik denken. Het spreekt in elk geval niet vanzelf. Maar er was blijkbaar nog mér in het spel. Er staat immers: mede gelet op die omstandigheid. Waarop lette de Hoge Raad daarnaast nog? Of staat "mede" hier voor "reeds"? Laat ik. het, in verband met art. $121 \mathrm{Gr}$.w., op het laatste houden.

\subsection{Nasleep: het "gebruik van enige betekenis" (1984-1989)}

Het spoor was nu getrokken. En er was geen uitspraak bij gesneuveld! Had het dus louter verbaal betekenis? ${ }^{75}$ of zou de aandacht zich toch meer op de specifieke feiten van het geval gaan richten?

Wat de "lagere" rechters deden, is natuurlijk moeilijk te achterhalen. De meeste uitspraken belanden slechts in een archief en worden nimmer gepubliceerd. Alleen als iemand ze toevallig heeft qngernerkt. of als er later een arrest over is gewezen, willen ze nog wel eens aan het licht komen. Zonder archief-onderzoek - en dat zal ik hier niet ondernemen - is er dus weinig over te zeggen. Maar weinig is niet niets. Over de rol van "hogere" rechters, zoals de Hoge Raad en de Afdeling Rechtspraak, valt bovendien al heel wat meer te achterhalen. Laat ik het spoor dus even blijven volgen.

- De Amsterdamse rechtbank kreeg begin april 1984 - kort na de publikatie van "Breda", "Zevenaar" en "Tilburg" in de NJ - te oordelen over het Bussumse plakverbod. De verdachte had zich toen zelfs aan twee strafbare feiten schuldig gemaakt. Hij had zowel "een regelkast, toebehorende aan de gemeente Bussum, in ieder geval een eigendom van een ander, welke van de weg af zichtbaar was, wederrechtelijk (...) beplakt", als 's nachts om tien over éen "op de voor het openbaar verkeer en voor het publiek feitelijk toegankelijke weg (...) enig aanplakbiljet en/of enig plakmiddel en/of enig plakgereedschap" bij zich gehad. Maar de rechtbank liet zich ter terechtzitting door twee getuige/deskundigen voorlichten. En naar aanleiding daarvan kwam $\mathrm{zij}^{76}$ tot het cordeel:

"dat in Bussurn voor 'aanplakken' geen gebruik van enige betekenis is overgebleven.

Er zijn geen aangewezen plaatsen om te plakken. De gemeente wil ook niet dat op haar eigendommen wordt geplakt. Beide getuige/deskundigen hebben gezegd geen particuliere rechthebbenden op onroerend goed in de gemeente Bussum te kennen die zouden toestaan dat 
op dat onroerend goed wordt geplakt. Ook plakken op slooppanden wordt niet toegestaan, zodat al met al niet gezegd kan worden dat met enige inventiviteit binnen de gemeente Bussum een redelijk aantal plaatsen te vinden zou zijn waarop zonder bezwaar van de rechthebbende zou kunnen worden geplakt".

Die laatste zin was ongetwijfeld geïnspireerd door het vonnis van de Arnhemse rechtbank ${ }^{n}$, dat we al eerder zijn tegengekomen en waarmee de hele nieuwe ontwikkeling - vrijwel onopgemerkt ${ }^{78}$ - werd ingezet. Dat de rechtbank zich had ingespannen om de feitelijke toestand in Bussum te achterhalen, was niettemin duidelijk. Aangenomen dat de getuigen werkelijk deskundig waren, mocht in Bussum zelfs nergens worden geplakt. Het aan "Arnhem" ontleende criterium - dat met enige inventiviteit een redelijk aantal plaatsen te vinden zou zijn - werd dus bij lange na niet gehaald. De door Kistenkas - tot tweemaal toe aantal plaatsen" niet tekort werd gedaan aan de kwalitatieve eisen - een redelijk aantal borden langs een "stil en verlaten landweggetje" was bijvoorbeeld nauwelijks zinvol te noemen - die vraag kwam hier dus feitelijk niet aan de orde. Maar nog afgezien daarvan: waarom zou een redelijk aantal uitsluitend op de kwantiteit zien? Immers: redelijk met het oog op wàt? Daai kan, lijkt mij, van alles en nog wat onder worden gebracht: het absolute aantal, de spreiding, het gemiddelde oppervlak per plaats, de minimale oppervlakte, en misschien zelfs al die criteria tegelijk.

Hoe dan ook, het plakverbod was volgens de rechtbank onverbindend. Maar het verbod om 's nachts met plakspullen op straat te lopen - voor zover je tenminste niet aannemelijk kon maken dat die "voorwerpen of stoffen" niet "gebezigd of bestemd" waren voor "handelingen" die volgens het plakverbod verboden waren - dat verbod bleek niet onverbindend te zijn.

"Deze bepaling heeft", aldus de rechtbank, "de kennelijke strekking om het wederrechtelijk plakken, kladden en dergelijke zovee! mogelijk te voorkomen gedurende de beperkte tijd dat het toezicht daarop door de duisternis wordt bemoeilijkt, en is als zodanig toelaatbaar".

Hoewel het plakken-zelf - in verband met de onverbindendheid van het plakverbod - niet straftoaar was, kon je dus wèl gestraft worden voor het rondlopen met plakartikelen. Niet echt een vanzelfsprekende uitkomst, iijkt mij - maar "als zodanig" ook niet uitgesloten. Alleen, waarom de Hoge Raad zich in eerdere zaken - waarin het eveneens slechts om het nachtelijk rondlopen ging ${ }^{20}$ - well over het plakverbod had gebogen, was op die manier niet goed meer te vatten; ook bij een onverbindend plakverbod, zou het rondlopen immers strafbaar blijven! $!^{81}$ 
- De Rotterdamse rechtbank, daarentegen, ging onmiskenbaar verder dan de Hoge Raad. Zij verklaarde het Goudse plakverbod, dat erop neerkwam dat slechts door of met toestemming van de rechthebbende mocht worden geplakt, onverbindend..$^{82}$ Maar: niet vanwege de specifieke omstandigheden ter plekke. Nee, de rechtbank vond:

"dat (...) art. $7 \mathrm{Gr} . w$. met zich brengt, dat een gemeenteraad die rechthebbenden op onroerend goed tegen aanplakkers wenst te beschermen zulks dient te doen op een zodanige wijze dat onverlet blijft de mogelijkheid om van het middel 'plakken' gebruik te maken om gedachten en gevoelens te verspreiden, ook zonder voorafgaand verlof van die rechthebbenden" (curs. RdW).

En wel onder meer omdat:

"Van algemene bekendheid is dat middenstanders het meest geneigd zijn burgers in de gelegenheid te stellen om van hun onroerend goed gebruik te maken voor aankondigingen en mededelingen door middel van aanplakbiljetten. In het algemeen zullen zij echter minder geneigd zijn dit te doen naarmate de aankondiging of boodschap op het aanplakbiljet van minder neutrale aard is. Juist als het betrokken grondrecht meer in het geding komt, zal de mogelijkheid om van het middel 'plakken' gebruik te maken afnemen".

Dat was weliswaar heel realistisch, lijkt mij, maar niet bepaald toegesneden op het voorliggende geval. Dus kon het, volgens de Hoge Raad ${ }^{83}$ niet door de beugel:

"Het (...) vonnis behelst niet de vaststelling van bijzondere plaatselijke omstandigheden welke zouden medebrengen dat meergenoemde verbodsbepaling in feite geen mogelijkheid tot gebruik van enige betekenis van dit middel tot verspreiding openlaat".

Had de rechtbank volstaan met de kale vaststelling dat aannemelijk was geworden dat het Goudse plakverbod in feite geen mogelijkheid tot gebruik van enige betekenis openliet, dan was er vermoedelijk geen vuiltje aan de lucht geweest. Maar nu zij zo expliciet was geweest dat ondubbelzinnig vaststond dat zij op de verkeerde (namelijk: te algemene) gronden tot die conclusie was gekomen, kon er slechts vernietigd worden. ${ }^{84}$ In sommige opzichten vertoont cassatierechtspraak nu eenmaal een opvallende overeenkomst met het Romeinse formula proces...

- Geheel volgens het (gedeeltelijk eigen) boekje was weer een vonnis van de rechtbank in Arnhem ${ }^{85}$ - toch al "trendsetter" in deze materie. Had zij, zoals bekend, het lokale plakverbod - rekening houdend met de inventiviteit van plakkers - eerder nog in orde bevonden ${ }^{86}$, deze keer was het Arnhemse verbod om wederrechtelijk te plakken volgens haar onverbindend. Niet 
alleen tengevolge van "de sindsdien in de maatschappij geëvolueerde opvattingen" (zoals zij het uitdrukte), maar ook "vanwege de thans in het onderzoek ter terechtzitting (...) gebleken vrijwel feitelijke onmogelijkheid om legaal van dit middel van verspreiding gebruik te maken". Een getuigedeskundige (ambtenaar van de gemeente Arnhem) had namelijk verklaard dat al in 1978 een bestuursakkoord tot stand was gekomen,

"waaruit bleek dat de frakties van de gemeenteraad van oordeel waren, dat, om aan de bestaande behoefte om gedachten en gevoelens in drukwerk neer te leggen en om dezelve in het openbaar aan het publiek bekend te maken te voldoen, voldoende plaatsen (na onderzoek door de gemeente bepaald op het aantal van zestien) waar deze bekendmakingen aan het publiek openbaar kunnen worden gemaakt, noodzakelijk waren". 87

Slechts twee daarvan waren intussen "gerealiseerd". Bovendien was "geblesen dat de gemeente het wederrechtelijk plakken niet (zou) gedogen, dat wil zeggen ook niet op haar eigendommen ${ }^{88}(. .$.$) , zodat mogelijke inventiviteit$ van de plakkers hen niet (zou) baten".

Zelfs de inventiviteit, die de vorige keer nog als deus ex machina fungeerde om het plakverbod te redden, mocht nu dus niet meer baten. Dat was "feitelijk" uitgemaakt. Over de manier waarop zoiets werd uitgemaakt, waren we helaas nog altijd weinig wijzer geworden. Hoe werd je bijvoorbeeld "deskundige" op dit terrein?

- De vraag of er nog wel "gebruik van enige betekenis" mogeiijk was, kwam eind '85 (op een tamelijk buitenissige manier) ook aan de orde bij de Centrale Raad van Beroep. ${ }^{89}$ Een gerechtssecretaris bij de Rotterdamse rechtbank had - in het kader van vakbondsacties tegen een korting op ambtenarensalarissen - op het raam van zijn kamer in de rechtbank wat affiches opgehangen, "zodanig dat deze vanaf de openbare weg zichtbaar waren". De griffier van de rechtbank maakte daar bezwaar tegen en gaf de gerechtssecretaris "te verstaan" dat de affiches verwijderd moesten worden; "in verband met de onafhankelijkheid van de rechterlijk macht" mocht de actie namelijk niet "als een actie van de rechtbank naar buiten (...) worden gebracht". In de "werkruimten van het personeel" mochten echter wèl affiches worden opgehangen.

Ging dat niet te ver? De Centrale Raad vond dat de overheid zich in elk geval niet op haar eigendomsrecht van het gebouw kon laten voorstaan; in aansluiting op de Memorie van Toelichting bij de grondwetsherziening wees hij er in dit verband op

"dat de onderhavige casus de verhouding tussen een overheidsorgaan en i.c. een ambtenaar betreft en dat het betreffende overheidsorgaan 
(ook) in deze relatie de grondrechten in acht dient te nemen. Dat de overheid in dit geval tevens eigenaar is van het gebouw, waar de kwestie zich afspeelde, treedt daarbij op de achtergrond".

Aanknopend bij de verspreidingsjurisprudentie van de Hoge Raad, bleek het rechtscollege echter niet van mening dat in dit geval

"van een middel van verspreiding, dat naast andere middelen zelfstandige betekenis heeft en met het oog op die verspreiding in een bepaalde behoefte kan voorzien, geen gebruik van enige betekenis overblijft. Immers, de bestreden beperking laat van het onderhavige verspreidingsmiddel - zijnde: het ophangen van affiches, en niet: het ophangen van affiches in/aan het gerechtsgebouw van de Noordsingel op voor. publiek zichtbare plaatsen - binnen en vooral buiten het gerechtsgebouw vele gebruiksmogelijkheden onaangetast".

Een opmerkelijk visie, die in elk geval geen recht deed aan de opvatting van de Hoge Raad, lijkt mij. Wat voor een boodschap had de griffier bijvoorbeeld aan de "vele gebruiksmogelijkheden' buiten het gerechtsgebouw?

"Als dit argument valide zou zijn", schreven Hennekens en Kortmann in hus noot onder deze uitspraak, "zou een gemeentebestuur een beroep kunnen doen op 'buiten de gemeente' gelegen vele mogelijkheden. De griffier heeft buiten dit gerechtsgebouw geen geboden te stellen terzake van het opplakken van affiches".

Ik denk dat zij gelijk hebben. Trouwens, hoe wist de Raad eigenlijk dat er buiten het gerechtsgebouw feitelijk inderdaad "vele gebruiksmogelijkheden" bestonden? Van enige onderzoek daarnaar blijkt niets. En waarom moest het verspreidingsmiddel zo gedefinieerd worden als de Raad het deed - zonder enige aanduiding van de plaatsen waarvandaan die affiches (alleen affiches?) zichtbaar moesten zijn? Nee, de boodschap was klaarblijkelijk nog niet naar dit college overgewaaid. ${ }^{90}$

- In Utrecht had iemand in september 1982 op een "verkeerslichteninstallatiekast" de tekst "Geen boom is hoog genoeg voor Zeevalking" (de toenmalige staatssecretaris van Justitie) aangebracht. Dat leidde op grond van art. 69 van de APV Utrecht (dat we ook al in het kader van de "Utrechtse muurkrant" ${ }^{\prime 91}$ tegenkwamen) tot een veroordeling tot vijftig gulden boete. Zonder vergunning van $B$ en $W$ mocht je volgens die bepaling - op enkele uitzonderingen na, waaronder de "door $\mathrm{B}$ en $\mathrm{W}$ bij openbare kennisgeving daartoe aangewezen plaatsen" - niet plakken. De rechtbank vond dat niet gezegd kon worden "dat art. 69 APV (...) zo ver (ging) dat van het in dat artikel bedoelde middel van bekendmaking geen gebruik van enige betekenis meer mogelijk (was) ${ }^{\prime \prime} .^{92}$ Immers: 
"Blijkens het uitvoeringsbesluit ex art. 69 APV (...) van B en W, in werking getreden op 10 juni 1981, (waren) op een zestigtal punten in de gemeente Utrecht op de openbare weg geplaatste borden aangewezen als plaatsen waar meningsuitingen of bekendmakingen (mochten) worden aangebracht".

Of die plaatsen redelijk over de gemeente verspreid waren (en voldoende oppervlak bezaten, om nog een andere variabele te noemen), werd er door de rechtbank niet (uitdrukkelijk) bij betrokken. Maar de Hoge Raad nam met het oordeel van de feitenrechter zonder meer genoegen. De omstandigheid dat een getuige ter terechtzitting had verklaard

"dat de legale plakborden vol waren met affiches van toekomstige evenementen en dat dezelfde avond al weer over de door hem opgehangen affiches was heen geplakt", kon daar niet aan afdoen.

"De Rechtbank heeft vastgesteld", aldus de Hoge Raad", "dat niet aannemelijk is geworden dat art. 69 APV Utrecht onder de door haar aangenomen omstandigheden geen gebruiksmogelijkheden van enige betekenis van het in dat artikel bedoelde middel van verspreiding van meningen overlaat. Dit oordeel kan als van feitelijke aard in cassatie niet op zijn juistheid worden getoetst. Het is niet onbegrijpelijk".

Wat precies bedoeld is met "de door haar aangenomen omstandigheden" (curs. RdW), is mij (eerlijk gezegd) niet duidelijk. Voor het overige was deze uitkomst niettemin geheel en al voorspelbaar. Opnieuw bleek de Hoge Raad niet bereid enig inzicht te verschaffen in de door de feitenrechter te hanteren criteria. Het oordeel van de rechtbank werd niet onbegrijpelijk bevonden; niet gebleken was, met andere woorden, dat het op onjuiste gronden tot stand was gekomen. Daar schieten we weinig mee op.

- Het vereiste van "een gebruik van enige betekenis" leek onderwijl 6́́k bij art. 7 lid $3 \mathrm{Gr}$.w. opgang te doen. In augustus 1985 werden in het kader van een volkspetitionnement tegen de plaatsing van kruisraketten in Nederland zogeheten "petitiekaarten" ingezameld in Oegstgeest. De bedoeling was daarbij ook vijf geluidwagens in te zetten. Maar B en W weigerden daarvoor toestemming te geven. Op grond van art. 14 van de Verordening op de geluidhinder was het namelijk verboden om "in de openlucht een geluidapparaat $(. .$.$) in werking te hebben op een zodanige wijze dat voor een omwo-$ nende of overigens voor de omgeving geluidhinder wordt veroorzaakt"; slechts in "bijzondere gevallen" konden B en W ontheffing verlenen. En het beleid was dat dit louter in geval van "calamiteiten" gebeurde, zij het dat in het verleden ook wel eens ten behoeve van politieke partijen een uitzondering was gemaakt. 
De Afdeling Rechtspraak van de Raad van State*, die over deze zaak moest oordelen, overwoog - om te beginnen - het volgende:

"Hoewel het derde lid van art. 7 geen belemmeringen bevat voor niet de inhoud betreffende voorschriften - ook van lagere wetgevers omtrent bijvoorbeeld plaats, tijdstip en wijze van openbaarmaking en verspreiding door andere dan in de voorgaande leden genoemde middelen, mag door zodanige voorschriften het feitelijk functioneren van het recht om door deze andere middelen gedachten of gevoelens te openbaren niet volledig onmogelijk worden gemaakt".95

De uitwerking die hier vervolgens aan werd gegeven, vertoonde een frappante overeenkomst met de oudere rechtspraak van de Hoge Raad, waarin het begrip "gebruik van enige betekenis" tot ontwikkeling werd gebracht ${ }^{96}$ : ook het "neerkomen op" een verbod bleek namelijk niet te mogen, zelfs niet als er in sommige opzichten nog wel gebruiksmogelijkheden resteerden. In dit verband werd het gebruik van geluidwagens "op zichzelf" door de APV-bepaling - gezien de ontheffingsmogelijkheid - niet uitgesloten. De enge toepassing die de gemeente aan die ontheffingsmogelijkheid gaf, stuitte bij de Afdeling echter op bezwaren:

"Naar het oordeel van de Afdeling gaan verweerders hiermee niet alleen in tegen de uitdrukkelijke bedoeling van de gemeentelijke wetgever, maar komt het door hen gevoerde ontheftingsheleid er tevens op neer dat het gebruik van geluidwagens, als middel van openbaarmaking van gedachten of gevoelens anders dan bij een calamiteit onmogelijk wordt gemaakt. Dit beleid moet dan ook in strijd worden geacht met art. 7 derde lid Gr.w. De omstandigheid dat verweerders op dit beleid voor politieke partijen een uitzondering plegen, althans plachten te maken, maakt dit, wat daar ook van zij, niet anders, omdat niet alleen aan politieke partijen het grondrecht van meningsuiting is toegekend". ${ }^{97}$

In latere uitspraken keerde de Afdeling nog bij herhaling terug op dit thema. En het aardige is natuurlijk dat zij daarbij - anders dan de Hoge Raad ${ }^{98}$. ook op feitelijke omstandigheden lette. Zij kon niet volstaan met de constatering dat ergens een gebruik van enige betekenis kon resteren, nee: zij moest zelf vaststellen of het resteerde. Daardoor moest zij ons een kijkje in de keuken gunnen en konden we zien waar de Afdeling feitelijk op lette.

Welnu, zoals ook al uit die Oegstgeestse zaak bleek, stelde zij eerst vast of de in het geding zijnde bepaling-zelf door de beugel kon. Pas als dat het geval was, bekeek zij de toepassing die er in concreto aan werd gegeven. Zo bleek ook het Alkmaarder verbod om - behalve met ontheffing van B en W een "standplaats" op de weg in te nemen "op zichzelf niet in strijd met art. 7 eerste en derde lid Gr.w." te zijn. ${ }^{99}$ Het feitelijk functioneren van het recht 
om op die manier gedachten of gevoelens te openbaren werd daardoor immers "op zichzelf" niet volledig onmogelijk gemaakt. Maar:

"Het vorenstaande neemt niet weg dat de wijze waarop verweerders gebruik maken van hun bevoegdheid om ontheffing te verlenen dan wel te weigeren mede van invloed is op het antwoord op de vraag of in een bepaald geval van schending van de grondwettelijke waarborgen moet worden gesproken".

En juist op dat punt rezen er problemen. $\mathbf{B}$ en $\mathbf{W}$ hadden namelijk geweigerd de Zuidafrikaanse werkgemeenschap ontheffing te verlenen voor het neerzetten van een marktkraampje in het centrum van Alkmaar ter verspreiding van lectuur en het verstrekken van mondelinge informatie; daarbij had het college zich beroepen op ernstige vrees voor verstoring van de openbare orde. Volgens de Afdeling was die stelling evenwel "onvoldoende gefundeerd":

"Meer in het bijzonder is geen ter zake dienend schriftelijk rapport van de plaatselijke politie overgelegd. Evenmin hebben verweerders aandacht besteed aan het verloop van soortgelijke door appellante in andere gemeenten gevoerde acties. Voorts is niet gebleken dat verweerders reeds op grond van de jaarverslagen die appellante desgevraagd aan hen heeft overgelegd tot de slotsom hebben kunnen komen dat gegronde vrees bestaat dat het innemen van een standplaats door appellante op de door haar gewenste dag in de binnenstad van Alkmaar - ongeacht de plaats waar zulks geschiedt - tot ordeverstoringen zou leiden".

De weigering was, met andere woorden, te lichtvaardig tot stand gekomen. Een wonder van motivering, vergeleken met de vonnissen waar de Hoge Raad tot dusver genoegen mee nam, lijkt mij!

Ten aanzien van het $Z$ wolse verbod om "in de openlucht een geluidsapparaat (...) in werking te hebben op zodanige wijze dat voor omwonenden of overigens voor de omgeving geluidhinder wordt veroorzaakt", ging het net zo. De bepaling-zèif, die wederom gepaard ging met een ontheffingsmogelijkheid, werd door de Voorzitter van de Afdeling in orde bevonden ${ }^{100}$ :

"Die voorschriften hebben immers niet tot noodzakelijk gevolg dat de activiteiten van verzoekster" - de Evangelie Gemeente De Deur, "een geloofsgemeenschap die zich in het bijzonder richt op het publiekelijk uitdragen van haar boodschap" en daarbij (ter versterking van die boodschap?) geluidsapparatuur wilde gebruiken; RdW - "in de gemeente Zwolle volledig onmogelijk worden gemaakt". ${ }^{101}$

Maar:

"Wij overwegen (...) tevens dat, nu het hier de uitoefening van een grondrecht betreft, verweerders bij hun besluitvorming een grote mate 
van zorgvuldigheid in acht dienen te nemen".

Dat was, voor zover ik weet, de eerste keer dat een bijzondere status werd toegekend aan een grondrecht, zij het dat in het midden werd gelaten op welk grondrecht de Voorzitter doelde (vrijheid van godsdienst of vrijheid van meningsuiting?). Kennelijk moest met grondrechten zorgvuldiger worden "omgesprongen" dan met andere rechten. En aan die zorgvuldigheid ontbrak het nodige, meende de Voorzitter:

"Als vaststaand moet worden aangenomen dat verweerders in het kader van het aangescherpte beleid ruimte aanwezig achten voor het verlenen van ongeveer 50 ontheffingen per jaar, waarvan 20 voor zogenoemde incidentele evenementen zoals de bijeenkomsten van verzoekster. Niet is gebleken dat verweerders dit uitgangspunt in enig beleidsdocument hebben neergelegd, laat staan verantwoord. Het is mede daardoor niet mogelijk om de redelijkheid ervan te toetsen. Voorts moet worden vastgesteld dat verweerders geen duidelijk inzicht hebben kunnen geven in de aard en de omvang van de vraag naar incidentele ontheffingen, in het bijzonder van de zijde van groeperingen die uiting willen geven aan een bepaalde mening of religieuze overtuiging. In dit verband is van belang dat, voor zover de beschikbare gegevens strekken, bij andere op geloofsverkondiging gerichte gemeenschappen slechts een verhoudingsgewijs geringe belangstelling voor ontheffing op grond van artikel E23A, tweede lid, (= het geluidoverlastverbod, RdW) bestaat. Het betreft ongeveer vijf groeperingen die gemiddeld éénmaal per jaar ontheffing vragen en waarvan er inmiddels én heeft opgehouden te bestaan".

Kortom: alweer een (relatief) diepgaand onderzoek naar de feitelijke gang van zaken. Het bracht de Voorzitter ertoe als voorlopige voorziening op te leggen dat "De Deur" in elk geval even vaak een ontheffing zou krijgen als het jaar daarvo6r (te weten vijf keer), omdat "niet is gebleken dat dit tot problemen van betekenis heeft geleid".

En diezelfde "lijn" werd opnieuw in een tweede zaak over "De Deur" gevolgd. Behalve in Zwolle viel er kennelijk ook in Arnhem nog het nodige te evangeliseren... Dus moest daar eveneens onn ontheffing worden gevraagd van het verbod "op of aan de weg of op de openbare grond al dan niet door middel van een geluidversterker tot het publiek een spreekkoor ten gehore te brengen of te organiseren, te zingen of muziek te maken". Het verzoek om midden op de Korenmarkt een versterker neer te mogen zetten, werd door de gemeente echter niet gehonoreerd. De Afdeling Rechtspraak keek om te beginnen weer naar de APV-bepaling. ${ }^{102}$ Daar viel - zoals te verwachten was - niets op af te dingen: "gegeven het bestaan van de mogelijkheid van ontheffing en de limitatieve opsomming van weigeringsgronden"103 
werd "het feitelijk functioneren van het (in art. 7 lid 3 Gr.w. bedoelde; $\mathrm{RdW}$ ) recht niet volledig onmogelijk (...) gemaakt". En wat die weigering ten aanzien van de Korenmarkt betreft: daar viel op zich weinig op af te dingen. Immers:

"Op grond van de beschikbare gegevens (kon) niet worden staande gehouden dat elders in de binnenstad van Arnhem geen zinvolle mogelijkheden voor het organiseren van de door appellante gewenste evangelisatie-acties (overbleven)".

Dat er in de binnenstad "zinvolle mogelijkheden" bestonden, gaf dus kennelijk de doorslag. Daarmee was "en passant" opnieuw een criterium aangedragen waar ook andere rechters hun voordeel mee konden doen; tot dusver bestond hier onduidelijkheid over ( $\mathrm{vgl}$. het Hilversumse ventverbod dat onder 6.6 aan de orde kwam). Maar hoe dit verder ook zij, juist ten aanzien van die andere plaatsen in de binnenstad waren B en W tekort geschoten. Zij hadden volgende verzoeken van "De Deur", die eveneens op het voetgangersgebied in het centrum betrekking hadden, namelijk afgewezen op grond van "een bestaande beleidslijn die zou inhouden dat het gebruik van geluidversterking in het voetgangersgebied niet wordt toegestaan", zoals de Afdeling eén en ander samenvatte. Maar het beleid was niet "vervat in enig beleidsdocument of ander schriftelijk stuk, laat staan dat het als zodanig ter openbare kennis (was) gebracht". Daardoor was "de strekking ervan niet met voldoende zekerheid vast te stellen", terwijl bovendien niet duidelijk was hoe zo'n beleid onder de weigeringsgronden was te brengen, die in de APVbepaling waren genoemd. De bijzondere status van het grondrecht bleek nu wederom beslissend. Immers:

"Reeds de omstandigheid dat hier de uitoefening van een of meer grondrechten aan de orde is, bracht met zich dat verweerder zich grondig op de reikwijdte van het door hem te voeren beleid had behoren te bezinnen. Van zulk een bezinning blijkt niet (...)."

Die latere weigeringen konden dus niet door de beugel. Stelde de strafrechter zich net zo secuur ${ }^{104}$ op bij het vaststellen van de feitelijke omstandigheden ter plekke?

- Terug naar de strafrechter, en naar art.7 lid 1. In Eindhoven was weer eens iemand betrapt die 's nachts aanplakbiljetten bij zich had. En dat was - het zal niet meer verbazen - verboden, tenzij je aannemelijk kon maken dat ze niet "gebezigd of bestemd" waren voor illegale plakactiviteiten (art. 85 APV). Wanneer was plakken illegaal in Eindhoven? Als je geen schriftelijke toestemming van de rechthebbende(n) had - aangenomen tenminste dat je zelf niet rechthebbende was, want dan was plakken (op eigen zaken) niet verboden (art. 84 APV). 
De verdachte beriep zich erop dat het plakverbod "zodanig (was) geredigeerd dat het niet of niet voldoende gelegenheid (bood) om openbaar de vrije mening te uiten door middel van het plakken van aanplakbiljetten". Daardoor zou ó́k die andere bepaling - die onder meer het nachtelijk rondlopen met aanplakbiljetten verbood - onverbindend zijn, nu daarin immers was verwezen naar het plakverbod. Bovendien zou dat nachtverbod "buiten de bij art. 168 gem.w. aan de gemeenteraad opgedragen bevoegdheid om verordeningen te maken" liggen. De rechtbank in Den Bosch ${ }^{105}$ was evenwel van oordeel:

"dat niets de gemeente Eindhoven verplicht tot het verschaffen van gelegenheid tot aanplakken en voorts dat er voldoende andere mogelijkheden bestaan om de eigen mening vrijelijk te uiten door van andere rechthebbenden dan de gemeente toesternming tot aanplakken te verkrijgen;

O. dat de Rechtbank voorts van oordeel is, dat de bepalling van art. 85 van genoemde verordening eveneens niet onverbindend is, nu die bepaling kennelijk de strekking heeft om het wederrechtelijk plakken zoveel mogelijk te voorkomen gedurende de beperkte tijd dat het toezicht daarop door duisternis wordt bemoeilijkt, welke laatste bepaling de Rechtbank als passend binnen het kader van de in art. 168 gem.w. vastgelegde bevoegdheid als zodanig toelaatbaar acht".

Die laatste overweging zijn we - vrijwel letterlijk - al eerder tegengekomen, en wel in een vonnis van de Amsterdamse rechtbank over het Bussumse plakverbod. ${ }^{106}$ Alleen, in die zaak werd het nachtelijk verbod juist gesauveerd ondanks de onverbindendheid van het plakverbod. Nu de rechtbank het plakverbod deze keer wel verbindend achtte, rijst natuurlijk de vraag waarom zij die geleende "Bussumse" overweging nog nodig had. Wilde zij (voor de zekerheid) van twee walletjes eten door zich enerzijds in te dekken tegen critici die art. 85 in het verlengde van art. 84 zagen, en anderzijds tegen critici die de "Bussum-formule" volgden en beide APV-bepalingen "los" van elkaar beschouwden? ${ }^{i 07}$ Nou ja, misschien had die overweging voor deze gelegenheid louter betrekking op het verband met art. $168 \mathrm{gem} . \mathrm{w}$. Daar was trouwens inderdaad wel iets voor te zeggen, lijkt mij.

Maar nu de eerste overweging. Moeten we de mededeling "dat er voldoende andere mogelijkheden (bestonden)" als een feitelijke vaststelling aanmerken? Dat zou dan wel een erg mager onderbouwde vaststelling zijn. De weerlegging van een verweer moet je immers beoordelen in het licht van dat verweer-zelf. Welnu, dan ging het er dus om of art. 84 APV zodanig geredigeerd was dat het niet of niet voldoende gelegenheid bood om te plakken. Dat was, met andere woorden, niet noodzakelijkerwijs een beroep op de feitelijke omstandigheden ter plekke. Dus hoefde de rechtbank daar 
ook niet in te "duiken".

Dat laatste was ook de opvatting van de advocaat-generaal (Meijers). Hij vond de weerlegging van het verweer, met andere woorden, toereikend, al was hij over de bewering "dat niets de gemeente Eindhoven verplicht tot het verschaffen van gelegenheid tot aanplakken" niet erg te spreken. Integendeel, het leek hem nogal waarschijnlijk dat een gemeente die er een dergelijk plakverbod op na hield - gezien de feitelijke belemmeringen om te plakken al gauw het risico van onverbindendheid loopt als zij niet overgaat "tot het verschaffen van gelegenheid tot aanplakken". Hier was dat echter niet aan de orde.

Wat, tenslotte, het standpunt van de Hoge Raad was, valt helaas niet te achterhalen. De rechtbank had het verweer, volgende de Hoge Raad ${ }^{108}$, "verworpen op gronden welke die verwerping kunnen dragen". Daar moesten we het mee doen. En daar konden we het ook eigenlijk wel mee doen, nu geen van de vijf cassatiemiddelen - evenmin als het voor de rechtbank gevoerde verweer - art. 7 Gr.w. zelfs maar noemde! De zaak was eenvoudig verprutst.

- Heel anders ging het in Haarlem toe! Ook daar een nachtbraker die "met een plakmiddel en aanplakbiljetten en plakgereedschap, te weten een kwast" op straat werd aangetroffen. Dat leverde een overtreding van art. 68 APV op, nu de "verdachte" niet kon "aantonen dat genoemde: materialen niet bestemd of gebruikt (waren) voor handelingen welke in artikel 67 (waren) verboden". Dat laatste artikel behelsde natuurlijk - want er was (ook 's nachts) niets nieuws onder de zon - het verbod om "zonder toestemming van de rechthebbende" te plakken.

In afwijking van de Amsterdamse rechtbank - denk aan het Bussumse plakverbod, dat we zojuist nog tegenkwamen ${ }^{109}$ - begon de Haarlemse ${ }^{110}$ als volgt:

"De redactie van de hierboven geciteerde bepaingen, in onderling verband bezien, wettigt de (...) conclusie dat er tussen die bepalingen een zodanige samenhang bestaat, dat aan artikel 68 APV geen zelfstandige (in de zin van: los van artikel 67 APV) betekenis toekomt, zodat, indien artikel 67 APV onverbindend zou zijn, dat evenzeer zal gelden voor artikel $6 \overline{8}$ APV."

Kortom:

"Nagegaan dient te worden of de APV het recht tot het gebruik van een bepaald zelfstandig middel van bekendmaking erkent en mogelijk maakt, dan wel zodanig beperkt dat een dergelijk gebruik geen of nauwelijks betekenis heeft." 
Welnu (na wat obligate zinswendingen over art. 7):

"In het licht van het onderhavige geval brengt artikel 7 Grondwet naar het oordeel van de Rechtbank met zich dat een gemeenteraad die rechthebbenden op goederen tegen aanplakking wenst te beschermen, dat dient te doen op zodanige wijze dat onverlet blijft de mogelijkheid om van het middel "plakken" gebruik te maken om gedachten en gevoelens te verspreiden, ook zonder voorafgaand verlof van die rechthebbenden."

Daarmee was door de rechtbank een criterium geformuleerd dat ertoe diende vervolgens de feitelijke situatie ter plekke te beoordelen. Een gemeenteraad moest de mogelijkheid om zonder voorafgaand verlof van rechthebbenden te plakken onverlet laten. Die regel gold dus in de eerste plaats niet uitsluitend voor de Haarlemse gemeenteraad - het was een regel die voortvloeide uit art. $7 \mathrm{Gr}$.w., oftewel: een rechtsregel - en in de tweede plaats week hij af van hetgeen tot dusver door de Hoge Raad werd aangehouden - zelfs wanneer je uitsluitend met toestemming van rechthebbenden mocht plakken, was er (soms) immers nog gebruik van enige betekenis mogelijk (zoals we zagen). ${ }^{111}$

Toegepast op de situatie in Haarlem leidde een en ander, volgens de rechtbank, tot het volgende:

"Ten aanzien van het verbod om te plakken als vervat in de APV blijkt niet van een uitzonderingsbepaling waardoor de afhankelijkheid van een voorafgaand verlof van derden wordt voorkomen. Onder de processtukken bevindt zich een brief d.d. 7 juli 1986 van Burgemeester en Wethouders van Haarlem aan de Officier van Justitie, met - voor zover van belang - de navolgende inhoud:

'In antwoord op uw verzoek tot opgave van de in onze gemeente aanwezige plaatsen waar het verbod gesteld in artikel 67 van de APV niet van toepassing is, delen wij $u$ het volgende mede. Uit een onzerzijds ingesteld onderzoek is gebleken dat van gemeentewege de volgende plakmogelijkheden zijn gecreëerd:

- op de Grote Houtbrug één bord ter grootte van circa $2 \times 1,50$ meter;

- aan de linkerzijde van de Vishal zes borden ter grootte van $1 \times 1,10$ meter.

Daarnaast blijven uiteraard andere verspreidingsmogelijkheden voor het aanplakken van biljetten over, zoals het meedragen ervan, bijvoorbeeld als 'sandwichman' of het aanbrengen van aanplakbiljetten op eigendommen van betrokkenen en diens medestanders'.

Het bovenstaande brengt met zich dat, in aanmerking genomen de omvang van de gemeente Haarlem, de 'vrije' plakmogelijkheden in 
Haarlem, bezien naar aantal, oppervlakte en plaats - waarbij opgemerkt dient te worden dat die plakmogelijkheden, naar in Haarlem van algemene bekendheid is, zich alle in het directe centrum bevinden -, zodanig onvoldoende zijn dat van enig ree̋el gebruik van het onderhavige middel van bekendmaking geen sprake kan zijn. Hieraan doet (...) niet af dat er in het standpunt van de gemeente behalve bovengenoemde 'vrije' plakmogelijkheden ook andere verspreidingsmogelijkheden voor verdachte zouden openstaan".

Dat laatste was natuurlijk buiten kijf: voor ieder zelfstandig middel van bekendmaking moest een gebruik van enige betekenis mogelijk blijven. En, het moet gezegd worden: eenmaal uitgaande van het vereiste van voldoende "vrije" plakmogelijkheden, klonk ook de rest heel plausibel, hoewel de rechtbank er kennelijk vanuit ging dat "vrije" plakmogelijkheden uitsluitend van gemeentewege gecreëerd konden worden, om vervolgens haar onderzoek naar de feitelijke stand van zaken te beperken tot hetgeen van die zijde was verricht. ${ }^{112}$ Dat was echter al heel wat meer dan menige andere rechtbank had klaargespeeld. Toch rees de vraag of de Hoge Raad het vonnis in stand zou laten: had de rechtbank immers wel de juiste maatstaf ("vrije" plakmogelijkheden) aangelegd?

De Hoge Raad begon met een korte parafrase van de geijkte zinswendingen over art. 7 lid 1, deze keer echter eindigend met de opmerking dat een beperking niet zo ver mocht gaan dat het gebruik van een middel van bekendmaking "in het algemeen zou worden verboden of van een voorafgaand verlof afhankelijk zou worden gesteld" - let wel: niet het voorafgaand verlof der overheid, maar voorafgaand verlof zonder meer. Louter een verschrijving of moesten we daar iets uit afleiden? We zullen zien.

Daarna overwoog de Hoge Raad dat de rechtbank had

"vastgesteld dat de vrije plakmogelijkheden in Haarlem, bezien naar aantal, oppervlakte en plaats, zodanig onvoldoende zijn dat van enig reëel gebruik van het onderhavige middel van bekendmaking geen sprake kan zijn. Aldus heeft de Rechtbank geen blijk gegeven van een onjuiste rechtsopvatting, terwijl evengenoemde vaststelling niet onbegrijpelijk is en vanwege haar feitelijk karakter in cassatie niet op haar juistheid kan worden getoetst".

In een noot onder dit arrest schreef ik destijds dat uit de opmerking dat de rechtbank "geen blijk (had) gegeven van een onjuiste rechtsopvatting" over het algemeen nauwelijks iets viel af te leiden. ${ }^{113}$ De rechtsopvattingen van een rechtbank zijn immers vaak allerminst duidelijk.

"Maar", zo ging ik verder, "in dit geval ligt dat anders. De Haarlemse Rechtbank had zich juist uitgesloofd om haar rechtsopvatting omstandig uit de doeken te doen. Bovendien was het door de Rechtbank 
gehanteerde vereiste van 'vrije plakmogelijkheden' ook nog eens een keer uitdrukkelijk 'meegenomen' in die overwegingen van de Hoge

Raad. Dat criterium werd, met andere woorden, in orde bevonden". En daarmee was dan in éen keer tevens verklaard waarom opeens niet meer van "voorafgaande verlof der overheid" werd gerept; het ging er immers orn dat je van niemand - overheid, noch particulieren - voorafgaand verlof nodig had. Het sloot allemaal als een bus.

Toch ben ik er - achteraf bezien - niet zeker van dat dit echt de enig mogelijke interpretatie was. Eerst, namelijk, vatte de Hoge Raad in eigen woorden samen wat de rechtbank over de vrije plakmogelijkheden had overwogen en vervolgens stelde hij vast dat de rechtbank aldus geen blijk had gegeven van een onjuiste rechtsopvatting. Daarmee was, met andere woorden, geen uitspraak gedaan over het vonnis-zèlf, maar slechts over de weergave ervan door de Hoge Raad. Welnu, de rechtbank had, volgens de Hoge Raad, vastgesteld dat in Haarlem zo weinig vrije plakmogelijkheden waren dat van enig reëel gebruik van het middel "plakken" geen sprake kon zijn. De reden waarom de rechtbank tot die conclusie kwam, was echter weggelaten. Daardoor paste het resultaat zowel in de klassieke visie van de Hoge Raad (waarin het op zichzelf niet uitgesloten was dat er pas voldoende gebruiksmogelijkheden waren wanneer er tot op zekere hoogte "vrij" kon worden geplakt), als in de visie van de rechtbank (waarin voldoende vrije plakplaatsen een noodzakelijke voorwaarde vormden voor "gebruik van enige betekenis"). De enkele omstandigheid dat de Hoge Raad er niets op af te dingen wist, zegt - zo bezien - niets. Het orakel is weliswaar tot op zekere hoogte getemd, maar het blijft ondoorgrondelijk.

- Op 22 februari 1989 was het opnieuw het Nijmeegse plakverbod dat de aandacht vroeg; deze keer van de kantonrechter (mw. Litjens-Roessel). ${ }^{114}$ $\mathrm{Zij}$ vond de plakmogelijkheden nog steeds onvoldoende. Interessant was echter vooral dat zij - net als de Haarlemse rechtbank - verschillende "ijkpunten" hanteerde. Immers: wanneer staan er voldoende plakplaatsen ter beschikking?

"Het begrip 'voldoende' dient daarbij", meende de kantonrechter, "gerelateerd te zijn aan de grootte van de gemeente, te weten zowel het aantal inwoners als ook het totale bebouwde oppervlak van de gemeente alsook aan de spreiding van het aantal plakplaatsen over de verschillende stadsdelen.

Tevens dient de totale 'te beplakken oppervlakte' van deze plakplaatsen aan dezelfde criteria te worden gemeten."

Dat leidde tot de conclusie dat de twee bestaande plakplaatsen in de binnenstad van Nijmegen "bij lange na niet voldoende" waren. Bovendien mocht 
je daar uitsluitend met toestemming plakken. Geheel in het spoor van de Haarlemse rechtbank gaf dat de kantonrechter aanleiding tot een tweede argument voor onverbindendheid:

"Een bepaling in de Algemene Politieverordening, die plakken behoudens toestemming verbiedt, is slechts dan niet in strijd met het recht van vrije meningsuiting, als voor de burger voldoende mogelijkheid is geschapen om in zijn gemeente zonder toestemming - en dus zonder censuur - door aanplakking van zijn mening blijk te geven.

Daar thans nog geen in deze zin 'vrije' plakplaatsen zijn aangewezen is het algemene in artikel 199 APV vervatte verbod om aan te plakken behoudens verkregen toestemming in strijd met artikel 7 Grondwet en derhalve onverbindend".

Wie zich nog herinnert dat de gemeente Breda in 1983 zelfs zonder problemen schriftelijke toestemming van de rechthebbende(in) kon vergen ${ }^{115}$, realiseert zich dat er intussen heel wat in beweging was gekomen. Desondanks verliep de discussie nog steeds via dezelfde begrippen ("zelfstandig middel", "voorafgaand verlof", "gebruik van enige betekenis"). Ging het daarbij uitsluitend om de vorm, of had de "leer" waar alle betrokkenen zo trouw aan refereerden óók enige inhoud? Nou ja, wèl enige: sommige uitkomsten (vergunningstelsel, absoluut verbod) waren vermoedelijk echt uitgesloten. Maar was dat voldoende om van een "leer" te spreken? Laten we het spoor verder volgen.

- In Groningen had iemand 's avonds om tien over half elf op de Vismarkt dertien aanplakbiljetten van Loesje bij zich gehad. Dat was op dat tijdstip (namelijk tussen 's avonds negen en 's ochtends zes uur) verboden, tenzij je aannemelijk kon maken dat die aanplakbiljetten "niet (waren) gebezigd of bestemd voor handelingen, welke ingevolge (het plakverbod, RdW) (waren) verboden" (art. 17 APV). Nu was dat plakverbod (art. 15 en 16 APV) volgens de raadsman van de verdachte echter onverbindend:

"Van gemeentewege zijn geen legale aanplakgelegenheden, beschikbaar gesteld (...).

Middenstand en gemeentelijke diensten zijn niet bereid het plakken op hun eigendommen te gedogen. Particulieren, die daartoe bereid zijn, zijn evenmin bekend".

En omdat art. 17 APV geen "zelfstandige betekenis" (los van het plakverbod) had, was ook die bepaling volgens de raadsman onverbindend, zodat de verdachte moest worden ontslagen van alle rechtsvervoiging.

De rechtbank ${ }^{116}$, echter, ging daar - evenmin als de kantonrechter voordien - op in. Het betoog "dat wegens de vermeende onverbindendheid van (het plakverbod, RdW) het vervoeren van plakmiddelen te allen tijde een 
legale bezigheid zou zijn", ging volgens haar niet op:

"De raadsman ziet dan over het hoofd, dat ook niet strafrechtelijk verboden gedrag nog wel in strijd met andermans rechten kan komen en om wille van handhaving van de openbare orde kan leiden tot. zelfstandig geldige strafbaarstelling van gevaarzettend vervoer van voor zulk wederrechtelijk gedrag aan te wenden middelen tussen 21.00 en 6.00 uur".

Ook "los" van de artikelen 15 en 16 APV (het plakverbod), was art. 17 APV dus verbindend.

Leijten vatte de problematiek vervolgens, in zijn conclusie ${ }^{117}$, kernachtig samen:

"als die APV-bepaling niet geldig is:

als het dus niet strafbaar is, zonder vergunning aanplakbiljetten

aan te brengen aan de in art. 15 en 16 genoemde objecten,

hoe zou dan de voorbereidingshandeling daartoe:

het aanwezig hebben en vervoeren van het aan te plakken biljet

en eventueel van de kwast wèl strafbaar kunnen zijn.

Ik geloof dat de Rechtbank daar anders over denkt: al is het plakken niet strafbaar, dan kan het nog wel onrechtmatig zijn (in strijd komen met andermans rechten) en de aanwezigheid of het vervoer van tot het begaan van zulk onrechtmatig ('wederrechtelijk') handelen bestemde middelen kan dan zelfstandig strafbaar gesteld worden als de openbare orde dat vordert.

De geheimzinnigheid is opgeheven. Het betoog is, in wezen, en duidelijk en - hoe kan het anders - rationeel verdedigbaar.

Toch zal ik niet adviseren het over te nemen. De ratio van de strafbaarstelling van het handelen omschreven in art. 17 lid 1 APV is gelegen in de bewijsnood die vaak zal bestaan ten aanzien van het plakken zelf. (...) Er is sprake van een strafbaarstelling bijwege van hulpmiddel".

En:

"Als men ter wille van de vrijheid van meningsuiting of -verspreiding straffeloos mag plakken, mag men ook straffeloos hetgeen geplakt moet worden en waarmee geplakt moet worden, aanwezig hebben en vervoeren".

Ook de Hoge Raad bleek vervolgens van oordeel dat artikel 17 enerzijds, en de artikelen 15 en 16 anderzijds, zozeer met elkaar samenhingen dat "in het geval de laatstgenoemde bepalingen onverbindend zijn, het verbod van art. 17 (...) APV buiten toepassing moet blijven". ${ }^{118}$ De rechtbank had, met andere woorden, ook in dit geval de verbindendheid van het plakverbod moeten onderzoeken. De omstandigheid dat de Hoge Raad hier niet alsnog 
zèlf een oordeel over velde, bevestigde - nogmaals - dat het niet een louter juridische vraag betrof. De zaak werd, kortom, verwezen naar het Hof te Leeuwarden. Of Loesje uiteindelijk tòch nog gelijk heeft gekregen, weet ik niet. Bij de Hoge Raad kreeg zij in elk geval wat zij - gezien de eerdere jurisprudentie - kon verwachten, lijkt mij.

- De rechtbank in Breda hield intussen gewoon aan haar eigen jurisprudentie vast. Daar had zij ook alle reden voor, want haar "plak-vonnissen" waren tot dusver door de Hoge Raad steeds in stand gelaten. Op 22 april 1982 had zij - zoals we al eerder zagen - naar aanleiding van het Bredase plakverbod onder meer overwogen:

"dat zo'n beperking c.q. voorschrift in het onderhavige geval mogelijk een remmende werking heeft op de verspreiding van de aanplakbiljetten, doch dat (...) niet aannemelijk is geworden dat zulks die verspreiding onmogelijk zou maken c.q. in ontoelaatbare mate zou belemmeren". ${ }^{119}$

En korte tijd later, naar aanleiding van het Tiliburgse plakverbod:

"dat geenszins aannemelijk is geworden dat vrijwel alle eigenaren of huurders in de gemeente Tilburg hun toestemming zouden weigeren indien hen zou worden gevraagd om die te verlenen tot aanplakking op een hen goeddunkende wijze;

dat al evenmin aannemelijk is geworden dat eventuele toestemming van huurders zou kunnen worden ontkracht door optreden van verhuurders; dit met name niet voor de situatie waarin de toegestane wijze van aanplakking verhuurders niet in hun belangen raakt". ${ }^{120}$

Dus was in beide gevallen een gebruik van enige betekenis mogelijk ${ }^{121}$, en dat oordeel moest vervolgens in cassatie worden "geẽerbiedigd".

In een volgende zaak, die zich een paar jaar later afspeelde, werkte de rechtbank én en ander wat verder uit. Het ging daarbij opnieuw om het Tilburgse plakverbod. ${ }^{122}$ Liet de inmiddels ongewijzigde APV-bepaling - die het "aan anderen dan de rechthebbenden" verbood aan te plakken - nu well te weinig plakmogelijkheden intact? Volgens de rechtbank ${ }^{123}$ was daar nog steeds geen sprake van:

"Tijdens het onderzoek ter terechtzitting is niet aannemelijk geworden dat zich in de gemeente Tilburg bijzondere plaatselijke omstandigheden voordoen welke zouden meebrengen dat meergenoemde verbodsbepaling in feite geen mogelijkheid tot gebruik van enige betekenis van dit middel tot verspreiding openlaat. De vaststaande omstandigheid dat in de gemeente Tilburg van overheidswege geen openbare aanplakborden zijn opgericht, vormt niet een omstandigheid van een dergelijk, genoemd, gevolg. 
Niet aannemelijk is dat rechthebbenden na een tot hen met inachtneming van de normale omgangsvormen gericht verzoek, al dan niet gedaan onder aanbieding van enige vergoeding, op zodanige schaal zouden weigeren in te stemmen met aanplakking of bevestiging van biljetten op een wijze die hun goedkeuring heeft, dat in feite geen mogelijkheid tot gebruik van enige betekenis van dit middel tot verspreiding aanwezig is".

Het verweer van de "verdachte" dat een dergelijk gebruik in Tilburg niet meer mogelijk was, was op die manier, volgens de Hoge Raad ${ }^{124}$, "verworpen op gronden welke die verwerping kunnen dragen":

"In dit oordeel van de Rechtbank ligt immers besloten dat niet aannemelijk is geworden dat ten gevolge van de aangevoerde omstandigheden geen gebruiksmogelijkheden van enige betekenis van het onderhavige middel van verspreiding en bekendmaking zouden overblijven. Aangezien dit oordeel van de Rechtbank steunt op een waardering van de feitelijke omstandigheden welke zich in de gemeen-

te Tilburg voordoen, moet het in cassatie worden geëerbiedigd". Dat was ongetwijfeld een tamelijk obligate wijze van afdoening. Hoewel... sinds die eerdere Haarlemse $z^{2 a k^{125}}$ misschien toch veelzeggend! Want daarin leek te zijn vastgelegd dat "gebruik van enige betekenis" pas verzekerd was, wanneer er voldoende vrije plakplaatsen waren. Was dat dan toch inderdaad - zoals ik al even suggereerde - een valse illusie geweest? Laat ik - om de "spanning" erin te houden - volstaan met hetgeen ik destijds in een noot onder dit arrest schreef, waarbij ik me op het standpunt stelde dat het vereiste van "vrije plakplaatsen" inmiddels geldend recht was geworden ${ }^{126}$ :

"De Rechtbank had het verweer, volgens de Hoge Raad, "verworpen op gronden welke die verwerping kunnen dragen'. Daaruit is in dit geval niet zoveel af te leiden. De bestreden uitspraak blinkt immers niet uit door eenduidigheid. Er worden drie kwesties door de Rechtbank aangeroerd en niet duidelijk is of ze iets met elkaar te maken hebben. In de eerste plaats is volgens de Rechtbank niet aannemelijk geworden dat in feite geen gebruik van enige betekenis meer mogelijk is. Op zichzelf had men - ter weerlegging van het gevoerde verweer met die feitelijke (en in cassatie dus onaantastbare) constatering kunnen volstaan. Maar in de tweede plaats wordt overwogen dat de omstandigheid dat van overheidswege geen "openbare aanplakborden" zijn geplaatst niet ten gevolge heeft dat er geen gebruik van enige betekenis meer mogelijk is. Niet duidelijk is of een dergelijk gevolg in de zienswijze van de Rechtbank principieel is uitgesloten, dan wel dat het zich in casu slechts feitelijk niet voordoet; alleen het laatste lijkt juridisch houdbaar. In de derde plaats is niet aannemelijk dat 
rechthebbenden "op zodanige schaal zouden weigeren" toestemming te verlenen om te plakken "dat in feite geen mogelijkheid tot gebruik van enige betekenis van dit middel tot verspreiding aanwezig is".

Slechts wanneer deze derde overweging tevens redengevend is geweest voor de allereerste vaststelling dat er nog ruimte is voor een gebruik van enige betekenis, slechts in dat geval is het vereiste van de viije plakplaatsen met dit nieuwe arrest komen te vervallen. Een dergelijke redengeving kan ongetwijfeld door de Rechtbank bedoeld zijn. Maar het hoeft niet. Uit de overweging van de Hoge Raad dat de Rechtbank het verweer heeft "verworpen op gronden welke die verwerping kunnen dragen", volgt met andere woorden niet dat de Hoge Raad is teruggekomen van het arrest over het Haarlemse plakverbod. Misschien is dat uit een volgend arrest wel af te leiden. Voorlopig is er geen aanleiding om de Hoge Raad van zwalken te betichten. Ook al sloeg de Rechtbank met haar laatste overweging de plak volledig mis, dan nog konden de gronden waarop het verweer was verworpen immers zodanig worden opgevat dat zij die verwerping konden dragen. Eén houtsnijdende overweging van de Rechtbank was daarvoor al voldoende. En dat zo'n overweging er, volgens de huidige stand van de jurisprudentie, was, lijdt geen twijfel."

- Het volgende (en in deze reeks laatste) arrest kwam al gauw, om precies te zijn: nog geen maand later. ${ }^{127}$ Het ging opnieuw over Tilburg. De overwegingen van de rechtbank waren letterlijk hetzelfde als de vorige keer, zij het dat zij haar vonnis op én punt een fractie scherper had geformuleerd; er was namelijk een klein (wat stekelig) zinnetje aan toegevoegd:

"Nog immer kan worden aangenomen, op grond van algemene ervaringsregelen, dat in Tilburg opgeld doet het gezegde: 'Met de hoed in de hand komt men door het ganse land'."

Voor de reactie van de Hoge Raad maakte dat niet uit. Het beroep op onverbindendheid bleek wederom te zijn "verworpen op gronden welke die verwerping (konden) dragen". En het oordeell van de rechtbank, dat nu weliswaar niet steunde op de waardering van de feitelijke omstandigheden, was "zozeer verweven met een waardering van de feitelijke omstandigheden welke zich in de gemeente Tilburg (voordeden)", dat het - alweer! - in cassatie moest worden "geëerbiedigd". Maar: er werd - in navolging van hetgeen de advocaat-generaal (Fokkens) in zijn conclusie had gesteld - nog iets aan toegevoegd. En juist dàt was veelzeggend:

"Voor zover het middel nog de klacht behelst dat in de gemeente Tilburg bij gebrek aan openbare plakplaatsen altijd toestemming van een derde noodzakelijk is voor het aanbrengen van aanplakbiljetten en 
dat zulks in strijd is met artikel 7 Grondwet, miskent het dat 'voorafgaand verlof' in evengenoemd artikel betrekking heeft op voorafgaand verlof van de overheid."

Daarmee was het verzuim in "Haarlem" - waar de overheid onder de tafel was verdwenen - in éen klap ongedaan gemaakt. Of liever: daarmee werd duidelijk dat in "Haarlem" sprake was van een verzuim. Tegelijkertijd konden alle hersenspinsels over de noodzaak van "vrije plakplaatsen" in de prullenbak worden geworpen. Het enige wat overbleef was dat we - strikt genomen - nog steeds niet zeker wisten of het werkelijk relevant was dat het in Tilburg "met inachtneming van de normale omgangsvormen (...), al dan niet (...) onder aanbieding van enige vergoeding" volgens de rechtbank nog wel zou lukken toestemming van rechthebbenden te verkrijgen voor "aanplakking of bevestiging van biljetten op een wijze die hun goedkeuring heeft". En afgezien daarvan: wie gelooft zo'n "vaststelling"? ${ }^{128}$ Of, zoals Van der Burg in een noot onder het arrest schreef ${ }^{129}$ :

"De Rb. Breda neemt aan dat men in Tilburg met de hoed in de hand overal komt, maar hoe weet de Rb. dat zo goed? (...) Op grond van mijn eigen waarnemingen als inwoner van Tilburg - nu enige jaren terug - mex ik dat er in Tíburg veei weru' gea'oogd en geaccepteerd, maar de figuur van de rechthebbende die aan een verzoeker met de hoed in de hand toestaat kritische teksten op te hangen, komt mij volkomen onbekend voor".

Is het niet verbazingwekkend dat de Hoge Raad zo'n bewering zonder enige motivering laat passeren, terwijl hij anderzijds zozeer in de wereld blijkt te staan dat hij de straatwaarde van heroïne en cocaïne als feit van algemene bekendheid beschouwt ${ }^{130}$, evenals trouwens het feit dat heroïne niet zelden via het vliegveld van Aruba wordt binnengebracht ${ }^{131}$, dat een proefritje met een motor geen etmaal duurt ${ }^{132}$, dat een stroomstoot van 220 Volt dodelijk kan zijn ${ }^{133}$, dat in Nederland onder 'roulette' 'Franse roulette' wordt verstaan $^{134}$, dat hevige emoties bij bejaarden dikwijls fatale gevolgen hebben ${ }^{135}$ en dat geen enkel deel van Rijksweg 12 binnen de gemeente Elst is gelegen ${ }^{136}$ ? Ik kan nog wel begrijpen dat beweringen, waarvan iedereen weet (of makkelijk kan nagaan) dat ze (zeer waarschijnlijk) kloppen, zonder meer worden aanvaard; maar waarom beweringen waarvan iedereen weet (of makkelijk kan nagaan) dat ze (zeer waarschijnlijk) niet kloppen, niet zonder meer worden verworpen (behalve als ze aannemelijk worden onderbouwd), is mij niet duidelijk. De Hoge Raad is in dat opzicht niettemin erg goedgelovig; veel goedgeloviger, denk ik, dan de Afdeling Rechtspraak van de Raad van State ten aanzien van bestuurders. De Afdeling wil nog wel eens motiveringseisen stellen (zoals we zagen); bij de Hoge Raad kwamen we dat fenomeen niet tegen. 
Wat die laatste Tilburgse zaak aangaat, wees Van der Burg ${ }^{137}$ trouwens nog op én ding:

"De term voorafgaand verlof ziet op voorafgaand verlof van de overheid zo zegt de HR, maar ziet 'verlof' nu alleen op een publiekrechtelijk verlof van de overheid of ook op een privaatrechtelijke toestemming van de overheid?"

Die kwestie was echter al beslecht, lijkt mij. Niet alleen impliciet, maar zelfs expliciet - te weten: in een eerder arrest over (hoe kan het anders?!) Tilburg. ${ }^{138}$ De gemeente mocht van de Hoge Raad, zo blijkt uit dat arrest, "als rechthebbende op gemeente-eigendommen" zelfs censuur uitoefenen.

\subsection{Vergunning- en ontheffingstelsels (1985-199i)}

Laten we, nu we weer terug zijn bij het voorafgaand verlof van de overheid - en wel met name de publiekrechtelijke variant daarvan - bezien hoe de gang van zaken ten aanzien van vergunningen en ontheffingen was. Aan het begin van de jaren zestig waren, zoals bekend, een paar arresten over vestigingsvergunningen gewezen, en nog langer geleden (in 1948) had de Kroon zich uitgesproken over het vergunningvereiste voor leesbibliotheken in Brunssum. In de tweede helft van de jaren zestig werd het ontheffingstelsel van de Noordhollandse Verordening Landschapsschoon onverbindend verklaard, waardoor de blauwe neonletters met "NEDERLAND ONTWAPENT" op de fabriekstoren bij Naarden mochten blijven staan. ${ }^{139}$

Een materieel identieke bepaling, waarmee een dergelijke consequentie heel vernuftig werd omzeild, kwamen we later in Pijnacker ${ }^{140}$ tegen. Daar gold geen verbod behoudens ontheffing (o.i.d.), maar was het "de eigenaai of gebruiker van enig onroerend goed verboden daarop of daaraan een verlichting of reclame te hebben, indien burgemeester en wethouders hem schriftelijk hebben medegedeeld dat die verlichting of reclame de verkeersveiligheid in gevaar brengt, of een voor de omgeving hinderlijk effect sorteert". Geen preventieve maatrege!, kortom, maar een repressieve (met een rechtsgang naar de Afdeling Rechtspraak). Van strijd met art. $7 \mathrm{Gr}$.w. was dan ook geen sprake; de bepaling behelsde immers "noch een algemeen verbod, noch (werd) het hebben van een reclame van een voorafgaand verlof van de overheid afhankelijk gesteld".

In de Amsterdamse bouwverordening stond een soortgelijke bepaling (art. 310a lid 1):

"Het is verboden, op van de openbare weg af zichtbare wijze enige reclame of ondersteuningsconstructie ten behoeve van reclame aan te brengen of te hebben, indien deze reclame of ondersteuningsconstruc- 
tie, naar het oordeel van B en W, zowel op zichzelf als in verband met de omgeving niet voldoet aan redelijke eisen van welstand".

Een lichtbak met de tekst "Antiekmarkt De Looier", die op een dak van de Lijnbaansgracht stond, moest - met een beroep op die bepaling uit de bouwverordening - uiterlijk 25 juli 1983 verwijderd worden, "bij gebreke waarvan" (zo hadden B en W geschreven) "van gemeentewege, doch op kosten van appellant, hiertoe (zou) worden overgegaan". Opnieuw bleek art. $7 \mathrm{Gr} . w$. voor de Afdeling Rechtspraak geen obstakel te zijn - al liet zij deze keer in het midden of we met het eerste, dan wel het derde lid van art. 7 te maken hadden. Na de constatering dat het voorschrift uit de bouwverordening "niet beperkt (was) tot het aanbrengen van handelsreclame", zodat de zaak niet eenvoudig via art. 7 lid 4 kon worden afgedaan, overwoog zij onder meer het volgende ${ }^{141}$ :

"Gelet op de bewoordingen waarin art. 310a eerste lid bouwverordening is gesteld, kan niet worden staande gehouden dat in dit voorschrift een algemeen verbod, dan wel een voorafgaand verlof ligt besloten. Het voorschrift geeft verweerders niet de ruimte voor een inhoudelijke beoordeling van de te openbaren of geopenbaarde gedachten of gevoelens. Zij hebben uitsluitend te beoordelen of aan redelijke eisen van welstand wordt voldaan. In zoverre is er weliswaar een beperking van het (...) verspreidingsrecht, doch deze beperking kan worden geacht in het belang van de huishouding van de gemeente te zijn.

Niet is gebleken dat het ter zake door verweerders genoemde beleid op gespannen voet staat met het bepaalde in art. 7 Gr.w.".

Desondanks werd de beschikking van B en W vernietigd - vanwege een motiveringsgebrek. Laat ik mij hier tot art. 7 beperken. Echt duidelijk lijkt de uitspraak mij niet. Wat moeten we uit die latste volzin afleiden? De Afdeling keek klaarblijkelijk niet alleen naar de bepaling-zelf, maar ook naar de toepassing ervan. Alleen, waar lette ze toen op? Volgens Van Buuren ${ }^{142}$ leed dat geen twijfel:

"Gelet op het beleid dat B en W met betrekking tot de uitvoering van dit voorschrift voeren - de Afd. besteedt aan dit beleid niet voor niets afzonderlijke aandacht - kan niet worden gesteld, dat er geen gebruik van betekenis van het onderhavige middel van bekendmaking overblijft".

Hoe wist hij dat zo zeker? We mogen, vrees ik, hoogstens hopen dat de Afdeling daarop lette. Zoals we daarnaast slechts kunnen hopen dat zij tevens alert was op mogelijke inhoudelijke effecten van het gemeentelijke beleid op dit punt. Immers: "ook kleur en vorm kunnen essentieel zijn voor de inhoud van de uiting", zoals Heringa bij een andere gelegenheid eens 
opmerkte. ${ }^{143}$

En afgezien daarvan: ging het in die Amsterdamse bepaling inderdaad - net als in Pijnacker - louter om een repressieve bepaling? In dit geval traden B en W weliswaar repressief op, maar ze hadden net zo goed preventief kunnen optreden. Ook het aanbrengen mocht al verboden worden. De afstand tot voorafgaand verlof was hier, met andere woorden, nog wat kleiner dan de vorige keer. Formeel, althans. Materieel was die afstand, zoals gezegd, allang overbrugd: "Hier zal men in de praktijk", aldus De Meij ${ }^{144}$, "toch wel het bord met tekst of afbeelding aan B en W gaan voorleggen, gezien de kans op een financiële strop als achteraf het bord verwijderd moet worden (in het onderhavige geval was dat 11.000 gulden plus kosten van demontage)". Juridisch werd die consequentie blijkbaar niet van belang geacht.

Net een stap te ver, daarentegen, ging men in Zandvoort ${ }^{145}$, en vervolgens nog in Bunschoten ${ }^{146}$, Schijndel ${ }^{147}$, 's-Hertogenbosch' ${ }^{148}$ en Arnhem ${ }^{149}$. Feitelijk allemaal zaken die in het verlengde van "Leiden" en "Den Haag" lagen. ${ }^{150}$ Telkens was het - behalve met vergunning of ontheffing van $B$ en $W$ - verboden reclame te maken of dingen op te hangen. Dan was het gebruik van het middel dus ècht - onontkoombaar - afhankelijk gesteld van voorafgaand verlof van de overheid. En dat bleek nog steeds onacceptabel. ${ }^{151}$

Waren al die uitkomsten dus volstrekt voorspelbaar? De ene méér dan de andere, lijkt mij. Of iets al dan niet "van voorafgaand verlof van de overheid afhankelijk" mag worden gesteld, is immers zèlf weer afhankelijk van de vraag of je al dan niet met een zelfstandig middel van bekendmaking te doen hebt. Je zult dus eerst moeten weten hoe ruim zo'n middel moet worden omschreven. Zandvoort en Bunschoten waren, gezien de eerdere jurisprudentie, het minst problematisch. Daar ging het respectievelijk om 1) het "bezigen" van een onroerende zaak "voor het daarop aanbrengen van reclame, opschriften, aankondigingen, uitbeeldingen of afbeeldingen in wellke vorm ook" (Zandvoort), en 2) het aanbrengen, in stand houden of gedogen van reclame die van de weg af zichtbaar is "op, aan of in hetzij een onroerend goed, hetzij enig daarop aanwezig roerend goed" (Bunschoten). Wie zich onder meer "Nederland ontwapent" 152 herinnert, zal zich niet verbazen dat ook hier geen voorafgaand verlof van de overheid geëist mocht worden.

In Schijndel, 's-Hertogenbosch en Arnhem lag het wat ingewikkelder. Weliswaar vond Brederveld de eerste uitspraak "geheel volgens het boekje", betrof de tweede volgens hem "opnieuw een voorbeeld van aperte strijd met de vrijheid van meningsuiting" en traceerde hij in de derde "langzamerhand zeer vertrouwde paden"153, toch bleef het telkens de vraag of we met een zelfstandig middel te maken hadden. In Schijndel, bijvoorbeeld, was "het 
plaatsen, aanbrengen of hebben van voorwerpen of stoffen op, in, over of boven de weg" zonder vergunning van $B$ en $\mathbf{W}$ verboden. Tegelijkertijd mocht je er als rechthebbende of met schriftelijke toestemming van de rechthebbende wèl "op de weg of op vanaf de weg zichtbare wijze op enig onroerend goed anders dan op daartoe ingerichte en geplaatste publicatieborden" plakken e.d. Moest het ene nu, naast het andere, als zelfstandig middel worden aangemerkt? Dat sprak "op zichzelf" niet vanzelf, lijkt mij. Maar de (waarnemend) Voorzitter van de Afdeling Rechtspraak (respectievelijk Kapteyn, Boukema en Van Zeben) maakte er geen enkel probleem van. En zo kwamen we aan de volgende middelen van bekendmaking die naast andere middelen zelfstandige betekenis bleken te hebben:

- "het aanbrengen van affiches en dergelijke op welke wijze dan ook op, over of boven de weg" (Schijndel en Arnhem);

- "het ophangen van spandoeken op welke wijze dan ook op, over of boven de weg" ('s-Hertogenbosch).

Op het eerste gezicht volstrekt onschuldige bepalingen werden op die manier "onderuit" gehaald. In Schijndel betrof het verbod, zoals gezegd, het plaatsen, aanbrengen of hebben van voorwerpen of stoffen op, in, over of boven de weg - voor sommige stoffen en voorwerpen ongetwijfeld een nuttige bepaling; maar zodra het over affiches e.d. gaat, ligt dat anders. In 's-Hertogenbosch was het zonder vergunning van $\mathrm{B}$ en $\mathrm{W}$ verboden voorwerpen of stoffen te plaatsen, aan te brengen of te hebben op, in, over of boven de weg - goed bedoeld, wellicht, maar opnieuw veel te ruim geformuleerd. En in Arnhem had je ontheffing van B en W nodig om "boven een weg of de openbare grond:

a. een voorwerp uit te steken;

b. een kabel, touw, ketting of draad te spannen."

Alweer niets bijzonders, eigenlijk, maar wel wat te veel van het goede. Geen van die bepalingen - die "op zich" niets met de vrijheid van drukpers uitstaande hadden - bleek splitsbaar te zijn in een verbindend gedeelte (over plantenbakken en meer van dat soort voorwerpen) enerzijds, en een onverbindend (over affiches en spandoeken) anderzijds. De tekst ervan bood daartoe, zoals de Voorzitter het - geheel in de traditie van de Hoge Raad uitdrukte, "onvoldoende aanknopingspunten". Daardoor "sleepte (...) het onverbindende deel het op zichzelf verbindende deel in zijn val mee omdat dat laatste deel nu eenmaal" - ik gebruik de woorden van Van Wijk ${ }^{154}$ "niet op zichzelf stond maar onlosmakelijk aan het andere vast heette te zitten". Een kwestie, waar ik (zoals ik al eerder opmerkte) in het kader van dit boek niet verder op in zal gaan. 
Een andere in het oog lopende bepaling, die "op zich" niets met de vrijheid. van drukpers uitstaande had, was art. 2 Hinderwet, op grond waarvan je voor het in werking hebben van "inrichtingen die daarbuiten gevaar, schade of hinder (konden) veroorzaken" vergunning nodig had (en trouwens nog steeds nodig hebt). Welke "inrichtingen" daarmee bedoeld werden, was te vinden in een algemene maatregel van bestuur: het Hinderbesluit - alweer een regeling die "op zich" losstond van de vrijheid van drukpers. Art. 1 aanhef en onder Ia daarvan luidde (en luidt) als volgt:

"Als inrichtingen welke daarbuiten gevaar, schade of hinder kunnen veroorzaken, worden aangewezen:

Ia: Inrichtingen waar een of meer electromotoren worden gebezigd met een vermogen of een gezamenlijk vermogen groter dan 1,5 $\mathrm{kW}$, met dien verstande, dat bij de berekening van het gezamenlijke vermogen buiten beschouwing blijven de electromotoren met een vermogen van niet meer dan $0,25 \mathrm{~kW}$, welke deel uitmaken van handgereedschap, ventilatoren en kantoormachines."

Die grens van 1,5 kW werd door een Amsterdamse drukker - met elektromotoren ten behoeve van onder andere drukpersen, zetmachines en een loodzaagmachine - ruimschoots overschreden. Toch had hij geen Hinderwetvergunning. En dat hoefde ook niet, meende zijn raadsman, want die bepaling uit het Hinderbesluit was (onder meer) in strijd met art. 7 lid 1 Gr.w. Daarbij beriep hij zich op het beroemde arrest van de Hoge Raad uit 1961 over het Vestigingsbesluit Grafische Bedrijven I 1952. ${ }^{155}$ In dat arrest besliste de Hoge Raad dat "het boekdrukbedrijf $(\ldots)$ - (..) omvattende (...) mede het ten behoeve van het publiek bedrijfsmatig door den druk vermenigvuldigen van voortbrengselen die voor de openbaring van gedachten of gevoelens plegen te worden gebezigd, als boeken, vlugschriften en nieuwsbladen - van overheidswege aan geen andere regeling mag worden onderworpen dan de zodanige welke de vervulling van die dienende taak onverlet laat". Daarom was het vereiste van een voorafgaande vergunning van de Kamer van Koophandel en Fabrieken voor het vestigen van een boekdrukbedrijf destijds ongeoorloofd.

Stond de Hoge Raad nu op hetzelfde standpunt ten aanzien van de vereiste Hinderwetvergunning? Het antwoord was kort: nee, en wel "op de gronden, uiteengezet in de conclusie van het Openbaar Ministerie". ${ }^{156}$ De advocaatgeneraal (Meijers) was klaarblijkelijk duidelijk genoeg geweest. Volgens hem hield de stelling dat er strijd met art. 7 lid 1 was "geen steek":

"De bedoelde bepaling van het Hinderbesluit beoogt evenmin als eventuele andere hinderwetvoorschriften voor de drukkersbranche de vrijheid van drukpers aan te tasten; zij wil gevaar, schade of hinder, die van het technische procédé van het drukken buiten de inrichting 
zijn te vrezen, voorkomen. Met een overweging van deze strekking heeft de Kroon verzoekers administratieve beroep verworpen (KB van 28 nov. 1980, nr. 45 ...).

\section{De Kroon overwoog:}

'dat (...) toepassing van de Hinderwet noch tot doel, noch tot effect heeft de verkoop van geschriften van meningsuiting te beletten, doch uitsluitend beoogt gevaar, schade of hinder van ernstige aard, welke daarbuiten van het onderwerpelijke bedrijf zijn te duchten, te ondervangen':

(...)

Van strijd met art. 7 Gr.w. zou eerst sprake zijn in het - gelet op de eisen waaraan de besluitvorming moet voldoen, theoretische - geval dat de vergunning verlenende autoriteit (...) haar bevoegdheid zou misbruiken om een drukker te muilkorven. Daaromtrent is is deze zaak niets aangevoerd of vastgesteld."

Een opmerkelijk resultaat! Ook dat Vestigingsbesluit beoogde destijds immers iets anders dan de aantasting van de vrijheid van drukpers; het zag op bevordering van kredietwaardigheid, handelskennis en vakbekwaamheid vinicin ue orancine. sterker, de toenmalige advocaat-generaal (s'Jacob) beschouwde de mogelijkheid van muilkorving - net als zijn latere collega als louter theoretisch (en wel: om dezelfde reden, zij het dat hij zich iets anders uitdrukte). Toch kwam de Hoge Raad nu opeens - in het voetspoor van zijn advocaat-generaal - tot een andere uitkomst. Was hij intussen "om" gegaan? Daar leek het wel op. Of was er nog een uitweg? De Meij ${ }^{157}$ herinnerde eraan dat de advocaat-generaal zich mede op de argumenten van de Kroon had beroepen, en die repte niet alleen van het oogmerk van de regeling (ofschoon Meijers dat wel leek te suggereren), maar ó́k van het effect: "dat (...) toepassing van de Hinderwet noch tot doel, noch tot effect heeft de verkoop van geschriften van meningsuiting te beletten". Weliswaar bleek het bij de "werkelijke" strekking die de Kroon ontwaarde vervolgens toch weer uitsluitend te gaan om hetgeen beoogd werd, Meijers' eigen conclusie kon daarentegen - ik moet het toegeven! - heel goed worden begrepen in termen van een mogelijk (zij het "theoretisch") effect. Blijft niettemin de vraag waarom dat effect zich hier niet voordeed, en bij het Vestigingsbesluit wel? Of deed het zich in dit geval wellicht óok voor, maar was het intussen - in cassatie - te laat voor zo'n feitelijke vaststelling? Dat was Meijers" zienswijze misschien; hij zei uitdrukkelijk dat "daaromtrent (...) in deze zaak niets is aangevoerd of vastgesteld". ${ }^{158}$ Maar hoe kon de Hoge Raad destijds dan wel ten aanzien van dat Vestigingsbesluit op eigen houtje vaststellen dat het te ver ging?

Nee, ik weet echt niets fraaiers te verzinnen dan dat de Hoge Raad op dit 
punt bakzeil heeft gehaald. De Meij ${ }^{159}$ suggereerde nog een andere afdoening waarmee de oude jurisprudentie well overeind gehouden had kunnen worden. Volgens hem

"zou het beter geweest zijn als enerzijds erkend was dat de Hinderwetgeving beperkingen meebrengt, maar ook dat hierdoor (in de woorden van het arrest over de vestigingsvergunning voor grafische bedrijven) de vervulling van de dienende taak van deze bedrijfstak onverlet wordi gelaten".

Of we daar veel mee geholpen waren geweest, lijkt me de vraag. Zeker, de "leer" zou dan onverkort gehandhaafd zijn. Maar wat was de betekenis daarvan? Waarom werd "de dienende taak" in het ene geval well "onverlet" gelaten, en in het andere niet?' Waarop moest je daarbij letten? En wanneer werd de grens overschreden, oftewel: wat betekende "onverlet laten" precies? Met zo'n leer kon je alle kanten op.

Hoe dan ook, de Hoge Raad hanteerde eenvoudig een andere "leer", vermoed ik. Voorafgaand verlof van de overheid leek opeens geoorloofd te zijn, zolang het maar niet tot doel of effect had de verspreiding van publikaties te "beletten". Moest verspreiding zonder vaorafgaand verlof dus tot op zekere (welke?) hoogte mogelijk blijven? Of was de zaak al in orde als het verlof in voldoende mate werd verleend, en het vooral niet vanwege de inhoud van de stukken werd geweigerd? De advocaat-generaal verschafte hier geen duidelijkheid over, al suggereerde hij het laatste. ${ }^{160}$

Stonden de uitspraken van de (Voorzitter van de) Afdeling Rechtspraak over het Zandvoortse reclameverbod e.d., die we zoëven tegenkwamen, niet op gespannen voet hiermee? Ook toen ging het immers om bepalingen die een vergunning of onthefĩing eisten en die er niet specifiek op gericht waren de verspreiding van stukken te beletten. Toch liepen die zaken allemaal verkeerd af voor de gemeente: het voorafgaand verlof kon niet door de beugel. Kwam dat wellicht omdat daarbij steeds een verspreidingsmiddel in zijn geheel in het geding was? Verschaften die uitspraken ons, met andere woorden, inzicht in hetgeen door de advocaat-generaal was betoogd? Ging het eronn dat vespreiding zonder voorafgaand verlof tot op zekere hoogte mogelijk bleef?' Konden we die andere optie voortaan vergeten? In Schijndel, bijwoorbeeld ${ }^{16 r}$, bleek "het aanbrengen van affiches en dergelijke op welke wijze dan ook op, over of boven de weg" aan een vergunningstelsel te zijn onderworpen. Dat was dus ongeloorloofd. Het gebruik van een drukpers, daarentegen, was - gezien het Hinderbesluit - niet categorisch afhankelijk gesteld van voorafgaand verlof. Weliswaar kon je met een motorvermogen van minder dan anderhalve kilo-Watt in de praktijk onmogelijk een krant produceren, maar die feitelijke omstandigheid kon in cassatie niet meer worden vastgesteld. Dat $66 \mathrm{k}$ het - ongetwijfeld zelfstandige - middel "krant" 
(net als "het aanbrengen van affiches en dergelijke") feitelijk altijd aan een vergunningstelsel was onderworpen, kon de uitkomst derhalve niet beïnvloeden.

Het klinkt allemaal tamelijk gezocht, maar onmogelijk is het niet. Een volgende uitspraak, deze keer van de waarnemend Voorzitter van de Afdeling geschillen van bestuur van de Raad van State ${ }^{162}$, ontnam ons echter ook dlfe "vluchtroute". In het spoor van Van Veen, die het vorige arrest in de NJ van een noot had voorzien, meende de waarnemend Voorzitter (B. Veldkamp) dat de Hinderwet "eisen mag stellen aan de technische uitrusting van drukkerijen, waarbij de inhoud van wat. er gedrukt gaat worden nimmer mee mag wegen". Er was, volgens hem, dan ook geen vuiltje aan de lucht te bekennen - tenminste: zolang bij de vergunningverlening maar niet gelet werd op "de inhoud van wat er gedrukt (ging) worden". Daarmee vielen die eerdere uitspraken over Zandvoort, Bunschoten, Schijndel, 's-Hertogenbosch en Arnhem, volgens mij, ongemogelijk te rijmen. Waren ze eenvoudig over het hoofd gezien, zoals ze ook in de literatuur in dit verband nergens worden genoemd? De ene afdeling van de Raad van State lijkt nu een ander criterium te hanteren dan de andere.. Of is de volgende stap dat "het aanbrengen van affiches en dergelijke" voortaan eveneens aan een vergunningstelsel onderworpen mag worden? Staan we, met andere woorden, aan de vooravond van een aardverschuiving op dit rechtsgebied? Ik kan het me niet goed voorstellen, maar een elegante uitweg is volgens mij niet meer voorhanden.

\subsection{Absoluut verbod (1989-1990)}

De tweede poot van de verspreidingsjurisprudentie - naast het voorafgaand verlof - was, zoals bekend, het absolute verbod. Een middel van verspreiding met zelfstandige betekenis mocht niet in het algemeen worden verboden. Alleen, dergelijke bepalingen bleken vrijwel niet voor te komen. Behalve in "Heerenveen", "Tilburg" en "Sittard" kwamen we ze nergens tegen. ${ }^{163}$ Normaliter gold een verbod slechts voor bepalde straten of perioden, of ging het met een ontheffings- of vergunningstelsel gepaard. De enigen die regelmatig verspreidingsverboden uitvaardigen, zijn presidenten van rechtbanken in het kader van een kort geding. En soms komt ook de strafrechter eraan te pas, als het gaat om inbeslagneming en onttrekking aan het verkeer van drukwerk (of apparatuur).

Hoewel dit boek daar niet over gaat, toch een enkele opmerking erover. Naar aanleiding van de inbeslagneming en verbeurdverklaring van het weekblad "BLUF!", waarin vertrouwelijke gegevens van de BVD waren gepubli- 
ceerd, rees de vraag of dat niet in strijd met (onder meer) art. $7 \mathrm{Gr}$.w. was. De Hoge Raad ${ }^{164}$ overwoog toen het volgende:

"Tot de middelen waarmee de belangen, die art. 98 en 98a Sr (verbod gegevens openbaar te maken "waarvan de geheimhouding door het belang van de staat of zijn bondgenoten wordt geboden", RdW) beogen te beschermen, kunnen worden veilig gesteld behoren niet alleen de strafrechtelijke vervolging en eventuele veroordeling van degenen die de in deze artikelen strafbaar gestelde feiten hebben begaan, maar ook de inbeslagneming en de onttrekking aan het verkeer volgens de bepalingen van het Wetboek van Strafvordering van voor het begaan van zodanige feiten bestemde drukwerken.

Toepassing van deze middelen (...) kan niet worden gelijkgesteld met het onderwerpen aan de voorwaarde van 'voorafgaand verlof' als bedoeld in (art. 7 lid 1 en $3 \mathrm{Gr}$.w.), ook al wordt als gevolg daarvan het desbetreffende drukwerk met de daarin neergelegde gedachten en gevoelens niet openbaar".

Daar lijkt mij - aangenomen dat met "openbaar worden" bedoeld werd "bekend worden" 165 niets op af te dingen. De inbeslagneming en verbeurdverklaring betrof immers stukken die al gedrukt waren, terwijl het "voorafgaand verlof"' in art. 7 juist ziet op de fase die daaraan voorafgaat. Het ging hier, met andere woorden, om een verspreidingsverbod, en wel op inhoudelijke gronden. De wetgever in formele zin had de rechter daartoe bevoegd verklaard en bovendien zèlf de toe te passen norm gesteld. Zelfs in het licht van de bekende arresten uit 1950 over Tilburg en Sittard was er dus niets nieuws onder de zon. BLUF! was het slachtoffer geworden van een repressieve (want pas ná de "openbaring" plaatsvindende) ${ }^{166}$ maatregel. Artikel 7 verzette zich daar niet tegen. We hadden het kunnen voorspellen...

Soms kan een maatregel, hoewel "op zichzelf" beperkt van aard, voor de betrokkenen toch neerkomen op een algemeen verbod. Dat ondervonden enkele anti-abortus propagandisten in het Zeeuwse Groede, en later ook in Rotterdam. Zij hadden vlak voor een abortuskliniek met alle mogelijke - soms erg opdringerige - middelen geprobeerd het personeel van hun gelijk te overtuigen en vrouwen ervan te weerhouden een abortus te ondergaan. Onder meer door folders en foto's uit te delen. Maar in beide gevallen werd hun dat door de president van de rechtbank verboden, ${ }^{167}$ Sterker: zij kregen een verbod opgelegd zich binnen een straal van 250 meter van de abortuskliniek te bevinden, in het ene geval gedurende zes maanden en in het andere zelfs voor onbepaalde tijd - "gelet op de hardnekkigheid waarmede gedaagden tegen de kliniek van eiseres in het geweer komen en de omstandigheid dat zij ter plaatse niets te zoeken hebben". Hun acties - waarbij door 
de president overigens geen onderscheid werd gemaakt tusssen het uitdelen van drukwerkjes en ingrijpender zaken, zoals het vastklampen van bezoekers en het blokkeren van de ingang - zouden de vrouwen, die immers in een "kwetsbare gemoedstoestand" verkeerden, te zeer van streek hebben gemaakt. Zo wees de Middelburgse rechtbankpresident erop

"dat vele vrouwen de confrontatie met gedaagden, juist voor de ingang van de kliniek, moeilijk aankunnen en dat dit zowel voor hen zelf als voor de kliniek, die de betrokkenen dient te begeleiden, een zware belasting vormt".

Kortom: wèl vrijheid van meningsuiting, maar niet op die plaats. "Wellicht zal hiermee", aldus de Haagse president, "in de ogen van gedaagden het protest aan effectiviteit inboeten, maar van een wezenlijke aantasting van enig hen toekomend recht is geen sprake". Ik vrees dat er een goede kans bestaat dat hij daar - in elk geval wat art. 7 lid 1 Gr.w. betreft - gelijk in had. Als rechter had hij trouwens - zich beroepend op dreigende onrechtmatigheid - nog wel verder kunnen gaan. Ik laat dat in het kader van dit boek echter "lopen". Hier gaat het mij slechts om de bewering dat een verbod om je mening op een bepaalde plaats te verspreiden geen "wezenlijke aantasting" van de vrijheid van drukpers inhoudt. Voor de betrokken actievoerders was die plaats vermoedelijk namelijk wel "wezenlijk". De Middelburgse president vond het althans

"op zichzelf begrijpelijk dat gedaagden vanu it hun standpunt de laatste kans om iemand van abortus af te houden willen aangrijpen. Het wekken van onrust of betrokkene wel de juiste beslissing heeft genomen is hun doel".

Toch kwam ook hij, zoals gezegd, vervolgens tot een straatverbod. Maar stel nu dat het niet een kort geding betrof, maar een gemeenteraad, die - wederom ter voorkoming van pijnlijke confrontaties - wilde verbieden binnen een straal van 250 meter van de ingangen van ziekenhuizen (waaronder ook abortusklinieken werden gerekend), kerken, begraafplaatsen en crematoria drukwerk (om niet of te koop) aan te bieden. ${ }^{168}$ Was dat geoorloofd? Er bleven nog tal van plaatsen over waar wel gecolporteerd mocht worden. Het "feitelijke" oordeel dat er een gebruik van enige betekenis mogelijk was, zou dus - zeker door de Hoge Raad - al gauw geaccepteerd worden. Alleen, hier doemt toch een probleempje op: heeft dat "gebruik van enige betekenis" uitsluitend een kwantitatieve strekking, of zit er ook een kwalitatieve kant aan? Of, anders geformuleerd: is het uitdelen op juist dre plaatsen niet bij uitstek geschikt om - zoals Röling het in zijn beroemde noot uit 1951 uitdrukte ${ }^{169}$ - personen te bereiken, "die door andere wijzen niet of minder gemakkelijk kunnen worden benaderd"? Kortom: hebben we in zo'n geval niet te doen met een middel van bekendmaking dat naast andere zelfstandige 
betekenis heeft? Dan kwam het "op zichzelf" beperkte verbod realiter dus neer op een algemeen verbod. En dat kon "natuurlijk." niet door de beugel. $^{170}$

Of het in werkelijkheid $66 \mathrm{k}$ zo zou gaan, blijft intussen de vraag. Over een kwalitatieve "invulling" van het "gebruik van enige betekenis" bestaat nog altijd weinig duidelijkheid (evenmin als over de kwantitatieve "invulling" ervan, trouwens). En wàt precies de criteria zijn om als zelfstandig middel te worden aangemerkt, is al evenzeer onduidelijk. Het enige wat we erover weten, is dat de Afdeling Rechtspraak van de Raad van State in dat opzicht iets royaler lijkt dan de Hoge Raad. Misschien "verklaart" dat ook waarom de Afdeling er in én van haar uitspraken over de Evangelie Gemeente "De Deur" niet mee akkoord ging dat de binnenstad van Arnhem voor evangelisatie-acties - kort gezegd - "zomaar" gesloten bleef. ${ }^{171}$ Wie weet is "de deur" naar erkenning van plaatsgebonden bekendmakingsmogelijkheden daarmee op een kier gezet. Zo danken we dan toch nog fets aan het Evangelie...

\subsection{Verspreiding van drukwerk (1983-1990)}

Zonder drukwerk (of wat daarmee gelijk wordt gesteld) geen verspreiding. We komen dan aan art. 7 lid 1 niet eens toe. Maar hoe ver reikt dat begrip eigenlijk? In de gemeente Wervershoof (tussen Medemblik en Enkhuizen) had je vergunning van B en W nodig om "op de openbare weg een standplaats in te nemen", behalve als het daarbij ging om het aanbieden van "gedrukte stukken en hetgeen daarmee op één lijn moet worden gesteld". Een vergunningaanvrage van Allwave BV om een standplaats in te nemen voor de verhuur van video-banden, werd vervolgens afgewezen. De vraag rees in dat verband of video-banden op én lijn moesten worden gesteld met drukwerk. Dan was het vergunningvereiste immers niet op Allwave van toepassing. De waarnemend Voorzitter van de Afdeling Rechtspraak ${ }^{172}$ ging ervan uit dat bij die uitzondering "slechts de bedoeling (had) voorgezeten om al die middelen van openbaarmaking onder een noemer te brengen, welke ingevolge de jurisprudentie op art. 7 (oud) Gr.w. - welke bepaling woordelijk overeenstemde met het eerste lid van art. 7 van de huidige Gr.w. dezelfde bescherming (genoten) als gedrukte stukken". Dat betekende dus dat hij moest beslissen of video-banden "ingevolge de jurisprudentie op art. 7 (oud) Gr.w. (...) dezelfde bescherming (genoten) als gedrukte stukken". Het antwoord was ontkennend. "Gezien het onderscheid dat in het (huidige art, 7) wordt gemaakt tussen het openbaar maken van gedachten en gevoelens door de drukpers onderscheidenlijk radio en televisie enerzijds, en door de overige middelen anderzijds", moest naar zijn voorlopig oordeel worden 
"aangenomen dat videobanden als zelfstandig - overwegend visueel - middel van openbaarmaking onder de werking van het derde lid van art. 7 (vielen)". Daarbij wees hij op de volgende passage uit de Memorie van Toelichting op de grondwetsherziening:

"Het is in beginsel niet uitgesloten, dat plaatsing van art. $7 \mathrm{Gr}$.w. in het kader van het voorgestelde art. 1.7 een zekere invloed kan hebben op de afbakening van de uitingsmiddelen die door de verschillende leden van dat laatste artikel worden beschermd. Het spreekt daarbij vanzelf, dat na uitbreiding van de grondwettelijke waarborgen voor het openbaren van gedachten of gevoelens door de drukpers met waarborgen voor andere uitingsmiddelen, er geen enkele reden meer zal zijn bandopnamen, grammofoonplaten, video-tapes en filmrollen, die in de jurisprudentie thans niet onder 'drukpers' worden begrepen, alsnog onder het bepaalde in het eerste lid te laten vallen".

Dat laatste - over de jurisprudentie op bandopnamen, grammofoonplaten, video-tapes en filmrollen - was, zoals we al eerder (onder 6.3) zagen, geheel en al uit de duim gezogen. Laten we dus hopen dat de Voorzitter zich niet om de tuin heeft laten leiden. Maar ook "los" daarvan kwam zijn oplossing niet echt onverwacht. Immers, zoals Versteden al in januari 1982 schreef ${ }^{173}$ :

"Het is nog maar de vraag of de rechters bij deze nieuwe tekst hun ruime uitleg van het begrip "drukpers' kunnen blijven handhaven".

Dat het voorafgaande toezicht op ondertitelde buitenlandse tv-programma's evenmin onder de noemer van het eerste lid werd gebracht ${ }^{174}$, hoefde vervolgens geen verbazing meer te wekken (hoewel het bij ondertiteling toch bij uitstek om letters ging!). Hier gold tegenwoordig art. 7 lid 2 Gr.w. Het veriofstelsel, dat erop gericht was te voorkomen dat kabelexploitanten (ondertitelde) reclameboodschappen zouden verspreiden, bleek overigens $66 \mathrm{k}$ met deze bepaing in strijd te zijn. Zo"n regime kwam immers "in feite" neer, meende de Hoge Raad, "op het vergen van voorafgaand toezicht op de inhoud van de over te brengen, vanuit het buitenland aangeboden televisieprogramma's". En:

"Dat het voorafgaande toezicht uitsluitend beoogt na te gaan of en in. hoeverre in die progamma's sprake is van het 'maken van handelsreclame' in de zin van iid 4 van gemelde Grondwetsbepaling doet daaraan (...) niet af: artikel 7 lid 4 strekt niet ertoe orn, in in weerwil van de voorafgaande leden die zich met inbegrip van lid 2 tweede zin, tegen preventieve censuur richten, een dergelijke censuur niettemin te veroorloven in geval die censulir het bij voorbaat afdwingen van een verbod op het maken van handelsreclame beoogt"'. 
Zo staken we en passant via het tweede lid van artikel 7, dat in dit opzicht niet minder verstrekkend bleek te zijn, tevens iets op over het eerste lid. Gemeentebesturen, die in verband met lid 4 overwegen het aanbrengen van reclameteksten op gebouwen te onderwerpen aan een vergunningstelsel, kunnen daar hun voordeel mee doen. ${ }^{175}$ Maar dit terzijde.

Terug naar het drukwerk, en de verspreiding daarvan. De Socialistische Partij wilde op 2 mei 1981 in Venray pamfletten uitdelen en daarbij tevens van een geluidswagen gebruikmaken. Alleen, zonder vergunning van $B$ en W was het in die gemeente "verboden bij het venten, verspreiden van gedrukte stukken of collecteren gebruik te maken van geluidsversterkers, dan wel luid te roepen" (art. 11 lid 3 APV). En zo'n vergunning werd - conform een al jaren gevolgd beleid - slechts verleend "in noodsituaties dan wel onvoorziene omstandigheden zoals een afgelasting van een bijzonder evenement". Daarvan was in dit geval geen sprake. Dus werd de vergunning geweigerd. Was dat niet in strijd met art. 7 (oud) Gr.w.? Nee, besliste de Afdeling Rechtspraak $^{176}$ : art. 7 (oud) had alleen betrekking op "leesbare uitingen van gedachten en gevoelens" (curs. RdW). Dat kan weliswaar "vergezeld gaan van mondelinge uitlatingen of toelichting, doch dit brengt niet met zich dat deze mondelinge uitlatingen, al dan niet versterkt, op zichzelf de bescherming van art. 7 Gr.w. (oud) genieten". De geluidswagens vielen zèlf dus buiten de sfeer van art. 7 (oud); wie zou - na de demonstratie van "De Rooie Reus" in Helden ${ }^{17}$ - iets anders hebben verwacht? Alleen dat vereiste van "leesbaarheid" bleef natuurlijk, zoals gezegd ${ }^{178}$, problematisch; denk bijvoorbeeld aan afbeeldingen (sinds de opkomst van "colourfield painting" en "land art" overigens een allesbehalve simpel begrip) en neonreclames van Chinese restaurants, die - naar we mogen aannemen - zelfs voor rechters in het algemeen onleesbaar zijn, maar die desondanks op éen lijn met drukwerk geplaatst zullen worden (zij het dat we ze vervolgens - via lid 4 - weer kunnen afvoeren).

Kon het gebruik van geluidswagens in samenhang met het uitdelen van pamfletten wellicht als zelfstandig middel van verspreiding worden aangemerkt? Het antwoord van de Afdeling Rechtspraak kon - gezien de oude "roep-en-schreeuw-jurisprudentie" - alweer nauwelijks verbazing wekken:

"Nu art. 11 derde lid APV Venray het verspreiden van gedrukte stukken niet verbiedt doch slechts verbiedt bij die gelegenheid gebruik te maken van geluidsversterkers dan wel luid te roepen is dit voorschrift, gezien het vorenstaande, niet in strijd met het bepaalde in art. 7 Gr.w."

Pas met de grondwetsherziening van 1983 werd er (afgezien van art. 10 EVRM en art. 19 IVBP) een bescheiden plaatsje ingeruimd voor geluidswagens $^{179}$, en - naar ik veronderstel - ook voor geroep en geschreeuw. 
Collectes bij gelegenheid waarvan (zoals de Hoge Raad het uitdrukte) stukken werden aangeboden, konden daarentegen well als zelfstandig middel van verspreiding worden aangemerkt. Dat bleek, zoals we al eerder zagen, uit een arrest van eind jaren zeventig over het Eindhovense collecteverbod. ${ }^{180}$ Toen zich in Zwolle opnieuw zo'n zaak voordeed, werd het verbod door de rechtbank dan ook onverbindend verklaard. In beide gevallen ging het immers om soortgelijke bepalingen. Het eerste lid verbood zonder vergunning van B en W "geld of goederen" in te zamelen. Het tweede lid luidde respectievelijk als volgt:

Eindhoven:

"Onder inzameling van geld of goederen wordt mede verstaan het daartoe aanbieden van bonnen, speldjes, prentbriefkaarten, kalenders, briefpapier of dergelijke voorwerpen, alsmede van snuisterijen en versnaperingen".

Zwolle:

"Onder inzameling van geld of goederen wordt mede verstaan, het bij het aanbieden van bonnen, speldjes, geschreven of gedrukte stukken en dergelijke voorwerpen, alsmede van snuisterijen, versnaperingen en andere waren, of goederen aanvaarden van geld of goederen voor een kerkelijk, liefdadig of ander niet commercieel doel, indien bij dit aanbieden op het helpen verwezenlijken van dat doel een beroep is gedaan".

De Hoge Raad meende destijds (in 1978) dat met die Eindhovense bepaling het gebruik van een zelfstandig middel van verspreiding, "namelijk het aanbieden - zij het dan bij gelegenheid van een inzameling van of geld of goederen - van stukken", afhankelijk werd gemaakt van een voorafgaande vergunning van $B$ en $W$. Daarom miste zij "verbindende kracht". Idem dito in Zwolle, aldus de rechtbank ${ }^{181}$ :

"In het arrest leest de rechtbank immers als het oordeel van de Hoge Raad dat het aanbieden bij gelegenheid van een inzameling van geld of goederen van gedrukte stukken waarin gedachten of gevoelens worden geopenbaard, een middel is tot verspreiding van die stukken dat, naast andere, zelfstandige betekenis heeft en met het oog op die verspreiding in een bepaalde behoefte kan voorzien. Dan kan het ook geen verschil meer maken of an een vergunning gebonden wordt, zoals door de Eindhovense verordening geschiedde, het aanbieden van gedrukte stukken met het doel geld of goederen in te zamelen, dan wel, zoals in de Zwolse verordening geschiedt, het aanvaarden van geld of goederen bij het aanbieden van gedrukte stukken".

De verdachte, die De Tribune "aan de man" had gebracht en "tegelijkertijd" geld had ingezameld voor de gezinnen van stakende Britse mijnwerkers, ging 
- met andere woorden - vrij uit; hij werd ontslagen van alle rechtsvervolging.

Remmelink $^{182}$ concludeerde vervolgens echter tot vernietiging van dat vonnis. Hij vroeg zich af:

"of het Eindhovense artikel niet minder pejoratief geïnterpreteerd had kunnen worden. Het tweede lid daarvan, vergelijkbaar met het Zwolse, zag naar mijn mening slechts op het inzamelen van geld of goed, waarbij het aanbieden van drukwerk juist geen zelfstandige functie had, maar hoogstens een hulpmiddel (in werkelijkheid wellicht camouflage) van de inzamelingsactie was. In de Zwolse APV is dat karakter nog eens geaccentueerd doordien wordt gesteld, dat het aanbieden van drukwerken gepaard dient te gaan met een beroep op het doel van de inzameling. Wellicht wordt dit nog ondersteund door vervanging van het woordje 'daartoe' door (kort gezegd) 'daarbij". Kortom drukwerkaanbieding is aldus losser komen te staan van inzameling".

Volgens Leijten, die kort tevoren over hetzelfde Zwolse collecteverbod had geconcludeerd $^{183}$, was dat laatste inderdaad kenmerkend voor het verschil tussen beide bepalingen. En daarom kon het Eindhovense verbod, in tegenstelling tot het Zwolse, niet door de beugel:

"Daar - te Eindhoven - werd ook het aanbieden van gedrukte stukken, waarin gedachten en gevoelens werden geopenbaard van een vergunning athankelijk gesteld. Dat dit gebeurde bij gelegenheid van een inzameling van geld kon de Hoge Raad niet vermurwen".

Met andere woorden: niet "het aanbieden van gedrukte stukken bij gelegenheid van een inzameling" moest als zelfstandig middel worden aangemerkt, zoals de rechtbank (en ook ik, zij het na enige aarzeling ${ }^{184}$ ) meende, maar "het aanbieden van gedrukte stukken" op zichzelf. Alleen, waarom kon die beperking tot inzamelingen de Hoge Raad dan niet "vermurwen"? Er was toch geen algemeen verbod (of iets wat daarop neerkwam) in het spel? Je kon die stukken nog op tal van andere wijzen zonder vergunning aanbieden. Nee, als "verklaring" van de Eindhovense beslissing lijkt dat verhaal me niet overtuigend. ${ }^{185}$

Hoe oordeelde de Hoge Raad? De Zwolse bepaling hield, volgens hem ${ }^{186}$ "niets in hetwelk een inbreuk zou kunnen betekenen op de in artikel 7, eerste lid, Grondwet gewaarborgde vrijheid van drukpers of op het in de rechtspraak erkende daarmede connexe ${ }^{187}$ recht tot verspreiding van gedrukte stukken. Immers, - kort samengevat - verbiedt het eerste lid het in het openbaar inzamelen van geld en goederen, terwijl het tweede lid tot uitdrukking brengt, dat van "inzamelen" sprake blijft indien het aanvaarden van geld of goederen voor een niet-commercieel 
doel geschiedt 'bij', dat wil zeggen gelijktijdig of in samenhang met, het aanbieden van voorwerpen waaronder gedrukte stukken. Een en ander laat de vrijheid tot verspreiden van gedrukte stukken onverlet". Is het eerdere standpunt van de Hoge Raad hiermee verlaten? Ik denk het wel. Er is zelfs geen ruimte gelaten voor een constructie als door Leijten geopperd. Dan had het woordje "bij" niet als "gelijktijdig of in samenhang met" kunnen worden vertaald. Onder het aanbieden van gedrukte stukken in samenhang met een collecte, valt immers $66 \mathrm{k}$ het Eindhovense daartoe aanbieden van die stukken. De Zwolse en de Eindhovense bepaling werden hier, met andere woorden, ovei één kam geschoren. ${ }^{188}$ Beide bleken de vrijheid tot het verspreiden van gedrukte stukken nu opeens "onverlet" te laten. En inderdaad, je kon natuurlijk ook zonder te collecteren gedrukte stukken aanbieden. Hoewel... Kon je bijvoorbeeld Unicef-kaarten te koop aanbieden? Of posters voor Greenpeace? Dan valt het aanbod feitelijk samen met de collecte. De verspreiding van sommige gedrukte stukken gaat nu eenmaal hand in hand met collectes. Was die variant over het hoofd gezien? Het hoofdstuk "inzamelingen" is, kortom, nog niet afgesloten met dit arrest. Hoe het verder gaat? We kunnen er alleen naar gissen.

Onduidelijk was - tenslotte - ook nog altijd de status van standplaatsen. In het geval van de Zuidafrikaanse Werkgemeenschap, dat we eerder tegenkwamen $^{189}$, ging het om een marktkraampje dat zowel voor "het verspreiden van lectuur" als "het verstrekken van mondelinge informatie" moest dienen. Dat was dus niet zuiver een kwestie van art. 7 lid 1. En in een eerdere zaak uit $1976^{190}$ - waarin het om een "staanplaats" voor het "uitstallen, althans verkopen (...) van reproducties van schilderijen of tekeningen" ging - was niet duidelijk of het vergunningstelsel werd gesauveerd omdat "staanplaatsen" niet als zelfstandig middel werden aangemerkt, of omdat elders in de gemeente zonder vergunning een "staanplaats" voor drukwerk kon worden ingenomen.

Welnu, op 18 oktober 1990 had het dagelijks bestuur van de Rotterdamse deelgemeente Prins Alexander geweigerd iemand een standplaatsvergunning voor de verkoop van reprodukties op het Poolsterplein te verlenen. Zo'n vergunning was nodig op grond van de Standplaatsenverordening. $\mathrm{Zij}$ kon onder meer geweigerd worden "indien het belang van het uiterlijk aanzien van de gemeente dit (vergde)" en "indien dit gelet op de ruimtelijke omstandigheden ter plaatse (werd) gevergd". Een en ander resulteerde in het beleid van de deelgemeente "met betrekking tot het Poolsterplein (...) dat geen permanente standplaatsen op het plein (werden) toegewezen vanwege de representatieve functie van het plein". Alleen voor de verkoop van oliebollen werd in november en december een uitzondering gemaakt. Was dat vergun- 
ningstelsel, voor zover het om de verkoop van stukken ging waarin gedachten of gevoelens tot uitdrukking werden gebracht, niet in strijd met art. 7 lid 1 Gr.w.? De waarnemend Voorzitter van de Afdeling Rechtspraak (Van Zeben) was daar heel kort over ${ }^{191}$ :

"Door verweerder is ter zitting gesteld", overwoog hij, "dat er binnen de deelgemeente alle ruimte is voor de verspreiding dan wel vertoning van onder meer gedrukte stukken.

Naar Ons oordeel kan niet met vrucht worden gesteld dat het handhaven van het in geding zijnde vergunningenstelsel op gespannen voet staat met het in art. $7 \mathrm{Gr}$.w. gewaarborgde recht van drukpersvrijheid en het recht op openbaren van gedachten en gevoelens met andere middelen als in art. 7 derde lid bedoeld".

De eerste overweging verwijst klaarblijkelijk naar andere verspreidingsmogelijkheden. Dat duidt er wellicht op dat het innemen van een standplaats door de waarnemend Voorzitter niet als zelfstandig middel van verspreiding werd aangemerkt; anders zou die beschikbaarheid van alternatieven immers niet relevant zijn: geen enkel zelfstandig middel van verspreiding mag van voorafgaand verlof afhankelijk worden gesteld. Maar misschien behelst die eerste overweging enkel en alleen wat ter zitting door de deelgemeente werd gesteld en is zij niet tevens redengevend voor het resultaat. In dat geval moeten wij het stellen met de tweede overweging, die in het geheel niet gemotiveerd is. Het enige wat eruit is af te leiden is dat de waarnemend Voorzitter kennelijk zowel op art. 7 lid 1 als op art. 7 lid 3 heeft gelet. Het vergunningstelsel was, volgens hem, met geen van beide leden in strijd. Dan moet hij er dus vanuit zijn gegaan dat hier geen zelfstandig verspreidingsmiddel in de zin van het eerste lid in het geding was. Hoogstens viel zo'n standplaats onder art. 7 lid 3. En dan was een vergunningstelsel (zolang de inhoud van de uiting althans niet als aanknopingspunt voor de vergunningverlening diende) in principe niet problematisch. ${ }^{192}$ De enkele omstandigheid dat op het Poolsterplein alleen maar oliebollenkraampjes werden getolereerd - en dan nog slechts gedurende een beperkte tijd van het jaar zei bovendien niets over de verdere toepassing van het vergunningstelsel. Wie weet waar allemaal wèl standplaatsen voor de verkoop van drukwerk werden toegestaan! $!^{193}$ Niettemin was het natuurlijk veelzeggend dat de "representatieve functie" van het plein, volgens de deelgemeente, minder werd aangetast door oliebollen, dan door drukwerk. 


\subsection{Gedachten of gevoelens (1986-1992)}

Alleen het openbaren van gedachten of gevoelens geniet bescherming op grond van art. 7 lid $1 \mathrm{Gr}$.w. In het verleden bleek al dat niet alles daaronder te brengen viel. Denk bijvoorbeeld aan de "Manege Rehoboth" en "CafeRestaurant de Huifkar". ${ }^{194}$ In geen van beide gevallen waren er, volgens de Hoge Raad, gedachten of gevoelens in het spel. De mededeling dat je over honderd meter van een kop Rombouts koffie kon genieten, stond blijkbaar voor iets anders. Welke maatstaf werd daarbij gehanteerd? En wat kon nog mér niet als gedachte of gevoelen worden aangernerkt?

In het midden van de jaren tachtig besloten enkele gemeenten op de Veluwe te verbieden "in het openbaar de naam van God te gebruiken", dan wel "ruwe of onzedelijke taal te gebruiken" - voor zover die materie tenminste niet ook al door het Wetboek van Strafrecht werd bestreken. Daarmee gaven die gemeenten opnieuw gestalte aan een eeuwenoude traditie. In het "Kerkelyk Plakaatboek" dat in 1722 door Nikolaas Wiltens bijeen werd gebracht, vond ik bijvoorbeeld een "Ordonnantie van de Policie" uit 1531 "beroerende de Tavarnen, Cabaretten ofte Logysen bezydens weeghs, of op Sondagen te gaan drinken, item, tegens de Blasphemateurs". ${ }^{195}$ Godslasteraars werden daarin met een gevangenisstraf - "te water ende te broode" - bedreigd voor "den tijdt van eender maendt". En, erger nog:

"die geene die Godt, of sijnder Moeder, of den Heyligen loochenen, afgaen of versmaden souden met eenen quaden en fellen moede, ende herte, boven de voorschreve gevangenisse, sullen op een Schavot de Tonge openbaarlijck doorsteecken worden, sonder gratie, respyt ofte verdragh".

In vergelijking daarmee stelde zo'n Veluws vloekverbod natuurlijk nauwelijks iets voor. Gombault ${ }^{196}$ had er in 1921, toen dergelijke bepalingen sinds korte tijd weer in zwang waren geraakt, op gewezen dat zo'n verbod "gemakkelijk tot een risé wordt, zoals indertijd het geval is geweest met eene politiebepaling, verbiedende het zitten van ongehuwde personen van verschillende sexe langs de bermen van openbare wegen, die ten slotte weer moest worden ingetrokken, of in vergetelheid is geraakt, althans niet kon worden uitgevoerd, omdat men aan de neuzen der menschen noch aan hunne gestalten of gedragingen nu eenmaal niet gemakkelijk kan zien of ze wel of niet gehuwd zijn." Wat daar verder ook van zij, in dit geval hoefden die bepalingen niet eens te worden ingetrokken, of in vergetelheid te raken; vór het zover was, werden ze al vernietigd. En wel: wegens strijd met art. 7 lid 3 Gr.w.

"Dit grondrecht", aldus de Kroon ${ }^{197}$, "beschermt in beginsel elke openbaarmaking van een - meer of minder weloverwogen - gedachte 
of een gevoelen, ongeacht de intenties of motieven van degene die zich uit;

Het vloekende gebruiken van de naam van God of het gebruik van ruwe of onzedelijke taal is - daargelaten uiteraard de waarde van dergelijke uitingen - in beginsel ook als openbaarmaking van een gedachte of gevoelen aan te merken;

Blijkens, de zinsnede "behoudens, ieders verantwoordelijkheid volgens de wet' mogen op het recht in vrijheid de inhoud van de geopenbaarde gedachten of gevoelens te bepalen alleen bij wet in formele zin beperkingen worden aangebracht".

Dus konden de vloekverboden, die door gemeenten in het leven waren geroepen, niet door de beugel. En dár was - eenmaal aangenomen dat we met. "gedachten of gevoelens" te maken hadden - gezien het beroemde arrest over het Tilburgse pornoverbod uit $1950^{198}$ natuurlijk weinig tegenin te brengen. Op de vraag of gedachten of gevoelens in het geding waren, werd in de Nota van Toelichting bij het KB nog wat uitgebreider ingegaan:

"Tot 'gedachten of gevoelens' rekent de Hoge Raad", aldus die toelichting, "alle uitingen tenzij deze een opschrift of een standaardmededeling in de bedrijfssfeer betreffen. Bij de grondwetsherziening heeft de regering gesteld dat onder het begrip 'gedachten of gevoelens' mede 'feitelijke mededelingen en inlichtingen' vallen, tenzij het bijvoorbeeld mededelingen betreft op de verpakkingen over de samenstelling van waren.

Dit betekent dat het begrip 'openbaren van gedachten of gevoelens' blijkens jurisprudentie en blijkens de toelichting op artikel 7 herziene Grondwet welhaast grammaticaal moet worden uitgelegd. Elke uiting van een gedachte of een gevoelen, ongeacht de intenties of motieven van degene die zich uit, wordt door artikel 7 van de Grondwet bescherma.

Uitzonderingen hierop betreffen (naast de uitdrukkelijk uitgezonderde 'handelsreclame', artikel 7, vierde lid) alleen standaardmededelingen in de bedrijfssfeer. Het in het openbaar gebruiken van ruwe of onzedelijke taal of het vloekende gebruiken van Gods naam is, hoewel er gevallen kunnen zijn waarin aan een vloek elke gedachte of elk gevoelen vreemd is, in beginsel een uiting van een gedachte of gevoelen. Deze uitingen liggen niet in de besproken uitzonderingsgebieden". Of we met die toelichting veel verder komen, lijkt me de vraag. In de eerste plaats is de weergave van de opvatting van de Hoge Raad op dit punt op z'n minst speculatief. In feite had de Hoge Raad zich, zoals we zagen, nooit over enig criterium voor "gedachten of gevoelens" uitgelaten. We kenden niet meer dan enkele uitkomsten van zaken, en aan de hand dárvan konden 
we een poging wagen zo'n criterium te reconstrueren. De in deze toelichting gegeven reconstructie was zeker niet de enig denkbare. Maar afgezien daarvan (en ook afgezien van de vraag wat het gewicht van de Memorie van Toelichting in dit verband was): wat betekende die welhaast grammaticale interpretatie van het begrip "openbaren van gedachten of gevoelens" precies? En hoe kon je überhaupt spreken van een "uiting van een gedachte of gevoelen" zonder daarbij oog te hebben voor "de intenties of motieven van degene die zich uit"? Ik kan dat allemaal niet zo goed volgen, moet ik bekennen. Misschien omdat het "op zichzelf" al vreemd is iets als "uiting van een gedachte of gevoelen" aan te merken. Dat veronderstelt een soort vertaalprocédé: eerst was er een "gedachte of gevoelen", waaraan vervolgens op de éen of andere manier uiting is gegeven. Alsof vorm en inhoud los van elkaar staan. "Wat bedoelt de schrijver als hij zegt...?", vraagt men dan. Of: "Wat stelt dit eigenlijk voor?" Een weinig vruchtbare benadering, lijkt mij. En de Grondwet dwingt er ook helemaal niet toe. Het gaat daarin louter om het openbaren (dat wil zeggen: beschikbaar maken voor anderen) van gedachten of gevoelens, niet om het uiten ervan (wat meer op expressie lijkt te wijzen). Wijst dat niet vooral op bescherming van het resultaat (waarbij als aanknopingspunt dient hetgeen daaruit is af te leiden). Welke intenties er achter schuilgingen (if any!), is dan bijzaak geworden. Waarom ik vloekte, is niet van belang. Waar het op aankomt, is hoe mijn vloek kon worden opgevat. Maar dat is - wie schetst mijn verbazing? - precies hetzelfde als in de toelichting op het vernietigingsbesluit stond! Heb ik me alleen door het ongelukkig gekozen woordje "uiting" om de tuin laten leiden?

Hoe dan ook, "de intenties of motieven" werden door de Kroon buiten de deur gehouden. Vandaar ook, denk ik, dat er niet moeilijk werd gedaan over de vraag of de openbaarmaking "meer of minder weloverwogen" had plaatsgevonden. Over het te hanteren criterium wisten we overigens nog steeds niets. Onder welke omstandigheid was er sprake van het openbaren van gedachten of gevoelens? Was er - behalve iets waar je dan niet op mocht letten, te weten intenties of motieven - $60 \mathrm{k}$ iets waarop je geacht werd wel te letten? De Kroon bleef ons het antwoord op die vraag schuldig. Het enige wat duidelijk werd, was dat gevloek "in beginsel" (dat wil zeggen: uitzonderingen daargelaten) gedachten of gevoelens betrof.

$\mathrm{J} . T h$. Begheyn ${ }^{199}$ vond niettemin dat de Kroon daarmee te ver was gegaan. Bij de "uitbreiding van de vrijheid van drukpers tot vrijheid van meningsuiting" in 1983, had men volgens hem met name voorbeelden voor ogen gehad (zoals film, toneel, exposities en concerten) waarbij "het toch steeds om uitingen van gedachten en gevoelens (ging), waarover (was) nagedacht, die zonder meer als handelingen - en niet louter als gedragingen - (konden) worden beschouwd". 
"Criterium (was)", naar zijn idee, dan ook "de weloverwogenheid (in intersubjectieve zin) van een uiting (wilde) men over 'meningsuiting' kunnen spreken. (...) Bovendien (ging) het in alle genoemde gevallen om een zich richten tot een publiek, dat in meer of mindere mate ervoor kiest zich met deze uiting te confronteren".

Als "normdoel van deze vrijheid van meningsuiting" zag hij daarom:

"een niet door de overheid gefrustreerde uitwisseling van communi-

catie tussen burgers die voor die uitwisseling kiezen".

Dat die vloekverboden door hem vervolgens niet in strijd met de Grondwet werden bevonden - "althans niet wanneer men de vrijheid van meningsuiting op zinnige wijze uitlegt", zoals hij er fijntjes aan toevoegde - hoeft vervolgens niet meer te verbazen. ${ }^{200}$

Twee criteria, kortom: weloverwogenheid (zij het "in intersubjectieve zin") en bereidheid tot confrontatie. Het eerste richt zich tot de "zender", het tweede tot de "ontvanger". Het vereiste van weloverwogenheid was door de Kroon met zoveel woorden aan de kant gezet. Geen wonder, lijkt mij, want daarmee zou de deur naar oeverloosheid wijd open zijn gezet: hoe stel je immers vast of iemand "weloverwogen" tot een gedraging is gekomen - zelfs "in intersubjectieve zin" zal dat niet meevallen! Waarom zouden andere - spontane - gedragingen bovendien minder bescherming verdienen? Ik vind dat in het kader van de vrijheid van meningsuiting niet erg vanzelfsprekend. Het tweede criterium - de bereidheid tot confrontatie aan de kant van het publiek - was daarnaast ronduit in strijd met hetgeen door de Hoge Raad en de Afdeling Rechtspraak was aanvaard. Daarvoor hoef ik slechts te herinneren aan al die zaken waarin het ging om vanaf de weg zichtbare opschriften (bijvoorbeeld "Nederland ontwapent") - wie niet blind was, werd er 6ók mee geconfronteerd als hij daar niet "in meer of mindere mate" voor gekozen had. Gelukkig maar, zou ik denken, want juist dáárin schuilt misschien de grootste waarde van het verspreidingsrecht. Begheyn toonde, met andere woorden, volgens mij wat al te veel consideratie met diegenen die "bij zinnelijke gehechtheid aan eigen meening en rigting slechts lezen hetgeen met hunne meeningen en rigting overeenkomt, zoodat de hooggeroemde strijd der meeningen voor hen niet bestaat", om een woord van De Bosch Kemper ${ }^{201}$ te gebruiken.

Wie overigens dacht dat het nu eindelijk afgelopen was met die vloekverboden, vergiste zich. Eind 1988 kwam de gemeente Nunspeet - ook alweer zo'n wereldstad! - in het nieuws met een nieuwe poging. ${ }^{202}$ Daar wilde men het vloeken verbieden, voor zover het althans niet om "het openbaren van gevoelens of gedachten zoals bedoeld in artikel 7 van de grondwet" ging. Symbolische wetgeving, kortom, want erg veel zou daar wel niet mee bewerkstelligd worden. Toch vond dat voorbeeld navolging. In NRC- 
Handelsblad van 12 september 1992 las ik dat B en W van het Zuidhollandse Zevenhuizen-Moerkappelle een soortgelijk voorstel hebben gedaan. Wat is het aantrekkelijke daarvan? Is zo'n verbod slechts "expressief doch niet instrumenteel", om twee begrippen aan een recent boek over symbolische wetgeving te ontlenen? ${ }^{203}$ "Het bevestigt, verstevigt en brengt tot uitdrukking datgene waarin de betreffende maatschappij (lees: gemeente; RdW) zichzelf herkent". Ongetwijfeld, maar zou er niet $66 \mathrm{k}$ een voirm van intimidatie "achter" schuil gaan?

Dat handelsreclame sinds de grondwetsherziening van 1983 geen bescherming (meer?) geniet op grond van art. $7 \mathrm{Gr}$.w., blijkt al uit de tekst van die bepaling. Wat precies onder "handelsreclame" moet worden verstaan, is echter minder duidelijk. Vreemd genoeg is er nauwelijks iets over te vinden. Een "bord met de vermelding 'Ondernemerspark Eikenburg, uitbreiding 1988" met vier onderborden en een bord met verwijzing en vermelding van diverse bedrijven op het ondernemerspark Eikenburg" in Rosmalen, moest volgens de Afdeling Rechtspraak ${ }^{204}$ als "handelsreclame" in de zin van enkele lokale bepalingen worden aangemerkt, "aangezien het in het onderhavige geval - daargelaten het oogmerk dat appellante met het aanbrengen van het bord had - onmiskenbaar (ging) om het onder de aandacht van derden brengen van ter plaatse aanwezige bedrijven". Ik denk niet dat er enige aanleiding is te veronderstellen dat de Afdeling in de context van art. 7 Gr.w. iets anders onder "handelsreclame" zou verstaan. Dergelijke borden vallen dus (naar ik veronderstel) buiten de sfeer van art. 7 lid 1, zodat het plaatsen ervan zonder meer aan een vergunningstelsel kan worden onderworpen, of zelfs helemaal verboden kan worden (even afgezien van art. 10 EVRM en art. 19 IVBP).

In een uitspraak die daar bijna vier jaar aan voorafging, gaf de Afdeling ${ }^{205}$ uitdrukking aan de opvatting dat door handelsreclame in de zin van art. 7 lid 4 geen "gedachten of gevoelens" werden geopenbaard. Daarmee werd wellicht geprobeerd de oude lijn van de jurisprudentie - die volgens sommigen immers, zoals we eerder zagen, inhield dat handelsreclame iets anders was dan het openbaren van gedachten of gevoelens - over te planten op het nieuwe grondwetsartikel. Vermeulen ${ }^{205}$ betitelde die werkwijze als "onzuiver". Dan zou lid 4 immers overbodig zijn. Daar zit wat in, lijkt mij. Aan de andere kant kun je natuurlijk even goed zeggen dat lid 4 er juist toe dient controversen over de status van handelsreclame uit te sluiten. Zo bezien is het dus een aanwijzing voor hetgeen vandaag-de-dag onder "gedachten of gevoelens" moet worden verstaan. Hoe dan ook, in beide gevallen is het resultaat hetzelfde. Het komt, met andere woorden, niet altijd op zuiverheid aan. 
Ik hou het hier op de zienswijze van de Afdeling Rechtspraak, omdat ik me nu eenmaal heb voorgenomen het spoor van de jurisprudentie in dit boek - zo maar enigszins mogelijk - vast te houden. Kortom: als iets handelsreclame is, gaat het niet om "gedachten of gevoelens". Alleen, werd de Afdeling vervolgens niet het slachtoffer van een klassieke redeneerfout? Uit de stelling "Als A zich voordoet, is er geen sprake van B" leek zij te willen afleiden dat er well sprake van B is, als A zich niet voordoet. Oftewel: als iets geen handelsreclame is, zouden er automatisch wèl "gedachten of gevoelens" in het spel zijn. Tenminste... dat zou volgens sommigen zijn af te leiden uit een uitspraak over een uithangbord in Arnhem. ${ }^{207}$ In die gemeente was het

"de rechthebbende van enig onroerend goed (...) verboden dit goed of enige zaak daarop aanwezig, geheel of ten dele aan te wenden of de aanwending daarvan te gedogen voor opschriften, aankondigingen of afbeeldingen in welke vorm ook, die van een openbare weg of een openbaar vaarwater af of van een openbaar vervoermiddel (uitgezonderd een vliegtuig) uit zichtbaar zijn".

Met ontheffing van B en W mocht het echter wel. Was het verspreidingsmiddel dus afhankelijk gesteld van voorafgaand verlof? Nee, want er was nòg iets; het verbod was niet van toepassing:

"op opschriften, aankondigingen of afbeeldingen, welke dienen tot het openbaren van gedachten of gevoelens als bedoeld in artikel 7 van de Grondwet".

De vraag rees daarom of voor een uithangbord met het opschrift "RIVA" (afkorting voor "Regioneell Instituut Verpleegkundigenopleiding") een ontheffing nodig was. De Afdeling Rechtspraak vond van niet:

"De Afdeling stelt vast dat het bedoelde uithangbord (...) dient tot het openbaren van gedachten of gevoelens als bedoeld in artikel 7 van de Grondwet en niet betreft het maken van handelsieclame als bedoeld in het vierde iid van dat artikel".

Dat maakte, volgens Brederveld ${ }^{20 s}$, "de indruk dat de Afd. wil zeggen: betreft het hier het maken van handelsreclame?; zo neen, dan gaat het dùs om gedachten of gevoelens". Off, zoals Boon ${ }^{209}$ het uitdrukte:

"Het uithangbord met het opschrift 'RIVA' bevat geen handelsreclame als bedoeld in art. 7 lid $4 \mathrm{Gr}$.w. en dient dus tot het openbaren van gedachten of gevoelens als bedoeld in art. $7 \mathrm{Gr}$.w. De Afd. zegt het niet letterlijk zo, maar men kan de desbetreffende overweging toch nauwelijks anders lezen".

Ik denk dat zo'n andere lezing wel degelijk mogelijk was. De Afdeling had hier te beslissen of er sprake was van een opschrift of aankondiging dienend tot het openbaren van gedachten of gevoelens als bedoeld in art. $7 \mathrm{Gr}$.w. Dat 
was immers de uitzonderingsgrond, zoals die door de gemeente was geformuleerd. Kennelijk had de gemeente met het oog op art. 7 lid 1 Gr.w. een uitzondering willen maken, louter en alleen om strijdigheid met die grondwetsbepaling te voorkómen. Dus was er volstrekt geen reden om zo'n uitzondering ruimer te interpreteren dan ter voorkoming van strijdigheid nodig was. Alleen díe openbaarmakingen die op grond van art. 7 lid 1 beschermd werden, moesten uit het verbod gelicht worden. En daar hoorde handelsreclame nu eenmaal - gezien lid 4 - niet bij. Vandaar dat de Afdeling eerst - zonder enige motivering overigens - vaststelde dat er gedachten of gevoelens in het geding waren, om vervolgens te constateren dat zij niet op grond van lid 4 weer afgevoerd konden worden. Dus moest het gemeentelijk verbod er in dit geval voor wijken.

Klinkt dat niet veel plausibeler dan die lezing van Brederveld en Boon? De enige prijs die we ervoor moeten betalen, is dat we moeten aannemen dat de Afdeling haar standpunt over handelsreclame inmiddels gewijzigd heeft: het gaat daarbij kennelijk niet langer meer om iets anders dan "gedachten of gevoelens". Anders hoefde immers na de vaststelling dat gedachten of gevoelens in het geding waren niet meer gekeken te worden of er wellicht tevens sprake was van handelsreclame; dan was het ofwel het én, ofwel het ander. Waarom hier trouwens, anders dan bijvoorbeeld bij "Rehoboth" of "CaféRestaurant De Huifkar"210, well gedachten of gevoelens werden geopenbaard, is niet ogenblikkelijk duidelijk. Misschien is het begrip "gedachten of gevoelens" met de inwerkingtreding van het nieuwe art. 7 Gr.w. in 1983 enigszins van betekenis veranderd. Sindsdien biedt het vierde lid van die bepaling immers mogelijkheden die er voordien slechts op grond van interpretatie waren. Een verwijzing naar een bedrijf, die tegenwoordig eenvoudig via het vierde lid als handelsreclame kan worden "afgevoerd" (zoals we in die zaak over Rosmalen zagen), kon vroeger slechts aan de bescherming van art. 7 worden onttrokken door er geen gedachten of gevoelens in te herkennen. Vandaar, denk ik, dat handelsreclame vớr 1983 (soms) niet als gedachte of gevoelen werd aangemerkt, terwijl dat nadien zonder meer well kon. En hetzelfde gold kennelijk voor zo'n uithangbord met RIVA erop.

Incidenteel kwam de vraag of we wel van "gedachten of gevoelens" konden spreken, ook in andere zaken aan de orde. In Groningen had iemand 's avonds laat bijvoorbeeld een stapeltje Loesje-affiches bij zich, met de volgende tekst:

"drie uur thuis, gelukkig piept de achterdeur niet meer zo".

Leijten $^{211}$ schreef toen in zijn conclusie: "Ik vraag mij af of dat een meningsuiting is". Het was verder niet van belang, dus kon hij het bij die vraag laten. Gelukkig maar, want ik vrees dat ik zijn antwoord wel kan 
raden. Je kunt op dat vlak, wat mij betreft, niet voorzichtig genoeg zijn. ${ }^{212}$ Iedere grens is hier aanmatigend. Laat ik - bij wijze van illustratie - volstaan met én gedichtje van K. Schippers ${ }^{213}$ :

\section{THE BEATLES}

\section{George Harrison \\ John Lennon \\ Paul McCartney \\ Ringo Starr}

Is dàt een meningsuiting? Ik mag het hopen, maar ik ben er lang niet zeker van dat Leijten mijn standpunt deelt.

In Heerlen kwam het er korit geleden een keer echt op aan. Daar gold een verbod

"zonder vergunning van burgemeester en wethouders op of aan de weg of aan een openbaar water aan huis danwel op een andere - al dan niet met enige beperking - voor het publiek toegankelijk en in de open lucht gelegen plaats, goederen te koop aan te bieden, te verkopen of af te geven".

Wie langs de deur ging met "gedrukte of geschreven stukken, waarin gedachten of gevoelens worden geopenbaard ais bedoeld in art. 7 eerste lid van de Grondwet", kon evenwel ook zonder vergunning zijn gang gaan.

Een inwoner van het nabijgelegen Kerkrade, die zonder vergunning huis aan huis "wenskaarten" probeerde te verkopen, beriep zich dan ook op art. 7. Tevergeefs, echter. De Hoge Raad ${ }^{214}$ gaf een handzame samenvatting van de gang van zaken en knoopte daar een eigen oordeel aan vast:

"Het gaat in deze zaak (...) om het door de verdachte te koop aanbieden en verkopen van in de bewijsmiddelen en de bewezenverklaring als zodanig aangeduide "wenskaarten' waarvan de Rechtbank kennelijk, en terecht, van algemene bekendheid heeft geacht, dat deze wensen bevatten als 'van harte beterschap' of 'van harte gelukgewenst", en dergelijke wensen.

De Rechtbank heeft (...) het namens de verdachte gedane beroep (op de uitzondering ten aanzien van stukken in de zin van art. 7 lid 1 Gr.w.;RdW) - welk beroep inhield 'dat de kaarten die door de verdachte te koop werden aangeboden gedrukte stukken betreffen waarin gevoelens werden geopenbaard', verworpen op grond van haar oordeel 'dat de teksten op bedoelde kaarten geen gevoelens openbaren".

Dit beroep verwerpend als hier is weergegeven, in welke verwerping 
de Rechtbank onder gevoelens kennelijk de gedachten en gevoelens van de verdachte heeft verstaan, heeft de Rechtbank niet blijk gegeven van een onjuiste opvatting omtrent het bepaalde in art. 7, eerst lid, van de Grondwet. Haar oordeel is niet onbegrijpelijk en is ook overigens toereikend gemotiveerd".

Worden boekhandelaren, kioskhouders en "loslopende" kranteventers voortaan dus $\delta \delta \mathrm{k}$ alleen nog maar beschermd voor zover ze hun eigen gedachten of gevoelens "aan de man" trachten te brengen? Dat lijkt me sterk! En zo hoeft dit arrest - gelukkig - ook niet gelezen te worden. Waar het op aankomt, denk ik, is dat de wens op zo'n kaart nog tot niemand gericht is. Het is, als het ware, een open norm die nadere invulling behoeft. En die invulling wordt er pas aan gegeven nadat de kaarten van de hand zijn gedaan. Er kunnen dus wel gedachten of gevoelens aan verbonden worden, maar op het moment van het aanbod is dat nog niet gebeurd. Dat in die kaarten geen gedachten of gevoelens van de venter zijn neergelegd, is dan ook - naar ik veronderstel - alleen in dre context van belang: bij wijze van contrast dat erop duidt dat er nadien door anderen wel degelijk gedachten en gevoelens "ingestopt" kunnen worden. ${ }^{215}$

Maar duidt die voorkeur voor wenskaarten "op zichzelf" dan niet al op bepaalde gevoelens of gedachten, bijvoorbeeld dat men medeleven met anderen moet tonen? Wellicht, maar hier geldt vermoedelijk hetzelfde als ten aanzien van collectes ${ }^{216}$; je hoort het de Voorzitter van de Afdeling Rechtspraak al zeggen: "het te koop aanbieden van wenskaarten kan weliswaar voortkomen uit een bepaalde mening maar vormt zelf geen meningsuiting". Of heb ik het mis? We zullen zien. Over honderd jaar schrijf ik het tweede deel van dit boek. 


\section{Hoofdstuk 8 Slot}

Een eeuw rechtsontwikkeling op de vierkante millimeter. Is er iets uit af te leiden ter grootte van een vierkante centimeter? "De betekenis van al deze jurisprudentie dunkt ons duidelijk", schreef Burkens ${ }^{1}$ nog maar kort geleden aan het slot van een beschouwing over art. $7 \mathrm{Gr}$.w. Hij nam kennelijk met weinig genoegen. Duidelijk is, volgens mij, voornamelijk dat alle betrokkenen zich geleidelijk van dezelfde terminologie zijn gaan bedienen.

Zowel voor-als tegenstanders van bepaalde arresten beroepen zich telkens weer op dezelfde "leer". Dat de Hoge Raad, die het allemaal heeft verzonnen, soms wat minder duidelijk is, schijnt niemand te deren. De leer staat als een huis. Tegelijkertijd biedt zij aanknopingspunten voor tal van - onderling onverenigbare - opvattingen. Je kunt er alle kanten mee op. Of overdrijf ik nu? De uitkomsten in cassatie zijn vandaag-de-dag immers heel wat vaker conform de conclusies van het Openbaar Ministerie dan vroeger. Is er dan tòch lijn in gekomen? Nee, dat volgt daar niet uit. Ook wie er enkel aan vasthoudt dat het in cassatie slechts zelden op vernietiging uitdraait, zal in het gros van de gevallen de afloop weten te voorspellen. ${ }^{2}$ Zeif vond ik het juist opvallend hoeveel er nog in twijfel kon worden getrokken in allerlei "op zich" eenvoudige zaken. Tenminste: wanneer je "vanuit" die zaken keek en er niet mee volstond ze achteraf in te passen in de leer. De uitkomst sprak dan allerminst vanzelf. Dat het "forum" daar nauwelijks oog voor had, zegt vooral iets over dat forum, lijkt mij. Volgens Witteveen ${ }^{3}$ is het recht weliswaar een argumentatiecultuur, maar dat wil helaas niet zeggen dat louter goede argumenten aan bod komen.

Over het algemeen werd de leer volstrekt eenduidig geacht. Kwam de Hoge Raad tot een ander resultaat, dan werd door critici meestal betoogd dat hij het mis had. Toch waren die arresten, op hun beurt, telkens weer $d$ wingend geformuleerd: "they are worded as if correct decisions were arrived at by logical deduction from a precise and pre-existing body of legal rules", zoals Jerome Frank ${ }^{4}$ - de beroemde "legal realist" uit de Verenigde Staten - het eens naar aanleiding van Amerikaanse uitspraken formuleerde. Vanwaar die hang naar eenduidigheid? Frank $k^{5}$ ontwaarde er een "basic legal myth" in.

Een onvolwassen "fear of the vague things that stalk the darkness, fear of the unruly, the unseen, the horrible bogies of the unknown" zou ons volgens hem $^{6}$ parten spelen:

"To the child the father is the Infallible Judge, the Maker of definite rules of conduct. He knows precisely what is right and what is wrong 
and, as head of the family, sits in judgment and punishes misdeeds. The Law - a body of rules apparently devised for infallably determining what is right and what is wrong and for deciding who should be punished for misdeeds - inevitably becomes a partial substitute for the Father-as-Infallible-Judge. That is, the desire persists in grown men to recapture, through a rediscovery of a father, a childish, completely controllable universe, and that desire seeks satisfaction in a partial, unconscious, anthropomorphizing of Law, in ascribing to the Law some of the characteristics of the child's Father-Judge. That childish longing is an important element in the explanation of the absurdly unrealistic notion that Law is, or can be made, entirely certain and definitely predictable"'?

Wie weet, misschien had Frank gelijk. Maar zijn verhaal is ontoetsbaar; het is eerder een duiding dan een theorie. En het is zeker niet de enig denkbare duiding. Roscoe Pound ${ }^{8}$, een generatiegenoot van Frank, beschreef bijvoorbeeld eens

"an idea of law as a tradition of the old customs which have proved acceptable to the gods and hence point the way in which man may walk with safety. (...) The general security requires that men do only those things and do them only in the way which long custom has shown at least not displeasing to the gods. Law is the traditional recorded body of precepts in which that custom is preserved and expressed".

Ook dat zou als "verklaring" kunnen dienen voor de bijna rituele herhalingen die we in de voorgaande hoofdstukken zo dikwijls tegenkwamen. Niet letterlijk, natuurlijk, want daar zijn we inmiddels te "beschaafd" voor. Maar denk bijvoorbeeld aan de door Frank ${ }^{9}$ ten tonele gevoerde rechter die er niet in slaagt "old word-patterns" te vinden om zijn vonnis in te vatten en die er tegelijkertijd tegenop ziet "a so-called new rule" te formuleren uit angst dat die nieuwe regel in de toekomst tot onwenselijke resultaten zal voeren. Dat klinkt toch tamelijk vertrouwd, lijkt mij. Ligt zoiets niet in het verlengde van die "primitieve" neigingen waar Pound het over had? Ach ja, misschien. Maar wat ligt niet "in het verlengde" van iets anders? Laat ik, met andere woorden, geen poging wagen "diepzinnig" te worden.

We kunnen het, wat mij betreft, ook laag bij de gronds houden. Is het niet al vreemd genoeg dat er een rechtsorde zou bestaan waarin alles voorzien was? Hoe zouden alle denkbare gebeurtenissen op voorhand geregeld kunnen zijn? En wie zou dat gedaan moeten hebben? De Schepper-zelf wellicht? Het valt niet mee daar iets over te achterhalen. De oprichting van onze rechtsorde zal, naar te vrezen is, wel altijd onopgehelderd blijven. Laten we het er - gemakshalve, ik geef het toe! - op houden dat ze er altijd al was; tenrnin- 
ste: zolang er mensen zijn. Er zijn alleen steeds stukjes aangebreid en andere afgevallen. ${ }^{10}$ Het precieze patroon is (voor zover bekend) niet ontworpen. Het is geleidelijk ontstaan, omdat zich nu eens het ene probleem voordeed en dan weer het andere. Soms greep de wetgever in, andere keren vond de rechter een oplossing. En tal van zaken hangen nog in de lucht, of we zijn ze niet eens op het spoor gekomen. Want dàt is natuurlijk een eerste vereiste: vórdat je iets kunt oplossen, moet je erop stuiten. Zo was er vór 1892 bijyoorbeeld nog geen oplossing voor het probleem van de verspreiding, eenvoudig omdat het nog niet aan het licht was gekomen. en zo doen zich ook vandaag-de-dag nog steeds nieuwe kwesties voor. Kennen wij bijvoorbeeld een recht op verdwijnen? In de Volkskrant van 26 september 1992 las ik daar het volgende bericht over:

"De meesten mensen hebben er ooit wel eens last van: de wens om ergens ver weg een nieuw leven te beginnen. Minnaars, schuldeisers of justitie zijn meestal de oorzaak. Sinds kort hoeft de droom geen droom meer te blijven. Aspirant-vluchters kunnen terecht bij Umberto Gallini, een creatieve ondernemer uit de Noorditaliaanse industriestad Lecco. Tegen betaling van een half miljoen lire, 675 gulden, organiseert deze voormalige reisbureau-eigenaar de vlucht uit de boze wereld.

Vorig jaar kreeg Gallini genoeg van het populaire tv-programma Wie heeft hem gezien?, de Italiaanse versie van Adres onbekend, waarin de hulp van de kijkers wordt ingeroepen om verdwenen mensen op te sporen. Hij vond het absurd dat de mensen een elementair recht werd ontzegd: dat om spoorloos te verdwijnen.

Die verontwaardiging deed hem een gat in de markt ontdekken, dat nu gevuld wordt met Anfep, een lelijke Italiaanse afkorting van een mooie naam: Nationale Alliantie voor de Gelukkige Uitwijking. In een jaar heeft Anfep 85 Italianen ondergebracht in Madagascar, de Filippijnen, Costa Rica, Argentinië en Brazilië."

Juristen zullen zich afvragen of zo'n "recht" - eventueel tot op zekere hoogte - is in te passen in de rechtsorde. Daarbij zullen zij bijvoorbeeld aan art. 8 EVRM denken, of aan art. $10 \mathrm{Gr}$.w.: de eerbiediging van de persoonlijke levenssfeer.

Rechters zijn dan ook, in de woorden van Hayek", belast met "the maintenance of an ongoing order of actions". Zij houden het geheel gaande. Daartoe beschikken zij over de nodige regels. Zeker! Maar dat wil niet zeggen dat hun beslissingen dus uit die regels volgen. Valt iets er bijvoorbeeld well of niet onder? Oftewel: wat is de reikwijdte van zo'n regel? Wanneer verschilt een geval zo zeer van andere gevallen dat we te maken hebben met een uitzondering? Daar is een beslissing voor nodig. ${ }^{12}$ Omge- 
keerd moeten we ók beslissen of de regel onverkort van toepassing is op alle gevallen die zich aandienen. ${ }^{13}$ Misschien is hij immers wat ruim geformuleerd. En er is, zoals gezegd, geen aanleiding ervan uit te gaan dat het recht - anders dan andere menselijke vindingen - een méér dan tentatieve waarde heeft. ${ }^{14}$

Dat je aan de ene kant een leerstuk hebt en aan de andere kant niet precies kunt voorspellen tot welke uitkomsten het leidt, is "op zich" dan ook zo vreemd nog niet, denk ik bij nader inzien. Opmerkelijker is misschien dat in het kader van de verspreidingsjurisprudentie - dus bij de toepassing van het leerstuk - hoe langer hoe minder blijkt van enige visie op de vrijheid van drukpers. Zo mocht de verkoop van drukwerk in Rotterdam bijvoorbeeld aan méér beperkingen worden onderworpen dan de verkoop van oliebollen. ${ }^{15}$ En zo mocht het aanbrengen van teksten op gebouwen weliswaar niet van een vergunning afhankelijk worden gesteld ${ }^{16}$, maar mocht er well repressief tegen worden opgetreden (uit oogpunt van stadsschoon of iets dergelijks) ${ }^{17}$, hoewel daarmee hetzelfde effect werd bereikt, te weten: dat vooraf werd geïnformeerd of er bezwaren bestonden. Tegelijkertijd gold voor hinder door "inrichtingen" een heel ander regime dan voor hinder door neervallende borden en dergelijke: het ene mocht met behulp van een vergunningstelsel wèl voorkómen worden ${ }^{18}$, het andere niet. ${ }^{19}$

Ik heb geen idee wat daar allemaal achter schuil gaat. Zou het iets anders dan toeval zijn? Toch niet het grondrechtelijk karakter van de verspreiding?! Alleen de Afdeling Rechtspraak van de Raad van State herinnerde daar een enkele keer aan en leidde er een motiveringsplicht voor de overheid uit af. ${ }^{20}$ De Hoge Raad, daarentegen, zweeg hierover. En niet alleen hierover. Hij hield zich in toenemende mate afzijdig. Achter de feitenrechter en geholpen door apodictische formuleringen, die aan de jaren dertig herinneren, wist hij zich veelal verborgen te houden. Ten aanzien van centrale begrippen als het "gebruik van enige betekenis", het "zelfstandige middel van bekendmaking" en "gedachten of gevoelens" zijn we dan ook al jaren geen stap verder gekomen. Nog steeds tasten we in het duister over de betekenis ervan. We weten niet eens waar we op moeten letten, laat staan dat we kunnen nagaan of we ook maar enige aanspraak op bescherming maken. Een schamel resultaat na zoveel zaken...

Maar - eerlijk is eerlijk! - het forum laat zich in dat opzicht (van oudsher, overigens) wel erg veel welgevallen. Je kunt moeilijk volhouden dat het de rechter op de huid zit. Soms is het weliswaar kritisch gestemd, alleen: kritiek die geen hout snijdt maakt weinig indruk. En helaas... Nou ja, laat ik hier niet herhalen wat in de loop van dit boek al zo pijnlijk naar buiten is gekomen. Misschien krijgt een rechtsgebied gewoon de "leer" die het verdient, en is dat dus de heersende leer. Dan is het net als bij echte heersers. 
Die zijn er - zeker zolang er geen geweld in het spel is - mede dankzij hun onderdanen. Immers, zoals Morris Cohen ${ }^{21}-66 \mathrm{k}$ alweer een tijdgenoot van Jerome Frank - schreef:

"The demand for government rests not only on the fear of disorder but on the positive need for being governed. Most people find deliberation and the necessity of making a choice very painful. It requires thought, which is not to most people an agreeable exercise. And it requires the assumption of responsibility, which most people find vexatious. To find somebody to decide for us and obey his orders is a relief for which people are willing to pay heavily".

Is de prijs, met andere woorden, onderhand niet wat te hoog geworden? Een tikkeltje meer tegenspel kan geen kwaad, lijkt mij. Maar laten we vooral niet te optimistisch zijn. "Rechters zijn er niet om recht te spreken, maar om kwesties te beëindigen", zei Multatuli eens (al weet ik niet meer bij welke gelegenheid). En inderdaad, zij moeten hun zaken in de eerste plaats zien af te doen. Dan ligt het voor de hand dat zij een soort economisch principe hanteren. De eenvoudigste afdoening zal, met andere woorden, de voorkeur genieten. Zodra eenmaal een weggetje is gevonden, zal daar bovendien aan worden vastgehouden. Dat wil zeggen: totdat blijkt dat het geen uitkomst biedt. Vooral formele obstakels maken dan ook indruk. Koersverlegging is in die gevallen immers onvermijdelijk.

Alleen, dáí ligt juist het probleen. Formeel sluit de "leer" immers als een bus. De bezwaren zijn eerder materieel van aard. Is het bijvoorbeeld niet vreemd als ergens wel een oliebollenkraampje mag staan, maar geen boekenstalletje? Of: moet niet voorkómen worden dat de kans op repressief ingrijpen er feitelijk toe dwingt voorafgaand verlof te vragen? En: wat heb je aan "gebruik van enige betekenis" dat louter in theorie iets om het lijf heeft? Om nog maar te zwijgen over de vraag of iets wel of niet is aan te merken als "gedachte of gevoelen"...

Formeel is in al die gevallen geen vuiltje aan de lucht. Je kunt dan wel suggesties doen - bijpoorbeeld: dat er extra motiveringseisen gesteld moeten worden (wat ik in de loop van dit boek ook bij herhaling heb gedaan) - maar is het aannemelijk dat zoiets aanslaat? Waarom zou de rechter afwijken van zijn routine zolang hij er nog redelijk "uit" komt? Hij heeft het al druk genoeg. Pas wanneer het spaak dreigt te lopen - als rechterlijke uitspraken bijvoorbeeld massaal genegeerd dreigen te worden - moet de koers verlegd worden. Voordien kunnen we daar slechts op hopen. Al krijgt het forum dus de rechtspraak die het verdient, de vraag blijft altijd hoeveel er te verdienen vàlt. 
. 
1. HR 7 november 1892, W. 6263 .

2. In het algemeen Rijksarchief zijn hun namen nog terug te vinden: Jan van Harte (29 jaar, arbeider), Cornelis Antonius Stalenhoef ( 23 jaar, bakker) en Pieter Henri of Pieter Menno Arnolli (27 jaar, rietwerker). Respectievelijk zaak nr. 236, 237 en 238.

3. Zie de redactionele aantekening onder het arrest, waarin verwezen wordt naar HR 29 juni 1891 , W. 6068 , en HR 30 juni 1890, W. 5908. In het laatstbedoelde geval luidde de verbodsregeling als volgt: "Het is verboden waren van welken aard ook, langs de huizen of aan den openbaren weg te venten of te koop aan to bieden, zonder vergunning van Burgemeester en Wethouders. Overtreding van dit artikel wordt gestraft met eene geldboete van ten hoogste $f 20$ ".

4. Per 1 mei 1894 , op grond van de Wet van 2 oktober 1893, S. 149.

5. J.J. van Riemsdijk Kreenen, Het venten van drukwerk op de openbare straat, p. 17, Leiden 1895 (diss. Leiden).

6. D. Graevestein van Heyst, Het venten van geschriften op den openbaren weg als strafbaar feit beschouwd, p. 41-42, Zutphen 1894 (diss. Utrecht). Vgl. ook Van Riemsdijk Kreenen (a.w., noot 5), p. 18 en J.G. Westra van Holthe (De gemeentebesturen tegenover de artikelen 7 en 9 van de Grondwet, p. 16, Leiden 1893). J. d'Aulnis de Bourouill (Het venten van drukwerken in het openbaar, Themis 1895, m.n. p. 83-84) omschreef de achtergronden als volgt: "Geeft men echter zich rekenschap van de aanleiding tot de pogingen om door plaatselijke verordeningen den openbaren verkoop van gedrukte stukken aan beperkende voorwaarden te onderwerpen, dan blijkt dat wat de gemeentebesturen hebben willen tegengaan eigenlijk geheel iets anders is. De verstoringen der openbare orde vloeiden niet voort uit het pak couranten, dat de colporteur droeg, doch uit de eigenaardige gedragingen, welke de colporteur zich veroorloofde. (...) Naar het schijnt, bestaat dit eigenaardige gedrag in het uitroepen van den inhoud van het blad op zoodanige wijze dat zulks andersdenkenden of zelfs bepaalde personen beleedigt. Hetzelfde nu kan zich voordoen bij het venten van heiligenbeelden, photographieën ${ }_{n}$ en andere reproductiën. Waarom echter kan men die bijzondere manier van venten niet verbieden? Vermoedelijk is men enigszins verlegen met de nauwkeurige omschrijving van de overtreding."

7. Na het wegvallen per 1 mei 1894 van de wet op het recht van patent ( $\mathrm{vgl}$. noot 4) werden ook algemener gestelde verbodsbepalingen - zoals de eerdergenoemde Zwolse door de Hoge Raad getoetst aan art. 7 Gr.w.; zie bijv. HR 1 november 1897 , W. 7036 (Zuidbroek) en HR 5 december 1898, W. 7213. De A-G Gregory vroeg zich - reagerend op het gevoerde pleidooi - in zijn conclusie vó6r HR 7 november 1892, W. 6259 (Haags ventverbod) af of het Haagse verbod zich wellicht "niet bij het venten van geschreven of gedrukte stukken had moeten bepalen, maar zich tot het verkopen van alle (curs. RdW) waren had moeten uitstrekken". Immers, "wanneer men eenvoudig het vrije verkeer op de openbare straat had willen verzekeren", lag zo'n beperking tot het venten met drukwerk niet voor de hand. Nu leek het er veeleer op dat men de drukpersvrijheid had willen aantasten. Hij vond die 
gedachtengang echter "meer spitsvondig dan juist". Want: "de gemeenteraad kan van oordeel zijn dat in het venten van andere waren geen bet minste bezwaar bestaat voor bet vrije verkeer, doch dat juist het te koop aanbieden van geschriften op de openbare straat eene bron voor wanordelijkheden is". Diezelfde opvatting vindt men bij Graevestein van Heyst (a.w., noot 6), p. 23. Beiden zagen - vreemd genoeg! - over het hoofd dat een dergelijke adgemeen gestelde bepaling destijds hetzelfde lot zou hebben ondergaan als de Zwolse: onverbindendheid wegens strijd met de wet op het recht van patent. (Misschien is de advocaat-generaal hieraan voorbij gegaan omdat in de Zwolse zaak door zijn collega Patijn, en dus niet door hemzelf, werd geconcludeerd; de A-G Patijn maakte later - in zijn conclusie vóor HR 5 december 1898, W. 7213 - wèl een opmerking van die strekking).

8. Ktr. 's-Gravenhage 17 maart 1892, W. 6153.

9. Rb. 's-Gravenhage 30 mei 1892 , W. 6187.

10. Conclusie vóór HR 7 november 1892, W. 6259.

11. HR 7 november 1892, W. 6259 (Haags ventverbod). Het was het eerste arrest van de Hoge Raad, "waarbij aan eene bepaling in eene plaatselijke politieverordening verbindende kracht werd ontzegd op grond van strijd met art. 7 Gr.w.", aldus het Weekblad van het Recht op 30 maart 1896 (nr. 6781). Ik heb inderdaad geen eerder arrest van die strekking gevonden. (Vgl. ook W. 6786, p. 4).

12. Enkele voorbeelden: Van der Pot/Donner/Prakke e.a., Handboek van het Nederlandse staatsrecht, 12e druk, p. 283, Zwolle 1989; C.A.J.M. Kortmann, Constitutioneel recht, p. 379, Deventer 1990; Compendium van het staatsrecht, 6e druk, no. 157, Deventer 1992; P.J. Boon, Zonder voorafgaand verlof, 4e druk, p. 8, Nijmegen 1988; J.M. de Meij, Uitingsvrijheid, p. 83 en 100, Amsterdam 1989; F.H. Kistenkas, Vrije straatcommunicatie, p. 11, Deventer 1989.

13. E.A. Alkema, noot (punt 4) onder HR 21 januari 1986, AB 1986, 572 (Gouds plakverbod).

14. Alexander Zinoviev, The Madhouse, p. 13, London 1986 (oorspronkelijk 1980).

15. K.R. Popper, The poverty of historicism, Londen 1957 (diverse malen herdrukt; paperback-editie 1961, p. 150).

16. F.G. Scheltema, Werkelijkheid, recht en gerechtigheid, p. 7, 's-Gravenhage 1927 (oratie UvA 1927).

17. A.M. Donner, De leesbibliotheek-verordeningen, Bestuurswetenschappen 1948 , p. 161 .

18. HR 28 november 1950, NJ 1951, 137 (Tilburg); zie voorts NJ 1951, 138 en 369.

19. A.M. Donner, a.w. (zie noot 17), p. 161-162.

20. Vgl. bijv. zijn polemieken over "Heerenveen" met Snoep, Zacijen en Jansen in NJB 1939, en met Van Haren en Kallen over dezelfde materie in het Weekblad voor gemeentebelangen 1939.

21. G. van den Bergh, De leesbibliotheek-verordeningen, Verzamelde staatsrechtelijke opstellen, deel I, p. 68, Alphen aan den Rijn 1949.

22. A.w. (noot 21$),$ p. 73 .

23. Een koekje van eigen deeg: mijn "theorie" ter verklaring van het onderscheid 
tussen "buiten toepassing" en "onverbindend" verklaren, zoals die te vinden is in NJB 1984, p. 1126 e.v., vind ik aanzienlijk minder geslaagd dan mijn latere poging in VAR-geschrift XCVI (1987), p. 236 e.v.

24. Zie bijv. HR 28 november 1950, NJ 1951, 137 en 138; tegenwoordig geeft de Hoge Raad soms openlijk aan dat er sprake is van een keerpunt: recentelijk bijv. HR 28 februari 1992, RvdW 1992, 73: "deze rechtspraak komt in aanmerking voor heroverweging". Zie ook M.B.W. Biesheuvel, Randverschijnsel, NJB 1992, p. 615 .

25. Voor bezwaren tegen dit hulpmiddel: R. de Winter en W. Witteveen, De wil van de wetgever en het afschuiven van verantwoordelijkheden, NJB 1981, p. 669 e.v. Zeer verhelderend is E. Chemerinsky, The vanishing constitution, Harvard Law Review 1989/90 (vol. 103), p. 43 e.v. Nog recenter: Why Learned Hand would never consult legislative history today, Note, Harvard Law Review 1991/92 (vol. 105), p. 1005 e.v.

26. J. d'Aulnis de Bourouill, a.w. (zie noot 6), p. 82.

27. J.T. Buys, De Grondwet, deel I, p. 56, Arnhem 1883.

28. E.C.M. Jurgens, Aardmannetjes-en Koboldenwet, Staatscourant 18 februari 1991 .

29. $\mathrm{Vgl}$. - heel kort - mijn bijdrage Wetshistorische interpretatie en het primaat van de democratie, in: NTBR 1992, p. 21 e.v. 
1. Rb. 's-Gravenhage 30 mei 1892, W. 6187; zie verder de inleiding van dit boek.

2. A-G Gregory vó́r HR 7 november 1892, W. 6259.

1. Dat op diezelfde dag opnieuw in deze zelfde zaak uitspraak werd gedaan door het Belgische Hof van Cassatie is een toevallige bijkomstigheid. Deze laatste beslissing, die pas op 25 november 1892 in het Weekblad van het recht (no. 6258) werd gepubliceerd, heeft - voor zover ik heb kunnen nagaan - geen rol meer gespeeld voor het Nederlandse arrest van 7 november 1892. Het Belgische Hof hield trouwens voet bij stuk, zodat - inhoudelijk gesproken - niets nieuws werd toegevoegd aan datgene wat al bekend was.

4. La Belgique judiciaire 1886, p. 1436-37. In 1879 (La Belgique judiciaire 1879, p. 684 e.v.) had het Hof van Cassatie zich al eens over een echte plakzaak gebogen. Een Leuvens "règlement communal" uit 1820 schreef voor "que toute publica-tion ou apposition d'affiches devia être faite par le crieur ou afficheur public ". Op eigen houtje mocht men dus niet plakken en dat was natuurlijk tòch gebeurd. Het hof kwam tot de conclusie dat zo'n verbod "ne donne pas nécessairement à l'autorité communale le droit d'interdire l'affichage, mais tend à lui permettre de prescrire, selon les circonstances et le caractère de l'affiche, les mesures qu'elle juge utiles, quant au lieu, au moment et au mode d'affichage, afin d'enı prévenir les inconvénients". Bovendien was helemaal niet vastgesteld "que l'autorité communale de Louvain aurait interdit la publication de l'affiche dont s'agit.". Geen vuiltje aan de lucht, kortom.

5. Die regel geldt feitelijk nog altijd in België. Op 29 oktober 1973 (Rechtskundig Weekblad 1974-1975, kol. 466 e.v.) overwoog het Hof van Cassatie "dat, zo krachtens artikel 14 van de Grondwet de Belgen hun mening op alle gebied vrij mogen uiten en de overheid derhalve de uitoefening van dat recht van vrije meningsuiting niet mag onderwerpen aan een voorafgaand toezicht op de meningen waaraan uiting zal worden gegeven, hierbij echter geen onbeperkte vrijheid wordt toegekend om zelfs voor dergelijke uiting gebruik te maken van de openbare weg, en dat, 20 artikel 18 de persvrijheid warborgt, die vrijheid geenszins tot gevolg heeft de onbeperkte vrijheid om op de openbare weg drukwerk te verkopen en te verspreiden". Daar kwam nog bij dat "de gemeentelijke overheid (...) belast is met het voorschrijven van de nodige maktregelen om an de inwoners het voordeel te verzekeren van een goede politie, namelijk de reinheid, de gezondheid, de veiligheid, de rust en het gemak van verkeer op de openbare straten, kaden, pleinen en wegen". Dis mocht de gemeente het verspreiden van drukwerk - met het oog op die belangen - 66k aan voorafgaand verlof onderwerpen, aldus het hof. Een dwingende logica is in deze redenering - om het voorzichtig uit te drukken moeilijk te ontwaren. Zie verder over deze materie: A. Alen, Rechtskundig Weekblad 1974-1975, kol. 508 e.v., en J. Velaers" De beperkingen van de vrijheid van meningsuiting, deel II, p. 750-759, Antwerpen/Apeldoorn 1991.

6. Hof van Cassatie 18 januari 1892, W. 6185.

7. Zoals - bijna honderd jaar later - de Centrale Raad van Beroep zich in Nederland overschreeuwde toen hij een ambtenaar op de griffie van de Rotterdamse rechtbank 
voorhield dat het hem niet vrijstond "het overheidsgebouw, waarin hij werkzaam is, ongelimiteerd en naar eigen goeddunken met affiches te behangen", waaruit vervolgens werd afgeleid dat hij dus geen enkele affiche voor het raam mocht hangen; zie CrvE 12 november 1985 , AB 1986, 579.

8. J.J. van Riemsdijk Kreenen, Het venten van drukwerk op de openbare straat (diss. Leiden), p. 16 (zie ook p. 30, waar hij van "een bloote utiliteitsgrond" rept), Leiden 1895. Ook J.G. Westra van Holthe (De gemeentebesturen tegenover de artikelen 7 en 9 van de Grondwet, diss. Leiden 1893, p. 32 jo. 22) wekte de indruk hier bij uitstek een taak voor de Kroon te zien. Zeer veel later werd door Duynstee nog een dergelijk standpunt ingenomen; zie F.J.F.M. Duynstee, preadvies. NJV 1949 I, tweede stuk, p. 113: hij zag i.c. slechts ruimte voor vernietiging door de Kroon wegens strijd met het algemeen belang, "en niet op grond van juridische onjuistheid".

9. HR 7 november 1892 , W. 6259 .

10. H. Krabbe, Art. 188, al. 2 Gemeentewet, opgenomen in: H. Krabbe, Staatsrechtelijke opstellen, deel I, m.n. p. 255, 's-Gravenhage 1927. Kamphuisen (zie noot 11) verwees naar deze passage. In de arresten van 28 november 1950 (NJ 1951, 137 en 138) kwam de rechtsgeschiedenis op het vlak van art. 7 nadien nog eens zeer uitdrukkelijk aan de orde; de auteurs raakten er onderwijl niet over uitgepraat. Zie bijv. S.F.L. van Wijnbergen in SEW 1960, p. 233 e.v., J.R. Stellinga in TvO 1961, p. 243, P.J. Boukema in RM Themis 1969, p. 119 e.v. en J.M. de Meij in TrO 1980, p. 123-124.

11. P.W. Kamphuisen, De interpretatie in het staatsrecht, p. 14, oratie KUN, Nijmegen-Utrecht 1933. A.A.H. Struycken concludeerde in zijn oratie tot niets minder dan "de noodzakelijkheid eener historische beoefening van het staatsrecht" (Positief recht, p. 25, Amsterdam 1906).

12. Respectievelijk HR 23 maart 1896, W. 6783, en HR 1 november 1897, W. 7036; in HR 1 februari 1897, W. 6928 werd een gemeentelijk ventverbod gesauveerd - ik kom daar later op terug.

13. H. Vos, De "geschiedenis" van art. 7 der Grondwet. Weekblad voor de Burgerlijke Administratie (WBA) 2528 (25 november 1897 ).

14. Zijn eerste uithaal dateert van 1894 (Themis 1894, p. 402 e.v.), zijn - voor zover ik weet - laatste van 1936 (Weekblad voor gemeentebelangen 28 februari 1936, p. 65-66). Vos was overigens alles behalve monomaan; er is vrijwel geen onderwerp dat hij onaangeroerd liet (zie, voor een selectie: Uit de geschriften van Mr. H. Vos, uitg. VNG, Alphen aan den Rijn 1933); het belangrijkst waren wellicht zijn pleidooien voor invoering van administratieve rechtspraak in Nederland. $\mathrm{Zijn}$ invloed is echter - buiten het gemeentelijke circuit - zeer beperkt

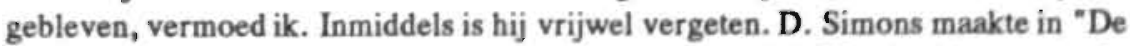
ontwikkeling van de rechtsbescherming tegen de overheid" (Honderd jaar rechtsleven, p. 237 e.v., Zwolle 1970) in het geheel geen melding van hem. M. Schreuder-Vlasblom (De macht der kritiek, Zwolle 1987) en J. Van der Hoeven (De drie dimensies van het bestuursrecht, Alphen aan den Rijn 1989) gingen aan zijn meer 
dan honderd bladzijden tellende bestrijding van het geruchtmakende pamflet van Struycken uit 1920 voorbij (Themis 1911, p. 1-80 en 396-416).

15. H. Vos, Overzicht van Rechterlijke Beslissingen betreffende Publiek Recht in Nederland, no. X, Themis 1894, respectievelijk p. 405 en 408.

16. J.T. Bluys, De Grondwet, deel I, p. 57-58, Arnhem 1883.

17. J.G. Westra van Holthe, De gemeentebesturen tegenover de artikelen 7 en 9 van de Grondwet, p. 9, Diss. Leiden 1893.

18. D. Graevestein van Heyst, Het venten van geschriften op den openbaren weg als strafbaar feit beschouwd, p. 36, Diss. Utrecht, Zutphen 1894.

19. J.J. van Riemsdijk Kreenen, Het venten van drukwerk op de openbare straat, p. 13, Diss. Leiden 1895.

20. C.F. van Maanen, Aanteekeningen van het verhandelde over de Grondwet van 1815, m.n. p. 229 en 232, Dordrecht 1887. Het jaar van publikatie van deze "aanteekeningen van het verhandelde in den boezem der Commissie voor eigen gebruiik opgeteekend door het lid dier Commissie C.F. van Maanen", verklaart we!licht waarom ze niet verwerkt zijn in bet commentaar op de Grondwet van Buys (dat - voor zover hier van belang - in 1883 verscheen). De hier bedoelde passage is later verwerkt in H.T. Colenbrander, Ontstaan der Grondwet, tweede deel, 1815 , p. 474 en 478 , 's-Gravenhage 1909.

21. Soeverein Besluit 24 januari 1814, S. 1814, no. 17.

22. J.G. Westra van Holthe, a.w. (noot 17), p. 18-19.

23. Die vraag is - bij mijn weten - overigens nooit door enige auteur in dit verband opgeworpen. F.H. van der Burg kende in ander verband eens bijzondere waarde toe aan de door J. Riphagen gegeven uitleg van wat tegenwoordig art. $94 \mathrm{Gr} . \mathrm{w}$. is, immers: "Mr. Riphagen was destijds (in 1953, RdW) als ambtenaar van het ministerie van Binnenlandse Zaken ten nauwste betrokken bij de Grondwetsherziening"; zie F.H. van der Burg, Splitsing van wettelijke bepalingen en abstracte toetsing, in: Gemeentelijke vrijheden (Van Vliet-bundel), m.n. p. 24, AJphen aan den Rijn 1983. Uit staatsrechtelijk oogpunt een merkwaardige manoeuvre, lijkt me. Ten aanzien van de toch al zo zwak gelegitimeerde grondwet van 1815 lijkt een dergelijke aanpak mij nog veel dubieuzer.

24. W. 6588, p. 4. De term "censuur" wordt hier in een ruime zin gebruikt en ziet dus niet louter op "een preventief toezicht op het drukken zelf". Zie in verband met de term "censuur", ruim een halve eeuw later, m.n. A.J.P. Tammes, preadvies NJV 1949, deel I, eerste stuk, p. 168, Zwolle 1949.

25. H. Vos, a.w. (noot 15), p. 405.

26. D. Simons, De vrijheid van drukpers in verband met het Wetboek van Strafrecht, m.n. p. 47 e.e. en p. 123 e.v., 's-Gravenhage 1883.

27. Opvallend is de methode aan de hand waarvan Simons vervolgens trachtte te achterhalen wat moest worden aangemerkt als "publiceren", oftewel "openbaar maken". Hij beriep zich daarbij met name op art. 261 lid $2 \mathrm{Sr}$ : er is sprake van een smaadschrift als het geschrift of de afbeelding is verspreid, openlijk tentoongesteld of aangeslagen. "Willen wij dus", aldus Simons, "uit de wet een antwoord 
afleiden op de vraag 'wanneer is een geschrift gepubliceerd', het zal niet anders kunnen luiden dan: "zoodra het is verspreid, openlijk tentoongesteld of aangeslagen'" (p. 50/51). Kennelijk was, volgens hem, in een eerder stadium nog geen sprake van publikatie. Dat volgt echter niet uit het voorgaande.

28. Van Riemsdijk Kreenen, a.w. (noot 19), p. 14.

29. J.G. Westra van Holthe, a.w. (noot 17), p. 27.

30. H. Vos a.w. (noot 15), p. 409.

31. D. Graevestein van Heyst, a.w. (noot 18), p. 39-40.

32. J.J. van Riemsdijk Kreenen, a.w. (noot 19), p. 15-16.

33. J. d'Aulnis de Bourouill, Het yenten van drukwerken in het openbaar, Themis 1895 , m.n. p. $80-82$ en 84 .

34. Zie noot 24.

35. Dat de opvatting van Vos iets royaler was dan die van Buys, was het Weekblad niet ontgaan. Het bracht daar echter tegenin dat voor het onderscheid van Vos "tusschen essentieele en niet-essentieele bestanddelen van het 'openbaren' van gedachten of gevoelens door de drukpers, tusschen 't geen voor 'dat openbaren' noodzakelijk is of bloot bevorderlijk, geen plaats is in de leer van Buys, dat art. 7 Gw. alleen verbiedt 'de Censuur' naar Fransch model, of, zooals de heer Vos zelf het uitdrukt: de zg. censuar, een preventief toezicht op het drukken zelf." (In werkelijkheid repte Buys overigens niet van censuur naar Frans model of iets dergelijks; hij omschreef het begrip niet, doch achtte in elk geval "het preventieve toezicht, in die censuur opgesloten", ongeoorloofd; "het verbod on dagbladen en andere periodieke geschriften op straat te verkoopen of met de post te verzenden" viel echter, naar zijn oordeel, buiten het bestek van art. $7 \mathrm{Gr}$.w. Zie J.T. Buys, a.w. (noot 16), p. 58). Het onderscheid tussen 'noodzakelijk' en 'bevorderlijk' werd in het Weekblad bovendien "zuiver willekeurig" genoemd, "maar deze geheele vraag kunnen wij laten rusten, omdat art. $7 \mathrm{Gw}$. geen aanleiding geeft om haar te stellen".

36. J.T. Buys, a.w. (noot 16), p. 57-58.

37. W. 6588, p. 4.

38. HR 7 november 1892, W. 6259, p. 2.

39. J.G. Westra van Holthe, a.w. (noot 17), p. 18.

40. H. Vos, a.w. (noot 15), p. 408.

41. De enige die hier gunstig bij afsteekt is Graevestein van Heyst (a.w. noot 18); let op het verschil in toonzetting: "Ik geloof dat uit de geschiedenis van de Grondwet yan 1815 duidelijk blijkt, dat men geen algemeenen waarborg voor de vrijheid van drukpers verlangde, maar alleen tegen het wederinvoeren van censuur" (p. 36). Hij is ook de enige die een - mogelijk - afwijkend geluid yan De Bosch Kemper en Schimmel in zijn boek toelaat (p. 31-32); Van Riemsdijk Kreenen (a.w. noot 19, p. 13) volstond met de vermelding dat De Bosch Kemper "het tegendeel (leert)". In schril contrast daarmee: Westra van Holthe (a.w. noot 17, p. 13), die De Bosch Kemper louter aanhaalt voor zover het in zijn eigen verhaal past. Helaas is het proefschrift van Graevestein van Heyst het minst aangehaalde in de literatuur. 
42. Ik ben dit argument in de literatuur niet tegengekomen. Ik vind het echter moeilijk mij aan de indruk te onttrekken dat het in het arrest over het Haags ventverbod een roll heeft gespeeld. (Ook de gerichtheid op "uitbreiding van kennis en voortgang van verlichting" is een aanwijzing dat tevens aan verspreiding is gedacht).

43. Zijn eerste poging luidde als volgt: "Niemand heeft voorafgaand verlof noodig om door de drukpers gedachten of gevoelens te openbaren. De verantwoordelijkheid voor een beleedigend gebruik dezer vrijheid wordt bij de wet geregeld " (Aanteekening op de Grondwet, 2e druk: (Amsterdam 1843, p. 301). Op een komma na bleef de eerste volzin in het ontwerp van de Negenmannen (1844) ongewijzigd; de tweede volzin werd enigszins gewijzigd: "De verantwoordelijkheid voor een, de regten der maatschappij of harer leden krenkend, gebruik dezer vrijheid, wordt door de wet geregeld". In het commissievoorstel van 1848 was de tweede volzin geheel komen te vervallen, wellicht omdat hij (volgens Thorbecke) "niets behelst dan eene hoogst eenvoudige, algemeen erkende waarheid" (Aanteekening, p. 299. 300) - waarom zou men zo'n vanzelfsprekendheid in de Grondwet opnemen? Uiteindelijk is een residu van die aanvankelijk geschrapte zin - zoals bekend - toch weer in het artikel opgenomen. In zijn Bijdrage tot de herziening der Grondwet (Leiden 1848) gaat Thorbecke er niet op in; geen wonder, het had volgens hem niets om het lijf (het "kon worden gemist"', schreef hij in zijn Aanteekening, p. 298).

44. J.R. Thorbecke, Aanteekening op de Grondwet, p. 299, Amsterdam 1843 (2e druk).

45. Graevestein van Heyst (a.w. noot 18, p. 33-34) volstond met de opmerking dat in Thorbeckes Aanteekening "weinig" over dit onderwerp is te vinden.

46. J. de Bosch Kemper, Handleiding tot de kennis van het Nederlandsche staatsregt en staatsbestuur, Amsterdam 1865. Zie verder noot 41.

47. I. de Bosch Kemper, a.w. (noot 45), p. 143.

48. De argumenten van de tegenstanders zijn in de literatuur nog jarenlang onderwerp van discussie geweest. Zie m.n. E. Diemer, Vrijheid van drukpers, p. 111 e.v. (diss. VU, Rotterdam 1937), waai de meeste latere auteurs zich op baseren. P. Dresen (De Vrije meningsuiting, diss. UvA, Amsterdam 1949, p. 169) schrok er zelfs niet. voor terug, Diemei voar zijn eigen karretie te spannen. Waar Diemer schreef dat de nadruk niet moest worden gelegd op het openbarendoor de drukpers aangezien een artikel dat slechts de vrijheid van drukken waarborgt "volkomen zinloos" zou zijn (p. 113), vroeg Dresen zich af "wat men zou hebben aan een vrije drukpers, die enkel het vervaardigen en niet het verspreiden zou betreffen". Vervolgens beriep hij zich op Diemer: "In dat geval, zegt: Diemer terecht, zou "het artikel zinloos zijn'." Wishful thinking? Pal daarop plagieerde hij diezelfde Diemer echter, maar nu zonder bronvermelding! "Wat de geschiedenis betreft", merkt Dresen op (p. 169), "ongetwijfeld werd in 1815 de 'preallablle censure' genoemd en bedoeld, omdat deze censuur allen nog het meest vers in het geheugen lag. Dat daarom de preallable censure min of meer toevallig met name genoemd werd, betekent daarom niet, dat de geschiedenis der totstandkoming van dit artikel zich 
tegen een dergelijke ruime uitleg zou verzetten, te meer waar deze zo geheel in. overeenstemming is met de geest en bedoeling van de drukpersvrijheid". Diemer had twaalf jaar eerder het volgende geschreven: "Aangezien alles doet vermoeden, dat men de drukpersvrijheid zooveel mogelijk grondwettelijk wilde waarborgen (...) is het niet gewaagd, om ondanks het feit, dat de 'prealabele censure", trouwens min of meer toevallig, met name werd genoemd, aan het grondwettelijk artikel om historische redenen ruimeren zin te verlenen".

P.J. Oud (Handboek voor het Nederlands gemeenterecht, deel II, p. 220-221, Zwolle 1959) blijkt zich zozeer op Diemer (p. 115) te hebben gebaseerd dat hij zelfs de onjuiste vindplaats van een arrest heeft overgenomen (W. 7820 in plaats van W. 7802). Dat hij vervolgens "met Diemer" tot één en dezelfde conclusie komt, wekt dan nauwelijks nog verbazing.

Het proefschrift van Boukema (Enkele aspecten van de vrijheid van meningsuiting in de Duitse Bondsrepubliek en in Nederland, p. 139, Amsterdam 1966) is daarmee vergeleken een verademing. Hij schrijft eenvoudig dat hij de lezing van Diemer "overtuigend" vindt.

De Meij (Uitingsverbod, p. 84, Amsterdam 1989) raakte daarentegen opnieuw geïnspireerd door het boek. van Diemer. Hij vond er een oud citaat in van Modderman: "Terecht zijn door de Grondwet alle preventieve maatregelen tegen de drukpers uitgesloten". En dat bracht hem tot de conclusie dat de ruime uitleg die de Hoge Raad in 1892 aan art. 7 Gr.w. had gegeven "niet volstrekt nieuw in die tijd" was. Maar waarom was Diemer zèlf niet tot dat inzicht gekomen? Omdat hij - anders dan De Meij, die verzuimd had de bron na te trekken - wist in welke context, die opmerking gemaakt was (zie H.J. Smidt, Geschiedenis van het Wetboek van Strafrecht, deel I, p. 437 e.v., Haarlem 1881). Het ging toen namelijk louter en alleen om de vraag hoe vermeden kon worden dat uitgevers en drukkers - ter voorkoming van tegen hen gericht repressief optreden van de overheid - ertoe zouden overgaạn hun auteurs vooraf beperkingen op te leggen; men wilde censuur, met andere woorden, niet alleen direct, maar $66 \mathrm{k}$ indirect tegengaan. De problematiek van het Haags ventverbod was, kortom, in de verste verten nog niet in zicht. Modderman doelde met het verbod van "alle preventieve maatregelen" klaarblijkelijk op alles wat - direct of indirect - aanleiding gaf tot censuur.

49. E. Diemer, a.w. (noot 48), p. 112.

50. Vandaag-de-dag lijkt dit in elk geval de opvatting te zijn van de civiele kamer van de Hoge Raad; zie HR 11 december 1987, NJCM-Bulletin 1988, p. 121 e.v. (Ondertitelingsverbod).

51. Graevestein van Heyst, a.w. (noot 18), p. 44, betoogde evenwel (conform de Belgische rechtspraak) dat "de mogelijkheid van misbruik eener bevoegdheid (...) de toekenning dier bevoegdheid niet onwettig (maakt)". Ruim een hal've eeuw later uitte de Hoge Raad zich in die zin: HR 20 juni 1950, NJ 1950, 619 (Breda).

52. Meestal wordt aangenomen dat de Hoge Raad pas veel later tot het inzicht kwam dat de bescherming voor ieder (zelfstandig) verspreidingsmiddel afzonderlijk geldt. Zie bijvoorbeeld H.D. van Wijk, Niemand heeft voorafgaand verlof nodig... (in: 
H.D. van Wijk, Besturen met recht, m.n. p. 180, 's-Gravenhage 1974) en J.M. de Meij, Uitingsvrijheid, p. 104, Amsterdam 1989. Vgl. cok - enigszins genuanceerder - P.J. Boukema, a.w. (noot 48), p. 124 (alsmede zijn noot 47 op diezelfde pagina). Anders: P.J. Boon, Zonder voorafgaand verlof, p. 10 en 14, Nijmegen 1988 (vierde druk).

53. J.G. Westrat van Holthe, a.w. (noot 17), p. 19-20.

54. J.G. Westrat van Holthe, a.w. (noot 17), p. 23.

55. Zie onder meer HR 12 januari 1960, NJ 1960, 273 (Alkmaar) en HR 2 oktober 1979, NJ 1980, 105 (Dordrecht), waarin de opvatting van Westra van Holthe nog steeds gehuldigd werd (hoewel de A-G Mok in zijn conclusie vóór het laatste arrest reeds wat relativerende opmerkingen makte). In HR 17 oktober 1989, NJ 1990, 223 werd die opvatting - althans in zijn meest rigide vorm - verlaten en werd (theoretisch) ruimte gecreëerd voor een relativering met het oog op een omstandigheid die volgens Remmelink (in zijn conclusie vóór HR 19 september 1977, NJ $1978,516)$ "als een casus non dabilis beschouwd (kon) worden". Een dergelijke ontwikkeling kan niettemin verstrekkende gevoigen hebben. Zo achtte Westra van Hoithe het destijds "niet wel denkbaar" dat zich in werkelijkheid ooit de situatie zou kunnen voordoen waar de Hoge Raad op doelde toen hij erop wees dat "niets gemakkelijker zoude vallen" dan de verspreiding "door verschillende bepalingen in rijkswetten en gemeenteverordeningen, ieder op zich zelve beperkt tot enkele daarbij aangewezen middelen van openbaarmaking, geheel te verijdelen" (p. 3132). Ik geloof dat hij daarin wel gelijk heeft gekregen. Niettemin wordt het resultaat van die op overdrijving berustende redenering door de Hoge Raad nog steeds gehuldigd. Wellicht omdat het niet de enige redenering bleek te zijn, die daartoe leidt. Zie onder meer HR 27 februari 1951, NJ 1951, 472 en HR 24 januari 1967, NJ 1967, 270 (Nederland ontwapent).

56. J.G. Westra van Holthe, a.w. (noot 17), p. 28-29.

57. Westra van Holthe verwees naar HR 7 maart 1871, W. 3387; zie echter ook W. 3386, waarin een arrest van dezelfde datum is afgedrukt, eveneens over de verhouding van deze verordening tot het recht van vereniging en vergadering.

58. Westra van Holthe, a.w., p. 25, zag voor de straat slechts één doel: "de vrije circulatie". Volgens hem hadden "allen (...) een gelijk recht om vrijelijk de openbare straat to gebruiken, maar natuurlijk niet anders dan volgens hare bestemming". Een dergelijke eenduidigheid erkende hij, naar ik aanneem, niet ten aanzien van "tapperijen". Mogelijk voedde dit zijn verbazing over het verschil in uitkomst van beide zaken; àls er al verschil moest zijn, had hij het vermoedelijk net andersom verwacht: de sluiting van "tapperijen" is eerder in strijd met het recht van vereniging en vergadering, dan het "sluiten" van de openbare weg in strijd is met de vrijheid van drukpers. Vandaar misschien dat het verschil in casuspositie hem ontging - het was (vanuit zijn eigen gezichtspunt) niet relevant.

59. J.G. Westra van Holthe, a.w., p. 30-31. Art. 188 gem.w. luidde destijós als volgt: "De politis over de schouwburgen, herbergen, tapperijen en alle voor het publiek openstaande gebouwen en zamenkomsten, openbare vermakelijkhedenen openlijke 
huizen van ontucht, behoort aan den burgemeester. Hij waakt tegen het doen van met de openbare orde of zedelijkheid strijdige vertooningen". Enkele jaren later (in 1899) werd overigens door Krabbe bestreden dat de burgemeester aan dit wetsartikel de bevoegdheid kon ontlenen "om de opvoering van een toneelstuk te verbieden" (opgenomen in: H. Krabbe, Staatsrechtelijke opstellen, deel I, p. 249 e.v. "s-Gravenhage 1927). Het artikel is niettemin nog decennia lang in die zin opgevat. De eerlijkheid gebiedt toe te geven dat ook bij de totstandkoming van het oude art. 188 gem.w. wel degelijk algemeen werd aangenomen dat dit wetsartikel op de mogelijkheid van censuur zag; zie J.H.G. Boissevain, De Gemeentewet opgehelderd door eene aanteekening, p. 241, Arnhem 1851.

60. D. Graevestein van Heyst, a.w. (noot 18), p. 44.

61. A.w., p. 37-39.

62. Naar aanleiding van HR 28 november 1950, NJ 1951, 137, kwam Boukema, a.w. (noot 48), p. 120, tot het subtiele "onderscheid tussen het grondrecht te openbaren en het recht openbaar te maken". Die terminologie lijkt mij in de eerste plaats ahistorisch en in de tweede plaats weinig verheiderend. Ik kom er bij de behandeling. van dit beroemde arrest uit 1950 op terug.

63. Opvallend is overigens dat de Hoge Raad hier de term "verspreiding" bezigde, en wel - naar ik veronderstel - in de betekenis van "openbaarmaking". Voor het overige is de Hoge Raad wèl consequent bij het hanteren van de gekozen terminologie.

64. Zie met name de conclusies van A-G Van Lier vóor HR 8 november 1937, NJ 1938, 367, A-G Remmelink vóór HR 19 september 1977, NJ 1978, 516 (Hengelo) en A-G Haak vóór HR 14 oktober 1980, NJ 1981, 566 (Doorn). De opvatting van de Hoge Raad werd in de latere literatuur bestreden door o.a. P.J. Oud (Handboek van het Nederlands gemeenterecht, p. 219, Zwoile 1959). "Wanneer men (...) aanvaardt, dat de gemeenteraad de verspreiding mag onderwerpen aan beperkingen in het belang van de openbare orde", aldus Oud, "dan kan ik niet inzien, waarom, als die orde het vordert - en het oorjeel daaromtrent kan toch alleen aan de Raad zijn -, een algemeen verbod niet toelaatbaar zou zijn. De Grondwet weet van een verschil tussen een algerneen verbod en een verbod, dat niet algemeen is, niets". Vervolgens betoogde hij dat het "duidelijk" is, "dat een verbod om op de openbare straat te verspreiden allerminst een algemeen verbod is. Tal van middelen - de winkelverkoop, de toezending per post, de bezorging aan huis, e.d. - blijven over" .

65. Zie over de - geringe - overtuigingskracht van dit argument de opmerkingen van Westra van Holthe, waarnaar verwezen wordt in noot 55 .

66. D. Graevestein van Heyst, a.w., p. 76. In "het Zuiden" was deze kwestie wèl al eerder beslecht; zie hierover noot 4 .

67. J.J. van Riemsdijk Kreenen, a.w. (noot 19), p. 20.

68. J.J. van Riemsdijk Kreenen, a.w., p. 16.

69. J.J. van Riemsdijk Kreenen, a.w., p. 3-4.

70. Naar aanleiding van een Zaanse verordening uit 1933, die enige gelijkenis vertoonde met de Amsterdamse die bij. Van Riemsdijk Kreenen zo in de smaak 
viel, schreef Diemer, a.w. (noot 48), p. 119: "De vraag kan gesteld worden, of door deze bepaling in de gemeentelijke verordening van Zaandam de vrijheid van drukpers, gewaarborgd in de Grondwet, niet wezenlijk wordt bedreigd. Immers wordt door dit artikel in abstracto de gelegenheid geschonken elke colportage te verbieden".

71. J.J. van Kiemsdijk Kreenen, a.w., p. 33-35.

72. Deze draad werd door Dierner (zie noot 70) weer opgenomen, zij het wat minder ver doorgevoerd; in zijn ogen rees er slechts ("in abstracto") een probleem als "elke colportage" zou worden verboden. Van Riemsdijk Kreenen zag al problemen als de uren en plaatsen "zeer ruim" werden genomen. Dresen, a.w. (noot 48), p. 221, kwam daar in 1949 dichterbij. Hij vond dat het "toch moeilijk in overeenstemming met de geest van de Girondwet genoemd (kan) worden (...) wanneer men b.v. ter bescherming van het verkeer, het venten practisch beperkt tot stille straten of tot uren waarop vrijwel geen publiek. op straat is, zodat men nauwelijks meer van verspreiding door venten kan spreken". Opvallend is overigens dat Diemer noch Dresen in dit verband naar Van Riemsdijk Kreenen verwees.

73. HR 17 maart 1953, NJ 1953, 389 (Nuth). Een voorloper van dit arrest was, zoals we nog zullen zien, HR 28 juni 1920, W. 10616.

74. Gst. 2149 (5 december 1892$)$.

75. Zie Gst. 2143 (24 oktober 1892). Zonder verwijzing tevens vermeld bij J.J. van Riemsdijk Kreenen, a.w., p. 4. Over de uitspraak van resp. de kantonrechter en - later - de rechtbank in hoger beroep vernemen we overigens niets bij hem, evenmin als bij Graevestein van Heyst, p. 4.

76. Gst. 2149 (5 december 1892).

77. Gst. 2157 (30 januari 1893). Letterlijk betzelfde bericht was opgenomea in het Weekblad voor de Burgerlijke Administratie (WBA) 2277 (2 februari 1893).

78. Zie hierover WBA 2330 (8 februari 1894).

79. Zie J.J. van Riemsdijk Kreenen, a.w., p. 3-4, en WBA 2350 (28 juni 1894).

80. WBA 2350 (28 juni 1894).

81. WBA 2358 (23 augustus 1894); in WBA 2353 (19 juli 1894) was eerder te lezen dat gedeputeerdestaten "goedkeuring onthouden" hadden - een formulering die ook destijds al weinig gelukkig was: zie de toenmalige artikelen 167-169 gem.w.; dat gedeputeerde staten "hun goedkeuring weigerden te verlenen", zoals Graevestein van Heyst, a.w., p. 4, schreef, kan al evenmin een fraaie beschrijving van de gang van zaken heten.

82. Zie WBA 2353 (26 juli 1894).

83. WBA 2364 (4 oktober 1894).

84. KB 21 december 1894 , Stb. 237 , W. 6587 . Vlak vóór de vernietiging was de bepaling - conform de toenmalige artikelen 168 en 170 lid 2 gem.w. - afgekondigd; zie WBA 2373 (6 december 1894).

85. WBA 2377 (3 januari 1895).

86. Art. 150 luidde als volgt:

"De plaatselijke verordeningen waaronder alle voorschriften en beschikkingen van 
den Raad en van burgemeester en wethouders worden verstaan, treden niet in. hetgeen van algemeen Rijks- of provinciaal belang is.

Bij twijfel, of eene verordening dit deed, verbindt zij, tot dat art. 153 is toegepast."

Art. 153 bepaalde vervolgens:

"De plaatselijke verordeningen kunnen, zoover zij met de wetten of het algemeen belang strijden, door Ons worden geschorst of vernietigd."

$\mathrm{Vgl}$. in verband met de stelling dat de rechter gehouden was de verordening toe te passen totdat deze op grond van art. 153 jo. 150 gem.w. was vernietigd (of geschorst, waar het onderschrift in het WBA ongelukkigerwijs aan voorbij ging): HR 8 maart 1909, W. 8838.

87. W. 6589 , p. 4 .

88. Verwezen werd naar de voorganger van het toenmalige art. $7 \mathrm{Gr} . \mathrm{w} .$, te weten art. $227 \mathrm{Gr} . w .1815$, waarin de frase over verantwoordelijkheid als volgt luidde: "blijvende nogtans elk voor hetgeen hij schrijft, drukt, uitgeeft of verspreidt, verantwoordelijk aan de maatschappij of bijzondere personen, voor zoverre dezer regten mogten zijn beleedigd".

89. J.J. van Riemsdijk Kreenen, a.w., p. 20-25.

90. KB 30 augustus 1895, Stb. 154, W. 6696.

91. H. Vos, Een gevaarlijke wijze van wetsuitlegging, W. 6702 (vrijdag 27 september 1894), p. 3-4.

92. G.M.W. Jellinghaus, Art. 7 der Grondwet, W. 6705 (vrijdag 4 oktober 1895), p. 4 .

93. Gst. 2300 ( 28 oktober 1895), p. 1. Het betoog behelsde voor het overige voornamelijk een herhaling van zetten; de redactie schaarde zich achter het betoog van Vos in het Weekblad van het Recht.

94. J.J. van Riemsdijk Kreenen, a.w., p. 16.

95. J.J. van Riemsdijk Kreenen, a.w., p. 34. We dreigen hier verzeild te raken in de problematiek van de "onsplitsbare wilsverklaring", die ik in dit verband echter wil laten rusten; het leerstuk was destijds nog niet als zodanig herkend - dat gebeurde pas in 1927 door F.J.A. Huart in zijn beroemde artikel Het toetsingsrecht van gemeente-verordeningen en de leer der "onsplitsbare wilsverklaring", opgenomen in f.J.A. Huart, Verspreide geschriften, p. 75 e.v. (m.n. p. 88-89), Alphen aan den Rijn 1949.

96. W. 6589 , p. 4. Zie over de toenmalige stand van zaken met betrekking tot de verhouding tussen Kroon en rechter bij toetsing van verordeningen: Toetsing van plaatselijke verordeningen aan de wet, W. 6786 (10 april 1896).

97. Ktr. Leiden 29 september 1894, W. 6571.

98. Vgl. H. Vos, a.w. (noot 15), m.n. p. 405; zie verder onder 1.3 bij noot 25 en 26. Dat het artikel van Vos pas na het vonnis van de kantonrechter (29 september 1894) verscheen (hoewel het "19 augustus 1894" gedateerd is), blijkt uit de datering ("10 October 1894") van een bijdrage aan de rubriek Varia in hetzelfde nummer (LVste Deel, Derde stuk; per jaargang verschenen 4 stukken). Een eerste 
advertentie voor het betreffende nummer van Themis vond ik in W. 6569 (21 november 1894); het nummer werd besproken in W. 6588 (4 januari 1895). Op zijn beurt maakte Vos overigens geen melding van het Leidse vonnis; zijn stuk was op 19 augustus klaarblijkelijk echt afgesloten (hoewel het misschien nog niet perse was gegaan).

99. WBA 2406 (25 juli 1895).

100. GS 2320 (16 maart 1896).

101. De Hoge Raad verklaarde de bepaling uiteindelijk onverbindend bij arrest van 29 juni 1910, W. 9062, waarover later mér. De minister van Binnenlandse Zaken had zich al bij een eerdere gelegenheid op dit standpunt gesteld: zie missive aan gedeputeerde staten van Zeeland d.d. 17 november 1903, in: GS 2805 (1 juli 1905), no. 4.

102. HR 23 maart 1896, W. 6783.

103. J. d'Aulnis de Bourouill, a.w. (noot 33), p. 81. D'Aulnis was blijkens een dankbetuiging in het proefschrift van Graevesteia van Heyst (a.w. noot 18) kennelijk diens Utrechtse leermeester.

104. Denk aan de toetsing aan het toenmalige art. 135, het huidige art. 168 en het toekomstige art. 150 gem.w.!

105. P. Dresen, a.w. (noot 48), p. 179.

106. P.J. Boukema, a.w. (noot 48), p. 123.

107. P.J. Boukema, Vrijheid van meningsuiting en artikel 7 van de Grondwet, RM Themis 1969 , m.n. p. 127.

108. A.M. Donner, De leesbibliotheek-verordeningen en de circulaire van 8 Januari 1948, Bestuurswetenschappen 1948, p. 160 e.v.

109. P.J. Boukema, a.w. (noot 107), p. 127.

110. De laatste die een deel van het arrest citeerde was Diemer, a.w. (noot 48), p. 113; daarbij ging het echter niet over deze kwestie, maar om de "ruime uitlegging" die - net als in het arrest over het Haags ventverbod - aan het begrip "openbared" werd gegeven. Het arrest figureerde tevens in de veelvuldig aangehaalde opsomming van de A-G Berger vóór HR 21 maart 1938, echter evenmin met het oog op de motief-problematiek.

111. Vgi. noot 64 .

112. HR 1 februari 1897, W. 6928.

113. Ik volg de weergave van het verbod in het arrest van de Hoge Raad; merkwaardigerwijs wijkt de weergave van deze bepaling door de advocaat-generaal hier enigszins van af.

114. Dat de Hoge Raad op dit punt consequent was, bleek later uit HR 25 januari 1904, W. 8023: een verbod dat was toegespitst op schreeuwen bij het venten van eetwaren, bleek bij die gelegenheid eveneens door de beugel te kunnen. De issue was toen echter of het schreeuwen zelf gelijk kon worden gesteld met het openbaar maken door middel van de drukpers.

115. J.G. Westra van Holthe, a.w., p. 26-27.

116. H. Vos, a.w. (Themis 1894), p. 409. 
117. D. Graevestein van Heyst, a.w., p. 41.

118. J.J. van Riemsdijk Kreenen, a.w., p. 23.

119. Zie m.n. KB 21 december 1894, Stb. 237. J. d'Aulnis de Bourouill, a.w. Themis 1895), p. 79, nam het in dit opzicht voor de Kroon op.

120. J. d'Aulnis de Bourouill, a.w. (Themis 1895), p. 78-79.

121. Vreemd genoeg heeft het arrest in de literatuur nooit veel aandacht gekregen, althans niet vanuit deze probleemstelling.

122. Gst. 2654 (6 augustus 1902), p. 2. De Gemeentestem verwees naar deze gang van zaken naar aanleiding van het bericht dat de minister van Binnenlandse Zaken op 17 juli 1902 afwijzend had beschikt "op een ingediend verzoek tot vernietiging van de Amersfoortse verordening, die het luidkeels venten van couranten enz. verbiedt". De gang van zaken rond dit besluit is te vinden in WBA 2836 (1903). De jurisprudentie van de Hoge Raad op dit punt werd in datzelfde jaar overigens door een nieuw arrest bevestigd: HR 27 oktober 1902, W. 7825. Zie voorts: HR 20 november 1905, W. 8298 en HR 23 juni 1910, W. 9052 (zelfde uitkomst); nadere nuanceringen zijn te vinden in HR 29 juni 1910, W. 9062 (over "bekend maken") en HR 10 juni 1952, NJ 1952, 688 (over "hoorbaar aanbevelen").

123. Voorafgaande aan de weigering van de minister om in te gaan op het verzoek tot vernietiging van een soortgelijke Amersfoortse bepaling; zie WBA 2836 (1903). Vgl. verder noot 122 .

124. Gst. 3002, no. 6 (10 april 1909); hetzelfde bericht stond een week later in WBA 3122 .

125. WBA 3231 (20 mei 1911),

126. HR 4 april 1910, W. 9018.

127. HR 1 november 1897, W. 7036.

128. Conclusie vóór HR 1 november 1897 , W. 7036.

129. De Hoge Raad bleek, met andere woorden, bereid tot "splitsing" - een problematiek waarop ik in het kader van dit boek (zoals gezegd, vgl. noot 95) niet verder zal ingaan. Het spiegelbeeld van de hier aan de orde zijnde zaak deed zich voor ten aanzien van een ventverbod op Marken; iemand die met manufacturen had gevent kon zich niet met succes op art. $7 \mathrm{Gr} . w$. beroepen, omdat zijn "zaak" daar geen betrekking op had (hoewel de betreffende bepaling inderdaad te ruim was geformuleerd): zie HR 5 december 1898, W. 7213; voorafgegaan door Rb. Haarlem 12 juli 1898 , W. 7146. Speciaal voor F.A.M. Stroink wijs ik in dit verband tevens op een vonnis van de Ktr. te Groenlo d.d. 21 mei 1897, W. 7163: ook hier ging het om iemand die met manufacturen had gevent, terwijl de te ruim geformuleerde bepaling evenmin onverbindend werd verklaard wegens strijd met art. $7 \mathrm{Gr}$.w. (waar trouwens ook geen beroep op was gedaan); vgl. F.A.M. Stroink, De plaats van de rechter in het staatsbestel, p. 29, Deventer 1990. Het valt dus misschien wel mee met het schrikbewind dat ons te wachten staat als deze kantonrechter over toetsingsrecht beschikt; in dit geval liep de kantonrechter met zijn (gematigde) vonnis althans voorop (en wees hij de Hoge Raad wellicht de weg).

130. Zie HR 2 oktober 1979, NJ 1980, 105 (Dordrecht). 
131. Ktr. Groningen 5 februari 1902, W. 7744.

132. Zie noot 66.

133. Conclusie vớr HR 26 mei 1902, W. 7780.

134. HR 26 mei 1902, W. 7780 . En passant werd hier tevens op het vermeende doelcriterium afgedongen.

135. E. Diemer, a.w. (noot 48), p. 114.

136. Ook C.F.J. Gombault (Communaal strafrecht, p. 82, Alphen aan den Rijn 1921) ontwaarde niets bijzonders aan dit arrest. Hij repte slechts zeer in het algemeen van "de stroom van arresten van den Hoogen Raad aangaande dit onderwerp, nu eens in toelatenden, dan in verbiedenden zin"; vervolgens lichtte hij er enkele zaken uit, waaronder niet dit arrest van 26 mei 1902.

137. Zelfs indien het arrest niets nieuws zou hebben opgeleverd, is het opmerkelijk dat het niet voorkomt in de opsomming van arresten die door de A-G Berger werd gegeven in zijn conclusie vó́r HR 21 maart 1938, NJ 1938, 655. Het heeft er immers alle schijn van dat de Hoge Raad in 1902 tot een andere uitkomst kwam dan de advocaat-generaal in 1938 bepleitte. Was hier sprake van verzwijging? Ook een eerdere keer was het op een relevant ogenblik al weggevallen, te weten in de viijwel identieke opsomming die hij gaf in zijn conclusie vóor HR 18 november 1935, NJ 1936, 40 (zie hoofdstuk 3). Het arrest was wel gewoon vermeld in Léon's Rechtspraak, deel I, Afl. I. Een aanwijzing dat de advocaat-generaal zich daar niet van bediend heeft, vormt echter de vermelding van het arrest van 8 maart 1915; in Léon's Rechtspraak staat vermeld: 5 maart. Hoe dan ook, Van der Pot verwees in de eerste druk van zijn Handboek van het Nederlandsche Staatsrecht, p. 396 (Zwolle 1940), uitgerekend naar díe opsomming van Berger voor een opgave van de jurisprudentie. Tammes deed in zijn NJV-preadvies van 1949 (p. 171) hetzelfde: "Opsomming van alle arresten, die in deze van belang zijn, in de conclusie van de adv.-gen. Berger, HR 21 Maart '38, NJ '38, no. 655". En F.H. Kistenkas (Vrije straatcommunicatie,p. 18, Deventer 1989) schreefeveneens, nadat hij (toevallig?) naar p. 171 bij Tammes had verwezen: "Vgl. ook de arresten in deze van belang genoemd in de concl. van A.-G. Berger" etc. Duynstee, die vee! minder school heeft gemaakt, verwees in zijn NJV-preadvies van 1949 naar "de jurisprudentie door den Advocaat-Generaal aangehaald" vóór HR 31 oktober 1938, NJ 1939, 206; ook daarin stond het arrest uit 1902 overigens niet vermeld. Oud (a.w., p 221) zang de relevantie van dit arrest in zoverre in dat hij het als strijdig met HR 21 maart 1938, AB 1938, 758 aanrnerkte.

138. HR 23 juni 1902, W. 7802.

139. De Gemeentestem van 28 juni 1902 (no. 2648) bevatte al wel een zeer summiere samenvatting van het arrest.

140. Conclusie vóór HR 23 juni 1902, W. 7802.

141. HR 23 juni 1902, W. 7802. Ter herinnering: de Hoge Raad sloeg hier duidelijk een andere weg in dan het Belgische Hof van cassatie in 1879; vgl. noot 4.

142. HR 26 mei 1902, W. 7780 (Groningen).

143. G. van den Bergh, Verzamelde staatsrechtelijke opstellen, deel 1, p. 56; oorspron- 
kelijk in NJB 1939, Alphen aan den Rijn 1949.

144. T. Sybenga, De Grondwet van 1887 , 6e druk, p. 51, 's-Gravenhage 1921.

145. T. Sybenga, a.w., p. 52.

146. Vgl. T. Sybenga, a.w., p. 52.

147. D. Spanjaard, Artikel 7 der Grondwet, en het arrest van den Hoogen Raad dd. 23 juni 1902 (W. 7802), in: W. 7809, p. 3 (24 oktober 1902).

148. T. Sybenga, a.w., p. 52.

149. E. Diemer, a.w. (noot 48), p. 115.

150. P.J. Oud, Handboek voor het Nederlands gemeenterecht, p. 221, Zwolle 1959. Zoals al eerder opgemerkt, blijkt overigens uit de onjuiste bronvermelding (W. 7820 in plaats van W. 7802) dat Oud vermoedelijk blindelings op Diemer heeft vertrouwd, die immers dezelfde plaats aanwijst.

151. In 1902 ging het bijvoorbeeld nog twee keer over "luid(keels) roepen": ministerièle beschikking tot weigering van vernietiging, 17 juli 1902 (WBA 2836) en HR 27 oktober 1902, W. 7825 (Arnhem). Zo ook in HR 20 november 1905, W. 8298 (Den Haag; in GS 2832 ien onrechte gedateerd op 6 november) en HR 13 juni 1910, W. 9052 (Bussum). 
1. Vgl. HR 20 november 1905, W. 8298.

2. Zie HR 1 februari 1897, W. 6928 (Olst).

3. Conclusie vóór HR 2 juni 1903, W. 7936.

4. W. 7780 .

5. De suggestie van 0.m. F.H. Kistenkas (Vrije straatcommunicatie, p. 15, Arnhem 1989) dat handelsreclame niet onder "gedachten of gevoelens" werd gebracht, klopt dus niet. Dezelfde vergissing werd eerder gemaakt door P. Dresen, De vrije meningsuiting, p. 172 (Amsterdam 1949). Ik kom hier nog uitgebreid op terug.

6. WBA 3129 , p. 1-2 (1909). Eerder die jaargang (op 17 april 1909, nr. 3122) kon men lezen dat dat GS van Zeeland bezwaar hadden gemaakt tegen een verbod op Tholen om "voorwerpen of waren, van welken aard ook" zonder vergunning van B en W "hetzij op de straat, hetzij aan de huizen, te koop aan te bieden of te venten". Daarmee werden immers ook drukwerken geraakt en dat zou "strijden met de opvatting van art. 7 der Grondwet, welke bij bet arrest van den Hoogen Raad van 7 november 1892 (...) gehuldigd wordt. De Minister vereenigde zich met dat bezwaar, waarop de Raad, om vernietiging te voorkomen, in het artikel eene uitzondering voor drukwerken opnam".

Of een dergelijke ingreep - hoe elegant ook - werkelijk noodzakelijk was op grond van de jurisprudentie van de Hoge Raad, lijkt me de vraag. Zolang de bepaling maar niet op drukwerken werd toegepast, kon zij destijds zonder meer door de beugel, vermoed ik. En voor zover er drukwerk in het spel was, zou zij eenvoudig in zoverre buiten toepassing worden gelaten, aldus de eerdere jurisprudentie op dit punt; vgl. HR 1 november 1897, W. 7036 (Zuidbroek).

7. Helemaal uit de lucht kwam de gedachte van GS natuurlijk niet vallen. Nog maar vijf jaar eerder werd bijvoorbeeld het bekende Lantaarnpaal-arrest gewezen (HR 14 maart 1904, W. 8050), al evenzeer een symptoom dat de eigendom destijds een centrale positie innam.

8. Vgl. HR 26 mei 1902, W. 7780.

9. HR 2 juni 1903, W. 7936.

10. Beschikking van 3 juni 1909, WBA 3231 (20 mei 1911).

11. De filosofen onder ons zouden vermoedelijk vooral aandacht hebben gevraagd voor de logische structuur van het verbod. Immers, wanneer het verbod ingaat om zes uur 's avonds en niet is aangegeven wanneer het ophoudt, moeten we aannemen dat het voortduurt. Het verbod om na zes uur te venten, geldt dus (strikt genomen) ó́k vóór zes uur (althans nadat het voor de eerste keer na inwerkingtreding zes uur is geworden). In die (onbeoogde) zin gaat het m.a.w. om een absoluut verbod.

12. Het arrest van 11 februari 1892 werd genoemd; bedoeld was klaarblijkelijk de uitspraak van 1 februari 1892, W. 6928 over de APV van Olst (luid roepen of schreeuwen).

13. HR 4 april 1910, W. 9018 .

14. Een aanwijzing daarvoor is dat de advocaat-generaal o.a. naar het werk van Sybenga verwees (vgl. hoofdstuk 1, noot 144), Zelf had ik slechts de beschikking over de vijfde en zesde druk van diens boek over de grondwet van 1887; Ledeboer verwees naar de vierde druk. Het zou mij echter zeer verbazen wanneer de tekst 
op dit punt zou verschillen, aangezien Sybenga zijn opmerkingen maakte naar aanleiding van HR 23 juni 1902, W. 7802 en hij het arrest van 4 april 1910 in de latere drukken slechts noemde.

15. $\mathrm{Vgl}$. hoofdstuk 1 bij noot 145 .

16. Of hij zelf eveneens vond dat hij een subtieler standpunt innam, is overigens de vraag, gezien zijn uitdrukkelijke verwijzing op dit punt naai Sybenga en De Savornin Lohman. De laatste (Onze constitutie, 2e druk, p. 343, Utrecht 1907) schreef letterlijk (naar aanleiding van HR 7 november 1892):

"de overheid mag wel ter beveiliging van het openbaar verkeer het venten verbieden, mits maar niet hetzij eenig soort van geschrift in ' $t$ algemeen verboden, hetzij de verspreiding ervan van verlof afhankelijk gemaaki wordt. Een onvoorwaardelijk verbod om geschriften van welken aard ook op de openbare straat of in bepaald aangewezen straten te verspreiden, of die aan te plakken op plaatsen waarover het gemeentebestuur zelf het beheer heeft, schijnt derhalve geoorloofd". Ten tijde van de eerste druk van De Savornin Lohmans boek (in 1901) was zo'n standpunt wellicht nog te handhaven. In het licht van HR 26 mei 1902, W. 7780 en HIR 23 juni 1902, W. 7802 was dat inmididels (zoals gezegd) op z'n minst lastiger geworden. (De Savornin Lohman noemde deze arresten zelfs niet; hij beperkte zich tot de uitspraak over het Haags ventverbod; wel kon men uit zijn boek (p. 341) onder meer leren dat "de vrijheid voor allen (...) het gevolg (is) van de vrijheid, die den Christen toekomt").

17. HR 23 juni 1902, W. 7802 .

18. Zie HR 26 mei 1902, W. 7780 (Groningen).

19. In het Weekblad van het Recht staat "verbod"; ik houd dat voor een "kennelijke zetfout".

20. Frappant is dat de bewoordingen waarin de eerstvolgende schreeuw-en-roep-zaak door de Hoge Raad werd afgedaan grote overeenkomst vertoonden met de hier gebezigde frasen; zie FR 13 juni 1910, W. 9052 (Bussum).

21. HR 18 april 1910, W. 9027.

22. J. d'Aulnis de Bourouill, Het venten van drukwerk in het openbaar, Themis 1895 , p. 83. Hij wees, als mogelijke oplossing, op de Utrechtse bepaling (die ik al eerder ten tonele voerde): "Hij, aan wien bij eene volksverzameling op den openbaren weg door de politie gelast wordt zich uit de volksverzameling te verwijderen, is verplicht aan dien last onmiddellijk te voldoen". Geen fraaie waarborg tegen willekeur, vrees ik.

23. E. Diemer, Vrijheid van drukpers, p. 116, Rotterdam-Utrecht 1937. H. Vos gaf in Léon's Rechtspraak, deel 1, afl. 2 (Rechtspraak en literatuur op de Gemeentewet, 's-Gravenhage/ Leiden 1934), p. 284, een ongelukkige en daardoor onjuiste weergave van het arrest van 18 april. Hij schreef dat de Maastrichtse bepaling verbindend was "omdat deze bepaling, buiten het daarbij genoemde geval, onaangetast: laat de vrijheid om gedrukte stukken op elke andere plaats en op elke andere wijze, en zonder voorafgaand verlof, openlijk: te verspreiden". Die alternatieve plaatsen en wijzen golden natuurlijk niet alleen "buiten" het hier 
bedoelde geval, maar $66 k$ - en daar kwam het juist op aan! - in het hier bedoelde geval.

24. Zie onder 1.5 (bij noot 100 en 101).

25. HR 29 juni 1910 , W. 9062 (Hilversum).

26. Conclusie vó́r HR 29 juni 1910 , W. 9062.

27. HR 13 juni 1910, W. 9052 (Biussum). De advocaat-generaal verwees overigens niet naar dit arrest (dat geheel in de lijn van vorige arresten was).

28. Zie Gist. 2805 , no. 4 (1 juli 1905).

29. Vgl. HR 1 november 1897, W. 7036. De Hoge Raad overwoog toen ten aanzien van het te ruim geformuleerde ventverbod dat "hiervan het gevolg zal zijn, niet dat (het) in zijn gehee! verbindende kracht moet worden ontzegd, maar alleen dat het verbod niet verbindend moet worden geacht ten aanzien van de verspreiding van drukwerk". Ik zal, zoals ik al een paar keer eerder heb gezegd, in het kader van dît boek niet verder ingaan op de splitsingsproblematiek.

30. T. Sybenga, De Grondwet van 1887, 5e druk, p. 41, 's-Gravenhage 1913 (6e druk, 1921, p. 54).

31. E. Diemer, Vrijheid van drukpers, p. 117, Rotterdam-Utrecht 1937.

32. Vgl. HR 10 juni 1952 , NJ 1952,688 .

33. Vgl. HR 4 april 1910, W. 9018 (Maastricht).

34. Vgl. HR 2 oktober 1916, W. 10005 (Rosendaal).

35. J.M. de Meij (Uitingsvrijheid, p. 92, Amsterdam 1989) schreef - onder verwijzing naar HR 8 maart 1915, W. 9797 - sen onrechte dat de Hoge Raad "reeds in een uitspraak uit 1915 (...) prentbriefkaartenonder de werkingssfeer van artikel 7 (had) gebracht". In het betreffende arrest ging het uitdrukkelijk slechts om de vraag of het venten met prentbriefkaarten onder het tweede lid van het oude Rozendaalse (toen nog met een " $z$ ") ventverbod viel; dat wil zeggen: of in zo'n geval sprake was van "het te koop aanbieden of venten van gedrukte stukken". Dan was het verbod namelijk niet van toepassing. De Hoge Raad loste die vraag op door aan "gedrukte stukken" die betekenis te hechten, "die aan zoodanige stukken in het dagelijiksch leven wordt gegeven, dat is van stukken welker inhoud oor den druk is verveelvoudigd". Daarom vielen prentbriefkaarten, "dat ziji briefkaarten waarop een beeld, al dan niet met bijschrît, is afgedrukt, onder gedrukte stukken". Dus gold het ventverbod niet ten aanzien van prentbriefkaarten. En daarmee was de zaak uit! Konom: geen letter over art. 7 Gr.w. Wellicht heef De Meij zich laten misleiden door het subsidiaire onderdeel van het eerste middel en eroverbeen gelezen dat het hier geen overweging van de Hoge Raad betrof. Helaas is het niet de enige kwestie die in zijn boek slordig wordt afgedaan. Uit de formulering in dit arrest over Rosendaal blijkt in elk geval dat prentbriefkaarten slechts indien zij gedachten of gevoelens in gedrukte of geschreven vorm openbaarden, onder art. 7 Gr.w. werden gebracht. (Vgl. ook De Meij, a.w., p. 96).

36. HR 2 oktober 1916, W. 10005.

37. Zie bijvoorbeeld de Hilversumise zaak van zoëven, waarin het onvoorwaardelijke karakter van het verbod (wellicht) juist fataal bleek. De "stelling van Tak" werd niettemin opnieuw betrokken door de A-G Berger in zijn conclusie vóór HR 18 
november 1935, NJ 1936, 40; volgens hem "werd bij dit arrest de verbindende kracht aan voormelde verordening ontzegd op grond van het daarbij uitdrukkelijk gevorderde voorafgaande verlof". Waar dat precies uit bleek, zei de advocaatgeneraal er helaas niet bij.

38. Ik denk aan de voorgeschiedenis, die erop duidt dat de gemeente prentbriefkaarten uit het eerder bestaande tweede lid heeft gelicht, dat zeer in het algemeen een uitzondering maakte voor "het te koop aanbieden of venten van gedrukte stukken"; vgl. HR 8 maart 1915, W. 9797 waarin de Hoge Raad prentbriefkaarten als "gedrukte stukken." aanmerkte, zodat de verkoop daarvan niet verboden was. Door verplaatsing van "prentbriefkaarten" naar het eerste lid heeft men (naar ik aanneem) geprobeerd die verkoop alsnog te verbieden.

39. E. Diemer, a.w. (noot 31), p. 118, noemde het arrest slechts als b́n van de vele waarin "het eerder uiteengezette standpunt van den Hoogen Raad bleef gehandhaafd". P. Dresen, De vrije meningsuiting (Amsterdam 1949) en P.J. Boukema, Enkele aspecten van de vrijheid van meningsuiting in de Duitse Bondsrepubliek en in Nederland (Amsterdam 1966) gingen er zelfs aan voorbij. F.J.F.M. Duynstee (preadvies NJV 1949, p. 108), volstond met het weergeven van de twee belangrijkste overwegingen van het arrest, zonder ze van commentaar te voorzien. En - om nog één ander te noemen - C.F.J. Gombault (Communaal strafrecht, p. 83, Alphen aan den Rijn 1921) gaf een achtregelige samenvatting.

40. Zie HR 28 juni 1920, W. 10616. In de zaken van 8 maart 1915 (W. 9797) en 2 oktober 1916 (W. 10005) ging het om dezelfde "verdachte", te weten: "W.L.R., venter, geboren te Arnhem den 11 len Nov. 1896, wonende te Arnhem". Het arrest van 28 juni 1920 betrof een ander ("L.E.R., geboren te Arnhem, 10 mei 1903, en wonende aldaar"; wellicht staat de. "R" voor dezelfde familienaam - ik ben er niet voor afgereisd naar Den Haag om het uit te zoeken in het Rijksarchief).

41. Hij concludeerde in dit soort zaken tot dusverre altijd in het voordeel van gemeenten; er was in zoverre dus weinig nieuws onder de zon.

42. De advocaat-generaal leek hier te suggereren dat "verspreiden" geen vorm van "openbaarmaking" was. De jurisprudentie impliceerde echter het tegendeel!

43. Conclusie vóór HR 28 juni 1920, W. 10616.

44. Alweer zo'n dubbelzinnige uiting over de verhouding tussen art. 135 Gem.w. (oud) en art. $7 \mathrm{Gr} . w . !$ Of duidt deze zinsnede er toch op dat art. $7 \mathrm{Gr}$.w. hoogstens een grens aangeeft van wat een gemeente door middel van een - uiteraard! - bevoegd gegeven voorschrift vermag? Laat ik proberen mijzelf op dit punt niet telkens te. herhalen.

45. HR 28 juni 1920, W. 10616.

46. Vgl. HR 17 maart 1953, NJ 1953, 389 (Nuth). Eigenlijk begon de renaissance van deze gedachte al iets eerder, maar meestal wordt vooral Nuth in dit verband genoemd; zie verder hoofdstuk 4.

47. Geciteerd in de conclusie van A-G Van Lier vóor HR 5 november 1928, W. 11913 (Sanitas).

48. Des te opmerkelijker dat hier een ander adres genoemd werd dan aan de andere 


\section{zijde!}

49. Conclusie vó́r HR 5 november 1928, W. 11913.

50. Wat er verder ook zij van dit resultaat, het was volgens mij in elk geval niet in strijd met de bekende frase van de Hoge Raad (vgl. laatstelijk HR 28 juni 1920, W. 10616 , over de gemeente Rosendaal), waarin werd gesteld dat "de vraag of de openbare orde in de genoemde gemeente de voorgeschreven beperking vordert, betreft de doelmatigheid der verbodsbepaling, welke niet staat ter beoordeeling van de rechterlijke macht". De advocaat-generaal meende immers dat het voorschrift niet gezegd kon worden de openbare orde e.d. te betreffen; het was (volgens hem) dus, onmogelijk - kortom: geen kwestie van smaak (oftewel van "doelmatigheid").

51. P. Dresen, De Vrije meningsuiting, p. 174, Amsterdam 1949.

52. HR 5 november 1928, W. 11913 (Sanitas).

53. J.H.P.M. van der Grinten, De Hooge Raad en art. 7 der Grondwet, Gemeentebestuur, 1929, m.n. p. 72 e.v.

54. Een voorbeeld van verblinding! Ik sta - helaas - niet "boven" de personages die dit boek bevolken...

55. G. van den Bergh (Het openbaren van gedachten en gevoelens door de drukpers, Weekblad voor gemeentebelangen, 1939, p. 388) nam een ander standpunt in: "De befaamde Maastrichtse verordening verbood (ik bekort de inhoud zoveel mogelijk), geschriften, die tot bestemming hebben of geschikt zijn om onder bedekte termen bekend te maken adressen, waar op aanvraag verkrijgbaar zijn... enzv. ". Bestudering van de bepaling leert, zoals gezegd, iets anders. Het standpunt van Van den Bergh werd overigens gedeeld door Dresen (a.w., p. 173/4). Deze laatste verweet ie Hoge Raad bovendien dat hij "niet voldoende heeft weten te onderscheiden tussen de modus quo en het id quod" (een door Dresen geïntroduceerd onderscheid tussen respectievelijk de wijze waarop de inhoud wordt geopenbaard en de inhoud van het geopenbaarde). Hij constateerde, met andere woorden, een innerlijke tegenstrijdigheid. En daarvan maakte hij de Hoge Raad een verwijt. Vanuit zijn gezichtspunt lag dat tamelijk voor de hand: hij poneerde - zoals de meeste auteurs een eigen leer en pretendeerde niet een beschrijving van de jurisprudentie te geven. F.J.F.M. Duynstee (preadvies NJV, 1949, p. 112) verklaarde zich enerzijds "met Van den Bergh en Dresen accoord, dat de Maastrichtse verordening gericht was tegen gedrukte geschriften, welke een bepaalde strekking hebben". Anderzijds, echter, zag hij het arrest "als een der toepassingen van het stelsel van het arrest van 1910 (algemeen verbol niet toelaatbaar)". Ik kan daar weinig mee...

56. H. Vos (Ait. 7 der Grondwet, Weekblad voor gemeentebelangen, 1936, p. 66) noemde het arrest naderband nog steeds - zij het ongemotiveerd - "merkwaardig".

57. P.J.M. Kallen, Het openbaren van gedachten en gevoelens door de drukpers, Weekblad voor gemeentebelangen, 1939, m.n. p. 371 .

58. Vgl. HR 23 juni 1902, W. 7802.

59. G. van den Bergh, a.w. (́noot 55).

60. Van den Bergh was op zich gecharmeerd van het standpunt dat sommige stukken geen uitingen van "gedachten of gevoelens" behelsden. Dat bleek bijvoorbeeld uit een bijdrage die oorspronkelijk in NJB 1939, p. 724 e.v. verseheen (vgl. G. van 
den Bergh, Verzamelde staatsrechtelijke opstellen, I, m.n. p. 56-57): "Allereerst: het artikel heeft slechts betrekking op openbaarmaking van gedachten en gevoelens. Gedrukte aankondigingen van openbare verkopingen, handelsaanbiedingen, andere zuiver feitelijke mededelingen, enz. staan geheel buiten deze materie". In hoeverre dit overigens strookte met de stand van de jurisprudentie, is de vraag: zie HR 2 juni 1903, W. 7936. Het standpunt van Van den Bergh werd - naar mijn smaak overtuigend - bestreden door P.J. Oud (Handboek voor het Nederlands gemeenterecht, p. 221, Zwolle 1959): "Men kan de werkelijkheid openbaren met zeer propagandistische bedoelingen. Een foto van een rij krotwoningen geeft niet anders dan de werkelijkheid weer, doch kan gebezigd worden als uitdrukking van het gevoelen, dat een gemeentelijke overheid volkomen te kort is geschoten in haar taak om de belangen van de volkshuisvesting te behartigen. Dit kan zelfs gebeuren, als de foto in het geheel niet met die bedoeling is gemaakt". Onjuist is (volgens mij) tenslotte de opmerking van P.J. Boukema (Enkele aspecten van de vrijheid van meningsuiting in de Duitse Bondsrepubliek en Nederland, p. 113, Amsterdam 1966) dat de Hoge Raad in het geval van het Sanitas-verbod niet is toegekomen aan de beantwoording van de vraag of er "gedachten of gevoelens" in het geding waren. Die vraag moet wel bevestigend beantwoord zijn, omdat strijd met art. 7 Gr.w. anders onmogelijk was geweest! 
1. P.J. Oud (Handboek voor het Nederlands gemeenterecht, p. 221, Zwolle 1959) schreef naar aanleiding van HR 26 mei 1902 (W. 7780) in vergelijking met HR 21 maart 1938 (NJ 1938, 655): "In de gevallen, waarin het ging om aankondigingen, die naar 's Hogen Raads mening wel gevoelens openbaarden, kan ik intussen in zijn jurisprudentie niet veel lijn ontdekken".

2. HR 1 februari 1897, W. 6928.

3. Conclusie vóór HR 24 oktober 1932, W. 12580.

4. Vgl. de eerder vermelde missive van de minister van Binnenlandse Zaken d.d. 17 november 1903 (Gst. 2805, nr. 4), waarin een verbod, "zonder vergunning van den burgemeester", van "reclameborden" en "zichtbare teekenen" ongeoorloofd werd geacht. Opvallend is overigens dat de procureur-generaal in het geheel niet naar de "roep-en-schreeuw" uitspraken verwees; gold hier de oude wet van de retorica dat de parallel ogenblikkelijk ter discussie zou zijn gesteld door haar te noemen? (Vgl. J.P. Guépin, De beschaving, p. 109, Amsterdam 1983).

5. HR 24 oktober 1932, NJ 1932, 1755, W. 12580.

6. J.M. de Meij (Uitingsvrijheid, p. 101, Amsterdam 1989) schrijft naar aanleiding van (onder meer) dit arrest: "In de vooroorlogse jurisprudentie werden echter regelingen van de verspreidingsvrijheid geaccepteerd, zolang zij slechts een bepaalde wijze van verspreiden betroffen". Ik vind dat een voorbarige conclusie, die in elk geval geen recht doet aan de oudere jurisprudentie. Het probleem was veeleei dat sommige vormen niet als "wijze van verspreiden" (lees: "middel van openbaarmaking") werden aangemerkt. P. Dresen (De vrije meningsuiting, p. 219, Amsterdam 1949) was De Meij in dit opzicht voorgegaan; daarnaast meende hij - mede - op grond van het arrest over Rotterdam dat de Hoge Raad ertoe was overgegaan bepalingen te accepteren die een voorafgaand verlof eisten, zolang althans duidelijk was dat de vergunning alleen in verband met de "modus quo" (zie hoofdstuk 2, noot 55) kon worden geweigerd en dus niet vanwege de inhoud. Die conclusie lijkt mij in de eerste plaats te speculatief; tot het tegendeel blijkt, houd ik het erop dat de Hoge Raad niet van koers is veranderd. Bovendien lijkt de kans op een (verhuld) inhoudelijk oordeel mij in de Rotterdamse constructie niet bepaald denkbeeldig; Dresen, daarentegen, vond het "duidelijk, dat de vergunning hier enkel geweigerd kon worden in verband met de modus quo". Misschien bedoelde hij dat zo'n vergunning alleen dàn geweigerd mocht worden. Hij had zich - denk ik - laten inspireren door A.M. Donner, De leesbibliotheekverordeningen en de circulaire van 8 Januari 1948, Bestuurswetenschappen 1948, m.n. p. 166; de rechter had in dit geval, volgens Donner, opgemerkt dat de verspreiding niet werd belemmerd, maar alleen een bepaalde wijze van verspreiding werd uitgesloten.

7. HR 18 november 1935, NJ $1936,40$.

8. Vgl. resp. HR 26 mei 1902, W. 7780, HR 2 oktober 1916, W. 1005 en HR 28 juni 1920, W. 10616.

9. HR 26 mei 1902, W. 7780 .

10. Vgl. annotator Taverne in zijn noot onder het arrest: "En wat art. 7 Grondwet betref, moge met een korte opmerking worden volstaan. Dat de Hooge Raad het art. niet geschonden acht is met zekerheid te constateren. Anders ware het ontslag 


\section{(...) gehandhaafd (...)".}

11. HR 28 juni 1920 , W. 10616.

12. Zie J. Oppenheim (bewerkt door C.W. van der Pot), Het Nederlandsch gemeenterecht, deel I, 5e druk, p. 289, Haarlem 1928. Oppenheim behandelt deze materie zeer uitvoerig (en leesbaar!) op p. 387-412; zie deel III (1932), p. 62-68. Ten aanzien van vent- en plakverboden kon het oude art. 179 onder h Gem.w. wellicht uitkomst bieden: "Tot het dagelijksch bestuur der gemeente, aan burgemeester en wethouders opgedragen, behoort: (...) de zorg, zoover van ben afhangt, voor de instandhouding, bruikbaarheid, vrijheid en veiligheid der publieke wegen, bruggen, veeren, wateren, vaarten, straten, plantsoenen, pleinen en andere plaatsen, tot gemeene dienst van allen bestemd"; vgl. Oppenheim/Van der Pot, deel I, p. 389-399. Dan kwam de zaak als het ware "van nature" aan B en W toe en dankte het college zijn bevoegdheid niet aan de raad. In de daaropvolgende bladzijden worden nog meer voorbeelden gegeven van "'s Hoogen Raads leniger geworden standpunt tegenover het delegatie-vraagstuk" (p. 401). Maar er bleef reden tot twijfel "nopens den omvang van de speling, die de Hooge Raad (gedoogde)" (p. 403).

13. Vgl. HR 2 oktober 1916, W. 10005, waarin de Hoge Raad zich uitsprak over een eerdere versie van het Rosendaalse verbod: het venten was toen niet op alle tijdstippen verboden, maar de bepaling werd tòch onverbindend verklaard.

14. De zaak uit 1902 werd, opvallend genoeg, door Taverne in het geheel niet vermeld. Was het toeval dat ook de advocaat-generaal (Berger) er in zijn conclusie vóór het arrest geen melding van maakte? (Vgl. hoofdstuk 1, noot 137).

15. Zie HiR 8 november 1937 , NJ $1938,367$.

16. Zie noot 15. J.M. de Meij, Uitingsvrijheid, p. 96 (Amsterdam 1989), schreef naar aanleiding van onder meer deze zaak: "Uit de rechtspraak krijgt men de indruk dat de Hoge Raad met name commerciële reclame buiten de werkingssfeer van het drukpersartikel wilde houden, omdat anders een vergunningenstelsel voor bet plaatsen van borden met reclameteksten vrijwel onmogelijk zou zijn" "Deze verordening zag in elk geval niet in het bijzonder op commerciële reclame en ook Mussert werd in het algemeen niet als handelswaar gezien. Hoe De Meij aan zijn "indruk" is gekomen, is mij kortom een raadsel. Zie verder noot 30 .

17. HR 5 november 1928, W. 11913. Van Lier, die op 22 juni 1927 tot advocaatgeneraal werd benoemd, was ten tijde van de hier bedoelde conclusie dus nog maar betrekkelijk kort werk.zaam in zijn nieuwe ambt. Of het één met het ander verband hield, is natuurlijk een kwestie van gissen. $(\mathrm{Vgl}$. in verband met personalia: P.J. van Koppen en J. ten Kate, Tot raadsheer benoemd, p. 199, Arnhem 1987).

18. HR 24 oktober 1932, W. 12580.

19. De destijds "heersende" cassatie-cultuur werd wellicht verwoord door Taverne in zijn noot onder HR 18 november 1935, NJ 1936, 40 (p. 89, r.k.). Het lijkt een aanwijzing dat de Hoge Raad zich alleen verplicht achtte ergens uitdrukkelijk op in te gaan, als het ook uitdrukkelijk aan de orde was gesteld. Werd een vraag door de algemeenheid van het middel hooguit geïmpliceerd (zoals in casu), dan ging hij 
er - tenzij op die grond tot vernietiging moest worden besloten - vermoedelijk niet op in. Alle aandacht richtte zich dus op de toelichting van het (algemeen gestelde) middel.

20. Vgl. HR 24 oktober 1932, W. 12580. P.J. Boukema (Vrijheid van meningsuiting en artikel 7 van de Grondwet, RM Themis 1969, m.n. p. 125-126) koos - overigens zonder van enige andere optie melding te maken - voor deze variant.

21. Ik laat de in dat jaar tot stand gekomen grondwetsherziening buiten beschouwing. Oorspronkelijk werd daarbij tevens aan een aanvulling van art. 7 gedacht. Een discussie over de betekenis van het toenmalige art. 7 (vgl. het huidige art. 7 lid 1) was het gevolg. Sommigen betrokken bij die gelegenheid de (oude) stelling dat het artikel uitsluitend de invoering van censuur verbood; anderen kenden er een ruimere strekking aan toe. Ter vermijding van verdere controversen werd van indiening van een wijzigingsvoorstel afgezien. Een korte weergave van de gang van zaken is te vinden bij: J.M.H. Dassen, De grondwetsherziening 1938, p. 212-218 (Maastricht 1938, en H.F.J. Westerveld, Grondwetsherziening 1938, p. 6-7 (Amsterdam 1938). Ook de diverse handboeken bieden een beschrijving (soms zelfs beter!).

22. HR 18 november 1935 , NJ 1936,40 .

23. HR 26 mei 1902, W. 7780 .

24. In die zin: P.J. Oud, Handboek voor het Nederlands gemeenterecht, p. 221, Zwolle 1959.

25. HR 21 maart 1938, NJ 1938, 655. Het is misschien aardig op deze plaats te herinneren aan een al eerder genoemde missive van GS in Utrecht, gepubliceerd in WBA 3129 (5 juni 1909). Gedeputeerde staten verklaarden in dit schrijven een soortgelijke bepaling als in Oss, zij het dat toen alleen "door den gemeentebode" (maar "zonder onderscheid") mocht worden geplakt, in strijd met art. 7 Gr.w. De omstandigheid dat het volgens deze bepaling verboden was "inededeelingen te doen door aanplakking aan eigen voorwerpen" was volgens GS fataal. Dat standpunt is nu klaarblijkelijk niet overgenomen door de Hoge Raad. Ook het verbod in Oss strekte zich immers uit over "eigen voorwerpen"; de plakker in kwestie had wellicht het raam van zijn eigen woning beplakt. (Vreemd, trouwens, waar het motief van de bepaling niet op bescherming van het stadsschoon zag, op grond waarvan aantasting van onder meer bet eigendomsrecht nog enigszins te begrijpen zou zijn geweest, maar vermoedelijk louter op handhaving van de openbare orde; zie voorts HR 31 oktober 1938, NJ 1939, 206, hierna te bespreken).

26. Vgl. HR 28 jtini 1920, W. 10616 . Het al dan niet bestaan van een uitvoeringsvoorschrift kon nog wel worden vastgesteld door de Hoge Raad. Maar de vaststelling of er wellicht zo weinig straten waren aangewezen dat "gezegd kon worden" dat het middel "metterdaad" niet meer benut kon worder, was van feitelijke aard. In die zin was er verschil met de situatie in Rosendaal, waar het ging om de vraag of voldoende tijd beschikbaar was.

27. Ik schreef: "in dit geval". Wanneer er uitdrukkelijk verweer op was gevoerd, lag het anders, vermoed ik. Bovendien bestaat de mogelijkheid dat een feitelijke vaststelling van een en ander in dit geval was af te beiden uit de (niet 
gepubliceerde) bewijsmiddelen.

28. Zie de conclusie van A-G Rombach vó́r HR 31 oktober 1938, NJ 1939, 206.

29. HR 8 november 1937 , NJ 1938, 367.

30. Conclusie vór HR 31 oktober 1938, NJ 1939, 206. Opvallend is in dit verband dat De Meij (vgl. noot 16) juist dit arrest als tweede - en laatste - zaak noemt ter staving van zijn eerder genoemde "indruk dat de Hoge Raad met name commerciële reclame buiten de werkingssfeer van het drukpersartikel wilde houden" (Uitingsvrijheid, p. 96). De Hoge Raad kwam in deze zaak aan de door De Meij bedoelde kwestie in het geheel niet toe, zoals dadelijk zal blijken!

31. In HR 7 november 1892 (W. 6259) wees de Hoge Raad erop dat "niets gemakkelijker zoude vallen dan het grondwettelijke voorschrift door verschillende bepalingen in rijkswetten en gemeenteverordeningen, ieder op zich zelve beperkt tot enkele daarbij aangewezen middelen van openbaarmaking, geheel te verijdelen". In deze zaak uit 1938 zien we hoe eenvoudig het was een middel van openbaarmaking "geheel te verijdelen" door verschillende bepalingen in wetten, provinciale en gemeenteverordeningen, "ieder op zich zelve beperkt tot enkele daarbij aangewezen" plaatsen of tijdstippen. Het criterium dat zo'n middel "metterdaad" gebruikt moest kunnen worden, had enig soelaas kunnen bieden.

32. Een geheel andere opvatting over de reikwijdte van art. $7 \mathrm{Gr}$.w. werd enkele jaren later door G. van den Bergh verkondigd (zie G. van den Bergh, Verzamelde staatsrechtelijke opstellen, deel I; p. 42-43, Alphen aan den Rijn 1949. Oorspronkelijk gepubliceerd in NJB 1940).: "Wanneer een schrijver (wat in de tegenwoordige tijd ongebruikelijk en onpraktisch, maar daarom toch niet onmogelijk is) zijn pennevruchten vermenigvuldigt door ze zelf al dan niet met een schrijfmachine, al dan niet bij ến exemplaar tegelijk, over te schrijven (of ze door anderen te laten overschrijven) en ze daarna laat verspreiden, $z a l$ hij ten volle de bescherming van artikel 7 van de Grondwet genieten. Niemand, die eraan twijfelt. Ja, zelfs het vermenigvuldigen is geen essentieel element. Wanneer de auteur slechts één exemplaar schrijft, en dit als een 'vliegend blaadje' van hand tot hand laat gaan, of woorden, die gedachten of gevoelens uitdrukken, met grote letters op een bord geschilderd, boven de menigte uitdraagt, zal hij nog steeds de bescherıning van artikel 7 genieten" (curs. RdW). De samenvatting die P.J. Boukema (Enkele aspecten van de vrijheid van meningsuiting..., p. 137, Amsterdam 1966) van zijn opvatting geeft, is niet echt gelukkig te noemen. "In het kort" kwam Van den Bergh's opvatting er volgens Boukema op neer, "dat het enige criterium voor de toepasselijkheid van art. 7 is, of de: openbaring is geschied op een wijz.e die èn plaats èn tijd overwint". Op p. 48 a.w. betoogt Van den Bergh echter precies het tegendeel! Hij schrijft daar: "Of een openbaring van gedachten en gevoelens tijd en plaats overwint, is volkomen accidenteel gevorden; het heeft iedere essentiële betekenis verloren". Eerder ( $t . w$. in het Weekblad voor gemeentebelangen 1939 , p. 388) schreef Van den Bergh echter: "Het enige werkelijke kriterium, dat voor de toepasselijkheid van art. 7 beslissend is, is dit: of de openbaarmaking is geschied op een uvijze die èn plaats èn tijd overwinnen kan". 
33. HR 31 oktober 1938, NJ 1939, 206 (AB 1939, 580).

34. HR 8 november 1937, NJ 1938, 367. W.F. Prins ging er kennelijk vanuit dat beide arresten dezelfde boodschap behelsden; vgl. zijn noot onder HR 24 januari 1967, NJ 1967, 270 (Nederland ontwapent).

35. In HR 24 oktober 1932 (W. 12580, NJ 1932, 1754) was, zoals gezegd, een verbod geaccepteerd dat beperkt bleef tot het met reclamemiddelen rijden, gaan of staan. Achteraf bezien wellicht een aanwijzing dat inderdaad de beperktheid van het verbod de doorslag gaf.

36. HR 7 november 1938, NJ 1939, 269.

37. HR 29 juni 1910, W. 9062 . Ook volgens de eerder besproken Zaanse bepaling was het "bekendmaken" al aan banden gelegd, zij het niet onvoorwaardelijk; bovendien was het "bekendmaken" in de zaak over die bepaling niet bewezen verklaard: zie HR 18 november 1935, NJ 1936, 40.

38. Zie zijn conclusie vóór HR 7 november 1938, NI 1939, 269. W. Pompe plaatste dit arrest (in zijn noot onder HR 31 mei 1939, NJ 1939, 769: Heerenveen) op één lijn met HR 24 oktober 1932 (W. 12580: Rotterdam) en HR 21 maart 1938 (NJ 1938, 655: Oss), "omdat de daarin vervatte verboden beperkt zijn tot bepaalde middelen (reclamemiddelen), wijzen van aanbieden (luid roepen of schreeuwen), of middelen en plaatsen". De ordening die men ontwaart, is kennelijk sterk afhankelijk van het beginpunt dat men kiest - maar waarom wordt welk beginpunt gekozen?

39. HR 14 november 1938, NJ 1939, 268.

40. Vgl. HR 28 juni 1920, W. 10616.

41. Dat het arrest van 26 mei 1902 (W. 7780) over het Groningse plakverbod inmiddels "overruled" was, bleek, zoals gezegd, al eerder uit de zaak over het Zaanse ventverbod (HR 18 november 1935, NJ 1936, 40). F.J.F.M. Duynstee (preadvies NJV 1949, p. 109-110) plaatste het Zaanse en het Arnhemse ventverbod op één lijn; merkwaardigerwijs meende hij dat de Hoge Raad zich in het arrest over het Zaanse verbod niet had uitgesproken over "de vraag hoever de raad mag gaan met beperkingen ten aanzien van de tijd en plaats". Of in het Arnhemse geval trouwens "gezegd kon worden" dat het openbaringsrecht "metterdaad" was "opgeheven", hing gedeeltelijk (namelijk ten aanzien van de aangewezen straten) af van de feitelijke situatie ter plekke; daar kon de Hoge Raad geen onderzoek naar doen, maar hij kon wel vaststellen dat niet was gebleken dat "gezegd kon worden" etc.

42. HR 31 mei 1939 , NJ 1939, 769.

43. G. van den Bergh, Artikel 7 Grondwet en de lagere wetgever, in: G. van den Bergh, Verzamelde staatsrechtelijke opstellen, deel I, p. 50, Alphen aan den Rijn 1949. (Oorspronkelijk in NJB 1939, p. 724).

44. De verhouding tussen art. 220 en 168 gem.w. was destijds omstreden. Volgens Oppenheim waren de voorschriften van de burgemeester na beksachtiging door de raad aan te merken als gewone verordeningen van de raad; Van der Pot dacht daar anders over: "Ik acht dit laatste niet juist", schreef hij. "De voorschriften blijven m.i. voorschriften van den burgemeester, bekrachtigd door den raad. Ware het 
anders, men zou slechts door een geforceerde interpretatie ook na de bekrachtiging de strafbepaling van art. 443 Wetboek van Strafrecht nog toepasselijk kunnen achten en bovendien zou dan niet de burgemeester de voorschriften weer kunnen intrekken, als de buitengewone omstandigheden naar zijn oordeel hebben opgehouden te bestaan, maar zoti dan daarvoor een raadsverordening noodig zijn, welker van kracht worden altijd eenigen tijd vordert". Zie J. Oppenheim, Het Nederlandsch gemeenterecht, 5e druk (bewerkt door C. W. van der Pot), deel 2, P. 319 , Haarlem 1928. J.W.A.C. van Loenen, De gemeentewet en haar toepassing, 20 druk, p. 823, verwijst naar deze zelfde passage, doch neemt zelf - zoals meestal geen standpunt in (Alphen aan den Rijn 1934).

45. Is. Coopman, Art. 7 der Grondwet en de lagere wetgever, NJB 1939, p. 774.

46. F.J.F.M. Duynstee, Preadvies NJV 1949, p. 112.

47. W. Pompe, noot onder het arrest.

48. C.W. van der Pot, Handboek van het Nederlandsche staatsrecht, p. 395, Zwolle 1940.

49. F.M.J. Jansen, Hooge Raad en drukpersvrijheid, NJE 1939, p. 857 e.v.

50. J. Zaaijer, De Heerenveenschenoodverordeningen de drukpersvrijheid, NJB 1939, p. 704 e.v.

51. C.Ch.A. van Haren, Noodeloos alarm bij artikel 7 der Grondwet, Weekblad voor gemeentebelangen 1939 , p. 361 e.v.

52. G. van den Bergh, Artikel 7 der Grondwet, S.O.S., Weekblad voor gemeentebelangen 1939 , p. 377.

53. G. van den Bergh, Artikel 7 Grondwet en de lagere wetgever. Opgenomen in $\mathrm{G}$. van den Bergh, Verzamelde staatsrechtelijke opstellen, m.n. p. 51, Alphen aan den Rijn 1949. (Oorspronkelijk NJB 1939).

54. C.W. van der Pot, a.w. (noot 48), p. 395-396.

55. P. Dresen, De vrije meningsuiting, p. 177 e.v., Amsterdam 1949. Idem: F.M.J. Jansen, Artikel 7 der Grondwet en de gemeentelijke strafverordening, De Nederlandse gemeente 1948, p. 385; volgens deze laatste auteur "dekt de H.R. zeer positief het betoog van de Rechtbank" - hij las duidelijk te veel in het woordje "terecht", zoals hierna zal blijken.

56. Zie noot 44.

57. J. Zaaijer, a.w. (noot 50), p. 705.

58. C.Ch.A. van Haren, a.w. (noot 51), p. 363.

59. HR 24 oktober 1932, W. 12580.

60. HR 8 november 1937 , NJ $1938,367$.

61. HR 31 oktober 1938, NJ 1939, 206.

62. HR 14 november 1938, NJ 1939, 268.

63. Zie G. van den Bergh, naschrift bij F.M.J.Jansen, a.w. (noot 49), p. 860.

64. G. van den Bergh, Nogmaals: de drukpersvirijheid en de gemeentelijke verordening, Verzamelde staatsrechtelijke geschriften, deel I, p. 60-61. Alphen aan den Rijn 1949. (Oorspronkelijk: NJB 1946).

65. F.M.J. Jansen, a.w. (noot 49), p. 858. Van Haren (a.w., noot 51, p. 362) schreef: 
"Het doel, dat met het voorschrift werd nagestreefd, mag niet uit het oog worden verloren. Het is hetzelfde dat bij de colportageverboden voorzit. Met een dergelijk verbod beoogt men niet b.v. een politieke partij te verhinderen staatkundige inzichten te verkondigen, of gedachten of gevoelens te openbaren. Het doel is relletjes te voorkomen, de rust op straat te verzekeren enz." .

66. J.G. Westra van Holthe, De gemeentebesturen tegenover de artikelen 7 en 9 van de Grondwet, p. 32, Leiden 1893.

67. J.J. van Riemsdijk Kreenen, Het venten op de openbare straat, p. 18, Leiden 1895.

68. Zie noot 53. A.M. Donner (De leesbibliotheek-verordeningenen de circulaire van 8 Januari 1948, Bestuurswetenschappen 1948, p. 163) zag het heel anders; alsof hij het alleenrecht op nauwkeurigheid had, schreef hij tien jaar later: "Wie het omstreden arrest van 31 Mei 1939 nauwkeurig leest, bemerkt wel dat de H.R. niet spoedig geneigd is aan te nemen dat het belang van de openbare orde een verspreidingsverbod van bepaalde drukwerken vereist. Alleen omdat de burgemeester hier gebruik maakte van de hem bij art. 220 Gemeentewet gegeven bevoegdheden, en dus moest worden aangenomen dat zich een geval van stoornis der openbare orde voordeed, was de rechter bereid de Heerenveense verordening te accepteren". Hoe wist Donner dat zo zeker? Uit het arrest was het niet af te leiden; andere omstandigheden dan de in art. 220 bedoelde, waren eenvoudig niet aan de orde, en daar viel dus niets over te zeggen. Of hadden we hier te maken met een "subjectief aan wet en rechtspraak ten grondslag gelegde constructie" (vgl. p. 162) van Donner, waar hijzèlf - als het anderen betrof - zo op afgaf? Misschien had hij het van zijn vader begrepen, die het arrest immers als raadsheer had mede-ondertekend.

69. C.Ch.A. van Haren, a.w. (noot 51), p. 362-363.

70. Het gebeurde wel vaker dat de Hoge Raad zich over méér uitsprak dan gezien de bewezenverklaring noodzakelijk was; zie bijvoorbeeld HR 24 oktober 1932 (W. 12580: Rotterdams ventverbod), waarin de Hoge Raad zich niet alleen over het "roepen" uitsprak, dat bewezenverklaard was, maar tevens over het "met reclamemiddelen rijden, gaan of staan"; de bepaling werd als één geheel beoordeeld. Ook Dresen, a.w. (noot 55), p. 178-179, wees de door Van Haren gesuggereerde splitsing overigens af, maar hij beriep zich daartoe op bet eerste onderdee! van de derde overweging van het arrest over Heerenveen; ten onrechte, lijkt mij, want dat onderdeel (zie verder) behelst slechts een algemene stelling, die niet is toegesneden op het verbod in kwestie. Tenslotte - ik doe maar een greep, want in werkelijkheid was van een geordend debat geen sprake - werd de zienswijze van Van Haren eveneens verworpen door de A-G van Asch van Wijek in diens conclusie vóór HR 28 november 1950, NJ 1951, 137 (p. 262, l.k.); hij wees erop "dat de overwegingen van het arrest zo ruim zijn dat daaruit niet anders gelezen kan worden dan dat mede aan de lagere wetgever bevoegdheden zijn gegeven ten aanzien van het id quod" (oftewel: ten aanzien van de inhoud van bet geopenbaarde).

71. De stand van zaken was naar mijn mening heel wat minder "bewonderenswaardig" dan Van den Bergh hem afschilderde; vgl. noot 43. De zonnige visie van Van den Bergh had wellicht vooral een retorische functie. Het arrest over Heerenveen 
opende immers ongetwijfeld de mogelijkheid voor veel verdergaande beperkingen (al hoefde het daar niet noodzakelijkerwijs toe te leiden). Ter voorkoming van een dergelijke ontwikkeling bepleitte Van den Bergh - in een soort partizanenstrijd een jurisprudentie die daar minder aanknopingspunten voor bood. En inderdaad, vóor 1939 zou men niet gauw op de gedachte zijn gekomen dat de door Van den Bergh genoemde voorbeelden mogelijkerwijs door de Hoge Raad geaccepteerd zouden worden. Zijn artikel eindigt dan ook met de wens: "Moge de Hoge Raad spoedig terugkeren naar zijn oude beproefde jurisprudentie". Een gedegen, conservatieve pose, kortom. Of ben ik oneerlijk?

72. Vgl. het verbod van de gemeente Oss, waarover de HR zich op 21 maart 1938, (NJ 1938, 655) uitsprak.

73. J. Zaaijer, a.w. (zie noot 50), p. 705.

74. F.M.J. Jansen, a.w. (zie noot 44), p. 858.

75. Vgl. J.H.P.M. van der Grinten, De Hooge Raad en art. 7 der Grondwet, Gemeentebestuur 1929,p. 71 e.v. Ook J. Snoep, Artikel 7 der Grondwet (NJB 1939, p. 715) en P. Dresen, a.w. (noot 55), p. 177, wezen op de voortrekkersrol die Van der Grinten in dit. opzicht had gespeeld.

76. G. van den Bergh, a.w. (noot 53), m.n. p. 53 e.v.

77. P.J. Boukema, Vrijheid van meningsuiting en artikel 7 van de Grondwet, RM Themis 1969 , m.n. p. 129. Eerder had hij iets soortgelijks in zijn proefschrift betoogd: zie P.J. Boukema, Enkele aspecten van de vrijheid van meningsuiting in de Duitse. Bondsrepubliek en in Nederland, p. 128-130 (Amsterdam 1966).

78. Vgl. J. van der Hoeven, Het juridisch luistercollege, AA 1974, p. 21.

79. Resp. J.H.P.M. van der Grinten, a.w. (noot 75) en C.W. van der Pot, a.w. (noot 48), p. 395-396. Later viel m.n. F.J.F.M. Duynstee, a.w. (noot 46, p. 112-113, hem bij, zij het impliciet.

80. Een verre - maar naar ik vrees "onechte" - "nazaat" van Van der Pot toonde zich in dit opzicht A.F.M. Brenninkmeijer, Van drukpersvrijheid tot informatievrijheid, in: Grondrechten (Jeukensbundel), m.n. p. 180, Nijmegen 1982. Zelf noemde Brenninkmeijer zich "in academische zin" het achterkleinkind van Van der Hoeven (en het kleinkind van Prakke; vgl. A.F.M. Brenninkmeijer, Constitutioneel toetsingsrecht als vraagstuk van constitutioneel recht, NJB 1992, m.n. p. 725). Van der Hoeven is, op zijn beurt, een academische nakomeling van Van den Bergh. Van der Pot en Van den Bergh onderhielden echter, voor zover ik weet, geen academische familieband. Sterker, in het eerste deel van het Biografisch woordenboek van Nederland ('s-Gravenhage 1979) lees ik op p. 41 dat Van den Bergh in. 1936 slechts als nummer twee op de voordracht voor het hoogleraarschap stond. Maar: "bij de stemming (in de gemeenteraad, RdW) werden op de als eerste voorgedragene, prof. C.W. van der Pot (curs. RdW), 16 stemmen uitgebracht, terwijl Van den Bergh 26 stemmen verwierf, namelijk die van de sociaal-democraten, de communisten en enkele andere raadsleden". Beiden bleven elkaar over en weer publiekelijk overigens zeer vriendelijk bejegenen. Brenninkmeijers "misstap" zij hem dus vergeven... Zèlf zag Van der Pot. er sinds de zesde druk van zij 
handboek (1957) van af zijn opvatting over het wetsbegrip in art. 7 te memoreren. Boukema, a.w. (proefschrift, zie noot 77), p. 119, schaarde zich niettemin in 1966 nog achter Van der Pot.

81. G. van den Bergh, a.w. (zie noot 64), p. 59-60.

82. Vgl. HR 28 juni 1920, W. 10616 (Rosendaal). Of dit criterium voor ieder "middel van openbaarmaking" afzonderlijk gold, dan wel voor het openbaarmaken in het algemeen, was inmiddels - zoals eerder bleek - onduidelijk geworden. 
1. Vrij Nederland, 17 mei 1945 (achterpagina).

2. $\mathrm{Vgl}$. G. van den Bergh, Gemeentelijke bibliotheekverordeningenen de Grondwet, Verzamelde staatsrechtelijke geschriften, deel I, p. 63. (Oorspronkelijk: De Gemeente, 1947).

3. Tom Lanoye, Een slagerszoon met een brilletje, p. 55 e.v., Amsterdam 1985.

4. A.M. Donner, De leesbibliotheekverordeningen en de circulaire van 8 Januari 1948, Bestuurswetenschappen 1948, m.n. p. 167.

5. A.M. Donner, Het wetsontwerp op de leesbibliotheken II, T.v.O. 1949, p. 98.

6. A.M. Donner, a.w. (noot 4), p. 163.

7. F.M.J. Jansen, Artikel 7 der Grondwet en de gemeentelijke strafverordening (De Nederlandse Gemeente 1948, p. 586).

8. Vgl. A.M. Donner, a.w. (noot 4), p. 169-170 (Bijlage II).

9. A.M. Donner, a.w. (noot 4), p. 165.

10. G. van den Bergh, a.w. (noot 2), p. 65.

11. G. van den Bergh, a.w. (noot 2), p. 65. Het leek erop dat hij "Heerenveen" eenvoudig niet als recht erkende. "Het arrest neemt een uitzonderingspositie in", schreef P.J. Boukema (Enkele aspecten van de vrijheid van meningsuiting in de Duitse Bondsrepublieken in Nederland, p. 133, Amsterdam 1966) later. Nog geen reden om het te negeren, natuurlijk. Uitzonderingen bevestigen de regel immers niet.

12. A.M. Donner, a.w. (noot 4), p. 162.

13. G. van den Bergh, De leesbibliotheekverordeningen, Verzamelde staatsrechtelijke opstellen, deel I, p. 70. (Oorspronkelijk: Bestuurswetenschappen 1948).

14. G. van den Bergh. a.w. (noot 13), p. 73-74.

15. D. Graevestein van Heyst, Het venten van geschriften op den openbaren weg als strafbaar feit beschouwd, p. 44, Zutphen 1894.

16. J.J. van Riemsdijk Kreenen, Het venten van drukwerk op de openbare straat, p. 16, Leiden 1895.

17. Zie HR 20 juni 1950 , NJ 1950, 619 (Breda).

18. Vgl. bijv. H.D. van Wijk, Niemand heeft voorafgaand verlof nodig..., in: H.D. van Wijk, Besturen met recht, p. 177 e.v. (Corspronkelijk: De Nederlandse Gemeente 24 juni 1960, nr. 26).

19. Ik denk m.n. aan HR 27 oktober 1981, NJ 1982, 103 (Nijmegen).

20. Zie A.M. Donner, a.w. (noot 4), Bijlage I (p. 168).

21. A.M. Donner, a.w. (noot 4), p. 166.

22. KB 11 mei 1948, S. 184, AB 1948, 642.

23. J.M. de Meij (Uitingsvrijheid, p. 101, Amsterdam 1989) ziet in het KB-Brunssum een terugkeer van het "Heerenveense arrest", nu de inhoud toch opeens weer taboe bleek te zijn voor de lagere wetgever. In de eerste plaats, echter, ging het hier om een besiissing van een andere instantie, zodat moeilijk van een "terugkeer" kan worden gesproken. In de tweede plaats volgde - zoals gezegd - uit de Heerenveense zaak niet noodzakelijkerwijs dat. de inhoud nooit taboe zou zijn voor lagere wetgevers. En in de derde plaats ging het in Heerenveen niet om preventief 
roezicht, maar om een repressieve maatregel. De Brunssumse bepaling opende bovendien de mogelijkheid van censuur, dat wil zeggen dat voor opname in de coilectie toestemming van de overheid nodig was; in dat geval is het passeren van de censor zèlf a! aanleiding tot overbeidsingrijpen. De conclusie (nou ja, De Meij suggereert meer dan hij concludeert, want hij stelt slechts een - door hemzelf niet beantwoorde - vraag, dat het tij gekeerd was, of althans bezig was te keren, lijkt mij met ander woorden voorbarig. Vgl. in dit verband tevens $G$. van den Bergh, Artikel 7 der Grondwet en de gemeentelijke strafvervolging (De Nederlandse Gemeente, p. 509; het stuk is abusievelijk met F.M.J. Jansen ondertekend, hoewel het juist een reactie van Van den Bergh op Jansen betreft), waarin eveneens gewezen wordt op het preventieve karakter van de Brunssumse bepaling (in tegenstelling tot die van Heerenveen).

24. Conclusie v6or HR 10 juni 1950, NJ 1950, 619.

25. Zie HR 28 juni 1920 , W. 10616 . De vraag rijst opnieuw of dit punt niet toegespitst behoonde te worden op het middel van openbaarmaking (venten), in plaats van op het verspreiden in het algemeen (dat meer dan éen middel betreft). Ik volsta hier - na alle eerdere uitweidingeia hierover - met het stellen van de vraag.

26. HR 20 juni 1950 , NJ 1950, 619.

27. Het gaat in elk geval niet om een zelfstandige vaststelling van de Hoge Raad - de Hoge Raad stelt immers geen feiten vast, althans niet voor zover daartoe bekendheid ter plekke vereist. is.

28. Dat de Hoge Raad de regeling eerst los van de dispensatiemogelijkheden beoordeeldie, blijkkt niet alleen uit de eerder aangehaalde overwegingen, maar ook uit het feit dat de Hoge Raad het in de laatst aangehaalde overweging over "een geldige regeling" heeft, waarop de nader te bespreken "dispensatiebevoegdheid " betrekking heeft.

29. H.D. van Wijk, a.w. (noot 18), p. 182, had het over "een wel heel gering minimum" dat "door de Hoge Raad als voldoende (werd) aanvaard".

30. P.J. Boukema, a.w. (noot 11), p. 123. Wellicht zag Boukema over het hoofd dat - in elke geval formeel - in Breda (anders dan in 1892 in Den Haag) geen "volstrekt verbod" gold om, "zonder vergunning (...), gedrukte stukken op de openbare straat aan te kondigen, te venten, te verspreiden of te koop aan te bieden". Wal kon het verbod feitelijk - maar daar kon de Hoge Raad niet over cordelen - vermoedelijk met een dergelijk verbod gelijk worden gesteld (zeker in het licht van (atere jurisprudentie!). Dat lijkt mij echter iets anders. J.M. de Meij, a.w. (noot 23), p. 107, vergelijkt de overweging over de "possibilité de détournement de pouvoir" met het latere arrest over het ondertitelingsverbod (HR 11 december 1987, NJCM-Bulletin 1988, p. 121). Het laatste komt er veel beter af, maar het lijkt mij een vergelijking van appels en peren. In Breda ging het om een ontheffingsmogelijkheid van een op zich acceptabel verbod; er kon dus ook buiten het verbod om nog voldoende gevent worden. In de ondertitelingszaak was er eenvoudig geen andere weg beschikbaar dan die via het vragen van toestemming.

31. Vgl. K.B 11 mei 1948, S. 184, AB 1948, 642.

32. HR 28 november 1950, resp. NJ 1951, 137 (Tilburg), 138 (Sittard I), 369 (Sittard 
II).

33. In "Tilburg" was het OM in cassatie gekomen (tegen een ontslag van rechtsvervolging), in de Sittardse zaken de verdachte (tegen een veroordeling) - de ene keer mèt cassatiemiddelen, de andere keer zonder (wat ertoe leidde dat de Hoge Raad in dat geval ambtshalve casseerde). Daardoor zijn de arresten telkens iets anders opgebouwd. Materieel kan ik nauwelijks verschil ontwaren; op sommige punten lijkt "Sittard I" iets stelliger dan "Tilburg", terwijl bovendien één overweging in "Sittard I" van een extra - zij het weinig overtuigend - argument is voorzien. Later méér hierover.

34. Voor zover het Tilburgse verbod mér behelsde dan het Sittardșe, heb ik dat tussen haakjes weergegeven.

35. Conclusie vóor HR 28 november 1950, NJ 1951, 138 (Sittard II), p. 267 (l.k.).

36. Èr waren ook destijds al meer verlichte opvattingen in omloop; zie bijv. Leo Polak, Sexuele ethiek, Amsterdam.1936. Ook dit geschrift ging overigens mank aan de cultus van het Hogere, waarover Marcuse (zie hierna) zo aardig schreef.

37. Ludwig Marcuse, Obsceen, De geschiedenis van een verontwaardiging, p. 312, Amsterdam 1966. (Ik beschik helaas alleen over een Nederlandse vertaling van dit in 1962 verschenen boek).

38. P. Dresen, De vrije meningsuiting, p. 171, Amsterdam 1949. Het arrest kan inderdaad op die manier worden gelezen, maar het is - zoals hiervóór bleek - zeker niet de enige mogelijkheid, lijkt mij.

39. Conclusie vóór "Tilburg" (NJ 1951, 137, p. 260 r.k.). Meer dan Dresen poneerde Van Asch van Wijk zijn opvatting als een hypothese ter verklaring van de rechtspraak tot Heerenveen; ik denk dat het - gezien die rechtspraak - inderdaad een mogelijke hypothese is. Ook met deze "verklaring" blijven de uitkomsten echter moeilijk voorspelbaar; wèl kunnen ze op die manier achteraf onder één noemer worden gebracht. F.H. Kistenkas (Vrije straatcommunicatie, p. 21, Amsterdam 1989) meent dat "deze variatie van de A-G op Dresen" vervolgens door de Hoge Raad is overgenomen; ten onrechte, zoals we nog zullen zien.

40. Let wel: ook in HR 7 november 1892 (W. 259) werd in dit. verband heel in het algemeen van "het openbaar gezag." gerept; pas later kwam "de bevoegdheid van den gemeentelijken wetgever" ter sprake.

41. Conclusie voúr "Sittard I" (NJ 1951, 138, p. 267, r.k.).

42. Conclusie vóór "Sittard I" (NJ 1951, 138, p. 267, r.k.).

43. HR inzake "Tilburg" (NJ 1951, 137).

44. G. van den Bergh, Bona causa triumphat. G. van den Bergh, Verzamelde staatsrechtelijke opstellen, deel II, p. 77, Alphen aan den Rijn 1952. (Oorspr. NJB 3 maart 1951).

45. HR inzake "Tilburg" (NJ 1951, 137).

46. G. van den Bergh, a.w. (noot 44), p. 76.

47. Ik volg hier de versie van "Tilburg"; waar zich - naar mijn oordeel - relevante afwijkingen yoordoen van "Sittard I", maak ik daar melding van.

48. HR 7 november 1892, W. 6259. 
49. J. van der Hoeven (De plaats van de Grondwet in het constitutionele recht, p. 232-233, Zwolle 1958) meende dat het onderscheid tussen "uiten" en "bekendmaken" ertoe strekte "om de geschreven grondwetstekst te eerbiedigen, door toepassing van het grondrecht, dat ruimer is dan het grondwetsartikel, voorzover mogelijk uit dit grondwetsartikel te motiveren, en voor de toepassing waarbij zulks niet doenlijk is, het normatief verband met de wetstekst zo nauw mogelijk te leggen. Een rechtstoepassing dus, nauw aansluitend aan het wetsartikel en, voorzover van verder strekking, toch de grenzen van dit artikel onaangetast latend". Ik vind dit niet erg overtuigend, moet ik zeggen. In dat opzicht bood het arrest van 1892 een veel fraaier yoorbeeld, lijkt mij. In 1950 werd juist afstand genomen tot de grondwetstekst!

50. NJ 1951, 138, p. 266 (l.k.).

51. Vervolgens kreeg, in dit arrest de overweging over de gemeentelijke bevoegdheid tot beperking (wederom eindigend met "bepaaldelijk ter beveiliging van het openbaar verkeer") haar plaats. Alleen, deze keer stond er niet "dan ook" (of iets dergelijks) maar "echter" - alsof we met een tegenstelling te doen hadden. De Hoge Raad maakte het zijn lezers waarachtig niet makkelijk; geen wonder dat zelfs Van den Bergh afhaakte. Anderen wekken de indruk de raad van Van den Bergh - "hier niett te diep op in te gaan" - strikt te hebben opgevolgd. (Helaas geldt dat overigens niet uitsluitend voor dit arrest...). Van den Bergh's eigen benadering van art. 7 lijkt in het geheel niet beïnvloed te zijn door de arresten uit 1950; vgl. m.n. G. van den Bergh, De vestigingsbeschikking boekverkopersbedrijfen de Grondwet, in: G. van den Bergh, Verzamelde staatsrechtelijke opstellen, supplement deel III, p. 57 e.v., Alphen aan den Rijn 1961. (Oorspr.: Nieuwsblad voor de Boekbandel 1959). Röling had de arresten in 1952 klaarblijkelijk nog niet verwerkt; in zijn noot onder HR 29 mei 1951 (NJ 1952, 367) gaat hij nog uit van het oude begrip "openbaren" en onderzoekt hij de verhouding tot "verspreiden", echter zonder in te gaan op de verworvenheden (nou ja...) van 1950.

52. G. van den Bergh, Nogmaals: De drukpersvrijheid en de gemeentelijke verordening, in: G. van den Bergh, Verzamelde staatsrechtelijke, deel I, p. 59, Alphen aan den Rijn 1949. (Oorspr.: NJB 1946). In dezelfde zin (veel later): A.M. Donner, Grondrechten als constitutionele rechten, in: Speculum Langemeijer, p. 26, Zwolle 1973.

53. P.J. Oud (Handboek voor het Nederlands gemeenterecht, p. 221-223, Zwolle 1959) kwalificeerde het standpunt van de Hoge Raad als "zuiver opportunistisch": "Van dit onderscheid tussen openbaren en verspreiden zie ik in de Grondwet niets. $\mathrm{Zij}$ spreekt alleen van openbaren. $\mathrm{Nu}$ is het van tweeën een: het verspreiden behoort tot het openbaren of het behoort er niet toe. Behoort het ertoe - en ik acht het volstrekt onaannemelijk, dat het er niet toe zou behoren -, dan geldt alles wat voor het openbaren geldt ook voor het verspreiden". J.R. Stellinga (Twee belangrijke arresten betreffende de vrijheid van meningsuiting, TvO 1951, p. 150-153) klaagde erover dat de arresten "geen klaar antwoord" verschaffen "op de vraag, of de verspreiding nu wel of niet tot de drukpersvrijheid behoort". Volgens hem hield art. 7 "niets anders" in dan "het verbod van voorafgaande 
Overheidscensuur". De verspreiding zou daar "geheel naast" staan (p. 151).

"Nimmer mag", aldus Stellinga (p. 152), "een voorafgaande Overheidscensuur worden ingevoerd. De Rijkswetgever mag echter bepaalde openbaringen door middel van de drukpers strafbaar stellen. Door 'wet' in art. 7 formeel op te vatten, is dit terrein voor de gemeentelijke (en andere lagere) wetgevers gesloten.

De verspreiding, waar art. 7 dan geheel buiten staat, kan door de lagere wetgever aan beperkingen worden onderworpen. Voor de gemeenteraad geldt hier art. 168 der Gemeentewet, d,w.z. zodanige beperkingen kunnen gesteld worden, als het belang der openbare orde, zedelijkheid of gezondheid of andere belangen betreffende de huishouding der gemeente dit nodig maken. Men behoeft zich dan ook niet in te laten met de vraag of het verspreidingsverbod de drukpersvrijheid raakt of niet, waarbij natuurlijk allerlei grensgevallen mogelijk zijn en waarvan grote rechtsonzekerheid het gevolg kan zijn.

Is het nu niet mogelijk, zoals de advocaat-generaal Van Asch van Wijk stelde, dat de regeling van de verspreiding het grondrecht geheel illusoir maakt? Dan herinnere men zich weer, dat art. 7 geenszins algehele vrijheid van drukpers waarborgt: het verbiedt slechts voorafgaande censuur."

Opvallend genoeg leek juist de "modus quo" benadering van Van Asch van Wijk - zoals onder 4.3 naar aanleiding van een Eindhovense bepaling zal blijken - tot hetzelfde resultaat te voeren (zie zijn conclusie vó6r HR 27 februari 1951, NJ 1951, 472). Zie overigens, voor enig weerwerk tegen de opvatting van Stellinga op dit punt: W.L. Snijders, Drukpersvrijheid en verspreiding, TvO 1953, m.n. p. 198 e.v.

54. J. d'Aulnis de Bourouill, Het venten van drukwerken in het openbaar, Themis 1895 , p. 81.

55. Vg1. HR 23 maart 1896, W. 6783.

56. J. van der Hoeven, a.w. (noot 49), p. 231, beantwoordde die vraag kennelijk bevestigend, zij het dat niet duidelijk is of hij in dit opzicht een verschil zag tussen de uitspraak van 1892 en die van 1950. Deze opvatting werd in twijfel getrokken door P.J. Boukema, Vrijheid vari meningsuiting en artikel 7 van de Giondwet, Themis 1969, p. 129; hij zag een "bevestiging" van zijn zienswijze in HR 24 januari 1967, NJ 1967, 270 (Nederland Ontwapent), een ontwikkeling die in 1950 natuurlijk nog niet te voorzien was.

57. HR inzake "Tilburg" (NJ 1951, 137). Interessant is overigens dat de Hoge Raad hier en passant een omschrijving (definitie?) gaf van "openbaren", namelijk: "het doen drukken der uiting zelf".

58. HR 5 november 1928, W. 11913.

59. Vgl. J.H.P.M. van der Grinten, De Hoge Raad en art. 7 der Grondwet, Gemeentebestuur 1929 , p. 71 e.v. (waarover uitgebreid in paragraaf 2.6 van dit boek).

60. Hiermee wordt kennelijk gedoeld op de interpretatie van Van der Grinten.

61. De laatste zinsnede herinnert, naar ik vermoed, aan de Sanitas-beslissing van 1928. 
62. J.M. de Meij, Uitingsvrijheid, p. 102 (Amsterdam 1989). J.M.H. Dassen (De betekenis van artikel 7 der Grondwet, NJB 1971, p. 692) noemde de constructie "gekunsteld". Volgens hem was "het weinig opwindend effect, dat van deze nieuwe jurisprudentie op de doctrine uitging, (waarschijnlijk) toe te schrijven aan de omstandigheid, dat deze nòch aan de inhoud van het verspreidingsrecht nòch aan de reglementerende bevoegdheid van de plaatselijke wetgever tot beperking van dat recht realiter ook maar iets veranderde.

63. Zie HR 27 februari 1951, NJ 1951, 472.

64. Noot B.V.A. Röling onder HR 27 februari 1951, NJ 1951, 472.

65. HR 27 februari 1951, NJ 1951, 472.

66. HR 27 februari 1951, NJ 1951, 473. V'gl. ook J.M. de Meij, a.w. (noot 62), p. 105 .

67. Noot onder HR 27 februari 1951, NJ 1951, 472. P.J. Boukema, a.w. (noot 11), p. 125 , volgde de analyse van Röling volgens welke deze nuance beslissend was voor de uitkomst van de zaak, zij het dat hij - anders dan Röling - "de openbaarmaking door middel van reclameborden" (zie noot 68 ) niet opnam in zijn lijst van zelfstandige verspreidingsmiddelen (a.w., p. 124); dat laatste zou wèl consequent geweest zijn.

68. Röling noemde, in zijn eerder genoemde noot, naar aanleiding van dit tweede Eindhovense arrest "de openbaarmaking door middel van reclameborden" zelfs als voorbeeld van de hier bedoelde middelen van verspreiding: "De reden dat de gewraakte verordening toelaatbaar werd geacht werd blijkbaar gevonden in het feit dat niet elk gebruik vañ reclameborden werd verboden". Een dergelijke interpretatie is volgens mij niet te rijmen met de bewoordingen van het arrest. Zag Röling voorbij aan bet manipulatieve vermogen van de door de Hoge Raad gebruikte begrippen? Of houd ik ten onrechte vast aan de tekst van het arrest?

69. Vgl. HR 30 mei 1967, NJ 1968, 4. Ik ondersehrijf de zienswijze van De Meij (a.w., noot 62, p. 105).

70. J.P. Guépin, De beschaving, p. 109, Amsterdam 1983.

71. Conclusie vóór HR 29 mei 1951, NJ 1952, 367.

72. HR 29 mei 1951, NJ 1952, 367. F.H. Kistenkas, a.w. (noot 39), p. 32, leidde (kennelijk in navolging van P.J. Boukema, a.w. (noot 11), p. 124, zij het zonder verwijzing hiernaar) uit dit arrest af dat het in de verordening genoemde "op de openbare weg aankondigingen omroepen of bekend maken "door de Hoge Raad als "zelfstandig verspreidingsmiddel" werd erkend. Ten onrechte, zoals uit de aangehaalde overweging blijkt.

73. HR 27 februari 1951 , NJ $1951,473$.

74. Vgl. HR 28 juni 1920, W. 10616.

75. Of het andere auteurs is opgevallen, weet ik niet. Wel wordt dit arrest zowel door De Meij, a.w. (noot 62), p. 111, als door Kistenkas, a.w. (noot 39), p. 34, aangehaald als voorloper van HR 17 maart 1953, NJ 1953, 389 (Nuth), waarover straks meer. Röling ging in zijn noot onder het arrest niet in op de afwijkende terminologie; in plaats daarvan gaf hij ongelukkigerwijs voornamelijk blijk de arresten over Tilburg en Sittard uit 1950 niet te hebben opgemerkt, hetgeen 
resulteerde in een uitgebreid - en achterhaald - verhaal over "openbaren" en "verspreiden".

76. Röling ging in zijn noot aan deze optie voorbij. Hij hield het erop dat de Hoge Raad de bepaling anders las dan Langemeijer - dat was inderdaad $66 \mathrm{k}$ een mogelijkheid, maar niet de enige.

77. Zie HR 10 juni 1952, NJ 1952, 688.

78. HR. 7 november 1938, NJ 1939, 269 (Zwart Front).

79. Conclusie vóór HR 10 juni 1952, NJ 1952, 688.

80. Ook J.R. Stellinga (Het drama der verspreiding, TvO 1952, p. 482) vroeg zich af "of dit ook past in de lijn van de jurisprudentie van het hoogste rechtscollege"; hij wees daarbij op onder meer HR 24 oktober 1932, W. 12580. Voorts, in aansluiting op Stellinga.'s bijdrage: W.L. Snijders, a.w. (noot 51), m.n. p. 199 (r.k.).

81. HR 10 juni 1952 , NJ $1952,688$.

82. Vgl. daarnaast HR 24 oktober 1932 (W. 12580, INJ 1932, 1755), waarin een Rotterdamse bepaling werd gesauveerd die een uitzondering behelsde "voor zoover slechts de naam, en/of de prijs van eene courant of van een tijdschrift wordt genoemd". Ook die opening was i.c. niet voorhanden.

83. P.J. Oud (Handboek voor het Nederlands gemeenterecht, deel II, p. 220, Zwolle 1959) schreef naar aanleiding van dit arrest:

"Naast dit hoorbaar aanbevelen had de Deventerse verordening ook verboden 'gebruik te maken van een reclamebord of eenig instrument te bezigen om de aandacht te trekken'. Over de laatste middelen laat het arrest zich niet uit. Daardoor blijft het in het duister of de Hoge Raad tegen het verbod van 'hoorbaar aanbevelen' wellicht geen bezwaar zou hebben gemaakt, indien de 'zichtbare' aanbeveling zou zijn toegelaten gebleven, omdat dan voor het verspreidingsmiddel gebruik van voldoende betekenis zou zijn overgelaten".

Ik geloof dat Oud zich hier vergiste. Het verspreidingsmiddel waarvan i.c. "gebruik van enige betekedis" moest worden overgelaten was gmschieven als "het. op den openbaren weg te koop of om niet aanbieden van gedrukte of geschreven stukken (...) vergezeld (...) van een mondeling bekendmaken". De eventuele beschikbaarheid van enig ander "middel" voor aanbevelingen stond daar los van. J.R. Stellinga, a.w., (noot. 80), p. 482, constateerde - met annotator Pompe - dat, roepen, schreeuwen of zingen wèl "aan voorschriften onderworpen" mocht worden, maar spreken niet. "Ik vraag mij af", aldus Stellinga, "of men hier toch niet in zeer specieuze onderscheidingen vervalt. (...) Kan men precies aangeven, waar 'spreken' eindigt en 'roepen' begint?" Een retorische vraag; toch lijkt het mij niet echt verbazingwekkend dat een gemeente ons het spreken op straat niet mag verbieden, zèlfs al zijn we aan het venten... I Stellinga zag dit kennelijk anders: "Dit beperkt dus de verordeningsbeyoegdheid van de gemeenteraden weer veel verder", schreef hij nors.

84. Conclusie vóór HR 17 maart 1953, NJ 1953, 389.

85. Vgl. bijvoorbeeld HR 28 november 1950, NJ 1951, 137 (Tilburg), waarin expliciet. naar art. 168 gem.w. werd verwezen (p. 259 , r.k., 9e regel). 
86. HR 17 maart 1953, NJ 1953, 389.

87. Zie HR 28 juni 1920, W. 10616 in vergelijking met HR 2 oktober 1916, W. 10005. F.H. Kistenkas, a.w., (noot 39), p. 43, plaatst de casus van 1916 op één lijn met die van Breda in 1950 (HR 20 juni 1950, NJ 1950, 619) - een ongelukkige vergelijking, lijkt mij: in Breda ging het m.n. om de plaatsen waar gevent mocht worden, in Rosendaal om de tijden waarop het geoorloofd was.

88. J.J. van Rjemsdijk Kreenen, Het venten van drukwerk op de openbare straat, p. 34-35, Leiden 1895. Ook E. Diemer (Vrijheid van drukpers, p. 116, RotterdamUtrecht 1937) signaleerde de kwestie, evenals P. Dresen, a.w. (noot 38), p. 221. F.J.F.M. Duynstee (Preadvies NIV 1949, p. 114) was iets stelliger, "maar" - zo voegde hij eraan toe - "enigerlei duidelijke grens kan hier man de hand van de bestaande jurisprudentie niet meer worden getrokken".

89. P.J. Oud, a.w. (noot 83), p. 219-220. H.D. van Wijk (Niemand heeft voorafgaand verlof nodig..., in: H.D. van Wijk, Besturen met recht, p. 182, 's-Gravenhage 1974; oorspronkelijk: De Nederlandse Gemeente, 24 juni 1060) schreef: "Een wel heel gering minimum werd door de Hoge Raad als voldoende aanvaard in het geval-Breda; strenger oordeelde de Hoge Raad in het geval-Nuth (...)". Ook F.H. Kistenkas, a.w. (noot 39), p. 29 ziet kennelijk eea consistentie-probleem tussen "Nuth" en "Breda". Idem (gezien het gebruik van het woordje "echter"): Van der Pot/Donner/Prakke, Handboek van het Nederlandse staatsrecht, 12e druk, p. 286, Zwolle 1989.

90. De "feitelijke" vaststelling dat er geen gebruik van enige betekenis overbleef om drukwerk uit te delen, vergde vanzelfsprekend een walarde-oordeel omtrent het "venten": wanneer mocht je nog net wèl van venten spreken, en wanneer net niet? "Feiten zijn geen feiten", schreef J.F. Glastra van Loon eens (De Gids 1970, p. 87 e.v.). "What, then, is a fact?" vroeg. F. Waismann. (The principles of linguistic philosophy, p. 282, Londen 1965) zich eens af. "Can we pick out. some part of reality, draw boundaries to it, and say that this is the fact we mean? Let us try: I point to two books which are lying in front of me - what do I mean by this gesture? Do I mean the fact that there exist two books? Or their size, or their shape? Or do I mean that they are lying on the table, that they are paralle! to one another, that one is bigger than the other, or that they are both bound alike? Which of these facts does my gesture actually express? Clearly I cannot explain which is the fact I mean except by describing it. Thus a fact is what is deseribed by a sentence (...). There is, besides, another difficulty involved in this view - what fact is described by a false proposition?" Enzovoort, enzovoort. Ik hoef al die vragen hier gelukkig niet te beantwoorden (vgl. ook - helder en instructief - Derek L.. Phillips, Wittgenstein and scientific knowledge, p. 55-73, Londen 1977). Uit cassatietechnisch oogpunt ging het in "Nuth" om een vaststelling van feitelijke aard. Dat daarvoor mér komt kijken dan een eenvoudige registratie van "de werkelijkheid", is een ander hoofdstuk: (waar dit boek niet over gaat). 
1. Ik doel op HR 22 maart 1960, NJ 1960, 274. Het arrest geniet - onder de naam "Pocketbooks I" - tegenwoordig voornamelijk bekendheid in verband met het daarop voortbouwende arrest van 24 januari 1969, NJ 1969, 316: "Pocketbooks II".

2. HR 12 januari 1960 , NJ 1960, 273 (Alkmaar).

3. F.H. Kistenkas (Vrije straatcommunicatie, p. 57, Amsterdam 1989) meent dat een dergelijk verband "voor het eerst expliciet (werd) aangebracht in HR 5 januari 1988, NJB 1988, p. 576". Zo'n verband wordt echter niet door de Hoge Raad gelegd, maar is - uit strafrechtelijk oogpunt - inherent aan de bepalingen. Het speelde dan ook in 1960 al een rol bij de afdoening van deze zaak over het Alkmaarse verbod.

4. HR 28 november 1950, NJ 1951, 137.

5. De kwestie werd pas in 1978 opgerakeld door C.A.J.M. Kortmann, Algemene en bijzondere beperkingen van grondrechten, NJB 1978, p. 923. M.C. Burkens reageerde hierop in NJB 1979, p. 96; later kwam hij erop terug in zijn boek Algemene leerstukken van grondrechten naar Nederlands constitutioneel recht, p. 125-126 (Zwolle 1989) - deze en andere afwijkingen kenschetste hij hierin als "stilistische varianten van genoemd standaardarrest uit 1950, zonder dat hiermee beoogd is wijziging te brengen in de fundamentele juridische constructie".

6. Vgl. de jurisprudentie vanaf HR 27 februari 1951, NJ 1951, 472.

7. Vgl. F.H. Kistenkas, a.w. (noot 3), p. 39, die op dit punt een voorbeeldige voorzichtigheid tentoonspreidt.

8. P.J. Boukema, Enkele aspecten van de vrijheid van meningsuiting in de Duitse Bondsrepubliek en in Nederland, p. 123, Ansterdam 1966.

9. Vgl. A.W. Heringa en R. de Winter, Plakverordeningen en de vrijheid van meningsuiting, TvO 1980, p. 328 (l.k.).

10. Ik laat de reikwijdte van art. 168 gem.w. in het kader van dit boek rusten. Laat ik volstaan met een verwijzing naar mijn boekje De overheid, p. 131-133 ('s-Gravenhage 1991).

11. Volgens Boukema, a.w. (noot 8), p. 122-123, ging het om een verbod "geschriften e.d. aan te plakken tenzij B. en W. schriftelijk dạartoe vergunning hadden verleend". Hij achtte het dan ook "niet in overeenstemming met het arrest van de HR van 7 nov. 1892, w. 6259", dat dit verbod gesauveerd werd. In werkelijkheid was het plakken echter - anders dan hij het voorstelde - niet geheel en al afhankelijk gesteld van vergunning van B. en W.; hij streed hier tegen een windmolen...

12. Vgl. A-G Mok in zijn conclusie vóór HR 2 oktober 1979, NJ 1980, 105 (Dordrecht).

13. Boukema, a.w. (noot 8), p. 122 verzuimde deze toevoeging ("van de overheid") bij zijn bespreking van het arrest te vermelden; dat verklaart misschien zijn interpretatie van de uitkomst. Dat ook de overheid soms rechthebbende was, zal destijds overigens weinig indruk hebben gemaakt: dan trad zij immers niet "als overheid" op. Bovendien waren (en zijn) de meeste rechthebbenden particulieren, zodat er hoe dan ook een gebruik van enige betekenis werd overgelaten; op 
welwillendheid van rechthebbenden was je sowieso aangewezen - in dat opzicht voegde de regeling, ik herhaal mijzelf, niets toe aan bet bestaande regime (zij bet dat voortaan expliciet welwillendheid werd gevergd).

14. Vgl. mijn preadvies voor de VAR: De praktijk van toetsing van gemeentelijke regelgeving, p. 230-232. Geschriften van de VAR XCVI, Alphen aan de Rijn 1987.

15. Vgl. over deze kwestie H.K. ter Brake, Het strafrecht van de gemeente, p. 138-144, Amsterdam 1986. De Hoge Raad heeft in het vervolg, zoals nog zal blijken, altijd aan deze vondst vastgehouden; zie bijvoorbeeld mijn De triviale overheid, p. 18-20, Zwolle 1990. In meer algemene zin: A.W. Heringa, Preventief recht; een verdachte regressie, in: Staatkundig Jaarboek 1982-1983, p. 49-72.

16. Kurt Schwitters, Franz Müllers Drahtfrühling, p. 8-9, Hamburg (Edition Nautilus) 1991.

17. HR 22. maart 1960, NJ 1960, 274.

18. Een handzaam overzicht is te vinden bij J.R. Stellinga, Het pocketbook-arrest, TvO 1960, p. 134-135.

19. Vgl. HR 23 maart 1896, W. 6783.

20. Conclusie vó́r HR 22 maart 1960, NJ 1960, 274.

21. P. Dresen. De vrije meningsuiting. p. 213 e.v.. Amsterdam 1949. Te denken is in dit verband ook aan G. van den Bergh, bijvoorbeeld in: De leesbibliotheekverordeningen (Verzamelde staatsrechtelijke opstellen, deel I, p. 74-75, Alphen aan den Rijn 1949; oorspronkelijk: Bestuurswetenschappen 1948), en: De Vestigingsbeschikking Boekverkopersbedrijf en de Grondwet (Verzamelde staatsrechtelijke opstellen, supplement deel III, p. 59-61, Alphen aan den Rijn 1961; oorspronkelijk: Nieuwsblad voor de Boekhandel 1959).

22. HR 22 maart 1960, NJ 1960, 274.

23. Van der Pot/Donner/Prakke, Handboek van het Nederlandse staatsrecht, 12e druk, p. 285 , Zwolle 1989.

24. P.J. Boukema, a.w. (noot 8), p. 121.

25. J.M. đe Meij, Uitingsvrijheid, p. 106, Amsterdan 1989.

26. Vgl. HR 27 februari 1951, NJ 1951, 472.

27. J.R. Stellinga, a.w. (noot 18), p. 135.

28. S.F.L. baron van Wijnbergen, Vestigingswet bedrijven 1954/Art. 7 Grondwet, SEW 1960, p. 236.

29. J.R. Stellinga, a.w. (noot 18, p. 135 [I.k. D). Het is moeilijk een stuk van Stellinga aan te wijzen waarin een dergelijke zinsnede niet voorkomt. In twee eerder aangehaalde stukken zijn ze te vinden op de volgende plaatsen: TvO 1951, p. 151 (r.k.), TvO 1952, p. 481 (1.k. in de openingszin). Tot in lengte van dagen zou hij deze stijlfiguren handhaven.

30. J.R. Stellinga, a.w. (noot 18), p. 135-136.

31. H.D. van Wijk, Niemand heeft voorafgaand verlof nodig..., in: H.D. van Wijk Besturen met recht, p. 178 e.v., 's-Gravenhage 1974. (Oorspronkelijk: De Nederlandse Gemeente, 24 juni 1960).

32. HR 20 juni 1950, NJ 1950, 619. 
33. G. van den Bergh, a.w. (noot 21: supplement deel III), p. 59 e.v., had een soortgelijk karretje klaargezet vóórdat het arrest werd gewezen. Interessant (en consequent) was overigens de nuancering die Van Wijk (a.w. p. 181) op zijn standpunt maakte: "Bij een gebonden vergunning valt er m.i. over de aanvaardbaarheid van de regeling die deze behelst in het kader van artikel 7 der Grondwet te praten".

34. Alle betrokkenen leken het daarover eens te zijn; vgl. A-G Van Oosten, conclusie vóor HR 22 maart 1960, NJ 1960, 274 (p. 710, r.k.), Van den Bergh, a.w. (noot 33), p. 61 , en H.D. van Wijk, a.w. p. 182.

35. HR 29 november 1960, NJ 1961, 206.

36. Röling repte in zijn noot onder het arrest zelfs van "woordelijk gelijke overwegingen".

37. Zie conclusie A-G Van Oosten vó́r HR 29 november 1960, NJ 1961, 206.

38. Maar méér dan een stap was het natuurlijk niet. Wat K.R. Popper ooit "the attitude of reasonableness" noemde, is bij rechtspraak meestal ver te zoeken; vgl. K.R. Popper, Utopia and violence, in: Conjectures and reputations (3rd ed. Londen 1969), p. 355 e.v.

39. Noot onder HR 23 mei 1961, NJ 1961, 427.

40. J.R. Stellinga, a.w. (noot 18), p. 136. In gelijke zin: A-G s'Jacob in zijn conclusie vóór HR 23 mei 1961, NJ 1961, 427, p. 932 (I.k.), zij het dat hij deze stelling "een lichte overdrijving" noemt. Zèlf nam Stellinga in díe zaak overigens juist weer een ander standpunt in: "de bewoordingen van art. $7 \mathrm{Gr} . w$. verzetten zich (zijns inziens) rechtstreeks tegen het eisen van een voorafgaand verlof voor de vestiging van een boekdrukbedrijf" (J.R. Stellinga, De nieuwste jurisprudentie inzake de drukpersvrijheid, TvO 1961, p. 243).

41. G. van den Bergh, a.w. (noot 33), p. 61-62. Zie ook Pompe in zijn noot onder HR 22 maart 1960, NJ 1960, 274 (p. 714, 1.k.), waarop Stellinga reageerde in TrO 1960, p. 309. Van Wijnbergen, a.w. (noot 28), p. 238, wees er (reagerend op Van der Grinten) op dat de vrijheid van meningsuiting "noodzakelijk een zoom van gevallien moet omvatten, waarbij de vrijheid in ieder geval niet in gevaar wordt gebracht, doch die niettemin onder de bescherming vallen". Dat laatste ijjkt mij geen sterk argument, nu het er juist om ging hoe breed die "zoom" moest uitvallen.

42. Conclusie A-G s'Jacob vóór HR 23 mei 1961, NI 1961, 427.

43. HR 28 november 1950 , NJ $1951,137$.

44. Zie respectievelijk HR 22 maart 1960, NJ 1960, 274 en HR 29 november 1960, NJ 1961, 206.

45. Vgl. F.H. Kistenkas, a.w. (noot 3), p. 32; C.A.J.M. Kortmann, Constitutioneel recht, p. 380, Deventer 1990.

46. P.J. Boukema, a.w. (noot 8), p. 121-122. J.M. de Meij, a.w. (noot 25), p. 85-86, doet de zaak - onder verwijzing naar Boukema - uiterst kort en mistig af. Hij wijst. er nog met nadruk op dat niet geconcludeerd werd "dat het hier om een voorafgaand verlof - in casu een vestigingsvergunning - gaat"; ik begrijp niet wat hij 
hiermee bedoelt, waar de conclusie dat het verbod "wegens strijd met art. 7 Grondwet" niet in stand kan blijven, direct volgt op de overweging dat er een verbod in het spel is on zonder voorafgaande vergunning een grafisch bedrijf te vestigen.

47. HR 28 november 1950, NJ 1951, 137. Het boek van Boukema bevat ongelukkigerwijs opvallend veel fouten als het om verwijzingen gaat.

48. I.M.H. Dassen (De betekenis van artikel 7 der Grondwet, NJB 1971, p. 691) zag hieraan voorbij:

"Allereerst", zo schreef hij, "stelde de HIR 'het doen drukken' van gedachten en gevoelens gelijk met 'het openbaren', 'zo dat zij (d.w.z. de gedachten en gevoelens, D.) voor anderen kenbaar zijn'. Het is echter duidelijk dat deze beide begrippen elkaar geenszins dekken omdat het 'doen drukken' sec zonder tevens de gedrukten uit te geven of op andere wijze in omloop te brengen hoegenaamd niet effectueert en cok onmogelijk kàn effectueren, dat de inhoud der gedrukten dientengevolge ("zo dat') 'voor anderen kenbaar zijn'."

Hij trok het drukken klaarblijkelijk bij het openbaren (hetgeen op zich voor de hand lag, maar sinds het hier besproken arrest niet langer houdbaar bleek). Bovendien las hij in de "kenbaarheid" klaarblijkelijk mér dan de enkele mogelijkheid van gedachten en gevoelens kennis te nemen. Beslissend is echter, naar ik veronderstel, dat de voor anderen onkenbare gedachten en gevoelens hun neerslag hebben gevonden in een vorm (bijv. taal) die cok voor buitenstaanders te bevatten is.

49. J.R. Stellinga, De nieuwste jurisprudentie inzake de drukpersvrijheid, TvO 1961, p. 243.

50. Een foto van de plaats des onheils is te vinden in A.W. Heringa, R. de Winter en W.J. Witteveen (red.), Staatkundig Jaarboek 1987, p. 182.

51. Zie respectievelijk HR 8 november 1937, NJ 1938, 367 en HR 31 oktober 1938, NJ 1939, 206.

52. W.F. Prins, noot onder HR 24 januari 1967, NJ 1967, 270.

53. Zie $\mathrm{m} . \mathrm{n}$. HR 8 november 1937 , NJ 1938, 367, overweging naar aanleiding van het eerste middel (p. 501, r.k:).

54. Conclusio A-G Berger vóór HR 24 januari 1967, NJ 1967, 270. Ook art. 10 EVRM leverde volgens hem geen bezwaren op; in het kader van dit boek laat ik dat punt verder rusten.

55. Zie noot 52. G. van den Bergh (De artikelen 7 en 9 van de Grondwet in het licht van de moderne techniek, Verzamelde staatsrechtelijke opstellen, deel I, p. 42-43. Oorspronkelijk: NJB 1940) schreef ruim 25 jaar eerder al: "Niemand betwijfelt, dat artikel 7 niet uitsluitend betrekking heeft op de drukpers. Een ieder aanvaardt, dat hectograaf, fotografische reproductie-machine en alle andere moderne instrumenten, geschikt om gedachten en gevoelens in leesbare schriftekens vast te leggen, met de drukpers gelijk. gesteld moeten worden ten aanzien van de toepassing van artikel 7 van de Grondwet. (...) Ook op enige machine, geschikt om te vermenigvuldigen, komt het in het geheel niet aan. Wanneer een schrijver (...) zijn 
pennevruchten vermenigvuldigt door ze zelf al dan niet met een schrijfmachine, al dan niet bij één exemplaar tegelijk, over te schrijven (...) en ze daarna laat verspreiden, zal hij ten volle de bescherming van artikel 7 van de Grondwet genieten. Niemand die eraan twijfelt. Ja, zelfs het vermenigvuldigen is geen essentieel element. Wanneer de auteur slechts één exemplaar schrijft, en dit als een "vliegend blaadje" van hand tot hand laat gaan, of woorden, die gedachten of gevoelens uitdrukken, met grote letters op een bord geschilderd, boven de menigte uitdraagt, zal hij nog steeds de bescherming van artikel 7 genieten".

56. HR 23 mei 1961, NJ 1961, 427.

57. HR 24 januari 1967, NJ 1967, 270.

58. De Hoge Raad gebruikte deze keer de term "voorafgaand verlof" - sec - in plaats van (zoals gebruikelijk) "voorafgaand verlof der Overheid"; onduidelijk was of hier een "diepere" bedoeling achter schuilging. Er is echter geen aanleiding dat to veronderstellen; er werd (naar ik aanneem) vanuit gegaan dat de beperking tot de overheid vanzelf sprak (zie bijv. ook punt 2, hieronder). Eerder zagen we dat afhankelijkheid van toestemming van "rechthebbenden" volgens de Hoge Raad geoorloofd was; vgl. HR 12 januari 1960, NJ 1960, 273 (Alkmaar).

59. P.J. Boukema wees hierop in zijn bijdrage Vrijheid van meningsuiting en artikel 7 van de Grondwet, RM Themis 1969, p. 127. Zie ook. HR 28 november 1950, NJ 1951, 137 (Tilburg), p. 259, r.k.: hier was de Hoge Raad nog zeer dubbelzinnig. C.J.N. Versteden (De Afdeling rechtspraak en artikel 7 van de Grondwet, Gst. 6692, 22 januari 1982) hield jaren later niettemin nog steeds rekening met de mogelijkheid dat de Hoge Raad onder "openbare orde" in dit verband niet het hele scala van bevoegdheden van art. $168 \mathrm{gem} . w$. begreep; de ARRS had zich destijds al wèl uitdrukkelijk in die ruime zin uitgelaten.

60. J.M. de Meij (Uitingsvrijheid, p. 105, Amsterdam 1989) leidde uit bovenstaande passage af dat "het aanbrengen (...) in het landelijke gedeelte ener gemeente" als "zelfstandig verspreidingsmiddel" werd aangemerkt. Ten onrechte. In de eerste plaats repte de Hoge Raad in dit arrest niet van een "verspreidingsmicidel" (zoals in eerdere uitspraken), maar van een "middel van bekendmaking" (hetgeen mij een precisering lijkt). In de tweede plaats - en dat is veel belangrijker - vormde de toevoeging "in het landelijk gedeelte ener gemeente" slechts een aanduiding van de plaats waar het gebruik van het betreffende zelfstandige middel verboden was. Het was dus niet zo dat het aanbrengen "in het landelijk gedeelte ener gemeente" niet in het algemeen verboden, of aan voorafgaand verlof van de overheid onderworpen mocht worden. Dat blijkt ook uit het vervolg van het arrest, met name uit de overweging waarin de. Hoge Raad nagaat of i.c. sprake was van zo'n algemeen verbod of verlofstelsel. In de visie van De Meij zou daar niet zo'n subtiele afweging voor nodig zijn geweest. Ik denk dat De Meij zich op Boukema (zie noot. 62) baseerde.

61. Van een feitelijke vaststelling, dat inderdaad voor sommige gemeenten geen bebouwde kom was vastgesteld, of dat er gemeenten waren die zelf een soortgelijk: verbod hadden uitgevaardigd voor hun bebouwde kom, blijkt niets uit het arrest. 
Vgl. echter in dit verband de conclusie van de A-G Rombach vóór HR 31 oktober 1938, NJ 1939, 206 (p. 339, r.k., eerste alinea, latatste zin).

62. P.J. Boukema, a.w. (noot 59), p. 125.

63. HR 30 mei 1967 , NJ 1968, 4.

64. HR 27 februari 1951, NJ 1951, 473.

65. Zie weergave in HR 30 mei 1967, NJ 1968, 4.

66. HR 27 februari 1951, NJ 1951, 473.

67. HR 17 maart 1953, NJ 1953, 389.

68. De eerste die, bij mijn weten, op het verband tussen beide zaken wees, was P.J. Boukema, a.w. (noot 59), p. 126. In dezelfde zin als Boukema: J.M. de Meij, a.w. $($ noot 60$)$, p. 105.

69. Conclusie vóór HR 30 mei 1967, NJ 1968, 4.

70. HR 30 mei 1967, NJ 1968, 4.

71. F.H. Kistenkas, a.w. (noot 3), p. 32, houdt het blijkbaar op het laatste. Zelf gok ik op het eerste, omdat ik niet inzie waarom hier opeens een inhoudelijk aanknopingspunt in het spel zou zijn.

72. Noot onder NJ 1968, 5.

73. HR 30 mei 1967, NJ 1968, 5.

74. Weliswaar kunnen tegenwoordig, ook prenten "gelezen" worden, maar destijds was dat nog geen gangbaar taalgebruik. De hoogtijdagen van het structuralisme en de semiotiek moesten (althans in Nederland) nog aanbreken. Ook Boukema, a.w. (noot 59), p. 131, struikelde trouwens in 1969 al over de te beperkte omschrijving van de advocaat-generaal.

75. HR 30 mei 1967, NJ $1968,5$.

76. Ik ben die 'link' in de literatuur overigens nergens tegengekomen.

77. Eventueel kon men denken aan het toenmalige art. $9 \mathrm{Gr}$.w. (recht tot vereniging en vergadering). Zie over het juridische regime ten aanzien van "demonstraties" in die dagen: A.D. Belinfante, Vrijheid van demonstratie, Alphen aan den Rijn 1966. Ook Belinfante achtte art. 7 en 9 Gr.w. overigens ontoereikend ter bescherming van demonstratieve optochten; en passant wees hij erop "dat in de Nederlandse literatuur de vrijheid van demonstratie als zodanig niet ter sprake komt" (p. 2 ).

78. P.J. Boukema, a.w. (noot 59), p. 131.

79. Ktr. Maastricht 5 juli 1968, NJ 1970, 11.

80. Kir. Tilburg 24 november 1971, NJ 1972, 178.

81. HR 12 januari 1960 , NJ $1960,273$.

82. Vgl. HR 21 maart 1938, NJ 1938, 655.

83. 1.C. van der Vlies (Vrijheid van meningsuiting en het belang van de openbare orde, TvO 1982, p. 458) schreef begin jaren tachtig niettemin: "Het is vaste jurisprudentie dat aan een verordening verbindende kracht wordt ontzegd als ook aan de rechthebbenden verboden wordt hun eigen goed te beplakken.". Ik vrees dat hel geen toeval is dat: zij deze bewering met geen enkel voorbeeld staafde, terwij! zij voor het overige juist bepaald scheutig was met haar bronvermeldingen. Of was die zaak uit 1938 inmiddels wellicht verouderd? Het arrest over de manege Rehoboth (zie onder 5.6) zou een aanwijzing daarvoor kunnen zijn; de vraag die 
dan echter rijst is of het arrest na Rehoboth in alle opzichten verouderd is. Niet in dit opzicht, lijkt mij; in het begin jaren ' 80 gewezen arrest over de Utrechtse muurkrant (zie onder 7.1) werd wederom een bepaling gesauveerd die het onder meer aan rechthebbenden verbood hun eigen zaken te beplakken.

84. Vgl. HR 14 januari 1969, NJ 1969, 191.

85. Vgl. hiervóór onder 5.3.

86. W.F. Prins, noot onder NJ 1969, 191.

87. HR 1 november 1897 , W. 7036.

88. J.M. de Meij, a.w. (noot 60), p. 105 meent ook hier weer dat het element "in het landelijke gedeelte van een gemeente " deel uitmaakte van het betreffende middel van bekendmaking; opnieuw ten onrechte!

89. J.M. de Meij, Reclame en vrijheid van meningsuiting, NJB 1977, p. 927; zie ook J.M. de Meij, a.w. (noct 60), p. 96, waarin hij tot dezelfde interpretatie komt (zij) het veel cryptischer geformuleerd).

90. J.M. de Meij, a.w. (noot 60), p. 105.

91. K.R. Popper, Objective knowledge, p. 58, Oxford 1972.

92. J.M. de Meij, a.w. (noot 60), p. 105.

93. W. 6781., p. 40 (jig. 1896).

94. HR 21 maart 1938, NJ 1938, 655.

95. Opvallend in deze zaak was bovendien art. 3 lid 1 Verordening:

"Van het verbod, gesteld in art. 1, eerste lid, onder a, kunnen Gedeputeerde Staten onder nader te stellen voorwaarden ontheffing verlenen. $\mathrm{Zij}$ kunnen deze ontheffing slechts weigeren, indien naar hun oordeel het opschrift, de aankondiging of de afbeelding, alsmede de ten behoeve daarvan opgerichte constructie, ontsierend of storend is".

In de visie van s'Jacob (zie zijn conclusie vóór "Vietnam I", zoals hiervoor besproken onder 5.4) zou het verbod door deze bepaling vermoedelijk "gered" zijn. Uit de omstandigheid dat de Hoge Raad die mogelijkheid niet benut heeft, kan echter niet worden afgeleid dat de Hoge Raad er dus anders over dacht. Het OM had deze bepaling in zijn cassatiemiddel immers niet aangegrepen en in "OMcassaties" pleegt de Hoge Raad niet buiten het middel om te casseren. 
1. Zie HR 18 januari 1972, NJ 1972, 193 ("Huifkar").

2. P.J. Boon (Zonder voorafgaand verlof, p. 24 , Nijmegen 1988) schrijft naar aanleiding van dit arrest heel voorzichtig dat de Hoge Raad er kennelijk van uit gaat dat er feitelijke mededelingen zijn die buiten het begrip 'gedachten of gevoelens' vallen. Ik zou zeggen dat de Hoge Raad er blijkbaar van uit gaat dat er uitingen als bedoeld in art. 7 Gr.w. zijn die geen "gedachten of gevoelens" behelzen - iets wat trouwens (zoals we zagen) al veel eerder duidelijk was. Of het daarbij steeds om feitelijke mededelingen gaat - en zo ja: om alle - is allerminst duidelijk; uit de grondwetsherziening van 1983 blijkt dat de regering beoogde ó́6k (bepaalde) feitelijke mededelingen onder de sfeer van art. $7 \mathrm{Gr}$.w. te brengen (vgl. Algemene grondwetsherziening, deel 1a, p. 194, 's-Gravenhage 1979) - straks méér hierover.

3. Hij doelde, naar ik aanneem, op de campagne tegen zogeheten Angola-koffie.

4. J.M. de Meij, Reclame en vrijheid van meningsuiting, NJB 1977, p. 927.

5. Zie noot 2 .

6. Vgi. P.J. Boukema, Enkele aspecten van de vrijheid van meningsuiting in de Duitse Bondsrepubliek en in Nederland, p. 114-116, Amsterdam 1966.

7. Zie. HR' 15 april 1975, NJ 1976, 23.

8. Zie noot 7 .

9. HR 30 mei 1967, NJ 1968, 5. Ook Remmelink had in zijn conclusie op dit precedent gewezen en eruit afgeleid "dat art. 7 Gr.w. met deze materie in ieder geval niet te maken heeft"

10. Niki de Saint-Phalle vervaardigde aan het begin van de jaren ' 60 enkele schietschilderijen, waarbij zij het publiek liet schieten op witte gipsreliëfs waarin zakjes met verf verwerkt waren. De inhoud van die zakjes liep daardoor uit over het witte oppervlak en vormde op die manier - geheel volgens de wetten van het toeval - het schilderij.

11. A.L. Melai betoogde in zijn noot onder het arrest "dat art. 7 Gr.w. enkele samenhangende beginselen behelst inet het oog op de leesbare uiting van gedachten of gevoelens". Daarbij baseerde hij zich wellicht op de conclusie van de A-G s'Jacob vóór "Vietnam II" (HR 30 mei 1967, NJ 1968, 5). Ten onrechte, zoals ik ook bij de bespreking van het arrest al te berde bracht (zie hiervóór onder 5.4, noot 73 ).

12. Zie voor een weergave van de doctrine destijds: T. Koopmans, Compendium van het staatsrecht, 1e druk, p. 172, Deventer 1972.

13. Zie ook, anderhalf jaar later: HR 16 november 1976, NJ 1977, 378, een peek, over het algemene Amsterdamse verbod om een "staanplaats" in te nemen op de openbare weg, als voor de betrokken goederen (i.c. gedrukte stukken) een marktplaats was aangewezen. Niet duidelijk is of het cassatieberoep verworpen is vanwege de beschikbaarheid van andere markten - waarmee "Rehoboth" in zekere zin weer ongedaan zou zijn gemaakt - ofwel vanwege de omstandigheid dat het innemen van een "staanplaats" niet als middel van bekendmaking met zelfstandige betekenis werd gezien. Remmelink achtte het verbod (blijkens zijn conclusie) niet in strijd met. art. $7 \mathrm{Gr}$.w. gezien die andere markt(en) waar men een "staanplaats" 
kon innemen om gedrukte stukken e.d. te koop aan te bieden, "zulks temeer niet nu uit andere (verwante) gemeentelijke verordeningen (...) blijkt, dat de Amsterdamse wetgever, zodra het maar niet gaat om het innemen van zo'n "staanplaats", de verspreider of vertoner van gedrukte stukken enz. alle ruimte wil geven: aldaar heeft hij $\mathrm{nl}$. de gedrukte en geschreven stukken, benevens de afbeeldingen wel uitgezonderd". Met dat laatste leek Remmelink de uitwisselbaarheid van verspreidingsmiddelen te bepleiten - iets wat de Hoge Raad (zoals bekend) al bij herhaling had afgewezen. J.M. de Meij (Uitingsvrijheid, p. 105, Amsterdam 1989) leidde uit de peek van de Hoge Raad af dat impliciet

"de verkoop van drukwerken op een vaste standplaats buiten de aangewezen markten, niet als een zelfstandig verspreidingsmiddel (werd) erkend. De Amsterdamse verordening op de dienst van het marktwezen die een aantal markten aanwijst voor de verkoop van goederen, werd in dit geval niet onverbindend geacht. Andere verordeningen betreffende het venten en de straathandel zonder vaste standplaatsen boden namelijk voldoende mogelijkheden voor het verspreiden van drukwerken, aldus de Hoge Raad".

Aldus Remmelink, zal hij bedoelen! Hoe die laatste volzin trouwens te rijmen is met de stelling dat de Hoge Raad in het innemen van een standplaats geen zelfstandig middel zou hebben gezien, is moeilijk te vatten. Je moet, lijkt mij, ofwel voor de ene interpretatie kiezen, ofwel voor de andere: het gaat hier immers om twee verschillende interpretaties van hetzelfde fenomeen. Afgezien daarvan is de zienswijze van De Meij op dit punt, zoals hierboven bleek, niet de enig denkbare.

14. Wet van 28 juni 1979 , Stb. 1979,387 , en na tweede lezing in de Grondwet.

15. Naar een nieuwe grondwet, Documentatiereeks, deel 15: Algehele grondwetsherziening, eerste lezing, deel 1a, p. 32-33, 's-Gravenhage 1979. In de MvA aan de Eerste Kamer (Naar een nieuwe grondwet, Documentatiereeks, deel 18: Algehele grondwetsherziening, eerste lezing, deel 1b, p. 74, 's-Gravenhage 1981) is, in aansluiting hierop, te lezen, "dat de uitleg, die het begrip 'drukpers' in de jurisprudentie heeft gekregen, eveneens van toepassing zal zijn op hetzelfile begrip in het voorgestelde artikel. Daarom valt aan te nemen, dat uithangborden en neonletters, evenals thans, onder het begrip 'drukpers' gerangschikt zullen worden". (NB: deze MvA werd ontvangen op 17 maart 1977).

16. J.M. de Meij, Reclame en vrijheid van meningsuiting, NJB 1977, p. 927.

17. J.M. de Meij, a.w. (noot 16), p. 931. (In de zin voorafgaande aan het door mij geciteerde gedeelte, is helaas het woordje "niet" weggevallen; oningewijde lezers zullen destijds hun wenkbrauwen hebben gefronst).

18. Zie a.w. (noot 15), p. 74.

19. G. van den Bergh, De artikelen 7 en 9 vaũ de Grondwet in het licht van de moderne techniek, in: G. van den Bergh, Verzamelde staatsrechtelijke opstellen, deel I, p. 42 e.v., Alphen aan den Rijn 1949. (Oorspronkelijk: NJB 1940).

20. G. van den Bergh, a.w. (noot 19), p. 44. Zijn standpunt vond later navolging bij 
P. Dresen, De vrije meningsuiting, p. 158, Amsterdam 1949.

21. A.J.P. Tainmes, Preadvies NJV 1949, p. 170-171; F.J.F.M. Duynstee, Preadvies NJV 1949, p. 129-131.

22. P.J. Boukema, a.w. (noot 6), p. 138.

23. HR 23 mei 1961 , NJ 1961, 427.

24. G. van den Bergh, Artikel 7 Grondwet en de lagere wetgever, in: G. van den Bergh, Verzamelde staatsrechtelijke opstellen, deel I, p. 56, Alphen aan den Rijn 1949. (Oorspronkelijk NJB 1939).

25. Ik verwijs naar de in noot 2 weergegeven interpretatie van het Huifkar-arrest door P.J. Boon.

26. MvA aan Eerste Kamer, Naar een nieuwe grondwet, deel 18 (a.w. noot 15), p. 74-75. lets soortgelijks was eerder al te lezen in de MvA aan de Tweede Kamer, Naar een nieuwe grondwet, deel 15 (a.w. noot 15), p. 194. De regering had zich wellicht laten leiden door het standpunt van P.J. Boukema, a.w. (noot 6), p. 114.

27. HR 12 januari 1960 , NJ 1960, 273.

28. Zie HR 19 september 1977, NJ 1978, 516.

29. J.M. de Meij, Collecteren en de vrijheid van meningsuiting, NJB 1979, p. 782 (l.k.), dichtte deze overweging aan de Hoge Raad toe.

30. Iets dergelijks had hij - zoals gezegd (zie noot 13) - al eerder betoogd in zijn conclusie vóór HR 16 november 1976, NJ 1977, 378.

31. HR 12 januari 1960, NJ 1960, 273.

32. Het arrest over het Alkmaarder plakverbod leek de aanwezigheid van een middel van bekendmaking met zelfstandige betekenis al te impliceren - waarom anders die mededeling dat art. $7 \mathrm{Gr}$.w. "mede omvat" het recht om gedachten en gevoelens "in het openbaar aan het publiek bekend te maken, hetgeen onder meer kan geschieden door openlijk aanplakken of bevestigen"? Of heb ik hier te veel in willen lezen? De neiging dartoe is - zoveel is intussen wel duidelijk - haast niet te onderdrukken.

33. Deze interpretatie werd (min of meer) gevolgd door $\mathrm{M}$. Biesheuvel in zijn noot onder het arrest in NJCM-Bulletin, november 1978 (jaar 3, no. 11), p. 42. E.A. Alkema zag het in NJCM-Bulletin, februari 1979 (jaar 4, no. 14), p. 38, iets anders (hoewel hij schreef Biesheuvel te volgen): "Uit de beslissing zou men (...) kunnen opmaken, dat de HR het afficheren en het lopen met sandwichborden niet langer als twee zelfstandige middelen van verspreiding wenst te beschouwen". Deze laatste zienswijze lijkt mij, gezien de omstandigheid dat de Hoge Raad van "een beperking van het gebruik van bepaalde middelen van bekendmaking" repte, niet goed verdedigbaar. Niettemin werd de visie van Alkema onderschreven door J.A. Peters, Lokaal bestuur en grondrechten, NJCM-Bulletin 1980, p. 36.

34. Conclusie vóór HR 27 juni 1978, NJ 1979, 59.

35. Zie hiervóór onder 6.2 .

36. Zie R. de Winter, Hogere voorziening en rechterlijk goedvinden in strafzaken. Over 'peken'-beleid en ambtshalve cassaties, NJB 1986, p. 469.

37. HR 27 juni 1978, NJ 1979, 59. Of de bepaling als geheel "verbindende kracht 
mist", is uit het arrest niet op te maken. "Op zich" lijkt de bepaling zeer goed splitsbaar in een verbindend en een onverbindend gedeelte. Dat zon erop kunnen wijzen dat slechts van gedeeltelijke onverbindendheid sprake is.

38. E.A. Alkema in zijn "Kommentaar" op dit arresit in NJCM-Bulletin, februari 1979 (jaar 4, no. 14), p. 38.

39. J.M. de Meij, a.w. (noot 29), p. 782.

40. E.A. Alkema, a.w. (noot 38), p. 39.

41. E.A. Alkema, a.w. (noot 38), p. 39.

42. HR 10 juni 1952 , NJ $1952,688$.

43. HR 17 maart 1953, NJ 1953, 389.

44. J.M. de Meij, a.w. (noot 29), p. 782.

45. HR 30 mei 1967, NJ 1968, 5.

46. M. Scheltema, noot onder NJ 1979, 59.

47. E.A. Alkema, a.w. (noot 38), p. 40.

48. J.M. de Meij, a.w. (noot 29), p. 782-783. Ook Scheltema (zie noot 46) speculeerde al enigszins over het uitdijend effect.

49. A.W. Heringa, VNG in de fout?, NJB $\| 980$, p. 404-405.

50. Zie A.W. Heringa, a.w. (noot 49), p. 405.

51. Zie noot 50 .

52. De door De Meij (zie noot 48) gesignaleerde problemen ten aanzien van speldjes e.d. kwamen in de reactie van de VNG niet aan de orde; in verband met het eerste lid van de modelbepaling was dat tamelijk opmerkelijk.

53. ARRS 19 oktober 1978, tB/S III nr. 98 (p. 517 e.v.). I.C. van der Vlies (Vrijheid van meningsuiting en het belang van de openbare orde, TvO 1982, p. 457) schreef naar aanleiding van deze uitspraak: "In tegenstelling tot de Hoge Raad 'Eindhoven' beeft de Afdeling collecteren met gelijktijdig aanbieden van gedrukte stukken niet als een zelfstandig middel aangemerkt". Dat lijkt mij - zoals ik hierna zal illustreren - een voorbarige conclusie.

54. Hoe de vork precies in de steel zat, is (voor zover ik weet) ook uit latere jurisprudentie van de Afdeling niet af te leiden. In een uitspraak van 16 augustus 1979 (NJCM-Bulletin 1980, p. 78 e.v.) overwoog de Voorzitter van de ARRS (Van der Hoeven) dat "weliswaar het enkele inzamelen van gelden door middel van een collecte kan voortvloeien uit een bepaalde mening, doch niet zelf een meningsuiting vormt" (een frase die kort daarop werd herhaald in VZ ARRS 18 oktober 1979 , $\mathrm{tB} / \mathrm{S}$ VII, nr. 78, p. 277). Een dergelijk standpunt is zeer goed verenigbaar met het arrest van de Hoge Raad over het Eindhovens collecteverbod, lijkt mij, al getuigt het - naar mijn idee - niet onder alle omstandigheden van grote werkelijkheidszin; zo overwogen B en W van Amsterdam - ih verband met de collecte van het Medisch Komitee Palestina - bijvoorbeeld:

"dat de Stichting heeft erkend, dat met een dergelijke collecte ook andere doeleinden worden nagestreefd, zoals bewustwording van het publiek en het winnen van de sympathie voor de Palestijnse zaak en dat de vraag gewettigd is, nu blijkens mededelingen van de Stichting hett allergrootste deel van 
de ingezamelde gelden via de giro binnenkomt, of deze doeleinden niet vooropstaan" (tB/S III, nr. 98, p. 518).

Hoe dan cok, de Voorzitter week volgens mij in zijn uitspraak van 16 augustus 1979 niet af van de eerdere jurisprudentie van de Hoge Raad. In een latere zaak over het El Salvador Komitee Nederland' (ARRS 21 mei 1985, AB 1986, 28) was het "ter inzameling van gelden" aanbieden van "gedrukte stukken, voorzover daarin gedachten of gevoelens zijn geopenbaard, als bedoeld in art. 7 Gr.w." van het vergunningvereiste uitdrukkelijk uitgezonderd; ook uit die zaak is dus niets af te leiden omtrent het standpunt van de ARRS over deze kwestie. De Leeuwarder APV, daarentegen, waar het Nationaal Epilepsie Fonds de dupe van werd, verbood nog heel ouderwets om "zonder vergunning van B en W een (...) openbare inzameling van gelden of goederen te houden, al dan niet met gebruikmaking van lijsten van intekening, ongeadresseerde brieven of circulaires, bloempjes, speldjes, insignes, zegels, bonnen, prikkaarten of dergelijke voorwerpen" (curs. RdW). Die bepaling was (althans gedeeltelijk) niet goed verdedigbaar meer sinds het arrest over het Eindhovens collecteverbod, lijkt mij. Alleen, de zaak-żlf ging over het houden van een collecte sec; de gedrukte stukken (of datgene wat daarmee gelijkgesteld kan worden) kwamen dus niet aan de orde (zie Vz ARRS 2 januari 1986, $\mathrm{AD}$ 1986, 433). Welnu, waar de verbodsbepaling zich (zo nodig) zeer wel liet splitsen in een verbindend en een onverbindend deel, is uit het feit dat de Voorzitter van de Afdeling de weigering van de gemeente sauveerde, volgens mij niets af te leiden omtrent zijn standpunt ten aanzien van het Eindhovense arrest.

55. ARRS 23 oktober 1978, AB 1979, 499. F.H. van den Burg schrijet in zijn noot onder de uitspraak: De Afd. rechtspraak volgt in deze uitspraak de HR. Ik kan daar niet op afdingen. Idem: C.J.N. Versteden, De Afdeling rechtspraak en artikel 7 van de Grondwet (Gst. 22 januari 1982, nr. 6692), die er nog een beetje op probeert af te dingen (ik ben daar al eerder op ingegaan), en F.H. Kistenkas, Vrije straatcommunicatie, p. 51 (Arnhem 1989). In dezelfde zin als deze uitspraak over de Leidse Verordening op het stadsschoon-1965 was ARRS 13 juni 1980, AB $1981,311$.

56. Van het vroegere, subtiele onderscheid tussen het in art. 7 neergelegde recht om te "openbaren" enerzijds en het door de rechtspraak tot ontwikkeling gebrachte recht om bekend te maken anderzijds, werd - conform de nieuwste rechtspraak van de Hoge Raad (te beginnen bij HR 12 januari 1960, NJ 1960, 273, en zeer recent nog terug te vinden in HR 19 september 1977, NJ 1978, 516) - geen melding meer gemaakt. De Afdeling overwong eenvoudig - net als de Hoge Raad inmiddels was gaan doen - dat onder art. $7 \mathrm{Gr}$.w. mede moest worden begrepen het recht om stukken bekend te maken (zij het dat...).

57. HR 24 januari 1967 , NJ 1967, 270.

58. HR 14 januari 1969, NJ 1969, 191.

59. Zie hiervóór onder 5.5: Ktr. Tilburg 24 november 1971, NJ 1972, 178.

60. Ktr. Tiel 12 december 1978, NJCM-Bulletin februari 1979 (jaar 4, no. 14), p. 33 e.v.

61. Pijnlijk is eigenlijk ook dat het vonnis in het NJCM-Bulletin terecht is gekomen; 
dat duidt erop dat het NJCM niet goed op de hoogte was van de stand van zaken. F.H. Kistenkas, a.w. (noot 55), p. 42, noemde "dit Tielse vonnis cen eenzame nog. te vroege zwaluw"; ik ben geen ornitholoog, maar mag toch hopen dat zwaluwen er vlugger bij zijn!

62. Resp. HR 12 januari 1960, NJ 1960, 273 (Alkmaar) en (kort tevoren) HR 19 september 1977, NJ 1978, 516 (Hengelo; gepubliceerd ruim vórdat het vonnis van de kantonrechterwerd gewezen, namelijk in de NJ van 7 oktober 1978 - het vonnis is gedateerd 12 december 1978).

63. Zie HR 22 mei 1979, NJ 1979, 505, waarin het hier bedoelde vonnis van 3 november 1978 (dat aan het arrest vooraf ging) grotendeels is weergegeven.

64. HR 20 juni 1950, NJ 1950, 619.

65. Zie resp. G. van den Bergh, Nogmaals: de drukpersvrijheid en de gemeentelijke verordening (Verzamelde staatsrechtelijke opstellen, deel I, p. 59-60, Alphen aan den Rijn 1949; oorspronkelijk: NJB 1946) en H.D. van Wijk, Niemand beeft voorafgaand verlof nodig... (Besturen met recht, p. 180, 's-Gravenhage 1974; oorspronkelijk: De Nederlandse Gemeente 1960). In "pakhuizen vol gedrukte stukken" (Van den Bergh), resp. het "op zolders en in pakhuizen opgeslagen liggen" (Van Wijk) zagen geen van beiden een verwezenlijking van de vrijheid van drukpers. "Er moet dus ook vrijheid van verspreidling zijn", schreef Van Wijk. En Van den Bergh: "De vrijheid tot openbaring van gedachten of gevoelens door middel van de drukpers impliceert de vrijheid tot verspreiding van de gedrukte stukken, waarin deze gevoelens en gedachten zijn uitgedrukt. Zonder deze laatste vrijheid heeft de eerste immers geen effect en dus geen zin".

66. Het gebruik van het woord "verspreiding" in plaats van "bekendmaking" duidt volgens mij niet op een principiële wending in de jurisprudentie; verspreiding is een vorm van bekendmaking. Orok eerder bediende de Hoge Raad zich al van deze afwijkende term.

67. I.C. van der Vlies, a.w. (noot 53), p. 458: "Als zelfstandige middelen zijn in de visie van de Hoge Raad derhalve nu te onderscheiden: te koop aanbieden, om niet aanbieden, tegen een bijdrage naar eigen inzicht aanbieden". Met dat laatste doelde zij op "het bij gelegenheid van een inzameling van geld of goederen aanbieden". Als samenvatting lijkt deze opsomming mij correct; er is echter geen reden om aan te nemen dat de opsomming - wat de verschillende vormen van aanbieden betreft limitatief is. Denk bijvoorbeeld aan het te huur of te leen aanbieden. (Over een bijzondere vorm van huur - nl. de leesbibliotheek - had de Hoge Raad zich trouwens al uitgesproken: zie HR 29 november 1960, NI 1961, 206).

68. Deze formulering gaf - ten overvloede - aan dat niet uitsluitend het verkeersbelang een toelaatbare beperkingsgrond opleverde.

69. Het verwijt van Kistenkas (De verspreidingsjurisprudentie in perspectief, TvO 1985 , p. 372), mede naar aanleiding van dit arrest, te weten dat "de rechter niet genegen is concreet te: toetsen of er door de betrokken APV ook feitelijk nog gebruik van enige betekenis van het zelfstandig verspreidingsmiddel overblijft", is volgens mij dan ook niet terecht. Die feitelijke toetsing moest alleen niet bij de 
Hoge Raad gezocht worden, maar bij de "lagere" feitenrechter. Of zij er inderdaad iets van terechtbrachten, was voor de Hoge Raad vaak nauwelijks te beoordelen (zoals ook uit deze Hilversumse zaak blijkt). Jets anders is dat de Hoge Raad soms wat erg veel fiducie in de feitenrechter tentoonspreidde en al gauw bereid bleek allerlei dingen in bun vonnissen in te lezen; ik kom hier later op terug.

70. Zie HR 2 oktober 1979, NJ 1980, 105.

71. Dat het "nieuwe" van deze zaak vooral in de confrontatie van deze criteria zat - en dat de uitkomst dus eigenlijk vooraf al vaststond - is in de discussie over dit arrest nooit goed uit de verf gekomen. Ik moet hierbij de hand cok flink in eigen boezem steken. Zie m.n.: A.W. Heringal en R. de Winter, Plakverordeningen en de vrijheid van meningsuiting (TvO 1980, p. 327 e.v.); F.H. van der Burg, Plakverordening Dordrecht (AA 1981, p. 372 e.v.); A.W. Heringa en R. de Winter, Plakverordening Dordrecht - een reactie (AA 1981, p. 718 e.v., met naschrift F.H. van der Burg); A.W. Heringa en R. de Winter, De kleefkracht van de vrijheid van meningsuiting (NJB 1982, p. 352 e.v.); F.H. Kistenkas (a.w., noot 55, p. 41).

72. M. Scheltema, noot onder het arrest (NJ 1980, 105).

73. HR 28 november 1950, NJ 1951, 137.

74. In de literafuur werd die zienswijze, voor zover ik weet, alleen door F.H. van der Burg verkondigd (AA 1981, p. 372): "Het lijkt mij dat dit arrest geheel ligt in de lijn van de jurisprudentie betreffende de drukpersvrijheid die de Hoge Raad in de loop der jaren heeft opgebouwd".

75. A.W. Heringa en R. de Winter, TvO 1980, p. 327 e.v., en AA 1981, p. 718 e.v. (vgl. noot 71).

76. F.H. van der Burg, a.w. (noot 74), p. 375.

77. Deze nuance is destijds een ieder (mijzelf incluis) ontgaan.

78. Dit is geen nieuw inzicht, zie: A.W. Heringa en R. de Winter, De kleefkracht van de vrijheid van meningsuiting, NJB 1982, p. 354. B.P. Vermeulen gaat in zijn commentaar op art. 7 (in: P.W.C. Akkermans en A.K. Koekkoek (red.), De Grondwet, p. 167, tweede druk, Zwolle 1992) belaas aan deze "verklaring" voorbij. Hij schrijft (vanuit een hedendaagse visie op "Nuth" en in het kielzog van de "uitstekende analyse van Kistenkas"): "Het Nuth-criterium speelt hierbij nauwelijks een rol: zo stelt de Hoge Raad dat ook dan nog sprake is van gebruik van enige betekenis van dit verspreidingsmiddel als niet iedereen daartoe in de gelegenheid is". Het lijkt mij niet aannemelijk dat de Hoge Raad een dergelijke inconșistentie zomaar liet passeren. Ik denk, met andere woorden, dat dit rechtscollege in het geheel geen inconsistentie ontwaarde. De Hoge Raad ging vermoedelijk van een ander idee omtrent "Nuth" uit dan wij vandaag-de-dag. Dat huidige idee moest destijds nog "bevochten" worden. Zie verder onder 7.4. 
1. Ktr. Leeuwarden 24 april 1980, weergegeven in HR 3 februari 1981, NJ 1981, 316.

2. A.J. Bok (Rechterlijke toetsing van regelgeving, p. 55, Deventer 1991) schrijft weliswaar dat "de jurisprudentie ex art. $7 \mathrm{Gr} . \mathrm{w} .(\ldots)$ per tijdsperiode een afzonderlijk 'gezicht' (vertoont)", maar dat klopt volgens mij niet helemaal met de werkelijkheid (hoewel in de jaren ' 80 onmiskenbaar méŕr plakzaken de revue passeerden dan voordien). Waarom een bepaald aspect in een bepaalde periode gezichtsbepalend was (en een ander niet), wordt door Bok overigens niet uitgewerkt - nou ja, daar ging zijn boek ook niet over.

3. J.M. de Meij, Utrechtse Muurkrant-verordening is onverbindend, TvO 1980, p. 121.

4. De advocaat-generaal (Biegman-Hartogh) noemde de zaak in haar conclusie vóor het arrest van de Utrechtse muurkant wèl, maar ging niet op dit aspect in; zie haar conclusie vóór HR 24 juni 1980, NJ 1981, 659.

5. HR 14 januari 1969 , NJ $1969,191$.

6. J.M. de Meij, a.w. (noot 3), m.n. p. 122-124. Ik zal dit rijk gedocumenteerde verhaal hier verder laten rusten. Opvallend is dat De Meij ook ná het arrest van 24 juni 1980, NJ 1981, 659 aan zijn opvatting is blijven vasthouden. "De Hoge Raad heeft (...) voor dit punt onvoldoende oog gehad en verwees ten onrechte naar het toetsingsverbod van art. 193 Gemeentewet", schreef hij in Uitingsvrijheid (p. 110), Amsterdam 1989. Wie het arrest erop naslaat, zal opmerken dat de Hoge Raad (onder no. 14) eenvoudig met De Meij van mening verschilde over de dwingendheid van een (mede) door hem (op p. 123) aangehaalde passage uit de MvT op het Wetboek van Strafrecht; de gedachte dat de Hoge Raad het beroep op uitputtendheid heeft afgedain via art. $193 \mathrm{Gem}$.w., berust. op slechte lezing van het arrest.

7. HR 28 november 1950 , NJ $1951,137$.

8. J.A. Peters, noot onder HR 24 juni 1980, NJCM-Bulletin 1980, p. 30C. M. Polak (Het recht van plakken, AA 1983, p. 38) zag in "de mogelijkheid tot anonieme verspreiding." juist cén van de bekoringen van het plakken; mede om die reden moest het plakken volgens hem als "zelfstandig middel" worden aangemerkt. Ook in die visie zou de Utrechtse bepaling dus als algemeen verbod moeten worden gekwalificeerd, oftewel: als strijdig met art. 7 Gr.w.

9. C.W. Opzoomer, Staatsregelijk onderzoek, p. 132-133, Amsterdam 1854. Onk De Meij (a.w., noot 3, p. 124-125) haalde dit werk al aan.

10. Conclusie vó6r HR 24 juni 1980, NJ 1981, 6.59 .

11. HR 24 juni 1980 , NJ 198 i, 659.

12. Let wel: hier is de plaatsbepaling ("in het niet-landelijk gedeelte van de gemeente ") opeens biijkwaar wèl relevant. In vorige uitspraken lag dat, zoals we zagen, anders. Stak daar een bedoeling achter? Een onsnapping via de "achterdeur"? Of was het gewoon een slordigheidje?

13. In "Rehoboth" betrof het verbod "het landelijk deel van een gemeente"; hier ging het om "het niet-landelijk gedeelte". Een klein verschil tussen beide zaken was er 
dus wel; maar of het ook een relevant verschil was? Ik kan het me niet goed voorstellen.

14. Vgl. HR 19 september 1977 , NJ 1978, 516 (Hengelo).

15. Zie HR 14 oktober 1980, NJ 1981, 566 (Doorn). Zie ook HR DD 81.026 (eveneens 14 oktober 1980), waarin een Zeister APV-bepaling werd gesauveerd, die een algemeen plakverbod behelsde, zij het dat de bepaling niet van toepassing was op handelingen verricht "door of vanwege de rechthebbende". Met dat laatste werd, volgens de Hoge Raad, "ook gedoeld op handelen met uitdrukkelijke of stilzwijgende toestemming van rechthebbende". Er was, met andere woorden, geen sprake van een exclusieve bevoegdheid van rechthebbenden. Ook hier gold dus het "gewone" Alkmaarse regime, dat via "Hengelo" en "Dordrecht" ook op "Doorn" was toegepast.

16. Zie HR 13 januari 1981, NJ 1981, 254.

17. Zie zijn conclusie vóór HR 19 september 1977, NJ 1978, 516.

18. Zie HR 2 oktober 1979, NJ 1980, 105.

19. Vgl. mijn preadvies voor de VAR (Geschriften van de Vereniging voor Administratief Recht XCVI, p. 205-206) uit 1987.

20. F.H. Kistenkas (Vrije straatcommunicatie, p. 44, Amsterdam 1989) zag "Arahem" gewoon als een tamelijk botte voortzetting op de al ingeslagen weg; zowel de rechtbank als de Hoge Raad kregen er in zijn boek van langs. Hij herkende in hun uitspraken slechts een herhaling van "de bezweringsformule om plakverboden (...) te sauveren".

21. ARRS 22 januari 1981, Gst. 6692 (22 januari 1982), no. 2.

22. ARRS 23 oktober 1978, AB 1979, 499.

23. ARRS 28 april 1981, AB 1981, 480.

24. We zullen straks zien (aan de hand van HR 27 oktober 1981, NJ 1982, 103) dat het Nijmeegse regime ook overigens niet bijzonder liberaal was. In samenhang met andere bepalingen uit de Nijmeegse APV bood het hier gewraakte APV-artikel dan ook de nodige aanknopingspunten voor de stelling dat het ruimer omschreven middel van bekendmaking te vergaand beperkt was. In dit geval beperkte de Afueling zich echter tot deze ene bepaling.

25. HR 24 juni 1980, NJ 1981, 659.

26. HR 14 januari 1969, NJ 1969, 191.

27. Zie A.W. Heringa en R. de Winter, De kleefkracht van de vrijheid van meningsuiting, NJB 1982, p. 352. Later ook: F.H. Kistenkas, Uitingsvrijheid en plakverboden: een nieuwe ontwikkeling?, NJB 1984, p. 1000, en F.H. Kistenkas, Vrije straatcommunicatie, p. 50-51, Ansterdam 1989. De - zeg maar - "zich toeëigenende" stijl van Kistenkas is hier frappant. Heringa en ik schreven in NJB 1982 (p. 354) onder meer: "De erkenning van plakken als 'zelfstandig middel van verspreiding' bracht de Afdeling (...) tot de conclusie dat overheidsonthouding op zich niet voldoende is ter verzekering van de mogelijkheid van een gebruik van enige betekenis. De overheid moet die mogelijkheid klaarblijkelijk creëren. (...) De Afdeling Rechtspraak kwam zo tot de erkenning van een sociale component van de vrijheid van drukpers". Kistenkas in 1989 (naar aanleiding van de Nijmeegse 
zaak): "Overheidsonthouding kan nog onvoldoende zijn ter verzekering van de mogelijkheid van een gebruik van enige betekenis; soms moet de overheid die mogelijkheid met betrekking tot een zelfstandig verspreidingsmiddel creëren c.q. de voorwaarden daartoe scheppen. (...) Men zou hier ook kunnen spreken van een. erkenning van een zorgfunctie voor de overheid, of van een sociale component van de uitingsvrijheid" (p. 51). Storend, maar ook wel komisch; de stelling-zèlf lijkt mij namelijk, nu zij mij weer onder ogen komt, niet goed houdbaar: de Afdeling nam in deze uitspraak, volgens mij, in het geheel geen standpunt in over de vraag in hoeverre de overheid actief moest optreden - het enige wat zij vaststelde, was dat deze maatregel te weinig van het grondrecht overliet (zeer "klassiek", kortom!).

28. ARRS 26 juni $1981, \mathrm{tB} / \mathrm{S}$ III, nr. 272.

29. tB/S III, nr. 272, p. 1494.

30. Vgl. HR 27 februari 1951, NJ 1951, 473.

31. Zie noot B.V.A. Röling onder HR 27 februari 1951, NJ 1951, 472. Letterlijk schreef hij dat blijkbaar bedoeld was "een wijze van verspreiden die personen kan bereiken, die door andere wijzen niet of minder gemakkelijk kunnen worden benaderd".

32. ARRS 20 augustus 1981 , Gst. 6692 (22 januari 1982), nr. 3.

33. C.J.N. Versteden, De Afdeling rechtspraak en artikel 7 van de Grondwet, Gst. 6692 (22 januari 1982), p. 24. Later, in dezelfde zin: J.M. de Meij, Uitingsvrijbeid (Amsterdam 1989), p. 108, naar aanleiding van ARRS 14 november 1985 , AB 1986, 458.

34. W. 601 (22 mei 1845), p. 1 (aan het slot van een serie van drie artikelen over de vrijheid van drukpers, waarin de redactie concludeerde dat die vrijheid destijds "alleen in naam" bestond). E. Diemer, Vrijheid van drukpers, p. 82, noot 193 (Amsterdam 1937) bracht mij op het spoor van deze - ook door hem aangehaalde passage, en daarmee van de hier bedoelde serie.

35. HR 9 juni 1981 , NJ $1981,516$.

36. HR 2 oktober 1979, NJ 1980, 105.

37. Vgl. Rb Zwolle 2 april 1981, aangehaald in HR 15 juni 1982, NJ 1983, 121:

"Er vallen in de stad wel gebouwen aan te wijzen, welke in een zodanige staat verkeren dat ervan uitgegaan mag worden dat de rechthebbenden tegen het beplakken ervan geen bezwaar zullen hebben. Bij dergelijke gebouwen zal het beplakken, hoewel zonder toestemming, doorgaans toch niet tegen de wil van, de rechthebbenden zijn".

De Hoge Raad heeft van dergelijke subtiliteiten nooit willen weten. Alle varianten (van "Alkmaar" tot "Hengelo") werden telkens onder één en dezelfde noemer gebracht: bescherming van "eens anders recht".

38. ARRS 28 april 1981, AB 1981, 480.

39. HR 27 oktober 1981, NJ 1982, 103.

40. Ik denk dat bedoeld is: een bepaling uit een gemeentelijke verordening.

41. Ik schreef daarover in mijn VAR-preadvies uit 1987 (zie noot 19), p. 236-239. B.P. Vermeulen, in: P.W.C. Akkermans en A.K. Koekkoek, De Grondwet, 2 e 
druk, p. 168 (Zwolle 1992), meent dat de Afdeling Rechtspraak met haar onverbindend verklaring "verder" ging dan de Hoge Raad. Wat hij daarmee bedoelt, licht hij echter niet toe.

42. Chronologisch: R. de Winter (VAR-preadvies 1987, (zie noot 19), p. 238); F.H. Kistenkas, a.w. (noot 20), p. 46; A.J. Bok, a.w. (zie noot 2), p. 67.

43. De advocaat-generaal (Mok) wees er bijvoorbeeld op dat voor de bekende aankondiging "Nederland ontwapent" destijds geen plaats was in Nijmegen; zie zijn conclusie vó́r HR 27 oktober 1981, NJ 1982, 103.

44. Zie HR 2 maart 1982, NJ 1984, 133.

45. Vgl. HR 28 november 1950, NJ 1951, 137 (Tilburg). Wellicht was deze hernieuwde aanhaling een aanwijzing dat de latere - beknoptere - formulering (zoals die vanaf HR 12 januari 1960, NJ 1960, 273 ("Alkmaar") werd gehanteerd) inhoudelijk niet afweek van de oorspronkelijke.

46. In NJ 1984, 133 staat ten onrechte "vaststelling"; vergelijking met de weergave van het arrest in DD 82.231 leert dat inderdaad het meervoud hiervan is bedoeld. Kistenkas, a.w. (noot 20), p. 47, houdt ongelukkigerwijs vast aan de tekst in NJ $1984,133$.

47. In die zin: mijn meergenoemde VAR-preadvies uit 1987 (zie noot 19, p. 206); idem: J.M. de Meij, Uitingsvrijheid, p. 113 (Amsterdam 1989), en F.H. Kistenkas, a.w. (noot 19), p. 47.

48. HR 13 januari 1981 , NJ $1981,254$.

49. F.H. Kistenkas, a.w. (noot 19), p. 47 en 52. Eerder leek Kistenkas uit diezelfde passage juist hoop te putten: zie F.H. Kistenkas, Uitingsvrijheid en plakverboden, NJB 1984, p. 1002.

50. Vgl. mijn boekje De triviale overbeid, p. 61-63, Zwolle 1990.

51. HR 12 januari 1960, NJ 1960, 273.

52. Zie over dit onderwerp: A.W. Heringa, Preventief recht; een verdachte regressie, in: Staatkundig Jaarboek 1982-1983, p. 49, Leiden 1982.

53. Zie over "De Rooie Reus": F. Bruinsma, Over bneren, burgers en buitenlui, in: Staatkundig Jaarboek 1982-1983, p. 73, Leiden 1982.

54. Rb. Roermond 15 april 1980, aangehaald in HR 17 februari 1981, NJ 1981, 299.

55. HR 30 mei 1967, NJ 1968, 5 (met name de derde overweging naar aanleiding van het tweede middel).

56. A-G Remmelink, conclusie vór HR 17 februari 1981, NJ 1981, 299.

57. HR 17 februari 1981, NJ 1981, 299.

58. Rb Breda 22 april 1982, aangehaald in: HR 5 april 1983, NJ 1984, 134.

59. Conclusie vóór HR 5 april 1983, NJ 1984, 134.

60. HR 2 maart 1982, NJ 1984, 133.

61. HR 5 april 1983, NJ 1984, 134.

62. HR 12 januar̃i 1960, NJ 1960, 273.

63. F.H. Kistenkas, a.w. (noot 20), p. 48-49, zag in dit Bredase arrest de zoveelste aanwijzing dat de Hoge Raad plakkers "toch wel erg koel" bleef bejegenen. Dit arrest leek, volgens hem, "zelfs in de richting van een grotere gestrengheid te gaan". Dat er sinds "Arnhem" een interessante ontwikkeling gaande was, was hem 
in zijn "uitstekende analyse" (woorden van B.P. Vermeulen, a.w. (noot 41), p. 167) helaas ontgaan.

64. HR 13 januari 1981, NJ 1981, 254.

65. HR 2 maart 1982, NJ 1984, 133.

66. HR 2 oktober 1979, NJ 1980, 105.

67. HR 28 juni 1982 , NJ 1984,64 .

68. F.H. Kistenkas, Uitingsvrijheid en plakverboden: een nieuwe ontwikkeling?, NJB 1984 , p. 1001 . Frappant is dat Kistenkas die passage later "klakkeloos" overnam in zijn proefschrift (Vrije straatcommunicatie, p. 52, Amsterdam 1989).

69. In mijn recensie van Kistenkas* proefschrift (NJB 1990, p. 562) betichtte ik hem er ten onrechte van niet te hebben nagegaan of de feitenrechter in dit geval iets over de feitelijke omstandigheden in Zevenaar had vastgesteld. Kistenkas schrijft - zo valt mij nu op - dat "blijkt dat deze geenszins nagegaan had of er toevallig nog. bijzondere plaatselijke omstandigheden aanwezig zouden zijn geweest, die impliceerden dat het Zevenaarse plakverbod in feite geen mogelijkheid tot gebruik van enige betekenis openliet" (NJB 1984, p. 1001, vrijwel letterlijk overgenomen in zijn proefschrift op p. 52). Mijn eigen opvatting was destijds als volgt:

"Nergens is uit af te leiden dat de feitenrechter zich met die vraag heeft beziggehouden. Toch kwam het niet tot vernietiging van het vonnis. Dat betekent dat de Hoge Raad de feitenrechter te hulp is gekomen. Weliswaar was niet gebleken dat er nog een 'gebruik van enige betekenis' resteerde, maar evenmin was gebleken dat het er niet was. Het was, met andere woorden, niet uitgesloten dat de zaak door de beugel kon. Daar nam de Hoge Raad kennelijk genoegen mee. Er werden geen motiveringseisen gesteld aan het vonnis" (a.w., p. 562).

Intussen ben ik - zoals hierna zal blijken - op het punt van de ontbrekende motiveringseisen weer enigszins gaan twijfelen.

70. HR 28 juni 1983, NJ 1984, 65. F.H. Kistenkas zag deze uitspraak oorspronkelijk min of meer in het verlengde van het arrest over Zevenaar (zie zijn aangehaalde bijdrage in NJB 1984, p. 1001); later meende hij (overigens zonder enige motivering, en voor mij ook volstrekt onbegrijpelijk) dat "Tilburg" in schril contrast stond tot "Zevenaar" (zie zijn proefschrift, p. 52). Zie in verband met het arrest-zelf ook noot 121 .

71. A.L. Melai in DD 1983, p. 953.

72. F.H. Kistenkas, a.w. (NJB 1984), p. 1001.

73. Naar een nieuwe grondwet, Documentatiereeks deel 15: Algebele grondwetsherziening, eerste lezing, deel la, p. 15, 's-Gravenhage 1979 . Vgl. in dit verband mijn bijdrage Deregulering van de grondwet, in: Staatkundig Jaarboek: 1983-1984, p. 107 e.v., Zwolle 1983.

74. Met deze passage lijkt de door F.H. van der Burg (zie zijn noot onder HR 17 oktober 1989, AB 1990, 318) opgeworpen vraag over dit onderwerp te zijn beantwoord.

75. Bij een eerdere gelegenheid (in mijn boekje "De triviale overheid", p. 62, Zwolle: 
1990) wees ikal eens op een nog steeds actueel citaat van Jacob Israel de Haan uit 1918, dat werd aangehaald door J. Meijer, De zoon van een gazzen, p. 160, Amsterdam 1967. Laat ik het hier nog één keer in herinnering brengen:

"Zeldzaam zijn de sterk gemotiveerde vonnissen, waarvan rechtskrachtuitgaat. Geen wonder: de lagere rechters vinden hun eer en veiligheid hierin, dat zij $200 \mathrm{~min}$ mogelijk gecasseerd worden. En de Hooge Raad vat zijn cassatie-taak niet zoo ruim mogelijk, maar zoo eng mogelijk op. Belangrijke rechtsvragen worden eenvoudig verklaard tot in cassatie onaanvechtbare feitelijke beslissingen. Wat rechtspraak heet, is niet meer dan een soort trucjes-orde, die geen redelijke kracht is in de maatschappelijke verstandhouding".

76. Rb Amsterdam 18 april 1984, NJCM-Bulletin 1985, p. 57 e.v. De rechtbank beschouwde de bepaling die verbood andermans eigendom, "voor zover dit eigendom van de weg af zichtbaar is, wederrechtelijk te beschrijven, te bekrassen, te beplakken of te bekladden, dan wel de weg of dat eigendom op andere wijze te verontreinigen" onverbindend "voorzover het aanplakken als onder 1 (d.w.z.: het eerste ten laste gelegde feit, RdW) omschreven wordt verboden". F.H. Kistenkas vroeg zich in een noot onder dit vonnis (p. 63) verbaasd af of we hier, volgens de rechtbank, te maken hadden met "een zeldzaam voorbeeld van een splitsbare wilsverklaring". Zo ja - en daau hou ik het maar op - dan was hij "benieuwd naar het aanknopingspunt (...) voor deze splitsing". Ik weet niet of die nieuwsgierigheid nog steeds bij hem bestaat, maar er is eenvoudig aan tegemoet te komen, lijkt mij. De onverbindendheid betrof namelijk uitsluitend het wederrechtelijk beplakken; over de rest van de opsomming - het wederrechtelijk beschrijven, bekrassen, bekladden, dan wel op andere wijze verontreinigen - sprak de rechtbank zich niet uit. In zoverre was de bepaling (wellicht) verbindend. De formulering van de bepaling - een opsonming - bracht mee dat het "beplakken" er zonder meer uitgelicht kon worden; de rest kon dus gehandhaafd blijven.

77. Weergegeven in HR 13 januari 1981, NJ 1981, 254.

78. De A-G Meijers noemde in zijn conclusie vór HR 23 juni 1987, NJ 1988, 222 "Maastricht" (HR 2 maart 1982, NJ 1984, 133), dat ruim een jaar later werd gewezen, als (eerste? RdW) arrest waaruit kon worden afgeleid "dat de rechter een verweer, inhoudende dat door omstandigheden ter plaatse bet plakverbod geen gebruik van betekenis voor het verspreidingsmiddel plakken overlaat, op zijn feitelijke juistheid moet onderzoeken".

79. F.H. Kistenkas, noot onder Rb Amsterdam 18 april 1984, NJCM-Bulletin 1985, p. 62, en F.H. Kistenkas, Vrije straatcommunicatie, p. 53, Amsterdam 1989.

80. Vgl. bijv. HR 12 januari 1960, NJ 1960, 273 (Alkmaar) en HR 2 maart 1982, NJ 1984, 133 (Maastricht).

81. Niettemin had de rechtbank - blijkens een uitdrukkelijke verwijzing naar het arrest over Zevenaar - duidelijk het oogmerk zich aan de rechtspraak van de Hoge Raad te conformeren; of was dat oogmerk er uitsluitend op het punt van het plakverbod?

82. Rb Rotterdam 3 december 1984, NJ 1985, 349. Letterlijk was het "aan anderen dan de rechthebbende verboden" te plakken; voglens de rechtbank was evenwel niet beoogd het plakken met toestemming van de rechthebbende strafbaar te stellen. 
Gezien HR 14 oktober 1980, DD 81.026 lijkt mij dat een plausibele interpretatie. Het vonnis van de Rotterdamse rechtbank stond overigens in schril contrast fot een eerder vonnis van diezelffle rechtbank ( $x i j$ het in andere samenstelling); zie Rb Rotterdam 27 november 1980, NJCM-Bulletin 1981, p. 90. De rechtbank overwoog toen nog dat het (Rotterdamse) plakverbod - een variant van het Dordtse - ook aan niet-rechthebbenden "ruime mogelijkheden" liet om te plakken: ze hoefden immers alleen maar toestemming te vragen...

83. HR 21 januari 1986, NJ 1986, 441, AB 1986, 572.

84. Volgens E.A. Alkema (in zijn noot onder dit arrest in AE 1986, 572) schiep de Hoge Raad met zijn vernietiging en verwijzing van de zaak naar het hof te 's-Gravenhage "de mogelijkheid voor de feitenrechter' om onder bijzondere omstandigheden van de gemeentelijke overheid te verlangen, dat zij ten behoeve van het aanplakken middelen ter beschikking stelt". Ik vrees dat we hier te maken hebben met een vorm van wishful thinking. Vermoedelijk werd de gemeente door het vonnis van de rechtbank nog eerder tot plaatsing van plakborden gedwongen (zij het indirect) dan door de motivering waar de Hoge Raad zich van bediende.

85. Rb Arnhem 8 februari 1985, NJCM-Bulletin 1985, p. 303.

86. Zie het eerdere vonnis van de rechtbank, aangehaald in HR 13 januari 1981 , NJ 1981, 254.

87. Het is moeilijk voorstelbaar dat deze zinsnede in 1985 werd opgeschreven. In sommige opzichten is er kennelijk weinig veranderd. Jacob Israel de Haan, die ik al eerder aanhaalde, schreef in 1919 (Rechtskundige significa, p. 111):

"Het geknoei begint op de lagere school. De meeste leerboeken waren tot voor korten tijd geschreven in een onnatuurlijk-plechtige taal. Het stel-onderwijs leerde een onnatuurlijk-plechtige taal gebruiken. Die niemand vanzelf schrijft.

Op de examens moet dezelfde onnatuurlijke taal worden gebruikt.

Daarbij komt de noodlottige gedachte, dat men bij plechtige gelegen-

heden onnatuurlijk moet spreken of schrijfen. Onmogelijk lange

zinnen. En dan veel metaforen. Veel mooie spraakbeelden".

Alleen het laatste bleef ons in het Arnhemse vonnis (gelukkig) bespaard.

88. De vraag rijst natuurlijk of het plakken niet ophoudt "wederrechtelijk" te zijn wanneer het door de rechthebbende (i.c. de gemeente) wordt gedoogd. De rechtbank had het woord "wederrechtelijk" hier, kortom, beter kunnen weglaten: de gemeente gedoogde niet dat haar eigendommen werden beplakt. Dat was - samen met het kleine aantal plakplaatsen - fataal.

89. CRvB 12 november 1985, AB 1986, 579 en NJCM-Bulletin 1986, p. 157-163, 237-238 en 449-451. Zie voor de hieraan voorafgaande uitspraak van de $\mathrm{Vz}_{\mathrm{z}}$ Ambtenarengerecht Rotterdam d.d. 13 december 1983: NJCM-Bulletin 1984, p. 167 e.v. De CRvB besliste naar aanleiding van de uitspraak van het Ambtenarengerecht van 8 maart 1984.

90. Inmiddels zal een zaak als deze, naar we mogen bopen, worden opgelost aan de hand van art. 125a Ambtenarenwet, en wel in bet licht van art. 6 EVRM en art. 19 TVBP. 
91. HR 24 juni 1980 , NJ 1981, 659.

92. Aangehaald in HR 10 juni 1986, NJ 1987, 133.

93. HR 10 juni 1986, NJ 1987, 133.

94. ARRS 19 januari 1987, AB 1988, 58.

95. P.J. Boon wijst er in zijn noot onder deze uitspraak op dat de Afdeling zich met deze formulering letterlijk aansloot bij het in de MvT bij de grondwetsherziening gehuldigde standpunt.

96. Zie bijv. HR 29 mei 1951, NJ 1952, 367.

97. F.H. Kistenkas (onder meer in Naar een grondrechtelijke evenredigheidstoetsing, Gst. 6925 (1991), p. 378) zag in deze uitspraak een principieel andere benadering dan in de zijns inziens ouderwetse "verspreidingsdogmatiek". Vandaar dat hij zich verbaasde over twee uitspraken van de Voorzitter van de Afdeling Rechtspraak "à l'ancienne", zoals hij het uitdrukte: Vz ARRS 15 maart 1990, resp. GS 6904, 9 en 6907,3 (hierna nog kort te behandelen). Vervolgens werd hij echter gerustgesteld door de uitspraken Vz ARRS 17 augustus 1990 (GS 6913,3) en Vz ARRS 7 december 1990 (KG 1991, 64), resp. over Zwolle en de Rotterdamse deelgemeente Prins Alexander (eveneens hierna kort te behandelen). Waar hij in dit verband ongelukkigerwijs aan voorbijging, was dat het in die uitspraken die hem niet bevielen over art. 7 lid 1 ging (waardoor een voorafgaand verlof niet door de beugel kon), terwijl de beslissingen die hem wèl aanstonden art. 7 lid 3 betroffen (waarbij een verlofstelsel is toegestaan, zolang het althans niet de inhoud van de uitingen raakt). Inmiddels lijkt Kistenkas werkelijk in de veronderstelling te verkeren dat een verlofstelsel vandaag-de-dag ó́k ten aanzien van lid 1 geoorloofd is; in Gemeenten en ongewenst drukwerk (GS 6947, p. 375) schreef hij onlangs naar aanleiding van een $\mathrm{Nijmeegs}$ plan een vergunningstelsel in te voeren voor de verspreiding van reclamedrukwerk: "Het betreft hier weliswaar een volgens de traditionele verspreidingsjurisprudentie verboden algeheel verlofstelsel, maar zelfs in het kader van art. 7 lid $1 \mathrm{GW}$ zal de (administratieve) rechter zo'n verlofstelsel sinds kort gewoon sauveren". Wishful thinking, naar ik veronderstel... (Wie niet overtuigd is leze bijv. (zeer recent): ARRS 24 juni 1991, AB 1992, 26).

98. A.W. Heringa (De vrijheid is niet van de straat, Mediaforum 1990, p. 45) wees daar terecht op in zijn recensie van Kistenkas' proefschrift. Menig verschil in benadering tussen de Afdeling en de Hoge Raad kan op die manier verklaard worden.

99. Zie ARRS 8 april 1988, AB 1989, 88.

100. Vz ARRS 17 augustus 1990, Gst. 6913, nr. 3.

101. Opvallend is dat de Voorzitter het hier had over de activiteiten van verzoekster die niet volledig onmogelijk werden gemaakt. In de eerdere uitspraken ging het steeds om het middel van openbaarmaking zèlf, waarvan het gebruik niet onmogelijk mocht worden gemaakt. Weliicht moet hieruit worden afgeleid dat, volgens de Voorzitter, een ieder van het betreffende middel gebruik moet kunnen maken; anders (zoals bekend): HR 2 oktober 1979, NJ 1980, 105 (Dordrecht). Wat was op dit punt "de heersende leer"?

102. ARRS 15 juli 1991, Gst. 6931 (1991), nr. 6 (p. 585 e.v.). 
103. Te weten: "wanneer er naar redelijke verwachting gevaar bestaat voor:

a. wanordelijkheden;

b. aantasting van de openbare zedelijkheid;

c. belemmering van het verkeer;

d. aantasting van de rechten en vrijheden van anderen".

104. Minder precies was Vz ARRS 7 december 1990, KG 1991, 64, waarin het ging om een standplaatsvergunning voor de verkoop van (niet nader aangeduide) reprodukties in de Rotterdamse deelgemeente Prins Alexander. De Voorzitter (Van Zeben) volstond hier met de ongemotiveerde mededeling dat "naar Ons oordeel (...) niet met vrucht (kon) worden gesteld dat het handhaven van het in geding zijnde vergunningenstelsel op gespannen voet (stond) met het in art. $7 \mathrm{Gr}$.w. gewaarborgde recht van drukpersvrijheid en het recht op openbaren van gedachten en gevoelens met andere middelen als in art. 7 derde lid bedoeld". De omstandigheid dat de Voorzitter zowel het eerste als het derde lid van art. $7 \mathrm{Gr} . w$. in zijn overweging betrok, geeft overigens aan dat hij het houden van een standplaats voor de verkoop van gedrukte stukken niet louter als verspreidingsmiddel in het kader van lid 1 beschouwde. Dat lijkt mij geen vanzelfsprekend standpunt.

105. Aangehaald in HR 23 juni 1987, NJ 1988, 222.

106. Rb Amsterdam 18 april 1984, NJCM-Bulletin 1985, p. 57 e.v.

107. Interessant in dit verband is de opvatting van A-G Meijers in zijn conclusie over deze zaak (NJ 1988, 222 onder nr. 21):

"Ik vraag mij af of de $\mathrm{Rb}$ het verweer niet reeds had kunnen verwerpen op grond van de overwegingen

a. dat aan verdachte overtreding van art. 85 lid 1 APV ten laste was gelegd;

b. dat weliswaar in art. 85 lid 2 naar art. 84 wordt verwezen, maar

c. dat op de rechtvaardigingsgrond van art. 85 lid 2 door of namens verdachte geen beroep is gedaan, zodat

d. de vraag naar de verbindendheid van art. 84 buiten de grenzen van bet geding valt."

108. HR 23 juni 1987, NJ 1988, 222.

109. Zie noot 106.

110. Aangehaald in HR 5 januari 1988, Gst. 6872, nr. 5; NJCM-Bulletin 1989, p. 439. Zie in verband met deze zaak ook: J.M. de Meij, De feitelijke mogelijkheid tot vrije meningsuiting, Mediaforum 1989, p. 16.

111. Hier doet zich overigens een begripsmatig probleem voor. Ook al worden er van gemeentewege op grote schaal plakborden geplaatst, dan nòg kan men stellen dat uitsluitend met toestemming van rechthebbenden geplakt kan worden: de gemeente stelt die borden immers - als rechthebbende! - beschikbaar. Naar de letter genomen, was het door de rechtbank geformuleerde criterium dus niet te realiseren. Ik denk dat de rechtbank bedoelde dat je óók moest kunnen plakken zonder voorafgaand verlof te vragen.

112. De verdachte werd overigens - pikant detail - opgepakt op de Grote Markt, een plein in het centrum van de stad, waar zich - zoals ik niet geheel toevallig weet - 
tevens de in de brief van B en W genoemde "Vishal" bevindt. In zijn directe omgeving stonden dus niet minder dan zes borden ter grootte van $1 \times 1,10$ meter. Gebruiksmogelijkheden te over, kortom! Maar dat was voor de rechtbank niet beslissend. De verordening kon nu eenmaal niet in het ene stadsdeel wèl en in het andere niet verbindend zijn. De verdachte ging dus vrijuit, hoewel hij zich beklaagde over iets waar hij eigenlijk niet over te klagen had...

113. Noot onder HR 5 januari 1988, in NJCM-Bulletin 1989, p. 445. De Meij (a.w., noot 110) kwam later tot een soortgelijke interpretatie als ik.

114. Ktr. Nijmegen 22 februari 1989, Praktijkgids 1989, p. 286 (nr. 3066). Intussen had de Hoge. Raad zich trouwens ook over een nachtbrakers-bepaling in de APV van de Noordoostpolder uitgesproken; er werd in herhaald dat zo'n bepaling niet in strijd is met art. 6 lid 2 EVRM en bovendien geen intenties strafbaar stelt (zie HR 22 maart 1988, NJ 1988, 848). Ik laat die zaak hier verder rusten; vgl. De triviale overheid, p. 18-20, Zwolle 1990.

115. Vgl. HR 5 april 1983, NJ 1984, 134.

116. Aangehaald in HR 18 september 1989, NJ 1990, 123.

117. Conclusie vóór HR 18 september 1989, NJ 1990, 123 (p. 500, 1.k.).

118. HR 18 september 1989, NJ 1990, 123. Ik wijs erop dat de Hoge Raad hier rept van "buiten toepassing" laten - een kwestie die eerder aan de orde kwam naar aanleiding van HR 27 oktober 1981, NJ 1982, 103 (Nijmegen). Met het arrest over Groningen was de eerdere uitspraak over het Bussumse nachtbrakersverbod (Rb Amsterdam 18 april 1984, NJCM-Bulletin 1985, p. 57) overigens expliciet weerlegd; zowel eerder als later was dat al bij herhaling impliciet gebeurd.

119. Rb Breda 22 april 1982, aangehaald in HR 5 april 1983, NJ 1984, 134.

120. Rb Breda 4 oktober 1982, aangehaald in HR 28 juni 1983, NJ 1984, 65.

121. Met name de overwegingen ten aanzien van "Tilburg" lijken mij niet erg dwingend. In de eerste ovenweging gaat het over toestemming om te plakken op een wijze die de eigenaar of huurder goeddunkt; vanuit het perspectief van plakkers bezien, is dat natuurlijk geen vanzelfsprekende benadering. De vraag of zoiets voldoende gebruiksmogelijkheden oplevert, is daarmee dan ook nog niet beantwoord, zou ik denken. In de tweede overweging wordt pressie van verhuurders niet aannemelijk geacht, met name niet als de toegestane wijze van aanplakking hen niet in hun belangen raakt. Voor zover de rechtbank daarbij louter aan materiële beschadigingen e.d. dacht, is er weinig op aan te merken. Maar als tevens gedoeld werd op een mogelijke inhoudelijke toetsing door verhuurders, ligt dat anders.

122. A.K. Koekkoek (RM Themis 1992, p. 284) opende zijn recensie van het proefschrift van Kistenkas, aldus: "Tilburg heeft een zekere traditie wat de jurisprudentie inzake de drukpersvrijheid betreft". Daar valt weinig op af te dingen, lijkt mij. Het hier te behandelen - door hem niet genoemde - arrest van 25 september 1989 bevestigt zijn stelling alleen.

123. Rb Breda, aangehaald in HR 25 september 1989, NJCM-Bulletin 1989, p. 950.

124. HR 25 september 1989, NJCM-Bulletin 1989, p. 950 e.v.

125. HR 5 januari 1988, Gst. 6872, nr. 5; NJCM-Bulletin 1989, p. 439.

126. Zie NJCM-Bulletin 1989, p. 951-952. 
127. HR 17 oktober 1989, NJ 1990, 222; AB 1990, 318, NJCM-Bulletin 1990, p. 444.

128. Ik herinner aan de conclusie van Meijers vó́r HR 23 juni 1987, NJ 1988, 222, onder 20. Onder verwijzing naar de Rb. Rotterdam (NJ 1985, 349) noemde hij de mogelijkheid dat van andere rechthebbenden dan de gemeente toestemming tot plakken wordt verkregen "goeddeels theoretisch".

129. Zie AB 1990, 318 (p. 949, r.k.).

130. HR DD 89.373 .

131. HR DD 86.112 .

132. HR DD 89.373.

133. HR DD 83.333.

134. HR DD 88.365.

135. HR DD 86.142/143.

136. HR DD 86.326.

137. F.H. van der Burg, noot onder HR 17 oktober 1989, AB 1990, 318. Voorts vroeg hij zich af "wat het onderhavige middel van verspreiding nu eigenlijk omvat". Daar is, volgens mij, geen eenduidig antwoord op te geven. De Afdeling Rechtspraak had, zoals we zagen, de neiging "kleinschalige" verspreidingsmiddelen eerder als "zelfstandig" aan te merken dan de Hoge Raad. Daarnaast lijken de verschillende verspreidingsmiddelen elkaar ook te kunnen overlappen.

138. HR 28 juni 1983, NJ 1984, 65 .

139. $\mathrm{Na}$ al het voorgaand met betrekking tot het Haarlemse plakverbod (zie onder 7.5) is het misschien nuttig erop te wijzen dat ook in het befaamde arrest "Nederland ontwapent" (HR 24 januari 1967, NJ 1967, 270) niet van "voorafgaand verlof van de overheid" werd gerept, maar zonder meer van "voorafgaand verlof". Destijds ongetwijfeld een slordigheidje, want later verscheen de overheid in dit kader weer gewoon ten tonele. In zoverre was "Haarlem" een herhaling van "Nederland ontwapent".

140. ARRS 20 augustus 1981 , Gst. 6692 , nr. 3 .

141. ARRS 14 november 1985, AB 1986, 458.

142. P.J.J. van Buuren, noot onder deze uitspraak in $A B$ 1986, 458.

143. A.W. Heringa, noot onder HR 26 mei 1987, in: NJCM-Bulletin 1987, p. 624. Hij sprak overigens ten onrechte van een bepaling die bet aanbrengen van reclame afhankelijk stelde van voorafgaand verlof van de overheid. Mijn eigen behandeling van deze zaak in NJCM-Bulletin 1988, p. 126-127 lijkt mij, achteraf beschouwd, trouwens evenmin erg geslaagd.

144. J.M. de Meij, Uitingsvrijheid, p. 108, Amsterdam 1989.

145. Vz ARRS 3 november 1987, Gst. 6855, ar. 5.

146. ARRS 8 april 1988, AB 1988, 357.

147. Vz ARRS 10 augustus 1989 , Gst. 6889, nr. 4.

148. Vz ARRS 15 maart 1990, Gst. 6904, nr. 9.

149. Vz ARRS 15 maart 1990, Gst. 6907, nr. 3.

150. Zie resp. ARRS 23 oktober 1978, AB 1979, 499 en ARRS 22 januari 1981, Gst. 6692 , nr. 2. 
151. Nogmaals: de "winds of change" die Kistenkas (F.H. Kistenkas, Gemeenten en ongewenst drukwerk, Gst. 6947 (1992), p. 375) op dit punt "bespeurt", heb ik nergens kunnen aantreffen. Nou ja, misschien in HR 11 februari 1986, NJ 1986, 673, waar ik zo dadelijk over kom te spreken; volgens Kistenkas speelde de verandering zich echter met name bij de administratieve rechter af.

152. HR 24 januari 1967 , NJ 1967, 270.

153. Zie zijn noten onder de bedoelde uitspraken (resp. in: Gst. 6889, ar. 4; 6904, nr. 9; 6907, nr. 3).

154. H.D. van Wijk, Formeel en vaag, p. 7, Alphen aan den Rijn 1958.

155. HR 23 mei 1961, NJ 1961, 427.

156. HR 11 februari 1986, NJ 1986, 673.

157. J.M. de Meij, Uitingsvrijheid, p. 86-87, Amsterdam 1989.

158. Daarmee is dan tevens "verklaard" waarom de advocaat-generaal niet inging op de omstandigheid dat - zoals De Meij (a.w. noot 157, p. 87) het uitdrukte "praktisch elke vorm van drukken behalve met een handpersje onder de Hinderwet valt". De Meij, die zich hierover verbaasde, zag vermoedelijk aan het cassatietechnische punt voorbij.

159. J.M. de Meij, a.w. (noot 157), p. 87.

160. In die zin vatte ook Van Veen de conclusie van Meijers op: "Drukkerijen hebben alleen dan met de Hinderwet te maken, als zij door hun machines gevaar en hinder oproepen. (...) Terwille van die belangen mag de wet eisen stellen aan de technische uitrusting van drukkerijen. Dat daarbij de inhoud van wat er gedrukt gaat worden nimmer mee mag wegen spreekt van zelf. De A-G Meijers zegt dat daarvan niets is gebleken en dat daarover ook niet is geklaagd". (Th.W. van Veen, noot onder HR 11 februari 1986, NJ 1986, 673).

161. Zie Vz ARRS 10 augustus 1989 , Gst. 6889 , nr. 4.

162. Vz Afd. geschillen van bestuur RvS 26 april 1991, Gst. 6931, nr. 7.

163. Zie resp. HR 31 mei 1939, NJ 1939, 76, en HR 28 november 1950, NJ 1951, 137,138 en 369.

164. HR 18 september 1989, NJ 1990, 94; NJCM-Bulletin 1990, p. 291.

165. Vgl. mijn noot onder dit arrest in NJCM-Bulletin 1990, p. 296.

166. Zie hiervóór onder 5.2.

167. Zie resp. Pres. Rb Middelburg 29 januari 1990, KG 1990, 81 en Pres. Rb 's-Gravenhage 14 december 1990, NJCM-Bulletin 1991, p. 128.

168. Het voorbeeld is niet geheel denkbeeldig. E. Diemer (Vrijheid van drukpers, p. 120, Amsterdam 1937) citeerde de volgende passage uit een stuk van A.N. Molenaar dat op 3 april 1936 in de Nieuwe Rotterdamsche Courant (Avondblad) was verschenen: "Een vergadering behoeft men niet te bezoeken, een courant niet to koopen, maar een betoogende menigte of colporteurs komt men ongemerkt tegen. Hier kan dus wel degelijk een beperking van de vrijheid worden bepleit, indien objectief kan worden vastgesteld, dat een normaal reageerend individu aan de vrijmoedige wijze, wasıop anderen zich uiten of gedragen, aanstoot kan nemen. En het motief is vooi mij dan hierin gelegen, dat het recht van den een om actief te getuigen vañ geen grooter waarde is dan het recht van den ander om zich 
getuigenissen van anderen niet bij voortduring te zien opgedrongen en of in zijn. innerlijke gevoelens te worden gekwetst. Zoo kan m.i. de colportage met antigodsdienstige geschriften bij den uitgang eener kerk, die de geloovigen juist in gewijde stemming verlaten, nimmer toelatbaar worden geacht".

169. B.V.A. Röling, noot onder HR 27 februari 1951, NJ 1951, 472.

170. Een soortgelijk betoog hield ik eerder in Verwijdering van vreemdelingen en spandoeken (NJB 1989 , p. 119 e.v.). Destijds wees ik (onder verwijzing naar HR 28 november 1950, NJ 1951, 137) op de "ratio" van de verspreidingsjurisprudentie, te weten dat verspreiding de ruimtelijke sfeer betreft. Beperkingen die niet uit dit specifieke ruimtelijke karakter voortvloeiden, konden dus niet door de beugel. Alleen, intussen denk ik dat er in principe nogal wat te brengen is onder die "ruimtelijke sfeer" - ook pijnlijke confrontaties, bijvoorbeeld. Enige beperking is op die grond dus wel te rechtvaardigen, lijkt mij; maar geen volstrekt verbod. B.P. Vermeulen liet zich in zijn commentaar op art. 7 (zie: P.W.C. Akkermans en A.K. Koekkoek, De Grondwet, tweede druk, p. 165, Zwolle 1992) helaas verleiden tot. een tamelijk demagogische afdoening van deze problematiek. Hij wees erop dat de "essentie van de verspreidingsvrijheid" niet is "dat men die verspreidingwijzen overal (bijv. op een bepaalde aantrekkelijke standplaats) en in elke modaliteit (bijv. door te schreeuwen, of door een optocht) moet kunnen uitoefenen". Hij kon mijn standpunt "dan ook niet onderschrijven". Dat ik er helemaal niet vanuit ging dat je overal en in elke modaliteit drukwerk moest kunnen verspreiden, liet hij (gemakshalve?) onvermeld. Ik vind dat een weinig verheffende manier van discussiëren. F.H. Kistenkas, tenslotte, kwam in zijn proefschrift tot een soortgelijke uitkomst als ik, zij het dat hij er geen positiefrechtelijke "inkadering" bij leverde (Vrije straatcommunicatie, p. 156-157, Amsterdam 1989).

171. Zie ARRS 15 juli 1991, Gst. 6931, nr. 6 (1991).

172. Vz ARRS 9 maart 1984, AB 1985, 192.

173. C.J.N. Versteden, De Afdeling rechtspraak en artikel 7 van de Grondwet. Gst. 6692 (1982), p. 24. Dat het onderscheid tamelijk willekeurig is, ben ik overigens met De Meij (Uitingsvrijheid, p. 93, Amsterdam 1989) eens; hij wees er (in een wat kromme zin) op dat zich "bij de verkoop en verhuur van grammofoonplaten of films (...) dezelfde openbare ordeproblemen (kunnen) voordoen of overlast worden veroorzaakt, als wanneer het om boeken gaat". Ten aanzien van videobanden ligt dat niet anders, lijkt mij.

174. Zie HR 11 december 1987, NJ 1990, 73; NJCM-Bulletin 1988, p. 121.

175. P.J.J. van Buuren wekte in zijn noot onder ARRS 14 november 1985, AB 1986, 458, de indruk dat een dergelijke constructie "op zich" door de beugel kon.

176. ARRS 17 mei 1983, AB 1983, 514.

177. Zie HR 17 februari 1981, NJ 1981, 299. Vgl. in verband met geluidswagens verder ARRS 19 januari 1987, AB 1988, 58, een uitspraak (over het huidige art. 7 lid 3 Gr.w.) die we al eerder tegenkwamen.

178. Zie hiervóór onder 5.4 , noot 74 .

179. Zie het buidige art. 7 lid 3 Gr.w.; vgl. voorts noot 177. 
180. HR 27 juni 1978 , NJ 1979, 59. Zie hiervóór onder 6.5.

181. Rb Zwolle 27 mei 1986, aangehaald in HR 26 mei 1987, NJ 1988, 1005; AB 1988, 106; NJCM-Bulletin 1987, p. 607 e.v.

182. Conclusie vóór het in noot 181 genoemde arrest.

183. Conclusie vóór HR 15 september 1986, NJ 1987, 387.

184. Zie hiervóór onder 6.5.

185. De VNG had eerder een soortgelijke "verklaring" geproduceerd, waar Leijten in zijn conclusie ook uitvoerig uit citeerde. In dat stuk werd echter evenmin uit de doeken gedaan waarom het tot een onverbindend verklaring kwam hoewel er nog allerlei gebruiksmogelijkheden resteerden. De visie van de Zwolse rechtbank, daarentegen, bood wèl een consistente "verklaring". A.W. Heringa wees in zijn noot onder het arrest in NJCM-Bulletin 1987, p. 623, al eerder op deze problematiek.

186. HR 26 mei 1987, NJ 1988, 1005; AB 1988, 106; NJCM-Bulletin 1987, p. 607 e.v.

187. Hiermee yond deze term, die in de literatuur al lange tijd opgang had gemaakt, eindelijk ingang in de jurisprudentie. Het begrip werd - als zelfstandig naamwoord - in Nederland geïntroduceerd door J. van der Hoeven (De plasts van de Grondwet in het constitutionele recht, p. 230, Zwolle 1958) en is ontleend aan Carl Schmitt. Van der Hoeven gaf er de positie van het verspreidingsrecht mee aan, zoals dit in het arrest over het Tilburgse pornoverbod (HR 28 november 1950, NJ 1951,137 ) was omschreven: er was, volgens hem, sprake van een "connex" (naast het grondrecht van art. 7 Gr.w.). Vervolgens werd in de literatuur op grote schaal van een connex recht gerept.

188. Ik onderschrijf de analyse van De Meij (Uitingsvrijheid, p. 94-95, Amsterdam 1989) dan ook niet: hij doet het (in navolging van Leijten, naar ik veronderstel) voorkomen of het verschil in uitkomst tussen "Eindhoven" en " $Z$ wolle" is terug te voerren tot een verschil in formulering van de APV-bepalingen. Daarbij beriep hij zich tevens op Heringa, die in zijn eerder aangehaalde annotatie (vgl. mijn noot 185) echter concludeerde dat de Hoge Raad was "omgegaan".

189. ARRS 8 april 1988, AB 1989, 88.

190. HR 16 november 1976, NJ 1977, 378. Zie hoofdstuk 6, noot 13.

191. Vz ARRS 7 december 1990, KG 1991, 64.

192. F.H. Kistenkas (Naar een grondrechtelijke evenredigheidstoetsing, Gst. 6925 (1991, p. 379) leidde uit deze uitspraak af dat "een verlofstelsel (niet langer) op gespannen voet met art. 7 lid 1 en lid $3 \mathrm{GW}^{*}$ staat. Een weinig subtiele conclusie, lijkt mij - tenminste: ten aanzien van lid 1; ten aanzien van lid 3 was dit een waarheid als een koe.

193. Dáár kwam het, zoals we eerder zagen, op aan in het kader van art. 7 lid 3; vgl. bijv. ARRS 8 april 1988, AB 1989, 88 .

194. Resp. HR 14 januari 1969, NJ 1969, 191 (zie hiervóór onder 5.6) en HR 18 januari 1972, NJ 1972, 193 (zie hiervóror onder 6.1).

195. Nikolaas Wiltens, Kerkelyk Plakaatboek, behelzende de plakaaten, ordonnantien, ende rosolutien, over de kerkelyke zaken; deel 1, p. 694, 's-Gravenhage 1722 (bij 
Paulus en Isaac Scheltus). Op gemeentelijk niveau speelde deze kwestie al evenzeer van oudsher. Bij een cerdere gelegenheid (VAR-preadvies 1987, p. 182) verwees ik naar een Rotterdamse "Keure ende Ordonnantie" uit 1722 "tegens het profaen spreken, schelden, ontheyligen ende misbruyken van den Heyligen Name Godts, mitsgaders het vloeken en vervloeken van sig selven ende zijn even-naasten, als andersints". Enige tijd later stuitte ik op een Utrechtse bepaling "legens het vloeken, zweeren en ontheiligen van des Heeren dag " uit 1752 (zie mijn boekje De triviale overheid, p. 78, Zwolle 1990).

196. C.F.J. Gombault, Communaal strafrecht, p. 126, Alphen aan den Rijn 1921.

197. KB 5 juni 1986 , Stb. 337-342.

198. HR 28 november 1950, NJ 1951" 137.

199. J.Th. Begheyn, De Veluwse vloekverboden, RM Themis 1988, p. 467 e.v.; hier m.n. p. $475-476$.

200. Op p. 483 van zijn artikel schrijft Begheyn (a.w., noot 199) "dat vloeken normaliter wel een uiting zal zijn, maar geen meningsuiting in de zin van art. 7 zoals hierboven gereconstrueerd". Let wel: normaliter, "er zijn immers ongetwijfeld gevallen denkbaar waarin men nadrukkelijk zijn mening gestalte geeft c.q. kracht bijzet met behulp van" - kort gezegd - gevloek. In die gevallen zou de bepaling volgens hem "buiten toepassing" gelaten moeten worden (een vondst clie hij - in platats van aan de Hoge Raad - toeschrijft aan P.J.J. van Buureni). De hepaling hoeft omwille van die gevallen - in zijn visie - dus niet onverbindend te worden verklaard.

201. J. de Bosch Kemper, Handleiding tot de kennis van het Nederlandsche staatsregt en staatsbestuur, p. 147, Amsterdam 1865.

202. Ik schreef daar eerder over in De triviale overheid, p. 78, Zwolle 1990.

203. Zie W.J. Witteveen, P. van Seters, G. van Roermund (red.), Wat maakt de wet symbolisch?, p. 11, Zwolle 1991.

204. ARRS 16 juli 1991, AB 1992, 42.

205. ARRS 31 augustus 1987, $A B$ 1988, 358. Het aanbrengen, in stand houden of gedogen van reclame was volgens de APV Bunschoten uitsluitend geoorloofd met ontheffing van B en W. Dat was, volgens de Afdeling, in strijd met art. 7 lid 1 Gr.w. De bepaling was daardoor onverbindend, aangezien "daarin geen voldoende aanknopingspunten (waren) te vinden voor een splitsing van de wilsverklaring van de gemeenteraad in het gebruiken van onroerend goed voor reclame, waarin gedachten of gevoelens (waren) geopenbaard en het aanwenden van onroerend goed voor reclame in de zin van art. 7 vierde lid Gr.w.".

206. B.P. Vermeulen, Commentaar op art. 7 Gr.w., in: P.W.C. Akkermans en A.K. Koekkoek (red.), De Grondwet, p. 151-152, Zwolle 1992.

207. ARRS 24 juni 1991, AB 1992, 26; Gst. 6930, nr. 3 (p. 544).

208. E. Brederveld, noot onder ARRS 24 juni 1991, Gst. 6930, nr. 3, p. 546.

209. P.J. Boon in zijn noot onder dezelfde uitspraak in AB 1992, 26.

210. Zie noot 194.

211. Conclusie A-G Leijten vóór HR 18 september 1989, NJ 1990, 123. 
212. Vgl. De triviale overheid, p. 75 e.v., Zwolle 1990.

213. K. Schippers, Een klok en profil, p. 19, Amsterdam 1965.

214. HR 23 juni 1992 (nr. 91.486), NJB-Rechtspraak 1992, p. 362: Hoge Raad (strafkamer) nr. 127. De advocaat-generaal (Meijers) kwam eerder al tot hetzelfde resultaat in zijn conclusie die aan dit arrest voorafging.

215. Ook in mijn "verklaring" blijft het opvallend dat de Hoge Raad uitsluitend oog lijkt te hebben voor het verbale element van wenskaarten. Dat is weliswaar geheel consistent met eerdere uitspraken - ik wees daar eerder al op in verband met "Rehoboth" en "Huifkar" - maar het blijft naar mijn idee vreemd.

216. Vgl. $V_{z}$ ARRS 16 augustus 1979, NJCM-Bulletin 1980, p. 78, en Vz ARRS 18 oktober 1979, tB/S VII, 78. 
1. M.C. Burkens, Algemene leerstukken van grondrechten naar Nederlands constitutioneel recht, p. 128, Zwolle 1989.

2. Vgl. mijn VAR-preadvies (Geschriften van de VAR XCVI) uit 1987, p. 235.

3. W.J. Witteveen, De retoriek in het recht, o.m. p. 6, Zwolle 1988.

4. Jerome Frank, Law and the modern mind, p. 9, Gloucester 1970 (6e druk, oorspr.: 1930).

5. Jerome Frank, a.w. (noot 4), p. 13.

6. Zie noot 4, p. 15.

7. Zie noot 4, p. 19.

8. Roscoe Pound, An introduction to the philosphy of law, p. 16 (Revised edition, New Haven 1954). Daarnaast onderscheidde Pound overigens nog elf andere "conceptions of what law is".

9. Zie noot 4, p. 165.

10. Vgl. in het bijzonder Karl Olivecrona, Law as fact, m.n. p. 65 e.v. (second edition, Londen 1971).

11. Vgl. F.A. Hayek, Law, legislation and liberty, deel I, p. 98 (Chicago 1973): "The aim of jurisdiction is the maintenance of an ongoing order of actions". In de nadruk op handhaving en het honoreren van verwachtingen schuilt, volgens mij, een normatief element in de benadeirng van Hayek. De gedachte dat het om een going order gaat, lijkt mij echter van belang. Zie ook p. 118-119: "The judge (...) serves, or tries to maintain and improve, a going order which nobody has designed, an order that has formed itself without the knowledge and often against the will of authority, that extends beyond the range of deliberate organization on the part of anybody, and that is not based on the individuals doing anybody's will, but on their expectations becoming mutually adjusted".

12. Vgl. R.M. Hare, The language of morals, p. 54, Londen, Oxford, New York 1970 (oorspr. 1952).

13. Vgl. R.M. Hare, a.w. (noot 12), hoofdstuk 4.

14. Vgl. HR 14 april 1989, NJ 1989 (Harmonisatiewet), overweging 3.9. De Hoge Raad hield hier uitdrukkelijk rekening met de omstandigheid dat de doorkruising van gewekte verwachtingen bij de totstandkoming van de gewraakte wetsbepaling onder ogen was gezien. Die omstandigheid was m.a.w. voorzien, hetgeen ertoe leidde dat toepassing van de wetsbepaling niet achterwege mocht blijven. Ging het om een onvoorziene consequentie, dan lag het klaarblijkelijk anders!

15. Zie Vz ARRS 7 december 1990, KG 1991, 64.

16. Zie bijv. HR 24 januari 1967, NJ 1967, 270 en ARRS 23 oktober 1978, AB 1979, 499.

17. Zie bijv. ARRS 20 augustus 1981, Gst. 6692, nr. 3 (1982).

18. Zie HR 11 februari 1986, NJ 1986, 673.

19. Zie o.m. Vz ARRS 10 augustus 1989, Gst. 6889, nr. 4.

20. Zie bijv. ARRS 15 juli 1991, Gst. 6931, nr. 6 .

21. Morris R. Cohen, Reason and Law, p. 155, New York 1961 (oorspr. 1950). 


\section{Chronologisch register van besproken Nederlandse uitspraken en beslissingen}

HR 7 maart 1871, W. 3386, p. 24

HR 7 maart 1871 , W. 3387, p. 24

Ktr. 's-Gravenhage 1 maart 1892, W. 6153, p.2

Rb. 's-Gravenhage 30 mei 1892, W. 6187, p. 3, 9

HR 7 november 1892 , W. 6259, p. 2, 3, 9, 10, 20, 85, 106, 110, 128, 137

HR 7 november 1892 , W. 6263, p. 1

Ktr. Leiden 29 september 1894, W. 6571, p. 36

KB 21 december 1894, W. 6587, p. 31

KB 30 augustus 1895 , W. 6696, p. 32

HR 23 maart 1896, W. 6783, p. 14, 37, 111, 130

HR 1 februari 1897, W. 6928, p. $14,40,51,55,76$

KB 29 april 1897, Stb. 114, p. 42

Ktr. Groenlo 21 mei 1897, W. 7163, p. 44

HR 1 november 1897 , W. 7036, p. 2, 14, 43, 53, 63, 155

Rb. Haarlem 12 juli 1898, W. 7146, p. 44

HR 5 december 1898, W. 7213, p. 2, 44

Ktr. Groningen 5 februari 1902, W. 7744, p. 44

Ktr. Tilburg 3 maart 1902, W. 7780, p. 47

HR 26 mei 1902, W. 7780, p. 45, 48, 52, 56, 75, 77, 78, 83, 88

HR 23 juni 1902, W. 7802, p. 21, 46, 47, 49, 50, 55, 56, 74

Min.v.Binnenl.Z. 17 juli 1902, Gst. 2654, p. 42

HR 27 oktober $1902, W .7825, p .42,50$

HR 2 juni 1903, W. 7936, p. 51, 54, 74

HR 25 januari 1904, W. 8023, p. 41

HR 20 november 1905, W. 8298, p. 42, 50, 51

Min.v.Binnenl.Z. 3 juni 1909, WBA 3231, p. 42, 55

HR 4 april 1910, W. 9018, p. 43, 55, 65

HR 18 april 1910 , W. 9027, p. 58

HR 13 juni 1910 , W. 9052, p. 42, 50, 57, 62

HR 29 juni 1910, W. 9062, p. 37, 42, 61, 87

HR 8 maart 1915, W. 9797, p. 65, 67

HR 2 oktober 1916, W. $1005, p .77$

HR 28 juni 1920, W. 10616, p. 29, 67, 68, 69, 71, 78, 83, 88, 98, 104, 118, 122

HR 5 november 1928, W. 11913, p. 70, 71,81, 112

HR 24 oktober 1932, NJ 1932, 1755; W 12580, p. 76, 77, 81, 82, 85, 86, 87, 92,

94,120 
HR 18 november 1935 , NJ 1936, 40, p. 46, 66, 77, $81,83,87,88$ HR 8 november 1937 , NJ 1938, 367, p. $27,80,84,86,92,142,143$ HR 21 maart 1938, NJ 1938, 655, p. 46, 75, 83, 87, 95, 154, 158 HR 31 oktober 1938, NJ 1939, 206, p. 46, 83, 84, 85, 92, 142, 145 HR 7 november 1938, NJ 1939, 269, p. 86, 87,120 HR 14 november 1938, NJ 1939, 268, p. 88,92 HR 31 mei 1939, NJ 1939, 769, p. 87, 89

KB 11 mei 1948, Stb. 184; AB 1948, 642, p. 103, 106 HR 20 juni 1950, NJ 1950, 619, p. 21, 102, 104, 122, 133, 177 HR 28 november 1950, NJ 1951, 137, p. 4, 6, 13, 27, 94, 106, 107, 109, 112, 121, $126,137,140,144,182,186,199,240,242,247,251$

HR 28 november 1950, NJ 1951, 138, p. 4, 6, 13,106,107, 108, 141, 240 HR 28 november 1950, NJ 1951, 369, p. 4, 106, 240 HR 27 februari 1951, NJ 1951, 472, p. 24, 111, 114, 117, 126, 132, 193, 242 HR 27 februari 1951, NJ 1951, 473, p. 116, 118, 146, 147, 193 HR 29 mei 1951, NJ 1952, 367, p. 111, 117, 118, 218 HR 10 juni 1952 , NJ 1952, 688, p. 42, 65, 119, 120, 170 HR 17 maart 1953, NJ 1953, 389, p. 29, 69, 118, 121, 147 HR 12 januari 1960, NJ 1960, 273, p. 24, 125, 144, 153, 165, 166, 175, 177, 199, $201,204,213$

HR 22 maart 1960, NJ 1960, 274, p. 125, 130, 131, 133, 136, 138 HR 29 november 1960, NJ 1961, 206, p. 134, 138, 147 HR 23 mei 1961, NJ 1961, 427, p. 135, 136, 143,164, 237 HR 24 januari 1967, NJ 1967, 270, p. 24, 86, 111, 142, 143, 144, 146, 154, 175, $233,235,262$

HR 30 mei 1967, NJ 1968, 4, p. 117, 146, 147, 148, 154 HR 30 mei 1967, NJ 1968, 5, p. 149, 150, 151,161, 162, 171, 202

Ktr. Maastricht 5 juli 1968, NJ 1970, 11, p. 152

HR 14 januari 1969, NJ 1969, 191, p. 154, 175, 186, 192, 250

Ktr. Tilburg 24 november 1971, NJ 1972, 178, p. 153, 175, 176 HR 18 januari 1972, NJ 1972, 193, p. 159, 250 HR 15 april 1975, NJ 1976, 23, p. 161 HR 16 november 1976, NJ 1977, 378, p. 162, 166, 248 HR 19 september 1977, NJ 1978, 516, p. 24, 27, 165, 175, 177, 189, 190 HR 27 juni 1978, NJ 1979, 59, p. 167-173, 246 ARRS 19 oktober 1978, tB/S III, p. 517, Gst. 6548, p. 173 ARRS 23 oktober 1978, AB 1979, 499, p. 174, 191, 235, 262 Ktr. Tiel, 12 december 1978 , NJCM-Bulletin 1979, p. 33, p. 176 
HR 22 mei 1979, NJ 1979, 505, p. 177.180

Vz. ARRS 16 augustus 1979, NJCM-Bulletin 1980, p. 78, p. 174, 258

HR 2 oktober 1979, NJ 1980, 105; AB 1980, 231, p. 24, 44, 128, 180, 182, 185, $190,195,205,219$

Vz. ARRS 18 oktober 1979, tB/S VII, p. 78, p. 174, 258

Ktr. Leeuwarden, 24 april 1980, NJ 1981, 316, p. 185

ARRS 13 juni 1980, AB 1981, 311, p. 174

HR 24 juni 1980, NJ 1981, 659, p. 185-189, 192, 216

HR 14 oktober 1980, NJ 1981, 566, p. 27, 189

HR 14 oktober 1980, DD 81.026, p. 189, 214

HR 13 januari 1981, NJ 1981, 254, p. 189, 200, 205, 213, 214

Rb Rotterdam 27 november 1980, NJCM-Bulletin 1981, p. 90, p. 214

ARRS 22 januari 1981, tB/S III nr. 233; Gst. 6692, p. 144, 191, 194, 235

HR 17 februari 1981, NJ 1981, 299, p. 201, 245

ARRS 28 april 1981, AB 1981, 480, p. 191, 196

HR 9 juni 1981, NJ 1981, 516, p. 195

ARRS 26 juni 1981, tB/S III nr. 272, p. 192

ARRS 20 augustus 1981, tB/S III, 288; Gst. 6692, p. 194, 233, 262

HR 27 oktober 1981, NJ 1982, 103, p. 102, 192, 196, 198, 228

HR 2 maart 1982, NJ 1984, 133, p. 199-201, 204, 205, 213

HR 15 juni 1982, NJ 1983, 121, p. 196

HR 5 april 1983, NJ 1984, 134, p. 203-206, 227, 229

ARRS 17 mei 1983, AB 1983, 514, p. 245

HR 28 juni 1983, NJ 1984, 64, p. 206

HR 28 juni 1983, NJ 1984, 65, p. 209, 229, 233

Vz. ARRS 9 maart 1984, AB 1985, 192, p. 243

Rb. Amsterdam 18 april 1984, NJCM-Bulletin 1985, p. 57, p. 212. 222, 228

Rb. Rotterdam 3 december 1984, NJ 1985, 349, p. 214, 232

Rb. Arnhem, 8 februari 1985, NJCM-Bulletin 1985, p. 303, p. 214

ARRS 21 mei 1985, AB 1986, 28, p. 174

CRvB 12 november 1985, AB 1986, 579; NJCM-Bulletin 1986 p. 160, 237, $449, p, 10,215$

ARRS 14 november 1985, AB 1986, 458, NJCM-Bulletin 1987, p. 623, p. 194, 234, 245

Vz. ARRS 2 januari 1986, AB 1986, 433, p. 174

HR 21 januari 1986, NJ 1986, 441; AB 1986, 572, p. 214

HR 11 februari 1986, NJ 1986, 673, p. 235, 237, 239, 262

KB 5 juni 1986, Stb. 337-342, p. 250

HR 10 juni 1986 , NJ 1987, 133, p. 216 
HR 15 september 1986, NJ 1987, 387, p. 247

ARRS 19 januari 1987, AB 1988, 58, p. 217, 245

HR 26 mei 1987, NJ 1988, 1005; NJCM-Bulletin 1987, p. 607; AB 1988, 106 , p. $246-248$

HR 23 juni 1987, NJ 1988, 222, p. 213, 221-223, 232

Vz. ARRS 3 november 1987, Gst. 6855, p. 235

HR 11 december 1987, NJ 1990, 73; NJCM-Bulletin 1988, p. 121, p. 21, 106, 244

HR 5 januari 1988, NJCM-Bulletin 1989, p. 439; Gst. 6872, p. 126, 223-226, 230

HR 22 maart 1988, NJ 1988, 848, p. 226

ARRS 8 april 1988, AB 1988, 357, p. 235

ARRS 8 april 1988, AB 1989, 88, p. 218, 248, 249

Ktr. Nijmegen 22 februari 1989, Praktijkgids 1989, 3066, p. 226

Vz. ARRS 10 augustus 1989, Gst. 6889, p. 235, 239, 262

HR 18 september 1989, NJCM-Bulletin 1990, p. 291; NJ 1990, 94, p. 240

HR 18 september 1989, NJ 1990, 123, p. 227-229, 256

HR 25 september 1989, NJCM-Bulletin 1989, p. 950, p. 229-231

HR 17 oktober 1989, NJCM-Bulletin 1990, p. 444; NJ 1990, 222; AB 1990, 318, p. 24, 212, 231-233

Pres. Rb. Middelburg 29 januari 1990, KG 1990, 81, p. 241-243

Vz. ARRS 15 maart 1990, Gst. 6904, p. 218, 235

Vz. ARRS 15 maart 1990, Gst. 6907, p. 218, 235

Vz. ARRS 17 augustus 1990, Gst. 1991, 6913; AB 1991, 44, p. 218,219

Vz. ARRS 7 december 1990, KG 1991, 64, p. 218, 221, 248, 262

Pres. Rb. 's-Gravenhage 14 december 1990, NJCM-Bulletin 1991, p. 128 , p. $241-243$

Vz. AGRvS 26 april 1991, Gst. 6931, p. 240

ARRS 24 juni 1991, AB 1992, 26, p. 218, 255

ARRS 15 juli 1991, AB 1992, 27; Gst. 6931, p. 220, 243, 262

ARRS 16 juli 1991, AB 1992, 42, p. 254

HR 23 juni 1992, NJB-Rechtspraak 1992, p. 362, p. 257 


\section{Summary}

This book is about printed matter. In 1892 the Dutch Supreme Court decided a case in which the circulation of printed nnatter was given protection under article 7 of the Dutch Constitution (free speech). It was decided that local authorities could only limit circulation; they were not allowed to make circulation fully dependent on licenses or to forbid it altogether. Some 130 other cases, focusing on several aspects of circulation, are known to have since been decided. In this study these cases are analysed chronologically, not, as is more commonly done, in retrospect. The cases are all presented through the spectacles of the day, i.e. without any reference to present-day ideas on the subject. They are looked upon from the point of view of a court (mostly in two or three instances) which is about to make its decision. Thus quite often an element of choice can be shown, whereas in retrospect such an element will mostly be obscured. So, in a way, this book is not limited to history as it actually was; it is also about history as it might have been. The book does not only deal with court decisions, but also with the abundant volume of writing on the subject. Again, a chronological approach is used, in such a way that the book may offer some insights in the functioning of a legal "forum". Apart from obvious misreadings, most authors proved to be satisfied after having found just one explanation for a court decision. Generally, they were recognizing either a confirmation of their own preferences, or something they vehemently disapproved of. That there might be more than just one interpretation of a court decision is something which simply did not occur to many authors. It is not surprising, therefore, that thorough analyses can hardly be found. Of course, after one century some basic insights have become obvious, but many questions still have to be answered. Nowadays, for instance, court decisions in this field are usually phrased in an almost ritual manner: the same concepts are being repeated again and again. But what they mean, we do not know.... 


\section{Curriculum vitae}

Reiner de Winter (Bloemendaal 1948) deed in 1968 eindexamen HBS-B te Haarlem. Hij studeerde aanvankelijk medicijnen en vervolgens - na het behalen van het destijds vereiste "pro-tentamen" Latijn - rechten aan de Universiteit van Amsterdam; doctoraal-examen (hoofdrichting privaatrecht): februari 1975. Van 1975 tot 1982 was hij - op én jaar na, waarin hij aan de University of Chicago (USA) verbleef - wetenschappelijk medewerker staats- en bestuursrecht aan de Rijksuniversiteit Leiden. Van 1982 tot 1985 was hij gerechtsauditeur ten behoeve van de strafkamer van de Hoge Raad der Nederlanden. Sinds 1985 is hij universitair hoofddocent staats- en bestuursrecht aan de Rijksuniversiteit Limburg. Hij werkte 0 .a. mee aan het Compendium van het staatsrecht en aan A.L. Melai e.a., Het Wetboek van Strafvordering, schreef voor de Vereniging voor Administratief Recht een preadvies over toetsing van gemeentelijke vorderingen, publiceerde een bundeltje essays en een inleiding tot het staatsrecht. 


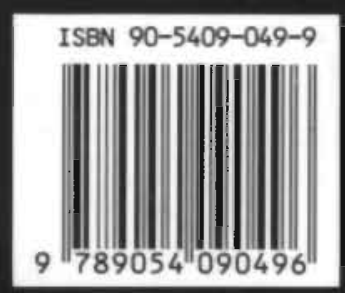

